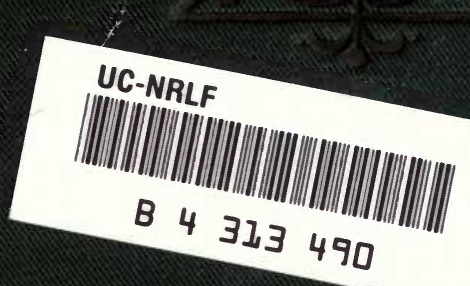

$$
\text { HISTORY }
$$$$
\text { FER N S. }
$$ 


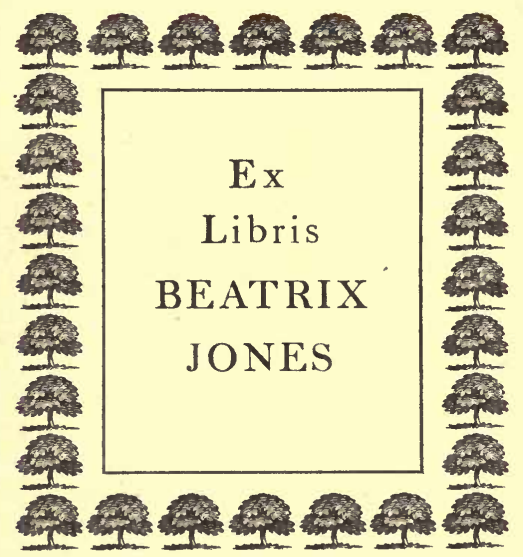

The Gift of Beatrix Farrand to the General Library

University of California, Berkeley

REEF POINT GARDENS

LIBRARY 

$\frac{\text { nyga }}{\text { orfare }}$ 


\section{HISTORIA FILICUM;}

\section{AN EXPOSITION}

OP THE

NATURE, NUMBER, AND ORGANOGRAPHY

OF

\section{F E R N S,}

AND

REVIEW OF THE PRINCIPLES UPON WHICH GENERA ARE FOUNDED, AND THE SYSTEMS OF CLASSIFICATION OF THE PRINCIPAL AUTHORS,

WITH A

NEW GENERAL ARRANGEMENT; CHARACTERS OF THE GENERA; REMARKS ON THEIR RELATIONSHIP TO ONE ANOTHER; THEIR SPECIES;

REFERENCE TO AUTHORS; GEOGRAPHICAL DISTRIBUTION; ETC., ETC.,

With 30 Lithographic Plates, by W. H. Frтc日, F.L.S., illustrating the Characters of the Tribes.

\section{Br JOHN SMITH, A.L.S.,}

Ex-Curator of the Royal Botanio Garden, Kew; Author of "Ferns, Beitish axd Foreigr," "Domostic Botanx," eTC., etc.

LONDON.

M A CMIL A N \& CO. 
LANDSCAPE

APCHITECTURE

LONDON :

H. M. POLLETT, HORTICULTURAL PRINTER;

12 to 15 BRidgewater Gardens; barbican, e.c.

Farrand Gift 
LANDSCAPE ARCH.

LIBRARY

\section{PREFACE.}

Is submitting this volume to the notice of those interested in the study of Ferns I consider it proper, though at the risk of being considered egotistical, to give a brief explanation of the circumstances that have led to its publication.

My first introduction to Ferns was in acquiring the names of the common British species. In 1823 the collection in the Royal Botanic Garden, Kew, came under my care; it then consisted of about forty hardy species, British and Foreign, and about the same number of tender exotics, the latter dispersed in various hothouses. In $1825 \mathrm{I}$ arranged the tender ones in a group at the end of one of the then lean-to houses, the space they occupied being 12 feet by 6 feet; these formed the nucleus of the present great collection.

New species were occasionally imported, and others raised from spores, the spores being obtained from collections of dried specimens, chiefly from the West Indies, Brazil, and Australia, also from a collection of 
Indian specimens presented to $\mathrm{me}$ in 1829 by the late Dr. Wallich, which led to my commencing a Fern Herbarium, that first received a special addition in the form of a collection of Jamaica Ferns, collected in that island by Mr. Robert Heward.

In 1841 I purchased a set of the great collection of Ferns made in the Philippine Islands by Mr. Hugh Cuming; of them I drew up a list, published in Hooker's "Journal of Botany." I then wrote a Memoir, entitled, "An Arrangement and Definition of the Genera of Ferns," which was read before the Linnæan Society, and published in Hooker's "Journal of Botany for 1841-42." In 1842 Hooker and Bauer's "Genera Filicum" was completed, wherein I described twenty new genera.

Collections of dried specimens were occasionally placed in my hands for naming, among which may be mentioned Schomburgh's "Ferns of British Guiana," published in Hooker's "Journal of Botany" for 1842. The "Ferns of New Zealand," in Dr. Hooker's "Flora of New Zealand," in 1854. Ferns collected during the voyage of the surveying ship "Herald" by Dr. Seemann, contained in the volume of the Bntany of that voyage in 1854. I also drew up a list of the great collection of Ferns made in India by Drs. Hooker and Thomson. 
My Herbarium continued to increase, not only by the addition of specimens from cultivated plants, but also of dried specimens received from the principal Fern regions of the world, either obtained by direct purchase or by presentation. The collection, numbering about 2,000 species-their various sizes and forms occupying 6,000 large folio sheets-were, in 1866, with the exception of one-third duplicates, purchased for the Herbarium of the British Museum.

In 1846 the Kew Garden collection had increased to 400 species, of which I made up a list, published in the volume of the "Botanical Magazine" for that year. This was followed in 1857 by the publication of a "Catalogue of Cultivated Ferns," 600 species being enumerated.

In May, 1864, in consequence of failing sight, I resigned the curatorship of the Royal Botanic Garden. $I$ at that time was preparing another catalogue of the Ferns in the Kew collection, which was published in 1866, under the title of "Ferns, British and Foreign,"* consisting of their History, Organograpy, and Classification, including a Treatise on their Cultivation. In this work 164 genera are described, each illustrated by a woodcut, and 1,084 species enumerated, including 56 Lycopods and their allies. The Kew

* A second edition is now in preparation. 
collection at this time occupied three hothouses, covering an area of 6,570 square feet.

I should, however, state that the greatness of this collection could not have been attained but for the powerful aid of the late Sir William Hooker, who also took great interest in the study of Ferns, as will be seen by the references to his works in the following pages. In the preface to the "Synopsis Filicum," speaking of the Garden collection, he says, "it is the finest in cultivation," and "the formation of this fine collection is mainly due to the exertions and ability of Mr. John Smith, who for forty-three years held an important position among the officers of the Royal Gardens. His knowledge of Ferns, and his writings on them, justly entitle him to rank among the most distinguished Pteridologists of the present day."

The above statement will, I trust, be sufficient to show that I have not written this work without long practical acquaintance and the derotion of much time to the study of Ferns, this leads me to hope that it will be found useful to, and worthy of the patronage of, Pterodologists and Botanists in general. I must, however, state that on account of my loss of sight the work is not so complete as I could wish. Latterly my materials have been obtained from books kindly lent me by $\mathrm{Dr}$. Hooker, and from various 
notes furnished by Mr. J. G. Baker, assistant Curator of the Kew Herbarium.

The original MS. was nearly ready for publication in 1864, since when it has been rewritten and revised under my direction, and before being sent to press submitted to Mr. James Britten, of the Botanical Department of the British Museum. The proof sheets have been (with the exception of a few of the early ones) corrected by Mr. Robert सteward, F.L.S., I therefore trust that the typographical errors, \&c., which may have escaped notice are few.

I should not have ventured to have added the plates to the work if it had not been that Mr. W. H. Fitch, the eminent botanical artist undertook to prepare the drawings, and to superintend them through the press; from having drawn all the figures of Ferns published by $\mathrm{Sir}$ W. Hooker in his several works, he has become well acquainted with the structure and generic character of Ferns. We have also for many years at various times exchanged views regarding special points of structure, I have, therefore, no hesitation in accepting the plates as correct.

Although this work is entitled the History of Ferns, it nevertheless must be understood that it does not describe species, nor does it treat of their microscopical structure or chemical products, the chief aim of the 
work being the definition of Genera, and their classification, founded on the different modes of growth, venation, and fructification.

\section{JOHN SMITH.}

Kew, September, 1875. 


\section{CONTENTS.}

\section{PART 1.}

EXPLANATION OF THE NATURE AND STRUCTURE OF THE PARTS OF FERNS ON WHICH GENERA ARE FOUNDED AND CLASSIFIED.

PAGE.

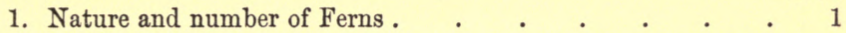

2. Organography.-Definitions of the parts of Ferns on which genera are founded and classified . . . . . 8

3. On the genera of early authors, and their systems of classification . . . . . . . . . 20

4. On the genera of modern authors, and review of their systems of classification . . . . . . . . . 25

5. On the genera and their classification as founded on their modes of growth and habit . . . . . . 61

\section{PART 2.}

General arrangement and characters of tribes and genera, with remarks on their relationship one to another, and the number of species . . . . . 77 to

\section{PART 3.}

1. On the reproduction of Ferns , . . . . . 371

2. On the geographical distribution of Ferns . . . . 377

3. On the properties and uses of Ferns . . . . . 385

\section{PART 4.}

1. Names of writers on Ferns, and their works . . . . 396

2. Etymology.-Derivations of generic names adopted in this work . . . . . . . . . . . 409

3. Alphabetical list of genera of authors not adopted . . . 422

4. Index to the tribes and genera adopted in this work . . 427 



\section{NAMES OF THE FIGURES ON THE PLATES, ILLUSTRATING THE TRIBES.}

\section{PLATE 1.}

a. Oleandra neriiformis. $b$. Oleandra Wallichii.

OBs. - With a portion of the caudex of Polypodium vulgare, showing the articulate vernation characteristic of the Division Eremobrya.

PLATE 2.

a. Humata heterophylla. b. Davallia pyxidata. c. Leucostegia immersa.

\section{PLATE 3.}

a. Polypodium vulgare. b. Phlebodium aureum. c. Pleuridium crassifolium.

\section{PLATE 4.}

a. Drymoglossum carnosum. b. Hymenolepis spicata. c. Leptochilus decurrens.

\section{PLATE 5.}

Platycerium Stemmaria.

PLATE 6.

a. Elaphoglossum latifolium. b. Polybotrya osmundacea. c. Gymnopteris nicotianæfolia.

\section{PLATE 7.}

a. Meniscium serratum. b. Meniscium simplex. c. Jenkensia undulata (Pœcilopteris sp., see Obs., p. 136).

\section{PLATE 8.}

a. Gymnogramma calomelanos. b. Hemionitis cordata. c. Llavea cordifolia. 


\section{PLATE 9.}

Ceratopteris thalictroides, showing sporangia and spores magnified.

\section{PLATE 10.}

$a$. Vittaria elongata. $b$. Vittaria scolopendrina.

c. Pteropsis angustifolia. $d$. Dictyoxiphium Panamense.

\section{PLATE 11.}

a. Monogramma furcata. b. Pleurogramma linearis. c. Xiphopteris serrulata. d. Grammitis furcata. e. Calymmodon cueullatus. f. Calymmodon clavifa.

\section{PLATE 12.}

a. Ctenopteris trichosora. b. Ctenopteris subtilis. c. Ctenopteris moniliforme. $d$. Ctenopteris peruviana. e. Ctenopteris rigescens. $f$. Ctenopteris discolor, g. Adenophorus tamarisci. $h$. Adenophorus tripinnatifidus.

PLATE 13 A.

a. Phegopteris macroptera. b. Goniopteris crenata. c. Dipteris Wallichii.

PLATE 13 B.

a. Aspidium trifoliatum. $b$. Nephrolepis exaltata. c. Lastrea patens.

\section{PLATE 14.}

$a$. Woodsia caucasica. $b$. Woodsia obtusa. $c$. Diacalpe aspidioides. d. Peranema cyatheoides.

PLATE 15.

$a$. Cyathea arborea. b. Hemitelia horrida. c. Alsophila excelsa.

PLATE 16.

$a$. Dicksonia arborescens. b. Cibotium Schiedei. c. Cystodium sorbifolium. $d$. Thyrsopteris elegans. 
PLATE 17.

a. Saccoloma elegans. b. Dennstadtia cicutaria. c. Microlepia platyphylla. d. Deparia prolifera.

PLATE 18,

a. Lindsæa trapeziformis. b. Schizoloma ensifolia. c. Synaphlebium recurvatum. d. Odontoloma repens.

\section{PLATE 19.}

a. Adiantum Capillus-Veneris. b. Adiantum obliquum. c. Hewardia adiantoides. $d$. Ocropteris pallens.

PLATE 20.

a. Nothochlæna squamosa. b. Cheilanthes radiata. c. Cheilanthes fragrans. $d$. Cassebeera triphylla.

PLATE 21.

a. Pteris nemoralis. b. Campteria biaurita. c. Doryopteris hastata. d. Lonchitis pubescens.

\section{PLATE 22.}

a. Blechnum occidentale. b. Woodwardia radicans. c. Lomaria striata.

\section{PLATE 23.}

a. Asplenium serratum. b. Neottopteris Nidus. c. Diplazium plantagineum. d. Hemidictyum marginatum.

\section{PLATE 24.}

a. Platyzoma microphylla. b. Gleichenia microphylla. c. Gleichenia gigantea. d. Matonia pectinata.

\section{PLATE 25.}

a. Hymenophyllum tunbridgense. b. Trichomanes alatum. $c$. Hymenostachys diversifrons. In the sterile fronds the veins anastomose, which has been inadvertently omitted to be shown on the plate. $d$. Féea spicata. e. Trichomanes pinnatum. $f$. Trichomanes reniforme. 
PLATE 26.

a. Schizæa dichotoma. b. Anemia mandioccana. c. Anemidictyon Phyllitidis. $d$. Lygodium volubile.

PLATE 27.

$a$. Osmunda regalis. $b$. Todea Africana.

PLATE 28.

a. Angiopteris evecta. b. Marattia purpurascens. c. Danea alata.

\section{PLATE 29.}

a. Ophioglossum vulgatum. b. Botrychium lunaria. c. Helminthostachys zelanica.

N.B.-In many of the figures the sori, sporangia, and spors are shown more or less magnified. 


\section{ERRATA.}

Page 49, line 13, for Lomogramma read Lomagramma.

\begin{tabular}{|c|c|c|}
\hline , 49, & ", & 13, for Miniscium read Meniscium. \\
\hline 56 , & , & 24, for Fadyena read Fadyenia. \\
\hline 63, & , & 9, for Sellegua read Selliguea. \\
\hline 64, & , & 22, for Saromanes read Soromanes.' \\
\hline 77, & ", & 13, for Davallie read Davallieæ. \\
\hline 85, & , & 25, for palmatafid read palmatifid. \\
\hline 86 , & , & 26, for obligatum read obliquatum. \\
\hline 90, & , & 2, for hypogaceous read hypogeus. \\
\hline 91, & , & 26, for Synaminia read Synammia. \\
\hline 93, & , & 8, for indusaform read indusæform. \\
\hline 93, & , & 28, for papyaceous read papyraceous. \\
\hline 94, & , & 28, for Anexetum read Anaxetum. \\
\hline 97, & , & 18, for adnescens read adnascens. \\
\hline 98, & , & 2, for specie read species. \\
\hline ", 98, & , & 16, for Thumb. read Thunb. \\
\hline , 101, & , & 3 , for tenulorus read tenuiloris. \\
\hline , 10 & ,, & 9, for Borg. read Bory. \\
\hline , 104, & , & 5, for peltedia read peltidea. \\
\hline , 106, & , & 7, for tubicles read tubercles. \\
\hline & ", & 22 , for ragadiolepis read rhagadiolepis. \\
\hline & , & 25 , for to read from. \\
\hline & , & 24, for cordex read caudex. \\
\hline
\end{tabular}





\section{PART I.}

EXPLANATION OF THE NATURE AND STRUCTURE OF THE PARTS OF FERNS ON WHICH GENERA ARE FOUNDED AND CLASSIFIED.

\section{1.-NATURE AND NUMBER OF FERNS.}

The plants which form the subject of this volume constitute a special Order in the Vegetable Kingdom, termed Filices, popularly known by the name of Ferns; they are plants of special habit and structure, and rank highest in the class Cryptogamia of Linnæus.

From circumstances explained hereafter, the number of species representing the present Fern flora is not well ascertained; it is sufficient here to say that about 2,500 have been described in books by different botanists, specimens of nearly that number being preserved in the principal herbaria of Europe, of which about a thousand have been introduced in a living state, and cultivated in the the gardens of this country. They are widely spread over the earth, being found in the tropics and temperate regions, and extending nearly to the limits of vegetable life in both the northern and southern hemispheres. In habit and mode of growth the greater number come under the category of herbaceous perennials, having seasons of growth and rest according with the nature of the different climates they inhabit. 
They vary considerably in size, many not being larger than mosses and liverworts and of as delicate a texture; a very few partake of the character of shrubs, and about one hundred and fifty assume the aspect of trees, some attaining the height of fifty or more feet.

As the special character of their structure is fully ex. plained further on, the above is sufficient to give an idea of the nature of Ferns.

Although Ferns possess but few economic properties, either as food, medicine, or in the arts, they have nevertheless become of great interest to botanists, their study being termed Pteridology, on which many books have been written, and during the last fifty years have also come into special favour with amateur plant cultivators, and lovers of pretty plants. The constant desire for novelty has led both public and private plant collectors and persons living in foreign countries to devote special attention to the collecting of Ferns, both for herbarium specimens and also as living plants. By these means the collections of Europe have become greatly enriched. It is recorded that the Royal Herbarium at Kew contains 50,000 specimens of Ferns, which have been communicated by no less than about 150 public, private, and trade collectors from all regions: the Fern collection in the herbarium of the British Museum is also very extensive. These, with the living collection at Kew, which in 1864 contained above one thousand species, have afforded ample means for study and determining the genera and species of Ferns. Many extensive living collections are also formed by amateurs, who in rivalry enhance their value to such an extent that as much as fifty guineas is frequently given for a single plant of fashionable repute at the time.

Of late years many books have been published on Ferns, 
but the different riews entertained by botanists, respecting the data on which genera and species are founded, renders the study of Ferns a task of no ordinary labour. This is owing to many causes, one of which is found in the fact that many species are normally heteromorphous; separate plants of the same species presenting different forms at the same or at different periods of growth, although growing under the same climatic influences; in some cases different fronds of the same plant, and even portions of the same frond when seen apart, have been characterized as distinct species, and have even been placed under different genera. It also frequently happens that two or more specimens present sufficient characters to be considered distinct species, but when the intermediate gradations of the series are supplied, only the most extreme states of any of the forms appear sufficiently distinct to be so considered. It often happens that plants of the same species at one time produce all simple, and at another time all pinnate or more highly divided fronds; it is therefore not surprising that different forms of indiridual species should be viewed as representing two or more species when known only from incomplete herbarium specimens.

It must also be borne in mind that the descriptions of many species found in books are derived from dried specimens, obtained in various parts of the world by trade collectors whose object is often only pecuniary gain, and whose profits are dependent on the number of forms found. Great caution is therefore necessary in accepting a collector's idea of species; it is only on the word of the independent and truly scientific collector that we can rely for correct information on the various aspects assumed by individual species growing in regions far away from where we write their history ; but even under the most favourable circum- 
stances of observation and discrimination, uncertainty often prevails. For instance, no class of plants has of late years been more written about than the Ferns of Great Britain; and yet much diversity of opinion still exists amongst British botanists regarding the number of species, although they have the opportunity of carefully and leisurely examining them under every circumstance con. nected with the different aspects they assume in their various places of growth. This surely offers some palliation for the errors committed by the general pteridologist, more especially when we consider that the Ferns of Great Britain are in number as one to sixty of the Fern-flora of the earth.

Having had under my observation for nearly half a century the Fern collection in the Royal Gardens at Kew, which, as already stated, amounted in 1864 to about a thousand species, and having during that period carefully noted their different modes of growth and aspects, I have been induced to consider that the differences seen in a series of closely allied living Ferns, are much more obvious than in examples of the same when seen in the herbarium. It is, however, often difficult to express their differences in words, but the eye readily distinguishes them, and knowing that each form maintains its own peculiar habit from year to year, reproducing its like from spores (seeds), I am, therefore, induced to consider that although closely allied, they are nevetheless sufficiently different to be regarded as distinct species.

Another point which renders it difficult to arrive at any satisfactory conclusion as to the correct number of species, is the botanical rule which prescribes that the specific name under which a plant is first described, is to be retained in whatever genus it may be referred to by 
subsequent authors; and in consequence of many species of Linnæus, Swartz, and other early authors, being but indifferently described, many being founded on imperfect specimens, and nothing but the meagre description left us for their identification. It frequently happens that some modern author detects or supposes that he has found out that the new species of his contemporary is one of the Linnean or Swartzian doubtful species, and on his decision being confirmed, names long familiar have to be changed. Again, by the distribution of trade and private herbarium collections, sets of the same specimens fall in the hands of different botanists at the same time, and each being eager to describe what he considers new, and not, in some instances, having studied the special families, nevertheless does not hesitate to describe new species, or to found new genera. This being done without inter-communication, different names are given to the same plants; when these are collated by the systematist, it often becomes difficult to decide which to adopt, thus burdening the science with synonyms.

Under this state of things few Ferns have now less than three names, many have twenty, thus rendering it in many cases impossible to reconcile one author's views with another's. For instance, the Fern known by the name of Ceratopteris thalictroides has been described by no less than twelve authors under as many different generic and specific names.

But the point upon which pteridologists appear to differ most, and upon which their only agreement seems to be an agreement to differ, is the definition of genera and their limits. I say emphatically appear to differ, for in the works of those most at issue the differences are not so much in the limits of the groups themselves as in the 
relative importance assigned to them. For example, while some, as Presl, Fée, Moore, and myself, break up the old Linnean genera, Polypodium, Aspidium, \&c., into a greater or lesser number of smaller genera, upon characters derived from differences in their anatomical structure and modes of growth ; others, as Hooker and Mettenius, prefer adhering to the Linnean genera, without greatly altering their characters, and adopting the modern generic names as sectional ones for such divisions as they find themselves compelled to make.

On reviewing what I have now stated it may naturally be asked, What is a species or genus? or, by what law of nature can this be determined? As generally understood by naturalists, a species is an organised structure specially created and endowed with an essence or quality peculiar to itself, possessing the power of increase and transmitting its primitive essence and anatomical structure and form without change, to its progeny for successive generations. But the difficulty of defining species becomes evident on taking a general view of the numerous forms which connect one with another. It will then be found beyond human power to ascertain whether the several gradations of allied forms are descendants of primitive specific creations, or are, according to the Darwinian theory of the " origin of species," only deviations from a few primordial creations, endowed with a protean principle which becomes manifest during the lapse of ages, and controlled by the different climatic and local influences under which the progeny of the original have become established, and which now form the flora of the earth. If the latter is admitted to be the case, and $w \theta$ are led to believe that intermediate forms originate during the slow progress of time, then all must be uncertainty, and the number of 
species will vary according to the evidence possessed by different authors, and the views they take of the apparent transition forms.

In verification of what is stated above respecting species, I quote the words of an eminent botanist, that "the preliminary exact determination of what is a species no one has yet succeeded in giving." It is well known that phænogamous plants assume different forms and aspects brought about by natural causes or the agency of man; the difference from the original types being often so great, that if evidence of the change were not on record, the botanist of the present day would be justified in describing them as distinct species, and originally created as such. With Ferns, we possess but little evidence of new forms having come into existence in modern times, the chief examples being found in several intermediate states in the genera Gymnogramme and Pteris, which of late years have made their appearance in gardens, some being so different from their supposed parents that, if they had been found wild they would by some botanists be considered sufficiently distinct to rank as species. If such changes do actually take place, and we are to deduce from them that races of intermediate forms originate in the progress of time, and through the causes above alluded to, great difficulty must attend any attempt to define species of Ferns.

These observations show the principal conflicting causes that have led to the confusion in the nomenclature of Ferns.

This may be considered a sufficient history. of species. I will now treat of genera and their classification; but to make the subject well understood, I deem it best to give first a general exposition of the structure of the different parts of Ferns, on which genera are founded and classified. 


\section{2.-ORGANOGRAPHY.}

DEFINITIONS OF THE PARTS OF FERNS ON WHICH GENERA ARE FOUNDED AND CLASSIFIED.

Filices or Ferns are flowerless plants, and form the highest order of the division of the Vegetable Kingdom termed Cryptogamia, which includes all plants having their organs of reproduction invisible to the naked eye. They have no true leaves, but produce leaf-like expansions, called fronds, which not only perform the functions of leaves, but also bear the organs of reproduction. The fronds are successively developed from the apex or sides of an accrescent stem (caudex), and before expansion are spirally coiled inwards (circinate). They are traversed by veins in various ways, and produce on their under surface, or on special appendages, round linear, or irregular masses of one-celled (sporangia) or many celled (synangia) cases, which contain numerous microscopic germs, called spores (seed). The masses of spare cases are called sori. They are either furnished with a special covering of various forms, called the indusium (indusiate), or they are naked (non-indusiate).

\section{VERNATION (sTEMs).}

The manner in which the fronds are developed from their axis is termed vernation, and their union with the axis is either adherent or articulate. Adherent vernation presents two forms. First-Fasciculate when the fronds are produced in a continuous spiral whorl from the apex of the axis with which their bases are adherent, and thus by their 
successive development form a stem (caudex), which is either erect or more or less decumbent. The caudex varies in size, according to the normal nature of the species. It is often very short, even consisting of a bud only, scarcely rising above the surface of the ground-such is termed acaulose-or it forms a low stem a foot or more in height (arboroid), or it assumes the height of a tree (arborescent). Second-Uniserial. This consists of a creeping rooting stem, termed sarmentum, which progresses by the successive evolution of single fronds from its apex, each succeeding frond being produced from the base of the preceding one, at more or less distance in advance. It either continues simple or branches, and varies in thickness from that of a thread to an inch or more in diameter, and is either epigeous, hypogeous, or epiphytal.

Articulate vernation also presents two forms. FirstFasciculate. This is peculiar to a few Tree Ferns and the order Marattiaceo, in which the fronds when mature fall away, leaving marks of rhomboid scars on the stem.* Second - Solitary. This consists of a creeping stem, termed surculum, emitting roots from its under surface, by which it adheres to the earth or other bodies, but generally trees (epiphytal), rarely hypogeous. It varies in size from short and thick to long and slender, and when young is densely covered with scales (squamoe). It is either simple or branching, and is distinguished from the sarmentum by its apex being always in advance of the forthcoming fronds. These are produced singly from special nodes on its sides, with which the base of the frond (stipes) is articulate, and there separate on becoming mature, leaving the mark of a round, slightly concave scar or cicatrix. 


\section{FRONDS.}

The fronds before expansion are involutely coiled, in the manner of a watch spring, and gradually uncoil during the period of growth, and with a few exceptions have all their parts formed before they begin to unfold (definite), all of which increase in size with the progress of the frond. Fronds present extreme variation in size and form, varying from less than an inch to 15 or 20 feet in length, and in form, from entire, like a blade of grass or ribbon to being compoundly divided. In describing them, the same terms are used as are applied to the leaves of flowering plants, that is, they are simple, entire, linear lanceolate, ovate, elliptical or sub-rotund, or they are pedate or palmately lobed, pinnatifid, or they are pinnate, bi-tripinnate, or more highly divided, and then termed compound multifid. They also vary considerably in texture, some being thin, pellucid, membranous, and flaccid ; while others are thick, fleshy, or hard and rigid.

In pinnate, bi-and-tripinnate fronds, the divisions (segments) of the first are called pinnæ and the second pinnules, each of which individually represents a simple frond. The margins of simple fronds, and of pinnæ and pinnules, are either entire or variously dentate or sinuose repand, regularly pinnatifid or otherwise divided, the divisions being called lobes or lacince. The general form of fronds, whether simple or in any way divided, is linear lanceolate, or oblong elliptical, or deltoid ; in deltoid compound fronds, the primary pinnæ assume the character of branches, the ultimate divisions of which are often divided into small lacinæ or dents, such being termed multifid. The axis of attachment of the pinnæ and pinnules is 
termed the rachis, the primary rachis being a continuation of the foot-stalk (stipes); its first branches the secondary rachis, that is the rachis of pinnules. The pinnæ and pinnules are as a rule alternate, but are also often opposite or nearly so, and they are either sessile or petiolate, and are either adhering and continuous with the rachis, or articulate with it, readily separating at the joint when mature, or earlier by dryness. In such the rachis remains long permanent, and even in some species of Nephrolepis the apex continues to grow, producing pinnæ. Their leafy part either tapers down to their base, such being termed sessile, or borne on a cylindrical or semi-cylindrical footstalk, but which is not special, being an integral part of the frond.

They either grow erect or verge in various angles from the axis of development, some being nearly horizontal or bent downwards, their apex in such cases being generally viviparous.

Fronds before evolntion are densely covered with scales, termed ramentce, or articulate hairs, these in most cases are early deciduous, except at the base of the fronds. In Pleopeltis, Lepecystis, and Ceterach, and some others, they are permanent, and specially characteristic. In some the under side is densely covered with silvery or goldencoloured farina ; others are furnished with various hairs or glands, which are generally viscid. Fronds are in most Ferns of two forms, sterile and fertile, but in the great majority the latter do not differ much from the former, though they are in general narrower in all their parts. In several tribes they are normally of two distinct forms (dimorphous), the sterile presenting the ordinary leafy character, the fertile being specially contracted and thickened. In some the contracted segments are very narrow 
(rachiform), in others they are involute, in the form of a pod or siliqua (siliquiform); in others plain, the under surface being densely occupied with sporangia; in some, the lower portion of the frond is sterile, while the upper portion is contracted and fertile.

The duration of fronds is variable, some remaining permanent for several years, but the greater majority, especially those in temperate and cold climates, develope and come to maturity in one year.

It is, however, otherwise with the genera Gleichenia, Iygodium, and Salpichlcena; in the first the fronds are dichotomous; and from the axis of the forks are successively produced other dichotomous branches, and the fronds thus continue long permanent.

As regards Lygodium, the fronds so called continue to lengthen and branch (indefinite), rambling over bushes or climbing the tops of lofty trees; such is also the case with the blechnoid Fern Salpichloena. The permanent nature of these climbing fronds (?) may be considered analogous to climbing flowering plants, such as Clematis; to these peculiar growing Ferns I apply the term Pterampelids.

\section{VENATION.}

The vascular structure of Ferns consists of cords of indurated tissue termed scalariform, which branches from the base of the previous frond into the nascent bud of the forthcoming frond, and lengthen upwards with the growth of the frond. It consists of one, two, or more cylindrical, flat, or channeled cords, which, on reaching the leafy part of the frond, divide and ramify through all its parts, the ultimate ramifications ending in the leafy part (lamina), being 
called veins; these veins, which either radiate from the base of some fronds as also from segments, in a flabellate manner; but are more generally produced from a midrib (costa), which in simple fronds is a continuation of the vascular cords of the stipes; and in segments of fronds, a branch of the rachis from which they are produced.

The costa is generally central, or in some excentric, or even quite on one side of the segment (unilateral); it generally terminates at or near the apex of the frond or segment, or it becomes undefined before reaching the apex, or is very short, rudimentary, or absent. It is generally elevated in the form of a ridge on one or both sides of the lamina, or it is in the form of a channel on the upper side, or it is imbedded in the substance of the frond, and then often obscure.

From the sides of the costa veins are produced at a more or less distance from each other, and generally equal or nearly so, on both its sides; they form a more or less acute, oblique, or nearly a right (patent) angle with the costa, and when free always directed outwards towards the margin or apex of the frond or segment. They are either straight, curved or flexuose, and are either simple or branch in various ways, the first are termed primary veins, their branches venules, and the branches of these veinlets, each being a diminutive of the preceding. In many cases the primary vein that rises direct from the midrib is very short, and branches sometimes close to the midrib, or even within the substance of the midrib, as in Neottopteris australiaca; in others they terminate at or near the margin, and when parallel to one another and very evident are termed costceform, and the diminutive costulce is applied to the primary veins of laceanæ.

Veins are termed free when all the branches of each 
fascicle terminate before reaching, or at the margin, their apices being free and unconnected; and anastomosing when the apices of the branches of each proximate fascicle unite with one another, which they do in various ways, forming regular, square, rhomboid, hexagonal, or unequal sided meshes (areoles). When the primary veins are not evident, and all the anastomoses of about equal size, it is termed reticulate venation.

Both free and anastomosing veins are spoken of as follows :-Simple, when each vein proceeds from the costæ to the margin without branching. Forked, when they divide at an acute angle into two or more branches, after leaving the costæ. Pinnately forked, when the primary veins are scarcely defined, the venules dichotomously branching. Pinnate, when the primary veins that run from the costæ to the margin are distinctly defined, and produce venules in regular order on both sides, forming a more or less acute or oblique angle with their axis.

The simplest form of anastomosing venation is when the apices of simple or forked veins are combined or connected by means of a vein close to and continuous with the margin, as in the genera Olfersia and Neottopteris. Pinnate and pinnately-forked veins anastomose by the uniting of the apices of the venules of the proximate fascicles, which they do at various angles, from acute to nearly a right angle, or even arcuate as in Meniscium, or straight as in Blechnum.

In most of these cases, the connected venules produce from the apex of their angular junction, or from their exterior sides, one or more outward directed veinlets (excurrent), which are either free or unite with the next exterior anas. tomose, thus forming in the latter case two or more rows of areoles between the primary veins. When anastomose venules form a right or nearly a right angle with the 
primary veins, they thus become parallel with the costr, and are then called transverse. In many cases the venules produce veinlets in an irregular manner, which either anastomose, or terminate within the areoles. When directed outwards they are termed excurrent, and recurrent when directed inwards; this is termed compound anastomose venation. In many cases, both in free and anastomose venation, the apices of the venules and veinlets is thickened (clavate) in the form of a gland.

\section{RECEPTACLES.}

The receptacles are the sites upon which the sporangia are seated, and are generally thickened points, or lengthened portion of some part of the venation. In position they are called terminal when on the apex of the veins or their branches; lateral when on the sides of the veins; axillary when on the forking; compital when on the angular crossing or points of confluence of two or more venules or veinlets. They are superficial or immersed in the substance of the frond, or elevated above its surface, and then columnar or globose. When in the form of a point or dot they are termed punctiform, and, when lengthened, elongated or linear; and amorphous when of no defined form (as in Acrostichum).

\section{SPORANGIA.}

The spore cases or sporangia are the organs which contain the reproductive spores, and are borne in masses upon the receptacles. They are thin and transparent, or horny 
and opaque. In form they are globose, oval or pyriform, pedicellate or sessile, and are either furnished with a more or less complete articulated elastic ring (annulate), or destitute of a ring (exannulate). This ring is said to be vertical when it passes over the apex of the sporangia, being a continuation of the pedicel; horizontal when it passes horizontally round the sporangium, either at or about its middle, or at the apex (apical); oblique when it passes round the sporangium in some direction intermediate between vertical and horizontal.

When the sporangia arrive at maturity, and are under certain conditions as to dryness, the elasticity of the ring causes them to burst open, and the spores are ejected. The opening takes place at or very near to a right angle with the direction of the ring-that is, those having a vertical ring burst horizontally, and those with a horizontal ring, by a vertical slit.

Exannulate spore cases are in texture coriaceous becoming horny. They are either free, or counate and called synangia, which are formed of a greater or lesser number of exannulate sporangia, laterally united, forming a series of cells, disposed in a circle or in two rows, side by side, which either remain united as in Danoce, or separate longitudinally in two valve-like lobes, as in Marattia. The cells open by slits or pores.

N.B.-About thirty species which constitute the order Marattiaceo have exannulate sporangia.

\section{SORI.}

The sori are masses of sporangia produced on the receptacle. Their form and position correspond with, and are 
dependent upon the form of the receptacles, which are their foundations. Thus, when the receptacles consist of a point only, the sori are always round, termed punctiform while linear receptacles bear sori of various forms, being oblong, elliptical, or linear, either simple, straight, or arcuate, forked or reticulated.

The sporangia of each sorus are generally crowded, or, in some cases, few, being side by side on the receptacle, as in Ceratopteris and Gleichenia. They are either seated on the margin (marginal) or near or close to the costa (costal), or on or about the middle of the disc (medial). When a little within the margin they are termed ante-marginal. In some they are in pedicellate dents, exserted on the margin. They are irregularly scattered over the surface or solitary in multifid laciniæ, or in regular rows, or continuous lines (serial). When the lines diverge at an angle from the mid-rib they are said to be oblique, and when parallel with either the margin or the costa, transverse.

For their position on the veins the same terms are used as those given for the receptacle.

As a general rule, each sorus is distinct and well defined, but in many cases the receptacles are so very close together that the sporangium of one sorus runs into that of the contiguous one (confluent), and thus normally punctiform sori become oblong or linear. In the tribe Acrostichece, in which the fertile fronds are contracted, the sori have no definite form, the sporangia occupying the whole of the under surface or in patches. They are borne on one side of contracted spikes, or on simple or compound racemes, as in Schizcea, Lygodium, Anemia, and Osmunda. 


\section{INDUSIUM.}

The sori are either naked or furnished with a special covering called the indusium, or involucrum by some, which presents many well marked different forms, and is highly important for distinguishing genera; it consists of three kinds-special, accessory, and universal. True or special indusia are more or less membranous, or thick and firm in texture, and rise from the receptacles to which they are attached in different ways. Some rise in the form of an orbicular disc, covering the sorus in the form of a shield (peltate); more frequently they are attached on the interior or exterior side of the receptacle; such are termed lateral, which open like a lid (operculiform) when attached on the side next the costa, interior, and when on the side next or on the margin exterior.

Lateral indusia partake of the form of the sori, being round, oblong, or linear; in punctiform sori they are attached by a point, or more or less by the base or sides, and are of various forms, being reniform, subrotund, oval, or oblong, sometimes very small (squamiform). Their surface is flat, vaulted, or when attached by their sides cucculate, their free margin being entire or variously lacinated or fringed.

Besides these two modes of attachment there is a third kind, in which the indusium is attached all round the receptacle-it is at first globose, and includes the sporangia, but ultimately their apex opens and widens, thus assuming the form of a cup (calyciform), the margin being more or less entire or deeply laciniated, even to be like a fringe; sometimes the attachment is only half round the receptacle (semicalyciform). 
Accessory indusia are formed of the entire margin of the frond, or a portion of it being changed in texture and form and inflexed, its margin conniving with the free margin of the interiorly attached special indusium, the two thus combined forming a continuous or interrupted groove, opening exteriorly. When the special indusium is produced on a punctiform receptacle, an urceolate, bitabiate, or tubular cyst is formed, which contains the sporangia, some being exerted beyond the margin (pedicellate); while in some cases the cyst is antemarginal, and is then termed cucullate, in all these cases opening exteriorly, but often more or less turned inwards, and then having the appearance of being on the under side of the margin.

Universal indusia occurs when the segments of the fertile fronds are contracted. They consist of the margins of the segments being more or less changed in texture, becoming membranous, and folded inwards (involute*), the two opposite margins generally meeting, and thus enclosing all the sori upon the segment, whatever may be their form or position upon the veins, the segments thus assuming the form of a pod or siliqua (siliquiform) as in Struthiopteris ; or of a berry (bacciform) as in Onoclea.

In some Polypodece the sori are furnished with scales of various forms; in Pleopeltis they consist of numerous orbicular peltate scales, imbricate over one another, and covering the sporangia of each sori ; in Hymenolepis they are very thin and membranous ; in Lopholepis they consist of numerous slender scales, longer than the sporangia ; in Schellolepis they are irregularly laciniated; club like and other forms are also common to the genera Vittaria and Toenitis. Such bodies are considered to be imperfect

* That is, the margins turned or rolled inwards, so as to face and meet one another on the under side of the frond or segment. 
sporangia, to which the term paraphysis is given. In Amphidesmium, Lophosoria, Trichopteris, and several species of Alsophila, numerous simple or articulate hairs are mixed with the sporangia, which impart to the sori a woolly or hirsute appearance.

The above is a general view of the form and position of the different organisation of Ferns, and furnishes data for the definition of genera and their arrangement; but as in many instances of botanical definitions, there are always exceptions to normal forms and position of parts, even to the sori being produced on the under side of the frond, as in Polystichum anomalum, a native of Ceylon; in some of its fronds the sori are as abundantly produced on the upper side as on the under, and bear the characteristic peltate indusium. The same also occurs in Trichiocarpe Moorei, a native of New Caledonia. Such seems to be the normal state of these two species even in native specimens, as also in plants cultivated in Kew.

3. ON THE GENERA OF EARLY AUTHORS AND THEIR SYSTEMS OF CLASSIFICATION.

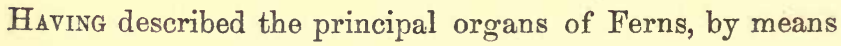
of which genera are defined and classified, I now proceed to give a brief review of the progress of Pteridology from the time of Linnæus to the present, noting the works of the principal systematic authors who have from time to time collated and characterised the genera and species of Ferns at their respective periods.

It appears that only about one hundred and ninety species were known to Linnæus. These he classified under eleven genera-viz. : Osmunda, Onoclea, Acrostichum, 
Hemionitis, Polypodium, Asplenium, Pteris, Blechnum, Lonchites, and Trichomanes. The data upon which they were founded were derived, as in flowering plants, from the different modifications and position observed in their socalled organs of fructification. The chief difference consisted in the fructification-spore cases or sporangia-being produced either in defined round masses, or in lines, or densely crowded together on the under side of the frond, or in simple spikes or panicles formed by the whole or a portion only of the fertile frond being contracted. Thus, according to Linnæus' characters, all Ferns having their fructification in simple or racemose spikes belong to Osmunda and Onoclea; in crowded masses to Acrostichum; in round masses or spots to Polypodium; in lines across one another to Hemionitis; in lines diverging from the mid-rib to Asplenium; in a line on each side of the mid-rib to Blechrom; in a line or dots on the margin to Pteris and Adiantum; in a sinus on the margin to Lonchites; and inserted on the margin to Trichomanes.

These Linnean genera are each composed of a greater or lesser number of species, each of which is presumed to agree in the form and position of the fructification with the respective generic characters as above stated. But the more careful examination by later observers of the same generic forms has revealed additional variations, which will come under notice as we proceed. It is worthy of remark, however, that the whole of the species of Ferns now known are capable of being referred to Linnean genera; but if such were done, species possessing very different appearances as regards habit and mode of growth would be brought together, and the genera would be of unwieldly dimensions.

The first author of importance after Linnæus was Dr. 
J. E. Smith,* who, after the death of the younger Linnæus, became by purchase the owner of the Linnean Herbariam. He published many botanical memoirs, and one on Ferns in 1793, in the fifth volume of the "Memoirs of the Academia of Turin," in which he characterised thirteen new genera-viz.: Darea, Scolopendrium, Woudwardia, Lindscea (Dryander, MS.), Vittaria, Davallia, Dicksonia (L'Heritier, 1788), Cyathea, Hymenophyllum, Schizcea, Gleichenia, Marattia, and Dancea. These, with the Linnean genera, raised the number to twenty-four, which he divides under two sections-viz., Annulatce and Exannulatse. The technical difference between these consists in the spore cases being furnished with a ring, or destitute of a ring. This mode of arrangement has since been adopted by all systematic writers on Ferns, as defining two distinct orders which will come under special notice hereafter.

The next general systematic work was the "Synopsis Filicum" of Dr. Swartz, published in 1806. In that excellent work nearly 700 species are described, and a great many doubtful species enumerated. The described species are classified under thirty-six genera, being an increase of twenty-five since those of Linnæus. Eleven of them are founded on species removed from Linnean genera, their separation being due to a special organ which I have already described under the name of indusium, by some called involucrum. Although this organ was noticed by Adanson and Necker, yet it was not employed by Linnæus in characterising his genera. It was first specially made use of by Sir J. E. Smith, in characterising his new genera, and also about the same time by the German botanist Roth, and was adopted by Swartz in the abovenamed work, in which he arranges twenty-five of the

$$
\text { * Afterwards Sir James Edward Smith. }
$$


genera under two divisions. The first, which he terms "Nudis," consists of six genera, characterised by the sori being naked, that is destitute of indusium, by some termed gymnosorus; this division contains 167 species. The other genera being furnished with an indusium he terms "Indusiates," which comprehends 467 species. These two divisions embrace all Ferns which have their sporangia furnished with a vertical ring; as also the genera Hymenophyllum and Trichomanes, in which the ring is horizontal.

The next systematic arrangement of Ferns appeared in 1810 , in the fifth volume of the "Species Plantarum" of Willdenow, wherein 1,010 species of circinate Ferns are described, comprehended under forty-one genera, being an addition of five new genera since Swartz. Three of these new genera are founded on species retained by Swartz in Linnean genera, the other two (Polybotrya and Pleopeltis), are each founded on a single species, for which the authority of Humboldt and Bonpland is given. As the characters upon which Willdenow founded his genera do not bring forward any striking new feature of structure, beyond certain modifications in the nature of the indusia and contraction of the fertile frond, I do not deem it necessary to speak further of them in this place. The first pictorial work at that period was the "Kryptogamische Gewächse" (plants), by Professor Schkuhr, of Wurtemburg, published in 1809 ; it is a quarto volume containing 196 finely executed coloured plates representing 263 species of circinate Ferns, and accompanied by 212 pages of descriptive text. The importance of this work is manifested by the fact that all succeeding pteridologists quote the figures as evidence in the identification of species.

The above were followed by special works and miscellaneous writings in journals on Ferns, the principal writers 
being Bernhardi, Robert Brown, Bory, Desvaux, Kaulfuss, Gaudichaud, Raddi, Martius, Presl, Don, and others*. In these works a number of new genera are characterised, but it is not necessary to enter into further details regarding them here, more especially as the principal of them are given hereafter, either as accepted genera or as synonyms.

These authors were followed by C. Sprengel, who, in the fourth volume of his "Systema Vegetabilium," published in 1827 , brought together and arranged in systematic order the whole of the species of Ferns known to him. Although this work cannot be looked upon otherwise than as a hasty compilation, and is of little value as a work of reference, yet it has the merit of bringing into a brief compass a descriptive enumeration of all the Ferns known at that period, collated from previously published works; the total number of his circinate Ferns being 1,309, which he arranges under fifty genera. This shows that a considerable increase of species had taken place since the time of Willdenow, and a glance at the author's names above mentioned proves that the study of Ferns had not been neglected.

The discoveries of Blume and Reinwardt in Java, led to the publication in 1830 of Blume's enumeration of the Ferns of that and other of the Malayan Islands, in which 460 species are described. Of these 300 were new, the whole being arranged under fifty genera, six of which were previously unknown.

This was followed by the splendid folio work, Blume's "Flora of Java," which contains finely-coloured plates of Ferns ; and in the letter press he gives many new ideas respecting genera. At this period Link and Kunze published several treatises on Ferns, the first an enumera-

* See list of authors and books. 
tion and description of Ferns in the Berlin Gardens, entitled "Hortus Berlinensis;" the second a work entitled "Analectæ Botanicæ;" as also a continuation of Schkuhr's "Filices." He also published many articles on Ferns in the "Linnæa," in which many new species are described.

In 1839 Professor Agardh, a Swedish botanist, published a memoir on the genus Pteris, of which ninety-four species are described.

\section{4.- ON THE GENERA OF MODERN AUTHORS, AND REVIEW OF THEIR SYSTEMS OF CLASSIFICATION.}

It would occupy too much space to enter into a review of the many works and the different views entertained by many of the above authors regarding the characters of genera, especially as all matters of importance relating to genera will be found noticed in their respective places.

The chief characters adopted by many of the preceding authors for defining genera consist in differences in the form and arrangement of the sori, and in the different forms of the indusium when present, and even some on the texture and pubescens, and in the contraction of the fertile fronds.

By the conjoint labour of authors the number of genera have been considerably increased since the time of Swartz, making the total number up to the time of Sprengel sixty-five, several of which may be viewed as natural genera. Eight are founded each on a single species, six contain two to four each; while the old Linnean genera Polypodium, Pteris, and Asplenium, and the Aspidium of Swartz collectively contain 648 species, being nearly one half of the whole number enumerated by Sprengel. Although this great number of species agree in the technical characters of their respective genera, as founded on 
their fructification, yet a great many differ so widely in general habit and mode of growth, that any systematic arrangement, founded on genera so constituted, must be received as purely artificial, and only admissible on the principle of its bringing together under a few brief characters a number of species possessing such characters in common. This being the case, modern Pteridologists have found it necessary to seek for other characters in order to classify the various groups in accordance with their natural relationship to one another, as exhibited by their general appearance in habit and mode of growth. This became the more necessary on account of the great increase in the number of species from time to time brought into notice by botanical collectors as previously explained. Robert Brown was the first to point out and use an additional character for defining genera. In 1810, in characterising the genera Cyathea, Hemitelia, and Alsophila, he took into account the difference of the position of the sori on the veins, and this he again brought into special notice in the character of his genera Matonia and Hypoderris, first described in Wallich's "Plantæ Asiaticæ Rariores." In Horsfield's "Plantæ Javanicæ Rariores," published in 1838, he enters more fully upon the importance of employing venation as affording auxiliary generic data. He there sketches out a method for dividing the large genus Polypodium into groups of species naturally allied in general habit, on characters derived from the structure of the venation and position of the sori on the veins.

About this period several botanists on the Continent directed their attention to the study of the venation of Ferns. The first worthy of notice is Ferdinand Schott, Director of the Imperial Gardens at Vienna, who, in 1834, commenced a work entitled "Genera Filicum." This 
work consists of quarto plates, each plate illustrating a genus by figures, showing a portion of the fronds natural size and also magnified, in which the anatomical structure (venation) and the form and position of the sori and other parts of the fructification are distinctly shown, each plate being accompanied with descriptive letterpress. At the time of the author's death, only forty plates of this practical and useful work were published.

With the works of Schott and Brown commenced a new era in the history of Pteridology. It is, however, to Professor Presl, of Prague, that the credit is due of being the first to publish a general systematic arrangement of genera founded on venation, which appeared in 1836 in his celebrated work entitled "Tentamen Pteridographeæ." In that work about 1,500 species of annulate Ferns are enumerated (exclusive of the tribes Hymenophyllece and Osmundece), which he classifies under 115 genera arranged ander two sub-orders, technically distinguished by the difference in the direction of the ring that surrounds the sporangium. The first he terms Helicogyratce, which is characterised by the ring being horizontal or more or less oblique with its point of attachment, it contains two tribes, viz. :-Gleicheniaceee and Cyatheaceoe, the first of which has five genera and twenty-three species; the second eight genera and twenty-four species. The second sub-order is termed Cathetogyratce, and contains all Ferns in which the ring of the sporangia is vertical.

The following is an abridgment of Presl's arrangement :-

Order I.-FILICES. Presl.

Sub-Order I.-Helicogrrate, Bernh. Ring horizontal or oblique. 
Tribe I.-Gleichentaceae.

(Ex. Platyloma, Br., and Gleichenia, Sm.)

Tribe II.-Cyatheaceae.

(Ex. Cyathea, Sm., Hemitelia, $B r$., Alsophila, $B r$.)

Sub-Order II.-Cathetograatae. Bernh. Ring vertical.

Cohors I.-Hymenophorem, $\mathrm{Pr}$. (indusiate genera.)

Tribe I.-Paranemaceae, $P r$.

(Ex. Paranema, Don., Thyrsopteris, Kze, Cibotium, Kaulf.)

Tribe II.-Aspidiaceae, $B r$.

Sect. 1. Nephrodiariae, Br. (Ex. Lastrea, Pr., Oleandra, Cav., Nephrolepis, Schott.)

"2. Aspidiariae, Br. (Ex. Polystichum, Schott, Aspidium, Schott, Didymochlaena, Desv.)

Tribe III.-Asplentaceae, $P r$.

Sect. 1. Cystopterideae, $\operatorname{Pr}$. (Ex. Cystopteris, Bernh., Leucostegia, Pr., Onoclea, Linn.)

"2. Blechnaceae, Pr. (Ex. Athyrium, Roth., Woodwardia, Sm., Blechnum, Linn.)

"3. Aspleniariae, Pr. (Ex. Asplenium, Linn., Hemidictyum, $P r$.)

„4. Diplazieae, $\operatorname{Pr}$. (Ex. Diplazium, Sm., Oxygonium, $P r$.)

„5. Scolopendrieae, Pr. (Ex. Scolopendrium, Sm., Antigramma, $P r$.)

Tribe IV.-Davalutaceae, Gaud.

Sect. 1. Davallieae, Pr. (Ex. Microlepa, Pr., Saccoloma, Kaulf., Davallia, Sm.)

„2. Lindsaeaceae, Pr. (Ex. Lindsæa, Dryand., Schizoloma, Gaud.)

Tribe V.-Dicksoniaceae, Pr.

(Ex. Balantium, Kaulf, Dicksonia, Pr., Culcita, Pr.) 
Tribe VI.-Adiantiaceae, $P r$.

Sect. 1. Adiantariae, Pr. (Ex. Haplopteris, Pr., Pteris, L., Adiantum, Linn.)

"2. Lonchitideae, Pr. (Ex. Hypolepis, Berrh., Lonchitis, $L$.)

Cohors II. Grunnsones, $\operatorname{Pr}$. (non indusiate).

Tribe VII.-Virtariaceae, $P r$.

(Ex. Vittaria, Sm., Prosaptia, Pr.)

Tribe VIII.-Polypodiacrae, $P r$.

Sect. 1. Struthiopterideae, Pr. (Ex. Struthiopteris, Willa.)

" 2. Polypodieæ, Pr. (Ex. Polypodium, Pr., Goniopteris, Pr., Phymatodes, Pr.)

, 3. Lecanopterideae, $P r$. (Lecanopteris, Bl., Calymmodon, $P r$.

\section{Tribe IX.-Grammitaceae, $P r$.}

Sect. 1. Grammitideae. (Ex. Monogramma, Schkr., Meniscium, Schrad., Selliguea, Bory.)

„2. Hemionitideae, Pr. (Ex. Heminoites, Linn., Gymnogramma, Desv.)

$$
\text { Tribe X.-T }
$$

(Ex. Pleurogramma, Pr., Notholæna, Br., Tænitis, Sw.)

$$
\text { Tribe XI.-Acrostichaceae, Pr. }
$$

(Ex. Polybotrya, H. B. K., Platycerium, Desv., Acrostichum, $\operatorname{Lin} n$.)

In 1845, Presl published a supplement to the above work, entitled, "Supplementum Tentamenum Pteridographiæ." It consists of 119 quarto pages (without plates) ; it embraces the tribes Marattiaceae, Osmundaceae, Schizaeaceae, and Lygodiaceae. Of the first he makes two sectionsMarattiaceae and Danaeaceae-of which he describes fortynine species, arranged under ten genera, five of which are 
now being constituted of species separated from the wellknown genera Marattia, Angiopteris, Danoea, the technical characters of which are, however, so slight that I do not consider them worthy of adoption.

Of Osmundaceae he describes twenty-four species, two of which he characterises as a new genus under the name of Leptopteris, but which I consider not worthy of being separated from Todea of Willdenow.

Of Schizaeaceae he enumerates sixty-five species, arranged under eight genera, three of which are new-Lophidium, consisting of five species separated from Schizoca, and the two others upon a single species each, founded upon doubtful and even mistaken data, one of them (Spathopteris) having no other authority than a figure of Plumier's "Filices," which, in my "Genera Filicum," published in 1841, I show to consist of a barren and fertile frond of two distinct Ferns.

With regard to Lygodiaceae he describes forty-one species, thirty-nine of which belong to the genus Lygodium of Swartz, and two to Hydroglossum of Willdenow. The number of species of the three latter genera are also in excess, Anemia alone having thirty-eight.

In 1848, Dr. Presl published another work, entitled "Hymenophyllaceæ," in which he describes 185 species, which had hitherto been comprehended under the wellknown genera Trichomanes and Hymenophyllum, but of which Presl makes no less than nineteen genera; and in his "Epimelia Botanica" he characterises three more, making twenty-two in all, about one-third of which are founded upon a single species each. The data upon which these genera are founded is derived chiefly from the size and form of the cellular parenchyma, and the slight modifications observable in the form of the indusium and 
sporangiferous receptacle, differences which, with two or three exceptions, appear to me to be more useful as specific than as generic characters; indeed, in some cases they are so trifling that I have failed to find them. Under these circumstances $I$ cannot see that any practical advantage will be gained by dividing Hymenophyllaceee into so many genera as Presl has done.

Hymenophyllacece also form the subject of a special monograph, published in 1858 by Dr. Van den Bosch, of Goes, Holland. It consists of seventy-nine pages octavo, and is entitled "Synopsis Hymenophyllacearum, Monographiæ hujus ordinis Prodromus." It contains simply an enumeration of names of genera and species with references to authors. He enumerates no less than 305 species, being 120 above that of Presl, and 156 above that enumerated by Sir William Hooker in the "Synopsis Filicum," hereafter to be noticed. The whole are arranged under nine genera, of which Hymenophyllum and Trichomanes alone contain 254 species. The remaining fifty-one are divided amongst seven genera, two of which contain a single species each. He does not characterise any new genera, and only adopts five of Presl's. But his number of species is so much in excess of that of other authors that, if he really had specimens of the whole in his herbarium he must have described his species on the different forms of fronds and other variable structure, which are always to be found in an extensive series of herbarium specimens, many such when carefully collated represent a single species only.

In 1849, Presl published another work, entitled "Epimelia Botanica," or additions to and emendations of his "Tentamen Pteridographeæ." In this work he characterised no less than thirty-five new genera, and described a consider- 
able number of new species, many of which appear to be founded on very imperfect, and not well-authenticated materials. A few of his new genera are admissible and will be noticed in their respective places; the greater number, however, are untenable; for instance, he describes about fifty species of the genus Blechnum, of authors, which he arranges under five genera, namely, Blechnum, Parablechnum, Distaxia, Mesothema, and Blechnopsis; the differential character of these genera is, however, so slight that I do not consider them worthy of adoption (see Blechnum).

Another instance of creating genera on what may be called fancied differences, is the genus Niphobolus of Kaulfuss, of which Presl enumerates thirty-nine species arranged under eight genera. On examining numerous sets of herbarium specimens said to be species of this genus, I find the intermediate forms are so numerous that it is impossible to collate them, so as to arrive at any satisfactory conclusion as to what number of them are distinct species, for with all the evidence that has come before me, I have not been able to define more than about a third of the species recorded by Presl, all of which I continue to retain under Niphobolus.

Many other of Presl's genera have as little title to rank as such as those of Blechnum and Niphobolus, and I deem it best not even to notice them as synonyms, as it would only add to the already overburdened Fern nomenclature.

In the preface to this book it is shown that it is now more than fifty years since the writer commenced to study the collection of Ferns in the Royal Botanic Garden at $\mathrm{Kew}$, then amounting to about forty exotic species; and, having had the opportunity of profiting by the verbal observations of Robert Brown, who often directed my attention to the mode of the arrangement of the veins in different species of the genus Polypodium, as forming 
auxilliary characters in the grouping of species, which with his published observations above noticed, I, in time, considered myself competent to publish my views. This I did in a treatise entitled "On Arrangement and Definitions of the Genera of Ferns," which was read before the Linnean Society in 1840, and afterwards published in Hooker's "Journal of Botany," in the volumes for 1841 and 1842, occupying 131 pages, and accompanied by a plate showing the principal forms of venation. In this I characterised 143 genera, accompanied by examples of a few of the most typical species of each genus, and with observations on the natural affinities of the genera. Just as my treatise was completed, but before its publication, I received Presl's great work "Tentamen Pteridographeæ," and it was gratifying to me to find that my views in general coincided with those of that celebrated Pteridologist. I, however, differed from him in some important particulars, chiefly with regard to the relationship of the genera to one another, consequent on the data on which Presl founded his tribes, placing naturally allied species far apart. My endeavour was to associate the species possessing the same general features in respect to their modes of growth (habit), so as to form natural sequences of genera. This I have endearoured to complete by drawing up a general arrangement, which forms the second part of this volume.

The following is an abstract of my arrangement in 1841 :-

Division I--POLYPODIACE $Æ, ~ R . ~ B r$.

Sporangia furnished with a vertical ring.

Tribe I.-Polispodiex, J. Sm.

Sori punctiform, oblong or linear, naked or included nnder the universal indusium.

Sect. 1. Orthophlebiese, J. Sm. Veins free. 
$E x$. Grammitis, $S w$., Polypodium, Linn., Struthiopteris, $W$. Sect. 2. Symplophlebieæ, J. Sm. Veins simple or compound anastomosing.

Ex. Goniopteris, Pr., Meniscium, Schred., Drynaria, Bory.

Tribe II.-Acrostichies.

Fertile fronds contracted. Sori amorphous, naked. Sect. 1. Orthophlebieæ. Veins free.

Ex. Elaphoglossum, Sohott, Stenochlæna, J. Sm., Polybotrya, Humb.

Sect. 2. Symplophlebieæ. Veins anastomosing in various ways.

Ex. Aconiopteris, Pr., Acrostichum, Linn., Platycerium, Desv.

$$
\text { Tribe III.-PTERIDee, J. Sm. }
$$

Sori marginal, punctiform or linear, or intramarginal transverse, furnished with a latter exterior attached indusium.

Sect. 1. Chilosorew, J. Sm. Sori seated on the margin.

Ex. Cheilanthes, Sw., Pteris, Linn., Adiantum, Linn. Sect. 2. Metasoræ, J. Sm. Sori oblong or linear.

Ex. Blechnum, Linn., Lomaria, Willd., Woodwardia, Sm.

\section{Tribe IV.-Aspleniez, $J$. Sm.}

Sori oblique, linear, single or binate, furnished with a lateral indusium.

Sect. 1. Orthophlebieæ. Veins free.

Ex. Asplenium, Linn., Diplazium, Sw., Scolopendrium, Sm. Sect. 2. Symplophlebieæ. Veins variously anastomosing. Ex. Neottopteris, J. Sm., Callipteris, Bory., Allantodia, R. Br.

\section{Tribe V.-Aspidiex, $J$. Sm.}

Sori round, furnished with an orbicular, or lateral interiorly attached indusiun. 
Sect. 1. Symplophlebieæ. Veins anastomising in various ways.

Ex. Aspidium, Sw., Pleocnemia, Pr., Nephrodium, Schott. Sect. 2. Orthophlebieæ. Veins free.

Ex. Lastrea, Bory., Polystichum, Roth., Didymochlæna, Desv.

$$
\text { Tribe VI. -Dicksonie e, J. Sm. }
$$

Sori marginal, round or linear, furnished with a special and accessory indusium, which united form a cyst or groove including the sporangia, and opening exteriorly. Sect. 1. Lindsææ, $J$. Sm. Sori linear, rarely round. Ex. Lindsæa, Dry., Dictyoxiphium, Hook, Odontoloma, $J . S m$.

Sect. 2. Davallieæ, J.Sm. Sori round or vertically oblong. Indusium cystiform, cuculate or tubular. Ex. Microlepia, Pr., Davallia, Sm., Loxoma, R. Br. Sect. 3. Trichomaneæ, J. Sm. Sporangia seated in a free columnar receptacle included in or inserted along the cyst.

Ex. Trichomanes, Linn., Hymenostachys, Bory., Hymenophyllum, $S m$.

Sect. 4. Dicksoniæ. Sporangia included within a concave, bilabiate, or calyciform, reflexed cyst. Ex. Sitolobium, Desv., Dicksonia, L'Herit., Cibotium, Kaulf.

$$
\text { Tribe VII.-Crathee, J. Sm. }
$$

Sori round intramarginal, receptacle elevated. Indusium calyciform, or lateral, trichiform or absent.

Ex. Cyathea, Sm., Hemitelia, $R$. Br., Trichopteris, Presl.

$$
\text { Dirision II.-GLEICHENIACE } 巴, R . B r \text {. }
$$

Sporangia furnished with a transverse ring. Sori round intramarginal.

Ex. Platyzoma, R. Br. Gleichenia, Sw., Mertensia, Willd. 


\section{Division III. - SCHIZ EACE E, Mart.}

Apex of sporangia rayed, analagous to a transverse ring, generally produced in simple spikes, racemes, or panicles. $E x$. Lygodium, $S w$. , Schizæa, $S w$. , Anemia, $S w$.

\section{Division IV.-OSMUNDACE正, Mart.}

Sporangia globose, reticulated, destitute of stria, opening vertically in two valves, produced on contracted fronds.

Ex. Osmunda, Linn., Todea, Willd.

\section{Division V.-MARATTIACE A, Kaulf.}

Sporangia opaque, horny, unilocular, or multilocular, destitute of a ring.

Ex. Angiopteris, Hoffm., Marattia, Sm., Danæa, Sm.

More than thirty years have now elapsed since the above arrangement was drawn up and published, and during that time about 1,000 cultivated species have come under my notice, as well as many additional herbarium specimens new to me, the consequence of which has been to greatly alter my views in the definition of genera and their arrangement, which is explained further on.

The next general arrangement of this family of plants to be noticed is that of Professor Fée, of Strasburg, who in 1852 published his "Exposition des genres de la famille des Polypodiacées." This great work consists of 387 pages of quarto letter press, in which is given the characters of 188 genera, with observations and examples of species of each genus, which are illustrated by figures occupying thirty-two plates, the whole evincing great talent and research. In this work 2,140 species are enumerated of annulate Ferns; he follows Presl's method in dividing them into two divisions founded on the direction of the ring, but restricts Helicogyrater to the tribe Cyatheæ, thus excluding Gleicheniacer, which is not taken 
up in the work. He classifies the genera under twenty-six heads, which bear the name of the leading genus of each, and adopts the different modes of venation and character of the sori as part of his generic character, but he introduces new elements in characterising his genera, such as giving the form and structure of the sporangia, and the number of articulations of the ring, also the different form of the spores; these form an important feature in his generic as well as in his specific characters; but with regard to their value, I candidly confess that in all my observations and experiences $I$ have failed to satisfy myself that either the number of articulations of the ring, or the form of the spores, can in any way be practically serviceable for defining either genera or species. The little value of such characters become obvious on comparing his descriptions of individual species with their respective generic characters, for example, in the generic character of Aspidium the number of articulations of the ring is stated to be 18-20, that is, all his species of Aspidium should not have less or more than the above number; but in ten of his new species of Aspidium, he describes the number of articulations as much below the number assigned in the character of the genus; hence, these species according to his own descriptions, should not be placed in Aspidium. As far as regards the characters derived from the spores, I am sensible that their forms are various and in some cases peculiar; but the spores of Ferns, like the seeds of other plants, will, if gathered before they are mature, shrivel and assume forms that will, in many instances, appear to the microscopic observer to be normal, and figures of such appearances are consequently drawn and published. In my opinion much examination is still required, before either the structure of the sporangium or 
microscopic spores can be made available as auxiliary characters, and this will require the labour of years ; and even when complete, will be of but little service either to the student or general observer ; for I am satisfied that, with our present knowledge of the more obvious outward features that distinguish Ferns from one another, these interesting plants can be readily arranged in groups forming natural genera and alliances, without requiring much aid from the microscopist.

Besides the additional characters derived from the structure of the sporangia, both Presl and Fee attach much importance to the difference in the number and forms of the bundles or plates of vascular fibre in the stipes. My observations upon that point tend to show, that, although the bundles are generally uniform in simple fronded species, yet in many others the number and form appear to vary according to the frond being more or less compound and varying in size, age, and vigour of growth of individual plants of the same species. In the stipes of a fullsized frond (ten feet in length) of Cyathea arborea, I found thirty-six vascular bundles in the stipes below the lowest pair of pinnæ, and this number nearly corresponded with the number of pinnæ forming the frond; in fronds of intermediate sizes the bundles were fewer, apparently formed suited to the more or less compound development of the frond consequent on the size and age of the plant; for instance, in fronds of the same species, a foot in length with few pinnæ has only three broad vascular plates in the stipes. It is reasonable to suppose that the shape or outward form assumed by every species is based upon a vascular frame-work, developed according to some definite plan inherent to each individual species, but varying according to the circumstances that influence the growth 
and age of individual plants of the same species. Further investigations, however, are required before the vascular structure of the stipes can be made of service as a distinguishing character for either genera or species, and this can only be satisfactorily obtained by a series of observations of living plants.

M. Fée gives a systematic arrangement of his method of classification, which occupies nearly five double-columned pages; but the many divisions, sub-divisions, figures, letters, and arterisk, renders it necessary to be very carefully studied before it can be well understood. The following is sufficient to show M. Fée's mode of classifying genera, from which it will be seen that plants most opposite in natural habit are associated, consequent on characters derived from the form and position of the sori, and in being naked or indusiate and the different forms of the latter, and therefore cannot be considered otherwise than as an artificial arrangement of complicated construction. Abstract of F'e's arrangement :-

\section{ORDER-POLYPODIACEA.}

I. Cathetogrratee.

Acrosticheae, Gen. 19. (Ex. Acrostichum, Platycerium, Leptochilus.)

Lomarieae. Gen. 8. (Ex. Blechnum, Acropteris, Hymenolepis.)

Vittarieae. Gen. 10. (Ex. Pteropsis, Drymoglossum, Lemogramma.)

Pleurogrammeae. Gen. 5. (Ex. Monogramma, Adenophorus, Xiphopteris.)

Pterideae.

1. Lindsayeæ. Gen. 5. (Ex. Isoloma, Schizoloma, Dictyoziphium). 
2. Adianteæ. Gen. 4. (Ex. Adiantum, Casebeeria, Ochropteris.)

3. Pterideae. Gen. 8. (Ex. Pellæa, Onychium, Amphiblestra.)

4. Lonchitideae. Gen. 1. (Lonchitis.)

Hypolepideæ. Gen. 2. (Hypolepis, Adiantopsis.)

Eucheilantheae. Gen. 6. (Ex. Myriopteris, Pleucosorus,

Nothochlæna )

Jamesonieae. Gen. 1. (Jamesonia.)

Hemionitideæ. Gen. 8. (Ex. Coniogramma, Hemionitis, Syngramma.)

Antrophyeae. Gen. 3. (Antrophyum, Colysis, Selliguea.) Leptogrammeæ. Gen. 6. (Ex. Pterogonium, Hecistopteris, Gymnogramma.)

Asplenieae. Gen. 9. (Ex. Neottopteris, Hemidictyon, Woodwardia.)

Scolopendrieæ. Gen. 3. (Scolopendrium, Antigramma, Camptosorus.)

Diplazieæ. Gen. 5. (Ex. Diplazium, Callipteris, Didymochlæna.)

Meniscieæ. Gen. 2. (Meniscium, Dryomenes.)

Struthiopterideæ. Gen. 3. (Struthiopteris, Onoclea, Ceratodactylis.)

Polypodieæ. Gen. 19. (Grammitis, Phegopteris, Drynaria.)

Cyclodieø. Gen. 8. (Ex. Polystichum, Cyclodium, Crytomium.)

Aspidieæ. Gen. 13. (Ex. Cystopteris, Nephrodium, Oleandra.)

Nephrolepideæ. Gen. 5. (Ex. Nephrolepis, Saccoloma, Humata.)

Davallieæ. Gen. 10. (Ex. Prosaptia, Microlepia, Odontoloma.) 
Dicksoniex. Gen. 6. (Ex. Dicksonia, Hypoderris, Woodsia.) Balantieæ. Gen. 4. (Ex. Balantiam, Leptopleuria, Cystodium.)

Cibotieæ. Gen. 1. (Cibotium.)

2. Helicogrates.

Cyatheæ. Gen. 7. (Ex. Alsophila, Hemitelia, Amphidesmium.)

Thrysopterideæ. Gen. 1. (Thrysopteris.)

Besides his general work on Polypodiacex, M. Fée has also published several memoirs on special genera, accompanied by figures, one forming a volume devoted to the tribe Acrosticheæ, in which he arranges the species under nineteen genera.

Vittaria and its allies form another memoir ; of Vittaria alone he describes and figures no less than twenty-five species and fire doubtful, but the examination of numerous sets of specimens justifies me in reducing the number to less than a dozen.

I have now given a general view of the systematic arrangements of Presl, my own, and Fee's, by which it will be seen that the first important divisional character is derived from the different directions of the ring that surrounds the sporangium. My reason for again reverting to this subject is in order to show that in some Cyatheoe the so called obliquity of the ring is more apparent than real. In my arrangement of $1841 \mathrm{I}$ have stated my riews on this point. I have there explained that the apparent obliquity of the ring in Cyathere is due to mechanical pressure, the sporangia of each sorus being crowded and sessile seated round a columnar elevated receptacle, and each sporangium being inclined upwards, consequently the pressure against each other imparts to them an oblong flattened form especially in the lower part on their inner 
side. This, according to my view, accounts for the ring appearing not to be truly vertical, but it is to be observed that the obliquity is not general, for in the figures of the sporangia of eight Cyatheaceous genera in Hooker and Bauer's "Genera Filicum," the ring is shown to be vertical. I therefore follow Robert Brown in placing Cyathece in Polypodiacece.

The next systematic work to be noticed is that of Professor Mettenius, of Leipzig, who, in 1858, commenced publishing a work entitled "Uber einige Farngattingen" ("On Some Genera of Ferns"), of which five parts have appeared. In order to explain this author's system of classification of species, I will give a brief outline of the manner in which he treats the genus Polypodium. He enumerates, and mostly describes in full, 258 species of this genus, including in it all the forms possessing punctiform, oval, or linear, naked sori, thus restoring it to nearly the state in which it was left by Swartz, Willdenow, and Sprengel, and even including in it the genus Grammitis of those authors. His reason for placing so many species under one genus is on account of the numerous intermediate or transition forms, which he says so pass into one another that he finds it difficult to define any group of species as a distinct genus in the manner that Presl and others had done. Notwithstanding this, however, he finds it quite possible to divide the genera into sections and subsections, of which he gives an elaborate synoptical table. He first divides the 268 species, according to their veins, being free or anastomose. Those with free veins are placed under four sections, and those with anastomose veins in thirteen sections. These sections and sub-sections (which are numerous) in most cases bear the names that designate the genera of Presl and others, and consequently 
contain the same species, or nearly so. His table of arrangement, showing the distribution of the species under the different sections, occupies thirteen pages of quarto of his Treatise, of which the following in an abridgment:-

\section{GENUS POLYPODIUM.}

$\S$ 1. Cænopteris (Adenophorus, Hook. Xiphopteris, Kaulf.).

$\S$ 2. Ctenopteris, Eupteris, vel Europteris (Grammites, Sw, Blume; Ctenopteris, J. Sm. Polypodium, J. Sm.).

$\S$ 3. Cænopteris, Ctenopteris, rarissime Eupteris (Pleopeltis in part, J. Sm.).

$\S$ 4. Marginaria ; folia conformia (Lepicystis, J. Sm.).

$\S$ 5. Marginaria-Goniophlebinm (Goniophlebium, Blume, J. Sm.).

$\S$ 6. Cyrtophlebium (Cyrtophlebium, R. Br. Campyloneuron, Presl).

$\S$ 7. Doodya ; naculæ exappendiculatæ (Dictymia, J. Sm.).

$\S$ 8. Doodya; naculæ appendiculatæ (Phymatodes in part, Presl).

$\S$ 9. Phlebodium (Pleopeltis in part, J. Sm.).

$\S$ 10. Marginaria ; folia difformia (Lopholepis, J. Sm.).

$\S$ 11. Phlebodium (Anapeltis, J. Sm. Phymatodes in part, Presl).

$\S$ 12. Anaxetum (Pleuridium in part, Presl, J. Sm.).

$\S$ 13. Anaxetum (Pleuridium in part, J. Sm., Selliguea, Blume, Loxogramma, Presl).

$\S$ 14. Drynaria (Pleuridium in part, J. Sm. Colysis, Presl. Drynaria, Bory. Depteris, Reinw. Monosorum Linbr).

$\S$ 15. Pleocnemia (Niphopsis, J. Sm.).

$\S$ 16. Pleocnemia (Niphobolus, Kaulf., Spreng., J. Sm.).

$\S 17$. Pleocnemia appendiculata, s., Drynaria (Niphobolus, Presl, J. Sm.). 
I must state that after much study of this arrangement I have not been able sufficiently to understand it to make it practically useful. I do not clearly see what object the author gains by introducing sectional names not before used in the genus, more especially as these names (Coenopteris, Eupteris, Neuropteris, Doodya, Pleocnemia, \&c.) are apparently not given as special sectional names, but used comparatively-that is, all the species under Coenopteris, Eupteris, \&c., are presumed to have venation similar to Ferns bearing those names. Therefore, in order to ascertain the venation of one Fern, it is first necessary to be acquainted with the venation of that with which it is put in comparison. As, for example, to know Dictymia, it is first necessary to be acquainted with the character of the venation of Doodia and Pleocnemia. Unfortunately too, the analogy in these two cases is far from obvious, the genera in both cases being in every respect of quite different habits. I therefore see no good reason for making such genera as Doodia and Pleocnemia types for arranging other genera by venation.

With regard to his arrangement of Phegopteris and Aspidium, of which he enumerates in consecutive order 299 species - thus viewing them as parts of a single genus -of these sixty-eight belong to the first part, Phegopteris ; the remainder to the second part, Aspidium. I do not consider it necessary to enter into further details. I will only add that the sectional names are upon the same principle as those of Polypodium, and that, in my opinion, a simple generic name for groups of naturally allied species, would render their study much easier than the complicated comparative similitude with one another. Mettenius has also published a memoir on the genus, Asplenium and several other genera. 
I have now to notice an important but yet incomplete work, the "Index Filicum," a synopsis with characters of the genera, and an enumeration of the species of Ferns with synonyms, and references, \&c., \&c., by Mr. Thomas Moore, Curator of the Garden of Apothecaries, Chelsea; the first part of this work appeared in 1857. The author first gives a synopsis of the orders and tribes, followed by a systematic arrangement and characters of the genera, each genus illustrated by a woodcut showing the character of the venation and position of the sori, also an analytical table of the genera and their synonyms.

With regard to the number of genera the author tells is that he has endeavoured "to hold a middle course between the excessive sub-division and the equally inconvenient non-division of older genera," and that the classification adopted is based on the plan on which the vascular structure is developed, in conjunction with the nature of the fructification. $\mathrm{He}$ enumerates 186 genera*, which he classifies under five orders, namely, Polypodiacece, Marattiacece, Ophioglossacece, Lycopodiaiene, and Marsileacea.

The following abstract will be sufficient to convey an idea of Mr. Moore's method of classification.

\section{FILICALES, SPORE-CASES.}

\section{ONE-CELLED.}

* Spore-cases furnished with a jointed ring, which is usually nearly complete, sometimes rudimentary.

ORDER I.-POLYPODIACE E.

|| Ring vertical, nearly complete.

Tribe I.-POLYPODINEe.

§ 1. Acrosticheæ (Ex. Elaphoglossum, Schott. Acrostichum, Linn.)

* This includes ten genera of the orders Lycopodiacex and Marsiliacere, which are not taken up in the present work. 
§ 2. Platycerieæ (Ex. Platycerium, Desv., Jenkinsia, Hook.)

§ 3. Lomarieæ (Ex. Lomaria, Willd., Blechnum, Lin.)

§ 4. Pleurogrammeæ (Ex. Monogramma, Schh., Hymenolepis, Klfs., Gymnopteris, Bernh.

§ 5. Tænitideæ (Ex. Lomogramma, J. Sm., Drymoglossum, Presl, Toniopsis, J. Sm.)

§ 6. Vittarieæ (Ex. Vittaria, Sm.)

§ 7. Lindsæeæ (Ex. Lindsae, Dryand., Dictioxiphium, Hook.)

§ 8. Adianteæ (Ex. Adiantum, Linn., Hewardia, J. Sm.)

§ 9. Cheilantheæ (Ex. Hypolepis, Bernh., Casebeera, Klfs.)

$\S$ 10. Pteride» (Ex. Onychium, Klfs., Haplopteris, Presl., Amphiblestra, Presl.)

$\S$ 11. Woodwardieæ (Ex. Woodwardia, Sm., includes Doodia, R. Br.)

$\S$ 12. Meniscie» (Ex. Brania, J. Sm., Meniscium, Schreb., Dryomenis, Fée.)

$\S$ 13. Asplenieæ (Ex. Actinicpteris, Link., Asplenium, Presl, Ceterach, Willd.)

§ 14. Didymochlæneæ (Ex. Didymochlaena, Desv., Mesochlæna, R. Br.)

§ 15. Hemionitideæ (Ex. Polytonium, Desv., Anetium, Klfs., Dictyogramma, Fée.)

§ 16. Gymnogrammeae (Ex. Grammitis, Sw., Stegnogramma, Bl., Selliguea, Bory.)

§ 17. Platylomeæ (Ex. I'lagiogyria, Kze., Llavea, Lagasca, Cryptogramma, R. Br.)

$\S$ 18. Polpodieæ (Ex. Struthiopteris, Willd., Jamesonia. Hook. et Grev., Drynaria, Bory.)

§ 19. Aspidie» (Gen. 12. Onoclea, Lin., Polystichum, Roth., Nephrolepis, Schott.)

§ 20. Cystopterideæ (Gen. 3. Cystopteris, Bernh., Acrophorus, Presl., Hunata, Cav.) 
§ 21. Davallieæ (Gen. 4. Microlepia., Presl., Davallia, Sm., Prosaptia, Presl.)

§ 22. Dicksonieæ (Gen. 7. Dicksonia, L'Herit., Dennstoedtea, Bernh., Cionidium, Moore.)

§ 23. Paranemeæ (Gen. 5. Diacalpe, Bl., Woodsia, R. Br., Hypoderris, R. Br.

||| Ring more or less obliquely vertical, nearly complete, narrow.

\section{Tribe II.-CYatheINEA.}

§ 1. Thyrsopteredeæ (Gen. 1, Thyrsopteris, Kge, T. elegans).

§ 2. Cyatheæ (Gen. 3, Cyathea, Sm., Hemitelia, R. Br., Amphicosma, Gard.)

§ 3. Alsophile» (Gen. 2, Alsophyloe, R. Br., Amphidesmium, Schott).

Tribe III.-Matoninem.

(Gen. 1. Matonia, R. Br., M. pectinata).

Tribe IV.-Gleichenines.

(Gen. 2. Platyzoma, R. Br., Gleichenia, Sm.)

Tribe 5.-Trichomanineas.

(Gen. 5. Loxoma, R. Br., Hymenostachys, Bory., Hymenophyllum, $\mathrm{Sm}$.

Tribe VI.-SCHIZ EINEA.

§ 1. Lygodieæ (Gen. 2, Lygodium, Sw., Hydroglossum, Willd.)

§ 2. Schizæeæ (Gen. 5, Anemia, Sw., Mohia, Sw., Trochopteris, Gard.)

Tribe 7.-Ceratopteridine

(Gen. 1. Ceratopteris, Brongn., C. thalictroides).

Tribe 8.-Osmundinet.

(Gen. 2. Osmunda, Lin., Todea, Willd.) 
* Spore cases without a jointed ring.

(a). Sori dorsal.

\section{ORDER.-MARATTIACE A.}

Tribe 1.-Maratrinez.

$\S$ 1. Angiopterideæ (Genus 1, Angiopteris, Hoffm.)

§ 2. Marattieæ (Gen. 3, Marattia, Sm., Gymnotheca, Presl, Eupodium, J. Sm.)

Tribe 2.-KaUlfussinete.

(Gen. 1, Kaulfussia, Bl., K. esculifolia).

Tribe 3.-Danemere.

(Gen. 1, Dancea, Sm.)

(b). Fructification marginal, on rachiform fronds or branches (venation straight).

\section{ORDER.-OPHIOGLOSSACE A.}

(Gen. 3. Botrychium, Sw., Helminthostachys, Klfs., Ophioglossum, Lin.)

Lycopodales.-Acrogenous plants with axillary radical or one-four-or many-celled spore cases.

* Spore cases one-three celled, in the axils of the stem. leaves or bracts.

\section{ORDER.-LYCOPODIACE $\nexists$.}

$\S$ 1. Phylloglosseæ (Gen. 1, Phylloglossum, Kze).

§ 2. Lycopodieæ (Gen. 4, Tmesipteris, Bernh., Psilotum, Sw., Selaginella, P. B.)

** Spore-cases (conceptacles) one-four-or many-celled, radical or petiolar.

\section{ORDER.-MARSILEACE $A$.}

$\S$ 1. Isoeteæ (Gen. 1, Isoetes, Lin.)

§ 2. Salvinieae (Gen. 2, Salvinia, Micheli, Azolla, Lam.) 


\section{§ 3. Pilularieæ (Gen. 1, Pilulariece, Lin.) \\ § 4. Marsileæ (Gen. 1, Marsilea, Lin.)}

The above classification shows that Mr. Moore has bestowed great ingenuity upon its formation, but I cannot view it otherwise than as an artificial arrangement founded upon certain technical data that normally characterise all true Ferns, whaterer size, habit, or mode of growth they assume. We need not therefore be surprised at finding, associated under the same sections, genera of extreme unnatural habit and mode of growth as also differing essentially in their vascular structure, such as Jenkinsia and Platycerium; Monogramma, Hymenolepis, and Gymnopteris ; Lomogramma, Drymoglossum, and Toniopsis ; Brainea, Miniscium, and Dryomenes; Didymochloena and Mesochloena; Calymmodon, Stegnogramma, Gymnogramma, Struthiopteris, Jamesonia, and Irymaria ; Onoclea, Polystichum, and Nephrolepis; Cystopteris and Humata; and Woodsia and Hypoderris : the placing of these in their respective sections being entirely guided by the character of the fructification, withont regard to natural habit. Any system of classifcation of Ferns based upon these principles may be viewed as analogous to the Linnean classification of phænogamous plants.

I have now to notice the next part of this work, which consists of an alphabetical arrangement of the whole nomenclature of Ferns, collated from the publications accessible to the author, "and blended with such personal information as the author has been able to bring to bear upon the subject." In order to appreciate the extent of this work, it is only necessary to state that up to September, 1862,* 396 pages were published, and which

* Up to the present time, 1874, no addition to the above has been published. 
extended only to Goniophlebinm, being the seventy-third genus in alphabetical order, up to which are enumerated 1,738 species with their synonyms; from this data it may be calculated that the number of species, when the work is complete, will amount to above 4,000. As an instance of the labour and investigation required, I will select the genus Acrostichum. Under this original generic name of Linnæus, no less than 461 specific names are enumerated in alphabetical rotation, with references to their authorities, occupying twelve pages : with the exception of nine names, the whole are in italics, signifying that they are synonyms, the nine being in roman type, indicating that they are the only true species of Acrostichum as now adopted. When complete, this work will be an invaluable treasure to Pteridologists.

I have now to notice the works of Sir William Hooker, who in 1820 became Professor of Botany in the University of Glasgow, and in 1841, Director of the Royal Gardens at Kew, but before the first date he had gained reputation as a cryptogamic botanist. His first great work on Ferns was in conjunction with Dr. Greville, of Edinburgh, also a famous cryptogamic botanist, entitled "Icones Filicum," a work of two folio-sized volumes, containing 230 finely executed plates of new and rare Ferns, each plate containing magnified portions of the fructification exhibiting the characters of the genera as then defined, with accompanying descriptive letter-press. In this work two new genera are characterised, viz., Deparia and Jamesonia, each founded upon a single species.

His next work of importance is Hooker and Bauer's "Genera Filicum," which commenced with a set of drawings begun in 1833 by the late eminent botanical draughtsman Francis Bauer, from specimens from time to time 
furnished by me, some from living plants from the garden, and others from herbarium native specimens. The drawings being highly appreciated by Sir W. Hooker, Mr. Bauer freely placed them in his hands for publication, and in 1842 a splendid volume consisting of 120 plates was completed,* each plate containing natural and highly magnified portions of fronds, exhibiting in different states the fructification and venation, accompanied with corresponding letter-press, giving the characters of each genus : there are on the whole 135 genera, many being derived from Presl's "Pteridiae Pteridographia," and twenty being named and described by me as new.

The learned editor, however, says he reserves for himself the power of rejecting such of them as on further examination he may consider himself justified in doing. With regard to that point he also says, "so completely do the ideas of Dr. Presl accord with my own in regard to the limits of many genera that I should do him injustice were I not in many cases to quote his characters verbatim, and indeed the more attentively I study his book and com. pare the descriptions with the plants themselves, the more satisfied I am that he has produced a work that will not easily be surpassed for accuracy of, and clear and perspicuous, arrangement."

In 1854 appeared the tenth volume of his work entitled "Icones Plantarum," containing 100 figures of new and rare Ferns, which was soon afterwards followed by another volume called a "Century of Ferns." This was followed by "Filices Exoticæ," consisting of 100 plates, which gare place to another volume entitled "Garden Ferns," contain-

* The drawings for the latter part of this work were executed by the equally eminent draughtsman Mr. Walter Fitch; this was consequent on the health of Mr. Bauer having failed. 
ing sixty-four plates, the drawings of the latter as well as part of the preceding being derived from living plants of the Kew collection. The practical use of these works is in assisting to determine species, and which, either under the same name or as synonyms, will be found in his last and great work the "Species Filicum," the most important systematic work on Ferns yet published, being a description of all known Ferns, particularly of such as exist in the author's herbarium (previously noticed), and such as are with sufficient accuracy described and figured in the works of other authors. It consists of five volumes, the first of which appeared in 1846, and the fifth in 1864, its preparation having occupied his leisure time for a period of not less than twenty years. It treats of the orders Gleicheniacece and Polypodiacea only, of which 2,401 species are described, with their synonyms, which amount to about 4,300 , as also their native countries and names of collectors, illustrated with 300 plates representing 522 species. He arranges the whole under sixty-three genera, fourteen of which contain only one species each, thus presenting a great contrast to the mass of species which he continues to retain under the characters assigned by Linnæus and Swartz, to such genera as Polypodium, Aspidium, Pteris, and Acrostichum, thus arowing his preference for large genera by strictly adopting the characters derived solely from the fructification. With regard to which he says, "Increased study has, he must confess, strengthened his convietion that those botanists who have shown themselves peculiarly addicted to multiplying genera have not always taken nature as their guide, nor succeeded in eliciting a simple nor tangible arrangement, yet have their close and accurate investigations thrown a new light on the study of Ferns, a light which cannot fail to aid the re- 
searches of future writers, and which ought therefore to be gratefully acknowledged; a middle course has been pursued between the highly multiplied genera of Presl and J. Smith, and the too meagre enumerations of Willdenow, Sprengel, Link, Kunze, and others."

By adopting the above view, hundreds of species become massed under one generic name, regardless of their dissimilar habits and anatomical structure. For instance, the genus Polypodium, as characterised in the "Species Filicum," contains 4.07 species, amongst which are found the greatest diversity of size and mode of growth, as also in anatomical structure. The small grass-like species characterised by Swartz and others under the genus Grammitis, and the many small pinnatifid species represented by Polypodium trichomanoides, Swartz, and P. pectinatum, Linn., and others, rank with the large fronded genus Drynaria of Bory, and the large decompound subarborescent species of the section Phegopteris. This is consequent on all Ferns having round or oblong sori being placed under the genus Polypodium. Upon such data, setting aside habit, the Tree-Fern genus, Alsophila, R. Br., might be correctly referred to Polypodium. The same applies to Aspidium and Nephrodium, which, between them, contain 227 species of very varied habit and venation.

Then, again, all species with linear naked sori diverging from the mid-rib, whether on free or anastomosing reins, and of whatever habit of growth, are placed under Gymnogramma, of which he enumerates seventy-four species, even including the genus Selliguea of Blume, which differs from the whole of the Gymnogramma alliance in having articulate venation. With regard to Acrostichum, 167 species are described, which Fée and other authors have placed under fifteen genera, many presenting a very distinct habit 
of growth and venation, but with the exception of five species of Platycerium he retains the whole under the genus Acrostichum.

Of the tribe Aspleniece he describes over 300 species, all comprehended under the genus Asplenium, except two species which constitute the two genera Allantodia and Actinopteris. With regard to Scolopendrium, some authors consider it as a genus scarcely separable from Asplenium, but in the "Species Filicum" it is characterised as a distinct tribe under the name of Scolopendriece. It consists of nine species, which agree in general habit with Asplenium, and present no special character to justify their separation as a tribe from Asplenieæ.

We give another instance,-in speaking of Hypoderris, he says :- "Considering as I do that the primary divisions should be taken as much as possible from the fructification, I have no hesitation in placing Hypoderris among the Dicksonice and near to Woodsia." No three genera can be more distinct in natural affinity than these-that is, as regards habit and anatomical structure; the only similitude is between Hypoderris and Woodsia, which have discal punctiform sori, with a very membranous cup indusium, therefore in that character are more properly though artificially related to Cyathea than to Diclisonia, which has marginal sori with cystiform indusia opening outwards.

Again, take the case of Matonia, a rare Fern with fanshaped fronds, in every respect allied to Gleichenia in habit, and also in the ring of the sporangia being horizontal, and differing only from Gleichenia in the sori being furnished with an inverted cup-shaped indusium, attached by its centre as in true Aspidium and Polystichum. Although such is the case, Sir William Hooker follows 
Presl by placing Matonia in alliance with Cyathea, with which in habit and even in technical character no generic affinity is traceable.

In his general arrangement he follows, with a partial exception, the sequence of Presl, arranging the whole under two sub-orders, Gleicheniacere and Polypodiacece, the latter consisting of twelve tribes, beginning with Cyathea, including Hymenophyllum, and ending with Acrostichum. With regard to Asplenium, Polypodium, and Aspidium, he, in a great degree, follows Mettenius and Feee's arrangement and descriptions of Acrostichum.

From what has now been stated it will be seen that, although Sir W. Hooker bestows great praise on his contemporaries, he nevertheless adopts but few of their genera, thus making it appear that but little advance has been made in our knowledge of the natural habit and anatomical structure of Ferns since the time of Sprengel (1827). $\mathrm{He}$, however, finds himself compelled to divide his large genera into sections, which are equivalent to the genera of authors; indeed, it is only by the sections that we are saved the labour of wading through 200 or 300 species in order to find out a single individual.

The following is a tabular view of the sequence of the tribes and genera as arranged in the "Dpecies Filicum ":-

Order I.-FILICES.

Sub-Order I.-Gleicheniaces.

Gen. 2. Platyzoma, Gleichenia.

Sub-Order II.-PoLyPodiaces.

Tribe I.-Crathes.

Gen. 3. Cyathea, Hemitelia, Alsophila. 
Tribe II.-Dicksoniex.

Sub-Tribe I.-HYPODERRIDEA.

Gen. 1. Hypoderris.

Sub-Tribe II.-WOODSIEA.

Gen. 4. Sphæropteris, Diacalpe, Arachniodes, Woodsia.

Sub-Tribe III.-EDdICKSONIEA.

Gen. 7. Thyrsopteris, Dicksonia, Cibotium, Deparia, Loxoma, Hymenophyllum,.Trichomanes.

Sub-Order III.-DaVALLIEE.

Gen. 2. Davallia, Cystopteris.

Tribe IV.-LindSFaCEe.

Gen. 2. Lindsæa, Dictyoxyphium.

Sub-Order IV.-PTERIDEe.

Gen. 12. Adiantum, Cheilanthes, Pellæa, Pteris, \&c.

Sub-Order V.-LomarieE.

Gen. 5. Lomaria, Blechnum, Sadleria, Woodwardia, Doodia.

Sub_Order VI.-AsPLenieA.

Gen. 3. Asplenium, Allantodia, Actinopteris.

Sub-Order VII.-SCOLOPENDRIEE.

Gen. 1. Scolopendrium, species 8.

Sub_Order VIII.-ASPIDIACEE.

Gen. 7. Didymochlæna, Aspidium, Nephrodium, Nephrolepis, Oleandra, Fadyena, Onoclea.

Sub-Order IX.-POLYPODIEE.

Gen. 1. Polypodium, species 409.

Sub-Order X.-GRAMniredeE.

Gen. 11. Jamesonia, Nothochlæna, Monogramme, Gymnogramme, Brainea, Meniscium, Antrophyum, Vittaria, Tænitis, Drymoglossum, Hemionitis.

Sub-Order XI.-Acrostichea.

Gen. 2. Acrostichum, Platycerium. 
OBS.-The genera founded by Sir William Hooker, of which there are five, are marked with an asterisk, and the number of species named and described by him in the "Species Filicum" amounts to about 600 .

In a notice at the end of the fifth volume of the "Species Filicum," he states, that "if his life and health be spared to him, he intends to accomplish a volume to be entitled 'Synopsis Filicum,' to contain brief characters of the sections, genera, and species of Ferns, general habitats, and references to the 'Species Filicum,' omitting all really dubious species, and including the sub-orders Osmundacece, Marattiacece, and Ophioglossacece," which it is hoped will form "a useful vade mecum for the travelling botanist, and the cultivator of Ferns, and for ready consultation in the herbarium."

Only one part, with the preface of this work, consisting of twenty-two pages, was printed at the time of the author's death (which took place in August, 1865); the remaining manuscript was placed in the hands of $\mathrm{Mr}$. J. G. Baker, who, shortly after Sir W. Hooker's death, received the appointment of Assistant Curator in the Kew Herbarium, and who has carried out the author's views, forming a volume of 482 pages, which was published in 1868, accompanied by nine coloured plates illustrating the characters of the genera, of which there are seventy-five.

In the arrangement of the tribes and genera this work does not differ materially from the "Species Filicum :" the number of species described of Gleicheniacece and Polypodiaceve amounts to 2,122, being 279 less than the "Species Filicum," while 106 are enumerated under the sub-orders Osmundaceoe, Marattiacece, and Ophioglossacece, thus making a total of 2,228 species, being chiefly founded on specimens in the Hookerian Herbarium, which, at the 
time of the publication of the "Synopsis," is stated to contain 50,000 specimens of Ferns, representing the many different states of the species therein described.

As might be expected from a new writer on Ferns, many changes have been made in the nomenclature and synonyms, as given in the "Species Filicum," there being no less than fifty of the names in the "Synopsis" having Mr. Baker's initials prefixed, which is principally consequent on his having removed species from one genus to another, and in many cases giving new specific names, as also by the addition of a considerable number of new species.

I have already noticed that in the "Species Filicum" species of very distinct habits and characters are placed in the same genus; of this there are several remarkable new examples in the "Synopsis," the most conspicuous of which will be found noticed under the respective genera in my general arrangement.

In December, 1874, a second edition of the "Synopsis" was published, containing an Appendix to the first edition prepared by Mr. Baker, regarding which he "says "I have endeavoured in this edition to briefly characterize and fit into their places the new discoveries and the plants found upon fuller information to have been inadequately dealt with in the first." This Appendix contains the names of 438 species, 198 of which bear the initials of $\mathrm{Mr}$. Baker; the principal authorities for the others being Mettenius, Klotzsch, Karstein, Grisebach, Moore, and Kuhn; with the exception of about twenty, the whole are additions to the 2,228 described in the first edition of the "Synopsis;" thus on the authority of that work the total number of known species of Ferns amounts to 2,616.

Whether the above number is represented by truly dis- 
tinct species may be doubted by some Pteridologists; but be that as it may, there can be no doubt but that the "Species Filicum" and "Synopsis" are highly valuable to students of Ferns,* possessing herbaria or cultivated collections, as also to travellers abroad.

I have now to notice another important work by Mr. Baker, published in 1870, namely, that part of Martius's "Flora of Brazil," containing the Ferns; a folio work of 317 pages, with fifty plates, each plate containing many figures of portions of fronds, showing the differential characters of the genera and species. Of the latter there are 387 described, the genera being arranged in the same order as in the "Synopsis Filicum." On taking into consideration the extensive territory of Brazil with its various climates favourable to the growth of Ferns, from those growing at elevations that may be termed sub-arctic, to others luxuriating in the lower hot valleys and rocky or forest ravines, the number of 380 species may be considered small ; but here again comes the question, what is a species? and judging from Mr. Baker's view, it would appear that many plants originally described as species, which successive authors have acknowledged to be distinct, are, nevertheless, in many cases regarded as synonyms; thus Ferns long accepted by previous pteridologists cease to be so. When I say long accepted, I go upon the eridence of Link, Kunze, Schott, Mettenius, and myself, who have had for many years under their observation living examples of species all well recognised as being different from one another by some important characters seen only in the living state, but Mr. Baker, with herbarium specimens, makes no scruple of lumping many of such

* The first published by Dulau and Co., 37, Soho Square, London ; the "Synopsis" by Hardwicke, 192, Piccadilly. 
under one specific name. For instance, under Polypodium lycopodioides there are no less than twenty-two synonyms, and under $P$. brasiliensis eighteen. These examples are additional proof of what has already been said of the confusion of the nomenclature of Ferns, brought about by the different views of Pteridologists.

I conclude this part by noticing a memoir, published in 1866, by J. E. Bommer, Secretary of the Royal Botanic Society of Brussels, in the bulletin of the Royal Society of Belgium, vol. 5, No. 3, 1866, entitled "Monographie de la Classe des Fougères," being a review of the writings on Ferns by different authors, beginning with Bernhardi, 1799. He gives an abstract of the classification of the principal authors, but as nothing specially new is brought forward above what is noticed in the preceding pages, it is not necessary to enter into details : he concludes by giving an arrangement of his own which also presents nothing new.

The memoir is accompanied by six finely executed plates; the first shows the different forms of the sporangia and synangia ; the other five plates contain portions of the fronds, illustrating the character of forty-one genera.

Abstract showing the number of genera of the preceding anthors :-

Sprengel, "Systema Vegetabilium" (1827), 65.

Presl, "Tentamen Pteridographiæ," and other works, including Hymenophyllea 35, 230.

J. Smith's Arrangement (1841), 143.

Fée, Polypodiaceæ only (1852), 181.

Moore's "Index Filicum" (1857), 178.

Hooker's "Species Filicum" 5 vols. (1864), 66.

Hooker's "Synopsis Filicum " (1874), ed. 2., 76.

J. Smith, in the present work, 220. 
5.- ON THE GENERA AND THEIR CLASSIFICATION, AS FOUNDED ON THEIR MODES OF GROWTH AND HABIT.

In the preceding pages I have given a general view of the principal writers on Ferns, and their systems of classification. I will now proceed to explain the reasons that have induced me to attempt to draw up a natural arrangement of Ferns, reviewing as I proceed the data upon which the genera are founded.

In my first general arrangement in 1841, I characterised the whole of the circinate Ferns under divisions and tribes, as shown in the abstract of my arrangement, given at page 33 , the characters of which are in general obvious, so that any Fern with perfect fructification can readily be referred to its proper tribe. A system of classification so based is therefore practically useful, but it must be viewed as purely artificial, for, although many of the genera in any one tribe are naturally allied in general habit, yet others of totally different habit, but possessing the technical character of the tribe, are found associated with them; while on the other hand genera closely allied in natural habit and organisation are placed in separate tribes. For example, the genus Goniopteris has naked sori, while its congener Nephrodium has indusiate sori, they are consequently placed apart in any arrangement which is based on the absence or presence of indusia. In both these genera the species are numerous, and in many cases are so alike that in the absence of the indusium, specimens of Nephrodium are referred to Goniopteris. The same applies to the extensive genera Lastrea and Phegopteris, both of which contain closely allied species.

When the indusium is absent in normal indusiate genera, it is in general impossible, even by the most careful micro- 
scopic examination to discover that it ever was present; that organ, therefore, cannot be depended upon for determining the genera of the tribe Phegopteridece by herbarium specimens.

The relation of one genus to another is also governed by the fertile frond being more or less contracted ; for instance, all contracted fronds with naked sporangia closely occupying the whole underside, or in irregular masses, are referred to the tribe Acrostichece; but in some this character is not always perfect. For instance, in the genus Pocilopteris, the fertile fronds vary in their degree of contraction, and some being but slightly contracted, the veins being distinct, forming obvious well-defined receptacles,* which, when viewed in conjunction with the general habit and mode of venation, indicates the relationship of Pocilopteris to be with Meniscium. This affinity is further confirmed on comparing it with the original herbarium specimens of Meniscium simplexs (Lond. Journ. Bot. v. 1, t. 11), which are strictly characteristic of the genus Meniscium, but since the species was first described it has been introduced in a living state to the garden collection, and has produced fertile fronds so completely contracted, that if such state had been in the first instance observed by the learned author, he would not have hesitated in referring it to Acrosticheoe. Other instances also occur to show that Meniscium and Poesilopteris are naturally related.

I have now said sufficient to show that the placing of such examples of naturally allied species in different genera must be admitted as only an artificial convenience for arrangement.

The various forms and direction of the sori also consti-

* On this state Sir William Hooker founded the genus Jenkinsia. Hook. Gen. Fil., t. 75, B. 
tute an important part in defining genera; but in many cases if the characters derived from the form are strictly adhered to, species possessing very different appearances are brought together. For instance, the small grass-like Ferns of the genus Grammitis of Swartz are characterised by having linear naked sori; but by adhering to this simple character alone, species of very different habit would be included, as Gymnogramma, Stegnogramma, Loxogramma, Pleurogramma, Sellegua, and others, which, as already stated, has to a considerable extent been so done in the "Species Filicum." The sori are also liable to vary in form and size in different specimens of the same species, or even on the same, or different fronds of the same plant. This usually happens by the contignous punctiform receptacles uniting laterally, when they assume on oval, oblong, or linear form. Examples of this may be found in the genera Pleopeltis, Phymatodes, Pleuridium, Drynaria, Aspidium, and others. A remarkable instance of this occurs in the splendid Fern Drynaria coronans (Polypodium coronans, Wall.), a species with large pinnatifid fronds, which in the presumed normal state as generally observed, has the sori distinctly punctiform, and produced in a single row between each pair of the primary veins. In some fronds, however, the sori are so completely united in a lino as to form a true linear sorus, and hence not only agree perfectly with the character of Grammitis, as defined by Swartz, but also with the genus Gymnogramma, as characterised in the "Species Filicum." These examples show that the form of the sori alone cannot be strictly depended upon for defining genera.

In previous remarks I have stated that the mode in which the vascular structure traverses the fronds (venation) affords important data in assisting to define the limits of genera. 
This is particularly the case in the extensive tribes Polypodiece, Acrosticheoe, Phegopterideoe, and Aspidiece, each of which contains groups of species possessing similar venation, and agreeing so perfectly in habit and mode of growth, that, in the absence of the fructification, it is often difficult to determine to which genus and tribe they should be referred. For instance, Phegopteris and Lastrea, Polybotrya and Polystichum, Goniopteris and Nephrodium, Dryomenes and Aspidium, respectively agree both in habit and venation, and all, with the exception of Polybotrya, have punctiform sori, and, as already stated, these and kindred genera can only be known from one another by the presence or normal absence of the indusium, or by the fertile fronds being contracted, as in Polybotrya. Therefore, taking all these points into consideration, it appears to me that, in order to arrive at the true affinity of Ferns, the vascular structure, in conjunction with mode of growth, must be viewed as forming the groundwork of any attempted natural classification. It must, however, be understood that differences in venation do not always indicate distinct modes of growth or habit; for example, Phegopteris and Goniopteris, Polybotrya and Saromanes, Pteris and Litobrochia, Adiantum and Hewardia, Lastrea and Nephrodium, Lindscea and Synaphlebium, respectively contain species perfectly analogous in habit and other characters, and only generically distinguished by the venation being free, or anastomose. Another circumstance to be considered is whether free or anastomose venation is always constant in the same species. In any uncertainty upon this point it is necessary to be first assured that the specimens under examination have arrived at sufficient age to have the normal structure of the species fully developed, for in fronds of young plants the renation is often free whilo in 
older or more perfect fronds of the plant, or different plants of the same species, it is anastomose. In some cases, however, the normal structure of the renation is partly anastomose, and partly free, as in the genera Goniopteris, Nephrodium, Hemitelia, \&c. In these genera the lower or basal venules of each parcel are anastomose, while the upper are free. In some genera, such as Adiantum, Lindscea, and Asplenium, the venation is normally free; anastomoses occasionally occur in different segments of the same frond, but such seem more accidental than normal.

From what I have now stated it will be seen that neither the form or position of the sori or venation, the absence or presence of indusium, taken singly or combined, can be depended on for determining natural genera. Such being the case, and having had under my notice examples of nearly 1,000 species of living Ferns, has led me to the conclusion that in order to form natural genera the different modes of growth must be taken into account, that is the manner in which the developing axis (caudex) increases, its direction, and the mode of evolution and attachment of the fronds. I find that Ferns present two very distinct modes of growth, which are comparatively as distinct as Exogens are from Endogens. My views on this subject first appeared in the "Botany of H. M. S. Herald," published in 1853 , but as that work may not be accessible to all engaged in the study of Ferns, I will repeat the substance of what is there given.

If Polypodium vulgare be examined, it will be seen that its fronds are produced singly from the sides of a creeping progressing stem, which has its accrescent apex always in advance of its young dereloping frond, each successive frond being produced singly from special nodes formed at more or 
less distance apart, and in an alternate manner on the sides of the progressing axis, the foot or base of attachment of the frond forming with the node a distinct and well marked articulation or joint, which ultimately becomes the point of separation of the mature frond, the node remaining permanent in the form of a round more or less elevated cicacrix. This mode of growth includes all Polypodiaceo, as restricted by me to the tribes Oleandrce, Davallice, Polypodece, and Platycerece. To this mode of growth I have given the name Eremobrya, and in characterising the genera the words vernation articulate are employed, and the progressing axis from which the fronds are developed surculum. The number of species referable to Eremobrya, however, are few in comparison with those which possess a very different mode of growth. If, for example, a plant of Lastrea Filic-mas be examined, the fronds will be found to be successively produced in a spiral manner from the apex of the stem, in the form of a corona or crown, and thus by successive development the stem is increased in height. All Ferns developing fronds in this manner, even the smallest, the axis of which does not rise above the ground, to lofty tree Ferns, belong to this division as also a numerous class which produce fronds similar to the above, but which form a decumbent stem lying on the ground or but slightly inclined upwards. This I term vernation fasciculate decum. bent, and the preceding vernation fasciculate erect. Another mode of growth is common to many Ferns, such for example in Pteris aquilina, Lastrea serra, Polybotrya osmundacea, the fronds are normally produced alternately, in a single series, from the apex of a decumbent or creeping stem (sarmentum). In some cases this mode of growth resembles that of Eremobrya, but from which it is quite distinct, and is readily known by the vascular structure of 
the stipes being continuous and intimately connected with the portion of the stem forming the internode between the fronds, from which they cannot be separated without laceration. In these three modes of growth - that is, whether the fronds are produced in a fascicle, forming an erect or decumbent axis, or in a single series-the principle of attachment is identical, and there being no articulation, as in Eremobrya, the bases of the stipes are so united and become indurated, forming the solid portion of the stem. To this mode of growth I have given the term Desmobrya, and in the definitions of the genera the venation is termed adherent.

The various modifications of Desmobrya $I$ have found useful as auxiliary characters in indicating natural genera, but there are exceptional cases of species of Lastrea and Nephrodium, with erect fasciculate vernation, not distinguishable by the character of their fronds from other species of the same genera with decumbent uniserial rernation; nevertheless the adoption of the vernation and the nature of the accrescent axis as part of the definition of genera is of much assistance in determining the relative affinities of many genera.

In general the difference between Eremobrya and Desmobrya, as above described, is obvious, and there can be no doubt that the two modes of growth are specially distinct, the plants being endowed with very different natures, the vital power and tenacity of life, and power of resisting drought being much stronger in Eremobrya than in Desmobrya ; and it is not a little remarkable that so far as observations upon cultivated plants enable me to ascertain, the latter are much more freely reproduced from spores than the former. It is also worthy of notice that in the importation of Ferns from distant countries, those of 
the division Eremobrya generally arrive in good condition, while those of Desmobrya, especially such as have slender stems, are often dead or in a very enfeebled state on their arrival.

The difference in the structure and mode of growth of the species of these two divisions may be admitted to be of equal importance for classification with the difference in structure of Exogens and Endogens in flowering plants. In all attempts to determine natural relationship on any special organ or structure, exceptions are never wanting. In the present case, examples of connecting links are in a few instances found between the two divisions. This is particularly so with the genus Elaphoglossum, which consists of numerous simple-fronded Ferns, and may be viewed as a truly natural genus. In many of the species the stipes have an evident articulation situated in some, more than half an inch above its base, and in many of the species it is marked by a slight swelling; and also by the part below the swelling being of a lark colour. No change, however, takes place in the structure, the bundles of vascular fibre pass uninterruptedly through the apparent articulation, but they are evidently weaker at that point; for, when mature, the stipes separate there, the base portion remaining attached to the developing axis, which is either fasciculate or uniserial and adherent. I therefore place Elaphoglossum in Desmobrya.

Another instance of the stipes being jointed above its base is characteristic of the original species of the genus Woodsia, as also in species of Arthropteris; but the base of the stipes being adherent, indicates their position to be in Desmobrya. Also special examples of the articulation of the stipes in fasciculate vernation is exhibited by the genus Trichopteris and several species of Cyathea; for 
instance, in C. arborea and C. serra, the fronds are terminal, forming the characteristic corona common to tree Ferns. When mature they separate from the stem, leaving a clean scar similar to Eremobrya, thus differing from the adherent vernation characteristic of the mass of the species of the tribe Cyathea; but as they agree in all the essential characters as regards the nature of their fronds and fructification, it is therefore necessary to obtain more evidence as to the mode of evolution and structure of these tree Ferns before any satisfactory conclusion can be arrived at, as to enable us to view it as a special character to mark distinct genera.*

This now leads me to notice another family of Ferns -namely, Marattiacece, which have a very distinct and special habit from other Ferns, and are well marked by the sporangia being destitute of a ring. The evolution of the frond is terminal and articulate to the caudex, as in Cyathea arborea above noticed, but differs in the fronds rising from between two stipuliform appendages in the form of a socket, analogous to the stipules of phænogamous plants. The speciality of this group of Ferns leads me to view it as constituting a distinct division, which I have named Scaphobrya.

This division comprehends but a small number of species as compared with Eremobrya and Desmobrya, the number probably not exceeding thirty or forty, the principal part of which are included under the genera Marattia, Angiopteris and Danea.

* Since the above was written, a valuable memoir " On the Structure and Formation of the Stems of the Tree Ferns of India," has been published in the thirtieth volume of the Transactions of the Linnean Society, 1874, by Mr. J. Scott, Curator of the Botanic Gardens, Calcutta. It consists of thirty-nine pages of letterpress, accompanied by eighteen plates. 
I have also to notice that articulation is not confined to the stipes alone; the segments of fronds-laciniæ, pinnæ, and pinnules-being in many instances articalate with their respective rachis, whether primary or secondary. This is particularly characteristic of the genera Drynaria, Arthromeris, Schellolepis, and Photinopteris in Eremubrya; and Nephrolepis, Isoloma, Didymo. chloena, Cystodium, and others in Desmobrya, as also in Scaphobrya.

By paying attention to these points they are found serviceable in determining the natural affinity of species. Several of the above genera, as also Arthropteris, Ceratopteris, Platycerium, and Amphiblestra, possess characters peculiar to themselves, which necessitates their consideration as aberrant genera; cousequently the nature of their fructification, venation, and habit, must be conjointly viewed in determining the tribe to which they seem most naturally to belong.

On taking a retrospective view of the preceding observations, it will be seen that every defined form of the organs or structure that serve for defining genera, whether artificial or natural, are liable to vary more or less from the adopted typical normal form, and thus afford ample scope for Pteridologists to name and classify genera according to their views of the value of the several organs. On this point two authors seldom agree; hence great confusion is introduced into the nomenclator of Ferns. Some may be called conservative, such as Hooker and Mettenius, who maintain entire the old genera of Linnæus and Swartz; while others, as shown in the preceding pages, break up these large genera into a number of smaller ones.

These different views are consequent on there being no 
law of nature to mark where a genus begins or where it ends. On this point, in my "Arrangement of the Genera of Ferns," published in 1841, I have said-" A gradual transition of form is seen to pervade through the whole, not in a lineal, but in a complex reticulated manner, it becomes very difficult to determine in which genus the extreme or transition species of groups should be placed."

On considering that in many cases habit is not excluded in assisting to define the genera of flowering plants, and in numerous instances it is allowed by eminent botanists to constitute the chief distinction between allied genera. For example, the order Liliacece is represented by nearly 1,700 species, arranged under about 150 genera, which all agree as regards their parts of fructification, the slight variations of which are made use of for defining genera; and, indeed, if it was not for the difference in habit, the number of genera are capable of being greatly reduced. This and other instances that might be quoted favour my view, that in order to constitute natural genera of Ferns, habit must play an important part; and so long as any number of species agree in habit, and possessing other characters in common, it matters not whether such groups are called genera, sub-genera, or sections of genera. For my own part, I prefer regarding them as genera, as it saves a great deal of unnecessary trouble in speaking or writing about Ferns, it being much easier to say Drynaria coronans than Polypodium (Drynaria) coronans, or Elaphoglossum conforme than Acrostichum (Elaphoglossum) conforme, or Gymnogramma calomelanos than Gymnogramma (Eugymnogramma) calomelanos; also by studying the character of the smaller groups individually, and treating them as genera, their nature at once becomes fixed upon the mind, without having to think of them being asso. 
ciated with a host of species differing widely in habit. Admitting that a greater or lesser number of species possess some character in common to entitle them to be called genera, nevertheless, genera may be said to have no real existence in nature, but, by adopting them, we are enabled to study and classify Ferns so as to convey to the mind our ideas regarding the various forms and nature of the numerous plants that come under our observation.

In the preceding observations I have shown that habit is of great importance as a character for determining the relationship of Ferns to one another, either as individual species or groups of species, but habit is not always available, especially in describing from herbarium specimens alone, for it is only the small growing kinds, with caudex and fronds united, that are suited for the herbarium. A great number consists of single fronds, or even portions of fronds, only, consequently, the nature of their vernation is unknown. Indeed, the great botanists of the present day content themselves with describing plants from dried specimens, many of which are often small and imperfect, and fail to convey the true nature of the plant in its living state.

The celebrated botanist Mr. Bentham says :- "I have published several thousands of new species of plants, I have never published one without examining it in a herbarium, and I have examined very few in botanical gardens." This practice I call unfortunate, for although the living collection at Kew may not at any time exceed one-tenth of the species in the herbarium collection, nevertheless it affords ample materials for verifying and assisting to correct errors in many descriptions made from herbarium specimens only. With regard to the collection of living Ferns, which the author of the "Species Filicum" calls 
" the finest in cultivation," it in 1864 consisted of nearly one-half of the number of the species described by him in that work, but of these the learned author made less use than might have been expected. This was consequent on finding a considerable difference in describing species from living plants and herbarium specimens; for in many cases it was found that it was not till specimens of the cultivated plants were dried that they could be identified with native specimens of the same supposed species in the herbarium; consequently the descriptions in the "Species Filicum" are, with few exceptions, entirely founded on specimens in the author's herbarium.

With me it was otherwise: the living collection requiring daily care and attention, led me to become acquainted with the special habits and modes of growth of the different species; and this has enabled me draw up the following natural arrangement. I say natural, but it must be understood that any sequence of allied genera has its limit, and that it is only in individual tribes that genera, in most cases, can be so arranged as to form natural transitions from one to another. By this several tribes become naturally connected, while others, such as Aspleniear, Hymenophyllex, and Gleichenieoe, may be called independent tribes.

The principle of the following arrangement is based on the different modes of vernation and habit. It begins with the division Eremobrya, followed by Desmobrya and Scaphobrya ; each of these divisions are divided into tribes, of which there are twenty-nine in all ; each tribe contains a greater or lesser number of genera, and the genera of each tribe when possessing any well marked differential characters are arranged under sections. The characters of each genus are giren, beginning with the nature of the 
rernation, followed by that of the fronds and renation, and ending with the form and position of the sori and indusium when present.

As regards synonyms of both genera and species, I have in the preceding pages shown that they may be termed legion, the number of generic names being above 500. To quote all or any considerable number of them, would be the means of making this book much larger than desirable, and add much to confuse students and dismay them from studying Ferns.

To each genus I have given its authority and date, followed by its principal synonyms and reference to the genus under which the species stand in Sir William Hooker's "Species Filicum;" and for their identification I have deemed it sufficient to quote the figures in Hooker and Bauer's "Genera Filicum," the "Synopsis Filicum." Moore's "Index Filicum," and my "Ferns, British and Foreign." These, with plates in this work illustrating the tribes and genera, and with the observations under each genus, will, I trust, be sufficient to convey to the student of Ferns a knowledge of their nature and the data upon which they are classified.

With regard to species, when few in a genus I have quoted the whole, and for examples of the large genera have quoted the principal and best known species; in several cases for their identification I have referred to figures in different works.

I have already shown that it is the rule to retain the original specific name of a species under whatever genus it may be placed by succeeding authors; some writers, however, in arranging them under different genera affix their initials to the specific name, from which it often appears as though the species were new and named and 
described for the first time. To avoid this I have as far as possible followed the plan adopted in my "Arrangement of Ferns," in 1841, where I have said that "The authority for the specific names being in a parenthesis denotes that such species stood formerly under one or other of the genera given as synonyms."

I have to add that on account of the gradual failure of my sight I have not been able to determine the position of certain species. I therefore direct the special attention of those who adopt my mode of classification, to the mass of species included under the section Eupolypodium of the "Species Filicum," of which the author says the stipes are "articulated upon the candex, as appears to be all of this group," of which there are 151 described. I have, however, failed to identify more than fifty of the species as having articulate vernation, and which 1 place under Polypodium as restricted by me, and as far as I have been able to determine the many species represented by $P$. trichoma noides, $P$. moniliforme, and $P$. peruviana, have adherent vernation, and which I refer to the genus Ctenopteris in Desmobrya. I also direct special attention to the arboroid species of Phegopteris, Lastrea, Goniopteris, and Nephrodium, which, on account of their special habit, and the pinno being articulate with the rachis appears to me of sufficient importance to warrant their separation from the more humble species of their respective genera.

The extensive genus Elaphoglossum also presents great difference in the nature of its vernation, which appears to be of sufficient importance to justify the species being arranged in separate generic groups.

I conclude my general observations on the classification of Ferns by saying that my views, like those of other writers, are open to criticism. If the critics have studied 
garden and herbarium collections of Ferns as zealously as I have done, whether their criticisms be favourable or unfavourable to my views as regards the genera of Ferns, it is hoped that their observations will, as Sir William Hooker said, be the means of throwing "a new light on the study of Ferns, a light which cannot fail to aid the researches of future writers." 


\section{PART II.}

GENERAL ARRANGEMENT AND CHARACTERS OF TRIBES AND GENERA, WITH REMARKS ON THEIR RELATIONSHIP ONE TO ANOTHER.

\section{ABSTRACT OF THE ARRANGEMENT.}

1.-Evolution of the Fronds circinate.

This includes all Ferns except the small tribe Ophioglos. sacece, in which the vernation is straight.

A. Ring of Sporangia vertical (Order Polypodiacece, R. Br.)

\section{DIVISION I. - EREMOBRYA.}

Fronds solitary, lateral, and articulate with the caudex.

Tribe 1.-OLeandreq.

Gen. 1. Oleandra, Cav.

$$
\text { Tribe 2.-Davallite. }
$$

Gen. 3. Davallia, Sm., Humata, Cav., Leucostegia, Pr.

$$
\text { Tribe 3.-PoLyPodiex. }
$$

Gen. 28. Ex. Polypodium, Phymatodes, Diynaria.

Tribe 4.-Hymenolepidia.

Gen. 6. Ex. Drymoglossum, Hymenolepis, Aeurodium.

Tribe 5.-Pratycerea.

Gen. 1. Platycerium. 


\section{Division II.-DESMOBRYA.}

Fronds terminal, solitary, fasciculate, adherent to the caudex.

Tribe 6.-ACROSTICHEA.

Gen. 22. Ex. Elaphoglossum, Polybotrya, Gymnopteris.

Tribe 7.-Meniscees.

Gen. 2. Meniscium, Dictyocline.

Tribe 8.-Grammitidea.

Gen. 15. Ex. Hemionites, Gymnogramma, Llavea.

Tribe 9.-Ceratopteridee.

Gen. 1. Ceratopteris.

Tribe $10-V_{\text {ITtARIE }}$.

Gen. 3. Vittaria, Pteropsis, Dictyoxiphium.

Tribe 11.-Pleurogrammee.

Gen. 8. Ex. Monogramma, Grammitis, Xiphopteris.

Tribe 12.-CTENOPTERIDEe.

Gen. 4. Ex. Ctenopteris, Adenophorus, Glyphotoenium.

Tribe 13.-Phegopteridea.

Gen. 29. Ex. Phegopteris, Aspidium, Dipteris, Lastrea.

T'ribe 14.-Physematee.

Gen. 4. Ex. Woodsia, Peranema, Diacalpe.

Tribe 15. Crathees.

Gen. 7. Ex. Cyathea, Hemitelia, Alsophila.

Tribe 16.-Dicksonia.

Gen. 5. Ex. Dicksonia, Thysopteris, Cibotium.

Tribe 17.-SACCOLOMEe.

Gen. 7. Ex. Microlepia, Loxoma, Saccoloma.

Tribe 18.-LINDSEex.

Gen. 4. Ex. Lindsoea, Schizoloma. 


\section{Tribe 19.-ADIANTE}

Gen. 2. Ex. Adiantuni, Hewardia.

Tribe 20.-Cheilanthes.

Gen. 8. Ex. Cheilanthes, Pellece, Cassebeera.

Tribe 21.-PTERIDEAE.

Gen. 8. Ex. Pteris, Litobrochia, Lonchitis.

Tribe 22.-BLECHNEA.

Gen. 11. Ex. Blechnum, Lomaria, Woodwardia.

Tribe 23.-AsPLeniez.

Gen. 12. Ex. Asplenium, Scolopendrium, Diplazium.

B. Ring of sporangia, horizontal, central.

Trỉe 24.-Gleichenies.

Gen. 4. Ex. Gleichenia, Matonia.

Tribe 25.-HyMenophrLles.

Gen. 4. Ex. Hymenoph̆yllum, Trichomanes.

C. Ring of sporangia horizontal, apical, in some incomplete.

Tribe 26.-Schizes.

Gen. 8. Ex. Schizcea, Anemia, Lygodium.

Tribe 27.-OSMUNDACE

Gen. 2. Osmunda, Todea.

D. Sporangia destitute of a ring.

Division III.-SCAPHOBRYA.

Fronds terminal, rising from between two stipuliform or socket-like appendages, and articulate with the caudex.

Tribe 28.-MaratTiace.

Gen. 5. Ex. Marattia, Danea, Angiopteris.

2. Evolution of the fronds straight.

Tribe 29.-OPHIOGLOSSACEA.

Gen. 3. Ophioglossum, Helminthostachys, Botrychium. 
GENERAL ARRANGEMENT, \&c. Evolution of the fronds circinate.

\section{Division 1.-EREMOBRYA. (Page 65).}

A. Ring of Sporangia vertical.

* Sori Indusiate.

\section{Tribe 1.-OLEANDREA. (Plate 1.)}

Sori round, lateral. Indusium lateral, interiorly attached or sometimes central, plane.

1. Oleandra. Cav. (1801).

Aspidium sp., Swartz. Newronia, Don. (1825). Ophiopteris, Reinw.

Surculum slender, creeping, or erect, and sub-frutescent. Fronds simple entire linear lanceolate, 1 to $1 \frac{1}{2}$ foot long, smooth or pilose. Stipes short, node of articulation sessile, or more or less elevated. Veins simple, or once or twice forked, venules free parallel, their apices curved outwards, forming a narrow cartilaginous margin. Sori punctiform lateral, scattered or transversely uniserial. Indusium plane, orbicular or reniform.

Type. Aspidium articulatum, Swartz.

Illust.-Hook. and Bauer, Gen. Fil. t. 45, B. Moore Ind.

Fil. p. 72 A. J. Sm. Ferns Brit. and For. fig. 1. Hook.

Syn. Fil. t. 5 , fig. 46.

OBs.-By early authors the species of this genus were placed in Aspidium, but their distinct and peculiar habit, together with their articulate vernation, does not accord with any genus of the Aspidece Alliance.

Fée enumerates thirteen species of this genus, but the great uniformity in the form of the fronds renders it quite impossible to find sufficient and permanent characters for that number; the most differential characters being in 


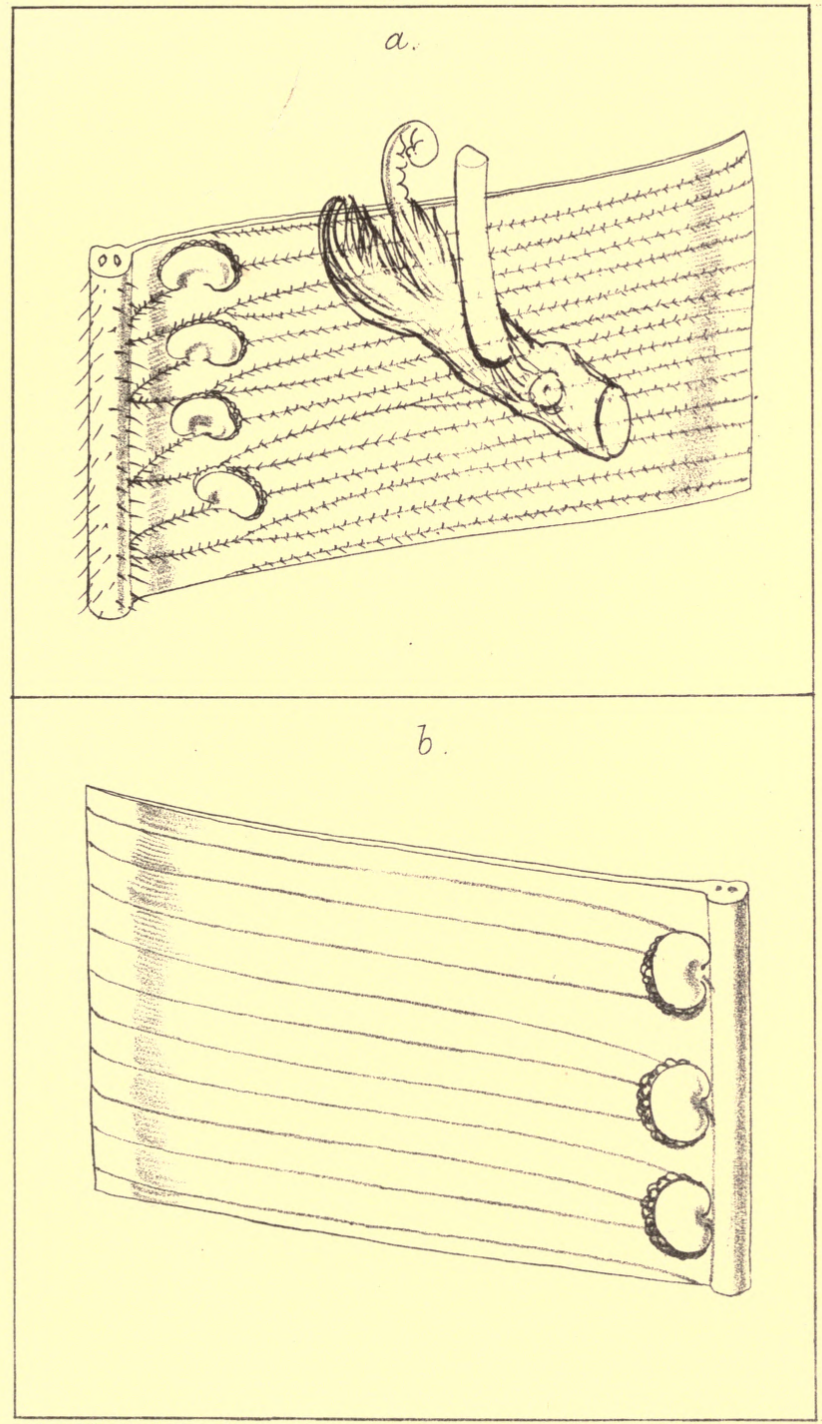



, 
PZ. 2 .

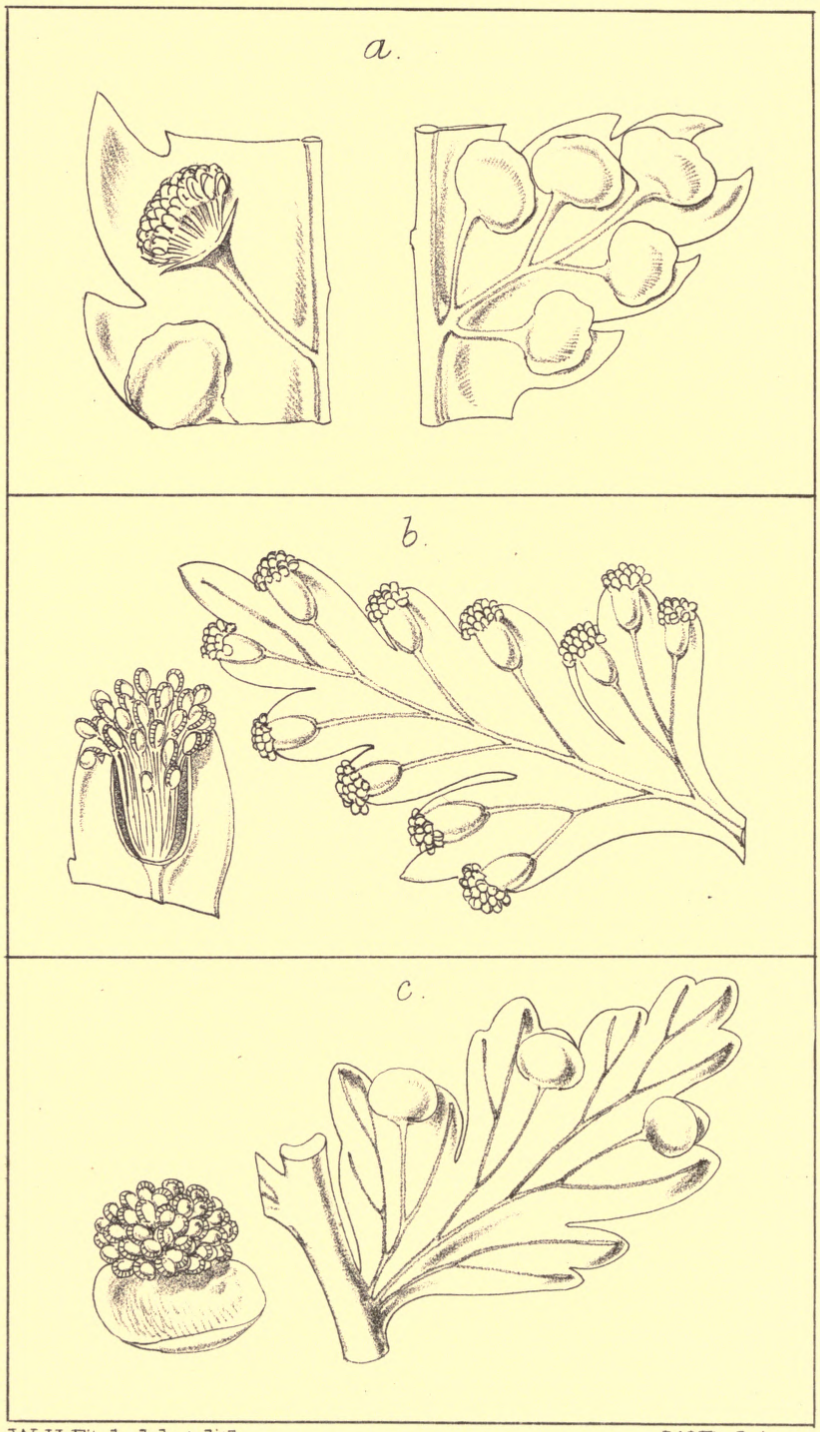

W.H.Fitch, del.et Jith. 
the decumbent or erect nature of the rhizome, and the more or less elevation/of the node of articulation, and in the position of the sori. The following are admitted in the "Synopsis Filicum" as distinct species.

Species :-O. neriiformis, Cav. ( $\mathrm{v}$ v. $)^{*}$; O. musæfolia, Kunze (Bedd. Ferns, Brit. Ind. pl. 264); O. articulata, Cav. ( $\vee$ v.) ; O. nodosa, Willd. (v v.); O. Wallichii, Hook.; O. Cumingii, J. Sm.

The genus is widely distributed, being found in the region of the Himalaya, Malay Archipelago, and Philippine Islands, as also in the West Indies and Tropical America. O. neriiformis is a peculiar Fern, differing from the rest of the genus in having erect frutescent branching stems, about half an inch in diameter, and rising to the height of from four to six feet, bearing lateral whorls of simple fronds. It may be viewed as the only representative of a shrub among Ferns. It is found throughout the tropics of America and India, and in the Malay and Pacific Islands.

\section{Tribe 2.-DAVALLIE $Æ$, J. Sm. (Plate 2.)}

Veins free. Sori terminal, marginal, punctiform. Indusium forming a more or less complete cyst, opening exteriorly.

OBs.-In the "Species Filicum," 112 species of Davallia are enumerated, which, in the "Synopsis," are reduced to seventy-nine. This number consists of species both with articulate and adherent vernation; the latter consequently comes under the division Desmobrya. About forty species have articulate vernation, and are comprised under the

* These letters indicate that the species have been cultivated at Kew, as recorded in "Ferns : British and Foreign." 
three following genera. They are all natives of the Old World, not being represented in America.

\section{2.-Humata, Cav. (1801.)}

Davallia in part; Smith and other authors.

Surculum slender. Fronds linear, lanceolate, entire, sinuose, pinnatifid, or deltoid bipinnatifid, rigid, glossy, rarely squamose, 4 to 12 inches in height. Veins simple or forked, free, often thickened upwards. Sori marginal or antimarginal. Receptacles punctiform. Indusium subrotund, or reniform, entirely attached by its generally broad base, shorter or equal with the margin, forming a bilabiate firm cyst.

Type. Davallia pedata, Smith.

Illust.-Hook and Bauer, Gen. Fil., t. 114 A ; Moore, Ind. Fil., p. 74.; J. Sm., Ferns Brit. and For., fig. 2; Hook. Syn. Fil., t. 2, fig. 18, a. b. c.

OBs.-This genus consists of about a dozen species, natives of the Malayan, Philippine, and Asian Islands of the Pacific Ocean. It is distinguished from true Davallia by the indusium being attached by its interior base only.

Ex.-H. angustata, Wall.; H. heterophylla, Sm. (i v.); H. pectinata, Sm.; H. parallela, Wall. ; H. pedata, Sm. ( $\vee$ v.); H. sessilifolia, Bl.; H. Cumingii, Hook. ( $\nabla$ v.); H. vestita, Bl.; H. Tyermani, Moore (App. Hook. Syn. Fil.).

\section{3.-Davallia, Sm. in part (1793).}

Davallia in part, Hoot. Sp. Fil.

Surculum creeping, or sub-erect and sub-frutescent. Fronds pinnate, bipinnate or deltoid multifid, firm and 
glossy, rarely flaccid, from 6 inches to 3 feet high. Veins forked, venules free; fertile venules sometimes very short, dentiform. Sori terminal. Receptacle punctiform. Sporangia vertical, included within an urceolate or tubular indusium.

Type. Davallia canariensis, Smith.

Illust.-Hook and Bauer, Gen. Fil., t. 27 ; Moore Ind. Fil., p. 75 B. ; J. Sm. Ferns Brit. and For., fig. 3; Hook. Syn. Fil,, t. 2, fig. 18, c.

OBs. This genus consists of about a dozen or more species, widely distributed over the Eastern Hemisphere, the extreme western limits being the Azores and Canary Islands. It differs from Humata in having the indusium attached by its base and sides, impressed in the substance of the fronds, thus forming an urceolate tubular cyst.

Ex.-D. triphylla, Hook.; D. pentaphylla, Bl. ( $\vee$ v.); D. bullata, Wall. ( $(\mathrm{v})$; D: mauritiana, Hook.; D. fijiensis, Hook. ; D. solida, Sw. ( $\left.\nabla \nabla_{0}\right)$; D. ornata, Wall. ( $\left(\nabla_{0}\right)$; D. pyxidata, Cav. ( $\left.\vee \nabla_{0}\right)$; D. divaricata, $B l$. ( $\vee$ v.) ; D. elata, $S w$. ( v .) ;"D. elegans, Sw. ( $\vee$ v.) ; D. pallida, Mett. (v v); D. nitidula, Kze. ( $\vee$ v.) ; D. Vogelii, Hook. ( $\vee$ v.) ; D. canariensis, Sm. ( $\vee$ v.) ; D. dissecta, J. Sm. ( $\vee$ v.).

\section{4.-Leucostegia, Presl (1836).}

Davallia, sp. Hook. Sp. Fil.; Acrophorus, Moore.

Surculum slender, or short and thick (hypogeous in $L$. immersa). Fronds lanceolate, bipinnatifid, or deltoid-multifid, generally membraneous and flaccid, from 2 inches to $2 \frac{1}{2}$ feet high, smooth, rarely pilose, the ultimate divisions mostly bifid and soriferous below the sinus. Veins forked; venules free, the anterior ones often very short. Sori terminal, sub-marginal. Receptacles punctiform. 
Indusium sub-reniform, oblong or nearly orbicular, plane, interiorily attached by its base, and partly by its sides, equal with, or shorter than the margin, thin, scariose.

Type. Davallia immersa, Wall.

Illust.--Hook and Bauer, Gen. Fil, t. 52, A ; Moore, Ind. Fil., p. 73, B. ; J. Sm., Ferns Brit. and For., fig. 4.

OBs.-This genus as founded by Presl consisted of only one species, namely Davallia immersa of Wallich, which has pale deciduous fronds, rising from a bypogeous creeping caudex. Although the character of the sori differs little from that of Humata, its distinct habit does not allow it to be associated with that genus or with Davallia; which is also the case with other species of Davallia of authors, which I here place under Leucostegia. They are widely distributed throughout the same countries as those of the preceding.

Sp.-L. parvula (Wall.) ( $\vee$ v.) ; L. falcinella (Pr.); L. affinis (Hook.) ( $\nabla$ v.) ; L. Griffithiana (Hook.); L. chærophylla (Wall.) ( $\left.\nabla \nabla_{0}\right)$; L. pulchra (Don.) ( $\left.\nabla \nabla.\right)$; L. immersa $(P r).(\nabla \vee$.$) ; L. membranulosa (Wall.); L. hirsuta (J.Sm.)$ ( $v$ v.); L. borneensis (J. Sm.) (Nephrodium, Hook.); L. assamica ( $\nabla$ v.) (Bedd. F. Brit. Ind. Fil. 94).

OBs.-In Moore's "Index Filicum," the above species are all placed in the genus Acrophorus of Presl, which is founded on Aspidium nodosum of Wallich, a large growing Fern of peculiar habit, and having no natural affinity with the species of Leucostegia, its vernation being adherent and fasciculate (see Acrophorus).

\section{* Sori destitute of Indusium.}

\section{Tribe 3.-POLYPODIE E. (Plate 3.)}

Veins free or anastomosing in various ways. Sori 


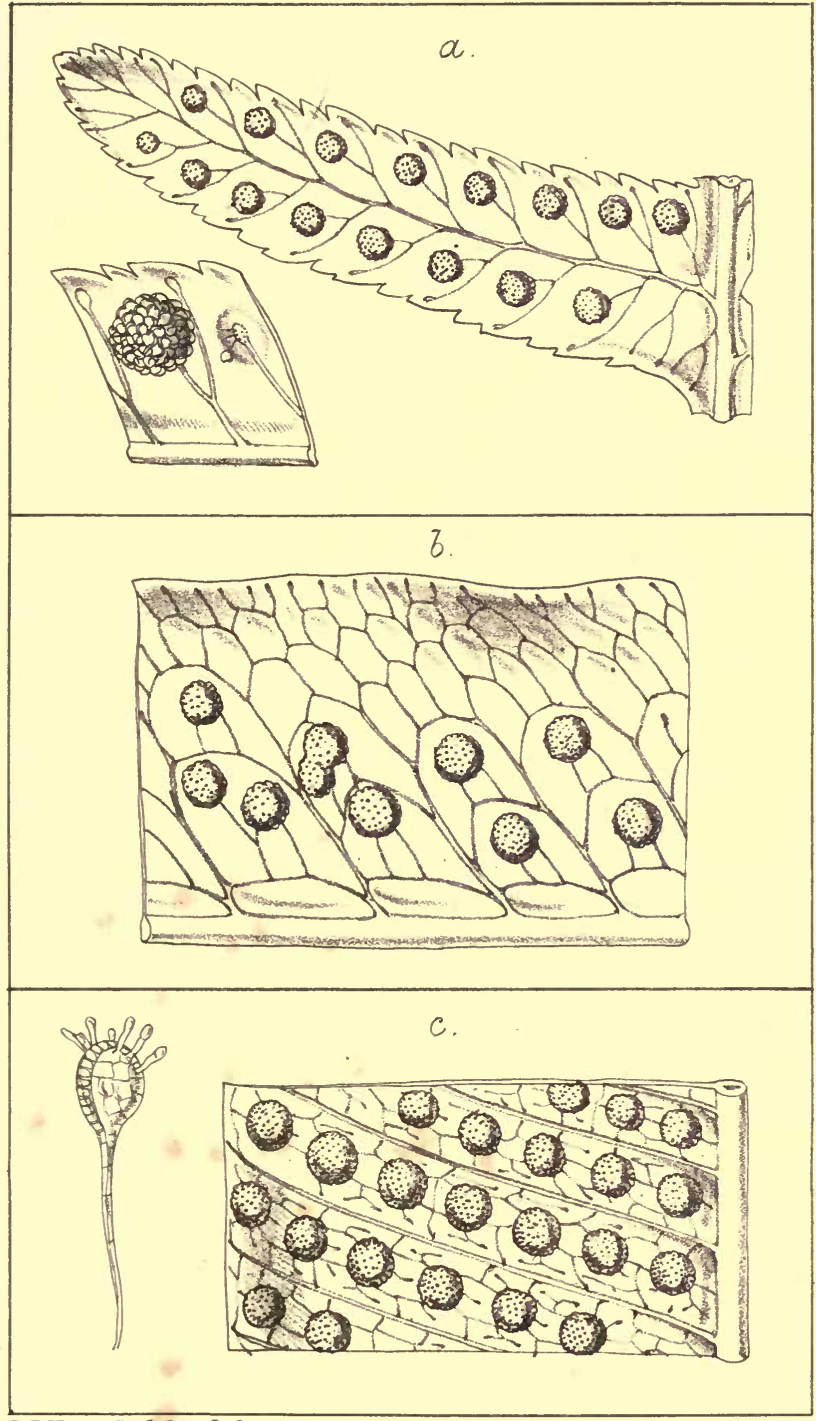

W.H.Fitch, del.et hith. 

terminal, lateral or compital, punctiform, oblong, or by confluence linear naked.

OBs.-This tribe consists of about 200 described species. The greater number come under the genus Polypodium, as characterised by early authors, that is in having punctiform naked sori. The greater mass of the species have anastomose venation, from simply reticulated to compound, with free veinlets terminating in the areoles. In many cases this difference alone is not sufficient to define natural genera; to do so it is necessary to make habit and any other special structure of the fronds an important character in arranging the species into natural groups, which, on account of the gradual transition, it in many cases becomes difficult to determine the group in which the transition species should be placed. Authors are much divided on this point, for instance, the venation of Phymatodes as characterised by Presl, I in 1841, considered it did not differ from the earlier founded genus Drynaria of Bory, while Moore, in his "Index Filicum," places the whole of Presl's Phymatodes, with the exception of the section Drynaria, under the early named genus Pleopeltis, also including under it the whole or a portion of the species of no less than twenty-four genera of different authors. Of Drynaria of Bory he says, "We have kept separate the very distinct-looking little groups of Drynaria and Dipteris, the former distinguished by its peculiar sessile, sterile fronds, the latter by its peculiar dichotomo-palmatafid fronds, rather perhaps than by differences of higher value." After having carefully considered the different views of authors, and having had examples before me of the greater number of known species, I have been led to arrange the tribe Polypodece as follows :- 
* Veins free.

Sect. 1.-Polypodee.

5. Prosaptia, Presl (1836).

Davallice sp., Swartz. Hook., Sp. Fil.

Surculum short, cæspitose. Fronds contiguous, linearlanceolate, pectinate-pinnatifid, 6 to 12 inches high ; laciniæ oblong or linear, obtuse. Veins simple, free, internal. Receptacles terminal, seated in a marginal cyst formed of the substance of the frond and containing the sporangia.

Type. Davallia contigua, Swartz.

Illust.-Hook and Grev., t. 105, 141. Moore, Ind. Fil., p. 76 B.

OBS. - The urceolate marginal cyst containing vertical sporangia is analogous to the indusiate sori of Davallice, but differs entirely in being formed in the substance of the frond, and in having no indusiate membrane. The texture and pinnate character of the fronds indicates the affinity to be with the pinnatifid section of Polypodium.

Sp.-P. contigua (Sw.). P. Emmersoni (Hook).

Natives of Ceylon, Malay, and Polynesian Islands.

\section{Cryptosords, Fée (1843).}

Polypodium, sp., Bl. Hoole. Sp. Fil. Coelopteris, A. Br.

Surculum short. Fronds contiguous, linear-lanceolate, pinnatifid-pectinate, 1 to $1 \frac{1}{2}$ feet long. Veins of laciniæ simple, internal. Receptacles immersed, forming an oval cyst, the margin surrounded by incurved rigid hairs in. closing the sporangia.

Type. Polypodium obligatum, Blume.

Illust.-Fée, Gen. Fil., t. 19. Blume, Fl. Jav., t. 58. B. 84. B. 
Oвs.-In my "Genera of Ferns," 1841, I noticed the peculiarity of the species in the preceding genus, and also of this, but then did not deem the characters sufficient to separate it as a genus from Polypodium. Later observations, and the views of both Presl and Fée, induce me now to separate them from true Polypodiums.

Sp.-C. obliquatus (Bl.), (Bedd. F. Brit. Ind. pl. 167), C. celebicus ( $B l$.$) , C. venulosum ( B l$.$) , C. blechnoides$ (J. Sm.), (Grammitis blechnoides, Grev. 1848*, Cryptosorus Seemannii, J. Sm., Bonplandia, vol. 9), C. Khasyanus (Hook.).

Natives of Java, Celebes, Luzon, Fiji, Ceylon and India.

\section{7.-Thylacopteris, Kze. Herb. (1856).}

Polypodium, sp. Blume. Hook, Sp. Fil.

Surculum slender. Fronds distant, stipate, linear, pinnatifid, membraneous, smooth, 1 to 2 feet high, 2 inches broad, laciniæ articulate with the rachis. Veins once forked, venules free, the exterior branch soriferous. Receptacles punctiform, terminal, deeply immersed in a cyst, forming elevated papillæ on the upper side. Sori transverse, uniserial near the margin of the laciniæ.

Type. Polynodium papillosum, Blume.

Illust.-Bl. Fl. Jav., p. 191, t. 88. Horsf. Pl. Jav. Rar., p. 6, t. 2.

OBs.-Finding that the Polypodium papillosum of Blume does not well associate with any of the species of Polypodium as here restricted, I therefore deem it best to follow Kunze in adopting it as a distinct genus. The forked venation distinguishes it from Prosaptia and Cryptosorus; and the deeply-impressed receptacles and the articulation of the segments with the rachis from true Polypodium. 
Sp. T. papillosa $(B l$.).

A native of Java and the Philippine Islands. With the exception of $P$. vulgare this is the only representative of the forked free-veined Polypodice in the Eastern Hemisphere.

\section{8.-Polypodium, Linn. in part (1737).}

Surculum generally short and thick, in some hypogeous. Fronds pinnatifid, pinnate, or rarely bi-tripinnatifid or simple, smooth, villose or squamiferous, from a few inches to two or three feet high. Veins once or more times forked free, exterior branch soriferous. Receptacles terminal, punctiform, superficial. Sori round, rarely oval, transversely uniserial or solitary on laciniæ of multipartate fronds.

Type. Polypodium vulgare, Linn.

Illust.-Hook and Bauer, t. 69, B. Moore Ind. Fil., p. 56, fig. 1. J. Sm. Ferns, Brit. and For., fig. 5. Hook. Syn. Fil., t. 5, fig. 48, a, b.

OBs. This genus as now restricted by me contains between thirty and forty known species, which, with the exception of $\boldsymbol{H}^{2}$. vulgare of Europe, are all natives of West Indies and the Continent of America, P. pellucidum extending west to the Sandwich Islands. The following are the principal species arranged in sections :-

\section{1.-Suspensum Group.}

Fronds linear, pinnatifid or subpinnate, villose, rarely smooth. Stipes long, slender, wiry, often arcuate. Veins sometimes simple, or with the soriferous branch very short.

Ex. P. comptoniæfolium, Desv. (P. scolopendrioides, Hook et Grev., p. 42); P. suspensum, Linn.; P. aspleniifolium, Linn.; P. cultratum, Willd.; P. Phlegmaria, J. Sm.; * P. lanigerum, Eat.; P. semiadnatum, Hook.; P. alternifolium, Hook.; P. melanopus, Grev.

$$
\text { * Lond. Journ. Bot., p. 196, vol. iv. }
$$




\section{2.-Pectinatum Group.}

Fronds linear or broadly elliptical, erect, somewhat rigid, more or less deeply pinnatifid.

Ex. P. Schkuhrii, Radd. ( $\nabla$ v.); P. laxifolium, Linn. ; P. pectinatum, Linn. ( $\nabla$ v.); P. Paradiseæ, Lang et Fisch ( $\vee$ v.); P. pulchrum, Mart. et Gal.

3.-Sororium Group.

Fronds erect, pinnate, pinnae sessile or petiolate, smooth or pubescent. Veins three to four times forked.

Ex. P. Martensii, Mett. ( $\vee$ v.), ; P. Hartwegianum, Hook.; P. puberulum, Schlecht.; P. subpetiolatum, Hook, ( v v.) ; P. sororium, H.B.K. ( $\vee$ v.); P. fraternum, Schlecht. $(\nabla \nabla$.

\section{4.- Vulgare Group.}

Fronds erect, generally thick, coriaceous, smooth, farinose or squamiferous, elliptical-lanceolate, pinnatifid, rarely simple or deltoid, and bi-tripinnately laciniated.

Ex. P. chrysolepis, Hook.; P. farinosum, Hook.; P. argyratum, Bory.; P. vulgare, Linn.; P. macrocarpum, Pr.; P. plebejum, Schlecht. ( $\vee$ จ.) ; P. madrense, J. Sm.; P. Skinneri, Hook.: P. fallax, Schlecht.; P. Frederichsthalianum, Kunze.; P. murorum, Hook.; P. onustum, Hook.; P. pellacidum, Kaulf.

OBs.-The fronds of the latter species and $P$. vulgare vary from pinnatifid to bi-pinnatifid, and even more divided and crested, of which $P$. vulgare presents many forms.

** Veins anastomosing in various ways.

Sect. 2.-Goniophlebie.

9.-Goniophlebium (1828) (Presl in part, 1836).

Polypodium, sect. Goniophlebium, Blume.; Marginaria, in part Presl; Polypodium; sp., auct., Hook. Sp. Fil. 
Surculum thick and fleshy, or slender and sub-hypogaceous. Fronds pinnatifid or pinnate, rarely simple, uniform, 1 to 3 feet high, smooth or slightly pubescent, segments and pinnæ adherent with the rachis. Veins once or more times forked, or equally pinnate, the lower anterior venule always free, the rest angularly anastomosing, and generally producing an excurrent free veinlet from their angular junctions. Receptacles punctiform, superficial, terminal on the anterior free venules, and also often on the excurrent veinlets. Sori round or rarely oblong, solitary in the areoles, transverse one to six serial, naked.

Type. Polypodium loriceum, Linn.

Illust.-Hook. and Bauer, t. 70, B. ; Hook. Syn. Fil. t. 5, fig. 48, h. ; J. Sm., Ferns Brit. and For., fig. 7.

OBs.-The name Goniophlebium was originally given by Blume to a section of Polypodium, consisting of a few species, natives principally of the Malayan Islands. Presl in his "Tentamen" raised the name to the rank of a genus, under which he enumerates eight species, three of which constitute Blume's section Goniophlebium, the others being natives of the West Indies and Tropical America. $\mathrm{He}$ also characterises another genus, and adopts for it the name Marginaria, first given by Bory to $P$. incanum of Swartz. Under this genus he enumerates thirty-six species, which he arranges under two sections. The first contains nine species, which differ entirely in habit from his second section, which consists of twenty-five species, sixteen of them, with the exception of $M$. amcena, being natives of America, and possessing no character either in habit or venation to distinguish them from Presl's American species of Goniophlebium. The other nine like those of the first species, although agreeing in venation, nevertheless differ entirely in habit. 
Under these circumstances, in my "Enumeration of Genera," in 1841, I deemed it proper to unite Marginaria with Goniophlebium, and stated that "the peculiarities of habit of the species forming this genus admit of their being arranged under several sections, which may with no great impropriety be considered as genera." And now (1875) finding that the species are variously arranged by different authors under at least ten or twelve different genera, although on bringing them together according to their natural habits, I find I cannot amend my original arrangement, I deem it best to rank the sections as genera.

In the "Species Filicum," Goniophlebium and Marginaria of Presl, are united and treated as a section of Polypodium in which are enumerated twenty-nine species, and in the "Synopsis," the number is increased to thirty-nine; but I must here observe that in consequence of determining species from herbarium specimens great confusion pervades the synonymy.

The following are examples of the best known species, of which fifteen have come under my notice in a living state :-

* Fronds simple.

G. glaucophyllum (Kze).

** Fronds pinnatifid.

G. Scouleri (Hook et Grev.), G. pectinatum (J. Sm. Bot. Voy. Herald), G. patens (J. Sm. Bot. Voy. Herald), G. triloba (Cav.), (Synaminia triloba, Presl), G. appendiculatum (Klot.), ( $\mathrm{v}$ v.), G. plesiosorum (Kze.), G. pubescens (Hook et Grev.), G. surrucuchense (Hook.), G. plectolepis (Hook.), ( $\vee$ v.), G. punctulatum (Hook.), G. loriceum (Linn.), ( $\nabla$ v.), G. latipes (Lang. et Fisch.), G. Catherinæ (Lang. et Fisch.), ( $\nabla$ v.), G. glaucum (Radd.), ( $\nabla$ v.), G. harpeodes (Link), $(\nabla \nabla \cdot)$, G. calpodes $\left(K_{z} e_{0}\right),\left(\nabla \nabla_{0}\right)$, G. lætum (Radd.), ( $\left.\nabla \nabla_{\bullet}\right)$, G. vacillans ( $\operatorname{Link}),(\nabla \nabla$.$) .$ 
**** Fronds pinnate.

G. fraxinifolium (Jacq.), ( $\mathrm{v}$ v.), G. distans (Radd.), ( $\mathrm{v}$ v.), G. menisciifolium (Lang et Fisch.), ( $\nabla$ v.), G. dissimile (Linn.), (v v.), G. chnoodes (Spring), G. attenuatum (H B.K.), G. inæquale (J.Sm.), ( $\vee$ v.), (Phlebodium, Moore), G. neriifolium (Schk.), ( $\left.\nabla \nabla_{0}\right)$, G. cordata (Kze.).

The whole of the above are natives of West Indies and America, extending to California and Chili; the greater number being found in the tropics.

No representative of the genus is recorded from Africa except the aberrant species, $G$. ensiforme (Polypodium ensiforme, Thunb.), a native of South Africa, which, although agreeing in venation, nevertheless differs essentially in the texture of the frond, which is thick and coriaceous, with immersed obscure veins, and large uniserial sori. In these respects it has the appearance of a Pleopeltis or Phymatodes, but is entirely destitute of scales.

The genus Synamia of Presl is founded on P. triloba of Cavanilles, and with it is associated Grammitis elongata of Swartz. The first is recorded above, and differs only from true Goniophlebium in having oblong sori; the other, which has also oblong sori, but differs essentially in habit, as also in venation, I place under Pleopeltis.

In $G$. incequale the costal areoles are void-that is, destitute of a free venule, in that respect agreeing with the allied genus Phlebodium.

10.-Schellolepis, J. Sm. (1866).

Goniophlebium sect. Schellolepis, J. Sm., 1841. Polypodium sp.; auct., Hook. Sp. Fil.

Surculum slender, sub-hypogeous. Fronds pinnate, rarely pinnatifid, generally slender and pendulous, $1 \frac{1}{2}$ to 
12 feet long, smooth, rarely pilose; pinnæ 5 to 10 inches in length, linear lanceelate, obtuse or acuminate, generally opposite or nearly so, and articulate with the rachis. Veins one or more times forked or pinnate, the lower exterior venules free and soriferous, the others angularly anastomosing. Receptacles punctiform, terminal, generally immersed. Sori transverse uniserial, furnished with indusaform lacinate scales.

Type. Polypodium verrucosum, Wall.

Illust.-Hook. and Bauer, Gen. Fil., t. 14. Hook. Gard. Ferns, t. 41. Moore Ind. Fil., p. 59, figs. 1-4. J. Sm. Ferns Brit. and For, fig. 8.

OBs.-The different aspect, and the pinnæ being articulated with the rachis, has induced me to separate the species of this genus from Goniophlebium. The species are also distinct geographically, being entirely natives of the eastern tropics.

* Fronds pinnatifid.

S. lachnopus (Wall.), S. amœna (Wall.).

** Fronds pinnate.

S. arguta (Wall.), S. cuspidata ( $B l$.$) , ( \nabla$ v.), S. subauriculata $\left(B l_{.}\right)$, ( $\left.\vee \nabla.\right)$. S. pallens $(B l$.$) , S. verrucosa (Wall.),$ ( $\mathrm{v}$ v.).

\section{1.-Phlebodidm, $R$. Br. (1838):}

Polypodium sect. Phlebodium, R. Br. Polypodium sp.; auct., Hook. Sp. Fil.

Surculum thick and fleshy. Fronds large, 2 to 6 feet high, pinnatifid or subpinnate, papyaceous, smooth, generally more or less glaucous, segments adherent. Veins pinnate, venules arcuately or angularly anastomosing, producing two or three excurrent veinlets, terminating in the 
areoles; the costal areoles always vacant. Receptacles punctiform on the combined apices of the excurrent veinlets. Sori round, transversely one to two serial, naked.

Type. Polypodium aureum, Linn.

Illust.-Hook. and Bauer, t., 112. Moore Ind. Fil., p. 58, figs. 1-3. J. Sm. Ferns. Brit. and For, fig. 9. Hook. Syn. Fil., t. 5, fig. 48 , g.

OBs.-This is a well-marked genus, containing about half a dozen species, all natives, of the West Indies and Tropical America. In general habit it resembles Goniophlebium, but is distinguished by the sori being borne on the combined apices of at least two excurrent veinlets, and by the costal aeroles having no free veinlet.

Ex.-P. aureum (Linn.),( $\nabla$ v.), P. sporodocarpum (Willd.), ( $\left.\vee v_{.}\right)$, P. areolatum (Willd.), ( $\vee$ v.), P. pulvinatum (Link), ( $\nabla$ v.), P. decumanum (Willd.), P. dictyocallis (F'ée), ( $\nabla$ v.).

Sect. 3.-Pleuridem.

\section{2.-Pledridium, Presl (1836).}

Polypodium, Sp. auth., Hook. Sp. Fil.; Phymatodes, section Pleuridium, Presl in part.

Surculum short, or elongating. Fronds simple, rigid, papyraceous, or coriaceous, from 6 inches to 2 feet in length, thick marginate. Primary veins costæform, elevated, straight. Venules compound anastomosing. Receptacles compital, punctiform. Sori round or oblong, obliquely one or two serial between the primary veins.

Type. Polypodium crassifolium, Iinn.

Illust.-Schott. Gen. Fil. t. 1 (Anexetum). Hook. and Bauer, Gen. Fil., t. 29. J. Sm. Ferns, Brit. and For., fig. 22 .

Oss.-Presl arranges the species of Phymatodes under 
three sections, namely, Euphymatodes, Pleuridium, and Drynaria. Under Pleuridium he places sixteen species, which although they all agree in having compound venation and compital sori, nevertheless as they differ in habit, I restrict the species to those bearing the above character.

* Sori oblique uniserial.

P. crassifolium, (Linn.), ( $\mathrm{v} \quad \nabla$.$) ; P. albo-punctissimum$

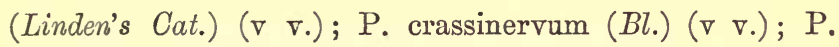
vulcanicum $(B l$.

** Sori oblique biserial.

P. rupestre $(B l).(\nabla \nabla)$; P. triquetrum (Bl.) ( $\nabla \nabla$.

The two first are natives of West Indies and Tropical America, the others of Malay and Philippine Islands.

\section{3.-Campyloneurdm, Presl (1836).}

Cyrtophlebium, R. Br.; J. Sm. Gen. Fil., 1841 ; Polypodium, sp. auct. Hook. Sp Fil.

Surculum short, cæspitose, or elongated, often subhypogeous. Fronds simple, linear lanceolate or broad elliptical, or pinnate, firm, rigid, 1 to 2 feet high. Primary veins costæform or undefined, elevated, or internal and obscure. Venules arcuately or angularly transversely anastomosing, producing two or more excurrent free veinlets, uniform, or sometimes irregular. Receptacles punctiform, terminal, or medial on the free veintets. Sori round, oblique biserial, or irregular, destitute of scales.

Type. Polypodium repens, Linn.

Illust.-Hook. and Bauer, Gen. Fil. t. 71 A. Moore, Ind. Fil.p. 60 ; J. Sm. Ferns, Brit. and For., fig. 27 ; Hook. Syn. Fil. t. 5, fig. $48, \mathrm{j}$.

Oes.-This genus consists of about a dozen described 
species, all natives of the West Indies and Tropical America. The principal character which distinguishes it from Phlebodium is the sori being produced on free excurrent veinlets, that rise from the arch formed by the venules between the primary veins, and which character in the greater number of the species is well defined, but in a few species with narrow linear opaque fronds the venation is obscure and not so regular, which is due to the narrowness of the fronds; great confusion exists as regards the synonyms of the species of this genus.

In Seeman's "Botany of the Herald" I have stated "that the general features of the so-called species of this genus are so much alike that the words used to describe one are in many cases quite applicable to others, the species varying merely in degree as to length, breadth, \&c. The differences in the anastomosing of the veins would appear to indicate distinctions, uniformity is not, however, the rule; fronds of the same individual plant, and even different parts of the same frond, are observed to vary in the more or less branching and anastomosing of the veins; so that I fear venation is of little value for specific distinctions." It is only by seeing them growing side by side under cultivation that the difference of their appearance appears manifest.

\section{* Fronds simple.}

Sp. C. ensifolium (Willd.) $\nabla$ v.); C. angustifolium (Sw.) (vv.); C. lucidum (Bory) ( $\vee$ v.); C. rigidum, (J.Sm. Ferns, Brit. and For.); C. fasciale (Willd.) ( $\vee v_{0}$ ) ; C. repens (Linn.) ( $\nabla_{.}$) ; C. Phyllitides (Linn.) ( $\nabla_{\odot}$ ) ; C. costatum (Kze.) ( $\nabla$ v.); (C. nitidum, J.Sm. Ferns, Brit. and For.); C. brevifolium (Link) ( $\nabla$ v.); C. sphenodes, (Kze.) ; C. immersum, (J. Sm. Bot. Voy. Herald). 

** Fronds pinnate.
C. decurrens (Radd.) ( $\nabla$ v.) ; C. Fendleri, Eaton.

\section{NipновоLUS, Kaulf (1824).}

Polypodium sp., auct.; Hook. Sp. Fil.

Surculum short or elongating. Fronds cæspitose or distant, simple linear-lanceolate, oblong elliptical or obovatesubrotund, rarely lobed, from less than an inch to two or three feet long, thick and fleshy or coriaceous, covered with sessile or stipate, white or brown stellate pubescence; the fertile usually more or less contracted and longer than the sterile. Veins obscure, undefined, or evident and costæform; venules compound anastomosing. Receptacles punctiform, immersed, terminal or medial, on simple or brachiate free veinlets, or compital. Sori round or oval sub-transverse multiserial or biserial between the primary veins, or irregular and confluent, protruding through the dense stellate pubescense.

Type. Polypodium adnescens $S w$.

Illust. Hook. and Bauer, Gen. Fil. t. 83 ; Hook., Ex. Fil.

t. 162 ; Moore, Ind. Fil. p. 61 ; J. Sm., Ferns, Brit. and For. fig. 26 ; Hook, Syn. Fil. fig. 48. k.

OBs.-This genus is readily known by the thick coriaceous fronds being covered with stellate pubescence, which gives them a hoary appearance when young; in some species this pubescence nearly disappears in age, especially on the upper side of the frond.

About forty species have been named and described by different authors, but a critical examination has led me to believe that not more than one-half of that number are distinct species. In the "Species Filicum," the number is reduced to twenty-two, which I believe might be still 
further reduced. Presl, however, not only maintains the highest number of specie but goes the length of creating no less than six additional genera. It is true that their venation and position of the sori is variable, but in all cases it is simple modifications of compound anastomosing, which is principally due to the more or less contracted state of the fronds, and which has led Presl to place the same species under different genera. The only very evident distinction is in habit, which admits of their being arranged under two sections, one having an elongated caudex, and the other with contiguous cæspitose fronds.

- Caudex elongated surculate. Fronds distant, the fertile specially contracted; primary veins undefined.

Sp. N. nummularifolius $(S w$.$) ; N. rupestris (R . B r).(\nabla \nabla$. N. serpens (Forst.) ; N. acrostichoides (Forst.) ; N. albicans (Bl.) ; N. Lingua (Thumb.) ( $\nabla$ v.) ; N. tricuspe (Thumb.) ( $\mathrm{v}$ v.)

OBS.-The numerous and intermediate forms and sizes of the preceding species from different localities render it almost impossible to collate and separate them into distinct species when many specimens are brought under view. The different form and colour of the scales of the caudex indicate specific characters, but even that seems to alter according to age.

** Caudex short, ccespitose. Fertile and sterile fronds nearly uniform. Primary veins defined.

N. Gardneri (Metten.) ( $\nabla$ v.); N. africana (Kunze); N. porosus (Wall); N. flocculosus (Don); Bedd. F. Brit. Ind. pl. 162 sub. ; N. costatus (Wall.) ( v v.) ; N. splendens (Pr.) ; N. Penangiana (Hook); N. subfurfuracea (Hook.); N. Boothii (Hook.). 
OBS.-Representatives of this genus are widely spread over the Eastern hemisphere, extending from New Zealand and Australia to the Polytesian and Malayan islands, Japan, India and South Africa, but none as yet have been observed in the Western hemisphere.

\section{Niphidium, J. Sm.}

Polypodium sp., auct; Hook. Sp. Fil.

Surculum thick cæspitose. Fronds stipate, linear lanceolate $1 \frac{1}{2}$ to $2 \mathrm{ft}$. long, attenuated, firm coriaceous, the upper side smooth and glossy, the under side densely stellatotomentose. Primary veins straight oblique. Receptacles compital, forming a row (of about four) of large oval sori, between each pair of primary veins.

Type. Polpodium americanum, Hook.

OBS.-The only representative of this genus is a native of Ecuador and Quito, observed by Dr. Jameson and Spruce, from whom Sir Wm. Hooker received specimens, and I possessed a specimen of it collected by Hartweg. In general appearance it resembles narrow fronds of Pleuridium crassifolium, with which it also agrees in the sori being large and in an oblique row between the primary veins, but differs in the under side being densely stellated tomentose, as in Niphobolus, but from which it differs in having oblique uniserial sori, which also distinguishes it from Niphopsis.

Sp. N. americana, J. Sm., Houk.

\section{Colrsis, Presl. (1849.)}

Polypodium sp. Gymnogramma sp. auct. and Hook. Sp. Fil.

Surculum short, sub-hypogeous. Fronds simple, lobed or pinnatifid, generally membraneous, flaccid, 1 to 3 feet long. 
Veins compound anastomosing; primary veins costæform, elevated or internal, generally flexuose, in some immersed. Receptacles compital, superficial. Sori punctiform, or by confluence oblong or linear, irregular or partially obliquely $1-2$ serial.

Type. Polpodium normale, Don.

Illust. Hook. and Bauer, Gen. Fil. t. 109, B. Hook. and Grev. Ic. Fil. t. 65. J. Sm. Ferns, Brit. and For., fig. 24. OBs.-The species of this genus agree with Phymatodes and Pleuridium, but differ in the nature of the caudex, and the fronds of the greater number of the species being thin and flaccid, as also in the irregular disposition of the sori. With Selliguea it is connected through C. membranacea, in which the punctiform sori are united, forming linear oblique sori, which character has led the author of the "Species Filicum" to place it in Gymnogramma. The irregular arrangement of the sori is also conspicuous in C. Samarense; in some fronds the sori are punctiform, while in others the receptacles unite, forming linear, or even transverse continuous sori, and also at the same time punctiform sori. This apparently double character induced me to elevate this species to the rank of a genus, which in 1841 I characterised under the name of Diblemma, but later observations have shown me that it cannot with propriety be separated from the present group.

The genus consists of about sixteen species, all natives of the Eastern Hemisphere, extending from Western Tropical Africa through India, the Malayan Islands, China, Australia, and Polynesian Islands.

* Fronds simple.

Sp. C. zosteræforme (Wall.); C. normale (Don.) (Poly. podium longifrons, Wall.); C. ovata (Wall.); C. membra- 


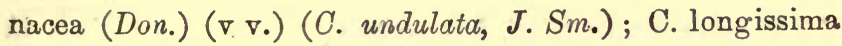
(Bl.) ; C. Zippelii (Bl.) ; C. Samarense, J. Sm. (Diblemma, $J . S m .1841)$; C. tenulorus, $J . S m . ;$ C. superficiale (Bl.); C. erioides (Poiv.) (Microsorum erioides, Link.)

** Ironds lobed or pinnatifid.

C. tridactylon (Wall.); C. Labrusca (Hook.); C. spectrum (Kaulf.); C. insigne (Bl.); C. dilatatum (Wall.); C. affine $(B l$.

\section{Selliguea, Bory. (1829).}

Grammites, Blume; Gymnogramma, Hook. Sp. Fil.

Surculum slender, elongating, epigeous, and squamose, or sub-hypogeous and naked. Fronds stipate, 1 to 2 feet long, simple, linear lanceolate or broad elliptical, rarely pinnatifid, smooth, opaque, the fertile longer than the sterile, and often sub-contracted. Primary veins costæform, straight. Venules compound anastomosing, with free veinlets terminating in the areoles. Receptacles compital, elongated, oblique, forming a continuous or sub-interrupted linear sorus between the primary veins.

Type. Selliguea Feei, Bory.

Illust. Hook. Grev. Ic. Fil. t. 5 and 6 ; Hook. Bot. Mag. t. 5328; Moore, Ind. Fil. p. 52 A.; J. Sm. Ferns, Brit. and For., fig. 23.

OBs.-The species comprehended under this genus agree in many respects with Pleuridium, but are technically distinguished by the fertile fronds being generally subcontracted, and the sporangia produced in a continuous line parallel with and between each two of the primary veins; this linear form of the sori may readily be conceived to be formed by the complete confluence or union of the normal punctiform receptacles of such species as Pleuridium crassifolium or $P$. crassinervum; indeed, it is difficult to 
deny some states of S. heterocarpa and S. Feei a place in Pleuridium.

This genus consists of about 8 to 10 known species, all natives of Tropical India, Malayan Peninsular and islands.

The genus Loxogramma contains species analogous in habit, venation, and linear sori, but differs in having adherent vernation.

\section{* Fronds simple.}

Ex. S. caudiforme (Bl.) (v v.); S. Feei, Borg.; S. macrophylla, $B l$.; S. Wrightii (Hook.); S. heterocarpa, Bl.; S. Hamiltoniana, Wall.

** Fronds pinnatifidly pinnate.

S. pothifolia (Don.) ( $\mathbf{v}$ v.)

Sect. 4.-Phymatodes.

18. Phymatodes, Presl (1836).

Polypodium sp. auct., Hook. Sp. Fil.

Surculum generally thick, short, or much elongated, becoming smooth. Fronds simple, pinnatifid, or pinnate, smooth, coriaceous, or thin, flaccid, segments adherent with the rachis. Primary veins undefined or evanescent, rarely defined. Venules compound anastomosing, with free veinlets terminating in the areoles, internal, obscure, or evident. Receptacles compital, in some deeply immersed. Sori round or oblong, sub-medial, transversely uniserial, or irregular by confluence, naked.

Type. Polypoctium Phymatodes, Linn.

Illust. Hook. Fil. Exot.t. 22, 25 ; Hook. Gard. Ferns, t. 47 ; Moore Ind. Fil. p. 62, fig. 7 ; J. Sm. Ferns, Brit. and For., fig. 21 ; Hook. Syn. Fil., t. 5, fig. $48 \mathrm{~m}$. 
OBs.-This genus is distinguished from Pleopeltis principally by the venules being more compoundly anastomose, the fronds being smooth, and the sori destitute of indusæform scales. It comprehends a considerable number of species, all, with two or three doubtful exceptions, natives of the tropical and sub-tropical regions of the Eastern hemisphere.

P. pustulata (Forst.) ( $\left.\nabla \nabla_{0}\right)$; P. Billardieri (R. Br.) ( $\left.\nabla \nabla_{.}\right)$; P. vulgare, Pr. ( $\left.\nabla \nabla_{\bullet}\right)$; P. longipes, J. Sm. ( $\left.\nabla_{.}\right)$; P. peltidea (Link.) ( $\left.\nabla \nabla_{0}\right)$; P. terminales (Link.) ( $\left.\nabla_{\bullet} \nabla_{\bullet}\right) ;$ P.

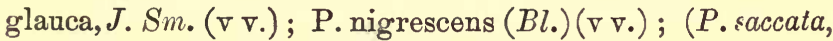
J. Sm., 1857) ; P. longissima, Bl. ( $\nabla$ v.); P. Schomburghiana, J. Sm. Lond. Jour. Bot. i. p. 196 (Polypodium Schomburgiana, Kze. in Schk. Supp. Fil. t. 42).

OBs.-This is a native of British Guiana, and is peculiar in being an example of Phymatodes, thus showing that the genus is not entirely restricted to the Eastern hemisphere. It, however, may be called an aberrant species; it has a remarkable caudex, from half an inch to an inch in thickness, densely covered with long lanceolate, acuminate, silky scales, very much resembling the well-known Hare's-foot Fern, Davallia canariensis ; the fronds are distant, short, stipate, oblong, elliptical, 1 to $1 \frac{1}{2}$ feet in length, and 2 to 3 inches in width, smooth, coriaceous, with thickened margin; the sori are large, round, or oblique oblong, forming a medial row on each side of the mid-rib. The peculiarity of this Fern has led Klotzsch to place it under a distinct genus, which he names Mecosorus. Another remarkable American species is Polypodium (Phymatodes) bifrons, Hook. "Species Filicum," and Hook. Fil. Exot., t. 52. The character of the caudex is described as being long, slender, naked; the sterile fronds being elliptical, 3 to 4 inches in length, the fertile narrow, linear, 5 to 6 
inches long; the sori large, oblong, parallel with and in a row on each side of the mid-rib. I have not had the opportunity of examining this Fern, and therefore place it here on the supposition that the vernation is articulate. In the "Species Filicum," P. terminales, P. peltedia, and $P$. longipes, are united under the original name of Polypodium Phymatodes, but having obserred them for many years under cultivation, I have been led to consider them to be as good species as many others described in the "Species Filicum."

\section{9.-Phymatopsis, $J$. Sm.}

Polypodium sp., auct.; Hook. Sp. Fil.

Surculum slender, elongating. Fronds simple, pinnatifid, or sub-pinnate, 6 to 12 inches in height, smooth, subcoriaceous. Irimary veins evident, costæform, terminating at or near the margin, which is thickened, and with a notch between each two veins. Venules compound, anastomosing. Receptacles compital, punctiform, superficial, one between each two primary veins. Sori tranverse, uniserial, naked.

Type. Polypodium palmatum, Blume.

Illust. Blume, Fl. Java, t. 64; Hook. Ic. Pl., t. 951.

OBS.-In general habit the species of this genus are similar to Phymatodes, but the well-defined costæform veins, thickened and notched margin, marks them as being worthy of being adopted as a distinct group; it consists of about a dozen species, all natives of India, Malay, and other tropical islands.

* Fronds simple.

P. accedens (Bl.) ; P. oodes (Kze.) ; P. rostrata (Hook.); P. rbynchophylla (Hook.); P. Griffithiana (Hook.) 


\section{** Fronds pinnatifid.}

P. ebenipes (Hook.) (Poly. melanopus, Wall.); P. trifidum (Don.) ( $\nabla$ v.) (Poly. oxylobum Wall.); P. palmata $(B l).(\nabla \nabla$.$) ; P. laciniatum (Bl.); P. incurvata \left(B l_{.}\right)\left(\nabla \nabla_{\bullet}\right)$.

20.-Niphopsis, J. Sm. (1857).

Polypodium sp., auct.; Hook. Sp. Fil.

Surculum short, slender. Fronds simple, linear lanceolate, coriaceous, opaque, 6 to 12 inches long, densely covered with stellate scales. Veins internal, obscure, compound, anastomosing. Primary veins indistinct. Receptacles punctiform, compital. Sori oval, large, transverse uniserial.

Type. Polypodium angustatum, Sw.

Illust. Hook. and Grev. Ic. Fil., t. 94 ; Hook. Gard.

Ferns, t. 20 ; J. Sm. Ferns, Brit. and For., fig. 14.

OBs.-This genus is founded on a single species, which agrees in general habit with Niphobolus, but differs in the sori being large, oval, and arranged in a regular transverse row on each side of the mid-rib, in that respect agreeing with the normal character of Phymatodes, to which it bears the same relationship as Niphidium does to Pleuridiurn.

Sp. N. angustata (Sw.) ( $\nabla$ v.) (Polypodium sphorocephalus, Wall.; Hook. and Grev. Ic. Pl., t. 94).

A native of India, Malayan, and islands of the Pacific and North Australia.

21.-Lecanopteris, Reinw. (1825).

Polypodium sp., auct.; Hook. Sp. Fil.

Surculum thick and fleshy, branching, thickly covered with large peltate imbricate scales, branches short, con- 
tiguous, the stipes raising from the apex of conical nodes. Fronds firm, coriaceous, the fertile partially contracted; perfect ones deeply pinnatifid, in some states sinuose only or simple, 6 to 18 inches long. Primary veins indistinctly costæform. Venules compound, anastomosing. Receptacles transversely oval, compital, deeply impressed in a cavity, forming tubicles on the upper surface. Sori large, round, or oval, transverse uniserial.

Type. Lecanopteris carnosa, Blume.

Illust. Hook. and Bauer, Gen. Fil., t. 90, B. (abnormal state); Moore Ind. Fil., p. 64, B.

OBs.-This genus was originally founded on an abnormal state of a very remarkable Fern, having fronds of different forms, one state having simple and sinuose fronds on the same plant, known as Polypodium sinuosum of Wallich. (Hook. Sp. Fil., t. 274); the more perfect state being a Luzon plant, which, in my "Enumeration of Philippine Island Ferns" (1841), I named Drynaria lomarioides, which has equal pinnatifid fronds, and as in Polypodium vulgare, the pinnæ occasionally become laciniated, each lacinia bearing a single sorus, and being concave, presents some similitude to the fructification of the Lichen called Lecanora (Nephroma) resupinata. Besides these characters, the very remarkable thick scaly rhizome marks it as a very peculiar Fern, worthy of being considered a distinct genus.

The different states have been found in Java Peninsula of Malacca, Borneo, Philippine and other eastern islands.

Sp. L. carnosa, Bl. (Polypodium sinuosum, Wall.; Drynaria lomarioides, $J . S m$.) 


\section{Sect. 5.-Drynarie.}

22. Drynaria, Bory. (1825).

Phymatodes, Presl; Polypodium sp., auct.; Hook. Sp. Fil.

Surculum short, thick, and fleshy. Fronds rigid, the sterile (when present) sessile, broad cordate, sinuose, or laciniated; the fertile stipitate or sessile, pinnatifid or pinnate, rarely simple, the segments articulated with the rachis; when sessile, the base is dilated similar in form to the sterile frond. Veins external, elevated, compound anastomosing, forming quadrate or hexagonal areoles. Primary veins costæform or obsolete. Receptacles compital. Sori round, small, numerous, and irregular, or transversely or obliquely serial, sometimes confluent, forming a linear sorus between the costæform veins.

Type. Polypodium quercifolium, Linn.

Illust. Hook. Gard. Ferns, t. 1 and 31 ; Fil. Exot., t. 13 ; Moore, Ind. Fil., p. 63, A; J. Sm. Ferns, Brit. and For., fig. 28.

OBs.-This is a well-marked and distinct genus of Ferns, its typical representative being the well-known Polypodium. quercifolium of Linnæus, which receives its specific name from the fanciful likeness of the sterile frond to the leaf of the common oak. In some species, however, it is much larger, even to a foot in length, oblong cordate, entire sinuose or deeply laciniated, and of a firm woody texture.

This genus consists of about nine known species, widely distributed over the Eastern hemisphere, in Mauritius, Ceylon, India, China, Malayan, Phllippine and Tropical Polynesian Islands, and Australia.

In general they are epiphytal, their large broad fronds imparting a special character to the trees on which they grow. 
A. Fronds uniform, base dilated.

* Sori numerous, irregular.

$\uparrow$ Fronds simple.

D. musæfolia $(B l$.$) ( \mathrm{v}$ v.)

t十 Fronds pinnatifid.

D. Heraclea (Kze.) ( $\nabla$ v.)

** Sori oblique serial.

$\dagger$ Fronds pinnatifid.

D. coronans (Wall.) $(\nabla \nabla)$.

B. Fronds dimorphous.

* Sori oblique, 1 to 2 serial.

+ Fronds pinnatifid.

D. Fortunei (Kze.); D. quercifolia (Iinn.) ( $\nabla \nabla$.

** Sori transversely uniserial.

+ Fronds pinnatifid.

D. propinqua (Wall.) ( $\nabla$ v.); D. Willdenovii (Bory.)

t+ Fronds pinnate (Poronema.)

D. diversifolia (R. Br.) ( $\nabla \nabla$.$) ; D. glaucistipes (Wall.)$

OBs.-The two last species differ from the rest in having pinnate fronds, and are specially marked by having a small impressed pore at the base of each pinnæ, which, with their pinnate fronds, is sufficient to mark them as a distinct group, under the sectional name of Poronema.

\section{Dryostachyum, J. Sm. (1841).}

Surculum short and thick. Fronds contiguous, sessile, rigid, 1 to 3 feet high, pinnatifid, segments articulated with the rachis, sterile below, the base dilated, the upper segments pinnate, contracted and fertile. Veins of sterile segments costæform; venules and veinlets compound anastomosing, forming nearly equal quadrangular areoles. 
Fertile pinnæ linear, 6 to 8 inches long, broad rachiform. Primary veins evident, short. Receptacles compital, forming a large quadrate sorus, in two transverse, nearly confluent rows on each segment (acrostichoid).

Type. Dryostachyum splendens, J. Sm.

Illust. Hook. and Bauer, Gen. Fil., t. 95 ; Moore Ind. Fil., p. 10, A.

OBs.-As a genus, this is distinguished from Drynaria by the upper portion of the frond being contracted into long linear sessile pinnæ, bearing large quadrangular sori. The receptacle of each sorus may be viewed as formed by the confluence of four (normal) punctiform receptacles, brought together by the contraction of the fertile disk, forming a broad sporangiferous area between each two of the primary veins, the sporangia thus forming two rows of squares on each pinnæ. According to Mr. Moore's classification, the seemingly amorphous sori leads him to place this genus in Acrostichece, but he admits that in habit and aspect it resembles Drynaria.

Sp. D. splendens, J. Sm. (Bedd. F. Brit. Ind. pl. 316); D. pilosum, J. Sm.

OBs.-First discovered in the Island of Luzon, by Cumings, and latterly in Singapore. D. pilosum is a much smaller plant than D. splendens, and is specially distinguished by the sporangia being pilose.

\section{Aglaomorpha, Schott. (1835).}

Psygmium, Presl, 1836 ; Polypodium sp., Hook. Sp. Fil.

Surculum thick. Fronds sessile (the base dilated), rigid, 2 to 3 feet long, pinnatifid and sterile below; pinnate, contracted, and fertile abore. Veins of sterile segment costæform; reinlets and venules compound anastomosing, 
forming nearly equal quadrangular areoles. Fertile pinnoe contracted linear, sinuously moniliform, 8 to 10 inches long. Receptacles compital, solitary on each lobule, forming a row of punctiform sori on each side of the mid-rib.

Type. A. Meyeniana, Schott.

Illust. Schott. Gen. Fil., t. 19 ; Hook. and Baner, Gen. Fil., t. 91 ; Moore, Ind., p. 63, B.

OBs.-This genus is founded on a remarkable and very splendid Fern, possessing the general habit of Drynaria coronans, but differing in the upper half of the frond being contracted into narrow sinuose pinnæ, and bearing a round sorus on each lobule, which latter character distinguishes it from Dryostachyum. It is also a native of Luzon.

Species. A. Meyeniana, Schott.

Since the publication of "Ferns, British and Foreign," this rare and remarkable Fern has been introduced in a living state to the gardens of this country.

\section{Arthromeris, $J$. Sm.}

Pleopletis, sect. Arthromeris, Moore's Index; Polypodium sp., auct. and Hook. sp. Fil.; Pleuridium sp., J.Sm. Ferns, Brit. and For.

Surculum short and thick. Fronds pinnate, stipitate, 2 to 3 feet long. Pinnoe elliptical, lanceolate, 6 to 8 inches long, 1 to $2 \frac{1}{2}$ inches wide; opposite petiole short, articulated with the rachis; margin entire, with a narrow membraneous border. Primary veins evident, costæform, straight; venules compound anastomosing. Receptacles punctiform, compital. Sori transverse, 1 or 3 to 5 serial.

Type. Polypodium juglandifolium, Don.

OBs.-In my Catalogue of Cultivated Ferns, and also in "Ferns British and Foreign," I placed the two known species that constitute this genus under Pluridium, but 
further consideration induces me to separate them. The chief distinction lies in the pinnæ being articulated with the rachis, and in the margins not being notched as in Pleuridium; the same character also distinguishes it from Phymatodes. The species are natives of India, Nepaul, Sikkim, and Boutan.

Species. A. venusta (Wall) ( $\mathrm{v}$ v.) ; A. juglandifolium (Don) ( $\nabla \nabla$.$) .$

Sect. 6.-Pleopeltee.

26. Lopholepis, J. Sm. (1841).

Polypodium sp., auct.; Hook. Sp. Fil.; Craspedaria in part, auct.

Surculum slender. Fronds simple, entire, 1 to 4 inches in length, the fertile contracted, linear, squamose. Veins forked; venules anastomosing, the lower exterior branch free and soriferous. Receptacles punctiform, superficial. Sori transverse uniserial, each furnished with a dense tuft of elongated scales.

Type. Polypodium piloselloides, Linn.

Illust. Hook. and Bauer, Gen. Fil., t. 51 ; J. Sm. Ferns, Brit. and For., fig. 10 ; Hook. Syn. Fil., t. 5, fig. 48, i. OBs.- On account of the renation being similar to that of Goniophlebium, I originally characterised this as a section of that genus. By Presl and others, the species have been placed in different genera; and as their habit is entirely different from that of true Goniophlebium, I deem it best to adopt Lopholepis as a distinct genus.

Sp. L. piloselloides (Iinn.) ( $\left.\nabla \nabla_{0}\right)$; L. ciliata (Willd $)$; L. vaccinifolia (Lang et Fisch.) ( $\left.\nabla \nabla_{0}\right)$; var. albida ( $\nabla \nabla_{0}$ ), J. Sm. F. B. and $F$.

Natives of the West Indies and Tropical America. 
27. Lepicystis, $J$. Sm. (1841).

Marginaria sp. Bory and Presl; Polypodium sp., auct. and Hook. Sp. Fil.

Surculum short and rigid; slender. Fronds pinnatifid, 6 to 18 inches high, densely covered with round or elongated fringed scales. Veins pinnately forked, anastomosing, lower exterior venules free. Receptacles punctiform, terminal on the free venules in the costal areoles, immersed. Sori protruding through the dense scales, transverse uniserial.

Type. Polypodium incanum, Linn.

Illust. J. Sm. Ferns, Brit. and For., fig. 6.

OBs.-In venation and position of the sori this genus agrees with Goniophlebium, but differs in the fronds being densely covered with elongated fringed scales, through which the sporangia protrude in a manner analogous to being contained within a calyciform indusium. In general habit the species agree in the squamose nature of the fronds, which indicates its natural affinity to be with Polypodium macrocarpum and $P$. madrensea.

Species. L. incana (Sw.) ( $\mathrm{v}$ v.) ; L. lepidopteris (L. et F.) ( $\left(\mathrm{v}\right.$ v.) ; L. squamata (Iinn.) ( $\mathrm{v}^{\mathrm{v} .}$ ) ; L. ragadiolepis (F'é) $(\mathrm{v} v \mathrm{v})$

Natives of West Indies and Tropical America, extending to south of the United States to South of Brazil.

28. Pleopeltis, H. et B. (1810).

Polypodium sp., auct.; Hook. Sp. Fil.

Surculum elongating; slender. Fronds simple, sinuose or pinnatifid, 4 to 12 inches long, opaque, squamiferous; rarely smooth. Veins more or less obscure, arcuately anas- 
tomosing. Receptacles punctiform or oblong linear, produced on the confluence of two or more excurrent arcuate veinlets, terminating in the medial areoles. Sori transverse uniserial, furnished with indusiform peltate scales.

Type. Polypodium percussum, Cav.

Illust. Hook and Bauer, Gen. Fil., t. 18 ; Moore Ind. Fil., p. 62, figs. 1, 2, 3, 4; J. Sm., Ferns, Brit. and For., fig. 12.

OBs.-In my genera of Ferns (1841) I made the genus Pleopeltis, as founded by Humboldt, a section of the genus Phlebodium of $\mathrm{R}$. Brown, but now considering that habit assists to detine groups of naturally allied species, and as the species of Phlebodium and those of the present group (Pleopeltis) differ entirely in habit, I deem it best to retain the two as distinct genera.

In order to show the different views entertained by Pteridologists respecting the limits of genera, I may here mention that Mr. Moore, in his "Index Filicum," includes nnder the genus Pleopeltis, the whole, or in some cases part only, of the species of no less than twenty-five genera of authors, of which he makes eight sections, which in most cases differ not only in habit, but also possessing other special cbaracters; I am, therefore, induced to adopt them as distinct genera.

The following are the principal species that represent Pleopeltis as here restricted. The greater number are natives of the West Indies and Tropical America, the three first are natives of the Eastern Hemisphere.

* Fronds smooth, glabrous. (Lepisorus, J. Sm. 1846).

P. lineare (Thunb.); (P.nuda, Hook. Ex. Fl., t. 63) ( $\left.\nabla \nabla_{0}\right)$; P. excarata (Bory); (P. nuda, Hook. and Baner, Gen. Fil., t.18, non Hook. Ex. Fl.) ( $\nabla$ ₹.) 
** Fronds scaly.

P. lepidota $\left(P r_{.}\right)$; P. lanceolata (Linn.) ( $\left.\mathrm{v} v\right)$; P. purcussa (Cav.) (v v.) ; P. squamata (Linn.) (v v.); P. elongata, J. Sm. (Grammitis, Sw.) (v v.) ; P. angusta (H. and B.); P. leucosporum (Klot.) ; P. tridens (Kze.)

OBs.-In $P$. elongata the receptacle is transversely elongated, forming oblong linear sori, which character led Swartz to refer this species to Grammitis. On this same character Klotzsch separates it as a genus, under the name of Mecosorus; but as other species of the genus have a tendency to produce oblong sori, I do not deem it worthy of adoption.

\section{Paragramma, Blume (1828).}

Polypodium sp. auct.; Hook. Sp. Fil.

Surculum short cæspitose or slender elongated. Fronds simple, linear lanceolate, obtuse, $\frac{1}{2}$ to $1 \frac{1}{2}$ foot in length, $\frac{1}{4}$ to $1 \frac{1}{2}$ inch broad, smooth, coriaceous. Veins compound anastomosing, internal, obscure, nearly uniform. Receptacles compital, deeply immersed, forming oblong or short linear cysts near to, and parallel with, the margin. Sori oblong linear, marginal, furnished with indusioid stipitate squamæ.

Type. Grammitis longifolia, Blume.

Illust. Hook. Fil. Exot., t. 20 ; Moore Ind. Fil., p. 19, B ; J. Sm. Ferns, Brit. and For., fig. 13.

OBs.-The oblong linear sori led Blume to place the typical species of this genus under Grammitis, for which he constitutes the section Paragramma; from Grammitis it differs in having articulate vernation, and having anastomosing veins and marginal sori. 
Sp. P. longifolia ( $B l$.$) ( \mathbf{v}$ v.) (Polypodium contiguum, Wall.); P. stenophylla (Bl.)

Natives of the Malay and Philippine Islands.

\section{Dictymia, J. Sm. (1846).}

Pulypodium sp. R. Br, and Hook. Sp. Fil.

Surculum short. Fronds simple, linear, or lanceolate, coriaceous, smooth, 6 to 18 inches long, half an inch broad. Veins reticulated, uniform, obscure. Receptacles punctiform, compital. Sori oval, transverse uniserial, destitute of scales.

Type. Polypodium attenuatum, R. Brown.

Illust. Hook. and Bauer, Gen. Fil. t. 71, B; Moore Ind. Fil., p. 57, B; J. Sm. Ferns, Brit. and For., fig. 15.

OBS.-On account of the similarity of the venation, Presl associated the typical species of this genus with several of the large compound fronded species constituting his genus Dictyopteris, which belongs to the division Desmobrya. In habit the species agree with Phymatodes, but differ in the venation being simply reticulated.

Sp. D. attenuata (R. Br.) (Polypodium Brownii, Hook. Sp. Fil. and Gard. Ferns, t. 30) ( $\nabla$ v.); D. lanceolata (Polypodium lanceolatum, A. Cunn. MSS., Dictyopteris attenuata, Hook. and Bauer t. 71, B, not Dictymia attenuata above given).

The first is a native of Australia, the second of New Zealand.

\section{Avapeltis, $J . S m$. (1846).}

Polypodium sp. auct.; Hook. Sp. Fil.

Surculum slender. Fronds simple, linear-lanceolate or elliptical, 1 to 6 inches long, smooth, generally opaque, the 
fertile usually contracted. Veins arcuately or angularly anastomosing. Receptacles punctiform, produced on the confluent apices of two or more excurrent veinlets, terminating in the medial areoles, sometimes partially compital. Sori round or ovate, transversely uniserial, naked.

Type. Polypodium lycopodioides, Linn.

Illust. J. Sm. Ferns, Brit. and For., fig. 11.

OBS.-In venation and position of the sori the species of this genus agree with Pleopeltis, but their smooth, generally shining fronds and naked sori is sufficient to rank them as forming a distinct group.

Sp. A. ovariensis (Desv.) ( $\left.\nabla_{0}\right)$; A. serpens $\left(S w_{0}\right)$; A. lycopodioides (Linn.) ( $\left.\nabla \nabla_{0}\right)$; A. nitida (J. Sm.) ( $\left.\nabla \nabla_{0}\right)$; A. stigmatica $(P r) \quad.\left(\begin{array}{r}\nabla \\ \text {. })\end{array}\right)$; A. squamulosa (Kaulf.) ( $\vee \nabla$.$) ; A. geminata (Schrad.) ( \vee$ v.) (Polypodium iteophyllum, Kze.)

OBS.-With the exception of $A$. ovariensis, a native of West Tropical Africa, the species are all natives of the West Indies and Tropical America.

\section{Microgramia, Presl. (1836).}

Polypodium sp. auct.; Hook. sp. Fil.

Surculum slender, branched. Fronds distant, rising from a short branch-like node, elliptical lanceolate, 4 to 8 inches long, firm, membranaceous. Veins irregular, compound anastomosing. Receptacles linear, compital, forming oblique linear sori.

Type. Polypodium persicariafolium, Mayer.

Illust. Schk. Fil. p. 187, t. 8, C. ; Presl Tent. Pterid., t. 9, f. 7.; Hook and Bauer, Gen. Fil., t. 73 A.

OBs.-This genus is founded by Presl upon a single species, native of Trinidad, Guiana, and Brazil. In general 

Pl.4.

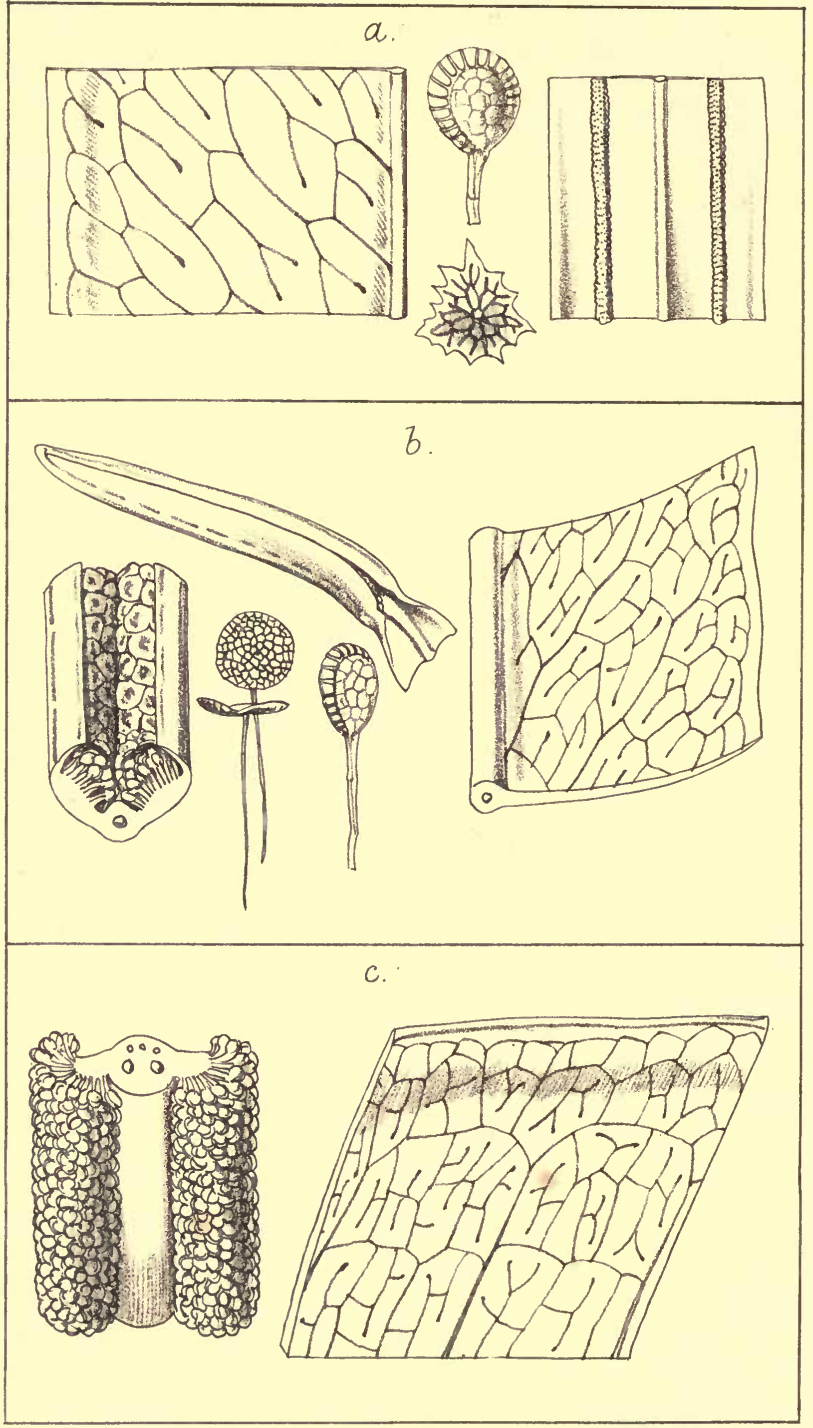

W. H.Fitch, del. et lith. 
appearance and venation it is evidently allied to Anapeltis; but its linear oblique sori being special not formed by the confluence of punctiform receptacles is considered sufficient character to retain it as a distinct genus.

Sp. M. persicariæfolia, Presl.

\section{Tribe 4.-HYMENOLEPIDEA (Plate 4).}

Fronds simple or pinnatifidly lobed, the fertile wholly or partially contracted. Veins anastomosing. Sori linear, continuous, transverse.

OBS.-This Tribe consists of about a dozen or more species agreeing in general habit and venation with the sections Pleopeltidece and Phymatodece of the preceding tribe, differing only in the fertile frond being usually more or less contracted, generally in the form of rachiform spikes, on which account several of the genera which I now place here have been placed by authors in the genera Tcenitis and Acrostichum, such relationship being consequent on the fertile frond, or in some, the fertile portion only, being contracted, thus bringing the normal punctiform receptacles so contignous to one another as to form a general linear sorus; this view is borne out by fronds of some species bearing punctiform sori as well as linear.

\section{Drymoglossum, Presl (1836).}

Hook. Sp. Fil.; Toenitis sp. auct.

Caudex slender surculose. Fronds simple, entire, 1 to 4 inches long, of two forms, the sterile subrotund, elliptical, the fertile contracted, linear. Veins obscure; venules com. poundly anastomosing. Receptacles elongated, compital. Sori linear, continuous transverse, ultra marginal, furnished with stellate indusioid scales. 
Type. Pteris piloselloides, Linn.

Illust. Hook. and Bauer, Gen. Fil., t. 78, A; J. Sm. Ferns, Brit. and For., fig. 16; Hook. Syn. Fil., t. 6, fig. 58.

OBs.-This genus consists of the following species, all natives of India, China, Malayan Peninsula and Islands. The first, $D$. piloselloides, has the sorus when young furnished with stellate pubescence, similar to Niphobolus, while $D$. carnosum has the line of sporangia covered with orbicular scales, analogous to Hymenolepis. This difference led Presl to characterise this latter species as a distinct genus, under the name Lemnophyllum, but I do not think the character is of sufficient importance to warrant its adoption as a genus.

Sp. D. piloselloides (Linn.) ( $\nabla$ v.) ; D. carnosum (Wall.) (Lemnophyllum, Pr.) ; D. Cunninghami, Moore (D. carnosum, J. Sm. non Wall.); D. ? rigidum, Hook. Sp. Fil. Ic. Pl.t. 996. This is a native of Borneo, and on account of its having no free veinlets, is probably not a true Drymoglossum. Moore refers it to Schizolepton.

\section{Hymenolepis, Kaulf. (1824).}

Acrostichum sp. Linn.; Hook. Sp. Fil.

Surculum short, cæspitose. Fronds simple, 6 to 12 inches long, linear lanceolate, coriaceous, smooth, the upper portion contracted and fertile, plicate and indusæform, forming a linear spike. Veins obscure. Venules compoundly anastomosing. Receptacles elongated, compital. Sori linear, continuous, transverse, confluent on the upper portion of the fronds, furnished with numerous suborbicular hyaline scales.

Type. Acrostichum spicatum, Linn. 
nlust. Hook. Fil. Exot., t. 78 ; Hook. Gard. Ferns, t. 3 ; Moore Ind. Fil., p. 15, A ; J. D̃m. Ferns, Brit. and For., fig. 19 ; Hook. Syn. Fil., t. 8, fig. 60, cc., dd., ee.

Obs.-This genus is distinguished from Drymoglossum by the fronds being uniform, and their contracted upper portion bearing the sporangia, which become confluent, and which led some authors to place it in the genus Acros. tichum.

Sp. H. spicata (Linn.) (v v.); H. platyrhynchos, J. Sm. ; H. brachystachys, J. Sm. (H. spicata var. brachystachys, Hook. Gard. Ferns) (v v.).

$H$. spicata is found very generally throughout the tropics of the Eastern Hemisphere, while H. platyrhynchos is as yet only known as a native of Luzon.

\section{Leptochilus, Kaulf. (1824).}

Acrostichum sp. auct.; Hook. Sp. Fil.

Surculum cæspitose, or slender elongating. Fronds 6 to 18 inches long, of two forms; the sterile simple, lobed, or pinnatifid, smooth ; the fertile contracted, linearrachiform, its margins revolute and indusæform. Primary veins of sterile frond evident, straight or flexuose, venules compoundly anastomosing. Receptacles elongated, compital. Sorus linear, continuous, uniserial, on each side of the costa, ultimately confluent, destitute of scales.

Type. Acrostichum aicillare, Cav.

Illust. Hook. Gard. Ferns, t. 6 ; J. Sm. Ferns, Brit. and For., fig. 20.

OBs.-I have already stated that on account of the contraction of the fronds in the preceding genera, the individuality of the normal punctiform receptacle is destroyed, and they become so connected as to form a continuous 
line. This is also the case with Leptochilus, and on the same grounds that Hymenolepis differs from Phymatodes, does Leptochilus differ from Colysis, with which it agrees in habit.

Sp. L. axillaris $\left(C_{a v}\right)$ ( $(\mathrm{v}$. $)$; L. decurrens $(B l$.$) ( \mathbf{v}$ v.); L. lanceolata (Linn.).

Natives of India, Malay and Philippine Lslands.

\section{Dicranoglossum, $J$. Sim. (1851).}

Tcenitis sp. auct.; Hook. Sp. Fil.

Surculum short, cæspitose. Fronds contiguous, furcately. pinnatifid, 6 to 12 inches long, coriaceous, sparsely squamiferous, segments lanceolate-cuspidate, the fertile slightly contracted. Veins obscure, simple or forked, free, or their apices arcuately anastomosing, forming linear transverse superficial receptacles, which by contiguity constitute a continuous or interrupted, linear, intramarginal, naked sorus.

Type. Tonitis furcata, Willd.

Illus. Hook. and Grev., Ic. Fil., t. 7 ; Moore Ind. Fil., p. 20, A ; J. Sm. Ferns, Brit. and For., fig. 18.

OBs.-In 1851 Fee separated the species of this genus from Toenitis, and constituted of them the genus Cuspidaria; but as that name had been previously occupied by both Link and De Candolle for two plants of different orders, I therefore in the "Botany of the Voyage of the Herald" substituted the above name. Fée enumerates three species, two of which I adopt; the third having fasciculate adherent vernation comes under the genus Pteropsis. In habit and texture of the fronds, the species of this genus, seem to mark their relationship to be with Pleopeltidece, but differ in the venules anastomosing, forming arches near the margin, on which the sporangia are produced. 
Sp. D. furcata (Willd.). (v v.); D. subpinnatifidum, (Moore).

OBs.-The latter species is probably a variety of the first, the chief difference being that in some specimens the venules of the lower part of the frond when sterile are free.

Natives of the West Indies and Tropical America.

\section{Neurodicm, Fée (1842).}

Tanitis sp. Sw.; Hook. Sp. Fil.

Surculum short, cæspitose. Fronds contiguous, simple, entire, 6 to 12 inches long, lanceolate, thick, the upper portion partially contracted and fertile. Veins obscure. Venules compoundly anastomosing. Receptacles compital, forming a continuous marginal sorus.

Type. Tcenitis lanceolata, R. Br.

Illust. Hook. Fil. Exot., t. 45 ; Moore Ind. Fil., p. 18, B ;

J. Sm. Ferns, Brit. and For., fig. 17.

OBs.-In my "Genera of Ferns," 1841, I placed this genus under Drymoglossum; but later observations lead me to adopt F'e's view in separating it as a distinct genus. It differs from Drymoglossum in the fronds being uniform, and bearing the sporangia towards the apex, which is but slightly contracted.

Sp. N. lanceolatum (Sw.) ( $\nabla$ v.)

Native of the West Indies and Tropical America.

\section{Schizolepton, Fée. (1842).}

Lindsece sp. auct.; Hook. Sp. Fil.

Surculum short. Fronds dimorphous, 6 to 12 inches long, stipitate, opaque and subcoriaceons, the sterile ones cordate, entire, or trilobed; fertile frond linear, more or 
less contracted. Veins uniform, reticulated, immersed, areolae narrow, oblique. Receptacles marginal, immersed in an indusioid groove, forming a continuous linear sorus.

Type. Schizoloma cordata, Gaud.

Illust. Fée Gen. Fil., t. 8, B, fig. 1; Hook. Sp. Fil. 1, t. 66, A; Moore Ind. Fil., p. 17, B.

OBs.-This genus is founded on a very rare Fern, hitherto only found in the Moluccas and New Guinea. On account of the sporangia being seated in a marginal groove, analogous to that of the tribe Lindsceece, consequently it has been by authors placed in that alliance; but it differs entirely in habit and texture, and in having no membraneous indusium. Fée has very properly characterised it as a distinct genus, and places it in alliance with Tonitis, with which it has some points of affinity in texture and venation, but it differs in the vernation being articulate, that of Tonitis being adherent.

Sp. S. cordata, Gaud. in Frecen. Voy., t., 6, 18.

\section{Tribe 5.-PLATYCERIEÆ (Plate 5).}

Fronds dimorphous, sterile depressed, conchiform, fertile fronds broad, repeatedly forked, the upper portion of the segments or lobes densely sporangiferous (amorphus).

\section{Platyceridu, Desv. (1827.)}

Hook. Sp. Fil.; Acrostichum sp., auct.

Vernation articulate. Surculum short, scarcely evident. Sterile fronds sessile, oblique reniform, round or elongated, depressed, the new successively overlapping the old, forming an epiphytal spongy convex mass, often 1 to 3 feet in diameter. Fertile fronds stipitate, rising from the sinus of 
Pl. 5.

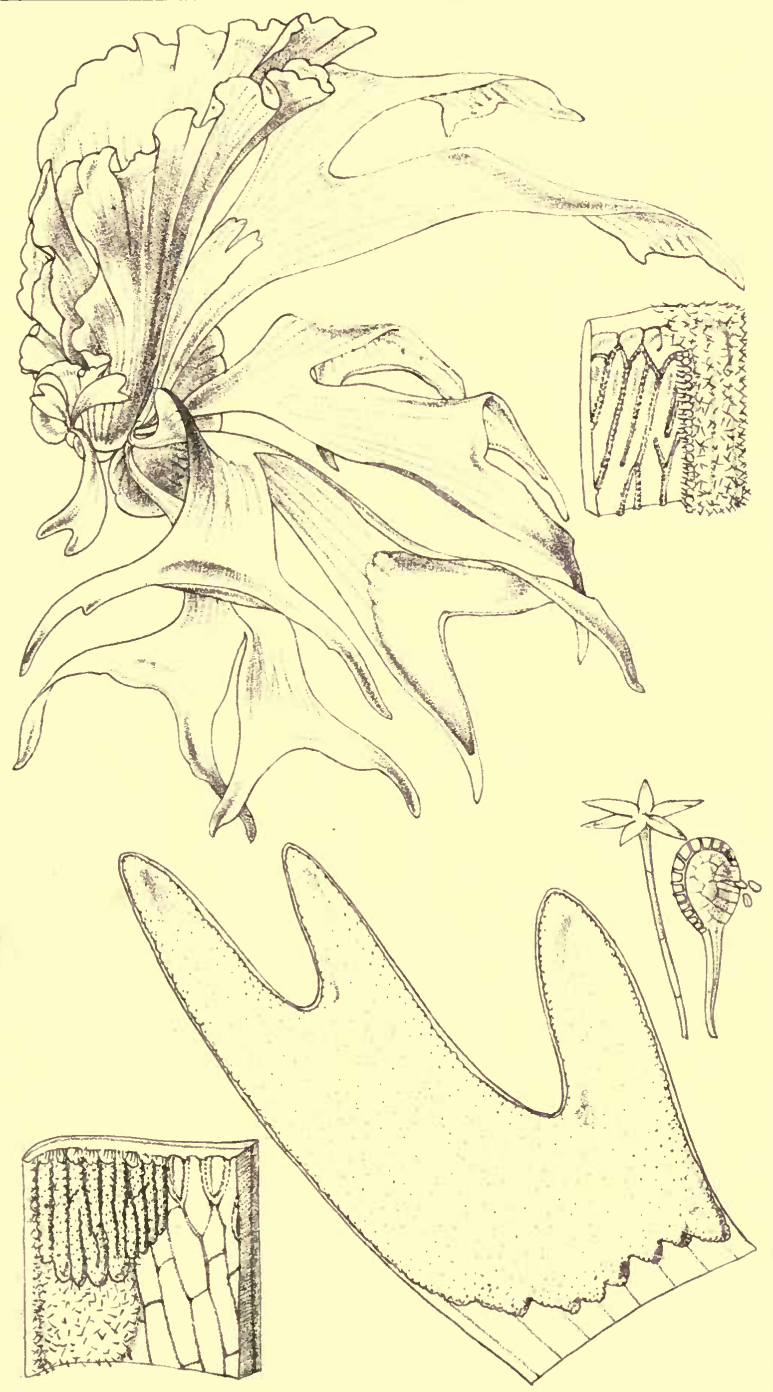

W. H. Fitch, del et lith. 

the sterile, once or many times dichotomously forked, 2 to 6 feet in length; segments broad, obtuse, densely covered with stellated scales, coriaceous. Veins internal, compound anastomosing. Receptacles amorphous, occupying more or less of the under side of the segments, or on a sessile or petiolate lobe, forming dense masses of sporangia.

Type. Acrostichum alcicorne, Swartz.

Illust. Hook and Bauer, Gen. Fil., t. 80 B.; Moore Ind. Fil., p. 9. B. ; J. Sm., Ferns, Brit. and For., fig. 46 ; Hook., Syn. Fil. t. 8, fig. 61.

OBs.-The whole babit and character of the species forming this genus is very peculiar, and totally distinct from any other genus of Ferns, but agreeing in the amorphous production of the sporangia with Acrostichum, but although the axis of the vernation is scarcely defined, it nevertheless exhibits the articulate node of Eremobrya. I therefore place it in this division. The thick coriaceous texture, and the stellated pubescense, show some analogy to Niphobolus. Besides its peculiar habit, the sporangiferous receptacle also presents a structure peculiar to this genus, being formed of an accessory layer of minute veinlets, which appear independent of the vascular structure.

Five species are described as belonging to this genus, which until lately were considered to be entirely natives of the tropics and extra tropics of the Eastern hemisphere, extending from Western Tropical Africa through the islands of the Indian Ocean, Malayan, Philippine, and other islands in the Eastern Pacific, as also the eastern coast of Australia, extending to about the latitude of Sydney. This wide eastern range is not now special, Mr. Spruce having recently discovered $P$. alcicorne at Tarapota, in the Andean regions of Brazil. 
Sp. P. alcicorne (Sw.) ( $\nabla \nabla$.$) ; P. Stemmaria (Desv.) ( \nabla \nabla$. (P. Athiopicum, Hook. Gard. Ferns, t. 9); P. grande (J. Sm.), Hook. Fil. Exot., t. 86 ; Bedd. F. Brit. Ind., pl. 326 ; P. biforme (Bl. Fil. Jav., t. 18) (v v.); Bedd. F. Brit. Ind., pl. 109 ; P. Wallichii (Hook. Fil. Exot., t. 97), ( $\nabla$ v) ; Bedd. F. Brit. Ind., pl. 108.*

OBs.-In Queensland P. grande grows to a large size on trees. The barren fronds overlapping each other, and forming a round or oblong convex mass, 2 to 3 feet in diameter, and as much high; which often becomes so surcharged with water, that the whole mass in time falls to the ground.

\section{Division II.-DESMOBRYA.}

Vernation terminal, adherent, uniserial, or fasciculate.

\section{Ring of Sporangia vertical.}

\section{Tribe 6.-ACROSTICHE王 (Plate 6).}

Fronds dimorphous, the fertile wholly or some portion of it contracted. Veins obscure. Sori amorphous.

OBs.-This tribe is composed of species of the genus Acrostichum, of Linnæus, Swartz, and other authors, as now restricted, the number of described species being about 140t They vary greatly in size and in the circumscription of their fronds, which, with the difference of their vernation and venation, afford sufficient characters to admit of the

* In the Gardeners' Chronicle, March 6th, 1875, Mr. T. Moore described a new species under the name of $P$. Willinickii, a native of Java. Its fructification is terminal, on narrow segments like that of $P$. alcicorne.

+In the Appendix to "Syn. Fil." forty additional species are enumerated. 
Pl. 6 .

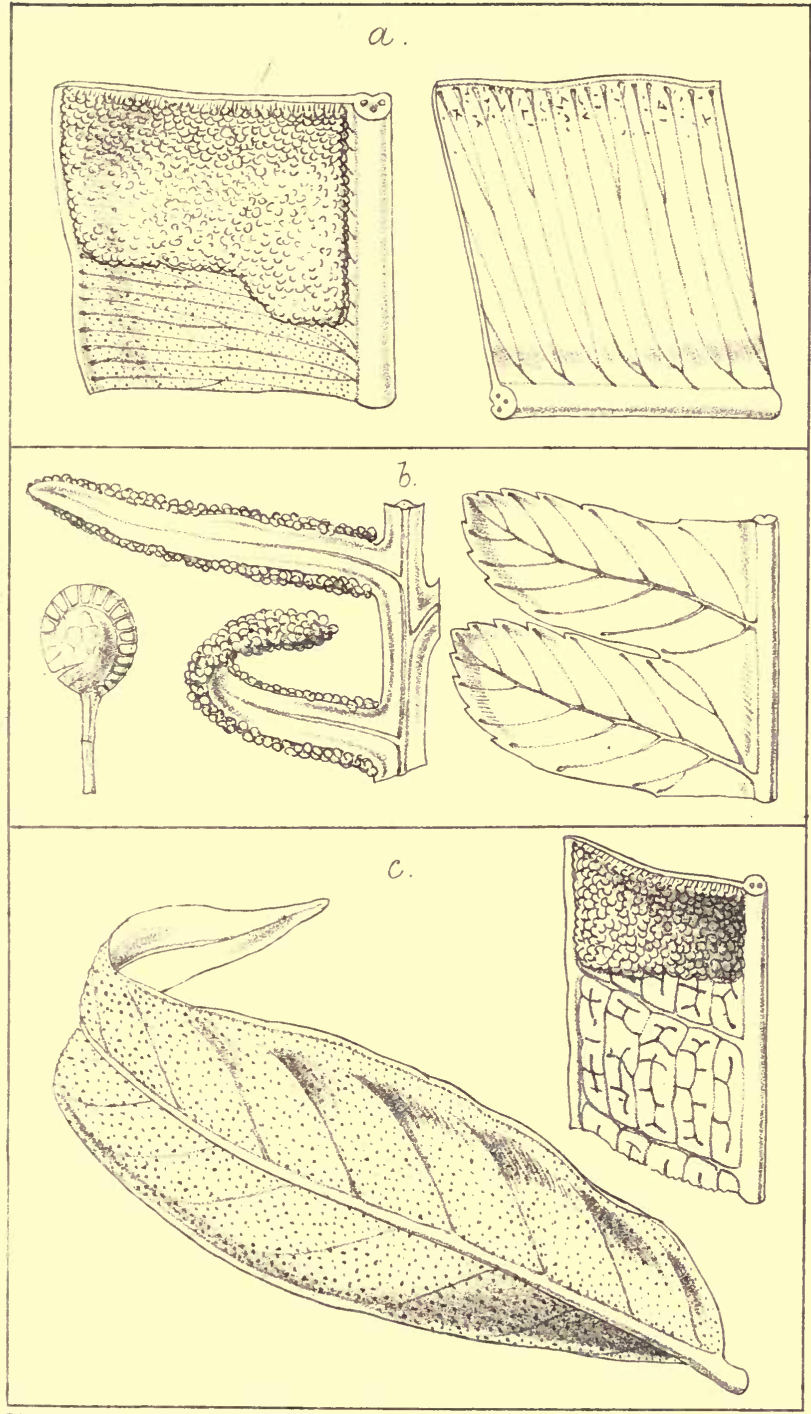

W.I Fitch, del.et lith 

species being arranged in natural groups, which are now by most authors ranked as genera. They are distinguished from the preceding and following tribes by the sporangia not being produced in defined, round, or linear masses (sori), but closely occupying the whole of the nnder side of the fertile fronds or segments, which are often contracted into rachiform spikes or panicles. By this contraction the venules are brought so close together that in many cases they seem to be entirely wanting, the whole disc becomes a sporangiferous receptacle; but in others this is a character of degree only, the contraction being often more or less definite in the same frond, there being instances of the veins being evident and sporangiferous, this variation has led to the different states being characterised by some authors as genera. Setting aside the contraction of the fertile frond, and the amorphous sori, many of the species agree in natural habit and venation with genera of the tribe Phegopteridece, which will be specially noticed under the respective genera.

\section{Section 1.-Elaphog Lossea.}

Fronds always simple. Veins free or rurely combined at the margin, or reticulate.

\section{0.-Elaphoglossum. Schott. (1834).}

\section{Acrostichum sp. Hook. Sp. Fil.}

Vernation uniserial or fasciculate. Fronds simple, entire, sessile, or stipitate, from 2 inches to $2 \frac{1}{2}$ feet long, smooth or squamose. Stipes often pseudo-articulate. Veins simple or forked, their apices free and clavate. Fertile fronds moderately contracted, the under side wholly sporangiferous.

'Type. Acrostichum conforme, Sxartz. 
Illust. Hook. and Bauer, Gen. Fil., t. 105, A ; Hook. Fil. Exot., t. 42, 29 ; Moore Ind. Fil., p. 2, B ; J. Sm. Ferns, Brit. and For., fig. 29; Hook. Syn. Fil., t. 7, fig. 60 , a. b.

Obs.-At page 68 of the Introduction I have shown that the vernation of Elaphoglossum is apparently intermediate between Eremobrya and Desmobrya, but more in favour of the latter.

In the "Synopsis Filicum" sixty-five species are described, and nearly as many more names recorded as doubtful; and in the Appendix thirty-four new species are described. M. Fée enumerates 116 species, of which sixty are represented by figures. On considering the very uniform character of the fronds, as regards circumscription and size, and that the principal differences consist in their being smooth or more or less villose or squamose, to which may be added slight variations in the venation, it becomes difficult to regard them as affording distinct characters for even the smaller estimate of species. As the evidence upon which the species are founded is entirely derived from herbarium specimens, the number consequently depends upon the views of authors.

The species are widely spread, being found very generally throughout the tropics, and extending to the latitude of Tristan d'Acunha in the southern hemisphere, and to Madeira in the northern, abounding in the West Indies and Tropical America, and in the Islands of the Indian and Malayan Archipelago in the east.

* Fronds smooth, or nearly so.

+ Vernation sarmentose. Fronds distant.

Ex.-E. stigmatolepis (Fée) (v v.); Bedd. F. S. Ind., pl. 196 ; E. Funckii (Fée) (v v.) 
†† Vernation fasciculate, decumbent.

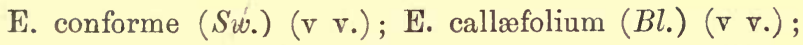
E. Sieberi (Hook. and Grev.) ( $\mathrm{v}_{0}$ ) ; E. crassinerve (Kze.) ( $\mathrm{v} v$.$) ; E. latifolium (S w).(\mathrm{v} v)$; E. L'Herminieri (Bory) ( $\vee$ v.) ; E. microlepis (Kze.) ( $\left(\mathrm{v} \mathrm{v}_{0}\right)$

** Fronds more or less densely squamiferous.

E. piloselloides $\left(P r_{.}\right)$( $(\mathrm{v}$ v.) ; E. rubiginosum (Fée) ( $\mathrm{v}$ v.) ; E. cuspidatum (Willd.) ( $\mathrm{v} \mathrm{v})$; E. muscosum $(S w$.$) ( \mathrm{v}$ v.); E. squamosum (Sw.) ( $\vee$ v.); E. vestitum (Hook. and Grev.) ( $\mathrm{v} \mathrm{v}$.

*** Fronds fringed or squamiferous at the margin only.

E. apodum (Hook. and Grev.) ( $\nabla$ v.); E. undulatum (Willd.) ( $\vee$ v.) ; E. scolopendrifolium (Radd.) ( $\vee$ v.)

\section{1.-Acontopteris, Presl (1836).}

Acrostichum sp.; Hook. Sp. Fil.

Vernation uniserial; sarmentum short, thick, squamose. Fronds contiguous, elliptical, or linear lanceolate, 6 to 12 inches long, smooth or squamiferous. Veins simple or forked, parallel, their apices combined near the margin by a straight or zigzag vein. Fertile frond linear, plain, wholly sporangiferous on the under side.

Type. Acrostichum nervosum, Bory.

Illust. Hook. and Bauer, Gen. Fil., t. 79, B; J. Sm. Ferns, Brit. and For., fig. 30 ; Hook. Syn. Fil., t. 7, fig. $60, p$ q.

Obs.-This as a genus was founded by Presl on Acrostichum nervosum of Bory, a native of St. Helena, to which has been added Acrostichum longifolium of Jacquin and A. gorgoneum of Kaulfuss, natives of the West Indies and Sandwich Islands. In habit they are allied to Elapho- 
glossum, but are distinguished by the veins being connected at the margin by a continuous zigzag or straight vein, similar to that of the genus Olfersia, but which has pinnate fronds, and also differs in the nature of its vernation.

Sp. A. nervosa (Bory) ( $\nabla$ v.) (A. subdiaphanum, Hook. and Grev.); A. longifolia (Jacq.) ( $\left.\nabla \nabla_{.}\right)$; A. gorgoneum (Kaulf.)

\section{2.-Hrmeñodidm, Fée (1844).}

Dictyoglossum, J. Sm., 1846 ; Acrostichum sp., Hook. Sp. Fil.

Vernation fasciculate, decumbent, thick. Fronds contiguous, stipitate, simple, entire, from 1 to 2 feet in length, broad elliptical, smooth or squamiferous, subcoriaceous. Veins uniform, reticulated, forming elongated oblique areoles. Fertile fronds the same shape as the sterile ones, but smaller.

Type. Acrostichum crinitum, Linn.

Illust. Hook. and Grev., t. 1; Hook. Fil. Exot., t. 6; Moore Ind. Fil., p. 6 A. ; J. Sm., Ferns Brit. and For., fig. 31.

OBs.-The reticulated venation distinguishes this genus from the two preceding ; it consists of three known species, two being natives of the West Indies and one of the Sandwich Islands.

Sp. H. crinitum (Linn.) ( $\vee$ v.) ; H. reticulatum (Kaulf.) ( $\vee$.) ; H. pachyphyllum $\left(K_{z}\right.$.).

43.-Anetium, Splitg. (1840).

Hemionitis, Hook. Sp. Fil. Antrophyum Fée.

Vernation uniserial, sarmentum slender. Fronds distant simple, oblong elliptical, acuminate, 6 to 20 inches long, 
smooth, membraneous. Veins uniform reticulated, forming trapezoid or hexagonal areoles. Receptacles undefined, the sporangia being thinly scattered, or collected in small irregular groups, over the whole under surface of the frond, or evident on the reins.

Type. Acrostichum citrifolium, Linn.

Illust. Moore Ind. Fil., p. 44, B.; J. Sm. Ferns, Brit. and For., fig. 32 ; Hook. syn. Fil., t. 6, fig. 59, B.

OBs.-In my definition of the genera of Ferns, 1841, I noticed the peculiarities of this Fern, and in 1846 I adopted it as a distinct genus under Kunze's sectional name, Anetium. It is decidedly what may be termed an aberrant species. Sir. Wm. Hooker places it in Hemionitis and Fée in Antrophyum, but the sporangia being thinly scattered over the whole under-disk indicate its relationship to be with Acrosticheæ.

Sp. A. citrifolium (Linn.) ( $\vee$ ₹.). (Hemionitis parisitica, Linn.).

A native of the West Indies, growing on trees.

Sect. 2.-Polybotryee.

Vernation generally uniserial, distant or contiguous. Fronds pinnate or bi-tripinnate, rarely flabellate, segments adherent. Veins free or combined at the margin or variously anastomosing.

*Veins free.

44.-Rhipidopteris, Schott. (1§34).

Acrostichum sp., Hook. Sp. Fil.

Vernation uniserial, sarmentum slender. Fronds flabelliform, stipate, 3 to 6 inches long, the sterile dichotomously 
multipartite, or sub-entire, cuniform, the fertile sub-rotund, entire or bilobed. Veins flabellately forked, free.

Type. Acrostichum peltatum, Sw.

Illust. Moore Ind. Fil., p. 2, A ; J. Sm. Ferns, Brit. and For., fig. 33 ; Hook. Syn. Fil., t. 7, fig. 60, k. 1.

OBS.-The slender sarmentose vernation and stipate small flabelliform frond marks the three species known of this genus as peculiar, having no direct affinity with any form of Acrostichece, their nearest being the following genus, Microstaphyla.

They are natives of the West Indies and Tropical America.

Sp. R. peltata (Sw.) ( $\nabla$ v.) ; R. flabellata (H. B. K.); R. fœniculacea (Hook.).

\section{5.-Mrcrostaphyla, Presl (1849).}

Polybotrya sp., Moore; Acrostichum sp., Hook. Sp. Fil.

Vernation uniserial, sarmentum short. Fronds numerous, contiguous, 3 to 8 inches high, the sterile linear lanceolate, sub-entire, unequally crenate, or laciniately pinnatifid, glandulose, segments and lacinæ cuneiform, entire or bitrilobed. Veins simple or forked. Fertile fronds contracted, shorter and less divided than the sterile.

Type. Acrostichum bifurcatum, $S w$.

Illust. Hook. Secd. Cent. of Ferns, t. 91 ; Schk. Fil., t. 2 ; J. Sm., Ferns, Brit. and For., fig. 34.

OBs.-The typical species of this genus is found only in the Island of St. Helena. It is a small-growing sleuder Fern, and like other genera of this tribe, distinguished more by habit than any technical difference of fructification. 
Sp. M. bifurcatum (Sw.) (v v.); M. dimorphum (Hook. and Grev., t. 145).

This species is also a native of St. Helena, and is considered by some to be only a form of the preceding.

$$
\text { 46.-Psomiocarpa, Presl (1849). }
$$

Polybotrya sp., J. Sm.; Acrostichum sp., Hook. Sp. Fil.

Vernation fasciculate, erect, acaulose. Fronds sub-bipinnatifid deltoid, the sterile 6 to 18 inches high, pilose, with articulate hairs, segments oblong lanceolate. Veins forked, venules free. Fertile fronds 8 to 12 inches high, long stipate, slender, wholly contracted, forming a sporangiferous panicle.

Type. Polybotrya apiifolia, J. Srn.

Illust. Moore Ind. Fil., p. 1, fig. 8; J. Sm. Ferns, Brit. and For., fig. 36.

OBs.-This genus is founded upon a very peculiar Fern, a native of the Philippine Islands, and was originally placed by me under Polybotrya. Setting aside the contraction of the fertile fronds, it might be taken for a small multifid species of Phegopteris or Lastrea.

Sp. P. apiifolia (J. Sm.) ( $\nabla$ v.) (Polybotrya apiifolia, J. Sm., 1841. Kunze in Schk. Fit., t. 62. Gard. in Field, Sert. t. 30,31$)$.

\section{7.-Egexolfia, Schott. (1843).}

Polybotrya sp., auct.; Acrostichum sp., Hnok. Sp. Fil.

Vernation sarmentose, short, sub-hypogeous. Fronds contiguous, stipate, pinnate, rarely bipinnatifid, 1 to 3 feet high, generally viviparous; sterile pinnæ linear lanceolate, sub-entire or dentate, laciniated or pinnatifid, sinus mucronate. Veins forked or pinnate, venules free. Fertile 
segments more or less contracted; venules evident, contiguous, forming a concrete amorphous receptacle, sometimes forming moniliform spikes.

Type. Acrostichum appendiculatum, Willd.

Illust. Schott. Gen. Fil., t. 35 ; J. Sm. Ferns, Brit. and For., fig. 35 ; Hook. Syn. Fil., t. 7, fig. 60, h., i., j.

OBs.-The species forming this genus are natives of the Eastern hemisphere, and were originally included by most authors under Polybotrya; but as they do not well associate in habit with the original species of that genus, I therefore adopt Schott's genus Egenolfia. At least eight species have been described as belonging to this group, but after comparing specimens representing the different species, the greater number of them seem to me to be only different forms of one or two, or at most three, species. The chief difference is in the pinnæ, which are entire or more or less laciniated, and the whole seem to run into one another.

Sp. E. asplenifolia (Bory); E. appendiculata (Willd.)

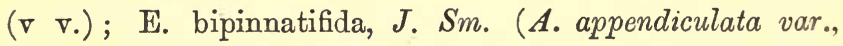
costulata, Hook. sp. Fil.).

OBs.- The regular bipinnatifid character of the fronds and their great length seems to mark the last as a distinct species.

\section{8.-Polybotrya, $H$. B. K. (1810). Acrostichum, Hook. Sp. Fil.}

Vernation uniserial, sarmentum thick, elongating, scandent, epiphytal, squamose. Fronds pinnate or bi-tripinnate, 2 to 4 feet long, glabrous, rarely villose. Veins pinnate, venules free. Fertile segments pinnatifid or spicæform, convolute, wholly sporangiferous. 
Type. Polybotrya osmundacea, H. B. K.

Illust. Hook. and Bauer, Gen. Fil., t. 78, B; Schott. Gen. Fil., t. 7 ; Moore Ind. Fil., p. 1, fig. 1 to 7 ; J. Sm. Ferns, Brit. and For., fig. 37; Hook. Syn. Fil., t. 7, fig. 60 , c. d. e.

OBs.-I now restrict Polybotrya to the species allied in general habit to the original type of the genus, Polybotrya osmundacea, of which there are about ten all natives of the West Indies and Tropical America. In general habit they are allied to the Tectaria section of Polystichum, the fronds of some of the latter being very similar in every respect to those of $P$. osmundacea, and in Polystichum ascendens the fertile fronds are contracted similar to those of Polybotrya.

* Fronds pinnate, pinnce dentate, or pinnatifid.

Sp. P. plumbicaule (Baker Syn. Fil.); P. fractiseriale (Baker Syn. Fil.); P. pubens, Kunze.

** Fronds bi-tri-quadripinnate.

P. acuminata Link. ( v v.) ; P. caudata, Kze.; P. nutans, Kze.; P. incisa, Link.; P. osmundacea, H. B. K. (v v.) ( $P$ cynlindrica, Kaulf.) ; P. caniculatum, Klot.; P. Lechleriana, Mett.

** Veins combined at the margin.

49.-Olfersia, Radd. (1819).

Acrostichum, sp. Hook. Sp. Fil.

Vernation uniserial, sarmentum thick, scandent, squamose. Fronds pinnate, 1 to 3 feet long; pinnæ ovate lanceolate, adherent and oblique at the base, smooth coriaceous. Veins uniform, simple, or forked, direct parallel, their apices combined by a transverse marginal vein. Fertile pinnæ linear or pinnatifid, convolute, wholly sporangiferous. 
Type. Acrostichum cervinum, sw.

Illust. Hook. and Bauer, Gen. Fil., t. 79, A; Moore Ind. Fil., p. 4, A ; J. Sm. Ferns, Brit. and For., fig. 39 ; Hook. Syn. Fil., t. 7 , fig. $€ 0$, m. n. o.

OBs.-This genus agrees with Polybotrya in general habit, but is technically distinguished by the veins being combined by a transverse marginal vein. Olfersia was originally founded by Raddi on a Brazilian Fern which he named $O$. corcovadensis, which is described as having the fertile pinnæ linear entire, thus differing from the usual forms of O.cervina, in which the fertile pinnæ are pinnatifid. Presl in his "Epimellia Botanica," raises O. corcovadensis to the rank of a genus, which he names Dorcapteris, but which is not tenable, for I have observed both forms produced on the same plant.

Sp. O. cervina, $S w$. (v v.) (Hook. and Grev., Ic. Fit., t. 81 ; O. corcovadensis, Radd. Fil. Bras., t. 14).

Native of West Indies and Tropical America.

*** Veins angularly or compoundly anastomosing.

$$
\text { 50.-Soromanes, Fée (1844). }
$$

Polybotrya sp., auct.; Acrostichum sp., Hook. Sp. Fil.

Vernation uniserial, sarmentum thick, scandent, elongating, squamose. Sterile fronds pinnate, 1 to 3 feet long; pinnæ ovate lanceolate, 4 to 6 inches long, the lower pairs pinnatifid. Veins pinnate; venules arcuately anastomosing, forming oblique elongated areoles, apices next the margin free and clavate. Fertile fronds bipinnate, segments convolute, wholly sporangiferous.

Type. Polybotrya serratifolia, Klot.

Illust. Moore Ind. Fil., p. 4, B; J. Sm. Ferns, Brit. and For., fig. 40 ; Hook. Syn. Fil., t. 7, fig. 60, r. s. 
OBs.-This genus is founded on a solitary species, a native of Venezuela and Mexico, which in general habit agrees with Polybotrya, but is distinguished by the venules being combined, forming oblique elongated areoles. In general the sterile fronds are pinnate, with nearly entire pinnæ; but in cultivated plants fronds are often produced with deeply laciniated pinnæ, similar to the states observed in Olfersia. In these specimens the veins of each of the lacinæ are partially thickened, and more or less united; and often towards the apex of the frond the lacinæ show some degree of contraction, and produce distant round masses of sporangia on their apex or margin, thus showing that the fertile fronds are only a highly contracted state of the sterile.

Sp. S. serratifolium, Fée Acrost., t. 43 (v v.).

\section{1.-Stenosemia Presl (1836).}

Polybotrya sp. auct.; Acrostichum sp. Hook. Sp. Fil.

Vernation fasciculate, acaulose. Fronds few, erect, deltoid, ternately pinnate, 6 to 18 inches long, segments laciniately lobed, bulbiferous. Veins pinnate; the lower venules transversely anastomosing, forming elongated costal and sub-costal areoles, the exterior venules free. Fertile. segments linear, rachiform, involute, nearly wholly sporangiferous.

Type. Polybotrya aurita, Blume.

Illust. Hook. Gard. Ferns, t. 81 ; Moore Ind. Fil., p. 6 B. ; J. Sm. Ferns, Brit. and For., fig. 411 ; Hook. Syn. Fil., t. 7 , fig. 60, t. u.

Ons.-This genus consists of a single species, a native of the Malayan and Philippine Islands, which to a certain extent in the character agrees with the following genus, 
Prcilopteris, but differs in its erect fasciculate vernation, and in the fertile segments being involute.

Sp. S. aurita (Blume Fil. Jav., t. 1) (v v.) (Polybotrya cicutaria, Bl.).

\section{2.-P๕cilopteris, Presl. (1836).}

Acrostichum sp. auct., Hook. Sp. Fil.

Vernation uniserial, sarmentum short or elongated. Fronds contiguous or distant, pinnate, 1 to 3 feet long, bulbiferous. Primary veins costæform, pinnate, venules arcuately or angularly anastomosing, producing on their exterior sides or angles one or more free or anastomosing veinlets, forming unequal areoles. Fertile pinno sometimes scarcely contracted, the venules then distinctly sporangiferous.

Type. Acrostichum punctulatum Linn.

Illus. Hook. and Bauer, Gen. Fil., t. 75, B ; Moore Ind.

Fil., p. 7 ; J. Sm. Ferns Brit. and For., fig. 42.

OBs.-The various and very different states exhibited by this genus has led not only to the forming of many species, but also to genera having been founded on different states of the same species, chiefly on the variations of the fertile frond being more or less contracted.

In some fronds of the same species the contraction of the fertile pinnæ is often very little, the venation is then more or less evident, and are then distinctly sporangiferous, forming linear anastomosing sori; this state constitutes the genus Jenkinsia of Hooker, figured and described in Hook. and Bauer's Gen. Fil., t. 75, B, which in some cases scarcely differs from Meniscium or Stegnogramma, and with which Pacilopteris agrees in habit, differing only in the reins of the sterile fronds being more compound anastomosed 
than in these two genera, but even in that character there are instances of different degrees of anastomosing found in the same or on different fronds of the same plant, therefore, setting aside the general acrostichoid character, Pocilopteris naturally associates with Meniscium.

Fée refers sixteen species to this genus which in the "Species Filicum" are reduced to twelve, and in the "Synopsis Filicum" the species are placed under two sections, Gymnopteris and Chrysodium, which between them contain 36 species, part of which have no natural affinity with either the original species of Pocilopteris or Gynnopteris; several even have articulate vernation and consequently belong to the division Eremobrya.

Sp. P. flagellifera (Wall. Hook. and Grev., t. 23) (v v.); P. Quoyanum (Gaud.); P. repanda (Bl.); P. crispatula (Wall.) (v v.) ; P. virens (Wall., Hook. and Grev., t. 221) ( $\vee$ v.) ; P. prolifera (Bl. Hook. Ic. Pl., t. 681-2) (v v.); P. costata (Wall.) ; P. punctulatum (Linn.) ( $\nabla$ v.) ; P. fluviatile (Hook.).

The two latter are natives of Tropical West Africa, the others of India and Malayan region.

\section{3.-Grmaopteris, Bernh. (1800).}

Acrostichum sp., Hook. Sp., Fil.

Vernation uniserial, sarmentum short or elongated. Fronds distant or contiguous and subfasiculate, simple, lobed or pinnate, rarely bipinnatifid, from 6 inches to 2 or 3 feet high, pinnæ 6 to 8 inches in length, ovate lanceolate. Primary veins costæform, venules compound anastomosing, with free variously directed veinlets, terminating in the areoles. Fertile pinnoe sometimes broad, densely sporangiferous on the under side. 
Type. Acrostichum nicotiancefolium, Sw.

Illust. Hook. and Bauer, Gen. Fil., t. 85: Moore Ind.

Fil., p. 8, A ; J. Sm. Ferns, Brit. and For., fig. 43.

Obs.-This genus was founded by Bernhardi in 1800, on the Acrostichum quercifolium of Retzius. As a genus it is technically distinguished from the preceding by the more compound venation, which is similar to that of the genera Dryomanes, Dipteris, Cheiropleuria, and Aspidium, which, with Gymnopteris, form a very natural group of Ferns, the several genera being distinguished from each other more by the grouping and position of the sporangia than by any great diversity in mode of growth or general habit of the fronds.

The genus consists of about sixteen species, natives of the Old and New World.

\section{* Indian and Malayan region.}

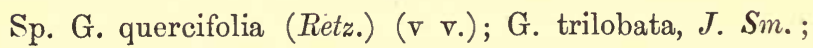
G. taccæfolia, J. Sm.; G. Harlandi (Hook) (G. decurrens, Hook. Fil. Exot., t. 94); G. subrepanda, J. Sm.; G. semicordata (Bak.); G. Presliana (Hook.).

\section{** Tropical West Africa.}

G. Gaboonense (Hook.) ( $v \vee$ ); G. Heudelotii (Hook.); G. salicina (Hook.)

\section{*** West Indies and Tropical America.}

G. pandurifolia (Hook.) ; G. oligarchica (Bak.); G. nicotianæfolia $(S w$.$\left.) ( \nabla \nabla_{0}\right)$; G. aliena $(S w$.$\left.) ( \nabla \nabla.\right)$; G. semipinnatifida (F'ée); G. acuminata (Willd.) ( $\nabla$ v.) (Plum. Fil., t. 115).

Oвs.-Acrostichum variabile, Hook. Sp. Fil. (Gymnopteris decurrens, Hook. Gard. Ferns, t. 6), is Leptochilus decurrens. 


\section{4.-Cheiropleuria. $\operatorname{Pr}$. (1849).}

Acrostichum, sp. Hook. Sp. Fil.

Vernation sarmentose. Fronds distant or contiguous, $1 \frac{1}{2}$ or more feet in length, long stipate, flabellately bi-tripartite, firm, coriaceous. Main veins, two to three, radiating from the base, venules compoundly anastomosing. Fertile fronds wholly, or the central lobes only, sporangiferous.

Type. Acrostichum bicuspe, Hook.

Illust. Hook. Sp. Fil. 5, t. 304.

Oss.-This genus consists of two species, which in venation agree with Gymnopteris, but differ so much in aspect and texture that I deem it best to follow Presl in viewing them as a distinct genus.

Sp. C. bicuspis (Hook.); C. vespertilio (Hook.), Lond. Journ. Bot., p. 193, t. 7 and 8; C. tricuspe (Hook.).

Sikkim, Java, and other Malayan islands.

OBs.-It is probable that the above three species are different forms of one only.

Sect. 3.-Arthrobotre.

Vernation sarmentose. Fronds pinnate or bipinnate, segments articulated with the rachis. Veins free or angularly anastomosing.

* Veins free.

55.-Lomariopsis, Fée (1844).

Polybotrya sp., auct.; Acrostichum sp., Hook. Sp. Fil.

Vernation uniserial; sarmentum scandent. Fronds pinnate, 1 to 3 feet high; pinnæ linear, elliptical, broad lanceolate, acuminate, 2 to 10 inches long, articulate with the rachis. Veins uniform, simple, or forked, direct, 
free. Fertile pinnce plain, sometimes only partially contracted, sporangiferous on the under side; margin membraneous, sub-indusæform.

Type. Acrostichum sorbifolium, Linn.

Illust. Hook. Gard. Ferns, t. 57 ; Moore Ind. Fil., p. 3, A ; J. Sm. Ferns, Brit. and For., fig. 38.

Obs.-In my "Arrangement of the Genera of Ferns," in 1841, I adopted Acrostichum scandens, Linn., as the type of a distinct genus, which I named Stenochloena, to which I also referred A. sorbifolia of Linn., and A. longifolia, Kaulf.; but not long after this was done, the three species came under my notice in a living state, and I then found that $A$. scandens differed from the two latter in having a transverse anastomose costal vein like that of Blechnum; this character indicates its relationship to be with Blechnum, the other two species being truly acrostichoid, and allied to a group of fifteen species which Fee places under the present genus; but on account of the variableness of the forms which come under this genus, it is difficult to determine which are species. In the "Species Filicum" no less than eighteen specific names and five genera are given as synouyms under $L$. sorbifolia; but it is quite probable that when seen under cultivation some of these forms may be found to be quite distinct species, of which $L$. sorbifolia and $L$. longifolia are proofs. They are widely dispersed over the Tropics of the Western and Eastern Hemisphere, and also represented in New Zealand.

Sp. L. sorbifolia (Linn.) ( $\nabla$ v.); L. longifolia (Kaulf.) ( $\nabla \nabla$.$) ,$ (Lowe's New Ferns, t. 37); L. Yapurense, Hook. (Gard. Ferns, t. 57) ; L. Smithii, Fée Acrost. p. 74, t. 33, fig. 2, (Stenochloena longifolia, J. Sm.) ; L. Boryana, Fée Acrost., t. 27 ; L. leptocarpa, Fée (Acrost., t. 29); L. cuspidata, Fée 
(Acrost., t. 27) ; L. heteromorpha, J.Sm. (Lomaria filiformis, A.Cunn., Hook. Sp. Fil. 3, t. 149; L. pimpinellaefolia Hook. fil. in Hook. Lond. Journ. of Bot. 3, p. 412).

OBs.-This last is a native of New Zealand, and very variable in the form of its fronds; in what may be termed the perfect state, the pinnæ are lanceolate, and 2 to 3 inches in length, whereas in the variety termed pimpinelloefolia they are numerous, small, and nearly round, not exceeding a quarter of an inch in diameter.

With regard to L. leptocarpa, it is peculiar in having a thickened base to the stipes, analogous in appearance to the articulate node that characterises the division Eremobrya. Fée describes it as "frondibus articulatis." My own observation, however, is that it is not jointed with the sarmentum.

56.-Arthrobotrya. $J$. Sm.

Polybotrya, J. Sm., 1841 ; Acrostichum sp., Hook. Sp. Fil.

Vernation uniserial, sarmentose. Fronds distant, bipinnate, 3 to 4 feet high, pinnæ alternate, 6 to 8 inches long, patent, articulate with the rachis; sterile pinnules contiguous, twenty to thirty pairs, obliquely oblong, $\frac{1}{2}$ inch in length, short petiolate and articulate with the rachis, which is subalate. Veins forked, free. Fertile pinnules linear falcate, smaller than the sterile, the under disk wholly sporangi. ferous.

Type. Polybotrya articulata, J. Sm.

Illust. Fée's Acrost., p. 74, t. 37.

OBs.-The Fern bearing the above character being so different in general habit from true Polybotrya, I am induced to separate it as a distinct genus. The articulate pinnæ and pinnules distinguishes it from Polybotrya, and the bipinnate fronds from Lomariopsis. 
This remarkable Fern has as yet only been found in the island of Leyte, Philippines.

Sp. A. articulata, J. Sm. (Acrostichum Wilkesianum, Hook., is probably the same; it is a native of New Caledonia and Society islands and shows that $A$. articulata has a wider range than the island of Leyte).

*** Veins anastomosing in various ways.

57.-Crrtogonium. J. Sm. in part. (1841). Acrostichum sp., auct.; Hook. Sp. Fil.

Vernation uniserial, sarmentum slender scandent. Fronds pinnate, 1 to $2 \frac{1}{2}$ feet long, pinnæ linear, lanceolate, acuminate, crenate-serrate, petiolate, articulate with the rachis. Veins short, pinnate, venules anastomosing, the costal areoles trigonal, larger than the exterior ones, which are obliquely rhomboid. Fertile pinnce contracted. Receptacles confined to the concentrated venules, forming reticulated lines of confluent sporangia.

Type. Acrostichum serratifolium, Mert.

Illust. Schotts. Gen. Fil., t. 12; Hook. and Bauer, Gen. Fil., t. 81, B ; Fée's Acrost., p. 94, t. 55, fig. 3.

OBs.-Cyrtogonium, as originally characterised, included species of Pocilopteris, but as now restricted it is distinguished by the pinnæ being articulate with the rachis.

Sp. C. serratifolium (Mert.) (C. fraxinifolium Hook. and Bauer.); C. scandens (Radd. Fil. Bras., t. 18) (A. Raddianum, Kze.); C. pinnata J. Sm. (Neurocallis, Moore Ind. Fil.)

The two first are natives of Brazil, and the last of India. 


\section{8.-Lomagramia, $J$. Sm. (1841).}

Cheilolepton, Fée (1844); Neurocallis, Pr. and Moore; Leptochilus sp., Blume; Acrostichum sp., Hook. Sp. Fil.

Vernation uniserial, sarmentum scandent. Fronds stipate, pinnate, or bipinnate, 2 to 3 feet high, membraneous, flaccid. Pinnce numerous, lanceolate, 6 to 8 inches long, base truncate, sessile, and articalate with the rachis. Veins uniform, reticulate; areoles oblong, hexagonoid. Fertile segments contracted, wholly sporangiferous, or sometimes the contraction only partial, and then the sporangia forming a broad marginal line; both states furnished with numerous peltate scales.

Type. Leptochilus lomaroides, $B l$.

Illust. Hook. and Bauer, Gen. Fil., t. 98 ; Fée Acrost., t. 51 ; Moore Ind. Fil., p. 18, A.

OBs.- This genus was originally founded on specimens of a Fern from the Philippine Islands, which I afterwards found had been previously described by Blume under the name of Leptochilus lomaroides. In general habit it agrees with Cyrtogonium as now restricted, but the numerous and curious peltate scales that cover the sporangia marks it as a distinct genus; it was originally supposed by me that the marginal sori was its normal character, but this is now found to be due to the fertile pinnæ being only partially contracted.

* Fronds pinnate.

Sp. L. lomarioides (Bl.) (L. pteroides, J. Sm. 1841, Acrost. Blumeanum, Hook. Sp. Fil. 5, p. 268.)

** Fronds bipinnate.

L. polyphylla, Brack. Fil. U. S. Exxpl. Exp., p. 83, t. 12, f. 3. 


\section{9.-Photinopteris, J. Sm. (1841).}

Lomaria sp., Blume; Acrostichum sp., Wall.; Hook. Sp. Fil.

Vernation uniserial, sarmentum scandent. Fronds distant, pinnate, 2 to 3 feet long, smooth, coriaceous, rigid, shining, the upper pinnæ contracted and fertile. Sterile pinne distant, alternate, elliptical, acuminate, 6 to 8 inches long, 2 to 3 inches wide, petiole short, attached to the rachis by a scutiform lobe. Veins costæform, venules and veinlets compound anastomosing, forming quadrangular areoles. Fertile pinnce linear, rachiform, 8 to 12 inches in length, their under side wholly sporangiferous.

Type. Lomaria speciosa, Bl.

Illust. Hook. and Bauer, Gen. Fil., t. 92; Moore Ind. Fil., p. 9, A ; Hook. Syn. Fil., t. 8, fig. 60, ff, gg, hh.

OBs.-My first knowledge of the singular Fern on which this genus is founded, was obtained from a specimen in the herbarium of Dr. Horsfield, which had been collected in Java, which led me to give it the specific name of Horsfieldii; in 1822 it was found near Singapore by Wallich, and was named by him Acrostichum rigidum. It was, however, first described by Blume, under the name of Lomaria speciosa. It was also found by Cuming in the Philippine Islands, who described it to me as growing on trees, and being conspicuous by its shining fronds. In vernation it agrees with Gymnopteris, but its peculiar habit and articulate pinnæ does not admit of its being associated with that genus; in these characters it agrees with Drynaria and Dryostachum, but its adherent vernation prevents its alliance with these genera.

Sp. P. speciosa (Bl.) (Acrostichum rigidum, Wall. M. S. Cat. Herb.; Bedd. F. Brit. Ind., pl. 211 ; P. Horsfieldii, J. Sm. Journ. of Bot., 1841 ; P. simplex, J. Sm.) ; P. drynarioides, 
J. Sm., Bedd. F. Brit. Ind., 325 (Acrostichum Photinopteris drynarioides, Hoote. Sp. Fil.)

A native of Penang and Solomon Islands.

\section{Sect. 4.-Acrosticheat.}

Vernation fasciculate erect, or decumbent. Fronds pinnate. Venation reticulated, without free veinlets.

$$
\text { 60.-Neurocallis, Fée. (1844). }
$$

Acrostichum sp., auct.; Hook. Sp. Fil.

Vernation fasciculate, decumbent. Fronds pinnate, 3 to 4 feet high, smooth. Sterile pinnoe elliptical, lanceolate, acuminate, entire, 8 to 10 inches long, 2 inches wide, sessile adherent with the rachis. Veins uniform, reticulated; areoles oblong, hexagonoid. Fertile fronds contracted, pinnæ linear, acuminate, plane, wholly sporangiferous on the under side. Sporangia destitute of indusioid scales.

Type. Acrosticinum proestantissimum, Bory.

Illust. Hook. Gard. Ferns, t. 58; Moore Ind. Fil., p. 5, fig. 1 and 5 ; J. Sm. Ferns, Brit. and For., fig. 44.

OBS.-This genus is founded upon a splendid pinnatefronded Fern, found only in the islands of Guadaloupe and Dominica. In the character of its venation it agrees with Lomagramma, from which it differs in the pinnæ not being articulate with the rachis.

Sp. H. præstantissima (Bory.) (v v.)

$$
\text { 61.-Acrostichum, Linn. (in part) (1737). }
$$

Chrysodium, Fée.; Acrostichum, Hook. Sp. Fil.

Vernation fasciculate erect. Fronds coronate, pinnate, smooth, 2 to 8 feet high ; pinnæ entire, from 6 to 18 inches 
long, 2 to 3 inches broad, the upper pairs of pinnæ contracted and fertile. Veins uniform, reticulated, forming numerous elongated subquadrangular parallel areoles. Sporangia. densely occupying the whole of the under surface of the fertile pinnæ.

Type. Acrostichum aureum, Linn.

Illust. Hook. and Bauer. Gen. Fil., t. 81 A.; Moore Ind. Fil., p. 8, B ; J. Sm. Ferns, Brit. and For., fig. 54 .

OBs.-This genus was founded by Linnæus in 1737, the typical species being Acrostichum aureum, but subsequently he, and other authors, added numerous other species to the genus, indeed it may be said that all Ferns in which the sporangia were not evident in well defined round or linear masses were referred to this genus, as shown by Moore's "Index Filicum," in which no less than 473 generic and specific names are recorded, of which about 140 now constitute the tribe Acrostichece : the principal are given as examples under the respective new genera as above defined.

The genus Acrostichum, as here restricted, consists of only one species, namely, $A$. aureum, which is found in most Fern regions throughout the tropics of both hemispheres, which under the different influences of climate, and growing in wet or dry places assumes very different aspects as regards size and texture, such being the case, has led to a dozen or more specific names being given by authors to the different states. In the "Species Filicum" they are all recorded as synonyms, in which I concur.

Sp. A. aureum, Linn. (A. marginatum, Schk., A. incequale, Willd., A. speciosum, Willd., A. dancefolium, Lang. et Fisch., A. fraxinifolium, R. Br., A. sculpturatum, Presl, A. obliquum, Bl., Chrysodium hirsutum, Fée.). 



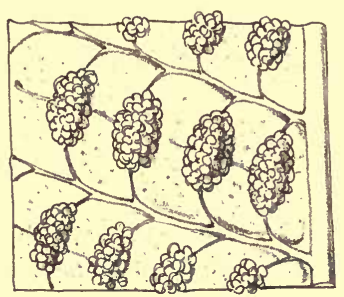

a.

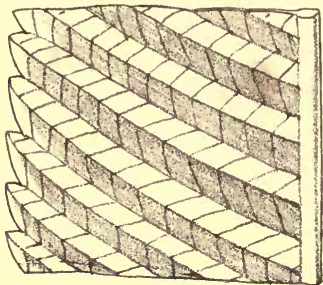

b
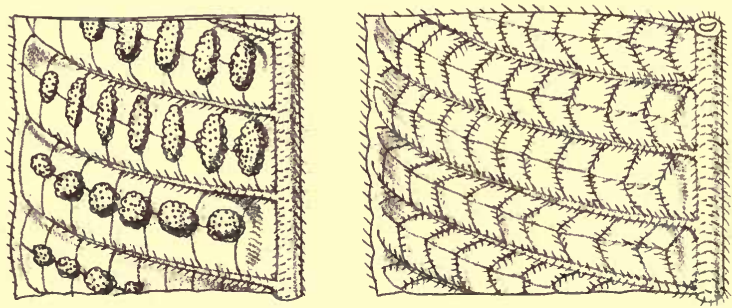

2

C.
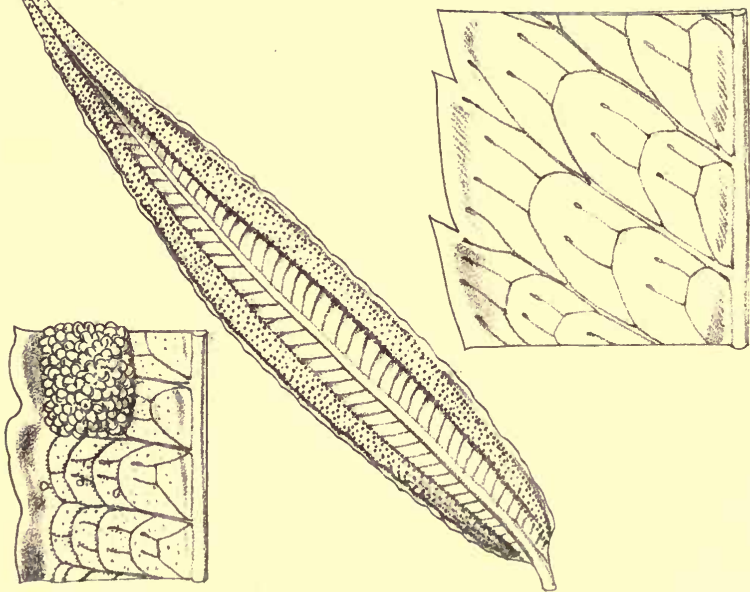

W. H.Fitch, del. et lith. 
OBs. $-A$. obliquum of Blume is founded on simple fronds, which may be considered as an abnormal state.

\section{Tribe 7.-MENISCE $\nexists . \quad$ (Plate 7.)}

Fronds pinnate, rarely simple. Veins anastomosing, evident. Sori linear, arcuate transverse or reticulated, often confluent.

OBS.-This tribe consists of about a dozen species, the principal number being comprehended under the genus Meniscium.

Hitherto I have associated Meniscium with Dictyopteris and Goniopteris, and there is no doubt that it forms a natural connection between Pocilopteris and these genera; but on viewing what I have stated under Precilopteris, I now consider it to have more relationship with that genus than with its former allies, I therefore rank it as a transition tribe between Acrostichea and Phegopterideo, of which Meniscium simplex is an example, and, as already stated at page 62 , cultivated plants become truly acrostichoid, but as the venation of the sterile frond is more in character with that of Meniscium than with Pocilopteris, I therefore retain it under the former.

\section{2.-Meniscium, Schreb. (1791).}

1 Verration decumbent, subfasciculate. Fronds contiguous, pinnate, rarely simple, 1 to 8 feet high. Primary veins costæform, pinnate, each opposite pair of venules angularly or arcuately anastomosing, and sporangiferous, producing from their junction an excurrent, free, sterile veinlet. Receptacles linear, continued across the junction of the venules, forming arcuate transverse sori. Sporangia in some species pilose. 
Type. Meniscium reticulatum, Schreb.

Illust. Hook. and Bauer, Gen. Fil., t. 40 ; Schott. Gen. Fil., t. 14 ; Moore Ind. Fil., p. 34 B.; J. Sm., Ferns, Brit. and For., fig. 63; Hook. Syn. Fil., t. 6, fig. 54.

OBS.-In the "Synopsis Filicum" ten species are described, six of which are natives of the tropics of the Eastern and four of the Western hemispheres.

* Fronds simple.

Sp. M. simplex, Hook. (v v.); M. giganteum, Hook. ( $\nabla$ v.). ** Fronds pinnate.

M. triphyllum, $S w .(\nabla \nabla$.$) ; M. serratum, Cav. ( \nabla$ v.) (M. palustre, Radd.) ; M. dentatum, Pr. ( $\vee \nabla$.$) ; M. reticulatum,$ Sw. ( $\vee$ v.) ; M. angustifolium, Willd.; M. salicifolium, Wall.; M. pauciflorum, Hook.

\section{3.-Dictrocline, Moore (1855).}

Hemionitis, Hook. Sp. Fil.

Vernation decumbent, sub-sarmentose. Fronds long stipitate, pinnatifid and pinnate, 3 to 4 pairs, petiolate, broad lanceolate, acuminate, falcate, 5 to 6 inches long, 1 to $1 \frac{1}{2}$ inches broad. Primary veins costæform, combined by transverse arcuate or zig-zag anastomosing venules, the lower forming one oblong costal areole, the others, three series of unequal sub-hexagonal areoles between the primary veins. Sori reticulate. Sporangia furnished with one or two straight setea.

Type. Dictyocline Griffithii, Moore.

Illust. Hook. Fil. Exot, t. 93 ; Moore Ind. Fil., p. 46, A.

OBs.-The present genus was founded by Mr. Moore upon a Fern from Assam, and placed upon account of its sori being reticulated, next to Hemionites, but it possesses 



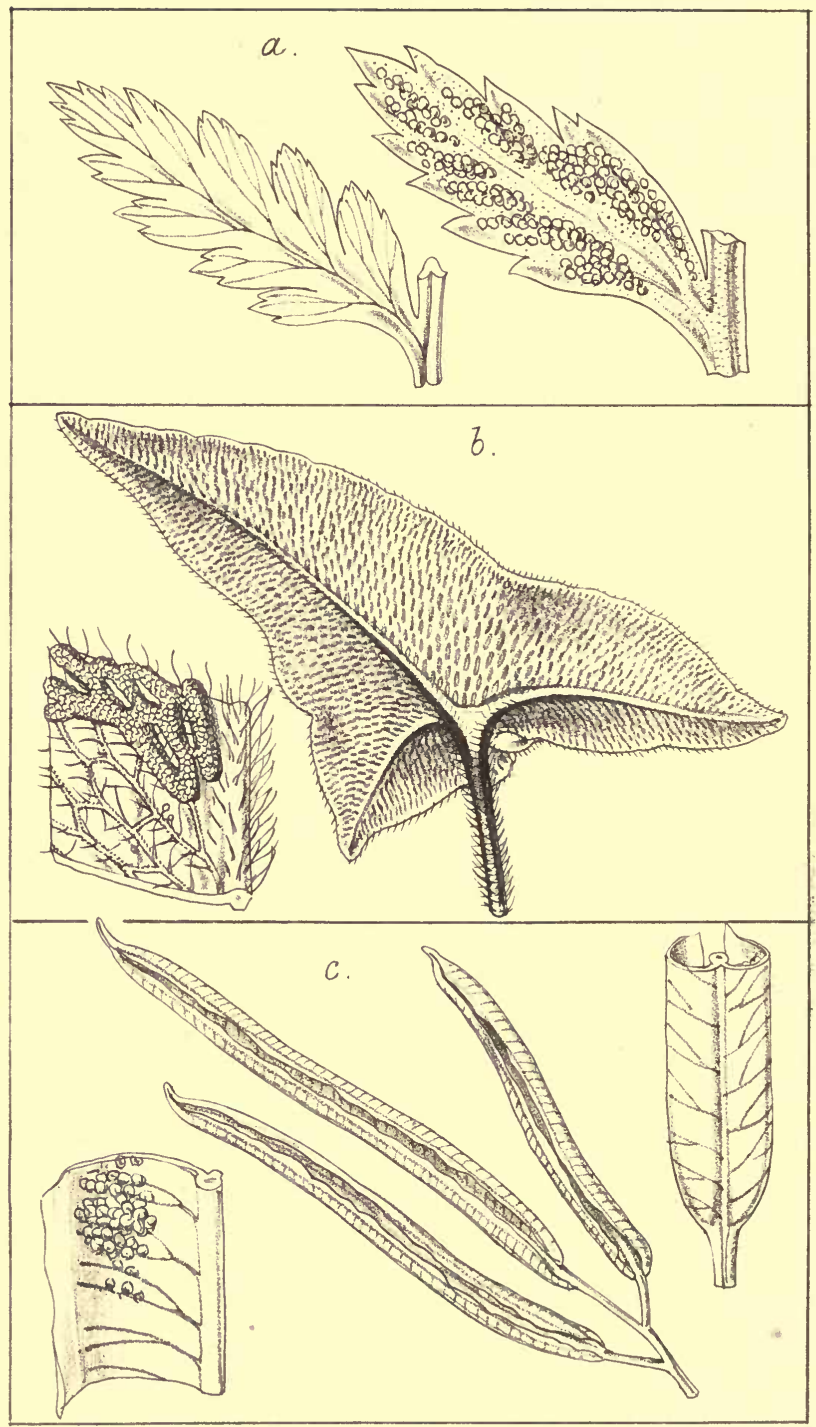

W. H. Fitch, del et hith

J.N. Fitch,imp 
no other point of relationship with that genus, its whole habit and structure resembling Goniopteris and Stegnogramma, while from Meniscium it is distinguished only by the more zig-zag anastomosing of the venules. Although it thus differs from these genera only in degree, I nevertheless think it desirable to adopt it as a genus.

Sp. D. Griffithii, Moore, Bedd.'F. Brit. Ind. pl. 150 ; D. Wilfordi, J. Sm. (Hook. Fil. Exot., t. 93).

These two species are very local, the first being a native of Assam, the other of Formosa.

\section{Tribe 8.-GRAMMITIDE $\not$ (Plate 8).}

Fronds varying from simple to decompound multifid, and from a few inches to several feet in height. Veins free or anastomosing. Sori linear, free or united, discal ; sporangia superficial or immersed in grooves, naked or included under an universal indusium.

Obs.-According to the "Synopsis Filicum" this tribe, as restricted by me, contains about one hundred species, the greater number being represented by the genus Gymnogramma. In some genera of the section Cryptogramma the sori are very short and even, nearly punctiform; the reasons for retaining such in this tribe are specially notified under the genera of that section.

Grammitidece is represented in all Fern regions, especially within or near the tropics.

\section{SERIES 1.-Veins anastomosing in various ways.}

Sect. 1.-Hemionitidez.

Venation uniform, reticulated, or the venules parallel and angularly anastomosing, near to, or at the margin only. Sori equally reticulate or connected on or next the margin. 
64.-Hemionitis, Linn., in part.

Hemionitis, Acrostichum, and Gymnogramma, sp. Hook. Sp. Fil.

Vernation erect or sub-decumbent, acaulose. Fronds simple, cordate, palmate or pinnate, smooth, villose or squamose, 6 to 12 inches in height. Veins uniform, reticulate; in some the venules free next the margin. Sporangia occupying the whole of the venation, forming reticulate, often confluent, superficial sori.

Type. Hemionitis palmata, Linn.

Illust. Hook. and Bauer, Gen. Fil., t. 74 B.; Hook. Ex. Fil., t. 33 ; Moore Ind. Fil., p. 45, B; J. Sm. Ferns, Brit. and For., fig. 54; Hook. Syn. Fil., t. 6, fig. 59, A. OBs.-The type of this genus is the well-known Hemionitis palmata of Linnæus, to which several other species have been added. Four of these possess the same general habit as the type ; but this cannot be said of H.cordata, H.vestita, and $H$.Muelleri, which, although I retain them as sections of Hemionitis, are nevertheless almost worthy of being regarded as types of distinct genera.

\section{* Hemionitis vera.}

Fronds palmate or lobed, pinnatifid or sub-pinnate, villose.

H. hederæfolia, J. Sm. (Hook. Syn. Fil.) ; H. palmata (Linn.) ( $\nabla \mathrm{v}$. ) ; H. podophylla (Hook.) ( $\nabla$ v.) (H. pedata, $J . S m . n o n S w$.$) ; H. pinnatifida, Baker; H. pinnata, J. Sm.$ (Hook. Syn. Fil.)

Natives of the West lndies and parts of Tropical America.

\section{** Sericonitis.}

Caudex decumbent, sub-sarmentose, short. Fronds contiguous, pinnate, 6 to 14 inches long; pinnoe contiguous, 1 to 
1을 inch long, 6 to 12 pairs, oblong elliptical, short petiolate, densely sericeo squamose. Veins uniform, anastomosing touards the margin. Sporangia obscure, hidden by the silky squamve.

H. vestita, J. Sm. (Grammitis, Wall., Bedd. F. Brit. Ind., pl. 154); H. Muelleri, J. Sm. (Gymnogramma, Hook.); H. aureo-nitens, J. Sm. (Acrostichum, Hook.)

OBs.-The fine silky hairs and squamæ common to these three species is sufficient to indicate that they are naturally allied; the latter, however, differs in having two kinds of fronds, the sterile being simple, oblong spathulate, and the fertile pinnate.

In the "Species Filicum," $H$. Muelleri is described as having free veins, but in the specimens which I have examined I found them to be netted.

These three species are very local, the first being a native of Nepal, the second of Queensland, and the third found only in the Galapagos.

\section{*** Cardinitis.}

Caudex decumbent, sub-sarmentose, short. Fronds stipitate, cordate hastate, firm, smooth. Sori copious, contiguous, becoming confluent.

H. cordata, Roxb. ( $\nabla \nabla$.

Throughout India, the Malay, and the Philippine Islands.

OBs.-For H. Griffithii, Hooker, and Wilfordii, Hook., see Dictyocline; and for H. citrifolia, Hook., see Anetium.

\section{5.-Syngramma, J. Sm. (1845).}

Gymnogramma sp., Hook. Sp. Fil.

Vernation uniserial, sarmentum short. Fronds stipitate, contiguous, smooth, entire, simple, linear lanceolate, oblong elliptical, or rarely pinnate, 6 to 12 inches long. Veins forked close to the mid-rib, venules direct parallel, their 
apices anastomosing at the margin, forming a continuous marginal vein, or one or more series of marginal areoles. Sporangia occupying the whole of the venules, forming linear parallel and reticulated sori.

Type. Syngramma alismofolia, J. Sm.

Illust. Lond. Jour. Bot., v. 4, t. 7, 8, B ; Moore Ind. Fil., p. 46, B ; Hook. Syn. Fil., t. 6, fig. 52, d. e. f.

OBs.-The species on which this genus is founded was originally described by Presl., in bis Rel. Haenlieano, as a species of Diplazium; but his original specimen having come into my possession, with the addition of others, clearly showed that the sori were destitute of indusium, having the true character of Gymnogramma, but differing in the venation being anastomose, this led me to characterise it as a distinct genus under the above name.

Sp. S. alismæfolia, J. Sm., (Bedd. F. Brit. Ind., pl. 240); S. vittæformis, J. Sm.; S. obtusifolia, Hook.; S. Lobbiana, Hook.; S. Borneensis, Hook.; S. Wallichii, Hook.; S. pinnata, Hook.

Natives of Malayan, Borneo, and Polynesian islands. Besides the usual pinnate fronds of $S$. pinnata it also produces simple fronds, which in the specimens seen by me were sterile; they are, nevertheless, extremely like the Hemionitis lanceolata, described and figured by Sir W. Hooker, in the Second Cent. Fern, t. 55, but the venation is more uniform reticulated and wholly sporangiferous, as in true Hemionitis. I am, however, inclined to consider it a state of $S$. pinnata.

66.-Dictrogramma, Fée. (1851).

Gymnogramma sp., Hook. Sp. Fil.

Vernation uniserial, sub-fasciculate, decumbent. Fronds contiguous, pinnate, or sub.bipinnate, 1 to 3 feet high, 
smooth, flaccid, pinnæ elliptical lanceolate, 6 to 10 inches long. Venation sub-uniform, reticulated, areoles subhexogonoid, oblique. Sporangia occupying the whole of the venules, forming netted sori.

Type. Hemionitis japonica, Thunb.

Illust. Fée Gen. Fil., t. 15, A ; Moore Ind. Fil., p. 47, A ; J. Sm. Ferns, Brit. and For., fig. 53; Hook. Syn. Fil., t. 6 , fig. 52 , c.

OBs.-This genus differs from the preceding chiefly in habit and in the venation being more uniform reticulated.

Sp. D. japonica, Fée ( $\vee$ v.) (Gymnogramma japonica, Kze. in Schk. Fil. Suppl., t. 116).

Native of Japan.

\section{7.-Tenitis, Willd. (1806).}

Vernation uniserial, sub-fasciculate. Fronds contiguous, long stipitate, smooth, firm, coriaceous, 1 to 2 feet in length ; pinnæ 4 to 6 pairs, linear-lanceolate or elliptical-acuminate, entire, 6 to 10 inches long, by 1 to 2 inches broad. Veins uniform, reticulated; areolea oblong, hexagonoid, oblique. Receptacles compital, oblong, oblique coalescing, forming a transverse line between the mid-rib and margin. Sporangia crowded, forming a broad compound continuous, sometimes interrupted, sorus.

Type. Toenitis blechnoides, $S w$.

Illust. Hook. and Bauer. Gen. Fil., t. 77, B.; Moore Ind. Fil., p. 17, A.; Hook. Syn. Fil., t. 6, fig. 57.

OBs.-This genus is founded on a single species, which agrees in general habit and texture of its fronds with Syngramma pinnata, but is distinguished by the sori being oblique oblong, and laterally confluent, forming a compound, transverse, medial sorus, but in some the line is interrupted, and then constitutes Toenitis interrupta of Hooker and 
Grevelle, t. 62. In some Fijian specimens the sori are scattered over the disk, being round or oval, and compital on the anastomoses of the veins, which may be considered an abnormal condition consequent on local influences.

Sp. T. blechnoides, Sw. (T. pteroides, Schk. Fil., t. 6, B); T. obtusa, Hook. Ic. Pl. t. 994.

OBs.-This is described as having fronds only $1 \frac{1}{2}$ to 2 inches long, and is probably only a young state of T. blechnoides. They are natives of Borneo, Malay, Philippine and Fiji islands.

68.-Antrophyum, Kaulf. (1824).

Hook. Sp. Fil.; Hemionitis sp., Linn. and auct.;

Polytorium, Desv.

Vernation uniserial, sarmentum, short, squamose. Fronds contiguous cæspitose, simple, linear-lanceolate, or oblongelliptical, or subrotund, smooth, coriaceous, with or without a defined mid-rib. Veins uniform, reticulated. Receptacles discal, immersed, forming grooves in which the sporangia are seated. Sori reticulated or interrupted.

Type. Antrophyum plantagineum, Kaulf.

Illust. Hook. and Bauer. Gen. Fil., t. 109 A. ; Moore Ind. Fil., p. 16, A., 44, A., 45, A.; J. Sm. Ferns, Brit. and For., fig. 55 ; Hook. Syn. Fil., t. 6, fig. 55 .

OBs.-The general aspect and mode of growth indicates the affinity of this genus to be with Vittaria, from which it is technically distinguished by its reticulate venation. Representatives of this genus are widely distributed throughout the tropics, being found in the islands of the Pacific and Indian Oceans, the continent of Asia, the West Indian Islands, Tropical America and Mauritius, and have also lately been found in West Tropical Africa. 
With such a wide range many species have been described by authors on very slight characters, chiefly in difference in size, for instance, in Moore's Index 55 names are recorded, of which only twenty-one are adopted as true species, and these in the "Synopsis Filicum" are reduced to sixteen. In many Aspleniece, plants while young and small produce fructification, and have been considered as distinct species, such is the case with Antrophyum nanum, Fée (A. obtusum, $B l$.), which is described as not more than an inch in length, but on collating numerous sets of specimens it is impossible to come to any other conclusion than that the intermediate sizes, even from the smallest to 2 feet in length, are only the graduations of a single species, the difference being consequent on age and climatic influences. The principle of creating species of Antrophyum upon difference of size, might with equal justice be applied to the common Harts'tongue Fern (Scolopendrium officinárum), fronds of which may be found in fructification from a little more than an inch to two feet in length.

The species vary in the sporangia being immersed or superficial, of which the following are examples.

\section{* Sporangia immersed.}

A. lineatum, Kaulf. (v v.) (Polytoenium, Desv.); A. immersum, Bory.; A. plantagineum, Kaulf.; A. Cumingii, Fée (A. latifolium, Reinw. non Bl.) ; A. reticulatum, Kaulf.; A. semicostatum, $B l$.

\section{** Sporangia superficial or slightly immersed.}

A. ensiforme, Hook. (Ic. Pl., t. 394, Second Cent. t. 70); A. lanceolatum, Kaulf. (v v.); A. Cayennense, Kaulf. ( $\nabla$ v.); A. latifolium, Bl.; A. Boryanum, Kaulf.; A. giganteum, Bory. 
OBs.-Mr. Moore in his "Index Filicum," has made $A$. ensiforme a type of a new genus which he names Scoliosorus, of which he says, "This plant, having neither netted veins nor netted sori, cannot belong to Antrophyum, and is quite distinct from every other established genus." This view is consequent on his having derived the character of his genus from Hooker's figure in the "Icones Plantarum," tab. 394, in which the sori are shown to be interrupted, and with no veins visible. An examination of herbarium specimens, however, shows that the fronds are traversed by veins which form irregular hexagonoid areoles. The sporangia are superficial and only partially occupy the venules, forming linear forked generally tortuous sori, their incomplete reticulation is not sufficient character to warrant the adoption of Scoliosorus as a separate genus.

\section{9.-Loxogramua. Presl., in part. (1836).}

Gymnogramma sp., Hook. Sp. Fil.; Grammitis, sp., $B l$. and Wall.

Vernation sub-fasciculate, decumbent, rarely short, sarmentose. Fronds simple lanceolate, 6 to 18 inches in length, coriaceous. Veins internal, obscure, rarely evident, uniformly reticulated, forming oblique elongated areoles. Receptacles compital, linear, forming oblique, naked sori.

Type. Grammitis lanceolata, Sw.

Mlust. Hook. and Bauer, Gen. Fil., t. 73, B; Hook. and Grev., Ic. Pl., t. 53 ; Moore Ind. Fil., p. 51, B.

OBS.-Hitherto this genus has been placed in alliance with Selliguea, but the vernation of Loxogramma being adherent, brings it more in alliance with Antrophyum, from which it differs in the sporangiferous receptacles 
crossing the angular junctions of the venules, thus forming compital linear sori. The species are entirely Indian and Malayan, L. lanceolata being found in Mauritius and Bourbon. On account of the variations of size and texture, consequent on localities, about a dozen specific names have been applied to them, but the whole seems to resolve into a few species, of which the following are examples.

In the "Species Filicum" the species of Loxogramma form part of the genus Gymnogramma, but they have no character in common with them except the oblique linear naked sori.

Sp. L. lanceolata, Sw.; L. involuta, Don. (Grammitis flavescens, Wall.; G. macrophylla, Wall.; G. acuminata, Wall.) ; L. advena, $B l$. ; L. coriacea, $P r$.

\section{Series 2.-Veins free.}

Sect. 2.-Gymnogrammat.

Veins generally forked, nearly their whole length occupied by the sporangia, forming forked, linear, naked sori, which are often confluent.

$$
\begin{gathered}
\text { 70.-Grmnogramma, Desv., in part (1811). } \\
\text { Honk. sp. Fil., in part. }
\end{gathered}
$$

Vernation fasciculate, erect, acaulose, in some becoming cæspitose. Fronds varying from entire to decompound multifid, and from a few inches to 2 to 3 feet in length, or their apex continuous, indefinite, and climbing, smooth, villose, squamose, or farinose. Veins forked, venules free, generally sporangiferous their whole length, forming linear sori, which are often confluent, naked.

Type. Acrostichum calomelanos, Linn. 
Illust. Hook. and Bauer, Gen. Fil., t. 37 ; Hook. Gard. Ferns, t. 50 ; Moore Ind. Fil., p. 48 ; J. Sm. Ferns, Brit. and For., fig. 50 ; Hook. Syn. Fil., t. 6, fig. 32, A.

OBs.-This genus as here restricted, includes a considerable number of species varying greatly in size and circumscription of the fronds, but all agreeing in having the sporangia produced on forked free veins, forming linear, naked sori, examples of the extreme sizes being represented on the one hand by $G$. leptophylla, an annual a few inches high, and the magnificent species, G. javanica and $G$. procera (Coniogramma, Fée), which have fronds 2 to 5 feet high, with broad pinnæ.

These differences have induced some authors to characterise the different groups as distinct genera, of which Professor Link has five, and with some alterations M. Fée makes ten, the whole including about forty species. Sir William Hooker, in his "Species Filicum," goes much beyond this; he includes all Ferns with oblong, linear, oblique, naked sori, thus including speciẹs with both free and anastomosing venation, under which he describes serenty-five species, thus making it a more unnatural genus than when it was in its original state; he, however, divides them into six sections, the last including the genus Selliguea of Bory, which belongs to the division Eremobrya, and therefore has no natural relationship with Gymnogramma. With regard to true Gymnogramma, I consider it best to adopt, so far as I find convenient, Link and Fée's generic names as sectional names only.

1. Fronds simple, entire, reniform, smooth (Pterozonium, Fée).

G. reniformis, Mart.; Hook. Second Cent. of Ferns, t. 9.

2. Fronds simple, entire, linear lanceolate, smooth (Asplenitis, J. Sm.).

G. marginata, Mett. 
3. Fronds pinnate or bipinnate, densely villose with articulated hairs.

G. rufa, Desv. (v v.); G. tomentosa, Desv. (v v.); G. pedata, Kaulf.

4. Fronds pinnate or bipinnate, 2 to 4 feet high; pinnoe bi-tripinnate, segments entire, covered with white or yellow farina on the under side (Trismeria, Fée).

G. trifoliata, Desv. (v v.) Hook. Gaird. Ferns, t. 4.

5. Fronds bi-tripinnate, 1 to 3 feet in length, ultimate segments numerous, small, lobed, dentate or serrate, the whole of the frond, in some, under side only covered with white or yellow farina (Ceropteris, Link.)

* Farina white.

G. ornithopteris, Klot. ( $\mathrm{v}$ v ); G. tartarea, Desv. ( $\mathrm{v}$ v.); G. peruviana, Desv. ( $\vee$ v.); G. calomelanos, Kaulf. (v v.); G. pulchella, Linden's Cat. ( $\nabla$ v.); G. rosea, Desv.

\section{** Farina yellow.}

G. triangularis, Kaulf. ( $\nabla$ v.); G. chrysophylla, Kaulf. ( $\left.\vee \nabla_{\circ}\right)$; G. L'Herminieri, Bory. ( $\nabla$ v.); G. Martensii, Kaulf. ( v.); G. sulphurea, Desv. ( $\vee$ v.) ; G. decomposita, Bak. Hort. Kew.

6. Fronds bi-tripinnate, 4 to 10 inches high, smooth, fragile (Anogramma, Link.).

G. leptophylla, Desv. (v v.); G. chærophylla, Desv. ( $\vee$ r.); G. conspersa, Kze. ( $\mathrm{v}$ ) ; G. microphylla, Kze. (v v.); G. Pearcei, Moore ( $\nabla$ v.).

7. Fronds pinnatifid, pinnate, or tripinnate, multifid, pilose, lanose, or viscose glandulose, from a few inches to 2 to 3 feet in length (Pleurosorus, Fée).

G. trichomanoides, J. Sm., Mss., Indian Fit. Fronds 2 
to 3 inches long, linear pinnatifid, densely covered with clavate viscid glands. Ceylon.

G. rutæfolia, Hook. and Grev., Ic. Fil., t. 90 (v v.) (G. glandulosa, Hook. and Grev., Ic. Fil., t. 91); G. Pozoi, Kze., Hook. Ic. t. 935 ; G. immersa, Moore; G. papaverifolia, Kze.; G. Schomburghkiana, Kze.; G. ottonis, Klot.; G. filipendulæfolia, Desv.; G. incisa, Mart. and Lind.; G. myriophylla, Sw.; G. flabellata, Hook.; G. ferruginea, Kze. ( $\vee$ v.); G. Hookeri, J. Sm., Hook. Syn. Fil.; G. aureonitens, Hook. Ic., t. 820 ; G. Matthewsii, Hook., Hook. Sp. Fil., 5, t. 290.

8. Vernation sarmentose. Fronds indefinite, climbing, bitripinnate, rachis flexuose, pinnoe refracted, pinnules small, cuneiform. Ampelogramma, J. Sm.

G. flexuosa, Desv. ( $\nabla$ v.) (G. retrofracta, Hook. and Grev., Bot. Misc., 13, t. 112).

The above are the principal representatives of the genus, with few exceptions they are natives of the West Indies and Tropical America, extending to Chili; one of them, $G$. calomelanos, is found in Western Tropical Africa, and also in Mauritius, but is believed to have been introduced. G. leptophylla, a small annual, has still wider geographical range, being found in Jersey, South of Europe, and regions of the Mediterranean, Western African Islands, Tropical America, South Africa, India (Neilgherries), and New South Wales; and G. Pozni, a native of the South of Europe, is represented in New South Wales and New Zealand by G. rutcefolia and G. glandulosa. 


\section{1.-Coniogramma. Fée. (1854).}

Gymnogramma sp. auct.; Hook. Sp. Fil.; Grammitis, Wall.

Vernation decumbent, sub-sarmentose. Fronds contignous, pinnate, or bi-pinnate, 2 to 5 feet high, smooth, pinnæ and pinnules broad, elliptical lanceolate, distant, smooth. Veins forked, parallel, free. Receptacles medial, elongated, occupying nearly the whole length of the venules. Sori linear, forked, contiguous, naked.

Type. Gymnogramma javanica, Blume.

Illust. Blume Fil. Jav., p. 95, t. 41 and 42 ; J. Sm., Fern, Brit. and For., fig. 51.

OBS-I agree with Fée in thinking that this magnificent Fern is worthy of being considered as a distinct genus ; its decumbent vernation distinguishes it from true Gymrogramma. It presents three distinct forms, which have been named as species, but they are united in the "Species Filicum." According to Hooker they are found in the Malayan Archipelago, India, Ceylon, and West Tropical Africa, and Sandwich Islands.

Sp. C. javanica, Blume ( $\vee$ v.); C. serrulata, Blume; C. procera, Wall.

\section{Sect. 3.-Cryptogramine.}

Veins forked, sporangiferous nearly their whole length or their upper portion only, included under the involute margin of the segments, which are often contracted, the margins conniving, forming a universal indusium.

\section{2.-Lluavea, Lag. (1816).}

Hook. Sp. Fil.; Ceratodactylis, J. Sm., 1839.

Vernation fasciculate, erect, acaulose. Fronds tri-quadripinnate, 1 to $2 \frac{1}{2}$ feet long, smooth, contracted and fertile 
above. Sterile pinnules oblong, elliptical, oblique subcordate, serrulate, 1 to $1 \frac{1}{4}$ inches in length. Veins forked; venules free. Fertile pinnules linear, 2 to 3 inches long, revolute, margins conniving and forming an universal indusium. Sporangia occupying nearly the whole length of the short venules, forming linear forked confluent sori.

Type. Llavea cordifolia, Lagasca.

Illust. Hook. and Bauer, Gen. Fil., t. 36 ; Moore Ind. Fil., p. 53, A. ; J. Sm. Ferns, Brit. and For., fig. 52 ; Hook. Syn. Fil., t. 3, fig. 28.

OBs.-This genus is founded on a Fern which I originally described in Hooker and Bauer's "Genera Filicum" as a new genus, under the name of Ceratodactylis, without at the time being aware that it had been previously described under the name of Llavea, by Lagasca. In habit the sterile portion of the frond resembles Osmunda regalis, and the fertile pinnules by their revolute membraneous margins, have much the character of the fertile pinnæ of Struthiopteris and Allosorus, while the forked linear sori gives it a claim to be associated with Gymnogramma.

Sp. L. cordifolia, Lag. ( $\nabla$ v.) (Ceratodactylis osmundioides, J. Sm. Hook. and Bauer, l. c.).

This Fern has only been found near Oaxaca in Mexico.

\section{3.-Plagiogria, Mett. (1858).}

Lomaria sp. Hook. Sp. Fil.

Vernation fasciculate, erect, acaulose, naked. Fronds pinnate, $1 \frac{1}{2}$ to 2 feet high, dimorphus; stipes 3 or 4 sided, thickened at the base, and furnished with spongy glands; sterile pinnæ 4 to 6 inches long, lanceolate acuminate, sessile or with a short petiole and articulate with the rachis. Veins simple or forked. Fertile frond con- 
tracted; pinnæ rachiform. Venules evident contiguous, parallel, and sporangiferous nearly their whole length. Sporangia confluent, forming a broad, transverse, compound sorus. Indusium narrow, attached on the interior edge of the margin, involute.

Type. Acrostichum triquetrum, Wall.

Oss.-In my herbarium Acrostichum triquetrum of Wallich and the species now associated with it long stood as a distinct group of Lomaria, and had also been early noticed as such by Kunze, and afterwards by Mettenius, who separated them as a distinct genus under the above name, in allusion to the obliquity of the ring of the sporangia ; but this I find to be only partially the case in one species, and as a generic character I consider it not worthy of consideration.

Six species are at present known referable to this genus, which in the "Species Filicum" are retained as a section of Lomaria, with which they agree in general aspect, but are destitute of squamæ and are peculiar in the base of the stipes being swollen; as also the fertile segments not being furnished with a transverse anastomose, the venules rising direct from the costa, and bearing the sporangia nearly their whole length, sufficiently distinct to be viewed as linear sori, similar to that of Gymnogramma, but differing in being furnished with a revolute indusium as in Lomaria. Under these circumstances I find it difficult to determine its natural position; the character of the fertile pinnæ, however, indicates its affinity to be with Llavea.

Sp. P. triquetra (Wall.) (Bedd. F. Brit. Ind., pl. 165); P. adnata (Bl.), Bedd. F. Brit. Ind., pl. 51 (Hook. Sp. Fil., 3, t. 147) ; P. glauca (Bl.), Bedd. F. Brit. Ind., pl. 90; P. pycnophylla (Kze.), Bedd. F. Brit. Ind., pl.52 (Hook. Sp. Fil., 3, t. 148); P. euphlebia (Kze.) (Hook. Secd. Cent., $t$. 89) ; P. biserrata (Mett). 
OBs.-The last named is a native of Mexico, Cuba, and other parts of Tropical America, the other five are natives of India, Malayan Peninsula and islands, and Japan.

$$
\begin{gathered}
\text { 74.-Platyloma, J. Sm. (1841). } \\
\text { Pelloea, sp. Hook. Sp. Fil. }
\end{gathered}
$$

Vernation uniserial, erect or decumbent, acaulose. Fronds pinnate or bipinnate, smooth, 1, 2, or more feet high; segments articulate with the rachis. Veins forked, their venules free, their upper portion sporangiferous, forming oblong sori, which become laterally confluent, forming a broad compound, continuous, marginal sorus, sub-included under the revolute indusæform margin of the segments, which in some is very narrow.

Type. Adiantum paradoxum, R. Br.

Illust. Hook. and Bauer, Gen. Fil., t. 115, A ; Hook. Fil. Exot., t. 21 and 48; Moore Ind. Fil., p. 52 B; J. Sm. Ferns, Brit. and For., fig. 92.

OBS.-Hitherto the species of this genus stood under the tribe Pteridece, but the sporangia being borne on free veins, and as they agree in habit and general aspect with Llavea, I therefore deem this section their natural place; but I must remark that several species of the genus Pelloea have a strong claim of relationship with Platyloma, and are only distinguished from the latter by the sporangia being borne on the combined apices of the veins, forming a continuous sorus on the axis of the indusium, as in true Pteris.

This genus consists of about a dozen species, widely distributed, being represented in Australia, New Zealand, South Africa, as also tropical and temperate North America. 


\section{* Fronds pinnate.}

P. Brownii, J. Sm. (v v.) (Adiantum paradoxum, R. Br.); P. falcata (R. Br.) ( $\left.\mathrm{v}_{\mathrm{v} .}\right)$; P. rotundifolia (Forst.) ( $\mathrm{v}$ v.); P. Bridgesii (Hook.)

\section{** Fronds bipinnate or more compound.}

P. atropurpurea $($ Linn.) ( $\vee$ v.); P. sagittata (Cav.); P. cordata (Cav.); P. calomelanos (Sw.) ( $\vee$ v.) ; P. dura (Hook.) ; P. flexuosa (Kaulf.) ( $\vee$ v.) ; P. andromedæfolia (Kaulf.)

OBs. - In the "Synopsis Filicum," $P$. flexuosa is made a synonym of $P$. cordata, but in cultivation they are seen to be quite distinct, P. flexuosa being scandent like Iygodium, and attaining considerable length.

\section{5.-Cincinalis, Desv. in part. (1811.)} Nothochloena sp. Hook. Sp. Fil.

Vernation fasciculate, erect, acaulose. Fronds tripinnate, 4 to 12 inches high, slender, pinnæ distant, spreading, pinnules ovate, hastate-lobed or trifoliate, plain, smooth, glaucous, or farinose. Veins forked, free. Receptacles terminal. Sporangic large, globose, sessile, few, in a short series on the upper portion of the venules, becoming laterally confluent, forming a broad sub-entire marginal sorus. Indusium narrow, rudimentary only.

Type. Pteris nivea, Swartz.

Illust. Hook. and Bauer, t. 76, A ; Fée Gen. Fil., 5, t. 30 ; J. Sm. Ferns, Brit. and For., fig. 90.

OBs.-This genus consists of about six species of small delicate Ferns, which, under cultivation, are almost annuals, but are freely propagated by spores; in habit they resemble Platyloma calomelanos and its allies, but are more 
delicate, their imperfect indusium and broad compound sorus shows them to be related to Platyloma.

They are natives of Tropical America, extending from Chili to Mexico.

$$
\text { * Fronds smooth. }
$$

C. tenera, Fée (Bot. Mag., t. 3055) ( $\nabla$ v.); C. pulchella, J. Sm. (v v.) (Mart. and Gal. Fil. Mex., t. 10, f. 1); C. Fendleri, Kze.

** Fronds farinose.

C. nivea, Desv. ( $\vee$ v.) (Kze. Fil., t. 22, f. 1 ; Lowe's Ferns, 1, t. 19, C.) ; C. Hookeri, J. Sm. (Lowe's Ferns, t. 10, f. 1) ( gramma, Hook. Fil. Exot., t. 47).

\section{6.-Allosorus, Bernh. (1806).}

Cryptogramma, R. Br., 1823; Hook. Sp. Fil.

Vernation fasciculate, cæspitose, acaulose. Fronds of two forms, 6 to 10 inches high, tri-quadripinnatifid. Fertile segments contracted, oblong or linear, $1 \frac{1}{2}$ inch in length, margins membranous, revolute, oppositely conniving, forming a universal indusium. Veins forked, free. Receptacles terminal, elongated, or punctiform, becoming laterally confluent, forming a broad or narrow transverse sorus on each side of the mid-rib, and both included under the universal indusium forming a siliqua.

Type. Pteris crispa, Linn.

Illust. Hook. and Bauer, t. 115 B.; Moore Ind. Fil., p. $53 \mathrm{~B}$, and 54, A.; J. Sm. Ferns, Brit. and For., fig. 89 ; Hook. Syn. Fil., t. 3, fig. 29.

Oвs.-This genus is founded upon the well-known Euro. pean Fern, Pteris crispus, of Linnæus, and is represented in Himalaya by A. Brunoniana, and in North West America 
by $A$. acrostichoides and $A$. Stelleri, all of which are in the "Species Filicum" considered as representing one species only. Many other species have been added from time to time to this genus, but, on account of their having a specially well-defined indusium, are now most of them referred to the genera Cheilanthes and P'ellcea, several of which, such as Pellaca marginata and $P$. angustifolia, have a strong claim in habit to be associated with Allosorus. Their special indusium however marks them as being distinct, the terminal oblong sori of Allosorus indicates its relationship to be with Gymnogramma.

Sp. A. crispus, Bernh. (v v.); A. Brunoniana, Wall.; A. acrostichoides, R.Br.; A. Stelleri, Rupr. (Pteris gracilis, Michx ); A. glauca, Cav. (Pelloea hirsuta, Hook. Syn. Fil.).

OBS. - The last two species are placed under Pellcea in the "Synopsis Filicum." See observation under Pellcea for my reason for placing them here.

\section{7.-JAMesoniA, Hook. and Grev. (1831). Hook. Sp. Fil.}

Vernation sarmentose, slender, elongating, naked, subhypogeous. Fronds short stipate, distant, linear, pinnate, erect, 1 to $1 \frac{1}{2}$ foot long, rigid, densely covered with tomentose articulate hairs when young; pinnæ numerous subrotund, $\frac{1}{3}$ to $\frac{1}{4}$ inch long, coriaceous, short petiolate, generally deflexed, contiguous and imbricate, margin revolute, indusæform. Veins flabellately forked. Sporangia occupying the lower part of the venules, forming short sori, which become confluent into one central sorus, covered with crinoid jointed hairs, and partially hid by the indusæform margin.

Type. Pteris imbricata, Cav. 
Illust. Hook. and Grev. Ic. Fil., t. 178; Hook. and Bauer, Gen. Fil., t. 13; Moore Ind. Fil., p. 55, A. ; Hook. Syn. Fil., t. 6, fig. 49.

Obs. - This genus is founded on a very peculiar Fern, which on account of the reflexed margin of the pinnæ was referred to the genus Pteris by Swartz, but it having been found that the sporangium was produced in the centre of the pinnæ, in the form of a single round sorus, led to its being characterised as a distinct genus by Hooker and Greville, under the above name, in the "Genera Filicum," however, Sir William Hooker says that "Mr. Bauer's dissections, and Mr. Smith's investigations, show that there are several small sori, which eventually become confluent."

This is one of the peculiar Ferns spoken of at page 12 of the Introduction, that continue to form and develope pinnæ from the apex of the frond, which lengthens indefinitely as long as the plant continues to receive influences favourable to its growth.

It is found only in the Andean regions of Tropical America, where it has a wide range, presenting different appearances in the various localities in which it is found: the different states being described by Kunze under at least five distinct species, which in the "Species Filicum" are considered as only synonyms of $J$. imbricata. Mr. Spruce, however, who has studied them in their native localities informs me that he considers there are at least two distinct species, and also refers Gymnogramma elongata to this genus.

Sp. J. imbricata, Hook. and Grev. Ic. Fil., t. 178 (J.scalaris, Kunze Fil., t. 71; J. verticalis, Kunze Fil., t. 82; $J$. canescens, Kunze, in Schk. supplt., t. 133 ; J. cinnamonea, Kunze, in Schk. Fil. supplt. t. 71); J. elongata, Fée. (Gymnogramma elongata, Hook., in Journ. of Bot., 1834, p. 61, t. 119). 
Jamesonia cannot be considered otherwise than a truly aberrant genus; according to my view its nearest relationship appears to be with Gymnogramma, and its revolute indusæform margin seems to warrant its being placed in the present section.

\section{8.-Plecosorus, Fée (1851). \\ Cheilanthes sp. Hook. Sp. Fil.}

Vernation fasciculate, erect, acaulose. Fronds stipate, lanceolate, $1 \frac{1}{2}$ to 3 feet high, bi-tripinnatifid, densely pilosquamose; pinnæ numerous, contiguous, sessile, linear lanceolate, 4 to 6 inches long; pinnules oblong lanceolate, $\frac{1}{4}$ to $\frac{3}{4}$ of an inch long, laciniately lobed, lobes small, margins inflexed, forming cucullate scariose universal indusia. Veins forked, obscure; venules free. Sporangia sub-terminal. Sori punctiform, contiguous, included under the cucullate indusia, ultimately confluent.

Type. Cheilanthes speciosissima, A. Braun.

Illust. Fée Gen. Fil., t. 13, fig. 1; Moore Ind. Fil., p. 28, A.

OBs.-This genus is founded on a solitary species, a native of Mexico. It is a Fern of peculiar aspect, possessing characters that makes its relationship doubtful. The multifid and squamose fronds point towards Nothochloena and Cheilanthes, but from which it differs in having lateral, intramarginal sori, which are involved in numerous hair-like scales, and which, being included under the indusæform margin, seems to indicate its affinity with Allosorus; under these circumstances I deem it best to place it in the present section in proximity to Jamesonia.

Sp. P.speciosissima, Moore (P. mexicana, Fée; Cheilanthes speciosissima, Kze. Analct., t. 23). 


\section{Tribe 9.-CERATOPTERIDEA (Plate 9).}

This tribe consists of one species only, originally named by Linnæus Acrostichum thalictroides, and by later botanists it has been characterised under no less than nine different generic and a dozen specific names.

\section{9.-Ceratopteris, Brongn. (1821).}

Ellobocarpus, Kaulf.; Parkeria, Hook.

Vernation fasciculate, erect, acaulose (plant annual). Fronds fragile; the fertile decompound; segments forked, linear; margins revolute, membranaceous, conniving, indusæform. Veins transversely elongated, distantly anastomosing. Sporangia occupying the transverse venules, superficial, large, disposed in a simple series, constituting two linear sub-parallel sori.

Type. Ceratopteris thalictroides, Brongr.

Illust. Hook. and Bauer, t. 12 ; Moore Ind. Fil., p. 94 A. ; J. Sm. Ferns Brit. and For., fig. 60 ; Hook. Syn. Fil., t. 3 , fig. 32 .

Oвs.-This genus is founded on a very remarkable and peculiar Fern, being one of the few that are annual. It is found widely spread in the tropics of both hemispheres, growing in wet places or even in shallow water, the sterile fronds floating on the surface, and being viviparous, and with the ready germination of the numerous spores, and rapid growth of the fronds, makes it abundant in the places of its growth. Besides the special habit of the plant, the sporangia exhibit a peculiar structure, being large globose, and either furnished with a broad nearly vertical or short imperfect ring, which is described by some authors as horizontal, and consequently has led Ceratopteris to be associated with 
PL.9
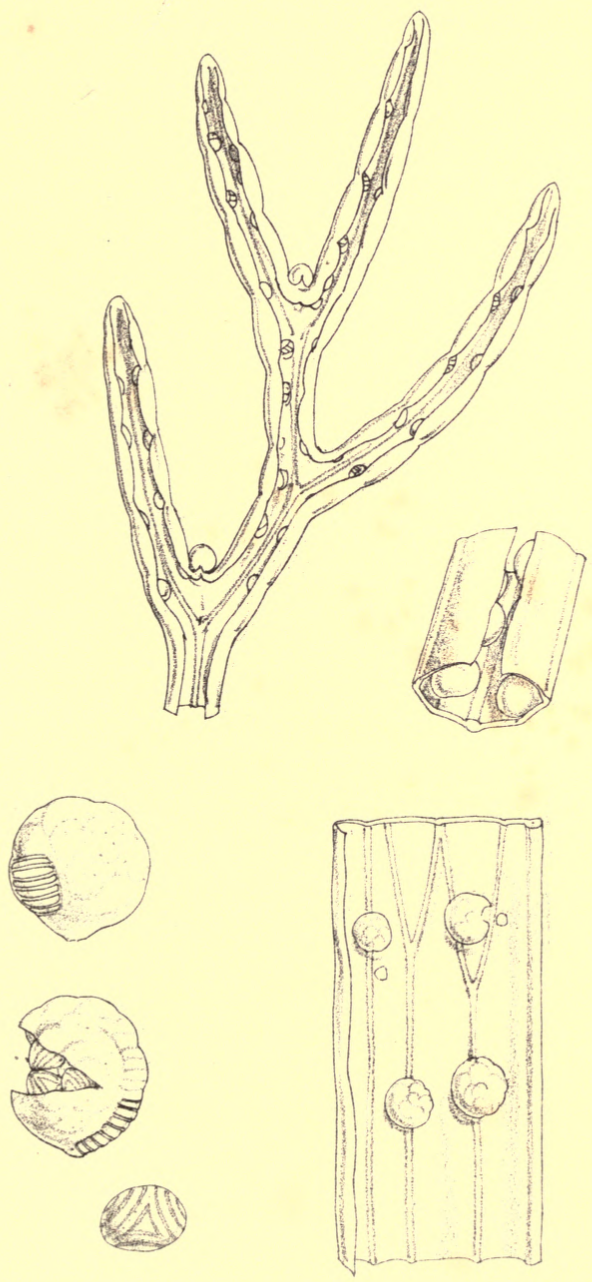

W. H. Fitch, del.et lith. 


PZ.10

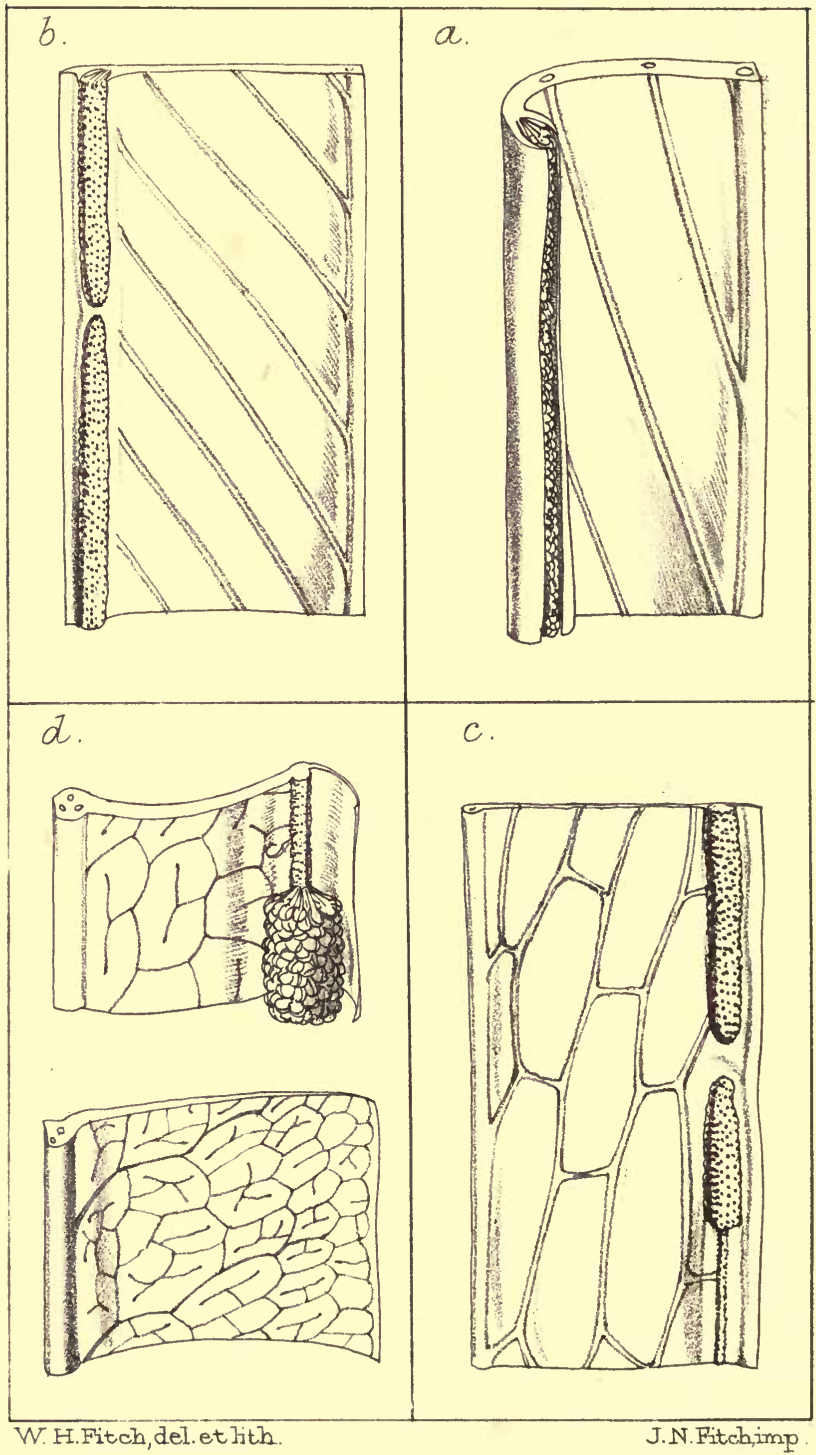


Gleicheneae and Cyatheoe, with either of which it has no natural relationship in habit. This may be termed a truly paradoxical Fern, for I find it difficult to fix its position in any sequence of genera; its partially reticulated sori seem to point to Hemionites, and the form of its fertile segments to Llavea and Allosorus, I therefore place it in proximity to these genera.

Sp. C. thalictroides, Brongn. ( $\nabla$ v.) (Parkeria Lockharti, Hook. and Grev., Ic. Fil., t. 97).

OBs.-In the Fern houses at Kew this Fern sprouted abundantly on all moist surfaces, and grew luxuriantly in the Victoria Lily tanks.

\section{Tribe 10.-VITTARIE $Æ$ (Plate 10).}

Fronds simple, entire. Veins simple, reticulated or compound anastomosing, combined at the margin in a sporangiferous receptacle, which is seated in a slit or groove.

OBS.-This tribe contains about a dozen species of grasslike Ferns, and as they do not well naturally associate with other genera I follow Presl (in part) in ranking Vittariece as a distinct tribe. Setting aside the difference of venation as a divisional character, they would then rank with the genera of the tribe Hymenolepidiece.

80.-Vittaria, Sm. (1793), Hook. Sp. Fil. Haplopteris, Pr., 1836 ; Toeniopsis, J. Sm., 1841.

Vernation uniserial, sarmentum, short, furnished with hyaline scales. Fronds contiguous, cæspitose, simple, linear, grass or tape like, from a few inches to 2 or 3 feet in length, often pendulous or rigid sub-erect. Veins simple, 
forming an acute angle with the mid-rib, their apices prolonged into a transverse, marginal vein, which becomes the receptacle. Sporangia seated in an extrose slit of the margin which represents an indusium, forming a continuous linear sorus.

Type. Vittaria lineata, $S m$.

Illust. Hook and Bauer, Gen. Fil., t. 76, B; Moore, Ind.

Fil., p. 21 ; J. Sm. Brit. and For., fig. 56.

OBS.-This genus is abundantly represented throughout the tropics and sub-tropical regions of both hemispheres, generally growing on trees, their pendulous linear fronds looking like bunches of grass. A considerable number of species have been described by different authors. They differ very little in general appearance, the most obvious difference consisting in the sporangia being seated either in a slit of the margin open exteriorly, or in a groove, formed by the margin being involute. In my "Genera of Ferns," 1841, I separated the species possessing the latter character from Vittaria, and characterised them as a genus under the name of Tceniopsis, which I afterwards found was synonymous with Haplopteris of Presl. Since then I have examined numerous herbarium specimens, and find it difficult in many cases to place them under the respective genera, and as there is no difference in general habit, and no practical advantage gained by the separation, I have reunited them, and given up Toeniopsis as a genus.

M. F'e has adopted the same course in his memoir of this genus, published in 1852. In that work he describes twenty-five species, eighteen of which are exemplified by figures. In his descriptions he attaches much importance to the fronds being membraneous or coriaceous, and to the mid-rib being more or less evident, but on comparing the figures with one another and with specimens, they appear 
to differ chiefly in degrees of length and breadth, the whole presenting but few obvious points of difference of specific value. He also attaches much importance to the different forms of the abortive sporangia (paraphyses), the number of articulations forming the ring, and the form of the sporangia, but much more investigation is wanted before these microscopic characters can be made available for determining species. The following are the principal well-marked species.

* Sporangia intramarginal; Hook. Syn. Fil., t. 6, fig. 56, b. c.

Ex. V. scolopendrina (Pteris, Bory; Haplopteris, Presl; Touniopsis, J. Sm.) (v v.); V. falcata, Kze.; V. Gardneriana, Fee; V. stipitata, Kze.; V. stricta, Carm.; V. lineata, Sw. (v v.) (Toeniopsis, Bedd. F. S. Ind., t. 54); V. remota, Fée.

** Sporangia in an extrose slit, margin not involute, Hook. Syn. Fil., t. 6, fig. 56 A.

V. elongata, $S w$. (V. zostercefolia, Willd) ( $\nabla$ v.); V. ensiformis, $S w$.

OBS.-In the "Synopsis Filicum" this with eight other species are included as synonyms of $V$. elongata. $V$. stricta is a native of Tristan d'Acunha, and in general appearance is similar to $V$. lineata, but differs in the short sarmentum being covered with undulate, crisp squamæ, not stiff and filiform as in $V$. lineata. Specimens collected by Griffiths in Bootan have the same kind of crisp squamæ as those from Tristan d'Acunha.

\section{1.-Pteropsis, Desv. in part (1827).}

Pteris sp., Linn.

Vernation uniserial, sarmentum short. Fronds contiguous, simple, linear acuminate, 6 to 18 inches long, rigid, smooth. 
Veins uniform, reticulated, forming transverse elongated, hexagonoid areoles. Receptacles compital, elongated on the exterior, transverse anastomose, forming a linear, continuous, marginal sorus.

Type. Pteris angustifolia, Swartz.

Illust. Hook. and Bauer, t. 77 A.; J. Sm., Ferns, Brit. and For., fig. 58.

OBs.-In general habit this genus agrees with Vittaria and Antrophyum, being distinguished from the first by its reticulated venation, and from Antrophyum by its strictly transverse marginal sorus. As now restricted, the genus consists of one species only; a native of the West Indies, and many parts of Tropical America.

Sp. P. angustifolia, Desv. (v v.) (Tanitis, Hook. Sp. Fil).

\section{2.-Dictroxiphium, Hook. (1838).}

Vernation fasciculate, erect, acaulose. Fronds simple, linear-lanceolate, attenuated and decurrent on the stipes, 1 to 3 feet long. Veins compound anastomosing, transversely combined at the margin by the sporangiferous receptacle, which is seated in an unequal-sided extrorse groove, the upper side being indusæform and inflexed.

Type. Dictyoxiphium panamense, Hook.

Illust. Hook. and Bauer, Gen. Fil., t. 62.; J. Sm., Ferns, Brit. and For., fig. 59 ; Hook., Syu. Fil., t. 2, fig. 30, b. c. ; Moore, Ind. Fil., p. 23 B.

OBs.-This genus is founded on a very distinct and peculiar Fern, a native of the district of New Granada, and the Isthmus of Panama on the coast of the Pacific.

It is with some hesitation that I place this genus in alliance with Vittaria, from which it differs in having fasciculate erect vernation, and in the veins being compound 

PL.II

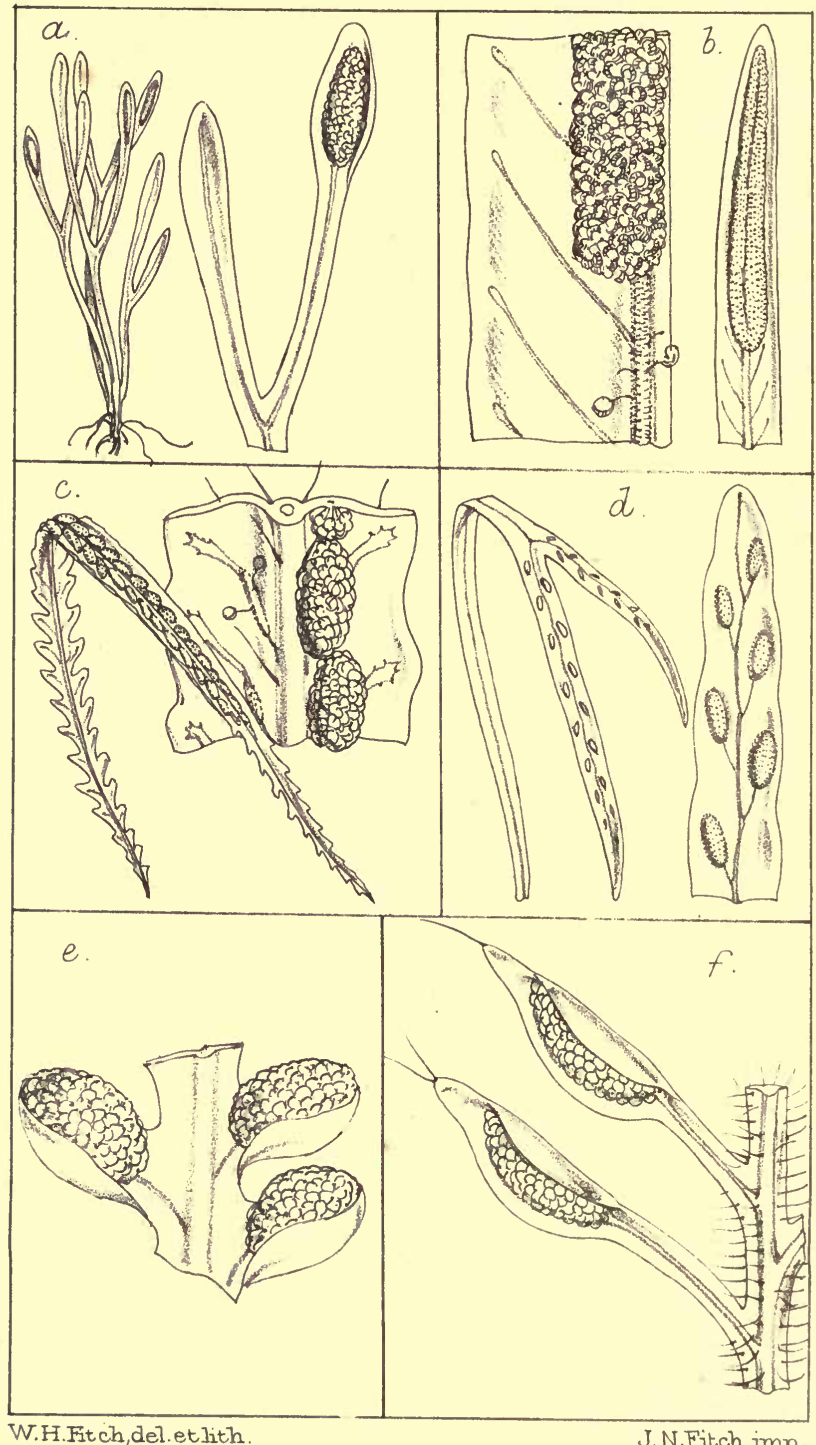


anastomose, but agrees in the sporangia being seated in a marginal groove. The upper of these is the largest, representing an indusium analogous to that of Lindscea, with which it is associated in the "Species Filicum," but its very different habit prevents its being associated with Lindscea. It is otherwise peculiar in being the only Fern in Desmobrya having transverse marginal sori, and compound anastomosing venation.

Sp. D. panamense, Hook ( $\nabla$ v.)., Hook. Fil. Exot., t. 54.

\section{Tribe 11.-PLEUROGRAMMEAE (Plate 11).}

Fronds simple, 1 to 10 and 12 inches in length, entire, serrate, rarely dentate or laciniated. Sori linear, transverse costal, or oblong sub-linear, oblique.

OBs.-This tribe contains about thirty small, and with the exception of a few, grass-like Ferns, and although the character of the sori does not technically differ from Gymnogramme, they nevertheless are so different in habit that they do not form a natural connection with that genus; I therefore deem it best to characterise them as a distinct tribe.

\section{3.-Monogramma, Schk. (1809).}

Vernation uniserial, sarmentum slender. Fronds simple, distant, linear, graminoid, 1 to 4 inches high. Veinless. Costa sporangiferous on its disk, or seated in a deep groove on one or both sides, forming a continuous or interrupted linear soris near the apex of the fronds, the margins of which are generally more or less incurved.

Type. Monogramma graminea, Schk. 
Illust. Schk., Fil., p. 82 ; Fée, Gen. Fil., p. 97, t. 9 B. ; Moore's Ind. Fil., p. 13 A.; Hook., Syn. Fil., t. 6, fig. 51, a. b.

OBS.-This genus represents the simplest state of venation in Ferns, the fronds being so small and narrow that no lateral veins are produced, the whole vascular structure consisting of the mid-rib only. In the typical species of the genus, $M$. graminea, the sporangia are produced on the face of the mid-rib; but in an additional species of recent discovery, the sporangia are seated in grooves on each side of the mid-rib, and although this is a very special character, it nevertheless does not seem to me sufficient to warrant their separation as a distinct genus.

Sp. M. graminea, Schk., Fil., p. 82, t. 9 ; M. trichoidea, J. Sm.; M. dareæcarpa, Hook., Sp. Fil. 5, t. 287 A.; M. subfalcata, Hook., Sp. Fil. 5, t. 219 A.; M. rostrata, Hook., Sp. Fil. 5, t. 287 B.

OBs.-These species are widely distributed, being found in South Africa, Mauritius, Borneo, Philippines, New Hebrides, also in the West Indies and Central America.

In $M$. trichoidea the line of the sporangia is interrupted, forming several short sori, each included in a fold of the frond, similar to a sheath, which M. Fée has considered worthy of being characterised as a distinct genus which he has named Vaginularea, but which I do not adopt.

\section{Diclidopteris, Brack. (1854).}

\section{Monogramma sp. Hook. Sp. Fil.}

Vernation uniserial, sarmentum short. Fronds contiguous, cæspitose, linear, 6 to 12 inches long, narrow, graminoid, flaccid, with a central costa and sub-parallel vein on each side, which are sporangiferous nearly their whole 
length, forming a continuous linear immersed sorus on each side of the mid-rib, and which become confluent.

Type. Diclidopteris angustissima, Brackenridge.

Illust. Brack., United States Expl. Exped. XVI. 135, t. 17 ; Moore, Ind. Fil., p. 13, B.

OBs.-The grass-like fronds of this Fern not exceeding a line in width, renders it difficult to determine the exact nature of its venation. Careful examination induces me to draw up the above character, which agrees with that given by Brackenridge ; but in the "Species Filicum" the line of sporangia are described as only occupying one side of the costa.

Sp. D. angustissima, Brack. (Monogramma Junghuhnii, Hool. Sp. Fil. 5, t. 289, B ; Bedd. F. S. Ind., pl. 210).

Native of Ceylon, Java, Philippines and Polynesian Islands.

\section{Pleurogramma, Presl. (1836).}

Monogramma sp. Hook. Sp. Fil.; Trenitis sp. Kaulf.

Vernation fasciculate, erect, acaulose. Fronds cæspitose, 1 to 6 inches high, simple linear or forked, opaque, the upper portion concave or folded. Veins in the lower part simple, direct, oblique, the upper or fertile part absent. Sporangia produced in a line on each side of the costa, becoming confluent, forming a central sorus.

Type. Pleurogramma linearis, Presl.

Illust. Hook. and Bauer, Gen. Fil, t. 75, A; Schott., Gen. Fil., t. 17, under Cochlidium; Moore, Ind. Fil., p. 14, A; Hook., Syn. Fil., t. 6, fig. 51, c. d.

OBs.-This as a genus differs from Monogramma by the presence of lateral veins, and in the sporangia being produced in a line on each side of, and close to, the mid-rib, also in having fasciculate vernation. 
Sp. P. linearis, $P r . ;$ P. graminifolia, $\operatorname{Pr}$. (Toenitis graminifolia, Hook. Exot. Fil., t. 77); P. seminuda, J. Sm. (Grammitis seminuda, Willd.; P. pumila, Pr.); P. furcata, J. Sm. (Grammitis, Sw.; Monogramma furcata, Desv.; Cochlidium graminoides, Kaulf., Schott. Gen. Fil., t. 19).

Small grass-like Ferns, growing in tufts; natives of the West Indies and Tropical America.

\section{6.-Hecistopteris, J. Sm. (1842).}

Gymnogramma sp., Hook. Sp. Fil.

Vernation sarmentose, slender, squamose, producing the fronds in fascicles. Fronds simple, linear, cuneiform, forked or more divided (palmoid), half an inch to 2 inches high, plane. Veins simply or flabellately forked, radiating from an evanescent costa; venules terminating in the lacinæ, sporangiferous nearly their whole length, forming linear, simple or forked sori.

Type. Gymnogramma pumila, Spreng.

Illust. Fée, Gen Fil., t. 16 B.; Hook., Secd. Cent. of Ferns, t. 8.

Oвs.-This small Fern was originally described by Sprengel as a species of Gymnogramma; but as it did not appear to me to form any natural alliance with any of the groups of species of that genus, I, therefore, in the Journal of Botany for 1842 , deemed it best to characterise it as a distinct genus. The fronds in some states being simple, and bearing only one sorus, seems to indicate its relationship with Monogramma and Pleurogramma.

Sp. H. pumila, J. Sm. (Gymnogramma, Spreng., Kze. Analec., t. 8, f. 1).

West Indies, Central America, Guiana, Brazil. 
87.-XIPHOPTERIS, Kaulf. (1824).

Grammitis sp. Sw.; Polypodium sp., Hook. Sp. Fil.

Vernation sarmentose, slender, sub-ascending. Fronds contiguous, sub-fasciculate, 2 to 6 inches high, linear, dentate-serrate, or pinnatifid below, sub-entire, and plicate or nearly plane above. Veins simple, free, very short. Sporangia borne on the short venules, forming oblong sori conniving with the mid-rib, included in the plicate apex of the frond.

Type. Grammitis serrulata, Swartz.

Illust. Hook., Gard. Ferns, t. 44; Hook., Exot. Fil., t. 78; Moore, Ind. Fil., p. 14 B.; J. Sm., Ferns Brit. and For., fig. 48.

OBs.-Distinguished from Pleurogramma by the sori being oblong and diverging from the mid-rib, but becoming confluent.

Sp. X. serrulata, Kaulf. ( $\nabla$ v.) ; X. myosuroides, Kaulf. X. Jamesoni, Hook. Second Cent. Ferns, t. 14.

OBs.-In the "Species Filicum" the above three species are considered as forms of one only. As regards $X$. Jamesoni (of which I have not seen specimens), it is said that the texture is so rigid that the thread-like mid-rib remains after the pinnæ fall. This singularity appears to me to be sufficient to mark it as a distinct species. They have a wide geographical range through Tropical America, the West Indies, Sandwich Islands, and also West Tropical Africa; $X$. serrulata being one of the few Ferns common to both Continents.

88.-Grammitis, $S w$. , in part (1800).

Polypodium sp., auct., and Hook Sp. Fil.

Vernation fasciculate, erect, acaulose or sarmentose. Fronds linear-lanceolate, entire, rarely sub-pinnatifid, plane, 
opaque, smooth or pilose, 6 to 10 inches high. Veins simple or forked, generally clavate, free; the anterior renule fertile. Receptacles elongated, medial terminal. Sori ovate, oblong or linear, oblique, sometimes punctiform, transverse uniserial.

Type. Grammitis australis, R. Br.

Illust. Họok. and Bauer, Gen. Fil., t. 72 B.; Hook. and Grev., t. 62 ; Moore Ind. Fil., p. 49, fig. 1 to 4 ; J. Sm. Ferns Brit. and For., fig. 47.

OBs.-Grammitis was first established by Swartz in his "Synopsis Filicum" in 1806, where he enumerates twelve species, all agreeing in having, "Capsulæ in lineolis rectis, sparsis. Indusia nulla," but differing in habit and venation so much that succeeding authors have distributed the whole except $G$. marginella amongst seven different genera. Since Swartz's time the discoveries of Blume and others have added many species possessing the same habit and character as G. marginella, and when grouped together these form a very natural genus, all having simple linear fronds of grass like appearance, and oblique oblong or linear naked sori in a single row on each side of the midrib. The form of the sorus, however, as in other cases is not always oblong or linear, but sometimes quite round (punctiform) and then does not differ technically from Polypodium, in which the group is placed by Mettenius, and followed by Sir William Hooker in his "Species Filicum." This amalgamation is due to these authors adopting the form of the sori alone as the distinguishing character for the genus Polypodium, thus including all Ferns with round or oblong naked sori without regarding the extraordinary disparity in the size, form, and mode of growth of the numerous species. Thus the present group having fronds like blades of grass are associated in the 
same genus with Drynaria and Phegopteris of this work. Under Grammites I comprehend all the simple linearfronded forms having free veins and one row of sori on each side of the mid-rib, the sori being more or less oblong or linear or sometimes even punctiform, the single row being the chief distinction between it and Ctenopteris. This latter genus, however, also contains a few singlefronded species, but they have a higher degree of development, the fronds being normally pinnatifid and each lacinæ having its mid-vein with soriforous venules on each side.

Blume, in his "Flora Javanica," figures and describes no less than twelve species of Grammitis as natives of Java. Not having seen specimens of many of these, and the figures being much alike, I am quite unable to arrive at a satisfactory conclusion regarding them. Sir William Hooker also appears not very satisfied with many of them. It can only be by careful examination and comparing them one with another in a living state, either in their native country or brought together under cultivation, that the species can be determined, they are widely dispersed, being found in both hemispheres, the greater number are found in the Malayan Islands, and extending to Australia.

Sp. G. tenella, Kaulf; G. furcata, Hook. and Grev.; G. Zeylanica, Fée; G. marginella, Swartz. ( $\nabla$ v.); G. aus'tralis, $R . B r$. ( $\vee$ v.) ; G. attenuata, Kunze.; G. fasciata, Blume; G. sessilifolia, Hook.; G. hirta, Blume; G. conformis, Brack and Hook.; G. setigera, Hook. and Arn.; G. fasciculata, Blume; G. Sprucei, Hook. 2nd Cent. of Ferns, t. 6; G. organensis, Gardn. Hook. Ic. Pl., t. 509; G. subpinnatifida, Blume. 


\section{Calymmodon, Presl. (1836).}

Grammites, Blume; Plectopteris, Fée; Polypodium, sp. Hook. Sp. Fil.

Vernation fasciculate, acaulose. Fronds linear lanceolate, 2 to 4 inches high, $\frac{1}{2}$ inch wide, pinnatifid, the upper segments folded longitudinally, forming a cyst, and fertile. Veins one in each segment and sporangiferous, forming oblong sori, included in the fold of the segments.

Type. Grammites cucullata, Blume.

Illust. Blume, Fl. Jav., t. 50, f. 3 ; Fée, Gen., p. 230, t. 19, B; Moore, Ind. Fil., p. $50, \mathrm{~A}$.

OBs.-This genus, founded on Grammites cucullata of Blume, is readily distinguished from its congeners by the segments being folded, forming a cuculus or cyst, including the sori. Two species possess the above character; natives of Ceylon, Java, Borneo, and Philippine Islands.

Sp. C. cucullatus, Blume; C. clavifer, Hook. (Grammites, Hook., Secd. Cent., t. 5).

\section{Lomaphlebia, $J$. S $m$.}

Grammizes, sp.Sw.; Sect. Chilopteris, Presl.; Polypodium, sp. Hook. Sp. Fil.

Vernation fasciculate, acaulose. Fronds cæspitose, stipate, simple, linear, entire, smooth, opaque, 4 to 6 inches high. Veins forked, apices of the venules combined by a continuous transverse marginal vein, the exterior venules of each fork fertile, bearing ovate, oblong oblique sori.

Type. Grammitis linearis, Swartz.

Illust. Schk. Fil., t. 7.

OBs.-The species on which this genus is founded, with 

PL. 12 .

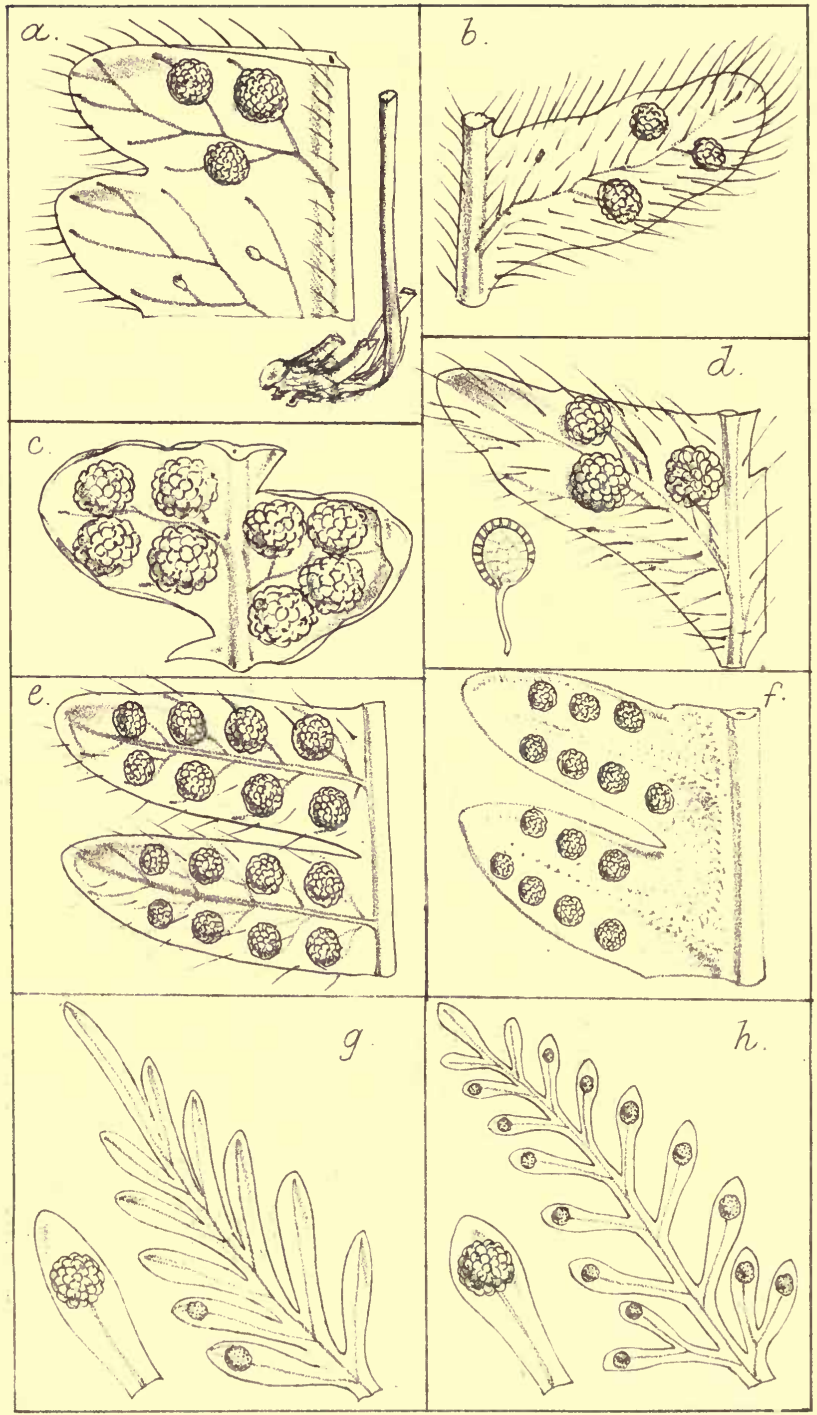

W.H. Fitch,delet lith.

J.N. Fitch imp. 
others, form the section Chilopteris of the genus Grammitis of Presl, but if he has had true specimens of $G$. linearis under observation, he has not noticed the connecting marginal vein which is peculiar to this species, and which has also been overlooked by the author of the "Species Filicum ;" and, as connecting marginal veins are admitted as of sufficient value to constitute genera, such as Aconiopteris, Olfersia, and Neottopteris, I therefore use this peculiarity in this group of Ferns to characterise Lomaphlebia as a distinct genus.

Sp. L. linearis, Swartz, Syn. Fil. (Polypodium gramineum, Sw., Fil. Flor. Ind. Occ. ; Hook., Sp. Fil., 4, p. 165).

Native of Jamaica.

\section{Tribe 12.-CTENOPTERIDEA (Plate 12).}

Fronds linear, repand sinuose, moniliform or pinnatifid, rarely pinnate, or more compound, from an inch to a foot or more in length. Veins free, sori punctiform, naked.

OBs.-This tribe embraces a group of small, slender Ferns, consisting of about 50 or 60 species, but in many cases the difference is so slight that it becomes difficult to determine the exact number of distinct species. In the "Species Filicum" they are all placed under Polypodium, in the section Eupolypodium, which embraces all freeveined species without regard to the vernation being articulate or adherent. They present two forms of vernation, the greater portion being fasciculate, forming cæspitose tufts, a few being sarmentose, with the fronds more or less distant. 


\section{1.-Ctenopteris, $B l$. (1828).}

Polypodium sect. Ctenopteris Blume; Polypodium sp. auct. Hook. Sp. Fil.

Vernation fasciculate, acaulose or sarmentose. Fronds linear lanceolate, sinuose, or more or less deeply pinnatifid or pinnate, rigid, erect, or thin and pendulous; segments entire, dentate, or laciniated. Veins simply forked, rising from the mid-rib of each segment or lacinæ, obscure, free. Receptacles terminal. Sori punctiform, solitary,.or few in each lacinæ or uniserial, often becoming confluent, naked.

Type. Polypodium trichomanoides, Swartz.

Illust. Hook. and Grev., Ic. Fil., t. 223. ; Schk., Fil., t. 10.

OBs.-This genus contains the principal number of the species which represent this tribe; as already stated, the greater number of them are very uniform in appearance, differing chiefly in being smooth, or more or less pilose, and in the difference of the number of sori produced on each lacinæ or pinnæ. They are natives principally of the West Indies and Tropical America, but a few are found in the Indian and Malayan regions.

* Fronds sinuose pinnatifid. Segments entire.

1. Trichomanoid Group.

Sp. C. trichosora (Hook.); C. jubæformis (Kaulf.); C. flabelliformis $\left(\operatorname{Lam}_{0}\right)$; C. trichomanoides $\left(S w_{0}\right), \operatorname{Bedd} . F$. Brit. Ind., pl. 2 ; C. confusa, J. Sm., 1839, Lond. Journ. Bot.1., p. 194; ; C. subtilis (Kze.); C. truncicola (Klot.); C. delicatula (Mart.); C. solidum (Kze), Mett. Polyp., t. 1, fig. 1 .

\section{Moniliform Group.}

C. moniliformis (Lagase.); C. peruviana (Desv); C. rigescens (Bory); C. firma (Klot.). 
3. Plumula Group.

C. subscabra (Klot); C. leucosticta (Fée); C. plumula (H. B. K.) ; C. mollicola (Bl.) ; C. parvula (Bory); C. nutans $(B l$.$) .$

4. Pendula Group.

C. discolor (Hook.); C. pendula (Sw.) ; C. Adenophorus (Hook.); C. pteropus (Hook.).

** Segments dentate serrate or pinnatifid.

5. Grammitidis Group.

C. glandulosa (Hook.); C. subfalcata (Bl.); C. Lobbiana (Hook.); C. achillæfolia (Kaulf.); C. tenuisecta (Bl.); C. grammitidis (R. Br.) (Grammitis heterophylla, Labill.).

\section{Gracile Group.}

C. decipiens (Hook.); C. gracile (Hook.); C. funicula (Fée); C. pilipes (Hook.), Hook. Ic. Pl., t. 221.

OBs.-The genus is represented in New Zealand and Tasmania, by C. grammitidis, which has ovate sori, and may be viewed as a multifid-fronded species of Grammitis. As regards C. trichomanoides, it is common throughout the tropics of the Western Hemisphere, and the different appearances it assumes have led to some of the forms being described as distinct species. It is also found in Sikkim Himalaya, but it is probable that if we had the opportunity of seeing living plants from the different localities, characters might present themselves to show that they are distinct species. Indeed, all that is known of the species of this genus is derived from herbarium specimens only, no living species having yet been introduced into this country. 


\section{2.-Micropteris, J. Sm. (non Desv.).}

Polypodium, sp., auct., and Hook. Sp. Fil.

Vernation uniserial, sarmentum slender, filiform, elongated. Fronds distant, 1 to 3 inches high, linear, gramineous serrate or pinnate, opaque, rigid. Sori punctiform or slightly oval, terminal, solitary in each segment.

Type. Polypodium fallax, Schlecht.

Illust. Mett. Polyp., t. 1., f. 4 to 6.

OBs.-The above character comprehends three very small Ferns, specially differing from each other by the fronds being simple and grass like in one, serrate-pinnatifid in another, and pinnate in the third, but agreeing so closely in their mode of growth and structure, that I deem it best to associate them together as a distinct genus, and this I do the more readily in consequence of their not possessing, either collectively or individually, direct affinity with any other genus.

$$
\text { * Fronds linear, entire. }
$$

Sp. M. graminoides, $J$. $S m$.

** Fronds linear, serrate.

Sp. M. monticole, Klot.

$$
\text { *** Fronds pinnate, pinnce cuneiform. }
$$

Sp. M. fallax, Schlecht.

These three species are very local, the first being found in Jamaica, the second in Columbia, and the third in Mexico.

\section{3.-Adenophords, Gaud. (1826). \\ Polypodium sp. auct., Hook. Sp. Fil.}

Vernation sarmentose. Fronds contiguous, cæspitose, bisub-tripinnatifid, 3 to 11 inches high, oblong lanceolate, 
rigid, erect, covered with clavate glands, lacinæ small oblong spathulate, each furnished with a clavate venule, which is sporangiferous on the apex. Sori round, solitary on each lacinæ.

Type. Adenophorus tripinnatifidus, Gaud.

Illust. Hook. and Grev., t. 174, 175, 176 (sub. Adenophorus), Fée Gen. Fil., t. 10, A, fig. 1.

OBs.-Gaudichaud, in Freycinet's Voyage, was the first to describe this genus, the speciality being the peculiar rigid habit and glandulose nature of the fronds. But owing to the sori not differing in character from Polypodium, as defined by early authors, has led it to be placed by Sir W. Hooker, and other authors, under that genus; but I agree with Fée in retaining it as a distinct genus. Three species are described; but all being natives of the Sandwich Islands, it is therefore probable that they may only be different states of one species.

Sp. A. hymenophylloides (Kaulf.); A. tamarisci (Kaulf.); A. tripinnatifidus (Gaud.)

\section{4.-Glyphoteniom, J. Sm. (1854).}

Ctenopteris (Glyphotoenium) J. Sm. Bot. Voy. of Herald; Polypodium Hook. Sp. Fil. Goniopteris sp. Moore Ind. Fil.

Vernation sarmentose, short. Fronds fasciculate, linear, sub-entire, sinuose repand, pendulous, 6 inches to $1 \frac{1}{2}$ feet long, 1 inch wide, villose, stipes slender, cylindrical. Veins pinnate, forked, and arcuate, venules unequally anastomosing, the superior ones free. Receptacles punctiform, immersed on free veinlets, and terminal. Sori subbiserial or irregular.

Type. Glyphotoenium crispatum, J. Sm. 
Illust. Seeman Bot. Voy. of H.M.S. Herald, p. 227, t. 48 .

OBs.-At page 227 of the "Bot. of Voy. Herald," I described the Fern from which the above character is derived, under the name of Ctenopteris (Glyphotonium) crispata, and stated that I considered it allied to Polypodium scolopendroides, Hook. and Grev. and P. suspensum, Sw., but from which it differs in having anastomose venation, and its vernation being adherent, not articulate, as in these two mentioned species ; I therefore deem it best to characterise it as a distinct genus under the above name. These characters, and the peculiar habit of the plant, renders it difficult to point out its true affinity otherwise than in Ctenopteris. It grows in a pendulous manner on trees in Darien and Panama.

Sp. G. crispatum, J. Sm.

\section{Tribe 13.-PHEGOPTERIDEÆ. (Plate 13).}

Fronds varying from simple to decompound multifid. Venation free or anastomosing in various ways. Sori punctiform or linear, naked or furnished with an indusium, which is either lateral, peltate, rarely calyciform.

OBs.-This is an extensive tribe of Ferns, comprehending all the Phegopteris section of Polypodium and the tribe Aspidiacece as given in the "Species Filicum," the number being, as reduced in the "Synopsis," 366; while Mettenius, in a special memoir of Phegopteris and Aspidium, enumerates 299*. In the greater number the vernation is fasciculate and acaulose, and in others uniserial. With few exceptions

* In the Appendix to Syn. Fil. sixty-one species are enumerated, the greater number of which belong to this tribe. 
Pl.13.A

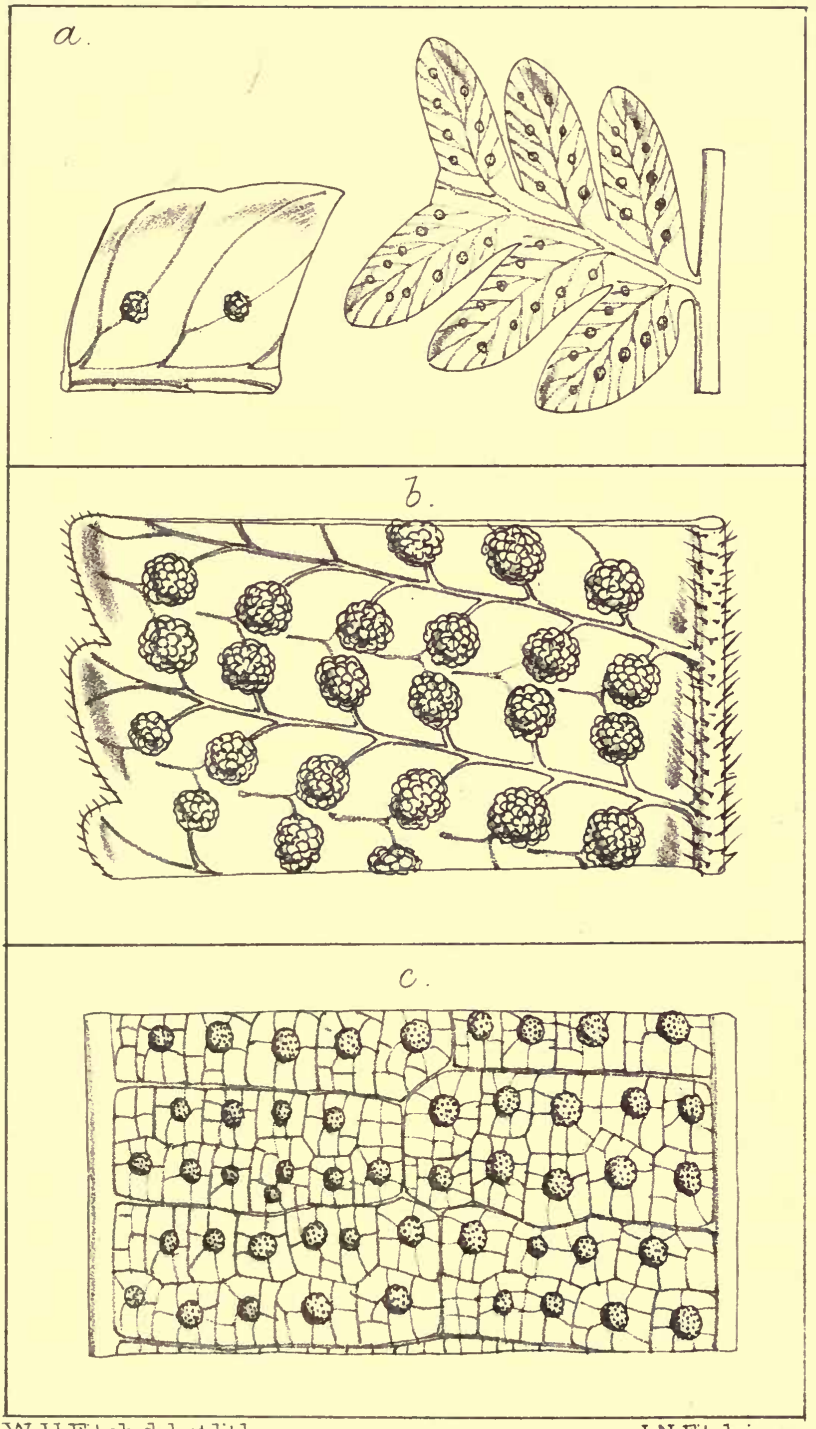

W. H.Fitch, del.etlith. 

they are epigeous, of a flaccid soft texture, easily affected by drought; the well-known Lastrea Filix-mas, L. Oreopteris, and $L$. dilatata being examples; or they are more firm, hard, and spiny, as in Polystichum aculeatum and allies.

The most important divisional characters consist in the veins being free or anastomosing in various ways, and in the sori being naked or furnished with an indusium, which in some is very small and fugacious, soon becoming obliterated, and which leads to some species being placed in indusiate genera by some authors, while others place them among the non-indusiate.

The normal character of the indusium is either lateral (interiorly attached) or peltate; in some multifid fronds, such as Lastrea deparioides, the indusium appears to coincide with the crenule or dent of the margin, so as to form a cyst similar to that of Microlepia, and in Trichiocarpa it is exserted beyond the margin in the form of a calyciform cyst, as in Deparia. In Amphiblestra the sporangia are produced in an irregular row close to the margin, which is inflexed in the form of an indusium like that of Pteris, but from which it differs entirely in habit and venation, which is that of Aspidium; and as regards Isoloma, although it has marginal sori similar to Lindscea, it nevertheless differs entirely in habit, which agrees perfectly with that of Nephrolepis. In Hypoderris the sori are discal and furnished with a small membraneous calyciform indusium similar to that of Woodsia. Although these four genera differ in the nature of their fructification from the normal character of the indusiate Phegopteridece, I nevertheless deem it best to place them in it, and as near as possible in contiguity with the genera to which they are most nearly allied in habit and venation. 
I arrange the genera of the tribe under the following heads :-

$$
\begin{gathered}
\text { Series 1.-Veins anastomosing. } \\
\text { * Sori naked. } \\
* * \text { Sori indusiate. }
\end{gathered}
$$

$$
\begin{gathered}
\text { Series 2.-Veins free. } \\
\text { * Sori indusiate. } \\
\text { ** Sori naked. }
\end{gathered}
$$

Series 1.-Veins anastomosing in various ways.

* Sori naleed.

Sect. 1.-Dictyopteridee.

Veins angularly or compoundly anastomosing. Sori punctiform, rarely oblong or linear.

$$
\begin{aligned}
& \text { 95.-Stegnogramme, Blume (1828). } \\
& \text { Gymnogramma, Hook. Sp. Fil. }
\end{aligned}
$$

Vernation contiguous, sub-fasciculate, decumbent. Fromls pinnate, 1 to 3 feet high, pilose; pinnæ lanceolate, 4 to 5 inches long, sub-pinnatifid. Veins costæform pinnate, venules acutely anastomosing, sporangiferous nearly their whole length, forming linear naked sori. Sporangia pilose.

Type. Stegnogramme aspidoides, Bhume.

Illust. Hook. Ic. Pl., t. 950 ; Moore Ind. Fil., p. 50 B.; Hook. Syn. Fil., t. 6, fig. 52 B.

OBs.-This genus consists of a single species, a native of the East Indies and Java. In habit and general appearance it resembles several species of Goniopteris, 
differing only in the sori being linear, thus agreeing as also in habit with Leptogramma, differing only in the venation of one being free and the other anastomose. On account of the sori being linear both the genera are in the "Species Filicum," placed in Gymnogramme.

Sp. S. aspidoides, Blume (Syneuron aspidioides, J. Sm. Hook. Ic. Pl., t. 950).

96.-Goniopteris, Presl. (1836). Polypodium, sp., auct.; Hook., Sp. Fil.

Vernation fasciculate, erect or decumbent, acaulose or subarboroid. Fronds pinnatifid or pinnate, rarely simple, 1 to 4 feet high. Primary veins costæform, pinnate; venules opposite, the lower pair only or more, or the whole angularly anastomosing, producing from their junction an excurrent sterile veinlet, which is either free or anastomose in the angle next above it. Receptacles lateral (between the base and angular junction of the venules). Sori punctiform, rarely oblong. Sporangia pilose in some.

Type. Polypodium crenatum, $S w$.

Illust. Hook. and Bauer, Gen. Fil., t. 38; Hook. Fil. Exot., t. 84 ; Moore Ind. Fil., 57 A.; J. Sm. Ferns, Brit. and For., fig. 64 ; Hook. Syn. Fil., t. 5, fig. 48 E.

OBs.--This genus agrees in general habit with the indusiate genus Nephrodium, but the technical distinguishing character is not always to be relied upon, the indusium of some species being often small and fugacious, consequently many specimens in herbaria have been referred to Goniopteris, but examination of living plants has proved the herbarium specimens to have been indusiate at some period during their growth.

Twenty-three species are described in the "Species 
Filicum," they are very widely spread in the tropics and extratropical regions of both hemispheres, extending to New Zealand in the south and Japan in the north.

\section{1.-Occidental Species.}

Sp. G. scolopendrioides, Linn. ( $\nabla$ v.); G. reptans, $S w$. ( $\nabla$ v.) ; G. gracilis, Moore ( $\nabla \nabla_{0}$ ); G. asplenioides, $S w .\left(\vee \nabla_{0}\right)$; G. asterothrix, Hook. ; G. serrulata, Sw. ( $\vee$ v.) ; G. mega-

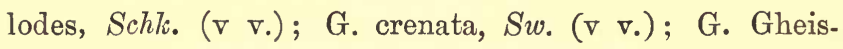
breghtii, Lind. ( $\nabla$ v.); G. tetragona, $S w$. ( $\left.\nabla \nabla_{0}\right)$; G. fraxinifolia, Jacq. (v v.) (G. vivipara, J. Sm. Ferns, Brit. and For.); G. Sandvicense, Hook.

\section{2.-Oriental Species.}

G. prolifera, Pr. (v v.); G. rubida, J. Sm.; G. costata, (Bedd. F. Brit. Ind., pl. 220); G. urophylla, Wall.; G. sub-pectinata, Wall. (G. crenato-dentata, Fée); G. lineata, Wall. (Bedd. F. Brit. Ind., pl. 3); G. unita, Hook.; G. pennigera, Forst. ( $\nabla$ v.); G. oppositifolia, Hook.; G. multilineata, Wall. (Bedd. F. Brit. Ind., pl. 231); G. Penangiana, Hook.; G. Fosteri, Moore ( $\nabla$ v.)

OBs.- It is difficult to reconcile the humble G. reptans and its allies as belonging to the same genus with the splendid $G$. Sandvicense and $G$. costata, the first being a native of the Sandwich Islands, having an erect arborescent cordex, $1 \frac{1}{2}$ feet high, bearing a crown of long stipate fronds 5 feet in length, which, with $G$. costata of India and $G$. pennigera of New Zealand, which also has an arborescent caudex, seems to have some claim to rank as a distinct genus.

In Beddome's "Ferns of British India," G. costata and G. lineata are said to be indusiate, and consequently belong to Nephrodium. 
97.-Dryonenes, Fêe (1851).

J. Sm. Bot. Voy. of Herald, 1853; Polypodium sp. Hook. Sp. Fil.

Vernation sub-sarmentose, decumbent. Fronds contiguous, simple, pinnatifid or pinnate, smooth, 1 to 3 feet in height, sub-membraneous. Segments large, 1 foot long, 2 to 4 inches wide. Primary veins costæform, transversely combined, and compound anastomosing, with free veinlets terminating in the areoles. Receptacles punctiform, compital. Sori round, or by confluence unequal oblong, oblique biserial or irregular, naked.

Type. Polypodium plantagineum, Linn.

Illust. Fée Gen. Fil., t. 18, A ; Moore Ind. Fil., p. 35, A; J. Sm. Ferns, Brit. and For., fig. 61 .

OBs.-This genus was established by Feee upon the Polypodium menisciicarpon of Blume, in which the sori are generally oblong and curved, but such I consider to be an abnormal form of punctiform sori; I, therefore, in the "Bot. Voy, of Herald," added a second pinnate species, as also the Polypodium plantagineum of Linnæus, all of which agree in habit and venation, and in having naked sori, the latter being the only character that separates them from true Aspidium.

Sp. D. plantaginea, J. Sm. (Linn. Jacq. Coll. 2, t. 3, fig. 1)* (v v.); D. menisciicarpon, Fée; D. Purdiei, J. Sm. Bot. Voy. Herald (Polypodium draconopterum, Eat. Hook. Sp. Fil.)

The first and last species are natives of the West-Indies and Tropical America, the second of Malay and Philippine Islands. 


\section{Amphiblestra, Presl. (1836). Pteris, sp., H. and B., Hook., Sp. Fil.}

Vernation fasciculate, erect (?). Fronds stipate, 2 to 3 feet high, pinnate, membraneous, flaccid, pinnæ 2 to 3 pairs, oblong acuminate, petiolate, 8 inches or more in length, 2 to 3 inches broad, entire or the lower ones lobed, subpinnatifid. Primary veins costæform, venules compound anastomosing, with free veinlets terminating in the areoles. Receptacles compital, contiguous, forming a linear subcontinuous marginal sorus, included under or near to the narrow inflexed membraneous indusæform margin.

Type. Pteris latifolia, $H$. and $B$.

Illust. Hook. and Bauer, Gen. Fil., t. 120, C; Moore, Ind. Fil., t. 33, A. Both copied from Presl.

OBs.-This genus is founded on a remarkable and rare Fern, first described by Willdenow in 1810, from specimens collected in Venezuela by Humboldt and Bonpland. At the time of the publication of Hooker and Bauer's "Genera Filicum "I had not seen specimens of this Fern, and therefore followed Presl in retaining it in Pteridece; having subsequently received specimens, I find its natural association to be with Dryomenes, Dictyopteris, and Aspidium, especially such as $A$. macrophyllum, with which it agrees in habit and venation, but differs from Aspidium in having the sporangia produced close to the margin, and forming an apparent linear sorus parallel with the margin which is inflexed in the form of a narrow membraneous indusium, which circumstance led authors to refer it to Pteris. I, however, view this Fern as an aberrant form of the Aspidece alliance.

Sp. A. latifolia, Pr., Kze. Schk., Supp. II., 43, t. 118. 


\section{Dictropteris, Presl, in part. (1836).}

Polypodium, sp., auct., Hook., Sp. Fil.

Vernation fasciculate, decumbent, or sub-erect. Fronds coriaceous, deltoid, bipinnatifid or bipinnate, 3 to 4 feet high, ultimate segments or pinnules sub-entire or sinuouspinnatifid, Veins costæform, venules and veinlets anastomosing (rarely few free, excurrent), forming oblique somewhat elongated areoles, the costal ones transversely elongated. Receptacles medial or compital. Sori round large, irregular or regular, or transversely one to two serial, sometimes crowded near the margin, naked.

Type. Polypodium irregulare, Presl.

Illust. Fée, Gen. Fil., p. 267, t. 31, A, f. 2 ; J. Sm., Fern, Brit. and For., fig. 62 ; Hook., Syn. Fil., t. 5, fig. 48,0 .

OBs.-This genus consists of a few large compoundfronded Ferns, natives of the East Indies, Malay, and Philipjine Islands, and one is found in Tropical West Africa. In general habit they resemble the preceding genus, as also Aspidium, as here restricted, but differing in having a more simple anastomose venation, and from the latter in being destitute of an indusium; but the latter character is probably not always normal, for in cultivated plants of $D$. irregulare a very minute indusinm was observed in the early stage of the sori, but as the sori increased in size it left no trace of its having been present.

Ex. D. irregularis, $P r .(\nabla$ v.) ; D. megalocarpa (Hook.); D. pteroides, Pr.; D. Cumingiana, Pr., in Epim. Bot. ( $\nabla$ v.) (D. macrodonta, J. Sm., Gen. Fil., 1841, and Ferns, Brit. and For.); D. Camerooniana (Hook.) ( $\mathrm{v}$ v.).

OBs.-In the herbarium specimens it is difficult to separate the many forms as distinct species, but cultivated 
plants show that $D$. irregularis and $D$. macrodonta (Cumingianum, Hook.) are distinct, the one having erect vernation, the other decumbent. In the "Species Filicum" eight species are described, but I very much doubt if they are all distinct.

100.-Dipteris, Reinw. (1825).

Polypodium, sp., auct., and Hook. Sp. Fil.

Vernation uniserial, distant, sarmentum setose-squamose. Fronds long stipate, 3 to 6 feet high, broad flabelliform in two lobes; the lobes digitately laciniated, lacinæ lanceolate, entire or serrate. Primary veins radiating in each lobe, 2 or 3 times forked; secondary veins transverse anastomosing, and producing numerous venules and veinlets, forming sub-quadrangular small areoles and containing free clavate veinlets. Receptacles punctiform, compital. Sori small, numerous, and irregular, or in one species longitudinal uniserial.

Type. Polypodium conjugatum, Kaulf.

Illust. Hook. and Grev., t. 168 and 169; Blume, Fil. Jav., p. 174, t. 81; Moore, Ind. Fil., p. 64, A.; Horsf., Flora Jav., 1, t. 1; Hook., Syn. Fil., t. 5, fig. $48, \mathrm{~N}$.

OBs.-This genus contains three known species, natives of the East India, Malay and Polynesian Islands, two of them being remarkable for having large fronds resembling Fan Palms. This genus agrees in venation and character of the sori with Drynaria, but its adherent vernation brings it under the division Desmobrya.

Sp. D. conjugata, Beinw. (P. Horsfieldii, Br.); D. Wallichii (Hook. and Grev.); D. Lobbiana (Hook.); Bedd. F. Brit. Ind., pl. 233. 



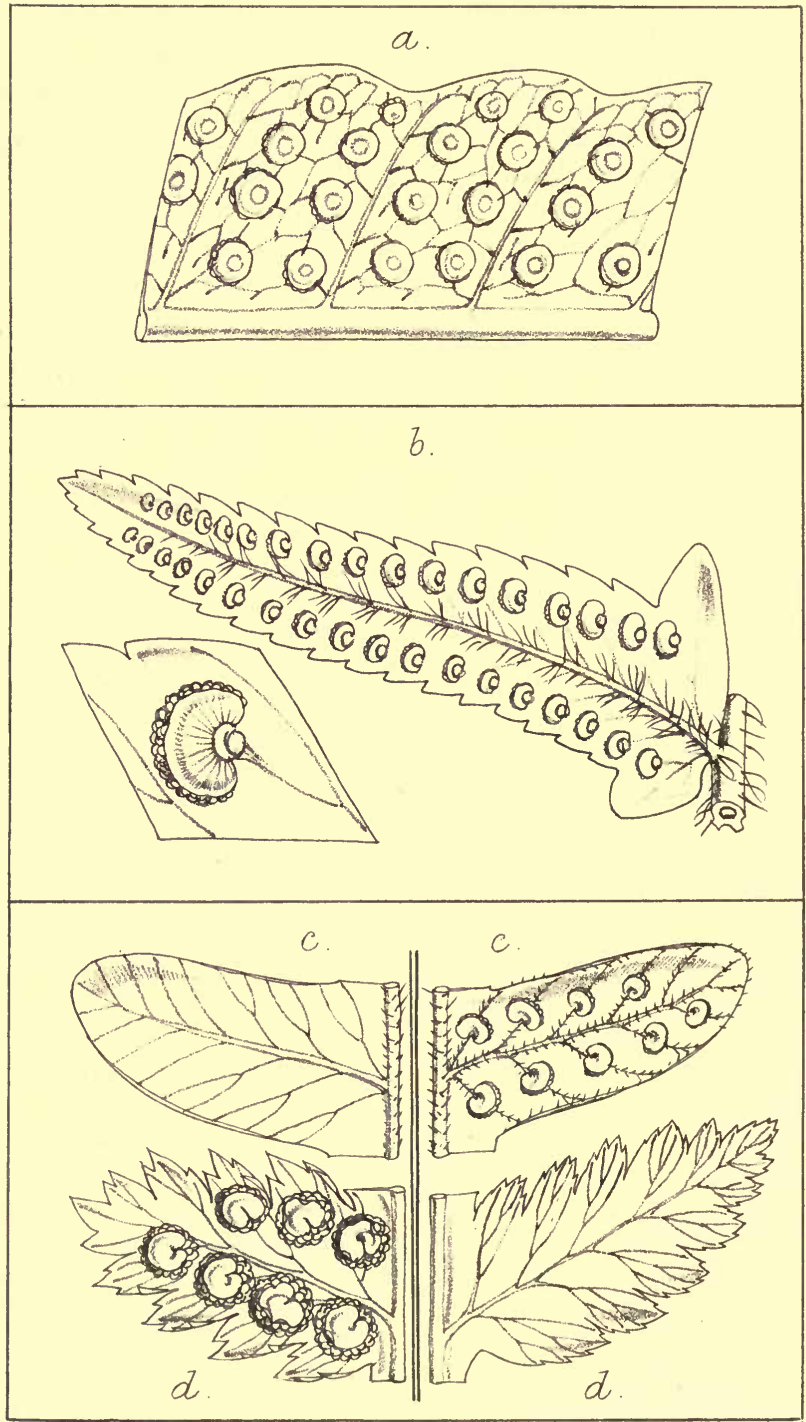

W.H.Fitch, del et Jith. 
The sarmentum of $D$. Wallichii is described as being hypogeous.

\section{** Sori indusiate.}

\section{Sect. 2.-AsPidem.}

Sori normally punctiform. Indusium orbicular peltate, or lateral interiorly attached, and then more or less reniform, rarely calyciform.

\section{A.-Indusium calyciform.}

101.-Hypoderris, R. Br. (1830).

Vernation uniserial sub-sarmentose. Fronds simple, entire or trilobed, 1 to 2 feet long. Primary veins costæform; venules compound anastomosing. Receptacles punctiform, compital, included within a calyciform obscure membraneous indusium. Suri round, irregular or oblique biserial between the primary veins.

Type. Hypoderris Brownii, J. Sm.

Illust. Hook. and Bauer, Gen. Fil., t. 1; Hook. Gard. Ferns, t. 24 ; Moore Ind Fil. p. 83 A.; J. Sm. Ferns, Brit. and For., fig. 72 ; Hook. Syn. Fil., t. 1, fig. 10.

OBs.-This genus was, until lately represented by a single species, as yet found only in the Island of Trinidad, West Indies. It is so similar in habit and venation with Dryomenes and Podopeltis, that without a very close examination of its sori it would pass for a species of Dryomenes, allied to $D$. plantaginea, but the sori are found to be furnished with a small membraneous calyciform indusium, similar to that of Woodsia.

In the "Species Filicum" it is placed in the Tribe Dicksonice, with which it has no affinity either in habit, venation, or position of the sori. 
Sp. H. Brownii, J. Sm. ( $\left.\nabla \nabla_{0}\right)$; Hook. Gard. Ferns, t. 24 .

In Seemann's Journ. Bot., 1869, p. 240, a second species is described, namely H. Seemanni, a native of Nicaragua, which is adopted in the "Synopsis Filicum" Addenda, p. 460. I have not seen specimens of this.

\section{2.-Trichiocarpa, J. Sm. (1866).}

Deparia, sect. Trichiocarpa, Hook.; Cionidium, Moore.

Vernation fasciculate, acaulose. Fronds bi-tripinnatifid, deltoid, 12 to 18 inches high, pinnæ distant, pinnate below, pinnatifid decurrent above; pinnules lanceolate, pinnatifid, or sinuose lobed. Veins uniform, reticulated; areoles transverse oblong, marginal venules free, exserted beyond the margin, bearing globose pedicellate sori. Sporangia included within a calyciform indusium, opening exteriorly.

Type. Trichiocarpa Moorei, J. Sm.

Illust. Hook. Journ. Bot. and Kew Gard. Misc., vol. 4, t. 3; Hook., Fil. Exot., t. 38; Moore, Ind. Fil., p. 80 A. ; J. Sm., Ferns, Brit. and For., fig. 73.

OBs.-This genus is founded on a remarkable Fern, a native of New Caledonia ; in habit it greatly resembles the multifid fronded specimens of Aspidium trifoliatum and allied species, but its marginal pedicellate sori marks it as specially distinct even as not belonging to Aspidece ; relying upon the character of the sori alone, there can be no doubt that Sir W. Hooker is right in describing it as a species of Deparia, but from which it differs, and from all Dicksonice, in having anastomosing veins.

In native and cultivated specimens that have come under my notice, I observed some of the sori to be intramarginal, and even some of them seated on the upper side 
of the frond as in Polystichum anomalum; in these cases the indusium forms a cucullate cyst. Judging from the whole aspect of the plant, and its anomalous fructification, it may be viewed as an abnormal form of the Aspidece above-mentioned; I therefore place it in the present sequence.

Sp. T. Moorei, J. Sm., Ferns, Brit. and For. ( $\nabla$ v.).

B. Indusium orbicular or reniform.

103. Podopeltis, Fée. (1851.)

Aspidium sp., auct.; Hook. Sp. Fil.

Vernation uniserial, sarmentum slender. Fronds simple, elliptical lanceolate, margin entire or sinuose, 1 to $1 \frac{1}{2}$ feet long (stipes long). Primary veins costæform, venules compound anastomosing, with free veinlets, terminating in the areoles. Sori punctiform, compital in two or more rows, or irregular between the primary veins. Indusium peltate.

Type. Aspidium Singaporianum, Wall.

Illust. Fée., Gen. Fil., t. 23 A., fig. 1.

OBs. Under this genus I include two species which differ from true Aspidium in having sarmentose vernation, and simple fronds.

Sp. P. Singaporiana (Wall., Hook. and Grev., Ic. Fil., t. 26); P. sinuata, J. Sm. (Bathmium, Fée).

OBS.-The first is a native of Singapore, and the other of Guiana. In the "Species Filicum" $P$. sinuatum stands as a synonym of Aspidium plantagineum, of which Sir W. Hooker says: "My copious specimens from the West Indies and the continent of South America, have satisfied me that the Polypodium plantagineum (Jacq.) and our Aspidium plantagineum are one and the same Fern, varying 
a good deal in outline, as above noted, and varying in the presence or absence of the involucre, whether from being quickly deciduous, or, as I apprehend, its entire suppression at times, it is hard to say." From this view I differ, for, in cultivated plants of $P$. plantagineum, as well as in many herbarium specimens of the same that have come under my notice, I found no traces of indusium, and therefore consider it to be normally absent; it consequently comes under the genus Dryomenes, while $P$. sinuata not only differs in the general outline of the frond, but also in the sori being furnished with a large peltate indusium, and as it agrees in general habit with $P$. Singaporiana, I therefore associate it with that species.

\section{Aspidium, $S w$., in part (1800). Hook., Sp. Fil.}

Vernation fasciculate, erect. Fronds trilobed, pinnate, bipinnatifid or bipinnate, 1 to 4 feet high, ultimate segments generally broad and flaccid. Primary veins costæform, renules simply or compoundly anastomosing. Receptacles compital or often on the apex of free veinlets, terminating in the areoles. Sori round. Indusium orbicular or reniform.

Type. Aspidium trifoliatum, $S w$.

Illust. Schott., Gen. Fil., t. 4 ; Hook. and Bauer, Gen. Fil., p. 33 ; Moore, Ind. Fil., p. 65, B ; J. Sm., Ferns, Brit. and For., fig. 70 ; Hook., Syn. Fil., t. 5, fig. 43, d.

OBs.-This genus consists of between twenty and thirty species of strong-growing Ferns, generally with membraneous flaccid fronds. They are widely distributed throughout the West Indies, Tropical America, West Africa, Mauritius, Ceylon, India, Malayan, Philippine, and Polynesian Islands. 
Although they agree in general habit they hare nevertheless been arranged by different authors under no less than at least six genera, the technical characters being chiefly derived from slight differences in the venation and position of the sori-for instance, Sagenia is characterised by Presl as having no free veinlets, but I find that that character is not constant, for in different specimens of the same species some have the venation of Sagenia, and others have free veinlets as in Aspidium, and sometimes the two forms are found on the same frond; the characters of the other genera of authors are also, I consider, untenable. I therefore retain them under Aspidium.

It often happens that the indusium is soon deciduous, and therefore when absent this genus cannot be distinguished from Dictyopteris and Dryomenes; also in some species, as for instance the well-known Aspidium macrophyllum, the indusium is as often reniform as peltate. This difference has led the author of the "Synopsis Filicum" to consider the reniform as the normal form, and accordingly places $A$. macrophyllum and other allied species in the genus Nephrodium, from which they differ entirely in habit.

In the "Gartenflora," 1866, page 335, Dr. Regel had characterised a new genus under the name of Grammatosorus, which is accompanied by a figure. It, however, appears to me to be founded on what may be termed an amorphous form of the sori of Aspidium alatum of Wallich, a large-growing Indian species, bearing numerous irregular small sori, which in specimens from Malacca are irregular. and confluent, forming linear transverse sori analogous to Meniscium, while others on the same segment form linear sori parallel with the primary veins. The same variableness $\mathrm{n}$ the form of the sori is also to be found in A. irreguum 
and A. heterocarpum, figured in Bedd., Ferns of Brit. Ind., pl. 47 , in which the sori are curved.

In Moore's "Index Filicum" no less than 976 names are alphabetically arranged under Aspidium, of these twentytwo are adopted species, the rest are synonyms, and are to be found either adopted or as synonyms principally of species of the genera Lastrea, Polystichum, Nephrodium, and Sagenia, the latter I include under Aspidium.

* Fronds pinnatifid; segments decurrent.

Sp. A. decurrens, $\operatorname{Pr}$. (A. pteropus, Kze.); A. alatum, Wall, Hook. and Grev., Ic. Pl., t. 184.

** Fronds pinnate, or sometimes only from three to five lobed; pinnce broad, entire, or the lower ones lobed.

A. angulatum, J. Sm. (Polypodium, Willd.) ; A. platanifolium, Mett.; A. Plumieri, Pr. ( $\left.\nabla \nabla_{\bullet}\right)$; A. trifoliatum, $S w$. ( $\nabla$ v.) ; A. polly morphum, Wall. ( $\nabla$ v.); A. irriguum, J. Sm. ; A. Barteri, J. Sm. ( $\nabla$ v.) ; A. macrophyllum, Sw. ( $\left.\nabla_{.}\right)$; A. Menyanthidis, Willd.; A. repandum, Willd.; A. pachyphyllum, Kze. ; A. Lobbi, Hook. ; A. grande, J. Sm. ; A. intermedium, J. Sm.; A. calcareum, Pr. ; A. variolosum, Wall. ( $\nabla$.) ; A. latifolium, J.Sm. ( $\nabla$.) ; A. subtriphyllum, Hook. $(\nabla \nabla$.$) .$

*** Fronds pinnate; pinnce always more or less sinuoselaciniated, pinnatifid or bi-pinnatifid.

A. coriandrifolium, ${ }^{*} S w . ; A$. cicutarium, $S w .(\nabla \nabla$. (A. hippocrepis, $S w$.$) ; A. giganteum, B l$. ( $\nabla$ v.); A. dela-

* I long considered my original Jamaica specimens of this to be a young state of $A$. cicutarium, but the receipt of additional specimens, apparantly in a perfect state, with the fig. of Plukenet, t. 284, quoted by Swartz, leads me to consider it as distinct. 
ceratum, Mett. ( $\left.\nabla \nabla_{0}\right)$; A. apiifolium, Schk. ( $\left.\nabla \nabla_{0}\right)$; A. coadunatum, Wall.* ( $\nabla \nabla$.$) .$

\section{5.-Crclodidm, Presl. (1836).}

\section{Aspidium, sp., auct. ; Hook. Sp. Fil.}

Vernation sub-sarmentose, hypogeous. Fronds pinnate, 2 to 3 feet high; sterile pinnæ broad elliptical, linearlanceolate. Veins pinnately forked; venules acutely anastomosing, producing from their angular junctions an excurrent free or anastomosing veinlet; fertile pinnæ contracted, linear lanceolate. Veins uniform, reticulated. Receptacles medial, punctiform. Sori round, confluent, and occupying the whole under surface. Indusium obicular.

Type. Aspidium confertum, Kaulf.

Illust. Hook. and Grev., t. 121 ; Hook. and Bauer, t. 49, B.; Moore Ind., p. 67, A.; J. Sm. Ferns, Brit. and For., fig. 67.

OBS.-In many points of structure this genus agrees with Cyrtomium, the chief difference being the hypogeous sub-sarmentose vernation, the more simply anastomosed renation, and the specially contracted fertile fronds. The latter character also is the chief distinction between this genus and some species of Nephrodium, in which the fertile fronds have a tendency to contraction. I restrict Cyclodium to three described species, natives of Eastern Tropical America. In the "Species Filicum" Hooker unites Aspidium confertum of Kaulfuss with A. meniscioides, Willdenow, but judging from cultivated specimens of $A$. confertum of British Guiana, as compared with herbarium specimens of $A$. meniscioides from Trinidad, they appear to me to represent distinct species.

* Phlebigonium, Fée, is probably only a starved imperfect specimen of this species. 
Sp. C. meniscioides, Presl. (Willd.); C. confertum, Presl. (Kaulf.) ( จ.) ; C. abbreviatum, Presl. (Schrad.).

\section{6.-Crrtomium, Presl (1836).}

Aspidium sp., Hook Sp. Fil.

Vernation fasciculate, erect. Fronds 1 to 3 feet high, pinnate, pinnæ elliptical lanceolate, 6 to 8 inches long, 1 to 4 inches wide, falcate, more or less auriculated at the base, the margin sub-entire or spinulose, veins two or three times forked or pinnate, venules alternate, the lower exterior branch free, the others acutely anastomosing, producing from their junctions free or anastomosing veinlets. Receptacles punctiform on or below the apices or points of junction of the venules. Sori round, transversely uniserial, or numerous and oblique serial. Indusium orbicular.

Type. Aspidium falcatum, Swartz.

Illust. Hook. and Grev., t. 171; Hook. and Bauer, t. 49, C; Hook. Fil. Exot., t. 92 ; Moore Ind. Fil., p. 66 ; J. Sm. Ferns, Brit. and For., fig. 68 ; Hook. Syn. Fil., t. 5 , fig. 43 , c.

OBs.-The few species constituting this genus agree in general habit with the pinnate species of Polystichum, but differ in having anastomose veins. I can find no character of sufficient value to retain Presl's genera Phanerophlebia and Amblia as distinct from Cyrtomium, these two genera being evidently founded on specimens off which the indusium had fallen; the only point that may give them an appearance of genuine difference is, that the typical species of Cyrtomium are Eastern, and those of the latter genera Western.

Sp. C. caducum (Wall.) (Hemigonum, J. Sm., 1841); C. 
falcatum (Sw.) ( $\nabla_{0}$ ) ; C. caryotideum (Wall.) ( $\nabla$ v.) ; C. Fortunei, J. Sm. (v v.) (Ferns, Brit. and For.); C. Juglandifolium, Kunze ( $\vee$ v.) (Amblia, Pr.); C. nobile, Kunze (Phanerophlebia, Pr.)

OBs.-The three first species are natives of India and Japan, the two latter of Mexico and Venezuela.

Although I have not seen specimens of the Fern described in the "Species Filicum" under the name of Polypodium (Cyrtomiphlebium) dubium, a native of Peru and Ecuador, I nevertheless believe it to be a species of Cyrtomium; and the reason for Sir William Hooker placing it in Polypodium seems to me to be consequent on the sori having through age or otherwise lost the indusium.

\section{7.-Pleochemia, Presl (1836).}

Nephrodium Hook. Sp. Fil.; Polypodium, Gaud.

Vernation fasciculate, erect, arboroid (vide Cuming). Fronds bi-tripinnatifid, 12 to 15 feet long; primary pinnæ $1 \frac{1}{2}$ to $2 \frac{1}{2}$ feet long; ultimate pinnæ uniformly pinnatifid. Veins of lacinæ costæform; venules forked, the lower ones arcuately and angularly anastomosing, forming unequal areoles next the costa; the exterior ones free. Fertile pinnules much narrower than the sterile. Sporangiferous receptacles medial on the free or anastomosing venules. Sori punctiform in a row on each side of the costreform veins of the lacinæ. Indusium reniform.

Type. Polypodium Leuzeanum, Gaud.

Illust. Hook. and Bauer, t. 97 ; Moore Ind. Fil., p. 70, A ; J. Sm. Ferns, Brit. and For., fig. 71.

OBs.-This genus is founded on a single species, and owes its generic importance more to its gigantic habit than to any real structural difference by which to dis- 
tinguish it from Aspidium. Setting aside its simple anastomosed venation, and viewing it in its general aspect only, it appears to be related to Lastrea villosa, than which, however, it assumes a more aboreous character. Its most natural affinity is with Aspidium macrodontum and $\Lambda$. giganteum. It is a native of India, Malay, Philippine, Fiji, and other islands.

Sp. P. Leuzeana, Presl, Bedd. F. Brit. Ind., pl. 134.

OBs.-In the "Species Filicum" four species are placed under the section Pleocnemia of Nephrodium, two of which possess no natural relationship with $P$. Leuzeana; and I am inclined to consider the fourth species, $N$. (Pleocnemia) excellens identical with the original species, though Presl makes a distinct genus of it (Proferea).

\section{8.-NEPHRODIUM, Schott. (1834).}

Aspidium sp., Sw.; Nephrodium sect. Eunephrodium, Hook. Sp. Fil.

Vernation fasciculate, decumbent or erect, acaulose or subarboroid, or uniserial sarmentose. Fronds 1 to 6 feet high, simple or pinnate; pinnæ entire, sinuoso or pinnatifid. Veins costæform, pinnate; the lower pair of venules only, or more, or the whole, angularly anastomosing, producing from their junction an excurrent veinlet, which is either free or anastomose in the angle of the next superior pair. Receptacles medial or sub-terminal. Sori round. Indusium reniform, rarely nearly orbicular.

Type. Aspidium molle, Swartz.

Illust. Schott Gen. Fil., t. 22 ; Hook. and Bauer, t. 48, B; Moore Ind. Fil., p. 70, B ; J. Sm. Ferns, Brit. and For., fig. 65 ; Hook. Syn. Fil., t. 5, fig. 44 , a, b.

OBs.-This genus as originally characterised embraced 
species with both free and anastomosing veins, the technical character consisting in all having a reniform indusium. Schott restricted the genus to the species having anastomose veins only.

In the "Species Filicum" thirty-four species come under this character, of which the following are the principal. It is well to notice that great confusion exists in the synonyms of many of the species; for instance, Aspidium molle, which is a very cosmopolitan species, has no less than a dozen names placed under it as synonyms, some having erect and others decumbent vernation, which evidently marks them to be distinct species, but at the same time possessing no special marked difference in the character of the fronds. They present at least two very distinct modes of growth, one set having fasciculate vernation and another uniserial, thus forming two groups, which may be viewed as characteristic of two natural genera.

\section{Sect. 1.-Eunephrodium.}

Vernation fasciculate, decumbent or erect, in some arboroid. * Fronds linear lanceolate, entire or pinnatifid.

Sp. N. Cumingiannm, J. Sm. Bot. Voy. of Herald, Kunze, Fil., t. 9, fig. 2 ; N. stenopteris, Hook.; N. simplicifolium, J. Sm., Hook., Second Cent. of Ferns, t. 19. (Polypodium sect. Goniopteris, Hook. Sp. Fil.)

\section{*** Fronds pinnate.}

† Pinnce broad, serrated or entire, or sub-tripinnatifid, all or nearly all the venules anastomosing.

Sp. N. acrostichoides, J. Sm. ; N. lineatum, Pr. ; N. granulosum, J. Sm. (v v.), Bot. Voy. of Herald ( $N$. glandulosum, Hool. Sp. Fil.); N. cyatheoides, Kaulf. (Polystichum 
Dubreuillianum, Gaud. in Frey. Voy., t. 9); N. aristatum, Fée (Hook. Sp. Fil.); N. ferox, Bl.; N. patens (Goniopteris, Fée); N. articulatum, Moore and Houlst ( $\mathrm{v}$ v.) (N. pennigerum, Hook. Sp. Fil.) ; N. truncatum, Pr. (v v.); N. abruptum, Pr.; N. arbuscula, Desv. (N. Hookeri, J. Sm.) ( $\left.\nabla \nabla_{0}\right)$; N. arbortivum, F'ée ( $\left.\nabla v_{0}\right)$; N. venustum, J. Sm. ( $\vee$ v.) ; N. refractum, Hook. ( $\nabla$ v.) ; N. brachyodon, Hook. (Phegopteris Seemani, J. Sm. in Bot. Voy. of Herald).

t十 Pinnoe narrow, generally deeply pinnatifid, with only 1 or 2 verules anastomosing.

N. hirsutum, J. Sm.; N. angustifolium, $P r_{0} ;$ N. mucronatum, J.Sm. ; N. diversilobum, Pr.; N. molle, R. Br. ( $\nabla$ v.).

Sect. II.-Nephrodinum.

Vernation distant, sarmentose. Fronds uniform bipinnatifid.

N. unitum, Hook. ( $\nabla$ v.) ; N. propinquum, R. Br.; N. varians, F'ée ; N. aridum, J.Sm. ; N. multijugum, (Wall.); N. pteroides, J. Sm. (Aspidium terminans, $W a l l)(\mathrm{vv}$,$) ; N. ve-$ nulosum, Hook. (v v.); N. extensum, Bl. (N. Cumingi, J. Sm. En. Fil. Phillip. Cuming, 391.); N. Haenkeanum, Pr.

OBs.-The above species are widely spread, being found in all fern regions within the tropics and sub-tropical regions of both hemispheres.

I have already stated that the presence or absence of indusia is the only character for distinguishing Nephrodium from Goniopteris, and that consequent on its fugacious nature the species normally indusiate when placed in the herbarium the indusium fall away and thus become Goniopteris, much depends upon the age of the fronds when gathered or the condition under which they are preserved, for it is known that in the herbaria of different botanists 
specimens of the same species are found, some with the indusia and some without, for instance, being present at the distribution of Cuming's Philippine Island collection of specimens in 1841, I noted that number 315 was indusiate, which in my enumeration of that collection I named Nephrodium simplicifolium. It was not till nearly twenty years afterwards when Cuming's specimens of this species came under Sir William Hooker's observation for entry in the "Species Filicum," that finding it had no indusium he placed it under Polypodium in the section Goniopteris.

Another example of the untrustworthiness of the indusium as a generic character is verified in Phegopteris Seemanni, described by me in the "Botany of the Voyage of the Herald," from specimens collected by Seemann in Darien; Mettenius also retains it in Phegopteris, but makes it a synonym of Aspidium brachyodon of Kunze, while in the "Species Filicum" it is placed in Nephrodium, the "involucre" being described as "small fugaceous," thus showing that at least some of the specimens in the Kew herbarium were indusiate; but as several American localities, as also the Malayan Peninsular and islands, are given as stations for this Fern, it is therefore quite possible that the American and Malayan specimens represent two distinct species, one with indusiate sori, and the other with naked. This and several other allied species is peculiar in having stout arboroid stems a foot or more in height, with the pinnæ articulate with the rachis, as also in the lobes of the pinnæ being joined by a line like a seam, which extends from the mid-rib of the pinnæ to the sinus between each two lobes, by which in time the lobes become separated as if artificially cut. Setting aside the presence or absence of the indusium, and in the venules being free 
or connected, this species, with several others, including Goniopteris Sandvicense and its allies, seems to form a natural group, which, with Lastrea villosa, may, on the character of general habit, be viewed as forming a natural genus of sub-arboroid Ferns.

\section{9.-Mesochlena, R. Br. (1838).}

Sphorostephanos, J. Sm. (1838); Nephrodium sp. Hook. S.p. Fil.

Vernation fasciculate, erect. Fronds 2 to 4 feet high, bipinnatifid. Veins costæform, pinnate; the lower pair of venules anastomosing, the others free, parallel. Receptacles medial, elongated. Sori oblong linear. Indusium oblong, attached longitudinally on the centre of the receptacle, having sporangia on its axis on each side, its margin free.

Type. Polypodium villosum and P. caudigerum, Wall.

Illust. Hook. and Bauer, Gen. Fil., t. 24; Hook. Fil. Exot., t. 62 ; Moore Ind. Fil., p. 43, B ; J. Sm. Ferns, Brit. and For., fig. 66.

OBs.-This genus was first noticed by Brown in Horsfield's "Planta Javanica," and about the same time described by me in Hooker and Bauer's "Genera Filicum" under the name Sphoerostephanos. Later observations have led me to view it as scarcely distinct from Nephrodium, with which the species agree in habit. The only difference that Brown and myself considered as generic consists in the sori being oblong linear, and furnished with an elongated indusium attached along the centre of the sorus, having the appearance of being double, like that of some species of Athyrium, but in Meschloena it is in a single piece, and cannot be viewed otherwise than as a lengthened reniform indusium of Nephrodium fitted to the lengthened 
receptacle. In the "Species Filicum" only one species is described, but according to my view, I consider there are two, natives of Malayan and other Eastern islands.

Species. M. Javanica, R. Br. ( $\vee$ v.); M. asplenioides, J. Sm. (Sphcerostephanos J. Sm. in Hook. and Bauer Gen. Fil.)

\section{0.-F FDYENIA, Hook. (1842). \\ Hook. Sp. Fil.}

Vernation fasciculate, acaulose, becoming cæspitose. Fronds simple, dimorphus, 5 to 6 inches long, sterile, lanceolate, attenuated, decumbent, its apex proliferous; fertile fronds erect, linear spathulate, obtuse. Veins forked, venules acutely anastomosing, free next the margin ; the lower exterior venule in the costal areoles free, its apex soriferous. Receptacle oblong. Indusium large, oblong reniform. Sori contiguous, transverse uniserial on each side of the costa.

Type. Fadyenia prolifera, Hook.

Illust. Hook. and Bauer, Gen. Fil., t. 53, B.; Hook. Fil. Exot., t. 36 ; Moore Ind. Fil., p. 68 ; J. Sm. Ferns, Brit. and For., fig. 69 ; Hook. Syn. Fil., t. 5, fig. 47.

OBs.-This genus is founded on a remarkable Fern, a native of Jamaica and Cuba. In habit it does not well associate with any of the Aspidece group, except Polystichum rhizophyllum, with which it agrees in the sterile fronds, being decumbent and proliferous; in that character as also in the texture and colour of the fronds, and in the oblong, apparent double indusium, seems to indicate a greater relationship with Antigramma in the tribe Aspleniece, rather than with any of the genera of the present sequence.

Sp. F. prolifera, Hook. ( $v$ v.), (Aspidium proliferum, Honk. and Grev. Ic. Fil., t. 96). 


\section{Series 2.-Veins free.}

* Sori Indusiate.

Sect. 3.-OREOPTEREA.

Sori punctiform. Indusium orbicular or reniform, plane.

$$
\text { 111.-Lastrea, Presl. (1836). }
$$

Polypodium sp. auct.; Nephrodium sp., Hook. Sp. Fil.

Vernation uniserial, sarmentose or fasciculate, erect or decumbent, acaulose, rarely sub-arboroid. Fronds varying from pinnatifid to decompound multifid, 1 to 6 feet high. Veins simple, or once or several times forked, or costæform and pinnate; venules free. Receptacles punctiform, terminal or lateral. Indusium reniform or sub-rotund, interiorly attached.

Type. Aspidium Fitix-mas, Sw.

Illust. Hook. and Bauer. Gen. Fil., t. 45, A. ; Hook. Brit. Ferns, t. 15; Hook. Fil. Exot., t. 98 ; Moore Ind. Fil., p. 71 ; J. Sm. Ferns Brit. and For., fig. 75 ; Hook. Syn. Fil., t. 5, fig. 44.

Oвs.-The above character embraces a large number of widely distributed species, abounding within the tropics, and extending to the furthest limits of Fern vegetation in both hemispheres. These numerous species vary greatly in the size and circumspection of their fronds, agreeing in general habit with the genus Phegopteris, the want of indusia in the latter being the only technical distinction, that organ, however, is often very small and soon becomes obliterated, and as stated under Nephrodium, when absent, the species of Lastrea are consequently placed under Phegopteris. The indusium varies considerably in size and texture and in the depth of the sinus, the latter being 
sometimes so deep as to give the indusium a bi-lobed character, while in others it is scarcely evident and the indusium is then nearly orbicular and thus characteristic of Polystichum. In the "Species Filicum" Lastrea ranks only as a section of Nephrodium; the author thus not admitting the difference between anastomose and free venation to be of sufficient generic value to warrant the separation of the two groups of species; in the section Lastrea 115 species are described, in the "Synopsis" the number is raised to 153, of which 65 have Mr. Bakers initials affixed, and in the Appendix 46 species are enumerated, a few of which are for the first time described as new species, but the greater number consists of removals from Aspidium, the specific name being changed in many cases.

Lastrea as here restricted contains about 100 species, of which 65 have been examined by me in a living state.

The difference in the position of the sori and forms of the indusium has led to the species being arranged under a dozen or more genera by different authors, none of which have sufficient character to warrant their adoption.

Sect. 1.-Vernation fasciculate, erect or decumbent, in some becoming arboroid (Dryopteris).

\section{1.-Oreopteris Grodp.}

Fronds lanceolate pinnate; pinnce more or less deeply pinnatifid. Veins pinnate in the lobes; venules simple, rarely forked.

Sp. L. decursivo-pinnata (Kze.) ( $\mathbf{v}^{\mathrm{v}}$ v) (L. decurrens $J . S m$.$) ; L. exigua (Kze.) ; L. viscosa (J.Sm.) ; L. sancta$ $(S w).(\nabla \nabla$.$) .$

OBs. - This has hitherto been ranked among nonindusiate Ferns, but having observed small indusia on cultivated plants, I therefore place it here. 
L. concinna (Willd.) ( $\nabla$ v.) ; L. oligocarpa (Klot.); L. contermina (Willd.) ( $\nabla v_{0}$ ) ; L. montana, Moore ( $\nabla$ v.); L. Sprengelii (Kaulf.) ( $\mathrm{v} \mathrm{v}_{\text {. }}$ ); L. patens ( $S w_{\text {. }}$ ) ( $\mathrm{v}$ v.) ; L. limbata $(S w$.$) ; L. glandulifera (Wall.) ; L. appendiculata (Wall.);$ L. calcarata (Bl.); L. falciloba (Hook.); L. cana (Wall.) ( $\mathrm{v}$ v.) ; L. crinibulbon (Hook.); L. crinita (Desv.) ( $\vee$ v.) ; L. velata (Hook.); L. vestata (Radd.) ( $\vee$ v.) ; L. macrotis (Hook.) ; L. caripense, Mett. ( $\nabla$ v.); L. immersa (Bl.) (L. verrucosa, J. Sm., En. Philip, 1841) (v v.); L. ligulata (Mett.); L. attenuata (Kze.).

OBs.-Sir W. Hooker places this and $L$. invisa, which somewhat resembles it under $L$. patens, but I am satisfied they are three distinct species.

L. similis, J. Sm., En. Philip., n. 390 ; L. deltoidea (Sw.) ( $\mathrm{v}^{\mathrm{v}}$ ) ; L. crassifolia, $B l_{\text {. }}$; L. spectabilis $\left(B l_{0}\right)$ ( $\left.\mathrm{v}_{\mathrm{v}}\right)$; L. Kaulfussii (Link.) ( $\nabla_{0}$ ) ; L. chrysoloba (Link.) ( $\nabla_{*}$ ) ) L. falciculata $\left(P r_{0}\right)$ ( $\nabla$ v.):

\section{2.-Filix-mas Grodp.}

Fronds lanceolate or deltoid, bi-tripinnatifid or bi-pinnate, rarely simply pinnate, usually firm and sub-coriaceous. Veins forked, generally immersed.

L. podophylla (Hook. Kew Gard. Misc., v. 5, t. 1) (v v.).

L. Sieboldi, J. Sm. (Nephrodium, Hook. Fil. Exot. t. 31. Pycnopteris, Moore) ( $\nabla$ v.).

Obs.-In Ferns British and Foreign I placed the latter as a synonym of the former, but later observation has led me to consider them as distinct.

L. hirtipes ( $B l$.$) ; L. lacera (Eat.) ( \mathrm{v}$ v.) ; L. apiciflora (Wall.) ; L. Brunoniana (Wall.) ; L. fragrans $(S w$.$) ; L.$ pumila, Hort. ( $\nabla$ v.).

OBs.- Living plants of this have been under my observation for forty years. It is said to have been found wild 
in Yorkshire; it always maintained its original dwarf character.

L. Filix-mas $(S w$.$) ( \mathbf{v}$.), var. parallelogramma (Kze.), var. paleacea (Don.) ( $\nabla$ v.), var. affinis $(F$. and $M$.$) , var.$ Borreri (Newman), var. incisa (Moore) ( $\nabla \nabla$.$) , var. elongata$ (Hook.).

OBs.-Although I have placed under L. Filix-mas the above varieties, they nevertheless, when seen growing side by side, present appearances to warrant some of them being admitted as distinct species.

L. remota (A. Braun) (v v.) ; L. rigida (Sw.) (v v.), var. L. pallida (Link.), var. L. arguta (Kaulf.); L. Goldiana (Hook.) ( $\nabla$ v.) ; L. marginalis (Sw.) ( $\nabla \nabla$.$) ; L. cochleata,$ (Don.) ; L. erythrosora (Hook.) ( $\left.\vee v_{0}\right)$; L. sparsa (Lon.) ( $\vee$ v.) ; L. mexicana (Hook.) ( v.); L. splendens (Wall.); L. Napoleonis (Bory) ( $\vee$ v.) ; L. cognata, (Hook.) ; L. ascensionis (Hook.); L. varia (Sw.) (v v.).

\section{3.-Dilatatum Grodp.}

Fronds deltoid bi-tripinnate, decompound, rarely lanceolate, generally more fragile and membraneous than in the preceding group, ultimate divisions generally mucronate or spinulose. Veins forked.

L. $\operatorname{aristata}(S w).(\nabla \nabla$.$) ; L. spinulosa (S w$.$) ( \nabla$ v.) ; L. dilatata $\left(S w_{0}\right)\left(\nabla \nabla_{0}\right)$; L. cristata $\left(S w_{0}\right)\left(\nabla \nabla_{0}\right)$; L. intermedia (Willd.) ( $\nabla \nabla$.$) ; L. æmula (S w$.$) ( \nabla \nabla$.$) ; L. inæqualis$ (Schlecht.) ; L. athamantica (Kze.); L. flaccida (Bl.); L. Falconeri (Nephrodium, Hook.); L. divisa (Wall.); L. membranifolia (Pr.) (L. Milnei, Hook. Secd. Cent., t. 62) (v v.) ; L. fuscipes (Wall.); L. latifrons (Hook.) ( $\nabla$ v.); L. ferruginea (Bedd. Fil. Ind., t. 100); L. propinqua (J.Sm.); L. squamigera (Hook.); L. rubiginosa (Hook.); L. hirsuta (Don.) ( $N$. eriocarpum, Wall.) ; L. Shepherdi (Kze.) 


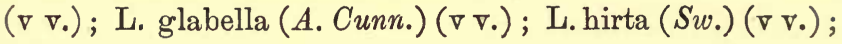
L. deparioides (Hook.) ( $\nabla$ v.) (Diclisodon, Moore).

\section{4.-Villosum Group.}

Fronds tripinnate, 12 to 18 feet long; stipes thick, paleaceous; pinnce 2 to $2 \frac{1}{2}$ feet long, lanceolate acuminate, deeply pinnatifid, segments entire or pinnatifidly lobed; ultimate lobes unisorus. Indusium almost peltate (Megalastrum $J$. Sm.)

\section{L. villosa $\left(S w_{0}\right)$ ( $\left.\nabla \nabla.\right)$.}

This is a native of the West Indies and Tropical America, and is described by the collectors, Wilson and Purdie, as having fronds 10 to 18 feet in length; the height of the stem is, however, not stated. In 1864, two plants in the Kew collection received from Jamaica, were producing fronds 5 to 6 feet in length, rising from a thick caudex, which had every appearance of in time becoming arboroid.

Although this species technically agrees with Lastrea in venation and character of the sori, the large fronds, and arboroid character of its stems, seems sufficient to warrant its being worthy to be ranked as a distinct genus.

Sect. 2.-Vernation sarmentose. Fronds more or less distant (Thelypteris).

* Sarmentum hypogeous, naked.

L. palustris (J.Sm.) ( $\mathrm{v}$ v.); (Thelypteris palustris, Schott. Polypodium Thelypteris, Linn.); L. squamulosa (Schlect.).

OBs. - In the "Species Filicum" this is made a synonym of the preceding, but I consider it sufficiently distinct to rank as a species. It is a native of South Africa, while $L$. palustris is a native of Europe.

L. Noveboracensis (Iinn.) ( $\nabla \nabla$.$) .$ 
** Sarmentum epigeous, squamose.

L. invisa $\left(S w_{.}\right)\left(\nabla \nabla_{0}\right)$; L. Serra $\left(S w_{0}\right)$; L. augescens $($ Link) ( $\nabla$ v.).

Fronds deltoid decompound. Polystichopsis, J. Sm.

L. hispida ( $\left.S w_{.}\right)\left(\nabla \nabla_{0}\right)$; L. pubescens $\left(S w_{0}\right)\left(\nabla \nabla_{0}\right)$; L. decomposita (R. Br.) ( $\nabla$ v.); L. quinquangularis (Kze.) ( $\vee$ v.); L. recedens $\left(J . S m_{.}\right)$( $\left.\nabla \nabla_{.}\right)$; L. elegans $\left(J . S m_{.}\right)$

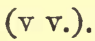

Obs.-Sir William Hooker unites this with L. recedens, but the two are quite distinct as is shown by cultivated plants.

L. sub-quinquefida (Beauv.) ( $\nabla$ v.) ; L. variabile (Hook.)

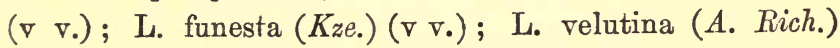
( $\nabla$ v.) ; L. pilosissima (J. Sm.) (G. Don in Hort.) ( $\nabla$ v.).

\section{2.-Polystichum, Schott. (1834).}

Aspidium sp., Hook. Sp. Fil.

Vernation fasciculate and erect, generally cæspitose or uniserial and sub-sarmentose. Fronds pinnate, bi-tripinnate or decompound, pinnæ and pinnules auriculated and lobed, dentate, rigid, spinulose, mucronate. Veins simply or pinnately forked; venules free, the lower exterior branch or more (of each fascicle) soriferous on, or generally below its apex. Receptacles punctiform. Sori round. Indusium orbicular or sub-reniform.

Type. Aspidium aculeatum, Swartz.

Illust. Hook. and Bauer Gen. Fil., t. 48, C. ; Hook. Fil.

Exot., t. 33 ; Schott. Gen. Fil., t. 9 ; Moore Ind. Fil., p. 67, B.; J. Sm. Ferns Brit. and For., fig. 74; Hook. Syn. Fil., t. 5, fig. 43, a. b.

OBs.-Between forty and fifty species are described as 
belonging to this genus; they have a wide geographical range; extending from the arctic to the antarctic circles, and abounding in the tropics, ascending to great elevations. Its most common representatives are forms analagous to the Polypodium aculeatum, Linn. (Aspidium, Su.), of the Eupropean flora, of which there are several states found in our own country sufficiently distinct to be considered separate species by some botanists, though others view them as only different states of one variable species. A similar difference of opinion exists regarding the foreign forms, the original discoverers having named and described plants from different localities as distinct species, and, indeed, in many instances they seem sufficiently distinct to be readily acknowledged as such, but on collating a general collection of specimens and regarding them from a Darwinian point of view, it is difficult to consider the great majority of them otherwise than as climatic conditions of a single species; and the same may be said of the group represented by $P$. coriaceum. The difference in some of the extreme forms is, however, so obvious, especially when living examples are examined, that it seems reasonable to distinguish them by different names, and I therefore, after much consideration, think it best to enumerate them under the original names given by authors.

As a genus, Polystichum is technically distinguished from Lastrea by its indusium being circular and peltate, instead of reniform, as in the latter. This character, however, cannot be invariably depended upon, for in some species with the habit of Polystichum have reniform indusium, and instances occur where peltate and reniform indusia are found on the same frond. To determine the genus, it is therefore necessary to study its habit. As a general rule, Polystichum may be known from Lastrea by 
the fronds being smooth, shiny, of a hard, dry texture, and by the ultimate divisions being terminated by a spiny point. The fronds of Lastrea, on the contrary, are soft, and generally villose, and soon wither and crumple up when separated from the plant.

In arranging the species I have followed the plan indicated in my "Catalogue of Cultivated Ferns," by which they are thrown into two natural groups; one with fasciculate vernation and lanceolate pinnate or bi-tripinnate fronds, typically represented by $P$. aculeatum, and the other with sarmentose vernation and generally distant, bipinnate or decompound deltoid fronds, like P. coriaceum.

\section{Sect. 1.-Polystichum verum.}

Vernation fasciculate, generally erect, acaulose.

* Fronds pinnate.

Type. Polypodiun lonchitus, Linn.

Sp. P. Plaschnickianum (Kunze); P. rhizophyllum $(S w$.$) ; P. auriculatum (S w$.$) ; P. mucronatum (S w)\left(\nabla \nabla_{0}\right)$; P. falcinellum $\left(S w_{0}\right)$ ( $\left(\nabla \nabla_{0}\right)$; P. acrostichoides $(S w$.$) ( \left(\nabla_{0}\right)$ (A. auriculatum, Schk. Fil., t. 30); P. munitum (Kaulf.); P. lepidocaulon (Hook.) (v v.); P. Lonchitis (Sw.) ( $\mathbf{v}$ v.); P.triangulum $(S w$.$) ( \nabla$ v.) ; P. obliquum (Don.) ( $\nabla$ v.) ; P. ilicifolium (Don.); P. tridens (Hook.)

** Fronds bipinnate.

Type. Polypodium aculeatum, Linn.

P. aculeatum $\left(S w_{0}\right)\left(\boldsymbol{\nabla} \nabla_{0}\right)$; P. lobatum $\left(S w_{0}\right)$; P. angulare (Willd.) ( $\mathrm{v}$ v.)

Indian, Malayan, Chinese, and Japanese.

P. Thomsoni (Hook.); P. Lachnense (Hook); P. Prescottianum (Wall.); P. lentum (Don.) ; P. discretam (Don.); P. Tsus-Simense (Hook.); P. tripterum (Kunze) ; P. obtu- 


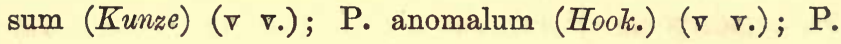
squarrosum (Don.) ( $\nabla \nabla$.$) ; P. biaristatum (Blume).$

South African, Austrian, and Polynestan.

P. pungens (Kaulf.) ( $\nabla$ v.); P. venustum (Hook.); P. proliferum (R. Br.) ( $\left.\nabla \nabla_{0}\right)$; P. vestitum $(S w$.$\left.) ( \nabla \nabla_{0}\right)$.

AMERICan.

P. mohrioides (Bory.); P. platyphyllum (Willd.); P: muricatum (Willd.) ; P. ordinatum (Kunze) ; P. viviparum (Mett.); P. Bridgesi (Sturm).

*** Fronds tripinnate.

P. moluccense (Blume).

Sect. 2.-Tectaria, Cav.

Vernation uniserial, sarmentose. Fronds deltoid, decompound.

Type. Aspidium coriaceum, $S w$.

P. coriaceum $(S w).\left(\nabla_{0}\right)$; P. adiantiforme (Forst.); P. discolor (Lang. and Fisch.); P. macroporum (Bory.); P. Capense (Willd.) ( $\nabla_{\text {v. }}$; P. Richardii (Hook.) ; P. amabile (Blume.) ( $\left.\nabla \nabla_{\bullet}\right)$; P. speciosum (Don.) ; P. aristatum (Sw.) ( $\left.\nabla \nabla_{\circ}\right)$; P.denticulatum $\left(S w_{.}\right)$( $\left.\nabla_{\bullet}\right)$; P. fœniculaceum $\left(H_{o o k}\right)$; P. frondosum (R. T. Lowe) ( $\left.\nabla \nabla_{0}\right)$; P. flexum (Kunze) ( $\nabla$ v.) ; P. Semani (Hook.); P. melanostichum, (Leib.); P. amplissimum $\left(P r_{0}\right)\left(\nabla \nabla_{0}\right)$; P. multifidum (Mett.) ; P. ascendens (Heward) ; P. coiifolium (Wall.) ( $\vee$ v.). Bedd., F. Brit. Ind., pl. 261.

OBs.-In $P$. lepidocaulon the veins occasionally anastomose. Of late years a great number of abnormal forms or what are generally termed varieties, of British species have been discovered or acquired by cultivation, and which are held in high estimation by amateur Fern cultivators, and even prizes awarded by the Horticultural Society. In the 
trade Catalogue of Mr. Stansfield, of Todmorden, no less than 96 of these names are given under Polystichum aculea. tum and angulare, and 66 under the British species of the genus, Lastrea.

\section{3.-Acrophords, Prest (1836).}

Aspidium Blume, Wall.; Davallia Sp. Hook.

Vernation fasciculate, erect, sub-arboroid. Fronds 4 to 6 feet high, stipate, deltoid, decompound multifid; primary pinnæ opposite, 1 to $1 \frac{1}{2}$ feet long, patent, their petioles short, forming with the rachis a thickened node, and furnished with a deciduous stipuliform scale; ultimate pinnules or segments sessile, $\frac{1}{4}$ of an inch long, oblong, oblique cuneiform, lobed or crenate on the upper edge. Veins pinnate; venules simple or forked, free, setulose on the upper side. Sporangiferous receptacles terminal, marginal. Sori punctiform, one, two, or three on each segment. Indusium sub-orbicular, laterally attached by its broad base on the inner side of the receptacle, at first cucullate, but at length reflexed.

Type. Aspidium nodosum, Blume.

Illust. Presl, Tent. Pterid., p. 49, t. 3, f. 2.

OBs.-This genus is founded upon a remarkable Fern, a native of India, Java, and other Malayan Islands. Like many other Ferns, its habit alone is sufficient to mark it as a distinct genus, but in venation and character of its sori it differs but little from Lastrea, the principal difference being in the form of the indusium, which is attached by its broad base, as in the Eremobryos genus Leucostegia; and on that character alone Mr. Moore places the species of Leucostegia under Acrophorus, in habit as two genera they are, however, quite distinct. 
Sp. A. nodosa, Presl Bedd. F. Brit. Ind., pl. 93 (Aspidium foliolosum, Wall).

\section{4.-Camptodium, Fée (1852).}

Pachyderis, J. Sm., 1854. Nephrodium sp., Hook. Sp. Fil.

Vernation fasciculate, erect, acaulose. Fronds stipate, deltoid, cordate, tri- or pedately-lobed, thick, coriaceous, smooth, 8 to 12 inches in length. Veins obscure, flabellately forking in the lobes. Receptacles punctiform, terminal. Sori large. Indusium reniform.

Type. Aspidium pedatum, Desv.

OBs.-This genus is founded on a solitary Fern, which differs from all free-veined Aspidece in its fronds being cordate, sub-entire, or more or less lobed, and of a thick, coriaceous, firm texture, and obscure veins; its peculiar habit induced me to characterise it as a distinct genus, under the name of Pachyderis, but which is superseded by the earlier one of Fée. It may be considered as holding a position intermediate between Polystichum and Lastrea.

Sp. C. pedatum, Fée.

Native of the West Indies, Jamaica.

\section{5.-AdeNoderris, $J$. Sm. (1852).}

Aspidium Sect. Polystichum, Hook. Sp. Fil.

Vernation fasciculate, erect, acaulose. Fronds 6 to 8 inches in length, oblong, lanceolate, pinnatifid, densely covered with pilose glands, decurrently attenuated to a short stipe. Veins pinnately forked. Receptacles punctiform, medial. Sori round. Indusium orbicular, occasionally reniform.

Type. Aspidium glandulosum, Hook. and Grev.

Illust. Hook. and Grev. Ic. Fil., t. 140. 
OBS.-This genus is founded on a solitary species, which in habit is so like some species of Ctenopteris, that it might be referred to that genus, but the presence of indusia shows it to belong to Aspidece. Its free veins, and generally orbicular peltate indusium, led me to originally refer it to Polystichum. In habit, however, it is totally at variance with any species of that genus, as also with Lastrea; I therefore deem it best to characterise it as a distinct genus, and view it with Camptodium as an aberrant species between these two genera.

Sp. A glandulosa, J. Sm. (Hook and Grev. loc. cite). Native of Jamaica and Cuba.

Sect. 4.-ARTHROPTERE正.

Fronds pinnate; pinnæ entire or subpinnatifid, articulate with the rachis.

OBs.-This section consists of a few special genera, which do not well associate with any of the genera in the preceding sections; but the pinnæ being articulate with the rachis, and the presence of white chalky dots on the upper surface, opposite the apex of each vein, seems to indicate their relationship to one another, which will be specially noticed under each genus.

\section{6.-Arthropteris, $J$. Sm. (1854).}

Polypodium, Nephrodium, and Nephrolepis, Hook., Sp. Fil.

Vernation uniserial; sarmentum slender, stipes pseudoarticulate; the node of articulation basal or more or less elevated. Fronds pinnate, 1 to 2 feet or more long, simple or repeatedly dichotomously branched; pinnæ oblong lanceolate, $\frac{1}{2}$ an inch to 2 or 3 inches long, entire or pinnatifid, articulated with the rachis. Veins simple, or forked, 
or pinnate; venules free. Sori punctiform, terminal. Indusium reniform or absent.

Type. Polypodium tenellum, Forst.

Illust. Schk. Fil., t. 16 ; Hook. Fil. Exot., t. 89 ; J. Sm., Ferns, Brit. and For., fig. 78.

OBs.-This genus was first characterised by me in Dr. Hooker's "Flora of New Zealand," the type being Polypodium tenellum Forster. I there stated that although no indusium had been detected on New Zealand specimens I nevertheless associated with it the Nephrodium obliteratum of Brown, which has a very small fugacious indusium, and although Aspidium albo-punctatum of Bory, has a welldefined reniform indusium, its other points of character seem to indicate its affinity with $A$. tenella. The apparent articulation at or near the base of the stipes of $A$. tenella and $A$. obliterata gives them some claim to rank in Erymobrya, and in A. albo-punctata the apparent joint is often 2 to 3 inches above the base of the stipes. These characters seem to indicate a natural relationship of these species to one another, to which I add Polypodium heteromorphum, a Fern of peculiar habit of growth, having slender dichotomous or unequally branching fronds, each branch being pinnate, the pinnæ numerous, oblong, entire or variously lobed, not exceeding half an inch in length, their bases articulate with the rachis, and having white dots on the upper surface, which, with the sori being terminal and naked, leads me to consider these points sufficient to warrant its being placed in the present genus. It is a native of Mexico, New Grenada, and other parts of tropical America, growing round the base of trunks of trees, on moist rocks, and even in caves, its slender fronds being pendulous, similar to some species of Ctenopteris and $H y$. menophyllum. 
Sp. A. tenella, (Forst.) (Schk. Fil., t. 16) ( $\nabla$ v.) ; A. ramosa (Beauv.) (Nephrodium obliteratum, R. Br.; A. obliterata, J. Sm., Ferns, Brit. and For.) ( $\nabla$ v.) ; A. altescandens, J. Sm. (Nephrolepis Hook. Syn. Fil.); A. heteromorpha, J. Sm. (Polypodium, Hook. and Grev. Ic. Fil., t. 108); A. albo-punctata (Willd.) (Hook. Fil. Exot., t. 89 ; Aspidium Boutonianum, Hook. Ic. Pl., t. 931) ( $\mathrm{v}$ v.) ; A. sub-biaurita, J. Sm. (Nephrodium, Hook. Sp. Fil.)

The above species are widely scattered, being individually represented in Australia, New Zealand, Juan Fernandez, tropical West Africa, and Mascaren Islands, and by $A$. heteromorpha in tropical America.

\section{7.-Crclopeltis, J. Sm. (1846).}

Aspidium sp., Hook. Sp. Fit.

Vernation fasciculate, decumbent. Fronds pinnate, 1 to 3 feet high, pinnæ entire, falcate, lanceolate, 4 to 9 inches long, sessile, anriculated at the base, articulated with the rachis. Veins two or three times forked, venules free, the lower exterior and interior ones sporangiferous on or below their apices. Receptacles punctiform. Sori round, transverse, biserial. Indusium orbicular.

Type. Aspidium semicordatum, $S w$.

Illust. Fée, Gen. Fil., t. 22, fig. 2 A ; J. Sm., Ferns,

Brit. and For., fig. 80.

OBs.-This genus is founded upon the Aspidium semicordatum of Swartz, a native of the West Indies and some parts of tropical America. It is closely allied to Nephrolepis, but differs in the vernation being fasciculate and decumbent, and not stoloniferous, as also in the sori being transverse biserial. A closely allied species is found in the Malayan, Philippine, and other islands, the principal 
distinction being that in the first the sorr are lateral, and in the latter terminal.

Sp. C. semicordata $(S w$.$\left.) ( \vee \nabla_{0}\right)$; C. Presliana, J. $S m$. (Lastrea Presliana, J. Sm., Cuming's Enumeration, 1841).

In the "Species Filicum" the latter is made a synonym of $A$. semicordatum.

\section{8.-NEPHROLEPIS, Schott. (1834).}

Hook Sp. Fil.

Vernation fasciculate, erect, stoloniferous. Fronds pinnate, linear, 1 to 6 feet long; pinnæ numerous, oblong or linear lanceolate and falcate, entire, dentate, or deeply crenate, upper side of the base auriculated, sessile, articulated with the rachis. Veins forked; venules free, clavate, the lower exterior branches fertile. Indusium reniform, or in some nearly orbicular, sometimes equal and conniving with the soriferous crenule, forming a marginal bilabiate cyst. Sori transverse uniserial.

Type. Aspidium exaltatum, Swartz.

Illust. Schott. Gen. Fil., t. 3 ; Hook. and Bauer, Gen. Fil., t. 35, 48 A; Moore Ind. Fil., p. 72, B ; J. Sm. Ferns, Brit. and For., fig. 79; Hook. Syn. Fil., t. 5, fig. 45.

OBs.-This is a truly natural genus, very generally distributed over the tropics of both hemispheres. The great uniformity in general character pervading the genus has, however, not prevented authors creating about forty species; and Fée has even gone so far as to divide them into two distinct genera, which he places far apart in his system, his character in the indusium being reniform in one and nearly orbicular in the other; but these characters are variable even in specimens of the same suite. On reviewing the whole, the genus appears to me to resolve 
into a few species. In the "Species Filicum" six species only are enumerated; but having had the opportunity of examining not less than eight species in a living state, has led me to increase the number to about a dozen. Sp. N. undulata $(S w$.$) ( \mathrm{v}$ v.).

OBs.-Sir Wm. Hooker unites this with $N$. tuberosa, but viewing living plants proves them to be very distinct. The fronds of the present species dying down annually, whereas in $N$. tuberosa they are permanent.

N. pectinata (Willd.) ( $\left.\nabla \nabla_{0}\right)$; N. pendula (Radd.); N. exaltata $(S w).(\nabla \nabla$.$) ; N. cordifolia (Linn.); N. tuberosa$ (Bory.) ( $\nabla \nabla$.$) ; N. volubilis (J.Sm.); N. ensifolia (Sw.) ( \nabla \nabla$.$) ;$ N. hirsutula $\left(S w_{0}\right)(\nabla \nabla$.$) ; N. biserrata \left(S w_{0}\right)\left(\nabla_{0}\right)$; N. splendens (Willd.); N. davallioides $(S w).(\nabla \nabla$.$) ; N. abrupta$ (J. Sm.) (Leptopleura abrupta, Presl.).

OBs.-This species is a native of Bourbon and is probably not distinct from the preceding one which is a very elegant species, a native of India and Java; it differs from other species of the genus in the upper pinnæ being contracted, which are sinuously lobed, each lacinæ and lobe bearing a sorus, furnished with a nearly orbicular indusium, the free exterior margin of which connives with the margin of the lobe, which becomes partially reflexed, and thus forming as it were a bilabiate cyst, analogous to the tribe Dicksonice, which circumstance led Presl to characterise it as a distinct genus under the name of Leptopleura.

\section{9.-Isoloma, J. Sm. (1841). \\ Lindscea, Hook. Sp. Fil.}

Vernation fasciculate, erect, stoloniferous. Fronds linear, 1 to 2 feet long, pinnate; pinnæ oblong, elliptical or lanceolate, falcate, coriaceous, the base truncate and sub-auriculate; petiole short, articulate with the rachis. Veins 
forked. Sori terminal, contiguous, confluent, forming a continuous marginal sorus. Indusium interiorly attached, continuous, forming with the margin a groove, containing the sporangia (as in Lindscea).

Type. Lindscea lanuginosa, Wall.

Illust. Hook. and Bauer. Gen. Fil., t. 102 ; Moore Ind. Fil., p. 22, fig. 1; J. Sm. Ferns Brit. and For., fig $79, \mathrm{~A}$.

OBs. - This genus was founded by me in 1841, on the Lindscea lanuginosa, of Wallich, a native of the Mauritius, Malayan Peninsula and Islands; to which I have since added two other species also natives of the same regions. In habit and general appearance Isoloma lanuginosa is similar to Nephrolepis ensifolia and $N$. hirsutula, but differing in the sori, being contiguous, forming a line on both margins of the pinnæ, and in having a continuous indusium opening exteriorally, in that respect agreeing in technical character with Lindscea, but the articulated pinnæ and central costa is at variance with the character of that genus. Its affinity with the present group is also indicated by its having the white chalky dot, characteristic of Arthropteridece.

Sp. I. lanuginosa (Wall.) ( $\nabla$ v.); I. Walkeræ (Hook.); I. divergens (Hook.).

Sect. 5.-DiDYMOCHLANex.

Caudex arboroid. Fronds bipinnate, pinnæ and pinnules articulate with the rachis.

\section{0.-Didrmochlena, Desv. (1811).}

Hook. Sp. Fil.; Aspidium sp. Sw.

Vernation fasciculate and erect, subarbroid. Fronds bipinnate, 2 to 6 feet long, smooth, glossy; pinnules oblong elliptical, oblique, base truncate, subsessile, articu. 
late with the rachis. Veins radiating, forked, costa excentric; venules direct free, their apices clavate, the anterior one sporangiferous. Receptacles oblong. Sori terminal, elliptical, sub-marginal. Indusium oblong, attached longitudinally.

Type, Aspidiem truncatulum, $S w$.

Illust. Hook. and Bauer. Gen. Fil., t. 8 ; Moore Ind. Fil, p. 43 A; J. Sm. Ferns Brit. and For., fig. 81 ; Hook. Syn. Fil., t. 4, fig. 41.

OBs.-The habit and general appearance of the Fern forming this genus is so peculiar and unique that it is difficult to point out its place in any natural sequence. Its texture, its articulated pinnules, and its terminal sori, indicate some connection with Nephrolepis, with which it also agrees in the apices of the veins being marked by white dots, which form a conspicuous row on the superior side of the pinnules.

In my observation on this genus in $1841 \mathrm{I}$ have said that "this is the only genus in Aspidece besides Mesochloena that has elongated sori," upon this character Mr. Baker, in the "Synopsis Filicum," has united Mesochlcena with Didymochloena, thus making a second species, which he names $D$. polycarpa. In doing this he entirely sets aside natural habit, as well as the position of the sori, and nature of the venation, for in habit Mesochloena scarcely differs from the group to which Nephrodium molle belongs, with which it agrees in the lower pair of venules anastomosing, and the sori being medial on the venules, and which is entirely at variance with the character of Didymochloena. Upon the same principle the simple fronded Fern Fadyenia prolifera is referable to Didymochloena.

Sp. D. lunulata (Desv.) (v v.), Hook. Sp. Fil., Hook. Gard. Ferns., pl. 17. 
OBS.-A native of the West Indies and many parts of tropical America, the East Indies, Malayan, Java, Philippine, and Fiji islands, tropical West and South Africa, and East African islands. As might be expected, this wide geographical range has led to this Fern being described under five generic and eight different specitic names.

** Sori punctiform, rarely linear, naked, or included under an universal indusium.

Sect. 6.-STruthiopterea.

Sori punctiform, included under an universal indusium.

\section{1.-Struthiopteris, Willd. (1810).}

$$
\text { Onoclea, sp. Hook., Sp. Fil. }
$$

Vernation fasciculate, erect, sub-arboroid. Fronds dimorphous, 1 to 3 feet high, the sterile lanceolate, pinnate, pinnæ lanceolate, sessile, 4 to 6 inches long, pinnatifidly lobed, venules in the lobes pinnate. Fertile contracted, produced in a compact fascicle, from the centre of vernation, shorter than the sterile, revolute, the opposite margins conniving, forming a universal indusium (siliquaform). Veins pinnate, venules short. Receptacles punctiform, lateral, pedicils of the sporangia concrete. Sori confluent, irregular, or in a transverse row.

Type. Struthiopteris germanica, Willd.

Illust. Hook. and Bauer, Gen. Fil , t. 69 A : Moore, Ind. Fil., p. 54 B. ; J. Sm., Ferns, Brit. and For., fig. 82.

OBs.-This genus agrees in habit and normal structure with the bipinnatifid species of Phegopteris, differing only in the fertile fronds being contracted as in Lomaria.

It is represented in Europe by $S$. germanica, and in North America by $S$. pennsylvanica, and in India by $S$. 
orientalis. With regard to the two first, herbarium specimens lead to the inference that they only represent one species, nevertheless, cultivated plants are readily recognised as being distinct. The Indian species differs in the fertile pinnw being less involute and more flat than in the preceding.

Although the species of Struthiopteris are perfectly dis. tinct in mode of growth and venation from Onoclea sensibilis, nevertheless they are in "Species Filicum" placed under the latter genus, and $S$. pennsylvanica is described as having a special indusium to each sorus, but which I have failed to discover.

Sp. S. germanica, Willd. ( $\nabla$ v.); S. pennsylvanica, Willd. ( $v$ v.); S. orientalis (Hook. 2nd. Cent. Ferns, t. 4).

Sect. 7. - Phegopterea.

Fertile pinnce plane. Sori punctiform, rarely oblong linear.

122.-Leptogramma, J. Sm. (1841).

Gymnogramma, sp. Sw.; Hook. Sp. Fil.

Vernation fasciculate, erect, acaulose, or decumbent. Fronds bipinnatifid, 1 to 3 feet high. Veins of lacinæ costæform, pinnate; venules free, a portion of their length sporangiferous, forming oblong or linear sori.

Type. Polypodium tottum, Willd.

Illust. Hook. and Bauer, Gen. Fil., t. 72; Moore Ind. Fil., p. 49 A, fig. 5 ; J. Sm. Ferns, Brit. and For., fig. 49.

OBS.-This genus agrees in habit and venation with the bipinnatifid species of Phegopteris, differing only in the receptacles being elongated on the venules, thus con- 
stituting linear simple sori, analogous to Grammitis, to which the species have been referred by some anthors, but their entirely distinct habit shows that they possess no direct affinity with Grammitis, as here defined. They have also been referred to Gymnogramma, under which genus they stand in the "Species Filicum."

The genus consists of about ten known species, of which six are natives of the West Indies and Tropical America, the other four being natives of Tropical Africa, India, Java, and Japan, L. totta having a very wide range, being found in the Azores, Madeira, Western and South Africa, Ceylon, East Indies, Java, China, and Japan.

Sp. L. asplenioides $(S w$.$\left.) ( \nabla v_{0}\right)$; L. totta (Willd.) ( $\mathbf{v} \nabla_{0}$ ) (Gymnogramma, Lowei, Hook. and Grev., t. 89); L. Linkiana (Kze.) ( $\nabla_{0}$ ) ; L. rupestris (Kze.) ( $\nabla_{0}$ ) ; L. villosa (Link.) ( $(\mathrm{v}$.$) ; L. polypodioides (Raddi) ( \mathrm{v} \mathrm{v}_{\mathrm{.}}$ ); L. gracilis (Hew.) ( $\vee$ v.) ; L. subsimilis (Hook.); L. decurrenti-alata (Hook.); L. obtusata (Blume).

\section{3.-Phegopteris, Fée. (1851).}

Polypodium sp., auct.; Hook. Sp. Fil.

Vernation uniserial and sarmentose, or fasciculate decum. bent, or erect, acaulose or subarboroid. Fronds varying from pinnate to deltoid decompound multifid, and from 1 to 6 feet high. Veins forked or pinnate; venules free. Receptacles punctiform, terminal, lateral or basal. Sori round, rarely oblong, naked.

Type. Polypodium decussatum, Linn.

Illust. Moore Ind. Fil., p. 56 A., fig. 5 ; J. Sm. Ferns Brit. and For., fig. 84 ; Hook. Syn. Fil., t. 5, fig. 48 , c. d.

OBs.-This genus consists of 50 or more species widely 
distributed, in both temperate and tropical regions, varying much in size and circumscription of the fronds, and in the position of the sori being terminal or lateral on the venules, which, although common to closely allied species, has however, been considered by many authors sufficient to characterise several genera. The most obvious differential character of species consists in some having erect vernation and the others decumbent, which admits of their being arranged in groups as follows :-

Group 1.-Vernation erect, acaulose or subarboroid

(Desmopobium).

* Fronds pinnate, pirnce entire or pinnatifid.

Sp. P. hastæfolia $\left(S w_{0}\right)$ ( $\left(\nabla_{0}\right)$; P. elongata (Wall.) ; P. Walkeræ (Hook.) ( $\nabla$ v.); P. Sieberiana (Kaulf.) ( $\nabla$ v.); P. appendiculata (Wall.); P. auriculata (Wall.); Bedd. F. Brit. Ind., pl. 203 ; P. erubescens (Wall.); Bedd. F. Brit. Ind., pl. 213 ; P. Tijucana (Radd.) ; P. Imrayana, J. Sm. (Nephrodium, Hook.) ; P. rotundata (Willd.); P. flavopunctata (Kaulf.) ; P. rude (Kze.); P. decussata, (Linn.) ( $\vee$ v.) ; P. caudata (Kaulf.)

\section{** Fronds bi-tripinnate, multifid.}

P. drepana $\left(S w_{0}\right)$ ( $\nabla^{\nabla}$ ) ; P. platyphyllum (Hook.); P. rufescens (Wall.) (v v.); P.grande (Pr.); P.ampla(H.B.K.) ( $\vee \nabla$.$) ; P.spectabilis (Kaulf.) ( \vee$ v.); P.lachnopoda (J.Sm.) ( $\vee$ v.) ; P. macroptera (Kaulf.) ( $\nabla$ v.) ; P. macrophylla (Hook.) ; P. molle (Roxb.) (Polypodium Dianea, Hook.)

\section{Grodp 2.-Vernation decumbent (Catapodium).}

P. alpestris (Hoppe) ( $\nabla$ v.); P. flexilis (Moore) ( $\nabla \nabla$.$) ;$ P. brunea (Wall.); P. paludosa (Bl.); P.divergens (Willd.)

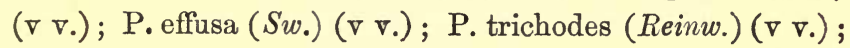
P. rugulosa (Labill.) ( $\vee$ v.); P. unidentata (Hook.) ( $\vee$ v.); P. ornata (Wall.). 
Group 3.-Phegopteris vera. Vernation uniserial, sarmentose, epigeous or hypogeous.

P. Dryopteris (Linn.) ( $\mathrm{\vee}$.); P. Robertiana (Hoffm.) ( $\left.\begin{array}{l}\nabla \\ \nabla\end{array}\right)$ (Polypodium calcareum, Sm.); P. vulgaris (Mett.) (v v.) (Polypodium Phegopteris, Linn.) ; P. aurita (J. Sm.) ( $\nabla$ v.) (Gymnogramma, Hook.) ; P. hexagonoptera (Michx.) ( $\nabla$ v.) ; P. aquilina (Thouars); P. pteroidea (Klot.); P. Keraudrenianum (Gaud.)

OBs.-In the "Synopsis Filicum," P. divergens, P. effusa, $P$. lachnopodium, $P$. amplum, and others, are placed in the indusiate genus Nephrodium. Although these have been under my observation for a number of years in a living state, and I have watched them carefully, I never found the least trace of indusia; therefore, if indusiate specimens are found in the herbarium, probably they represent distinct species, and allied to the multifid fronded species of Lastrea.

\section{4.-Hypolepis, Bernh. (1806). Hook. Sp. Fil. (in part).}

Vernation uniserial, sarmentose. Fronds, 1 to 6 feet high, bi-tripinnate, smooth, pilo-glandulose or aculeate. Veins forked or pinnate, venules free, the lower exterior branch sporangiferous. Receptacles terminal, punctiform, Sori marginal, seated on the axis of an inflexed indusæform crenule.

Type. Hypolepis tenuifolia, Bernh.

Illust. Hook. and Bauer. Gen. Fil., t. 67 B.; Moore. Ind. Fil., p. 27 A. ; J. Sm. Ferns Brit. and For., fig. 85 ; Hook. Syn. Fil., t. 2, fig. 24.

OBs.-The species included in this genus are Ferns with generally large decompound, multifid fronds, rising from a 

Pl. 14

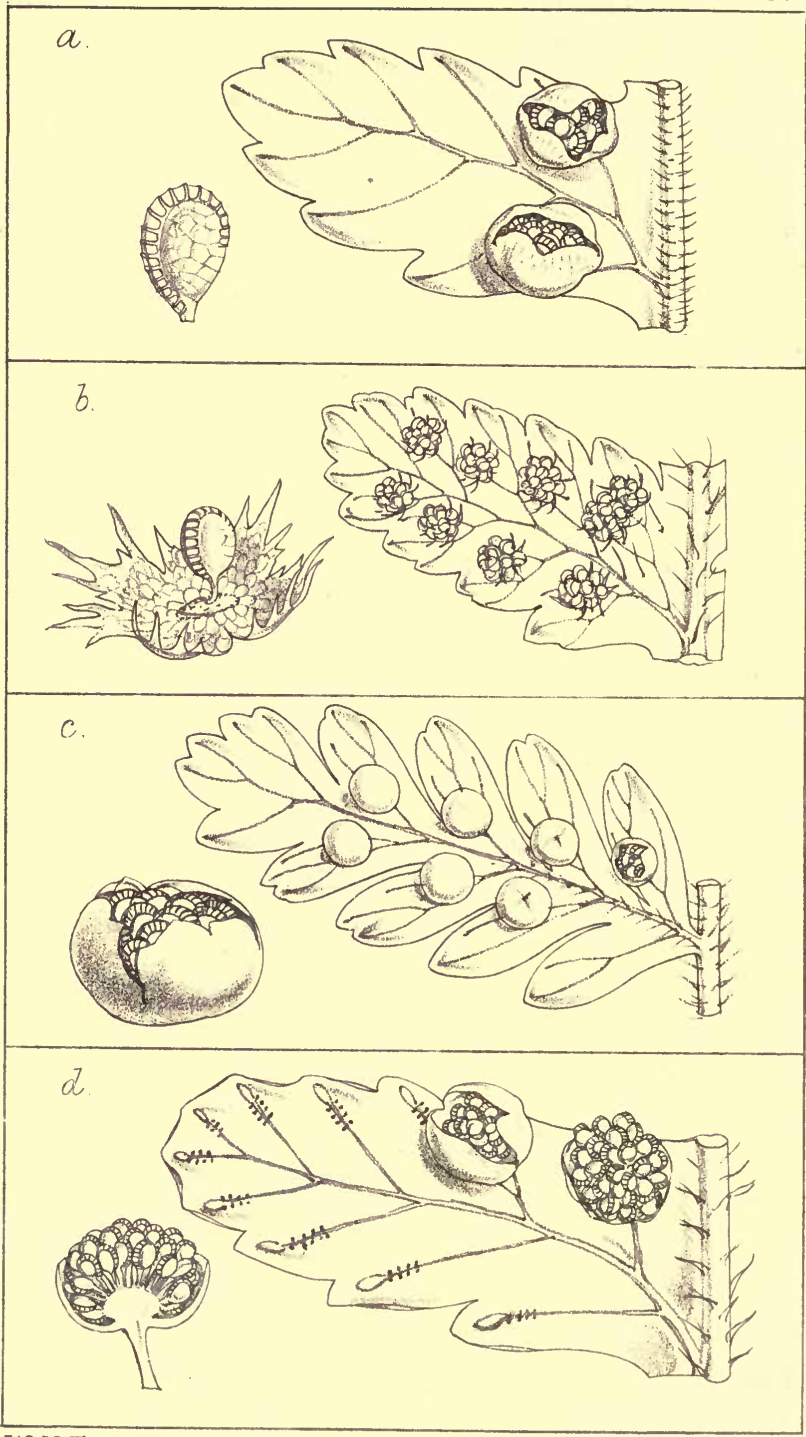

W. H. Fitch, deletlith. 
slender prolonging epigeous sarmentum. In habit they agree with the section Phegopteris, but are technically distinguished by the sori being terminal, and produced in the axis of reflexed crenules or lobules of the incised margin of the frond, in that respect analogous to the pteroid genus Cheilanthes, but the apparent indusium has no distinct axis of attachment, being merely a reflexed changed crenule, also the habit of the species which I restrict to Hypolepis are widely distinct from those of true Cheilanthes. In some cases the inflexed crenule is not very evident, and it is then difficult to distinguish the species from Phegopteris, for instance such species as $P$. ornata, which by some authors is referred to Hypolepis.

In Hooker's "Species Filicum" 30 species are described, which in the Synopsis are reduced to 11 . The following are the most well defined species. They are widely distributed, being found in the tropics, and extending to the latitude of New Zealand in the South and Japan in the North.

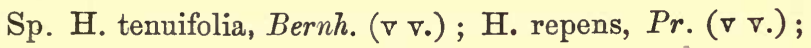
H. amaurorachis, Kze. ( $\mathrm{v}$ v.) ; H. distans, Hook. ( $\mathrm{\vee}$ v.); H. rugulosa (Labill.); H. anthriscifolia, Presl. (Cheilanthes commutata, Kze.; Hook. Gen. Fil., t. 67 A.); H. nigrescens, Hook.; H. parallelogramma, Hook. ; H. Purdieana, Hook.

\section{Tribe 14.-PHYSEMATE ÆE. (Plate 14).}

Vernation acaulose. Fronds varying from linear pinnate to deltoid decompound. Veins free. Sori punctiform. Indusium cucullate or calyciform.

OBs.-This tribe contains about twenty species; and although varying much in the size and circumscription of 
the fronds, they nevertheless all agree in general aspect with Phegopteris and Lastrea, differing only in the sori being furnished with a calyciform indusium.

\section{5.-Cystopteris, Bernh. (1806).}

Polypodium, Linn.; Aspidium sp. auct.

Vernation fasciculate or uniserial. Fronds slender, lanceolate, bipinnatifid, 6 to 15 inches high. Veins forked; venules free. Sori punctiform, lateral. Indusium cucullate, interiorly attached.

Type. Polopodium fragile, Linn.

Illust. Hook. and Bauer Gen. Fil., t. 52, B; Schott. Gen. Fil., fig. 8; Moore Ind. Fil., p. 73, A; J. Sm. Ferns, Brit. and For., fig. 76 ; Hook. Syn. Fil., t. 2, fig. 19.

OBs.-This genus contains low growing Ferns, with the general character of the small species of the Lophidium section of Lastrea, but it is technically distinguished by the indusium being short, ovate, or oblong, and vaulted, so as to form a cucullate marsupial cyst, opening exteriorly. It has also some claims of relationship with Athyrium; but the base of attachment of the indusium being across the venule-not longitudinally along one side as in that genus -indicates its natural affinity to be with Lastrea.

Representatives of this genus are found widely spread over the northern part of Europe, Asia, and America, even to within the Arctic circle, and also in several localities in the southern hemisphere. The different appearances of specimens and observation of living plants from different localities, have given rise to at least twenty species being described by various authors; but careful examination reduces that number to the following.

With the exception of $C$. montana, all the species have 
lanceolate fronds, growing in cæspitose tufts; but in that species the fronds are deltoid, and distinctly produced on a slender creeping underground sarmentum, in all respects similar to Phegopteris and Dryopteris, an apparent natural affinity which is overruled by the technical character in the sori of the latter being naked. On account of the cucullate indusia, this genus is by Sir. William Hooker and other authors placed in the Davallia alliance, but with this it has no relationship.

Sp. C. fragilis, Bernh. ( $\nabla$ v.); C. dentata, Hook. ( $\nabla \nabla$.$) ;$ C. regia (Linn.) ( $\nabla \nabla$.$) ; C. fumarioides, Kze.; C. tenuis$ $(S w$.$\left.) ( \vee \nabla_{0}\right)$; C. bulbifera (Linn.) ( $\left.\vee \vee_{0}\right)$; C. montana (Linn.) ( $\nabla \mathrm{v}$.

126.-WoOdSIA, R. Br. (1813).

Hook. Sp. Fil. ; Physematium, Kaulf.; Hymenocystis, Meyer.

Vernation fasciculate, erect acaulose. Fronds cæspitose, bi-tripinnatifid, rarely pinnate, 6 to 12 inches high, smooth, or squamiferous. Veins simple or forked, free, the lower exterior branch sporangiferous on or below its apex. Sori punctiform. Indusium calyciform, its margin nearly entire or deeply laciniated, lacinæ nsually terminating in long hairs, which involve the sporangia.

Type. Polypodium Ilvense, Sw.

Illust. Hook. and Bauer Gen. Fil., t. 3 and 119; Hook. Gard. Ferns, t. 32 ; Moore Ind. Fil., p. 82 ; J. Sm. Ferns, Brit. and For., fig. 77; Hook. Syn. Fil., t. 1, fig. 11.

OBs.-This genus consists of about a dozen known species, chiefly natives of the Northern hemisphere, being widely dispersed over Europe and Northern Asia and America, reaching even to the Arctic circle, and in Southern 
Europe inhabiting only Alpine situations. One species is found in South America and another has been discovered in Southern Africa, and one in Japan.

As originally characterised, Woodsia comprises only three species, which are not only peculiar in their singular capillary indusium, but in their stipes having a distinct articulation some distance above its base. This latter character is similar to the elevated node of Oleandra, but otherwise the technical characters of the two genera are quite different.

In the section Physematium, the indusium is so truly calyciform, that, in determining affinities from that organ alone, they (with fronds only a few inches high) would be associated with the arboreous genus Cyathea, and on account of the sori of $W$. caucasica being apparently marginal, led to its being first described as a species of Dicksonia.

\section{* Woodsia vera.}

Stipes articulated. Indusium deeply laciniated, fringed with long hairs.

Sp. W. Ilvensis, $R . B r$. (v v.); W. hyperborea, R. Br. (v v.); W. glabella, R. Br.

\section{**Physenratium.}

Stipes not articulated. Indusium complete, calyciform.

W. polystichoides, Eat., Hook. 2nd Cent. Ferns, t. 2, (v v.); W. elongata, Hook. Sp. Fil. 1, t. 21 C.; W. caucasica, J.Sm. (Hymenocystis, Meyer, Hook. and Bauer. Gen. Fil., t. ¿े); W. mollis, J. Sm. (Physematium, Kze., Anal., t. 27) (v v.); W.obtusa (Sw.) (Polypodium, Schk. Fil.,t.21; W. Perriniana, Hook. and Grev. Ic. Fil., t. 68) (v v.); W. guatemalensis, 
Hook. Sp. Fil. 1, t. 21 A.; W. Peruviana, Hook. Sp. Fil. 1, t. 21 B.; W. incisa, Gillies, Hook. and Grev. Ic. Fill., t. 191.

OBs.-The two first are natives of Great Britain, chiefly found in Scotland and Wales, but rare.

\section{7.-Diacalpe, Blume (1828). \\ Hook. Sp. Fil.}

Vernation fasciculate, acaulose. Fronds 2 to 3 feet high, stipate deltoid, decompound multifid; primary pinnæ alternate; ultimate pinnules small, $\frac{1}{4}$-inch in length, linear, obtuse, oblique, cuneate at the base. Veins simple or forked, free and clavate. Sporangiferovs receptacles medial, punctiform. Indusium globose, calyciform, opening irregularly, attached by a small point, including the sporangia, forming a sessile sorus.

Type. Diacalpe aspidioides, Blume.

Illust. Hook. and Bauer Gen. Fil., t. 99 ; Moore Ind. Fil,, p. 81, fig. 1 to 4 ; Hook. Syn. Fil., t. 1, fig. 7.

OBs.-This genus consists of one species only, native of Java, Assam, and Moulmein. In general habit it resembles some of the multifid species of Lastrea and Polystichum. Its complete globose cup indusium is similar to the section Physematium of Woodsia, as also to the following genus Peranema, differing only in the sori not being pedicellate; this, however, is more apparent than real, for in reality there is a slightly elevated point in Diacalpe, off which the entire sorus can be freely removed without rupturing the indusium or disturbing its sporangia.

Sp. D. aspidioides, Blume. 


\section{8.-Peranema, Don. (1825). \\ Sphoeropteris, Wall., Hook. Sp. Fil.}

Vernation fasciculate, decumbent, squamose. Fronds 4 to 6 feet high, stipate, deltoid, decompound, ultimate pinnules and lacinæ sessile, linear oblong, obtuse, half an inch long, pinnatifid, repand, or crenate. Veins forked clavate, free. Sporangiferous receptacles medial pedicellate, included within a calyciform indusium, forming globose elevated sori.

Type. Peranema cyatheoides, Don.

Illust. Hook. and Bauer Gen. Fil., t. 22 ; Schott. Gen. Fil., t. 4 ; Moore Ind. Fil., p. 80, B. ; Hook. Syn. Fil., t. 1 , fig. 5 .

OBS.-This genus also consists of a single species, a native of Nepal and Sikkim. In general aspect it resembles some of the large decompound species of Lastrea, such as $L$. villosa. It is specially remarkable in the sori being elevated above the surface of the frond, similar to the genus Eupodium in the tribe Marattiacece, although the calyciform indusium of this and the preceding genera is similar to that of Cyathea; nevertheless, their dwarf, stemless habit, prevents their natural association with tree Ferns.

Sp. P. cyatheoides, Don. Bedd. F. S. Ind., pl. 73 (Sphoeropteris barbata, Wall.)

OBs.-The stipes of this Fern are densely covered with hoary scales, which in its native places of growth imparts to it an aged appearance.

\section{Tribe 15.-CYATHE $\approx$ (Plate 15).}

Vernation terminal, fasciculate, forming tree-like stems, 50 or more feet high, Sori medial, round, rarely oblong. 
Pl. 15

$\alpha$

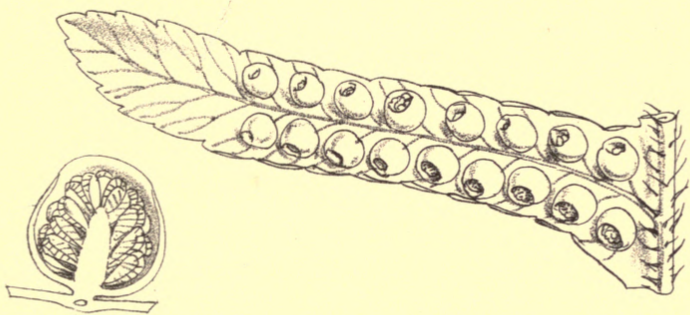

b.

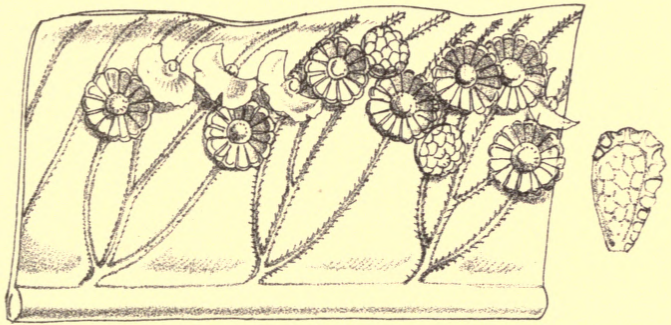

c

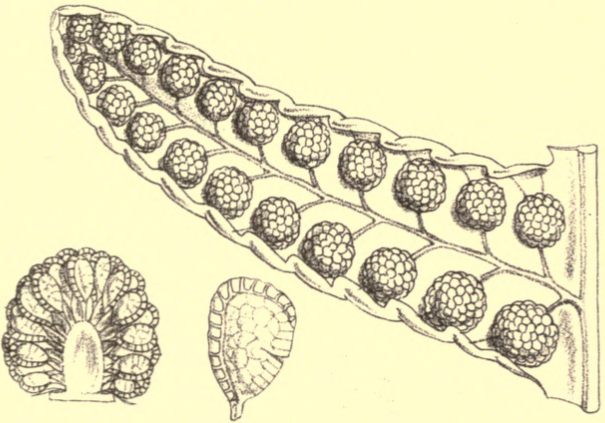



Receptacles more or less elevated. Indusium calyciform, semi-calyciform or lateral (scale like), or absent or represented by numerous articulate hairs.

OBS.- The piants constituting this tribe (together with those of the genus Dicksonia as here restricted) are truly the giants of the Fern race, their erect arboreous stems often attaining the height of 50 or more feet, and having a crown of decompound (rarely simple or simply pinnate) fronds, sometimes 20 feet in length, the bases of their stipes being either articulated with the stem and, when mature, separating at the articulation, the point of attachment being afterwards indicated by scars of an oblong rhomboid form, spirally arranged round the stem; or more or less of the lower part of the stipes remain permanent and become indurated, forming part of the solid structure of the stem, which is often much increased in thickness by the production of numerous outgrowing aerial, wiry, black roots, forming a coating from a few inches to a foot in thickness.

The species are widely distributed, chiefly within or near the tropies, the number being nearly equal in the old and new worlds. They love shade and solitude, and in humid regions within the tropics are found at elevations of from 3,000 to 6,000 feet, often in ravines. In Sikkim, Himalaya, the tribe is represented by eight or nine species, all of which are to be found within three miles of Rungbee. The stems often branch into many crowns. About a dozen are distributed throughout the islands of the Pacific Ocean, their southernmost limit being Tasmania, New Zealand, and Norfolk Island, where they grow at a lower elevation than within the tropics. Also several new species have recently been discovered in the Bellenden Ker range of mountains, Queensland. 
It is difficult to arrive at any satisfactory conclusion as to the number of species, Sir Wm. Hooker in his "Species Filicum " enumerates about 100, which in the "Synopsis" is increased to 139 , but that falls short of the number given by Mr. Moore in the "Index Filicum," where under the genera Alsophila, Cyathea, and Amphicosma (Hemenostegia), 176 are enumerated, and when Hemitelia (not yet indexed) is added, the total will be near 200 .

I am of opinion that important distinguishing characters are to be found in the formation of the stems. After the examination of a considerable number, I find that while some are slender and never exceed 1 to 3 inches in thickness, others are a foot or more in diameter, and that the difference is consequent on the normal number of fronds, constituting the series or whorle of the progressing axis being few or many. In some species three complete the whorle, that being the lowest number capable of forming an erect arborescent stem, but in others the series consists of a greater number, and consequently a stem of larger diameter is formed. I must, however, observe that a great deal is yet to be done in the examination of Tree Fern stems, before the differences in their structure can be made practically available for determining species.

The genera Cyathea, Alsophila, and Hemitelia include the greater mass of species belonging to this tribe, and although the technical characters are in many sufficiently obvious to enable us to refer many of the species to their respective genera without much trouble, the differences are not always well defined ; for instance, the transition between the complete cup of Cyathea and the small indusoid scale of some species of Alsophila, is so gradual that upon taking a general view the whole would seem to form one genus; but for the sake of convenience, and in order to show the principle 
differences, I have thought it best to adopt the following arrangement.

In general habit the Cyathece may be viewed as analogous to those species of Phegopteris and Lastrea, having terminal vernation, and large compound fronds rising from an erect caudex, and as some have naked sori, and others a lateral indusium not differing from that of Lastrea, the arboreous habit and elevated receptacles are, therefore, the only points that technically distinguish them, but, in some cases, even the elevated receptacle fails.

The apparent obliquity of the ring of the sporangia in Cyathea has been already explained at page 41 .

\section{9.-SchizoceNa, J. Sm. (1841). \\ Cyathea sp., Hook. Sp. Fil.}

Vernation fasciculate, erect. Caudex slender, 3 to 5 feet high. Fronds simple, pinnate, or bipinnatifid, 2 to 8 feet long, smooth, glossy, pinnæ articulated with the rachis. $V$ eins pinnately forked; venules free. Sori medial. Receptacles globose. Indusium calyciform, ultimately deeply laciniated.

Type. Cyathea Brunonis, Wall.

Illust. Hook. and Bauer. Gen. Fil., t. 2 ; Hook. and Grev., Ic. Fil., t. 106 ; J. Sm. Ferns Brit. and For., fig. 130 .

OBs. With regard to this genus Mr. Brown remarks in the "Prodromus Floræ Novæ Hollandiæ," that, besides the genuine species of Cyathea, characterised by having the sori seated on the fork of the veins, there are others from Malacea, which have the sori seated on the middle of the veins, which distinction I find normal to at least three species. It is, however, observed that in several species of true Cyathea the sori are seated a little above the 
fork of the vein; Schizoccena therefore depends for its separation from Cyathea more upon the distinct habit of the species than in the character of the sori.

Sp. S. sinuata (Hook. and Grev.) (v v.); S. Brunonis (Wall) (Bedd. F. Brit. Ind.pl. 87); S. alternans (Wall.).

OBS.-The first is a simple fronded species, a native of Ceylon, the two latter have pinnate and bipinnate fronds, and are natives of Penang and Malacca.

\section{0.-Cyathea, Sm. (1793). \\ Hook. Sp. Fil. (in part).}

Vernation fasciculate, erect, arborescent, squamiferous. Fronds bi-tripinnatifid, 5 to 15 feet long; pinnæ and pinnules in some species articulated with the rachis. Veins forked; venules free. Sori axillary. Receptacles columnar. Indusium complete calyciform, its margin entire or unequally laciniated.

Type. Polypodium arboreum, Linn.

Illust.-Hook. and Bauer Gen. Fil., t. 23 ; Moore Ind. Fil., p. 84, A; J. Sm. Ferns, Brit. and For., fig. 131 ; Hook. Syn. Fil., t. 4.

Oв. - In the "Species Filicum" thirty-six species are described, excluding Schizocana, which number is in the "Synopsis" increased to fifty, of which twenty-two are American, nine African, eleven Indian and Malayan, and ten Polynesian, Australian, and New Zealand. In the Addenda of the "Synopsis" twenty-five species are enumerated, of which the greater number are new. Many of them present great uniformity in the character of the fronds. It is probable that on better acquaintance with the nature of their stems, and with other peculiarities of habit, sufficient differences will be found to justify their 
separation into at least two distinct groups,-one to contain those species in which the stipes are adherent; and the other those in which the stipes are articulated with the stem, the pinnæ also being articulated, and having a black scutæform (generally oblong) gland at their base on the rachis.

\section{West Indian and American.}

Sp. C. arborea, $S m$. (v v.) ; var. C. pallida, Hook. Sp. Fil. OBs. Great uncertainty has always existed as to which West Indian tree Fern should bear the name of Cyathea arborea, a species founded by Linnæus on Plumier's figures of a Martinique Fern. The figure represents a tree Fern with a smooth, cylindrical, tesselated stem, described as being 10 to 11 feet high and 6 inches thick, and although the artist has exaggerated the tessellated character, it is evident that it is one of the species having the stipes articulated with the stem, indeed I have no doubt that it is the prototype of the fine tree Ferns cultivated in Kew Gardens under the name of Cyathea elegans Heward, received from both Martinique and Jamaica, one plant having a stem 10 feet high, as in Plumier's figure. Herbarium specimens of this and $C$. aculeata are very similar, and only specifically distinguished by the stipes of the latter being adherent and prickly

C. serra, Willd. ( $\nabla$ v.); C. insignis, Eat. ( $\nabla$ v.) (C. princeps, J. Sm. Ferns Brit. and For.); C. Imrayana, Hook.; C. Mexicana, Schlecht.; C. divergens, Kze.; C. Schanschin Mart.; C. cuspidata, Kze.; C. nigricans, Klot. ( $\nabla$ v.) ; C. aculeata, Willd. ( $\nabla$ v.); C. vestita, Mart.; C. Gardneri, Hook. ; C. equestris, Kze. ; C. muricata, Willd. (v v.) ; C. hirtula, Mart. 


\section{Tropical, South African and Astan Islands.}

Sp. C. canaliculata, Willd. ( $\nabla$ v.); C. lævigata, Willd. ( $\vee$ v.); C. excelsa, Sw. ( $\left.\vee \nabla_{0}\right)$; C. marattioides, Willd. C. glauca, Bory.; C. Dregei, Kze. ( $\nabla$ v.); C. Manniana, Hook. ( $v$ v.) ; C. Camerooniana, Hook.; C. Welwitschii, Hook. ; C. Angolensis, Welw. ; C. Kirkii, Hook. ; C. sechellarum, Mett.

\section{East Indian and Madayan.}

C. spinulosa, Wall. ; C. javanica, Bl.; C. crenulata, Bl.; C. integra, J. Sm. ( $\nabla$ v.) ; C. Hookeri, Thw. ( $\nabla$ v.)

Polynestan Isuands, Australia, and New Zeadand.

C. affinis $S w$. ; C. Cunninghami, Hook. ( $\nabla$ v.) ; C. dealbata, $S w$. (v v.); C. medullaris, $S w .(\nabla \nabla$.$) ; C. Smithii,$ Hook. ( $\vee$ v.)

\section{1.-Hemitelia, R. Br. (1810).}

Hook. Sp. Fil.; Cyathea sp. auct.; Cnemidaria, Pr.

Vernation fasciculate, erect, arborescent. Fronds bipinnatifid, 4 to 8 feet long, stipes smooth or aculeated. Veins simple, pinnately forked; venules all free, or the lower pair of the lowest fascicles angularly anastomosing, forming a costal arch or more or less acute angle. Sori medial. Receptacles globose. Indusium semi-calyciform.

Type. Cyathea grandifolia, Willd.

Illust. Hook. and Bauer Gen. Fil., t. 4 ; Hook. Fil. Exot., t. 66 ; Moore Ind. Fil., p. 84, B ; J. Sm. Ferns, Brit. and For., fig. 132.

OBs.-In the second edition of the "Synopsis Filicum" thirty species are recorded as belonging to this genus; but as the greater number agree in habit, and character of the 
sori with Alsophila, I refer them to the Hymenostegia section of that genus, restricting Hemitelia to about a dozen species, which are readily distinguished from Alsophila by the lower venules anastomosing opposite the sinus of the lacinæ, but in some species this character is wanting, the whole of the venules being free; their habit of growth and broad divisions of the fronds is indicative of their relationship to be with Hemitelia rather than with Alsophila; it, however, must be admitted that although the typical species of Cyathea, Hemitelia, and Alsophila, warrant their separation as distinct genera, the transition species however appears to unite them so as to form one natural group. The species as here restricted to Hemitelia, are all natives of the West Indies and Tropical America.

\section{* Fronds pinnate; pinnce entire.}

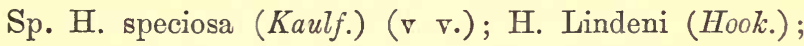
H. grandifolia (Spreng.) ( ( ₹.); H. obtusa (Kaulf.) (v v.)

** Fronds bipinnatifid.

H. Imyrana (Hook.) ( $\mathrm{v}$ v.); H. Karsteniana (Hook.) ( $\mathrm{v}$ v.); H. horrida (R.Br.) ( $\mathrm{v}$ v.) ; H. marginalis $(J . S m$.$) .$

132.-Alsophila, R. Br. (1810).

Hook. Sp. Fil.; Amphicosmia Gard.

Vernation fasciculate, erect, arborescent. Fronds bi-tripinnatifid, 5 to 15 feet long. Veins simple or forked, free. Sori axillary or medial. Receptacles elevated, globose, or columnar. Indusium semi-calciform, or small and squamæform, often wanting, in some trichiferous.

Type. Cyathea multiflora, Sm. 
Illust. Hook. and Bauer. Gen. Fil., t. 42 A; Moore Ind. Fil., p. 85 B ; J. Sm. Ferns Brit. and For., fig. 133.

OBS. - The general habit of the species of this genus agree in every respect with Cyathea, and are only distinguished by the technical character, which consists in the indusia of Alsophila being either absent, small, scale-like, or forming a nearly complete cup.

In my Genera of Ferns, 1841, I arranged the species of Alsoplita under two sections, the first Hymenostegia, including those having a membraneous indusium, very small in some, but in others forming a nearly complete cup, differing from Cyathea only by not completely surrounding the base of the receptacle, there being always an open sinus on the exterior side; and the second, Trichostegia, those in which the membraneous indusium is entirely absent, the sporangia being more or less covered with articulate hairs.

Although thirty years have elapsed since that mode of arrangement was published, and having observed much during that period, I find I can make little or no alteration in it, except by amalgamating the genus Gymnosphera, of Blume, with Alsophila, of the species of which I now form a third section, characterised by the sori being destitute of a membrane and of hairs, in that respect not technically distinct, except in the arborescent habit, from Phegopteris, to which it is otherwise related through the genus Lophosoria.

In the "Species Filicum" sixty-three species are described, of which about a dozen are marked dubious, the "Synopsis," however, enumerates ninety species including the Appendix. They are widely dispersed over both hemispheres. 
Sect. 1.-Hymenostegia, J. Sm.; Hook. Syn. Fil., t. 1, f. 5 A. Sori furnished with a lateral indusium, which is sometimes very small, or often nearly complete, calyciform.

Sp. A. capensis, J. Sm. (v v.) (Amphicosmia riparia, Gard.); A. multiflora, Pr.; A. Hostmanni (Hook.) ( $\nabla$ v.); A. lævis, J. Sm. ( $v$ v.); A. Parkeri (Hook.); A. tenera (Hook.); A. lunulata, R. Br.; A. Tahitensis, Brack.; A. Walkeræ, Hook. ; A. Beyrichiana, Pr.

Sect. 2.-Trichostegia, J. Sm., Hook. Syn. Fil., t. 1, f. 6.

Sori furnished with numerous articulate hairs.

* West Indian and American.

A. Miersii, Hook.; A. procera, Kaulf. ( $\vee$ v.); A. aspera, R. Br. ( $\nabla$ v.) ; A. serrata, J. Sm.; A. leucolepis, Mart.;

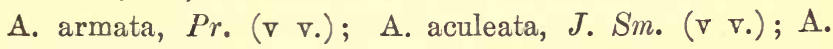
echinata, Moore; A. radens, Kaulf. ( $\nabla$ v.); A. elongata, Hook.; A. phalerata, Mart. ; A.infesta, Kze.; A. Poeppigii, Hook.; A. phagiopteris, Mart. ; A. paleolata, Mart. ( $\nabla$ v.) ;. A. oblonga, Klot. ; A. villosa, Pr. (v v.); A. nigra, Mart.; A. pycnocarpa, Kze.; A. Mexicana, Pr.; A. atrovirens, Pr.; A. axillaris, Moore.

\section{** East Indian and Malayan.}

A. crinita, Hook.; A. comosa, Wall.; A. latebrosa, Wall.; A. Brunoniana, Wall.; A. glauca, J. Sm. ( $\nabla$ v.); A. caudata, J. Sm.; A. lepifera, $J$. Sm.; A. podophylla, Hook.

*** Polynesian and Australian.

A. excelsa, $R . B r$. ( $\nabla$ v.); A. australis, $R . B r$. ( $\nabla$ v.); A. Leichardtiana, Muell. (A. Moorei, J. Sm., Ferns, Brit. and For., 1866) ( v.) ; A. Colensoi, Hook.; A. Moorei (Bak. Syn. Fit.) 
Sect. 3.-Gymnosphera.

Sori naked.

A. glabra (Blume); A. squamulata (Bl.)

OBs.-These two species are natives of India, Malacca, and Java.

In Norfolk Island, Alsophila excelsa (now nearly extinct) has been measured 60 to 80 feet in height, the stem being smooth and tesellated, as in Cyathea arborea. In Tasmania $A$. australis also attains a considerable height, forming a trunk a foot or more in diameter, which differs from A. excelsa in the base of the frond being permanent and muricate, thus forming a rough stem. On Mount Wellington it grows in ravines to a considerable elevation, even to the region of snow.

In Sikkim A. comosa attains the height of 25 feet, with a circumference of 7 feet 8 inches; the fronds are deciduous, falling away in August; they bear bulky stems, then standing in groups like pillars.

\section{3.-Trichopteris, Presl. (1822). Alsophi7a sp., Hook. Sp. Fil.}

Vernation fasciculate, erect, caudex arborescent. Fronds bipinnate, 4 to 6 feet long, smooth, stipes articulate with the stem; pinnæ distant; pinnules lanceolate, sub-serrate, short petiolate articulate with the rachis. Veins pinnately forked; venules free, their apices clavate. Receptacles lateral, scarcely elevated, oblong on the venule. Sor: contiguous, confluent, forming a broad compound transverse, medial sorus, and criniferous.

Type. Polypodium Tanitis, Roth. 
Hllust. Hook. and Bauer. Gen. Fil., t. 34 ; Schott. Gen. Fil., t. 5 ; Moore Ind. Fil., p. 93 B ; J. Sm. Ferns Brit. and For., fig. 134.

OBs.-The fronds being articulate with the caudex, and the pinnæ and pinnules articulate with the rachis, as also the sori being confluent in a transverse broad line, between the costa and the margin of the pinnules, marks this as a genus distinct from Alsophila. The arborescent stem and the articulated character of the fronds, being similar to several species of Cyathea as already noticed, gives it a claim to rank in the present tribe.

Sp. T. excelsa (Pr.) (Alsophila Toenitis, Hook. Sp. Fil., Mart. Flor. Bras., t. 37 ; Radd. Fil. Bras., t. 40) (v v.); T. elegans (Pr.) (Mart. Flora. Bras., t. 38.)

OBS. - In some specimens of T. elegans the line of sori is not so complete as in $T$. excelsa.

\section{4.-LopHOSORIA, Presl. (1847.)}

$$
\text { Alsophila, sp., Hook. Sp. Fil. }
$$

Vernation fasciculate, erect, arborescent, 6 to 8 feet high, densely laniferous. Fronds 3 or more feet in length, compound multifid, glaucous beneath. Veins simple or forked, venules free, their apices clavate. Receptacles small (not elevated), sub-terminal. Sori punctiform, solitary on the ultimate dents or lacinæ, criniferous.

Type. Polypodium pruinatum, $S w$.

Illust. Schk. Fil., t. 25 B.; J. Sm., Ferns, Brit. and For., fig. 135.

OBs.-The Fern on which this genus is founded is a native of Jamaica, Mexico, extending through tropical America, to Chili and the Island of Juan Fernandez. It was early described by Swartz under the name of Polypo- 
dium pruinatum, by later authors it has been referred to Alsophila, under which genus it stands in the "Species Filicum," but it differs from the true species of that genus in having deltoid multifid fronds. The only character that gives it a claim to rank as a species of that genus is its arborescent stem, and criniferous sori, which, in some specimens the latter character is scarcely evident; the stem also differs from true Alsophila in being densely laniferous, indeed, if it was not for its arboroid stem I would have no hesitation in placing it under Phegopteris, as an ally to Phegopteris lachnopoda. Presl has considered it worthy of being raised to the rank of a distinct genus, which, in order to mark its peculiarities I adopt, and, with Trichopteris and Amphidesmium, view it as an aberrant genus of this tribe.

Sp. L. pruinata (Presl) ( $\vee$ v.) (Polypodium griseum, $S c h k$. Fil., $t$. 25.)

\section{5.-AMPHIDESMIUM, Schott. (1834).}

Metaxya, Presl., 1836 ; Alsophila, Hook. Sp. Fil.

Vernation fasciculate, erect, arboreous, criniferous. Fronds pinnate, 4 to 6 feet long, smooth, glossy; pinnæ 6 to 12 inches long, linear lanceolate, acuminate, serrated towards the apex, adherent to the rachis. Veins simple or rarely forked near their base, parallel, patent. Sori punctiform, lateral, basal, transverse uniserial near the costa, as also scattered with two or more sori on some of the venules, densely furnished with criniferous hairs.

Typo. Polypodium blechnoides, Rich. (P. rostratum, Humb.) Mllust. Hook. and Bauer. Gen. Fil., t. 42 B; Moore Ind. Fil., p. $86 \mathrm{~A}$; J. Sm. Ferns Brit. and For., fig. 83.

OBS.-This genus is founded on a solitary species, a native 

PL.16

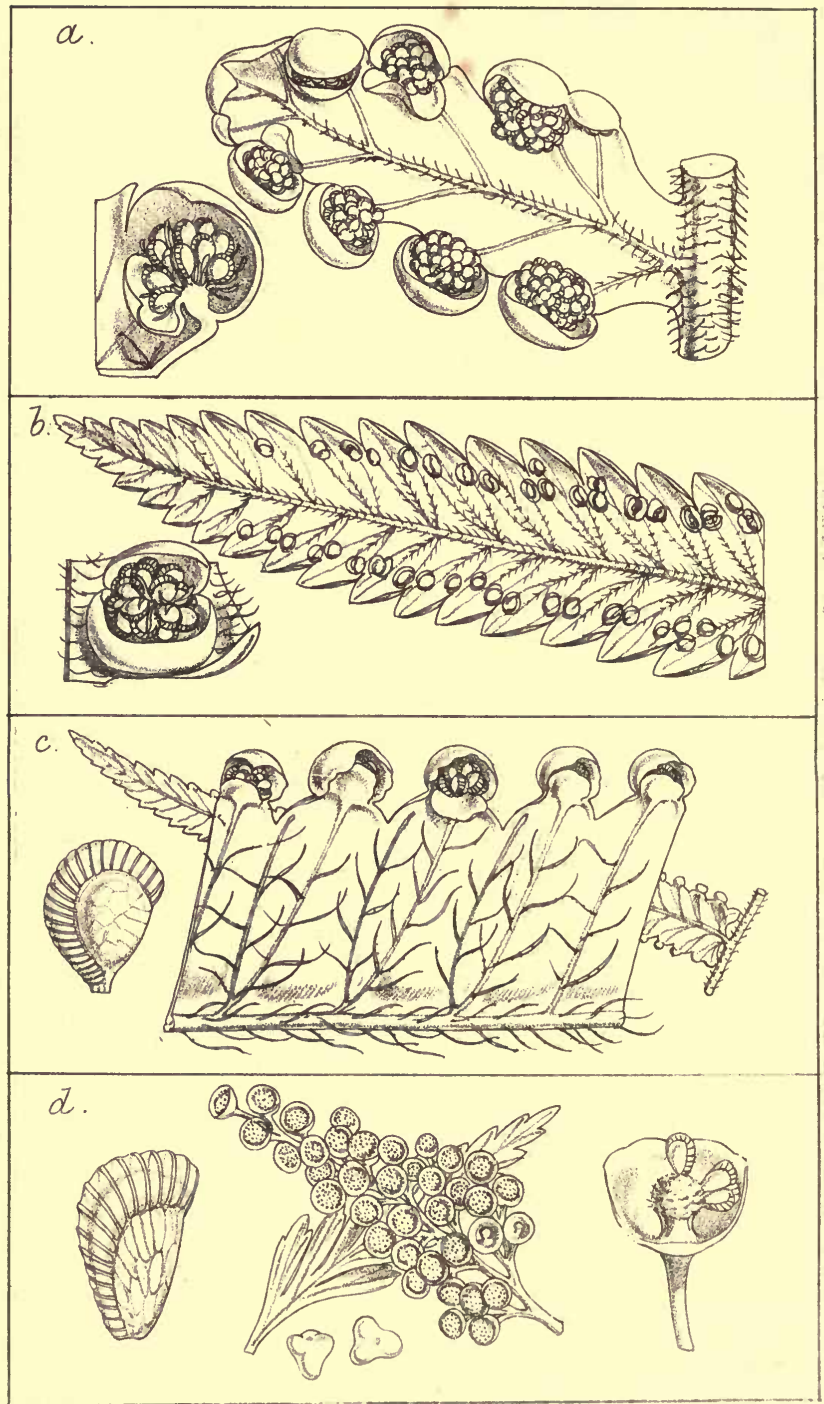


of many localities in tropical America, also found in Trinidad, it is peculiar for having two or more sori on some of the branches of the veins. Being arborescent, and the sori criniferous, has led several anthors to refer it to the genus Alsophila, but from which it differs in the vernation (base of the stipes), being criniferous, which is not the case with true Alsophila. The evidence of its being a tree Fern rests entirely on Wildenow's description, which says "caudex erectus arboreous," but according to a plant at Kew, which in 1864 had fronds 2 to 3 feet high, the caudex was decumbent, but which probably only required time to assume an arboreous character; whichever it may be, I find it difficult to point out its relationship with any sequence of genera, except that it may be ranked with Lophosoria in Phegopteris.

Sp. A. blechnoides, Klot. in Linn. (Metaxya rostratum, Hook. and Bauer.; P. Parkeri, Hook. and Grev., t. 232 ; Alsophila blechnoides, Hook. Sp. Fil.)

Nore.-In the preceding tribes the sori are discal ; and marginal in the six following.

\section{Tribe 16.-DICKSONIE ג. (Plate 16.)}

Vernation fasciculate, decumbent or erect, and becoming arborescent. Sori marginal, globose, or transverse oblong, furnished with an interior attached special indusium, which connives more or less with the changed indusioid margin of the frond, the two forming an urceolate, bivalved, marginal cyst, containing the sporangia.

OBs.-Hitherto I included under this tribe the genera Sitobotium, Lindscea, Microtepia, and other allied genera, which, although agreeing in the technical character of their sori, nevertheless differ widely in habit, so much so, 
that their union under one tribe is far from being a natural association of genera. I therefore now restrict the tribe Dicksonioe, as represented by the typical species $D$. arborescens and its allies, and the genera Thyrsopteris, Cibotium, and Balantium, the species of which amount in all to fourteen as at present known.

\section{6.-Dicksonla, L'Herit. (1788). Hook. Sp. Fil., in part.}

Vernation fasciculate, erect, arborescent, criniferous. Fronds bipinnate, 5 to 15 feet long; pinnules pinnatifid. Veins pinnate; venules, free, simple. Receptacles punctiform, terminal. Sori globose, large. Indusium bivalved, coriaceous; the outer valve (accessary indusium) concave, cucullate, conniving with the smaller, usually less cucullate, inner valve, or special indusium, forming an unequally valved marginal cyst, including the sporangia.

Type. Dicksonia arborescens, L'Herit.

Illust. Hook. and Bauer. Gen. Fil., t. 20 ; Moore Ind. Fil., p. 77 A.; J. Sm. Ferns Brit. and For., fig. 127.

OBS.-This genus as here restricted consists of eight known species of truly arboreus Ferns, some attaining the height of 20 or more feet, the trunks of some becoming much enlarged by a coating formed of outgrowing aerial rootlets. They have a wide geographical range, the typical species being found only in St. Helena, one in Java, one in Tropical America, one in Juan Fernandez, Fiji, and New Caledonia, two in New South Wales and Tasmania, and three in New Zealand.* In habit and general appearance they resemble Cyathea, but as a genus they are technically

* In the Addenda to "Synopsis Filicum" three new species are described, two found in New Caledonia and one in Fiji and Samoa. 
distinguished by the sori being terminal and marginal, as also by the fronds before evolution being densely criniferous, the hairs being long and articulated, thus differing from Cyathea, which instead of hairs, are furnished with squamæ.

Sp. D. arborescens, L'Herit. ( $\nabla$ v.); D. chrysotricha, Moore. (Balantium, Hassk.); D. squarrosa, Sw. ( $\nabla$ v.); D. fibrosa, Colenso; D. Sellowiana, Hook ( $\left.\begin{array}{ll}\boldsymbol{v} & \mathrm{v} .\end{array}\right)$; D. Berteroana, Hook; D. lanata, Col.; D. Youngii, C. Moore ( $\nabla$ v.).

\section{7.-Сівотіем, Kaulf. (1824.)}

Dicksonia, sect. Cibotium, Hook., Sp. Fil.

Vernation fasciculate, decumbent or erect, and arborescent, densely criniferous. Fronds bipinnate, 5 to 15 feet long; pinnules bipinnatifid, generally glaucous beneath. Veins simple, forked or pinnate, venules free. Receptacles punctiform, terminal. Indusium bivalved, horny, the outer valve (accessary indusium) concave, cucullate, adnate to the margin; the inner (special indusium) smaller, and conniving with the outer, forming an unequal bivalved boxlike cyst.

Type. Dicksonia glauca, Smith.

Illust. Hook. and Baner, Gen. Fil., t. 25 ; Moore, Ind. Fil., p. 78 B. ; J. Sm., Ferns, Brit. and For., fig. 128; Hook. Syn. Fil., t. 2, fig. 13, a. b.

OBS.-This is a very distinctly marked genus, readily distinguished from Dicksonia and its allies by the outer valve being special, and formed on the reflexed margin of the frond as in Dicksonia, but superficially seated on the edge of the segments, rising from the outer base of the receptacle, and conniving with the interior special indu- 
sium, representing little chests, the inner valve being the lid, which, when open, has the resemblance of gaping jaws, hence the name Hiatea given to the genus by Robert Brown.*

The genus consists of about six or seven species, found in the Sandwich Islands, Mexico, India, Malay, Philippine Islands, and China. With the exception of $C$. Barometz, which has decumbent caudex, the others are erect arborescent, the stem of $C$. glaucum attaining the height of 20 or more feet.

* Caudex decumbent.

Sp. C. Barometz (J. Sm.) (v v.) ; C. Assamicum (Hook.)

* Caudex erect, arborescent.

C. glaucum (Hook.); C. Menziesii (Hook.) ( $\vee$ v.); C. Chamissoi (Kaulf.); C. Schiedei (Schlect.) ( $\nabla \nabla$.$) ; C. regale$ Linden ( $\nabla \nabla$.

OBs.-Cibotium Barometz is a native of China, and plants cultivated at Kew were introduced some time before 1834 by John Reeves, who was for many years "tea Taster" at Canton, for the East India Company; he learned that this Fern was the origin of the fabulous story of "Barometz" or the "Tartarian Lamb."

\section{8.-THYRSOpteRIs, Kunze (1834). Hool. Sp. Fil.}

Vernation fasciculate, erect, arborescent. Fronds decom-. pound multifid, the fertile portion contracted, forming panicles of globose sori. Veins of sterile segments pinnate; venules free. Accessory and special indusia equal, uniform, constituting a calyciform cyst, including sessile compressed sporangia seated on an elevated globose receptacle.

Type. Thyrsopteris elegans, Kunze.

* In Herb, Menzies, Brit. Mus. 
Illust. Hook. and Baver, t. 44, A ; Moore Ind. Fil., p. 83, B ; J. Sm. Ferns, Brit. and For., fig. 129 ; Hook. Syn. Fil., t. 1, fig. 3 .

OBs.-This genus is found on a solitary species, a native of Juan Fernandez; it is said to have a slender arborescent stem, which seems to be correct, as shown by imported plants cultivated at Kew.

In the "Species Filicum" Thyrsopteris is placed in the tribe Cyathea, but its terminal marginal sori, and general habit, clearly indicates its relationship to be with Dicksonia. It agrees with the following genus, Balantium, in having decompound fronds, differing only in the fertile segments being contracted into pedicels, each bearing a globose sorus, forming panicles, hence the name Panicularia given to the genus by Colla in 1836 .

Sp. T. elegans, Kze. ( $\nabla$ v.) (Schk. Fil. Suppl., p. 3, t. 1.)

\section{9.-Batantidu, Kaulf. (1824.)}

Dicksonia, Hook. Sp. Fil.

Vernation fasciculate, decumbent, densely criniferous. Fronds deltoid, tripinnate, smooth; ultimate pinnules dentate, multifid. Veins pinnate, venules free, simple or forked. Receptacles punctiform, terminal. Sori large, transversely oblong, exserted in thryseform clusters. I76dusium bivalved, coriaceous, the two valves nearly equal, concave, reniform.

Type. Dickesonia Culcita, L'Herit.

Illust. Hook. and Bauer. Gen. Fil., t. 60 A.; J. Sm. Ferns, Brit. and For., fig. 126.

Oвs. The technical character of this genus differs but little from Thyrsopteris, but is distinguished by the candex being decumbent.

The typical species is a native of the Azores and Madeira, 
and is represented in New Grenada, Venezuela, Brazil, and Jamaica by $B$. coniifolium, which I consider to be scarcely distinct from the preceding.

Sp. B. Culcita (L'Herit) ( $v$ v.) ; B. coniifolium (Hook.)

$$
\text { 140.-Crstodidm, J. Sm. (1841). }
$$

Dicksonia, Sm., Hook. Sp. Fil.

Vernation fasciculate, erect, sub-arboroid? Fronds stipate, bipinnate, 2 to 3 feet long; pinnæ distant, 1 foot long, pinnules linear lanceolate, acuminate, dentate, sub-auriculated, truncate at the base, articulate with the rachis. Veins simple or forked, parallel, their apices free, terminating in the marginal dents, and sporangiferous ; accessory indusium concave, vaulted and conniving with the smaller, plane special indusium, the two together forming an unequal, bivalved cyst, forming a row of marginal denteform sori.

Type. Dicksonia sorbifolia, Sm.

Illust. Hook. and Bauer Gen. Fil., t. 96.

OBs.-This genus is founded on a very rare Fern, first described by Sir J. E. Smith in Ree's Cyclopædia, from specimens collected in the Island of Honimoe, Moluccas, by Christopher Smith, between seventy and eighty years ago. It appears not to have been since collected, as only three or four specimens are to be found in herbaria in this country, and these consist of portions of fronds only, and nothing is known as to whether it has acaulose or arboroid vernation. The marginal bivalved indusia agrees with some Diclesonia such as Cibotium, but its simple lanceolate pinnæ being articulate with the rachis, seems to indicate its relationship to be with the section Arthropterece of Aspidece rather than with any genus of Dicksonia, but till more is known of it, I place here.

Sp. C. sorbifolium (Sm.) (Hook. Sp. Fil., 1, t. 25 A) 


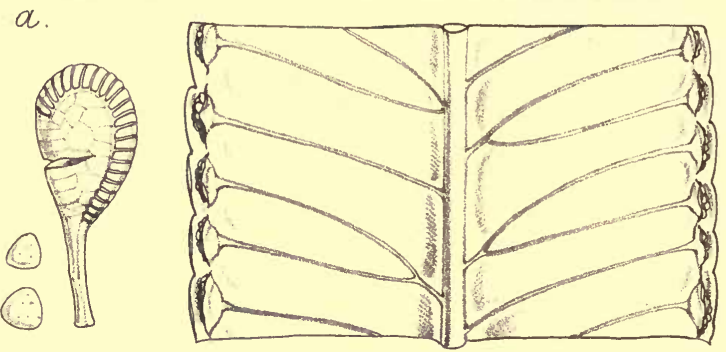

6
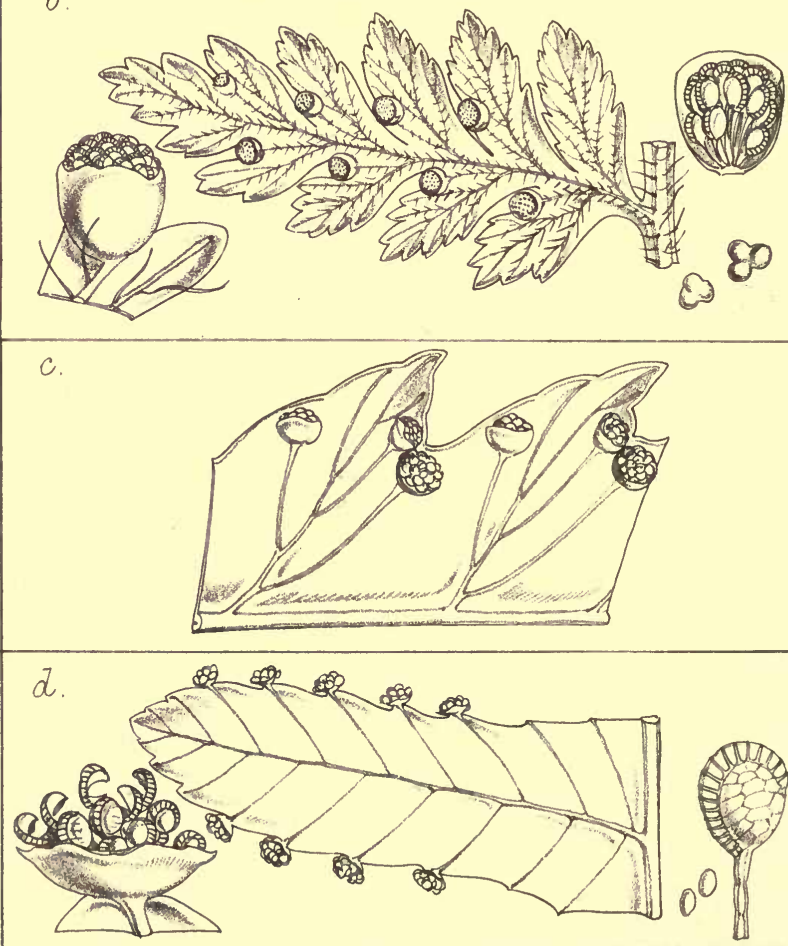

W. H. Fitch, del et lith

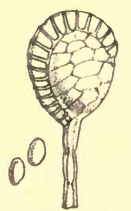




\section{TriZe 17.-SACCOLOMEAE (Plate 17).}

Vernation uniserial sarmentose, rarely fasciculate. Sori marginal. Special and accessory indusium forming marginal exserted or sub-marginal cysts, containing the sporangia.

OBs.-As stated under Dicksonice I deem it best to characterise the following genera as representing a distinct tribe, the sarmentose habit of growth being quite at variance with that of Dicksonice. The number of species amounts to about forty, which are widely distributed throughout the warm and temperate regions of both hemispheres, growing on the ground, rarely epiphytal, the greater number of species being retained in the genera Dennstcedtia and Microlepia.

\section{1.-Saccoloma, Kaulf. (1820). \\ Davallia sp., Hook. Sp. Fil.}

Vernation erect or sub-decumbent. Fronds 4 to 6 feet long, pinnate, smooth; pinnæ linear lanceolate, acuminate, 8 to 12 inches long, serrated at the apex. Veins simple, rarely forked, direct, parallel, free. Sori punctiform, contiguous, laterally coalescing and forming a compound, marginal, continuous line of sori. Special indusiun small, transverse, elongated, sub-scyphiform; accessory ones universal, formed of the continuous reflexed margin.

Type. Saccoloma elegans, Kaulf.

Illust. Hook. and Bauer., Gen. Fil., t. 58 B., figs. 1, 2 ; J. Sm. Ferns, Brit, and For., fig. 123.

OBs.-This genus is represented by probably two species, the typical species being a very elegant Fern, a native of the West Indies and tropical America, having resemblance to Pteris longifulia and $P$. moluccana, with which its reflexed 
indusoid margin also agrees, but the technical character of the sori distinguishes it.

In "Ferns, British and Foreign," I have described the vernation as erect, as shown by a young plant cultivated at Kew, received from Dominica, which agrees with the words "fronds tufted," as given in the "Species Filicum," whereas the specimen in the Kew Herbarium collected in Jamaica by Purdie is marked " Rhizome creeping; this singular Fern grows or rather climbs to a height of 20 feet." Of the correctness of this I have doubts; further observation is required to determine whether the two known species of the genus differ in their vernation, there being no specimens of the fronds attached to the caudex in the Herbarium.

Sp. S. elegans, Kaulf. ( $\nabla$ v.); S. Imrayana (Hook.) (Davallia, section Microlepia, Hook. Sp. Fil.; Davallia, section Humata, Hook. Syn. Fil.).

\section{2.-Microlepia, Presl (1836).}

Davallia auct., Hook. Sp. Fil.

Vernation uniserial, sarmentose. Fronds pinnate or tripinnatifid, or compound deltoid, 1 to 6 feet high. Veins simply or pinnately forked; venules free, the exterior one or more soriferous. Receptacles terminal, punctiform, marginal or sub-antimarginal. Indusium attached by its broad base only, or by its base and sides, constituting a simple, cucullate, or semiurceolate vertical cyst.

Type. Polypodium Spelunco, Linn.

Illust. Hook. and Bauer, Gen. Fil., t. 58, A; Hook. Fil. Exot, t. 19 ; Moore Ind. Fil., p. 75, A ; J. Sm. Ferns, Brit. and For., fig. 121 ; Hook. Syn. Fil., t. 2, fig. 18, d.

OBs.-This genus consists of a dozen or more species, 
widely spread over the tropics of both hemispheres; and on account of the apparent or but slightly varied forms being found in different countries, has led to great confusion in the species. In the "Species Filicum," under Davallia polypodioides, Sir William Hooker says: "The more I study the Ferns, and compare specimens from different countries, the more difficult I find it to define in a specific character the essential distinguishing character of species with the much divided fronds; so different are they, according to locality, to age on the various portions of the same individual, and other circumstances. Then the nature and degree of pubescence augment the difficulty'; and all these difficulties seem to be combined in the present species." Upon this view he unites about a dozen specific names of authors under Davallia polypodioides of Don, a species originally named and described by D. Don on Nepal specimens.

Sp. M. pinnata (Cav.) (D. flagellifera, Wall., Hook. and Grev. Ic. Fil., t. 183); M. gracilis (Bl.); M. Moluccana (Bl.); M. rhomboidea (Wall.) (Hook. Secd. Cent., t. 48); M. scabra (Don.) ( $\mathrm{v}$ v.); M. Khasyana (Hook.); M. cristata (Hook.) ( $\nabla^{\nabla}$.); M. calvescens (Wall.) ; M. Speluncæ (Linn.) (D. polypodioides, Don., Hook. Sp. Fil., D. flaccida, R. Br.) ( $\nabla$ v.); M. Novæ-Zelandiæ (Col.) ( $\nabla$ v.) (Acrophorus hispidus, Moore); M. strigosa (Sw.) ( $\left.\nabla \nabla_{0}\right)$; M. hirta (Kaulf.); M. trichosticha (Hook.) ( $\vee$ v.); M. alata (Hew.); M. adiantoides $(S w$.$) ; M. platyphylla (Don.) ( \nabla$ v.)

\section{3.-Scypholepia, J. Sm.}

\section{Davallia sp., Wall., Hook. Sp. Fil.}

Vernation uniserial. Fronds contiguous, pinnate, 2 to $2 \frac{1}{2}$ feet high; pinnæ lanceolate, 4 to 5 inches long, serrate, 
base truncate auriculate, sessile and articulate with the rachis. Veins once or twice dichotomously forked; venules sub-parallel. Sori punctiform, terminal on the exterior venule of each fascicle, seated anterior to the dents on the margin (which are not indusæform). Indusium short, cucullate.

Type. Davallia Hookeriana, Wall.

Illust. Hook. Sp. Fil, vol. 1, t. 47 B; Microlepia sp., Bedd., F. Brit. Ind., pl. 101.

OBs.-In the "Species Filicum " Davallia Hookeriana is placed in the sub-genus Saccoloma, and in the "Synopsis" it is placed under the section Microlepia, as characterised in the preceding genus, but from which the present species differ in having articulate pinnæ, this character and its special habit seem to indicate relationship with Nephrolepis. In order, therefore, to mark its peculiarity in the present group, I deem it. worthy to be ranked as a distinct genus.

Sp. S. Hookeriana ( Wall.).

A native of the principal Fern regions of India.

144.-Loxsoma, R. Br., MS. (A. Cunn. 1836).

Vernation uniserial, sarmentose. Frands long, stipate, deltoid decompound, 1 to $1 \frac{1}{2}$ foot high, glaucous beneath ; lacinæ lanceolate, dentate. Veins simple or forked; venules free, their apices prolonged beyond the margin, forming a free columnar receptacle. Special and accessory indusia united, forming a vertical, urceolate, extrorse cyst. Sporangia obovate, pedicillate, seated round the receptacle, which is elongated beyond the mouth of the indusium. Ring of sporangia oblique.

Type. L. Cunninghami, R. Brown. 
Illust. Hook. and Bauer, Gen. Fil., t. 15 ; Hook., Gard. Ferns, t. 31 ; Moore, Ind. Fil., p. 88 A; J. Sm., Ferns, Brit. and For., fig. 122 ; Hook., Syn. Fil., t. 2, fig. 15.

OBs.-This genus consists of a solitary species, a native of New Zealand, which in babit is similar to some species of Davallia as originally characterised, but more especially to the species placed under Microlepia; but differs in its sporangia being imbricate, round a columnar receptacle, similar to the genus Trichomanes. This, with the obliquity of the ring, renders Loxsoma of some importance as a connecting link between the present tribe and Trichomanes.

Sp. L. Cunninghami, R. Br. (v v.), Comp. Bot. Mag. 2, 366, t. $31-32$.

\section{5.-Odontosoria, Presl (1836.)}

Davallia, sp. auct.; Hook. Sp. Fil.; Stenoloma, Fée. .

Vernation sarmentose, contiguous, sub-fasciculate, or distant. Fronds bi-tripinnatifid, lanceolate or deltoid, 1 to 2 and 3 feet in length, or indefinite; ultimate seg. ments cuneiform, entire, lobed or laciniated. Veins dichotomously forked, venules free. Receptacles terminal, punctiform. Sori simple or binate. Special and accessory indusia forming a vertical, urceolate, or, by confluence, oblong, sporangiferous, marginal cyst.

Type. Davallia tenuifolia, Sw.

Illust. Hook. and Grev. Ic. Fil., t. 238 and 194 ; J. Sm., Ferns, Brit. and For., fig. 120.

OBS.-This genus consists of about a dozen species, widely distributed throughout the tropics of both hemispheres. They form two distinct groups, the first having 
definite fronds, and the other scandent and indefinite, the latter forming the genus Stenoloma of Fée.

* Fronds definite, not scandent.

Sp. O. tenuifolia $(S w$.$) ( \vee \nabla$.$) .$

OBS.-This is a widely spread species, being found in India, Malayan, and Polynesian Islands, also the Sandwich Islands, the latter being the nearest approach to the continent of America, where it has not yet been found.

O. bifida (Kaulf.) ; O. microphylla (Sw.); O. chinensis (Linn.) ; O. retusa (Cav.) ; O. clavata (Sw.)

** Fronds scandent (Stenoloma, Fée.).

O. divaricata (Schlecht.) (D. Schlechtendahlii, Hook.); O. aculeata $(S w).\left(\vee \nabla_{0}\right)$; O. fumarioides $(S w$.$) .$

146.-Dennsiadtia, Bernh. (1800).

Sitibolium, Desv. (1827); J. Sm. (1841); Patania, Presl. (1836); Dicksonia, Hook. Sp. Fil.

Vernation uniserial and sarmentose. Fronds bi-tripinnate, 2 to 6 feet high. Veins simple or pinnately forked, the exterior veinule or more soriferous. Receptacles terminal. Sori globose, reflexed. Special and accessory indusia united, and forming a reflexed, bilabiate, or subentire calyciform cyst.

Type. Dennstredtia punctiloba, Bernh.

Illust. Hook. and Bauer., Gen. Fil., t. 61 ; Moore Ind. Fil., p. 79 A.; J. Sm. Ferns, Brit. and For., fig. 125 ; Hook. Syn. Fil., t. 2, fig. 13.

OвS. This genus was originally founded by Bernhardi on Trichomanes flaccida of Forster, but was afterwards with its allies better known as Dicksonia, with which they agree in the technical character of the sori, but their sarmentose 
vernation marks them as a distinct group from the arborescent Dicksonia. The genus consists of about twenty species, widely distributed in the tropics and sub-tropical regions of both hemispheres, extending to New Zealand in the south and Canada and Japan in the north. In the "Species Filicum" thirty species are described, but many of them are very doubtful as true species.

Sp. D. obtusifolia (Willd.) ; D. adiantoides (H.B.) ( $\nabla$ v.) ; D. cicutaria $\left(S w_{0}\right)\left(\nabla_{0} \nabla_{0}\right) ;$ D. $\operatorname{dissecta}\left(S w_{0}\right)\left(\nabla \nabla_{0}\right) ;$ D. apiifolia $(S w$.$) ; D. rubiginosa (Kaulf.) ( \vee$ v.) ; D. anthriscifolia (Kaulf.) ( $\left.\nabla \nabla_{0}\right)$; D. davallioides (R. Br.) ( $\left.\nabla \nabla_{0}\right)$; D. straminea (Lab.); D. cuneata (Hook.); D. appendiculata (Wall.) ; D. punctiloba ( $S w$.$) ( (\mathrm{v}$. $)$; D. strigosa $(S w$.); D. Moluccana (Bl.) ( $\mathrm{v}^{\mathrm{v}}$ ) ; D. Alaccida (Bernh.) ; D. Pavoni (Hook.) ( $\nabla$ v.)

\section{7.-Deparia, Hook. and Grev. (1836).}

Hook. Sp. Fil.

Vernation sub-fasciculate, decumbent. Fronds bipinnatifid, 1 to $2 \frac{1}{2}$ feet long. Veins pinnate; venules free. Receptacles punctiform, terminal. Sori exserted; special and accessory indusia conniving, and forming a calyciform pedicellate exserted cup, containing the sporangia.

Type. Dicksonia prolifera, Kaulf.

Illust Hook. and Bauer, Gen. Fil., t. 44, B. ; Moore Ind. Fil., p. 79 B. ; J. Sm. Ferns Brit. and For., fig. 124; Hook. Syn. Fil., t. 2, fig. 14.

Oвs.-This genus is founded on a Fern, a native of the Sandwich Islands, and, in aspect, differs from the rest of the alliance, the habit being more analogous to Athyrium in the tribe Aspleniece. The exserted pateriform sorus distinguishes it from Microlepia, but on comparing it with 
Microlepia adiantoides, and that again with several species of Dennstcedtia, a gradual transition is seen to connect all these genera.

Sp. D. prolifera (Hook. and Grev., t. 154 ; Fil. Exot., t. 82) (v v.) ; D. concinna (Pr.) (D. Matthewsii, Hook. Sp. Fil., 1, t. 30, B.).

OBs.-The latter species is a native of Peru. In the "Synopsis Filicum" another species is described, namely, D. Moorei, which, although agreeing in having an exserted cup-like indusium, is nevertheless quite distinct in habit and venation. In this work it is characterised as a genus under the name of Trichiocarpa.

\section{Tribe 18.-LINDSAEE $\not$. (Plate 18.)}

Vernation sarmentose, slender, elongated, or short and cæspitose. Sori marginal, linear, continuous or interrupted, binate or punctiform. Special indusium plane, attached on the interior side, equal with, or shorter than the indusæform margin, forming a marginal groove, or bilabiate cyst, open exteriorly.

OBs.-A very interesting tribe of Ferns, in many respects similar in habit to Adiantum, but readily distinguishable by the indusium being attached on the interior side of the receptacle, and open exteriorly. This character, however, is not sufficient of itself for technically distinguishing Lindsceece from the tribe Saccolomeo, but their distinct habit marks them as representing a separate group.

About sixty species are described in the "Species Filicum," which in the "Synopsis" are reduced to fortyeight; from that number I exclude the species constituting 


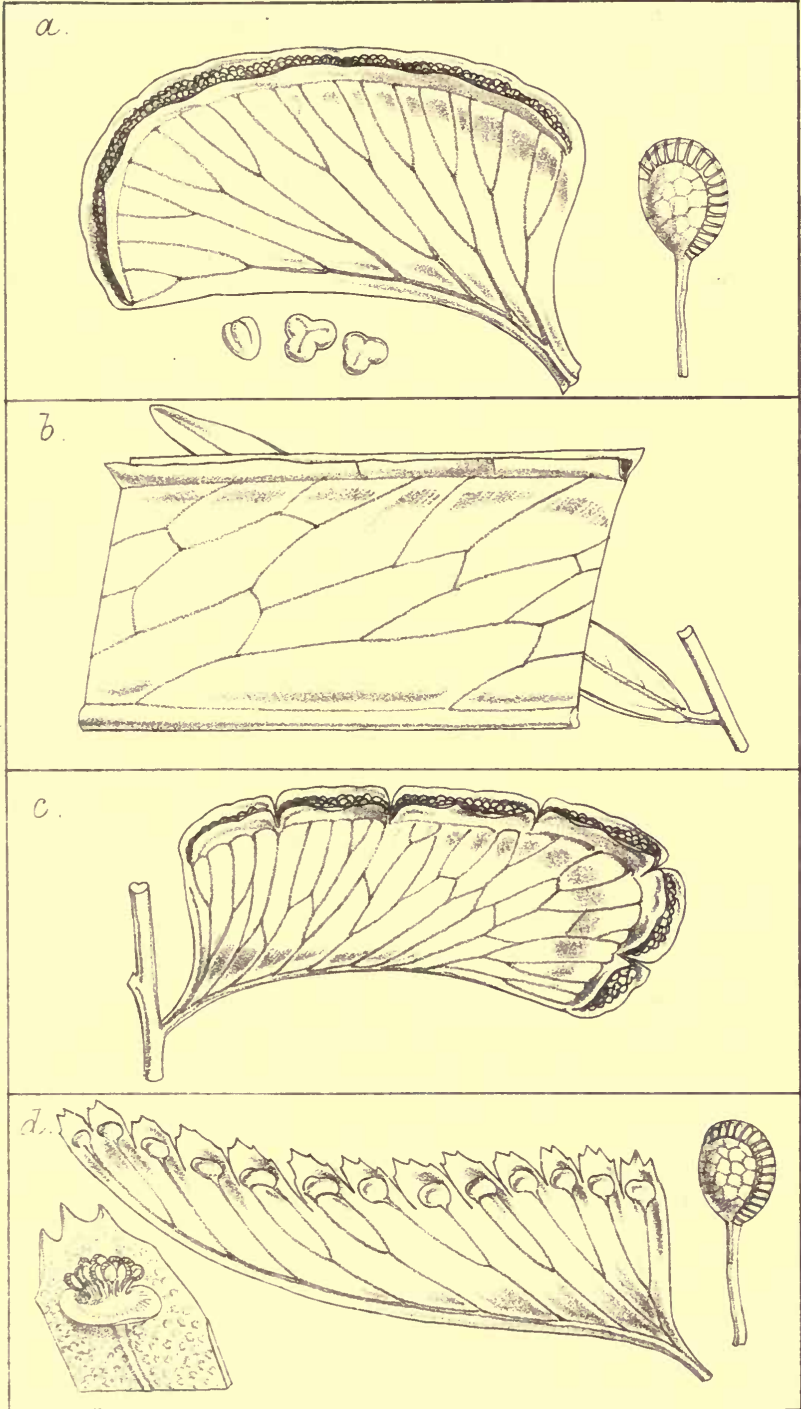

WH Fitch, aelet lith. 

the genera Schizolepton, Dictyoziphium, and Isoloma, which although agreeing in the technical character of the sori, are nerertheless widely distinct in vernation and habit, as will be seen on reference to their characters in their respective places.

The species of this tribe are widely distributed, generally natives of the tropics of both the Eastern and Western hemispheres, a few extending to New Zealand in the South.

$$
\begin{gathered}
\text { 148. - Lindsea, Dry. (1793). } \\
\text { Hook. Sp. Fil. }
\end{gathered}
$$

Vernation sarmentose, often short. Fronds distant or contiguous and sub-fasciculate, simple, pinnate, or bi-tripinnate; pinnæ and pinnules oblong, falcate, lunulate, upper margin fertile only; costæ eccentric. Veins radiating, or unilateral forked; their apices (in the fertile segments) combined by a transverse, marginal receptacle, forming a linear, continuous or interrupted marginal sorus. Indusium linear, its outer margin free, usually shorter than the indusæform margin.

Type. Lindscea trapeziformis, Dryander.

Illust. Hook. and Bauer, Gen. Fil., t. 63, A; Moore Ind. Fil., p. 22 ; J. Sm. Ferns, Brit. and For., fig. 118; Hook. Syn. Fil., t. 2, fig. 20, a.

OBs.-The fronds of some of the species of this genus vary from being simply pinnate, to bi- or even tri-pinnate, that authors have described the different forms as distinct species. They are chiefly tropical, L. trichomanoides being a native of New Zealand.

* Fronds simple, cordate-reniform.

Sp. L. reniformis, Dry. ( $\nabla$ v.); L. sagittata, Dry. ( $\nabla$ v.) 


\section{** Fronds pinnate.}

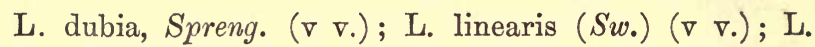
falciformis, Hook. ; L. ovata, J. Sm.; L. concinna, J. Sm.; L. adiantoides, $J$. $S m$. ; L. cultrata, $S w$. ( $\nabla$ v.) ; L. Lobbiana, Hook.; L.Seemanni, J. Sm.; L.lucida, Bl.; L.oblongifolia, Beinw.; L. scandens, Hook.; L. Lapeyrousii, Hook. ( $\nabla$ v.); L. falcata, Dry. ( $\nabla$ v.)

*** Fronds bipinnate, or 1 to 2 pinnate in the same species.

L. decomposita, Willd. ; L. caudata, Hook. ; L. trapeziformis, Dry. ( $\vee \quad \vee$.); L. pallida, Klot.; L. horizontalis, Hook. ; L. flabellulata, Dry.; L. tenera, Dry. ; L. quadrangularis, Radd. ; L. guianensis, Dry. ( $\vee$ จ.) ; L. stricta, Dry. ( $\nabla$ v.) ; L. rigida, J. Sm. ; L. pendula, Klot. ; L. crenata, Klot. ( $\nabla \nabla$.$) .$

**** Fronds deltoid, tripinnate.

L. trichomanoides, Dry. ( $\nabla$ v.).

149.-Srnaphlebium, $J$. Sm. (1841).

Lindscea, sp. auct.; Hook. Sp. Fil.

Character the same as Lindscea, differing only in the veins anastomosing.

Type. Lindscea recurvata, Wall.

Illust. Hook. and Bauer Gen. Fil., t. 101.

OBs.-The species of Synaphlebium differ from Lindscea in the venation being reticulated, in that respect agreeing with the genus Schizoloma, but differing in the eccentric costæ. The species are natives of the same regions as Lindscea.

Sp. S. recurvatum (Wall.); S. obtusum, J. Sm.; S. davallioides $(B l$.$) ; S. nitens (B l$.). 


\section{0.-Odontoloma, J. Sm. (1841).}

Davallia and Lindsaea, sp. auct.; Hook. Sp. Fil.

Vernation uniserial, sarmentose, epiphytal. Fronds slender, 1 to 2 feet high, 1 to 2 pinnate ; pinnæ and pinnules oblong, dimediate, the upper margin entire, dentate or incise lobed. Costoe eccentric. Veins unilateral; vennules direct, free. Receptacles terminal, punctiform. Sori round. Indusium sub-reniform, plane, its sides free, shorter than the subindusæform margin.

Type. Dicksonia repens, Bory.

Illust. Hook. and Bauer, Gen. Fil., t. 114, B.; Hook. and Grev., Ic. Fil., t. 143.

OBs.-Odontoloma having punctiform marginal sori similar to that of Davallia, has led the species to be placed by most authors in that genus, but the eccentric costa clearly shows its affinity to be with Lindscea, with which it also agrees in habit, only separated by the sori being punctiform, not linear and continuous as in true Lindsuea.

The genus consists of about half a dozen known species, they are widely distributed in or near the tropics, being represented in Guiana, the Mauritius, Malayan, Fiji, Sandwich, Philippine, and Polynesian Islands.

Sp. O. pulchella, J. Sm. ; O. repens $(S w$.$) ; O. Macræ-$ ana (Hook. and Arn.) (O. Hookeri, J. Sm., 1841) ; O. Parkeri (Hook.); O. fijiensis, $J$. Sm., in Seemann's list of Figi Plants; O. tenuifolia $(B l$.$) ; O. hymenophylloides \left(B l_{0}\right)$; O. triquetra (Bl.).

OBs.-Odontoloma repens affords a good example of the different views entertained by Pteridologists in defining the technical character of genera on the sori alone; this species is epiphytal, having a slender sarmentum and linear pinnate fronds, a foot or more in length, with dimediate 
pinnæ about half an inch in length, differing from true Lindscea only in the upper margin, being dentate, each dent bearing a single round terminal sorus, furnished with a bilabiate indusium, upon this character, Bory refers it to Dicksonia, in which genus it is retained by Swartz and Willdenow, along with the arborescent Dicksonia; it was afterwards referred by Desvaux to Davallia, under which genus it stands in the "Species Filicum" (sect. Odontoloma); which is certainly a more natural position than being ranked with the lofty Dicksonias. Presl places it in the genus Saccoloma. In Moore's Index it is found under the genus Acrophorus (A. repens), which genus was originally founded by Presl on a solitary species*, to which Moore adds no less than eighteen species, the greater number of which in this arrangement come under four distinct genera, namely, Odontoloma, Odontosoria, Microlepia, and Leucostegia, the latter differing from the former in having articulate vernation, and, therefore, belonging to Eremobrya. To depend on the character of the sori alone, many multifid species of Lastrea and Polystichum, with terminal, marginal sori, and even Mr. Moore's genus, Diclisodon, may be added to Acrophorus, all agreeing strictly in the sori being terminal, and the special indusium conniving with the indusoid margin. It is, therefore, only by studying the difference in habit that natural groups of species can be formed.

\section{1.-Schizoloma, Gaud. (1826). \\ Lindscea, Hook. Sp. Fil.}

Vernation sarmentose, short. Fronds contiguous, subfasciculate, pinnate; pinnæ oblong, or linear lanceolate, costæ central. Veins forked; venules anastomosing, form-

* See Acrophorus, page 221. 
ing oblique elongated areoles, transversely combined by an elongated receptacle on both margins. Sori linear, continuous. Indusium linear, usually equal, or shorter with the indusæform margin.

Type. Lindscea ensifolia, Swartz.

Illust. Hook. and Grev., Ic. Fil., t. 111 ; Moore, Ind. Fil., p. 23 A ; J. Sm., Ferns, Brit. and For., fig. 119 (non Hook. and Bauer, Gen. Fil., t. 63, which is an Adiantum.)

OBS.-The central costa, and reticulated vernation, dis. tinguishes this from Lindsece, and the sori being produced on both margins from Synaphlebium.

Brackenridge has characterised a genus which he calls Diellia, of which he describes three species, the principal difference being in the sori being slightly within the margin, and which is not altered in texture, and therefore can scarcely be called an indusium; it also differs in the sori being in short pieces, not continuous, which is consequent on the pinnæ being laciniated. The technical difference seems to me to be scarcely sufficient to warrant its adoption as a genus.

* Sori continuous. (Schizoloma vera.)

Sp. S ensifolia $(S w$.$) ( \nabla$ v.); S. Griffthiana (Hook. Sp. Fil. 1., t. 68 B.); S. macrophylla, Kaulf.; S. Fraseri (Hook.); S. heterophylla (Dry.).

OBs.-The fronds of this species vary from simply pinnate, with entire lanceolate pinnæ, 6 or more inches in length, to bipinnate, with short, oblong, oblique pinnules, in which the venation is occasionally free.

** Sori sub-intramarginal, interrupted. (Diellia, Brack.) S. erecta (Brack.); S. pumila (Brack.); S. falcata (Brack.) The three latter species are natives of the Sandwich Islands (Brackenridge); it is probable they are only 
different forms of one species. In the "Synopsis Filicum" a fourth species is described as belonging to this section, under the specific name of "Michleriana," a native of New Granada. It is described as being pinnate, 12 to 15 inches in length, the pinnæ 3 to 5 inches long, the veins forming hexagonal areoles, with free included veinlets, which seems to indicate its affinity with Dictyoxiphium; its mode of vernation is not described, and probably when that is known it will be found not to belong to this tribe.

\section{2.-GUerinia, J. Sm.}

Schizoloma sp. Gaud., Isoloma, Feé, Lindsaya, Hook.

Caudex slender, sarmentose. Fronds lanceolate, pinnate, 6 to 9 inches long, smooth. Pinnce ovate oblong, $\frac{1}{2}$ to $\frac{3}{4}$ of an inch long, falcate, sessile, articulate with the rachis; costæ slightly excentric. Veins reticulate, obscure. Receptacles marginal, immersed in an indusoid groove, forming a linear continuous sorus.

Type. Schizoloma Gueriniana, Gaud.

Illust. Gaud. in Voy. de L'Urinie, t. 18.

OBs.-The species on which this $g$ ?nus is founded differs in general appearance from the true species of Schizoloma, and especially in the pinnæ being articulate with the rachis.

It appears to be a rare Fern, as there is no specimen in the Hookerian herbarium; but the nature of the stipes of fronds in my herbarium* induces me to believe it to have articulate vernation.

The presence of white dots on the upper side of the pinnæ gives it some claim to be ranked with Isoloma and Nephrolepis, but till more of it is known I retain it here.

Sp. G. articulata, J. Sm. (Schizoloma Gueriniana, Gaud.) Native of the Molucca Islands.

* Now in the British Museum. 



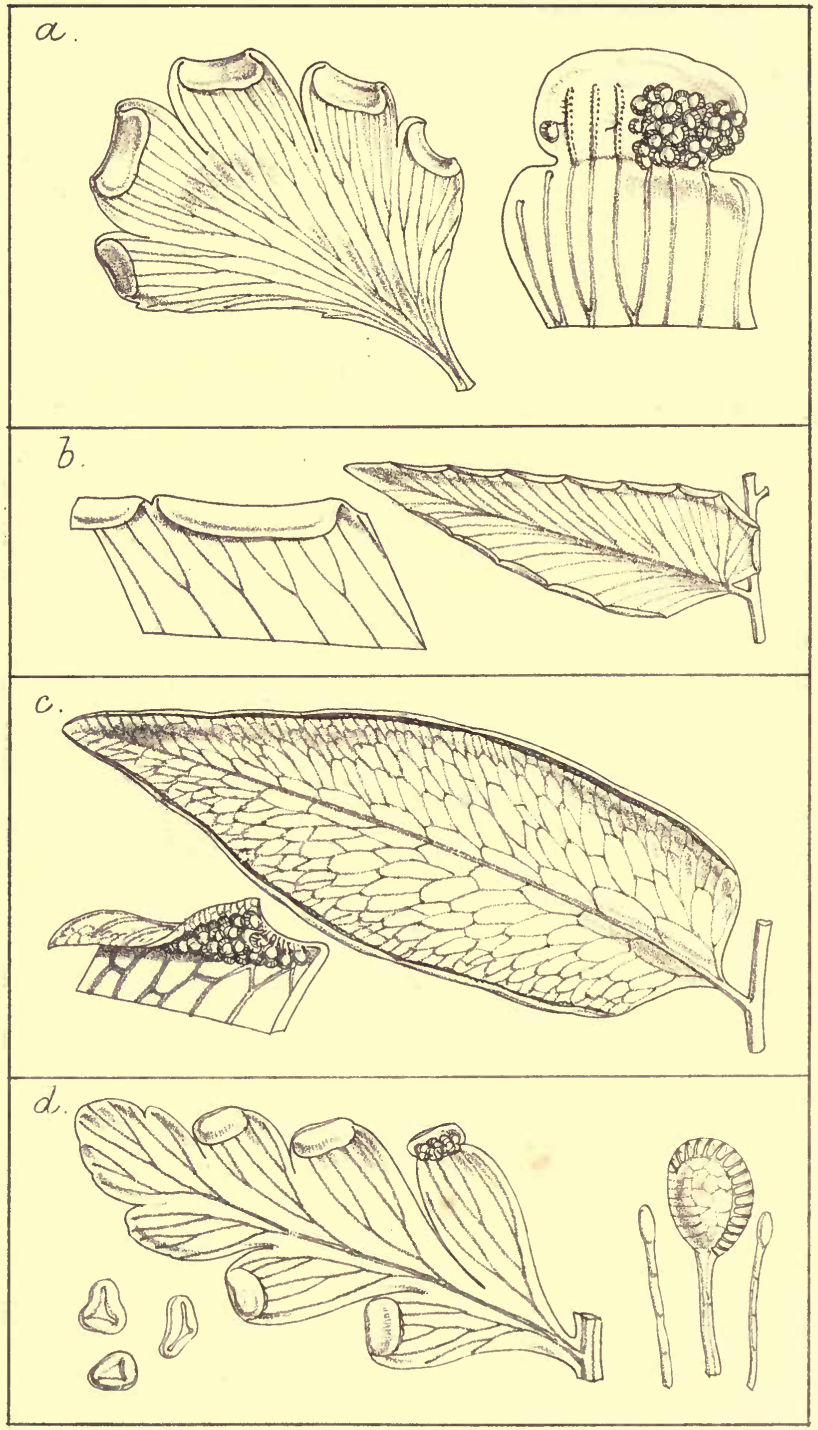

W.H. Fitch, del et Iith.

J.N. Fitch,imp 


\section{Tribe 19. ADIANTE 2 . (Plate 19.)}

Vernation fasciculate or sarmentose, generally hypogeous, and becoming cæspitose. Sori marginal, transverse, oblong, linear, or punctiform. Indusium lateral, exterior attached, bearing the sporangia on its under surface.

Obs.-This is truly a natural tribe of Ferns, having the smooth, polished, and flaccid character of Lindscea, but differing in the indusium being attached exteriorly, and its under surface venose, and bearing the sporangia, which latter character distinguishes it from the tribe Pteridece; it is formed of a portion of the laminæ of the margin of the frond, which is changed in texture, its form depending on the ultimate segments being entire, or more or less divided, thus varying from reniform, linear, to oblong, continuous, occupying the whole margin of the segments. Those with reniform indusia are distinguished from Cheilanthes not only by the indusium being sporangiferous on its disk, but also by its being produced on the convergent apices of two or more venules, whereas the sori of Cheilanthes are seated on the axis of a single venule, terminating in the axis of the indusium.

In the "Species Filicum" 109 species are described, but in the "Synopsis Filicum" the number is reduced to 62 ; the first number was arrived at by Sir W. Hooker, after more than half a century's study of Ferns, and the latter number by the editor of the "Synopsis" after three years' study of Sir W. Hooker's herbarium. This is a striking example of the different views taken by Pteridologists as to what constitutes species.*

*In the Appendix to the "Synopsis Filicum" nineteen additional species are described. 
They are very widely distributed throughout the tropical and temperate regions of the earth, growing on the ground $\mathrm{nr}$ in moist rocky places, but never epiphytal to my knowledge.

\section{8.-Adiantum, Linn. (1737). \\ Hook. Sp. Fil.}

Vernation fasciculate or uniserial, sarmentose, hypogeous. Fronds simple reniform, pinnate or bi-tripinnate; pinnæ and pinnules articulate with the apex of the petiole, often dimediate with an excentric oblique costæ, in some evanescent. Veins unilateral or radiating, forked; sterile venules free, the fertile combined in the margin, forming sori as described above.

Type. Adiantum cappillus-veneris, Linn.

Illust. Hook. and Bauer, Gen. Fil., t. 66, B; Moore Ind. Fil., p. 24; J. Sm. Ferns, Brit. and For., fig. 93; Hook. Syn. Fil., t. 2, fig. 21.

OBS. - The following are examples of the principal species of the genus, of which above forty have come under my notice in a living state.

\section{1.-Reniforme group.}

Fronds simple, reniform.

Sp. A. reniforme, Linn. ( $\nabla$ v.); A. asarifolium, Willd.; A. Parishii, Hook. Fil. Exot., t. 11.

2.-Caudatum group.

Fronds pinnate, pinnce narrow.

A. lunulatum, Burm. ( $\nabla$ v.); A. rhizophorum, Sw.; A. Edgworthii, Hook.; A. caudatum, Linn. ( $\nabla \nabla$.$) ; A. sorbo-$ liferum, Wall.; A. deltoideum, Sw.; A. dolabriforme, Hook. ( $\nabla$ v.). 


\section{3.-Macrophyllum group.}

Fronds pinnate, erect, pinnoe broad, elliptical_lanceolate.

A. lucidum, $S w .(\nabla \nabla$.$) ; A. obliquium, Willd. ( \nabla$ v.); A. Kaulfussii, Kze. ( $\nabla$ v.); A. Wilsoni, Hook. ( $\nabla$ v.); A. macrophyllum, $S w$. ( $\nabla$ v.); A. Seemannii, Hook.; A. Phyllitidis, $J . S m$.

\section{4.-Monosoratum group.}

Fronds uniformly bipinnate.

A. villosum, Linn. ( $\nabla$ v.); A. varium, H. B. K.; A. pulverulentum, Linn. ( $\vee$ v.); A. incisum, Presl.

\section{5.-Prionophyllum group.}

A. intermedium, $S w_{0}(\nabla \nabla \cdot)$; A. prionophyllum, H. B. K. ( $\vee \nabla$.$) ; A. velutinum, Moore (\nabla \nabla$,$) : A. fovearum, Radd.$ ( $\vee$ v.) ; A. rhomboideum, H. B. K.; A. urophyllum, Hook. ; A. melanoleucum, Willd.; A. glaucescens, Klot.; A. obtusum, Desv. ; A. Galeottianum, Hook.

\section{6.-Trapeziforme group.}

Fronds large, tripinnate; pinno distant, alternate.

A. subcordatum, $S w$. (v v.); A. Peruvianum, Klot.; A. speciosum, Hook.; A. trapeziforme, Linn. ( $\vee$ v.); A. pentadactylon, Lang. and Fisch. ( $\nabla$ v.); A. Matthewsianum, Hook. ( $\nabla \nabla_{0}$ ); A. cultratum, J. Sm. ( $\nabla_{\text {. }}$ ); A. sinuosum, Gardn.; A. curvatum, Kaulf. ( $\nabla$ v.) ; A. polyphyllum, Willd. ( $\left(\nabla_{.}\right)$; A. microphyllum, Kaulf.; A. cristatum, Linn. ( $\nabla$ จ.); A. Féei, Moore ( $\vee$ จ.) (A. flexuosum, Hook.).

\section{Formosum group.}

Fronds quadripinnate, decompound, with distant alternate pinnoe.

A. Brasiliense, Radd. ( $\left.\nabla \nabla_{0}\right)$; A. Wilesianum, Hook. ( $\mathrm{v} v$ ); A. Lobbianum, Hook.; A. affine, Willd. ( $\nabla$ v.); A. formosum, R. Br. ( $\nabla$ v.); A. Cunninghami, Hook. ( $\nabla$ v.). 


\section{Flabellatum group.}

Fronds dichotomously pedate-flabellate.

A. flabellatum, Linn. ( $\nabla \nabla$.$) ; A. patens, Willd. ( \nabla$ v.); A. pedatum, Willd. ( $\left.\nabla \nabla_{0}\right)$; A. hispidalum, $S w$. ( $\left.\nabla \nabla_{0}\right)$; A. setulosum, J. Sm. ( $\left.\nabla \nabla_{0}\right)$; A. fulvum, Raoul. ( $\left.\nabla \nabla_{0}\right)$.

\section{Tenerum group.}

Fronds dichotomously decompound.

A. tenerum, $S w$. ( $\nabla$ v.).

OBS.-A remarkable Fern has of late years appeared in garden collections under the name of $A$. Farleyense, it has the same habit as $A$. tenerum, but is much larger in size and in all its parts, and which has led it to become a favourite exhibition plant, it however does not produce fructification, and there being no wild specimens in herbaria, it is, therefore, supposed to be a hybrid, and to have originated in a garden in Barbadoes.

A. Henslovianum, Hook. fil.; A. rubellum, Moore; A. Veitchianum, Moore; A. sessilifolium, Moore; A. chilense, Kaulf. ( $\nabla$ v.) ; A. sulphureum, Kaulf. ( $\left.\nabla \nabla_{0}\right)$; A. emarginatum, Bory. ( $\nabla$ v.); A. fragile, $S w$.

\section{Capillus-Veneris group.}

Fronds compound multifid, slender, segments generally cuneiform, flabellate.

A. Capillus-Veneris, Linn. ( $\nabla$ v.); A. Athiopicum, Linn. (v v.); A. cuneatum, Lang and Fich. ( $\nabla$ v.); A. glaucophyllum, Hook.; A. venustum, Don.; A. assimile, Sw. ( $\vee$ v.); A. concinnum, H. B. K. ( $\nabla$ จ.); A. colpodes, Moore ( $\left.\nabla \nabla_{0}\right)$; A. tinctum, Moore ( $\left.\nabla \nabla_{0}\right)$; A. amabile, Moore. 

PL. 20.

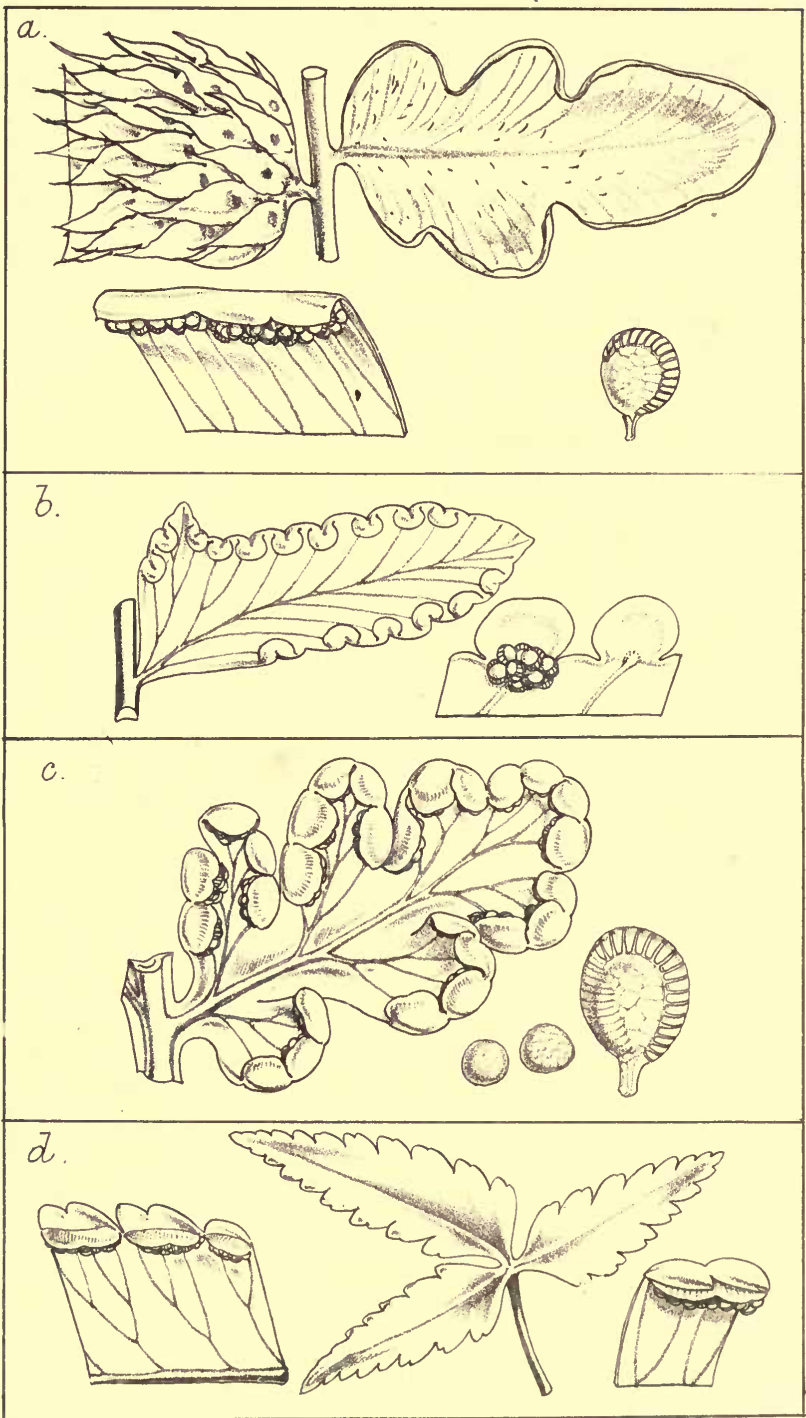

W. H. Fitch, del. et lith.

J.N. Fitch,imp 


\section{4.-Hewardia, J. Sm. (1840). Adiantum, sp., Hook. Sp. Fil.}

Vernation sarmentose (?) Fronds 1 to 2 feet high, pinnate, or dichotomously bipinnate, smooth, pinnæ and pinnules alternate, distant, petiolate (not articulate), sometimes falcate, 4 to 8 inches long, 1 to 2 inches wide. Costce evident, central. Veins uniform, reticulated, forming elongated, oblique areoles. Indusium marginal, continuous, venose, and sporangiferous on its under side, as in Adiantum, at length becoming replicate and involute, forming a continuous sorus, occupying both margins.

Type. Hewardia adiantoides, J. Sm.

Illust. Hook. and Bauer, Gen. Fil., t. 89 ; Moore, Ind. Fil., p. 25 A.

OBs. This genus is distinguished from Adiantum by having reticulate venation, on both sides of the central costæ. Sp. H. adiantoides, J. Sm., Hook. Journ. Bot., vol. 3, t. 16 and 17 ; H. dolosa, Fée, Hook. Sp. Fil., 1, t. 79 B.

Natives of Guiana and Brazil. Although the latter species agrees in general babit with $H$. adiantoides, the veins, however, are not so decidedly anastomose, and on account of $H$. Wilsoni and $A$. Leprieurii having occasional anastomose venation, they are therefore by some also referred to this genus.

\section{Tribe 20.-CHEILANTHE A. (Plate 20.)}

Fronds varying from simple pinnate to decompound multifid, and from a few inches to 2 feet in height, smooth, or densely tomentose or squamose. Venules free. Sporan. gia terminal, marginal ; sori punctiform, distinct, or two or more laterally confluent, seated in the axis of the inflexed membraneous margin of the segment (indusium). 
OBs.-This tribe consists of nearly 100 known species, typically represented by the genus Cheilanthes, as originally characterised by Swartz. I, however, include under it a number of species of Pteris of early authors. In most Cheilanthece the sporangiferous receptacles are free, not transversely connected as in true Pteris, but there are apparent exceptions to the correctness of this distinction; there being instances of the normal punctiform sori of some species of Pelloca so united and seated in the axis of the indusium, thus scarcely differing in technical character from Pteris. The smooth, polished, and generally firm texture of the fronds coincide, however, more with the species of Cheilanthes than with Pteris; I, therefore, deem it best to retain them in the present tribe, as being more their natural affinity than the tribe Pteridece.

With regard to the genera of Cheilanthece as here restricted, I must own there is much difficulty in defining their limits, as derived from the technical character of their fructification alone.

\section{5.-NотноснцжN,$R . B r .(1810)$.}

\section{Nothochloena and Cheilanthes, sp. Hook. Sp. Fil.}

Vernation fasciculate, cæspitose, acaulose. Fronds pinnate or bipinnate, 6 to 18 inches high, pilo-tomentose, squamose or farinose. Veins forked, free. Receptacles terminal. Sporangia few to each receptacle, contiguous, forming a marginal row in the axis of the inflexed rudimentary indusium.

Type. Pteris trichomanoides, Linn.

Illust. Moore, Ind. Fil., p. 55 B.; J. Sm., Ferns, Brit. and For., fig. 86 ; Hook. Syn. Fil., t. 6, fig. 50. 
OBS.-This genus consists of more than twenty species of small-growing Ferns, chiefly inhabiting dry, rocky places within or near the tropics of both continents, extending to South Africa and Tasmania, and in the North to the shores of the Mediterranean and the Alps of Europe. In habit they have great affinity with the Ereosorus section of Gymnogramma, differing only in the sporangia being terminal and the indusium rudimentary, they are, therefore, by many authors referred to the Gymnosorus division of Ferns, but I consider them to be more intimately related to Cheilanthes, and that the imperfect development of the indusium is due to the densely squamose and tomentose nature of the fronds.

* Lepichosma. Fronds densely squamose.

Sp. N. lævis, Mart. and Galeott. (v v.); N. sinuata, Kaulf. (v v.), Bot. Mag., t. 4699 ; N. squamosa, Hook and Grev.,

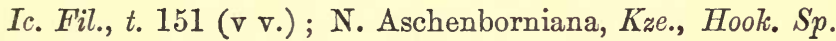
Fil., 5, t. 287 B. ; N. Marantæ, R. Br. (v v.) ; N. canariense, J. Sm. ( $\mathrm{v}$ v.) ; N. Eckloniana, $K_{z} e$. ( $\mathrm{v}$ v.) ; N. distans, R. Br. (v v.), Hook. Secd. Cent. of Ferns, t. 80.

** Eriochosma. Fronds densely tomentose, villose or hirsute.

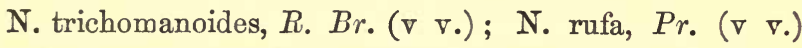
(N. ferruginea, Hook. Second Cent of Ferns, t. 52); N. hypoleuca, Kunze; N. bracypus, Kze. ( $\nabla$ v.); N. canescens, Fée; N. mollis, Kunze ( $\vee$ v.) ; N. eriophora, Fée, Hook. Ic. $P l .$, t. 991 ; L. lanuginosa, Desv. (v v.) ; N. inæqualis, Kze ; N. sulcata, Link. ; N. fragilis, Hook. Sp. Fil. 5, t. 287 A; N. hirsuta, Desv.; N. Pohliana, Kze., Hook. Sp. Fil. 5, t. $286 B$.

*** Chrysochosma. The under side farinose.

N. sulphurea, J. Sm., Bot. Voy. Herald, p. 233 (v v.) (Pteris, Cav.; Cheilanthes Borsigiana, Reichenb.). 
OBs.-The yellow farina characteristic of this species seems to indicate its affinity to be with Cheilanthes aurantiaca and $C$. chrysophylla, but its rudimentary indusium required it to be placed under the present genus.

\section{6.-Mrriopteris, Fée (1851).}

\section{Cheilanthes sp. auit.; Hook. Sp. Fil.}

Vernation fasciculate, cæspitose, acaulose, rarely sarmentose. Fronds 4 to 18 inches high, bi-tri-quadri-pinnatifid, pilose, squamiferous or viscose, ultimate segments minute, generally orbicular or cuneiform, concave, the margin membraneous, revolute, conniving, forming an universal cucullate indusium. Veins forked, free. Receptacles terminal. Sporangia few, confluent under the universal indusium.

Type. Cheilanthes lendigera, Swartz:

Illust. Fée Gen. Fil., t. 12 A., fig. 1 ; Moore Ind. Fil., p. 26, fig. 6-7. ; J. Sm. Ferns, Brit. and For., fig. 87.

OBs.-Presl was the first to indicate this as a distinct group of Cheilanthes, under the sectional name Physapteris, and Fée afterwards characterised it as a separate genus under the name here adopted.' This genus consists of about twenty species, distinguished from Nothochlcena and Cheilanthes by their small, concave, lenticular segments. They are natives chiefly of the Andean regions of America, extending to the Rocky Mountains in the North.

Sp. M. lendigera ( $S w$.$) ( \nabla$ v.); M. myriophylla (Desv.) ( $\nabla \nabla$.$) ; M. elegans (Desv.) ( \nabla$ $\left.\nabla_{.}\right)$; M. tomentosa (Link.) $(\nabla \nabla$.$) ; M. scariosa (Kaulf.) ; M. induta (Kze.) ; M. lanu-$ ginosa (Nuttall) ; M. Bradburii (Hook.); M. vestita (Sw.) ( $\nabla$ จ.) ; M. Lindheimeri (Hook.); M. Fendleri (Hook.); M. Mac-Leanii (Hook.) ; M. gracillima (Eat.); M. hirta 


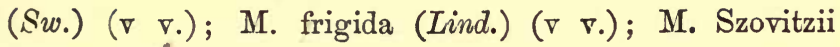
(Fisch. and Meyer).

This is the only species native of the $\mathrm{E}$. hemisphere, being found in Italy, Dalmatia, Western Asia, and the Himalayas.

\section{7.-OrMopteris, $J$. Sm. \\ Cassebeera sp., Hook. Sp. Fil.}

Vernation sarmentose. Fronds 1 to $1 \frac{1}{2}$ feet long, pinnate, smooth, coriaceous; pinnæ 2 to 3 inches long, linear, petiolate, deeply cut into numerous quadrangular concave lobes, not exceeding 1 line in breadth, which are incurved, and oppositely connive over the rachis, forming moniliform pinnæ. Veins free. Sporangia terminal, few, forming a single sorus seated in the hollow of each lobe, the margins of which are indusoid.

Type. Cassebeera gleichenioides, Gardn.

OBs.-This genus is founded on a peculiar and remarkable Fern, originally discovered in Brazil by Dr. Gardner, and described in Vol. VI. of Hooker's "I Icones Plantarum," under the name of Cassebeera gleichenioides, in which genus it is retained in Hooker's "Species" and "Synopsis Filicum," but as it always appeared to me not naturally related to the typical species of Cassebeera, I therefore deem it best to separate it as a distinct genus. In so doing I, how. ever, find it difficult to determine its position in this arrangement, but its small concave indusæform lobes, containing the sporangia, seems to indicate affinity with Myri opteris.

Sp. O. gleichnioides (Cassebeera gleichenioides, Gard.; Hook. Ic. Pl., t. 507).

Native of Diamond district, Brazil. 


\section{8.-Chemanthes, $S w$. (1806). .} Hook. Sp. Fil., in part.

Vernation fasciculate, erect or decumbent, acaulose, cæspitose. Fronds bi-tripinnate, rarely simple pinnate, 4 to 8 inches or more in height, smooth pilose, glandulose or farinose ; ultimate segments often small. Veins forked, free. Receptacles terminal, punctiform. Indusium reniform and special to each receptacle, or linear, including two or more contiguous receptacles, forming round, oblong, or linear sori.

Type. Cheilanthes tenuifolia, Swartz.

Illust. Hook. and Bauer. Gen. Fil., t. 106 B. ; Moore Ind. Fil., p. 25 B. and 26 ; J. Sm. Ferns, Brit. and For., fig. 88 ; Hook. Syn. Fil., t. 3, fig. 25.

OBS.-This genus consists of about thirty or forty known species of slender fronded Ferns, widely spread through the tropics and sub-tropical regions of both hemispheres. They vary considerably in size and the divisions of the fronds, as also in the indusium being of various forms, which in some cases might be considered sufficient to be of generic value, but as it often varies in form in the same species it cannot be viewed as of more than specific value. In some it is a distinct, round, inflexed crenule, containing on its axis a single receptacle, in others it is oblong, or more or less elongated, containing two or more receptacles, in some it is straight, in others it is crenulated and wavy. These differences admit of the species being arranged in groups as follows :-

\section{* Adiantopsis.}

Indusium subrotund or reniform, special to each cluster of sporangia. Fronds smooth.

Sp. C. monticola, Gard.; C. pteroides, $S w$. ; C. radiata, 
J. Sm. (Adiantum, Linn.) ( $\nabla$ v.); C. paupercula, Mett.; C. dichotoma, $S w$.; C. Seemanni, Hook.; C. pedata, J. Sm. ( $\nabla$ v.) (Hypolepis, Hook.); C. Schimperi, Kunze; C. ca-

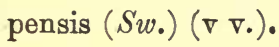

** Pteridopsis.

Indusium binate, or elongating sub-continuous, including two or more clusters of sporangia.

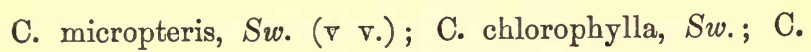
multifida, $S w .(\vee \vee$.$) ; C. mysurensis, Wall.; C. bullosa,$ Kunze.; C. Matthewsii, Kunze.; C. Wrightii, Kunze.; C. Tweediana, Hook.; C. Sieberi, Kunze. ( $\left.\nabla \nabla_{0}\right)$; C. viscosa, Link. ( $\vee$ v.) ; C. tenuifolia, Sw. ( $\vee$ v.); C. varians, Hook. ; C. fragrans, Webb. ( $\nabla$ v.) ; C. Moritziana, Kunze.; C. microphylla, $S w .\left(\nabla \nabla_{0}\right)$; C. alabamensis, Kunze. ( $\left.\nabla \nabla_{0}\right)$; C. chusana, Hook.

\section{**** Aleuritopteris.}

Indusium continuous, undulose crenulated, each crena including a cluster of sporangia.

$\dagger$ Fronds somewhat villose or slightly squamiferous.

C. Dalhousiæ, Hook.; C. subvillosa, Hook.

†† Fronds with white farina on the under side.

C. argentea, Kunze. ( $\nabla$ v.); C. argyrostigma, J. Sm.; C. pulveracea, Presl; C. farinosa, Kaulf. ( $\nabla$ v.).

OBS. - The latter species varies greatly in size, the fronds being sometimes so small that they are not distinguishable from $C$. argentea, which, as at present known, is never found exceeding 2 to 4 inches in height, whilst the native specimens of $C$. farinosa average from 6 to 12 inches, and when cultivated under favourable circumstances attain a height of two feet, cultivation has not, however, increased the size of $C$. argentea ; its small size may be considered constitu- 
tionally normal, consequent on the cold climate of the regions in which it is found, namely, Siberia and Kamschatka. C. farinosa has a wide geographical range, generally within or near the tropics of the Eastern Hemisphere, and recently it has been found in New Granada.

C. rufa, Don.

+ +† Fronds with yellow farina on the under side.

C. aurantiaca (Cav.), Hook. Ic. Pl., t. 904 ; C. chrysophylla, Hook., Fil. Exot., t. 95, fig. 1.

\section{9.-Casseberra, Kaulf. (1824). Hook. Sp. Fil.}

Vernation uniserial, sarmentum short. Fronds tripartite or pinnate, 6 to 18 inches high, long stipate, stipes and rachis smooth, castaneous; pinnæ oblong, 2 to 3 inches in length, margin thick, emarginate. Veins internal, obscure, forked, free. Sporangiferous receptacles terminal, punctiform, laterally connivent in pairs. Indusium intramarginal, in short, linear pieces, each piece including the connivent sporangia, forming oblong sori.

Type. Adiantum triphyllum, Smith.

Illust. Hook. and Bauer Gen. Fil., t. 66, A; Moore Ind. Fil., p. 27, B ; Hook. Syn. Fil., t. 3, fig. 26.

OBs.-This genus was originally founded upon two Ferns, natives of Brazil ; although not differing much in general habit or in technical characters from Pelloea, it is nevertheless retained by most authors as a genus; a third species, C. gleichenioides, has been referred to this genus by its discoverer, Dr. Gardner ; it is, however, so widely different in habit and appearanee, and in its technical characters, that I deem it advisable to separate it from Cassebeera (see Ormopteris).

Sp. C. triphylla, Kaulf.; C. pinnata, Kaulf. 
160.-Pelled, Link. (1841).

Hook. Sp. Fil.; Pteris, Cheilanthus and Allosorus sp. auct.

Vernation fasciculate, erect or decumbent, acaulose. Fronds deltoid lobed, pinnate or bi-tripinnate, one to two or more feet in height, smooth, castaneous or glaucous, pinnules articulate with the rachis, or to a short adherent petiole. Veins forked; venules free. Receptacles terminal, the sporangia becoming laterally confluent, forming a continuous transverse marginal sorus, included under a reflexed membraneous indusium.

Type. Pteris hastata, Sw.

Illust. Hook. and Bauer Gen. Fil., t. 5; Hook. Fil. Exot., t. 15 ; J. Sm. Ferns, Brit. and For., fig. 91.

OBS.-This genus as here restricted consists of about twenty or thirty species, which are widely spread over the tropics and sub-tropical regions of both hemispheres, with the exception of $P$. geranicefolia; the species of the Eastern and Western hemispheres are respectively distinct.

At page $278 \mathrm{I}$ have stated that it is more on account of habit and texture that has induced me to place this genns under Cheilanthece, than under the tribe Pteridece. In some species originally placed under Pelloea, the sporangia occupy a portion of the upper part of the venules, forming short linear sori, in such cases the apices of venules being free and not connected in a transverse receptacle as in true Pteris; consequently the inflexed margin cannot be viewed otherwise than as an universal indusium analogous to Allosorus.

* Species of the Eastern hemisphere.

Sp. P. geraniæfolia, Fée ( $\nabla$ v.); P. Tamburii, Hook.; P. auriculata, Link. ; P. deltoidea, Baker ; P. Doniana, Hook. ; P. hastata, Link. ( $\nabla$ ₹.); P. Boivini, Hook ; P. consobrina, 


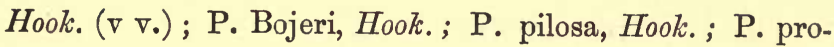
fusa, $J . S m .\left(\nabla_{0} v_{0}\right)$; P. nitidula, $J . S m$. ; P. pulchella, J. Sm.

** Species of the Western heMisphere.

P. lomariacea, Hook.; P. intramarginalis, J. Sm. ( $\nabla$ v.); P. rigida, Hook. (Cheiloplecton, Fêe, Iconogr. Nouv. 33) ; P. Skineri, Hook.; P. Seemanni, Hook.; P. mucronata, Eaton ( $\nabla$ v.) (P. Wrightii, Hook.); P. ternifolia, Link. ( $\left.\nabla \nabla_{0}\right)$; P. ornithopus, Hook.; P. densa, Hook.; P. marginata (Hook.); P. cuneata (Link.) ; P. angustifolia (Humb.)

\section{1.-Onусhium, Kaulf. (1820). \\ Hook. Sp. Fil.}

Vernation fasciculate and decumbent, or distant and subsarmentose. Fronds decompound, multifid, 1 to 3 feet high, smooth; sterile segments cuneiform. Veins forked, free, their apices clavate; fertile segments linear, apiculate, veins simple, short, their apices transversely combined by the receptacle, forming a linear sorus. Indusium slightly intramarginal, its free margin conniving with the margin of the opposite indusium (siliquiform), ultimately becoming replicate, the sporangia of both confluent.

Type. Onychium auratum, Kaulf.

Illust. Hook. and Bauer. Gen. Fil., t. 11 ;. Moore Ind. Fil., p. 28 B.; J. Sm. Ferns, Brit. and For., fig. 95; Hook. Syn. Fil., t. 3, fig. 27.

OBs.-Although the technical character of the sori of this genus does not differ from Pteris, the general aspect of the species is however entirely at variance with the whole of that genus, except $P$. scaberula, which in the smallness of its pinnules presents some similarity to Ony- 
chium. The multifid character of the fronds induces me to place it in Cheilanthece.

Sp. O. auratum, Kaulf. ( $\left.\nabla \nabla_{0}\right)$; O. Japonicum, Kunze. (Leptostigia lucida, Don.) ( $\nabla \nabla_{.}$); O. melanolepis, Kze. ; 0. strictum, Kze.

The three first are natives individually of Arabia, India, and Japan, and the fourth of Cuba.

\section{2.-OCROPTERIS, J. Sm. (1841). Hook. Sp. Fil.}

Vernation decumbent. Fronds contiguous, long stipate, deltoid, decompound, 2 to 3 feet high, smooth glossy; stipes and rachis pale, stramineous; ultimate pinnules and lobes oblong elliptical, cuneiform, marginate, usually oblique. $V$ ins pinnately forked, radiating ; venules direct, apices of the sterile clavate, free, the fertile 2 to 4 converging, and transversely combined by a thick, impressed, sporangiferous, marginal receptacle. Sori oblong, rarely two on each lobe. Indusium formed of the reflexed margin, thick, coriaceous.

Type. Adiantum pallens, Swartz.

Illust. Hook. and Bauer Gen. Fil., t. 106, A. ; Moore Ind. Fil., p. 29, A. ; J. Sm. Ferns Brit. and For., fig. 94 ; Hook. Syn. Fil., t. 2, fig, 22.

OBS.-This genus is founded on a solitary species of very distinct habit, a native of Mauritius. It was originally placed by Swartz in Adiantum, but it is readily distinguished from that genus by the sporangia being seated in the axis of the reflexed indusium and not on its disc, while the convergence of the fertile venules distinguishes it from Pteris.

Sp. O. pallens, J. Sm. ( $\mathbf{v}$ v.), Hook. Sp. Fil., 2, t. 77, B. 


\section{Tribe 21.-PTERIDE $\not A$ (Plate 21).}

Fronds varying from simple, entire, to decompound mul. tifid, and from 1 to 10 or more feet in height, and (with the exception of Doryopteris) of a thin flaccid texture. Veins free or anastomosing, their apices combined forming a transverse, marginal, sporangiferous receptacle, seated in the axis of an exteriorly attached inflexed special indusium forming oblong or continuous marginal sori.

OBs.-I have already explained under Cheilanthece my reasons for separating it from Pteridece, which as now restricted contains about one hundred described species of which the genera Pteris and Litobrochia contain the principal, which technically differ in the venation of the first being free and in the second anastomosed in various ways.

\section{Sect. 1.-Veins anastomosing.}

\section{3.-Doryopteris, J. Sm. (1841).}

Pteris sp. auct., sect. Litrobrochia, Hook. Sp. Fil.

Vernation fasciculate, erect, rarely sarmentose. Fronds simple, cordate-hastate, or palmately-lobed; pinnœ entire or lobed, smooth, opaque, castaneous, stipes and rachis often ebeneous. Veins internal, reticulated. Receptacles transverse marginal, seated in a narrow exterior attached indusium, forming a linear continuous sorus.

Type. Pteris pedata, Livon.

Illust. Hook. and Bauer Gen. Fil., t. 65, B. : Hook. Fil. Exot., t. 34; J. Sm. Ferns Brit. and For., fig. 98.

OBs.-This is a small group of pretty Ferns, with the same general character as regards texture, colour, and smoothness as Pelloea and Cassebeera, but technically distin. 
PL. 21

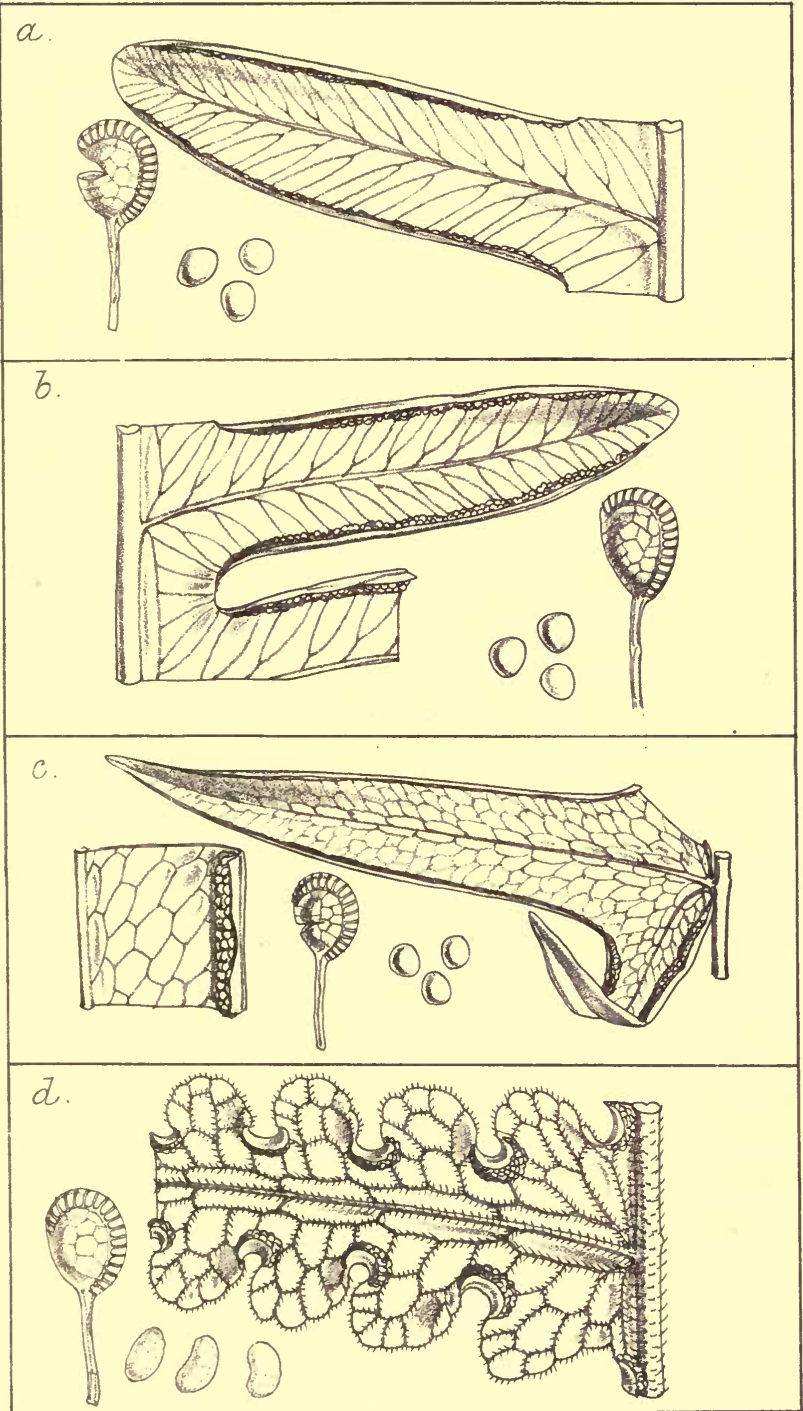

W. H. Fitch del et lith. 

guished by the venation being reticulated, in that respect agreeing with the following genus, Litobrochia.

The following are the principal well-marked species, all of which are natives of the Western hemisphere, except $D$. ludens, which is a native of the Malayan and Philippines, and which also differs from the rest of the species in its rernation being sarmentose.

* Vernation uniserial, sarmentose.

D. ludens (Wall.) (D. Wallichii, J. Sm., 1841; Bedd. F. Brit. Ind., pl. 27).

**Vernation fasciculate, generally coespitose.

D. sagittifolia (Raddi) ( $\nabla$ v.); D. lonchophora (Mett.); D. pedata (Lirn.) ( $\left.\nabla \nabla_{0}\right)$; D. palmata (Willd.) ( $\left.\nabla_{0}\right)$; D. collina (Raddi) ( $\vee \nabla$.$) ; D. ornithopus (Mett.) ; D. decipiens$ (Hook.) ; D. decora (Bracken. Fil., t. 13).

The two latter are natives of the Sandwich Islands, the other's are almost confined to Brazil.

\section{4.-PeLL年OPSIS, J. Sm. \\ Pellcea sp., Hook. Sp. Fil.}

Vernation fasciculate, sub-cæspitose. Fronds 6 to 18 inches or more in length, pinnate or bi-sub-tri-pinnate, firm, smooth, castania-ebeneus; pinnæ and pinnules sessile, articulate with the rachis. Veins anastomosing. Receptacles transverse, marginal, forming a continuous sorus. Indusium narrow.

Type. Pteris articulata, Kaulf.

OBS.-The two species which constitute this genus, agree in general habit with Pellcea, but differ in having reticulate venation, which brings them in affinity with Doryopteris, 
from which they differ in having pinnate fronds, and the pinnæ articulate with the rachis, these differences induce me to consider them as forming a transition genus.

Sp. P. Burkeana (Hook. Sp. Fil., 2, t. 126, B.); P. articulata (Hook. Sp. Fil., 2, t. 126, A.).

The first is a native of South Africa, and the latter of Mauritius, Borbon, and Madagascar.

\section{5.--Litobrochia, Presl. (1836). \\ Pteris. sp. auct., Hook. Sp. Fil.}

Vernation fasciculate, erect or decumbent, often cæspitose. Fronds pinnate or bi-tripinnate, decompound, deltoid, 1 to 10 feet or more in height; ultimate segments broad and often unequally lobed. Veins evident; venules wholly or partially anastomosing, forming unequal areoles, the exterior venules sometimes free. Sporangiferous receptacles linear, transverse marginal, seated in the axis of an inflexed special indusium.

Type. Pteris comans, Forst.

Illust. Hook. and Bauer Gen. Fil., t. 65 B. ; Moore Ind. Fil., p. 32 ; J. Sm. Ferns, Brit. and For., fig. 97 ; Hook. Syn. Fil., t. 3, fig. 31 h.

OBs.-In habit the species of this genus are similar in general appearance to those of the following genus Pteris, but are technically distinguished by their anastomose venation.

The species vary greatly in size, in the circumscription of the fronds, and in their mode of growth; occasionally, indeed, separate parts of a single frond differ so widely that in the herbarium they are apt to be viewed as distinct species.

In the "Species Filicum" thirty-nine species are enume- 
rated, but in the "Synopsis" that number is reduced to twenty-two. They are widely spread throughout the tropics of both hemispheres, extending to New Zealand in the south and Japan in the north.

* Vernation decumbent. Fronds pinnate, pinnoe entire, broad, or the lower one pinnate.

Sp. L. grandifolia (Linn.) ( $\vee$ v.) ; L. pulchra (Schlecht.); L. splendens (Kaulf.) ; L. Haenkeana, Pr. ; L. lanceofolia (Agardh.); L. Mannii (Baker).

** Vernation erect, generally coespitose. Fronds slender, pinnate, lower pinnce tripartite or pinnate.

L. denticulata $(S w).(\nabla \nabla$.$) ; L. leptophylla (Sw.) ( \nabla \nabla$.$) ;$ L. macelenta (A. Cunn.) ( $\nabla$ v.).

*** Vernation decumbent or sub-sarmentose. Fronds bipinnatifid or bipinnate, ultimate pinnules often unequal on the same frond.

L. Orizabø (Mart. and Gal.) ( $\nabla$ v.) ; L. spinulifera (Schum.) ( $\nabla \nabla_{0}$ ) ; L. comans (Forst.) ( $\nabla$ v.) ; L. Endlicheriana $($ Agardh.) ; L. Berteroana (Agardh.); L. Beechyana (Agardh.) ; L. propinqua (Agardh.); L. decurrens (Radd.); L. macroptera (Link.) ( $(\nabla \nabla$.$) ; L. elata (\operatorname{Agardh}).(\mathrm{v} \nabla)$; L. polita (Link.) ( $\mathbf{\nabla} \nabla$.$) ; L. Kunzeana (Agardh.) ( \mathbf{v}$. $)$.

**** Vernation fasciculate, erect, sub-arboroid. Fronds deltoid tripartite, rami, simple or again forked; pinnules pinnatifid.

L. Wallichiana (Agardh.) (Bedd. F. Brit. Ind., pl. 219); L. gigantea (Willd.) ; L. aculeata (Sw., in part); L. tripartita $\left(S w_{0}\right)$ ( $\left(\nabla_{0}\right)$; L. podophylla $\left(S w_{.}\right)\left(\nabla \nabla_{0}\right)$ 
OBs.-The latter species is a noble Fern. A plant received from Jamaica, and cultivated at Kew, attained in 1864 a stout caudex, nearly a foot in height, producing large, spreading, firm fronds, upwards of 10 feet long, with stipes at least 4 inches in circumference, thickly beset with muricate prickles. The large size and different aspect of this species from its congeners, when viewed with its stout arboroid caudex, seems sufficient to render it worthy of being ranked as a distinct genus.

\section{6.-LoNCHITIS, Linn. (1737). Hook. Sp. Fil.}

Vernation fasciculate, erect, subarboroid, laniferous. Fronds bi-tripinnate, 2 to 6 feet long, the ultimate pinnæ sinuouse-pinnatifid. Primary veins costæform, pinnate; venules anastomosing, forming irregular hexagonoid areoles. Sporangiferous receptacles transverse, on the apices of 4 to 5 venules, converging on the sinus of the lobes, forming an arcuate sorus on each sinus. Indusium linear.

Type. Lonchitis aurita, Linn.

Illust. Hook. and Bauer, Gen. Fil., t. 68 A.; Schott. Gen. Fil., t. 30 ; Moore Ind. Fil., p. 31 B.; J. Sm. Ferns, Brit. and For., f. 99 ; Hook. Syn. Fil., t. 2, fig. 23.

OBs.- This genus was founded by Linnæus on tab. 71 of Plumier's Filices, which is represented as having an arculeate stipes, but as no modern specimens of Lonchitis have been observed with that character I am inclined to consider it a mistake of the artist, the other parts of the figure agreeing with the species described by Hooker as $L$. Lindeniana, a native of Venezuela, Plumier's figure being derived from a Martinique plant. 
As a genus Lonchitis is distinguished from Litobrochia by the sori being seated in the sinus of the lacinæ, thus forming a semicircle or crescent, and also in the pubescent character of the caudex and fronds.

In the "Species Filicum" six species are described, but which in the "Synopsis" are reduced to one, a new described species is, however, added, namely, L. occidentalis, Baker. The following species appear to me to be specifically distinct, two of which have been under my notice in a living state.

L. aurita, Linn. (L. Lindeniana, Hook.) ( $\nabla$ v.); L. pubescens, Willd. ( $\nabla$ v.) ; L. Natalensis, Hook.

The first is a native of Mauritius, the two latter of Mauritius and Natal.

\section{7.-Campteria, Presl. (1836).}

\section{Pteris sp. auct., Hook. Sp. Fil.}

Vernation fasciculate, erect. Fronds long stipate, pinnate, 2 to 3 feet high ; pinnæ pinnatifid, the lower pair bipartite, or with one or more pinnules on the inferior side; lacinæ linear oblong, falcate, entire, or serrulate. Veins forked, the lower pair of venules anastomosing, forming a straight arcuate costal arch between the bases of the lacinæ, the rest of the sterile venules being free, the apices of the fertile combined, forming a linear, transverse, marginal sporangiferous receptacle, seated in the axis of an inflexed linear, special indusium.

Type. Pteris biaurita, Linn.

Illust. Hook. and Bauer Gen. Fil., t. 65, A.; Moore Ind. Fil., p. 31, A.

Obs. - The species on which Presl founded this genus agree in general habit with Pteris quadriaurita and its 
allies, but are distinguished by the lower pair of renules of each fascicle anastomosing, forming a row of elongated transverse areoles on each side of the mid-rib, which character I originally considered to be only a simple state of Litobrochia ; I, however, now deem it best to adopt it as a transition genus between Pteris and Litobrochia.

Sp. C. nemoralis (Willd.) ( $\left.\nabla \nabla_{0}\right)$; C. biaurita, (Linn.) ( $\vee$ v.) ; C. geminata (Agardh.)

Natives of the tropics of the Eastern and Western hemispheres. No less than thirty-eight synonyms are placed under C. biaurita by Dr. C. Luerssen.

\section{8.-Histiopteris, Agardh. (1839).}

Pteris sp. auct., Hook. Sp. Fil.

Vernation uniserial, distant; sarmentum elongated, generally epigeous and hirsute squamose. Fronds 1 to 8 feet high, or sometimes scandent, and then ascending to 15 or 18 feet, bi-tripinnate, smooth or glaucous beneath; primary pinnæ and pinnules generally horizontally patent, always opposite and sessile, the lower pair of pinnules of each pinnæ often short and stipuliform, ultimate pinnules or segments entire, sinuose or pinnatifid. Veins anastomosed, or sometimes free. Receptacles transverse, continuous across the anastomoses of the venules, forming a linear, marginal sorus, furnished with an exterior attached, linear indusium.

Type. Pteris vespertilionis, Labill.

Illust. Mett. Fil. Hort. Bot. Lips., p. 59, t. 14.

OBS.-This genus consists of a few species of peculiar habit, differing from Litobrochia in the same manner that Ornithopteris does from Pteris, in this case, as in others, habit being the most obvious distinction. 
Although the species are to all appearances few, their wide distribution has led to the creation of above a dozen species, which in the "Species Filicum" are reduced to five, and in the "Synopsis" to one only. Their mode and places of growth are similar to O. aquilina; among bushes or underwood they assume a scandent character, and often attain a great length. They are chiefly found within or near the tropics of both the old and new world, their most southern limit being Tasmania.

Sp. H. incisa (Thunb.) ( $\mathrm{v}$ v.); H. vespertilionis (Lab.) (v v.) (Nov. Holl, t. 245); H. aurita (Bl.) (v v.) (Mett. Fil. Hort. Lips, t. 14); H. sinuata (Brack. Fil., t. 14).

Sect. 2.-Veins free.

169. PTERIs, Linn. in part (1737).

Hook. Sp. Fil.

Vernation fasciculate and erect or decumbent, or sarmentose uniserial. Fronds pinnate, bi-tri-quadripinnate, rarely simple, from a few inches to 6 or 7 feet high; the ultimate segments entire, sinuose, lobed or pinnatifid. Veins forked; sterile venules free, the apices of the fertile transversely combined by the receptacle, forming a linear marginal sorus, furnished with an exterior attached linear indusium.

Type. Pteris longifolia, Linn.

Illust. Hook. and Bauer, Gen. Fil., t. 64 A. ; Moore, Ind. Fil., p. 30, fig. 1-4; J. Sm., Ferns, Brit. and For., fig. 96 ; Hook., Syn. Fil., t. 3, fig. 31 a. b.

OBs.- This is an extensive genus, containing according to the "Species Filicum" about sixty-three species, but which, in the "Synopsis" are reduced to forty-two. The species present great variation in the circumscription of 
their fronds, which with the vernation being erect or decumbent, enables us to arrange the species as follows.

* Vernation fasciculate, decumbent, ccespitose.

$$
+ \text { Fronds pinnate. }
$$

Sp. P. longifolia, Linn. ( $\nabla$ v.)

OBS. - The wide geographical range of this plant has given rise to the multiplication of specific names, many authors raising the representative of different localities to the rank of species, there being no less than eighteen synonyms given in the "Species Filicum."

P. Moluccana, $B l$.; P. opaca, J. Sm.

+ Fronds pinnate, the lower pair or more of pinnce equally or unequally lobed or pinnate.

P. pellucida, Pr.; P. cretica, Linn. ( $\nabla$ v.); P. heterodactyla, Reinw. (v v.); P. dactylina, Hook.; P. crenata, $S w$. ( $\vee$ v.); P. heteromorpha, F'ée; P. Griffithii, Hook.; P. serrulata, Linn. ( $\mathrm{v}_{0}$ ) ; P. mutilata, Linn. ( $\mathrm{v}_{0}$ ); P. distans, J. Sm. ; P. umbrosa, R.Br. (v v.) ; P. Dalhousiæ, Hook.; P. irregularis, Kaulf.; P. marattiæfolia, Hook.; P. semipinnata, Linn. ( $\mathrm{v}$.) ; P. heterophylla, Linn. ( $\mathrm{v}$.)

** Vernation fasciculate, caudex erect, simple, rarely coespitose.

† Fronds pinnate, pinnoe pinnatifid, the lower pair or more bipartite or pinnate.

P. longipinnula, Wall.; P. argyrea, Moore ( $\left.\mathrm{v} \mathrm{v}_{0}\right)$; P. aspericaulis, Wall. ( $\mathrm{v}$ v.); P. tricolor, Linden ( $\mathrm{v} \mathrm{v}_{\text {. }}$ ); P. quadriaurita, Retz. ( $\nabla$ v.); P. spinescens, Presl ; P. sulcata, Link. ( $\vee$ v.); P. repandula, Link.; P. glancovirens, Linden ( $\left.\nabla_{\bullet}\right)$; P. pungens, Willd. ( $\nabla$ v.); P. decussata, J. Sm. ; 
P. excelsa, Gaud. ; P. lata, Link. ( $\nabla$ v); P. paleacea, Roxb. ( $\left.\nabla_{.}\right)$; P. scabra, Bory. ; P. Kingiana, Endl. ( $\left.\nabla_{.}\right)$; P. flabellata, Thunb. ( $\nabla$ v.); P. straminea, Mett. ( $\vee$ v.); P. arguta, Ait. ( $\nabla$ v.) ; P. tremula, R. Br. ( $\nabla$ v.) ; P. Croesus, Bory.; P. felosma, J. Sm. (v v.) ; P. nemoralis, Hook. and Bauer, t. 64 A. (?) Willd.

†† Fronds tripartitely branched, deltoid, generally

quadripinnate.

P. deflexa, Link. ( $\vee$ v.); P. pellucens, Agardh.; P. connexa, J. Sm.; P. decussata, J. Sm. ( $\nabla$ v.); P. hirsuta, Hook. (Lonchitis, Linn.; P. laciniata, Willd.) ( $\nabla_{0}$ ); P. Griesbreghtii, $J . S m$. ( $\mathrm{v}$ v.).

The above species are widely dispersed, being found in the tropical and subtropical regions of both hemispheres.

170.-ORnithopteris, Agardh. (1839.)

Pteris sp. auct.; Hook. Sp. Fil.

Vernation uniserial, distant, sarmentum hypogeous, thick and fleshy, or epigeous and slender. Fronds tri-quadripinnate, deltoid, from 1 to 6 or 10 feet high, opaque, coriaceous; ultimate segments entire or unequally laciniated. Veins simple or forked, the sterile free, the apices of the fertile transversely combined by the receptacle forming a linear sorus, furnished with a special, exteriorly attached, linear indusium, and also with an accessory indusoid membrane, rising from the inner side of the receptacle, but often obsolete.

Type. Pteris aquilina, Linn.

Illust. Moore Ind. Fil., p. 30, fig. 5, 6 ; Hook. Sp. Fil., t. 141 ; Hook. Syn. Fil., t. 3. fig. 31 d. e. f.

OBs.-The sarmentose caudex and special aspect of 
Pteris aquilina marks it as a type of a small group, distinct from the preceding genus, and as such it is further distinguished by the presence of what is supposed to be an interior indusium, of which the author of the "Species Filicum" says, "Easily as the outer involucre of Pteris aquilina is to be seen, even with the naked eye, the inner one, except in a peculiar state of the sorus (before it is mature) can only be brought to view by careful dissection under the microscope. I have, however, satisfied myself of its existence, though I have often failed to detect it; indeed the fact appears to be ignored by the most distinguished writers on Ferns." My observation on this point is, that there is to be seen in the early stage of the sorus, rising from the interior side of the receptacle, a narrow, thin, elevated fimbriate ridge, but which in my opinion cannot be considered a special indusium analogous to that of Lindscea, and more especially as it is soon obliterated by the growth of the sorus. However, a more evident interior indusium is to be seen in Pteris glutinosa, a Fern of special habit, having alternately branched decompound fronds, agreeing in general mode of growth with Pteris aquilina. In this the sporangia are seated as it were in a slit, similar to that of Lindsaea, but, although such is the case, I cannot view the interior lobe of the slit otherwise than as a thickened lamina. It is, however, a specially marked character, and it is supposed to be the Fern described by St. Hilaire under the name of Poesia, which Mr. Moore adopts, and places it in his section Dicksoniece, next to Cibotium, but with which it has no natural affinity, and cannot be well separated from Pteris.

* Sarmentum thick, fleshy, hypogeous.

Sp. O. aquilina (Linn.); O.caudata (Linn.); O. esculenta (Forst.) 



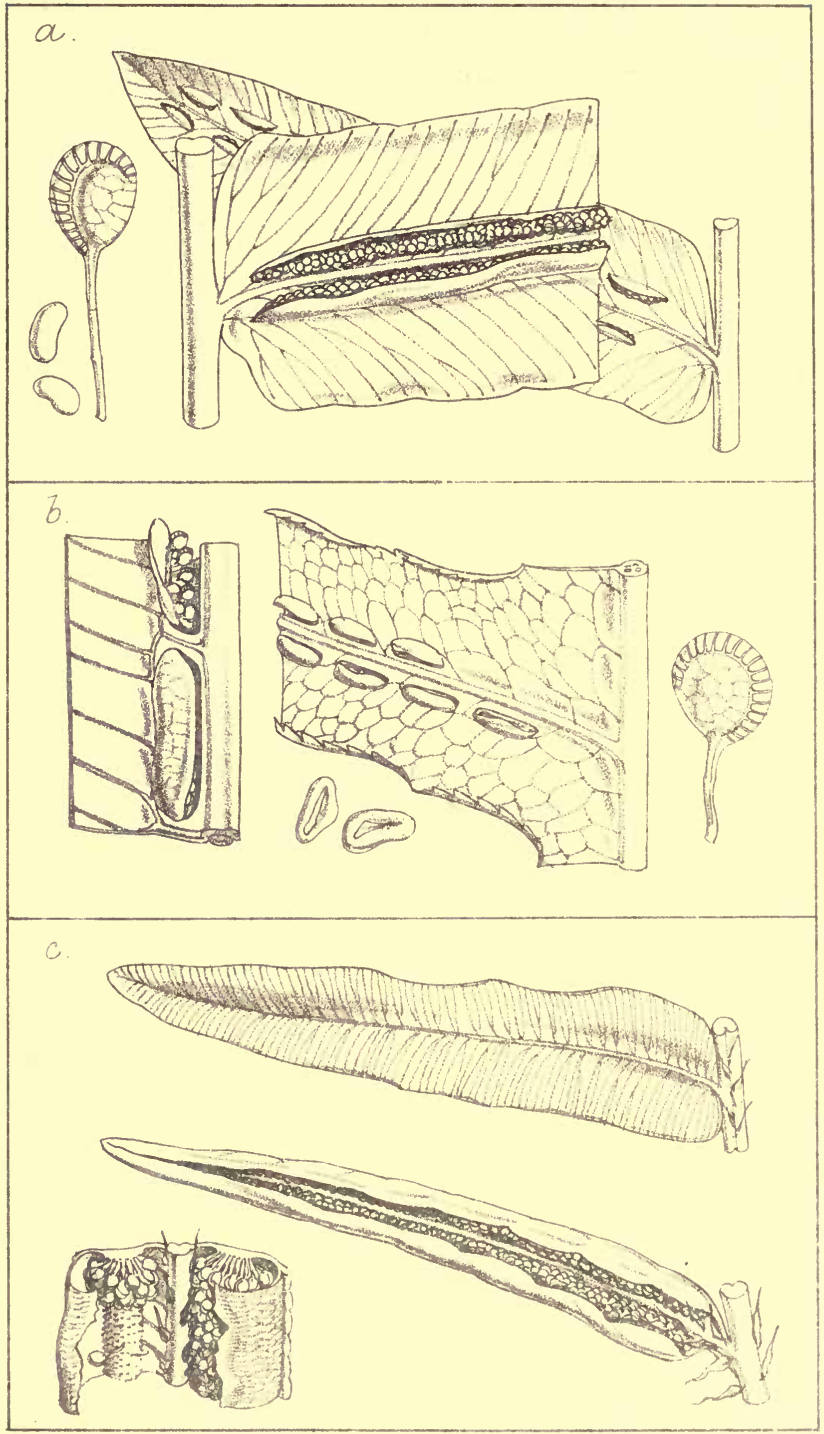

W.FI Fitch del ethth 
OBs.-These three, with their numerous intermediate forms, many of which are described as species by different authors, may be viewed as the most abundant of Ferns on the earth, being found in all temperate and tropical regions, and occupying vast tracts of plane and mountain slope.

** Sarmentum epigeous, paleaceous, sub-scandent.

A. glutinosa, J. Sm. (Pteris glutinosa, Wiles. Herb.; P. scalaris Moritz., Herb. Hook. Sp. Fil.; P. viscosa, Hook. Syn. Fil.; Poesia viscosa, St. Hil, according to Moore).

OBs.-Specimens of this Fern came into my possession about forty years ago, which had been collected in Jamaica by James Wiles, about the beginning of the present century, and named by him Pteris glutinosa. It is also a native of Venezuela and Peru.

O. scaberula (Rich.) (P. microphylla, A. Cunn.)

Native of New Zealand.

The sarmentose vernation of this species agrees with the preceding, but it has no trace of an interior indusium; the fertile segments are very small, with the opposite sori confluent, similar to Onychium.

O. rugulosa, Lab. Sert. New Caledonia, t. 8.

\section{Tribe 22,-BLECHNEA. (Plate 22).}

Vernation sarmentose, fasciculate, acaulose, or rarely subarborescent. Fertile fronds plane or contracted, rachiform. Sori transverse, oblong or linear, continuous, medial or costal. Indusium lateral exteriorly attached, inwardly inflexed, plane or vaulted (absent in Brainea).

OBS.-In the "Species Filicum" 107 species are described as belonging to this Tribe, the greater number being contained in the genera Blechnum and Lomaria. In the 
"Synopsis" of the above work, the number is reduced to seventy. With a few exceptions they are stemless, generally cæspitose, with smooth glossy fronds, a few only being slightly pilose or furnished with glands. The greater number have free venation, but anastomose venation characterises Woodwardia and its allies.

\section{0.-Blechndm, Linn., in part (1754). \\ Hook. Sp. Fil.}

Vernation fasciculate, cæspitose, often stoloniferous, or solitary erect, sub-arborescent. Fronds simple, pinnatifid or pinnate, from a few inches to 4 to 6 feet high; pinnæ adherent or rarely articulated with the rachis. Veins forked; the sterile venules free, or their apices thickened and forming a cartilaginous margin; the veins of the fertile pinnæ combined near their base by a transverse, continuous, sporangiferous receptacle, constituting a linear, costal, or rarely extra-costal sorus. Indusium linear, plane.

Type. Blechnum occidentale, Linn.

Illust. Hook. and Bauer, Gen. Fil., t. 54 B. ; Moore Ind., p. 11 B. ; J. Sm. Ferns, Brit. and For., fig. 100 ; Hook. Syn. Fil., t. 4, fig. 34.

OBs.-In the "Species Filicum" forty species of Blech. num are described, but in the "Synopsis Filicum" they are reduced to eighteen.

Great confusion exists in the synonymy of this genus with that of Lomaria, the most obvious distinguishing character being in the fertile fronds of the latter being contracted, but I must admit that this distinction is not always definite, it being difficult to determine to which genus certain intermediate forms belong, and, to make the matter worse, Presl characterises the species of Blechnum under 
no less than ten genera, several of which I adopt as sectional names only.

The species are widely distributed within or near the tropics of both hemispheres.

\section{* Apices of the venules free. \\ + Sori costal (Blechnum, Presl.).}

Sp. B. lanceola, Sw. ( $\nabla$ v.) var. B. trifoliatum, Kaulf.

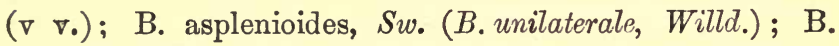
glandulosum, Link. ( $\nabla$ v.); B. cognatum, Presl ( $\nabla$ v.) ; B. polypodioides, Radd, Fil. Bras., t. 60, fig. 2 ( $\mathrm{v}$ v.) ; B. triangulare, Link. ( $\nabla$ v.) ; B. occidentale, Linn. ( $\nabla$ v.) ; B. campylotis, J. $S m$. ( $\nabla$ v.) (Lomaria, Kze.; B. arcuatum? $C$. Gay); B. australe, Linn. ( $\nabla$ v.) ; B. gracile, Kaulf. ( $\nabla$ v.); B. longifolium, H. B. K. ( $\left.\nabla \nabla_{0}\right)$; B. intermedium, Link. ( $\nabla$ v.); B. fraxineum, Willd. ( $\nabla$ v.); B. Fendleri, Hook. (Sp. Fil., 3 t. 158).

+† Sori medial or nearly so (Mesothema, Pr.).

B. hastatum, Kaulf. ( $\nabla \nabla$.$) .$

OBs.-Presl refers ten species to this section, several of which are not well identified species, and others more properly belong to Lomaria.

** Apices of the venules thickened, forming a cartilaginous margin (Blechnopsis, Presl). + Pinnoe adherent to the rachis.

Sp. B. brasiliense, Desv. ( $\mathrm{v}$ ) ; B. cartilagineum, $S w$.

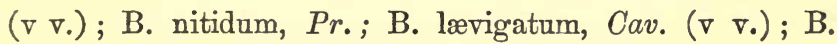
orientale, Linn. (v v.) ; B. Finlaysonianum, Wall.

+† Pinnce articulated with the rachis (Diafnia, Pr.). B. striatum, R. Br. ( $\nabla$ v.) ; B. serrulatum, Rich. ( $\nabla$ v.). 
OBs. - Of the twenty-two species here enumerated eighteen have come under my notice in a living state, several of which are recorded as synonyms in the "Synopsis Filicum," but my observations on the living plants satisfy me that the above are sufficiently distinct to be viewed as species. The synonymy of many of the species is, however, most difficult to unravel, for instance, $B$. orientale has no less than thirty-eight, and $B$. occidentale nearly twenty synonyms.

Blechnum melanopsis of the "Species Filicum" is described as being a pinnate species, about a span in length, similar in appearance to a young frond of $B$. orientale, but differing from Blechnum in having reticulate venation, which $\mathrm{Mr}$. Moore has thought proper to adopt as characteristic of a distinct genus, which he names Blechnidium. The description of this Fern is taken from a solitary frond gathered in Khasya, which probably may turn out to be a young state of a Woodwardia.

\section{1.-Lomaria, Willd. (1809).}

Hook. Sp. Fil.; Blechnum sp. auct.; Stegania, R. Br.

Vernation uniserial, sarmentose or fasciculate, erect, cæspitose or subarborescent. Fronds simple, pinnatifid, or pinnate, rarely bipinnatifid, 1 to 3 feet high, the fertile always contracted. Veins (of the sterile frond) forked; venules free, their apices usually clavate ; fertile segments rachiform, veins obsolete, or more or less evident, and by their contiguity forming a broad, transverse, continuous, sporangiferous receptacle, the sporangia becoming confluent over the whole disc of the segment. Indusium linear, sub-intramarginal, vaulted, and involute, the margin oppositely 
conniving enclosing the sporangia of both receptacles, ultimately becoming replicate and generally torn.

Type. Lomaria nuda, Willd.

Illust. Hook. and Baver, Gen. Fil., t. 64, B. ; Moore Ind. Fil., p. 11, A. ; J. Sm. Ferns Brit. and For., fig. 103 ; Hook. Syn. Fil., t. 3, fig. 33.

OBs.-As already stated, the only character that distinguishes this genus from Blechnum is in the fertile fronds being contracted. In the "Species Filicum," Sir William Hooker says, "a more careful investigation of several species of Lomaria shows that they gradually depart from their pteroid character, and completely merge into Blechnece."

The genus consists of between thirty and forty known species, and as in Blechnum, the synonym of the species is confusing; they are widely distributed throughout the tropical and temperate regions of both hemispheres, extending from the latitude of New Zealand in the South to the limits of Fern life in the North, where the genus is represented by the well-known Lomaria spicant, better known in this country as Blechnum boreale, of which, of late years, numerous abnormal forms have been discovered, consisting in the fronds being distorted in various ways; some of these are so unlike the typical form, that without being acquainted with their origin they would by some pterodologists be considered as types of distinct species, thirty-six of these forms are recorded in Mr. Stansfield's Catalogue.

* Vernation sarmentose, epiphytal. Sterile fronds pinnatifid, sinus generally large, obtuse, round (Lomaridium, Presl, J. Sm.).

Sp. L. onocleoides, Spr. ( $\mathrm{v}$ v.); L. Plumieri, Desv.; L. attenuata, Willd. ( $\nabla$ v.); L. pteropus, Kze.; L. elongata, Bl. $(\nabla$ v.) ; L. Colensoi, Hook. 
** Vernation fasciculate, generally cœspitose (Stegania, R.Br.)

+ Fronds simple, occasionally lobed or subpinnatifid. L. Patersoni (R. Br.) ( $\nabla$ v.).

+† Fronds (Sterile) linear lanceolate, pinnatifid, rarely subpinnate.

L. Spicant, Lesv. ( $\nabla$ v.) ; L. alpina, Spr. ( $\nabla_{0}$ ) ; L. Banksii, Honk. fil. ( $\nabla_{\text {v.) }}$; L. nigra, Col. ( ( v.) ; L. Germainii, Hook. ( $\vee$ v.) ; L. membranacea, Hook.; L. fluviatilis, Spr. ( $\vee \nabla$ ) ; L. aspera, Hook. ; L. rigida, J.Sm. (I. dura, Moore)

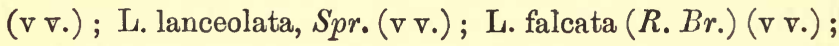
L. L'Herminieri, Bory. ( $\mathrm{v}$ v.) ; L. blechnoides, Bory. ( $\vee$ v.); L. discolor, Willd. ( $\left.\nabla \nabla_{0}\right)$; L. nuda, Willd. ( $\nabla_{0}$ ) ; L. vulcanica. $B l .\left(\begin{array}{r}\nabla \\ \nabla\end{array}\right)$.

*** Vernation erect, acaulose. Fronds pinnate (Loxochlena).

L. punctulata $\left(S w_{0}\right)$.

OBS. - This is a native of South Africa, and varies considerably in the character of its fertile pinnæ, some being so contracted as to justify the species being placed in Lomaria, while others are broad, and have distinct Blechnoid sori. Scolopendrium Krebsii of Kunze, also a native of South Africa, is considered by some to be a state of this species; it differs in the transverse soriferous vein not being straight, but forming numerous acute angles pointing outwards, the interior sides of the angles being sporangiferous, thus facing one another as in the scolopendroid genus Antigramma, which character led Kunze to refer it to Scolopendrium. In the "Species Filicum" it is viewed as a synonym of $L$. punctulata. But as living plants of both forms have been under my notice for many years, and as both have retained their respective characters, I am therefore inclined to consider them as distinct species. 
L. Krebsii, J. Sm. (Scolopendrium Krebsii, Kze. in Scht. Fil. Suppl., t. 74, Bot. Mag., t. 4768).

***** Vernation erect, acaulose or sub-arborescent (3 to 4 feet high) (Lomariocycas, $J$. Sm.).

+ Fronds pinnate.

L. Gilliesii, Hook. and Grev. ( $\nabla$ v.); L. minor, Spreng. ( $\nabla$ v.); L. procera, Spreng. ( $\nabla$ v.); L. tuberculata, J. Sm. ( $\mathrm{v}$ v.); L. longifolia, Schlecht.; L. capensis, Willd. ( $\vee$ v.); L. gigantea, Kaulf. ( $\vee$ v.) ; L. striata, Willd. ( $\nabla$ v.)

OBs.--In the "Flora of New Zealand" Dr. Hooker says that he cannot specifically distinguish Lomaria procera of New Zealand, the West Indian L. lineata, the South American L.chilensis, and the South African L. capensis one from the other; this view is also adopted in the "Species Filicum," with the addition of L. Gilliesii, $L$. daneacea, $L$. ornifolia, $L$. spectabilis, $L$. tuberculata, L. longifolia, L. vestitx, and L. squamulosa. Such is the decision arrived at by the examination of herbarium specimens; but six of the above number have been observed by me in a living state, which I have no hesitation in adopting as distinct species.

L. ciliata, Moore; L. gibba, Lab. ( $\vee$ v.) ; L. Boryana, Willd. ( $\nabla$ จ.)

OBS.-This Fern was originally described by Bory under the name of Pteris osmundioides, from specimens collected by him in Bourbon. In Swartz's "Synopsis" it is described under the name of Onoclea Boryana, and afterwards by Willdenow as Lomaria Boryana; it is described as having a stem 3 to 4 feet high, with a diameter of 5 to 6 inches, bearing a crown of firm pinnate fronds 2 to 3 feet in length. It is found or is represented by closely allied forms in many countries far apart, which circumstance has 
led to the creation of many species, one of which is $\boldsymbol{L}$. magellanica of Desvaux (Hook. Gard. Ferns, t. 52), a native of Tierra del Fuego, under which, in the "Species Filicum," L. Boryana is quoted as a synonym; but this is reversed in the "Synopsis Filicum." The following are also treated as synonyms of L. magellanica; L. cinnamomea, Kaulf, South Africa ; L. robusta, Carm., Tristan d'Achuna; L. setigera, Gaud., South Brazil ; L. zamioides, Gard. Brazil (Organ Mountains); L. Ryani, Kaulf., West Indies ; L. rufa, Spreng. (L. Chilensis, Kaulf.), Chili ; L. cycadifolia, Colla, Tropical America; L. palmoeformis, Thouars, Mauritius; L. lanuginosa, Kze., Natal. The only living examples of these seen by me are $L$. magellanica and $L$. cycadifolia, which I adopt as distinct species; and it is probable that some of the others when seen together in a living state, will also be recognised as distinct.

\section{t+ Fronds pinnate; pinnoe pinnatifid.}

L. Fraseri, $A$. Cunn.

OBs.-This is a native of New Zealand, it has a stem about the thickness of a walking-stick, attaining the height of several feet.

\section{2.-SADLERIA, Kaulf. (1824). \\ Hook. Sp. Fil.}

Vernation fasciculate, erect, arborescent ( 2 to 3 feet high), stout. Fronds 3 to 4 feet long, rigid, bipinnatifid, pinnæ linear lanceolate, 10 to 12 inches long, contiguous, sessile, articulated with the rachis, deeply pinnatifid, coriaceous, opaque; lacinæ $\frac{3}{4}$ to 1 inch long, linear falcate. Veins obscure, arcuately anastomosing, forming costal areoles; venules simple or forked, their apices terminating in a thickened margin. Sporangiferous receptacle transverse, 
linear, continuous on the costal anastomose, elevated in the form of a ridge. Indusium linear, laterally attached on the exterior side of the receptacle, its inner margin free, becoming reflexed, coriaceous, persistent.

Type. Sadleria cyatheoides, Kaulf.

Illust. Moore Ind. Fil., p. 12, B. ; Hook. Syn. Fil., t. 4, fig. 35.

OBS.-The type of this genus was originally described as a species of Blechnum, under which genus I placed it in 1841, my first arrangement, but on account of its very distinct habit I now deem it best to separate it from Blechnum. With Lomaria Boryana it agrees in having a stout arborescent caudex, but differs in having regular pinnatifid pinnæ, which are articulate with the rachis.

Sp. S. cyatheoides, Kaulf.; S. squarrosa, Gaud. Voy. Bonit. Atlas, t. 2.

Natives of Sandwich Islands. S. pallida, Hook. and Arn.; S. Souleytiana (Gaud.) and S. Kaulfussiana (Gaud.) are considered to be only different states of $S$. cyatheoides.

\section{3.-Bratnea, J. Sm. (1856).}

Hook. Sp. Fil., Bowringia Hook. (1853) non Benth.

$V$ ernation fasciculate, erect, arborescent, 2 to 4 feet high. Fronds pinnate, rarely sub-bipinnate, 2 to $3 \frac{1}{2}$ feet long; pinnæ linear lanceolate, 4 to 6 inches long, sub-sessile, base truncate above, auriculated below; margin crenate serrulate. Veins flabellately forked, free exteriorly, the lower venules short and angularly anastomosing, forming a row of oblique costal areoles. Sporangia produced on the angular anastomoses, and lower part of the exterior free venules, confluent, constituting a broad, compound, continuous or sub-interrupted, transverse naked sorus. 
Type. Brainea insignis, Hook.

Illust. Moore, Ind. Fil., p. 34 A.; J. Sm., Ferns, Brit. and For., fig. 103 ; Hook. Syn. Fil., t. 6, fig. 53.

OBS.-A solitary species constitutes this genus, the affinity to which is difficult to determine. The stout Zamia-like caudex, squamose vernation, and pinnate, rigid fronds indicate a relationship in natural affinity with Lomaria Boryana and Sadleria cyatheoides, but its being destitute of an indusium and the anastomose venation of its sterile fronds, distinguishes it from these genera. In the "Species Filicum" it is placed next to Gymnogramme, which includes species with both free and anastomose venation, and if the lines of sporangia of Brainea are viewed as simple sori, it has therefore as good a claim to be placed in Gymnogramme as many other species placed in that genus, as characterised in the "Species Filicum."

On taking all points into consideration, and the circum. stance of a cultivated plant of Brainea at Kew having produced a bipinnatifid or almost bipinnate frond, proves that the more usual simple pinnate state is not the normal condition of development, and such gives it more of an affinity with Sadleria It is found in two localities, namely, Hong Kong, Khasya in Eastern Bengal.

Sp. B. insignis (Hook.) ( $\nabla$ v.), Hook. Fil. Exot., t. 38.

\section{4.-DOODIA, R. Br. (1810). \\ Hook. Sp. Fil.}

Vernation fasciculate, erect, acaulose. Fronds lanceolate, pinnatifid or pinnate, the fertile sometimes sub-contracted, segments serrate or spinulose. Veins forked, the lower renules transversely anastomosing and sporangiferous. Riceptacles medial, elongated, constituting one, or some- 
times two, transverse rows of oblong, straight, or arcuate sori. Indusium plane.

Type. Doodia aspera, R. Br.

Illust. Hook. and Bauer, Gen. Fil., t. 54 A.; Moore Ind. Fil., p. 33 B., fig. 2-4; J. Sm., Ferns, Brit. and For., fig. 101; Hook. Syn. Fil., t. 4, fig. 37.

OBs.-This genus consists of about six presumedly distinct species, and which are better recognised by seeing the living plants than by herbarium specimens. They are natives of New Zealand, Australia, and the islands of the Pacific.

In habit they agree with Blechnum, but are distinguished by having definite oblong sori often in two rows, technically agreeing with Woodwardia, to which they are united by some authors. With Lomaria they are connected through D. caudata, which has two kinds of fronds, the fertile being contracted, and the sori sub-continuous.

\section{* Fronds pinnatifid.}

Sp. D. aspera, R. Br. ( $\nabla$ v.); D. blechnoides, A. Cunn. $(\vee \nabla$.$) ; D. dives, Kunze ( \nabla$ v.), Bedd. F. S. Ind., pl. 222 ; D. linearis, C. Moore ( $\nabla \nabla$.$) .$

\section{** Fronds pinnate.}

D. media, R. Br. ( $\left.\nabla \nabla_{0}\right)$; D. lunulata, $R . B r .\left(\nabla \nabla_{0}\right)$; D. connexa, Kunze; D. caudata, R. Br. ( $\nabla$ v.)

\section{5.-Woodwardia, Smith (1793).}

$$
\text { Hook. Sp. Fil. }
$$

Vernation fasciculate, decumbent. Fronds bipinnatifid, 4 to 6 feet long ; pinnæ lanceolate, entire, sinuose or deeply pinnatifid, 6 to 18 inches long. Veins reticulated, or the 
exterior venules free; the costal anastomoses transverse, elongated, and sporangiferous. Sori oblong, contiguous, forming a sub-costal medial row. Sporangia immersed. Indusium vaulted.

Type. Blechnum radicans, Linn.

Illust. Hook. and Bauer Gen. Fil., t. 17 ; Moore Ind. Fil., p. 33 B., fig. 1 ; J. Sm. Ferns, Brit. and For., fig. 104; Hook. Syn. Fil., t. 4, fig. 36 a.

OBS.-This is a well marked genus which in the "Species Filicum" is represented by six species, three of which I, however, exclude from true Woodwardia, as I consider them sufficiently distinct to warrant their adoption under the two following genera.

The species here restricted to Woodwardia are remarkable for producing numerous viviparous buds, which readily become plants.

Sp. W. radicans, $S m .(\nabla \nabla$.$) ; W. orientalis, S w .(\vee \nabla$.$) ;$ W. Japonica, $S w$. ( $\nabla \nabla$.$) .$

The two latter species are natives of China and Japan; the first is found in the South of Europe, Madeira, Azores, Java, Mexico, California, Guatemala, and Northern India.

\section{6.-Lorinseria, Presl (1849). \\ Woodwardia, Hook. Sp. Fil.}

Vernation uniserial, sarmentum hypogeous. Fronds distant, sinuose-pinnatifid or sub-pinnate, 1 to $1 \frac{1}{2}$ feet high, the fertile contracted. Veins of the sterile frond uniform reticulated; fertile segments rachiform, costal anastomoses transverse-elongated, sporangiferous. Sori oblong-linear, contiguous, forming a costal row. Indusium vaulted.

Type. Acrostichum areolatum, Linn. 
Illust. Metten. Fil. Hort. Lips., t. 6, f. 6, 7 ; J. Sm. Ferns, Brit. and For., fig. 107 ; Hook. Syn. Fil., t. 4, fig. $36 \mathrm{~b}$.

OBS.-The single species constituting this genus is placed by most authors in Woodwardia, but its sarmentose, hypogeous vernation and contracted fertile fronds have induced me to follow Presl, and adopt it as a distinct genus.

Sp. L. areolata, Presl ( $\nabla$ v.); L. Harlandii (Hook. Fil. Exot., t. 7).

The first is a native of North America and the second of Hong-Kong.

\section{7.-Anchistea, Presl. (1849).}

Woodwardia Sm. Hook. Sp. Fil.

Vernation uniserial; sarmentum hypogeous. Fronds bipinnatind, 1 to 2 feet high. Veins flabellately forked; the lower venules transversely anastomosing and sporangiferous. Sori oblong, contiguous, in a continuous costal row. Indusium linear plane.

Type. Blechnum virginicum, Linn.

Illast. Metten. Fil. Hort. Lips., t. 6, f. 1, 2 ; J. Sm. Ferns, Brit. and For., fig. 105.

OBS-The reasons assigned for retaining the last genus are applicable to this, which also consists of one species, a native of North America.

Sp. A. virginica, Presl. ( $\nabla$ v.).

\section{8.-ONOCLEA, Linn., in part (1751). \\ Hook. Sp. Fil., in part.}

Vernation uniserial, distant; sarmentum hypogeous. Sterile fronds sub-bipinnatifid. Veins reticulated. Fertile 
fronds contracted, bipinnate, segments baccæform, compactly filled with sporangia, which rise from four to six punctiform receptacles, each furnished with a lateral, cucullate, membraneous indusium.

Type. Onoclea sensibilis, Linn.

Illust. Hook. and Bauer, Gen. Fil., t. 82 ; Moore, Ind. Fil., p. 65 A. ; J. Sm., Ferns, Brit. and For., fig. 106 ; Hook., Syn. Fil., t. 1, fig. 9.

OBs.-This genus, as here restricted, consists of a solitary species of peculiar habit and somewhat doubtful relationship. In my Arrangement of 1841, and previously (1838), in a note at tab. 82 of Hooker and Bauer's "Genera Filicum," I stated that the membraneous scales found interposed between the confluent sori were truly special laterally attached indusia, and I therefore placed it in proximity with Aspidium, thas removing it from the vicinity of Blech. num and Woodwardia, where it originally stood, but later and more careful examination of the natural affinities of Ferns, has led me to place it again in the tribe Blechnece, its nearest ally being the genus Lorinseria.

In the "Species Filicum" the genus Struthiopteris is united with Onoclea, but it is quite at variance with Onoclea technically as well as in habit.

Sp. O. sensibilis, Linn. ( $\nabla \nabla$.

A native of North America.

\section{9.-Stenochlana, J. Sm. (1841).}

Acrostichum auct., Hook. Sp. Fil.

Vernation uniserial, distant, sarmentum elongated, scandent. Fronds 2 to 3 feet long, of two forms, the sterile pinnate, the fertile contracted, pinnate or bipinnate ; pinnæ articulated with the rachis. Veins rising from an obscure 
transverse vein, continuous with, and close to the mid-rib; venules simple or forked, direct, their apices clavate, united forming a pellucid cartilaginous spinulose margin ; fertile segments linear, rachiform, margin membraneous, involute, indusæform. Sporangia occupying the whole disc of the narrow segment.

Type. Acrostichum scandens, Linn.

Illust. Hook. and Bauer, Gen. Fil., t. 105 B.; Moore Ind. Fil., p. 3 B. ; J. Sm. Ferns Brit. and For., fig. 108 ; Hook. Syn. Fil. t. 7, fig. 60, f. g.

OBs.-In my original definition of this genus in 1841, the renation is said to be free, which is strictly the case with several species which $I$ then placed under it (now species of Lomariopsis). Since then I have had the opportunity of examining living plants of $S$. scandens, in which I find the pinnæ of the sterile frond have a transverse anastomose vein continuous with and close to the mid-rib, but which on account of the narrowness of the fertile pinnæ is not evident, the sporangia occupying the whole segment as in Lomaria, which with its narrow involute indusoid margin indicates its affinity to be with the present tribe Blechneoe, rather than with Acrosticheoe.

Sp. S. scandens (Linn.) ( $\left.\vee v_{0}\right)$ (Lomaria scandens, Willd.); S. Meyeriana, J. Sm. ( $\vee$ v.) (Lomaria, Kze.; Acrostichum, Meyeriana, Hook. Gard. Ferns, t. 16).

OBs.-The latter is a native of Natal, the first is very generally spread throughout India, the Malayan Archipelago, the Philippines, and the Islands of the Eastern Pacific, assuming different appearances according to the various local influences of climate, which has led to its being described by authors under many different names. The sterile pinnæ are occasionally variously lobed or sinuose, two of such forms having been named by Wallich 
Lomaria spondicefolia and L. limonicefolia. This species is also remarkable in producing on its sarmentum what may be termed an adventitious growth, so unlike the true fronds that, without good evidence, it would be difficult to believe that they are productions of the same plant. It is about 3 or 4 inches long, and not unlike some multifid species of Davallia or Cheilanthes. Wallich named it Davallia achilleifolia (Hook. Sp. Fil., 1, t. 56 d.), seemingly not aware that it grew on Stenochlcena. Tab. 209 of Beddome's "Ferns of British India" represents a state of this from Burmah. Its mode of production may be considered analogous to the growth observed on the stipes of some species of Alsophila, which Kaulfuss described under the name of Trichomanes? cormophyllum.

\section{0.-SaLpichlanka, J. Sm. (1841).}

Blechnum sp. Kaulf.; Hook. Sp. Fil.

Vernation sub-fasciculate, decumbent. Fronds bipinnate, flexuose, climbing, indefinite; pinnæ 1 to 2 feet long; pinnules 2 to 8 pairs, linear or broad-lanceolate, acuminate, 6 to 16 inches long, $\frac{1}{2}$ to 2 inches wide, smooth, shining, entire. Veins forked; venules combined in the sterile by a transverse marginal vein, and in the fertile by a transverse costal vein, which bears the sporangia, forming a linear, transverse, sub-costal sorus. Indusium laterally attached on the exterior side of the receptacle, involute, vaulted, cylindrical, its base partially sporangiferous, its inner margin free, becoming reflexed, rigid, separating in pieces, afterwards increasing in size.

Type. Blechnum volubile, Kaulf.

Illust. Hook. and Bauer, Gen. Fil., t. 93 ; Moore Ind. Fil., p. 12 A. ; J. Sm. Ferns, Brit. and For., fig. 109. 



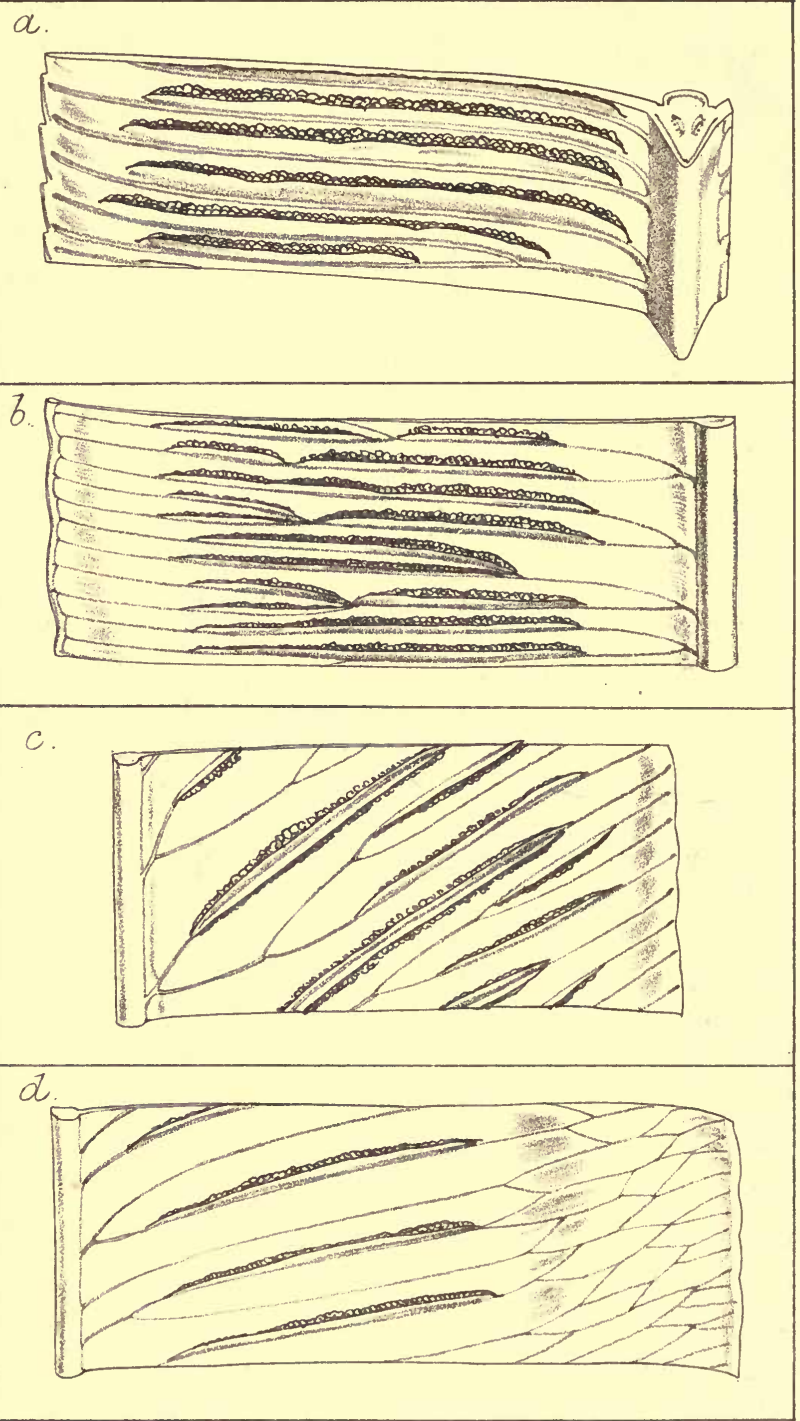


OBs.-This genus is founded on a remarkable Fern, a native of Brazil, New Granada, and other parts of Tropical America, climbing to the tops of lofty trees, similar to the genus Lygodium. In the character of its fructification it does not differ much from Blechnum, but has the veins combined at the margin, and, with the peculiar nature of the indusium, which continues long permanent, and even enlarges in size after it has become reflexed, is sufficient to mark this as a genus distinct from Blechnum.

Sp. S. volubile, J. Sm. (v v.) (Hook. Gard. Ferns, t. 15).

\section{Tribe 23.-ASPLENIE $\approx$. (Plate 23).}

Sori oblong or linear, oblique to the mid-rib or axis of renation. Sporangia produced on one side (unilateral) or on both sides of the same venule (bilateral), each furnished with a plane or vaulted lateral operculiform linear indusium, opening interiorly or exteriorly.

OBs.-In the "Species Filicum" 307 species are described as belonging to this Tribe, but which in the "Synopsis" of that work are reduced to 282 ; but in the Appendix to the second edition 50 additional are recorded. They are found in all regions of the earth favourable to Fern life, some growing on cliffs or rocks, exposed to the extremes of heat and cold, others in shady ravines or caves, others on the ground or on trees, presenting great variation in the size and form of their fronds, which are generally fasciculate or rarely uniserial, the axis of vernation being generally acaulose, a few becoming subarborescent. The numerons intermediate forms render it most difficult to arrive at any satisfactory conclusion as to the number of distinct species. In Moore's "Index Filicum" Asplenium occupies 70 pages, 
and which contains no less than 2,059 names, of which 335 are adopted species, the rest being synonyms.

The greater number were originally comprehended under two genera, namely, Asplenium and Diplazium, but even these are not considered by some to be generically distinct. In the greater mass the veins are free, in a fow they are anastomose, and which with the different modes of growth afford sufficient characters for arranging the species under the following genera.

* Veins free.

\section{1.-Asplenium, Linn. (1737).}

Hook. Sp. Fil.; Tarachia, Pr.; Loxoscaphe, Moore.

Vernation fasciculate, decumbent, or erect, acaulose, rarely uniserial sarmentose. Fronds varying from simple entire to decompound, and from a few inches to 2 to 6 feet high, generally smooth. Veins forked or pinnate, from a central or excentric costæ, or rayed; venules free, sporan. giferous on the superior side. Sori oblong or linear, in some very short and marginal. Indusium lateral operculiform, opening exteriorly.

Type. Asplenium marinum, Linn.

Illust. Hook. and Bauer Gen. Fil., t. 30 ; Moore Ind. Fil., p. 36 ; J. Sm. Ferns, Brit. and For., fig. 110.

OBs.-In the "Species Filicum" about 287 species are enumerated, which are divided into four sections, namely, Thamnopteres, Eusasplenium, Athyrium, and Eudiplazium, which I characterise as distinct genera. In "Ferns, British and Foreign," 120 species are enumerated as having been seen by $m e$ in a living state, and as they contain examples representing the principal sections and groups, I here enumerate them. 
* Vernation uniserial distant; sarmentum slender.

Sect. 1.-Cheilosorum, Mett.

Fronds pinnate, 6 to 14 inches long; pinnoe numerous, approximate, $\frac{3}{4}$ to 1 inch long, oblong lanceolate, dimediate. Costue excentric, contiguous to the lower entire margin, superior margin deeply laciniated. Sori short, oblong, on the apex of the vein terminating each lacince.

Sp. A. heterocarpum, Wall ( $\vee$ v.)

OBs.-In the general outline and glossy texture of the frond this agrees with the Trichomanoid section, but its uniserial vernation and apical sori mark it as being dis. tinct.

$$
\text { ** Vernation fasciculate. }
$$

Sect. 2.-Ceterachopsis, $J$. Sm.

Fronds 6 to 9 inches long, 1 to $1 \frac{1}{2}$ inch wide, smooth, deeply pinnatifid, lacince uniform, obtuse. Veins dichotomously forked. Sori oblong linear, the lower ones subparallel with the costce.

\section{A. alternans, Wall. ( $\nabla$ v $)$.}

Obs.-Of this species Sir William Hooker says, "this is a very peculiar looking plant, which, but for the absence of the scaly covering, might be mistaken for Asplenium ceterach, which also is known to have a minute asplenoid involucrum, in this species, however, the reins are free."

\section{Sect. 3.-Asplenites.}

Vernation erect or decumbent. Fronds simple or pinnate.

\section{Phylutiss Grodp.}

Fronds entire, linear lanceolate or broad elliptical.

A. ensiforme, Wall.; A. sinuatum, Beauv. ( $\nabla$ v.); A. squamulatum, Blume ( $\nabla$ v.); A. Griffthianum, Hook.; A. serratum, Linn. ( $\nabla$ v.). 


\section{Hemionites Group.}

Fronds hastate or palmately lobed.

A. subhastatum, Hook.; A. Hemionitis, Linn. ( $\nabla$ v.).

\section{Luciddm Group.}

Fronds pinnate; pinno generally oblique, cuneiform at the base.

A. lucidum, Forst. ( $\mathrm{v}$ v.); A. heterodon, Blume ( $\mathrm{v}$ v.); A. gemmiferum, Schrad. ( $\nabla$ v.); A. emarginatum, Beauv. ( $\vee$ v.); A. obtusatum, Forst. ( $\vee$ v.) ; A. obliquum, Forst. ( $\left.\vee \nabla_{\text {. }}\right)$; A. oligophyllum, Kaulf. ( $\left.\nabla \nabla_{.}\right)$: A. angustifolium, Mich.

\section{Auriculatum Group.}

Fronds pinnate; pinnce 1 to 2 inches in length, generally having a more or less evident lobe or auricle on the superior edge of their base.

A. hastatum,'Klotsch. ( $\nabla \nabla$.$) ; A. salicifolium, Linn. ( \nabla \nabla$.$) ;$ A. compressum, $S w$. ( $\nabla \nabla$.$\left.) ; A. obtusifolium, Linn. ( \nabla \nabla_{0}\right)$; A. tenerum, Forst., Schk. Fil., t. 69 ( $\nabla$ v.) ; A. marinum, Linn. ( $\nabla \nabla$.$) ; A. elongatum, Sw. ( \nabla$ v.); A. firmum, Kunze ( $\left.\nabla \nabla_{0}\right)$; A. pumilum, $S w .(\nabla \nabla$.$\left.) ; A. dentatum, Linn. ( \nabla \nabla_{0}\right)$; A. pulchellum, Radd. ( $\nabla \nabla_{0}$ ); A. elatum, Humb. ( $\left.\nabla \nabla_{0}\right)$.

\section{Trichomanes Group.}

Fronds pinnate, linear, 3 to 12 or more inches long; pinnce short, costce generally excentric.

A. Trichomanes, Linn. ( $\left.\nabla \nabla_{0}\right)$; A. ebeneum, Ait. ( $\left.\nabla \nabla_{0}\right)$; A. monanthemum, Linn. ( $\vee$ v.); A. Petrarchæ, De Cand. ( $\left.\nabla \nabla_{0}\right)$; A. formosum, Willd. ( $\left.\nabla \nabla_{0}\right)$; A. brasiliense, Radd. ( $\nabla \nabla$.$) ; A. tenellum, Roxb. ( \nabla \nabla$.$) (A. reclinatum, Moore,$ Hook. Fil. Exot., t. 72); A. erectum, Bory. ( $\vee$ v.); A. normale, Don. 


\section{RHIZOPHORUM GrodP.}

Fronds pinnate or bipinnate, the apex often long, attenuated (caudate), flagelliform, and viviparous; segments small, generally unisorus.

A. viride, Huds. ( $\left.\nabla \nabla_{0}\right)$; A. fontanum, Bernh. ( $\left.\nabla \nabla_{0}\right)$; A. flabelliforme, Cav. ( $\nabla$ v.); A. obtusilobium, Hook. ( $\nabla$ v.); A. cicutarium, $S w_{0}$ ( $\left.\nabla \nabla_{0}\right)$; A. myriophyllum, Presl ( $\left.\nabla \nabla_{0}\right)$; A. divaricatum, Kunze ( $\nabla$ v.); A. rhizophyllum, Linn. ( $\nabla \nabla$.$) ;$ A. cirrhatum, Rich. ( $\nabla \nabla_{0}$ ); A. rachirhizon, Radd. ( $\nabla v_{0}$ ); A. pinnatifidum, Nutt. ( $\nabla \nabla$.).

\section{Flaccidom Grodp (Darea, Willd.).}

Fronds pinnate, bipinnate, or decompound, often varying in the same plant; segments bifidly laciniated, bearing unilateral sori which are often very short, some of the species producing numerous viviparous bulbits on the upper surface.

A. brachypteron, Kunze ( $\nabla$ v.); A. prolongatum, Hook. ( $\vee$ v.) ; A. rutæfolium, Presl ( $\nabla$ v.) ; A. lineatum, $S w$. ( $\left.\nabla \nabla_{0}\right)$; A. Belangeri, Kunze ( $\vee \nabla$.$) ; A. flaccidum, Forst. ( \vee \nabla$.$) ;$ A. bulbiferum, Forst. ( $\vee$ v.); A. Fabianum, Hombr. ( $\vee \nabla$.$) ;$ A. appendiculatum, Labill ( $\nabla$ v.) ; A. Richardi, Hook. ( $\nabla$ v.); A. Hookerianum, Colenso ( $\left.\vee \nabla_{0}\right)$; A dimorphum, Kunze

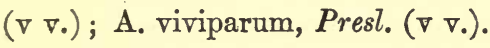

OBs.-Some of the species of this group are liable to extreme variation in the more or less divided state of the fronds. A. lineatum of $\mathbf{S w a r t z}$ for instance, is described as having entire pinnæ, but cultivated plants have shown me that it varies considerably, from entire to multifid, passing into the several daroid states represented by the different forms of $A$. flaccidum, several of which have been described as distinct species, such as $A$. inequale, Kunze, and $A$. bifi 
dum, Presl. When the ultimate segments are small, the sori are short, and become characteristic of certain Davallece of authors, which Mr. Moore has characterised as a distinct genus under the name of Loxoscaphe, but as the habit of these species is clearly indicative of their affinity being with the present group, I consider them as a section of Asplenium, as follows.

The principal character that entitles them to rank as a genus, consists in the sori being very short and oblique, with the indusium conniving with the margin of the seg. ment, which gives it the appearance of a round cyst opening outwards as in Davallioe, which is the only character that gives it any claim of relationship with that family.

\section{Gibberosum Group (Loxoscaphe, Moore).}

A. gibberosum, $J$. Sm. (Davallia, Sw.); A. concinnum, J. Sm. (Davallia, Schrad.); A. Schimperi, J. Sm. (Davallia, Hook); A. theciferum, J. Sm. (Davallia, H. B. K.) ; A. foniculaceum, H. B. K.

\section{Adiantum-nigrum Group (Tarachia, $P r$.)}

Fronds bi-tripinnate; ultimate segments or lacince with two or more sori.

A. Adiantum-nigrum, Linn. ( $\left.\nabla \nabla_{0}\right)$; A. lanceolatum, Huds. ( $\nabla$ v.) ; A. acutum, Bory. ( $\left.\nabla \nabla_{0}\right)$; A. auritum, $S w$. ( $\left(\nabla_{0}\right)$; A. dispersum, Kunze ( $\vee \nabla$.$\left.) ; A. macilentum, Kunze ( \vee v_{0}\right)$; A. fragrans, $S w .\left(\vee \nabla_{0}\right)$; A. mexicanum, Mart. et Gal. ( $\left.\nabla \nabla_{0}\right)$.

\section{Falcatum Group (Tarachia, $P_{r}$.).}

Fronds pinnate; pinnce 1 to 6 inches long, lanceolate or elliptical, acuminate or sub-deltoid, entire, serrated or erosely laciniated; veins forming an acute angle with the costoe. A. attenuatum, R. Br. ( $\nabla$ v.); A. longissimum, Blume $\left(\begin{array}{l}\nabla \\ \left.\nabla_{0}\right)\end{array}\right)$ A. nitens, Sw. ( $\left.\nabla \nabla_{0}\right)$; A. serra, Lang. et Fisch. 
( $\vee$ v.) ; A. polyodon, Forst. ( $\nabla$ v.) ; A. falcatum, Lam. ( $\nabla^{\vee} \vee$.) ; A. caudatum, Forst. ( $\left.\vee \nabla.\right)$; A. paleacum, R. Br. $(\mathrm{v} \nabla$.$) .$

\section{Erosum Group (Tarachia, Pr.)}

Fronds bi-tripinnate, decompound, rarely linear or simply forked; segments rarely otherwise than cuneiform, with erose apices; venation often flabellate, the costa being undefined or evanescent.

A. septentrionale, Schk. ( $\nabla$ v.) (Acropteris, Link.); A. germanicum, Weis. ( $\nabla$ v.); A. Seelosi, Siebold ( $\left.\nabla \nabla_{0}\right)$; A. Ruta-muraria, Linn. ( $\left.\nabla \nabla_{0}\right)$; A. cuneatum, Lam. ( $\left.\nabla \nabla_{0}\right)$; A. præmorsum, $S w .\left(\nabla \nabla_{0}\right)$; A. furcatum, Thunb. ( $\left.\nabla \nabla_{0}\right)$; A. laserpitiifolium, Lam. ( $\left.\nabla \nabla_{0}\right)$; A. dimidiatum, $S w .(\nabla \nabla$. (A. zannicefolium, Lodd.); A. contiguum, Kaulf. ( $\left.\nabla \nabla_{\bullet}\right)$; A. erosum, Linn. ( $\nabla$ v.); A. nitidum, $S w$. ( $\nabla$ v.).

\section{Sect. 4.-ACTINIOPTERIS, Link.}

Fronds stipate, flabellate, 6 to 8 inches high, rigid; segments linear rachiform. Veins radiating and dichotomous.

A. radiatum, $S w$. ( $\nabla \nabla$.$) .$

OBs. - This is a remarkable Fern, of which Sir William Hooker says, "perfectly sui generis. Even its place in the Fern arrangement is doubtful. The frond is in no way foliaceous, but rachiform in its divisions, and, before expansion, it is, as it were, refracted (not circinate) upon the stipes, and in appearance then, and even when fully developed, very much like some small Chamcerops among the Palms."

Although such is the view of this Fern, taken by Sir Wm. Hooker, I nevertheless do not find sufficient character beyond its habit, to separate it from Asplenium. It is 
referred to Blechnum by Presl, and to Pteris by Mettenius, but according to my view the blechnoid or pterioid character of the sori is entirely consequent on the narrowness of the segments. It varies in the form of the frond, some being nearly simple, others forked, which seems to show a relationship with Asplenium septentrionale.

It is a widely diffused species, found in many parts of India, Ceylon, Arabia, Egypt, Abyssinia, southward to Zambesi-land and Angola.

\section{2.-Diplona, Baker (1873).}

Vernation uniserial, sarmentum slender, wire-like, scandent. Fronds linear-ligulate, entire, 9 to 10 inches long, $\frac{1}{2}$-inch broad, obscurely crenate-repand, membranous, smooth, stipes short, articulate with the caudex. Veins distinct, patent, usually simple, sporangiferous along their centre, their whole length. Indusium bivalved, one on each side of the vein, linear, narrow, margins conniving, enclosing the sporangia, forming numerous contiguous sausage-like sori.

Type. D. integrifolia, Bak. in Journ. Bot., new serics, 2, p. 235, with figure; Append. Syn. Fil., p. 492.

OBs.- I have not seen this curious Fern, but learn from Mr. Baker that it is a native of the Solomon islands, and that the genus is founded upon a solitary frond, rising laterally from about an inch of wiry-like caudex to which it is attached by what appears to be a joint. As it cannot be well associated with any Erymobryous genus, $I$ therefore for the present place it in Aspleniece, with which it agrees in the general asplenoid habit, but is peculiar in having a double indusium to each receptacle.

Sp. As abore. 


\section{3.-Micropodidm, Mett.} Annals of the Leyden Museum. Asplenium and Scolopendrium sp., Hook. Sp. Fil.

Vernation uniserial, sarmentum slender, wiry, scandent. Fronds distant, simple, linear-lanceolate, rarely pinnate, 1 to 2 feet in length, 1 to 3 inches in breadth, smooth. Stipes in some articulate with the caudex. Veins simple or forked, sporangiferous on one or both sides. Indusium simple as in Asplenium, binate as in Diplazium, or oppositely conniving as in Scolopendrium. Sori linear continuous, having an elevated ridge or crest on their exterior side or between them.

Type. Scolopendrium longifolium, Presl.

Oвs.-The principal character that has led Mettenius to separate the species of this genus from Asplenium, is that the vernation of several of them is apparently articulate, as also having an elevated ridge on the exterior side of simple sori, and also between the connivent sori. The articulated vernation, if it really is so, is confined in this family to this and the preceding genus, but as the nature of the fronds agree with Asplenium, I therefore deem it best to place them here; they form a very natural group, distinguished by their slender creeping caudex from the great mass of Asplenium.

Sp. M. Ianceum (Thunb. Ic. Plant. Jap., Dec. 11. t. 18 ; Asplenium subsinuatum, Hook. and Grev. Ic. Fil., t. $27 ; A$. sect. Triblemma, J. Sm. Ferns Brit. and For., p. 209).

OBs.-The sori of Asplenium, Diplazium, and Scolopendrium, are often produced on the same frond of this species.

M. vittæforme, Mett. (Cav.) (Asplenium Amboinense, Brack. Fil., U. S. Expl. Eiep., p. 147, t. 19, f. 2) ; M. Sundense (Blume); M. Fijeense (Brack. Fil. U. S. Expl. Exp., t. 19, f. 1); M. scolopendrioides, J. Sm. (Hook. Ic. Pl., 
t. 930); M. longifolium, Mett. (Scolopendrium, Pr., Reliq. Hoenk., $p .48, t .9, f .1$ ) ; M. pinnatum, Mett. (Scolopendrum, J.Sm.); M. Durvillei, Mett. (Bory, Kunze, Suppl. Schk., p. 9, t. 5).

They are natives of Malay, Philippine, and Fiji islands.

M. pinnatum and M. Durvillei differ from the rest of the species in having pinnate fronds ; their sori are, however, characteristic of Micropodium.

\section{4.-SCOLOPENDRIUM, Sm. (1793).}

$$
\text { Hook. Sp. Fil., Asplenium, Linn. }
$$

Vernation fasciculate, erect, acaulose. Fronds simple, entrre, or lobed, from 6 inches to 2 and 3 feet long. Veins forked, venules free, the superior and inferior branch of each fascicle contiguous, parallel, and sporangiferous on their proximate sides, constituting two linear, confluent sori, each furnished with a linear indusium, the free margins of which connive, forming, as it were, one sorus.

Type. Asplenium Scolopendrium, Linn.

Illust. Hook. and Bauer, Gen. Fil., t. 57 B.; Moore Ind. Fil., p. 39 B ; J. Sm., Ferns, Brit. and For., fig. 112.; Hook. Syn. Fil., t. 4, fig. 41 A.

OBs.-This as a genus differs from Asplenium only in the sori being confluent in pairs, each furnished with its own indusium, the free edges of which connive, and thus forming a double sorus.

Although the connivent sori is the only point by which this genus is distinguished from Asplenium, Sir William Hooker has nevertheless in the "Species Filicum " raised it to the dignity of a tribe which he names Scolopendrieo; it contains only nine species, which he arranges under four sections, namely, Euscolopendrium, Antigramma, Schaff- 
neria, and Camptosorus. The first section contains four species, which have free venation; in the other three sections the veins anastomose, and are noticed further on.

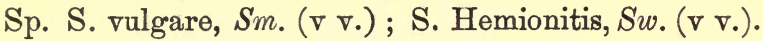

$S$. Hemionitis is found only in the south of Europe, while $S$. vulgare is widely spread throughout the temperate regions of the Northern Hemisphere ; it abounds in Europe, and in this country is well known as the Hart's-tongue Fern, and of which there are numerous abnormal forms, no less than 160 being recorded in Mr. Stansfield's Catalogue. For S. Krebsii, Kze. in Schk. Supp., t. 74, see Lomaria.

\section{5.-Diplazium, $S w$. (1800).}

Asplenium sect. Eudiplazium, Hook. Sp. Fil.

Vernation fasciculate, erect or decumbent, acaulose or sub-arborescent. Fronds simple, pinnate, or bi-tripinnate, 1 to 5 feet high, smooth, rarely pubescent. Veins forked or pinnate; venules free, the whole or the lower venules only sporangiferous on both sides, forming binate linear sori, each furnished with a linear indusium, the one opening interiorly, the other exteriorly.

Type. Asplenium plantagineum, Linn.

Illust. Hook. and Bauer, Gen. Fil., t. 55 B.; Moore, Ind. Fil., p. 41 B. ; J. Sm., Ferns, Brit. and For., fig. 111 ; Hook. Syn. Fil., t. 4, fig. 38 d. f.

OBs.-This genus differs only from Asplenium in the sporangia being produced on both sides of the venules, each furnished with its own indusium, thus forming binate sori : this character is constant to most of the species, especially those with simple or pinnate fronds, but in those with more compound fronds, the binate sori are only found on the lower exterior venule of one or more of the fascicles, 
the superior venules having unilateral sori as in true Asplenium.

The following species, taken from "Ferns, British and Foreign," are sufficient to illustrate the genus. They are widely diffused throughout the tropics of both hemispheres, with the exception of $D$. thelypteroides, which is found in North America.

\section{* Vernation erect. \\ $\uparrow$ Fronds simple.}

Sp. D. plantagineum, $S w$. ( $\nabla$ v.).

\section{+† Fronds pinnatifid.}

D. Zeylanicum, Hook. ( $\nabla$ v.).

\section{+† Fronds pinnate.}

D. pallidum, $B l$. ; D. grandifolium, $S w$. ( $\nabla$ v.) ; D. Juglandifolium, $S w .\left(\right.$ v $\left.\nabla_{0}\right)$; D, alternifolium, $B l .\left(\nabla \nabla_{0}\right) ; \mathrm{D}$. fraxinifolium, Wall.; D. celtidifolium, Kunze; D. Lobbianum, Hook.

\section{+ti† Fronds bipinnatifid or bipinnate.}

D. Shepherdi, Link. ( $\nabla$ v.) ; D. coarctatum, Link. ( $\nabla$ v.);

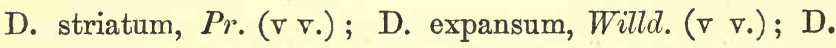
diversifolium, Wall. ( $\nabla$ v.); D. conchatum, Moore ( $\left.\nabla \nabla_{0}\right)$; D. polypodioides, Bl. ( $\nabla$ v.); D. Schkuhri, Mett.; D. Klotzschii, Moore ( $\nabla$ v.) ; D. lobulosum, Wall.; D. costale, $P r$.

\section{*** Vernation decumbent.}

D. sylvaticum, $S w .\left(\nabla \nabla_{0}\right)$; D. dilatatum, $B l .\left(\nabla \nabla_{0}\right) ; \mathrm{D}$. arborescens, $S w .\left(\nabla\right.$ v.) ; D. vestitum, $P r_{0} ;$ D. Thwaitesii, J. Sm. ( $\vee$ v.) ; D. flexuosum, Pr. ; D. thelypteroides, $P r$. ( $\left.\nabla \nabla_{0}\right)$; D. Franconis, Mett. ( $\nabla$ v.). 


\section{6.-ATHYRIUM, Roth. (1788).}

Allantodia sp., R. Br., 1810 ; Asplenium sp. auct., sect. Athyrium, Hook. Sp. Fil., J. Sm. Ferns Brit. and For.

Vernation fasciculate, ereet or decumbent, solitary or becoming cespitose. Fronds bi-tripinnatifid, 1 to 4 feet high, ultimate segments dentate, or deeply laciniated. Veins forked; venules free. Sporangia unilateral, or often bilateral on the lower exterior venule. Indusium generally vaulted, single or binate, or oblong reniforme, forming linear, straight, or curved, generally unequal-sided sori.

Type. Asplenium Filix-foemina, Bernh.

Illust. Hook. and Bauer. Gen. Fil., t. 16 ; Moore Ind. Fil., p. 37, A.; Hook. Syn. Fil., t. 4, fig. 38, E.

OBS.-The form of the sori in the species included in this genus is very variable, some being unilateral as in Asplenium, others binate as in Diplazium, while in others the indusium is oblong reniform as in Fadyenia, but the lobes are generally unequal, such differences being in many instances found in the same frond. In many the indusium is cylindrical and vaulted like that of true Allantodia.

In the "Species Filicum," as well as in "Ferns, British and Foreign," Athyrium is ranked as a section of Asplenium, but, for the sake of a more natural grouping of species, I deem it best to allow it to rank as a genus; more distinguished by its habit of growth and the soft and brittle nature, and highly compound character of the fronds, than by the character of the sori; and the species may be viewed as having more relationship with the compound-fronded species of Diplazium than with Asplenium.

In the "Species Filicum" twenty-nine species are enumerated, but in the "Synopsis" the number is reduced to nineteen, ten of which have come under my observation in 
a living state. This reduction is consequent on Mr. Baker having united, or what is termed "lumped," a number of forms described by authors as species, under A. Filix-foemina, which is widely diffused over the Northern hemisphere, presenting many different aspects in the more or less divided states of its fronds in different regions, some of which may be admitted to be as distinct species as many other closely allied Ferns.

The species are widely distributed, being found in India, Malay, and islands of the Pacific, A. Brownii extending to Southern Australia, A. umbrosum and $A$. axillare being found in Madeira. In this country, especially in Yorkshire, a number of what are called tasselled forms of A. Filix-foemina are found, which have become great favourites with amateurs; one trade catalogue alone contains the fanciful names and prices of no less than 115.

Sp. A. Filix-fœmina, Bernh. ( $\nabla \nabla$.$) ; A. crenatum (Fries.);$ A. Michauxii, Spreng. (v $\nabla_{0}$ ) ; A. eburnum, J. Sm. (v v.); A. denticulatum, $J . S m .(\nabla \nabla$.$) ; A. macrocarpum, Blume$ ( $\nabla$ v.) ; A. Nigritianum, Hook.; A. sandwichianum, Mett; A. nigripes, Mett. ( $\vee \nabla$.$) ; A. ceylonense, Klot. ( \nabla$ v.) ; A. decurtatum, Link. ( $\nabla$ v.); A. umbrosum, J. Sm. ( $\left.\nabla \nabla_{0}\right)$;

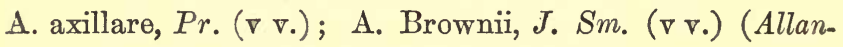
todia australis, R. Br.; see genus Allantodia).

** Veins anastomosing in various ways.

187.-Neottopteris, J. Sm. (1841). Asplenium sp. auct., section Thamnopteris, Pr., Hook. Sp. Fil.

Vernation fasciculate, erect. Fronds sessile, coronate, rarely stipate, simple, linear or broad elliptical-lanceolate, smooth, 1 to 6 feet long by 2 to 12 inches wide. Veins forked, venules parallel, sporangiferous on the superior 
side, their apices combined by a transverse, continuous marginal vein. Sori unilateral. Indusium plane, free exteriorly.

Type. Asplenium nidus, Linn.

Illust. Hook. and Bauer, Gen. Fil., t. 113 B.; Moore, Ind. Fil., p. 37 B.; J. Sm., Ferns, Brit. and For., fig. 113.

OBs.-This genus is distinguished from other simplefronded Asplenice by the apices of the parallel venules being combined by a continuous marginal vein; it has a wide geographical range, being represented throughout India, the Malayan peninsula and islands, Southern China, Philippine, Sandwich, and other islands of the Pacific Ocean, extending to Australia and Norfolk Island in the south, and Japan in the north.

In Seemann's "Botany of the Voyage of the Herald" it is there recorded to have been found in one or two localities on the Pacific side of the continent of America, but this seems to be a mistake, as the Hookerian herbarium contains no specimen of the genus from the American continent.

The simple form of the fronds does not afford much variety as regards difference that can well be explained in words, yet they vary very much in size and texture, which in some instances seem to be normal to the special localities, and which gives the semblance to there being a number of distinct species, thirteen being enumerated by Fée, which in the "Species Filicum" are reduced to seven; even this is more than can be satisfactorily determined by herbarium specimens only. The cultivated examples of four forms known to me, although difficult to recognise as distinct when put in the herbarium, are, however, readily seen to be distinct species in the garden, and it is probable that 
others from different localities, when seen cultivated, may also be called specifically distinct.

Sp. N. nidus (Linn.) ( $\nabla \nabla$.$) ; N. musæfolia (Mett.); N.$ australasica, $J . S m$. ( $\left.\vee \nabla_{0}\right)$; N. phyllitidis (Don.) ( $\left.\nabla \nabla_{0}\right)$; N. Grevillei (Wall.); N. Simonsiana (Hook.) (Bedd. F. Brit. Ind., pl. 248).

OBs. $-N$. muscefolia has the largest simple entire fronds of all Ferns; it is described by a Penang correspondent in the following words, "I saw two fine specimens of the Bird's-nest Fern; each had between forty and fifty perfect green leaves; the average length of the leaves was 6 feet, and from 1 foot to 14 inches across in the broadest part. They were growing on each side of the doorway of the mansion; when I was walking up to them I thought they were American Aloes."

188.-Antigramma, Presl (1836).

Camptosorus, Pr. Scolopendrium, Hook. Sp. Fit.

Vernation fasciculate, erect, acaulose. Fronds simple, cordate, lanceolate, 4 to 18 inches high, erect or decumbent, in their apex viviparous. Veins forked; venules straight or curved, angularly anastomosing, reticulated, the marginal veinlets free. Sporangia produced on the proximate sides of two contiguous venules, constituting two linear confluent sori, each furnished with a linear indusium, the free margins of which connive.

Type. Asplenium brasiliensis, $S w$.

Illust. Hook. and Bauer Gen. Fil., t. 57 A. C.; Moore Ind. Fil., p. 40 and 41 A.; J. Sm. Ferns, Brit. and For., fig. 114 ; Hook. Syn. Fil., t. 4, fig. 41 b. d.

OBs.-This genus consists of at least four species, all of which have opposite conniving sori, as in Scolopendrium, 
differing only in the reins being reticulated. They are placed in three different genera by authors, namely Antigramma, Camptosorus, and Schaffneria, but, unless the different habit and forms of the fronds are taken into consideration, they have no title to rank higher than sections of Antigramma.

Sect. 1.-Antigramma, vera.

Fronds linear lanceolate, or ovate cordate, 6 to 12 inches long.

Sp. A. brasiliense (Sw.) (v v.); A. plantaginea, $P r$. (Asplenium Douglassii, Hook, and Grev. Ic. Fil., t. 150).

Sect. 2.-Camptosonus, Presl. (1836).

Fronds lanceolate, auricled at the base, 4 to 9 inches long, decumbent, recurvate, with a rooting viviparous apex, forming compact patches of fronds. Sori short, generally curved.

A. rhizophylla, Pr. ( $\nabla$ v.); A. sibirica (Hook.).

Sect. 3.-Schaffneria, Fée. (1856).

Fronds stipate, round, obovate, 1 to $1 \frac{1}{2}$ inches broad, texture thick, firm. Veins reticulated, without a midrib. Sori oblong or linear, in irregular patches.

A. nigripes (Fée.); Kew Gard. Misc., 9, t. 9 (Scolopendrium, Hook. Syn. Fil., t. 4, fig. 41 c.).

OBs.-The two first are natives of Brazil, the third of North America, the fourth of Mexico.

189.-Oxigonidm, Presl (1836).

Anisogonium, Pr. (1836); Asplenium, sect. Anisogonium, Hook. Sp. Fil.; Diplazium sp., authors.

Vernation fasciculate. Fronds simple or pinnate, the simple ones sub-cordate, 1 to 2 feet high; pinnæ entire, 
ovate-lanceolate and acuminate. Veins pinnately forked, venules parallel till near the margin, then anastomosing, and reticulated, terminating with free marginal veinlets. Sporangia bilateral, constituting binate linear sori. Indusium plane.

Type. Diplazium alismoefolium, Presl.

Illust. Hook. Ic. Pl., t. 936 and 939; Moore Ind. Fil., p. $42, \mathrm{~B}$.

OBS.-This consists of a few species, differing from Diplazium, in the veins being parallel and acutely anastomosing near the margin, which latter, characterises it from the following genus, Callipteris, in which the venules anastomose in pairs between the primary veins.

Sp. O. cordifolium, (Bl.) (Diplazium ovatum, Wall.); 0. alismæfolium, $P r$. ; O. elegans, $J$. Sm. (1841).

OBs.-Natives of India, Malay, and Philippine Islands. The two first species were originally described as having only simple fronds, but we now possess specimens of simple and pinnate fronds growing from the same root, which shows the necessity of being careful in describing species from inadequate materials.

190.-CaLlipteris, Bory. (1804), J. Sm . (1841). Anisogonium, Pr. ; Asplenium, sect. Anisogonium, Hook. Sp. Fil.; Diplazium sp. auct.

Vernation fasciculate, erect, subarboroid. Fronds pinnate, or bipinnatifid and bipinnate, 2 to 5 feet high, often viviparous. Veins costæform and pinnate, each opposite pair of venules angularly anastomosing, the superior ones usually free, sporangiferous on both sides, constituting binate sori, each furnished with a linear indusium, the one opening interiorly the other exteriorly. 
Type. Asplenium decussatum, Sw.

Illust. Hook. and Bauer Gen. Fil., t. 56, A., B. ; Moore Ind. Fil., p. 42, A. ; J. Sm. Ferns Brit. and For., fig. 115 ; Hook. Syn. Fil., t. 4, fig. 28 , G.

OBs.-The species of this genus agree in habit with Diplazium, but differ in the venation being anastomose.

\section{* Fronds pinnate.}

Sp. C. prolifera, Bory. ( $\nabla$ v.) (Asplenium decussatum, Sw.); C. accedens $(B l$.$) ; C. spinulosa, (B l$.$) ; C. undulosa (S w$.$) .$ ** Fronds bipinnate.

C. esculenta $\left(S w_{0}\right)(\nabla \nabla$.$) .$

OBS.-This species has the honour of being ranked under seven genera, namely, Hemionitis, Kcnig. ; Asplenium, Sw. ; Diplazium, Sw.; Anisogonium, Presl; Digrammaria, Fée and Hook.; and Microstegia, Presl, which, with the different specific names, under these genera, raised the number of synonyms to thirty. The whole of the species are widely distributed throughout India, Malay, and the Pacific. $C$. undulosa is a native of Martinique, and in the "Synopsis," several species are described from tropical America.

191.-Asplenidictyom, $J$. Sm. (1854). Asplenium Sect. Asplenidictyum, Hook. Ic. Pl. Asplenium Sect. Hemidictyum, Hook. Sp. Fit.

Vernation fasciculate, erect. Fronds pinnate, 1 to 2 feet high, pinnæ elliptical-lanceolate, 3 to 8 inches long, $1 \frac{1}{2}$ to 3 inches broad, obtuse or long acuminate, entire, or unequally laciniated, base oblique cuneate; costæ obscure, evanescent. Veins uniform, angularly anastomosing, forming elongated subtransverse areoles, without free marginul 
venules. Sporangia unilateral, ånterior. Indusium plane, forming linear, sub-transverse sori.

Type. Asplenium Finlaysonianum, Wall.

Illust. Hook. Ic. Pl., t. 938, 937.

OBs.-This genus is founded on two species, which agree in habit and texture with the Falcatum group of Asplenium (Tarachia, Pr.), differing only in having anastomose venation. Mr. Moore makes it a section of the genus Hemidictyum, from which it differs entirely in habit and texture, and in the costæ being obscure and evanescent.

Sp. A. Finlaysonianum, J. Sm. (Asplenium, Wall. Bedd. F. Brit. Ind., pl. 72); A. Purdieanum, J. Sm. (Asplenium Hook. Ic. Pl., t. 937)'.

OBs. - The first is a native of India, Assam, Malay Islands, and Penang, the second of New Granada and Peru.

\section{2.-Allantodia, R. Br. (in part, 1810).}

Hook. Sp. Fil.

Vernation fasciculate, erect. Fronds pinnate, 2 to 3 feet high, pinnæ linear, membraneous, 4 to 6 inches long, 1 inch broad, with a central perfect costæ. Veins simple, sub-parallel, becoming forked towards the margin, and anastomosing, forming elongated areoles, with free, marginal, clavate veinlets. Sporangia unilateral, anterior on the lower part of the venule. Indusium vaulted, cylindrical, forming linear oblique sori.

Type. Asplenium reticulatum, Wall.

Illust. Hook. and Bauer, Gen. Fil., t. 120 A.; Moore, Ind. Fil., p. 38 B.; Hook. Syn. Fil., t. 4, fig. 39.

OBs.--The name Allantodia was in 1810 given by Robert Brown to the present species, which he associated with certain species, of very different habit, which Roth had 
previously characterised under the name of Athyrium, which has been viewed by most authors as a section of Asplenium, but which, for the sake of natural arrangement, I have adopted as a genus, and restricting true Allantodia to the present species.

Sp. A. Brunoniana, Wall.

Hab. A native of Ceylon, Nepal, and Java, also found in Otaheite.

\section{3.-Hemidictrom, Presl (1836).}

Asplenium, sect. Hemidictyum, Hook. Sp. Fil.

Vernation fasciculate, erect, arboroid. Fronds pinnate, 12 to 14 feet long; pinnæ sessile cordate, from 1 to $1 \frac{1}{2}$ feet long, by 3 to 4 inches wide. Veins forked; venules parallel till near the margin, then anastomosing and reticulated, combined by a transverse continuous marginal vein. Sporangia produced on the anterior side of the parallel venules, constituting unilateral linear sori. Indusium plain.

Type. Asplenium marginatum, Linn.

Illust. Hook. and Bauer Gen. Fil., t. 55 A.; Moore Ind. Fil., p. 38 A.; J. Sm. Ferns, Brit. and For., fig. 116 ; Hook. Syn. Fil., t. 4, fig. 38 h.

OBS.-This genus is founded on a magnificent Fern, a native of Tropical America and West India Islands, having a stem 5 to 6 feet in height, bearing a crown of pinnate fronds. measuring 12 to 14 feet in length. The chief point that distinguishes it from Allantodia is in the indusium being plane and in the exterior margin of the reticulated venation being combined by a transverse vein running parallel with and close to the margin. These slight dif-ferences are scarcely sufficient to charaoterise it as a genus 
distinct from Allantodia, especially as the general character of the fronds of Allantodia agrees with Hemidictyum. I nevertheless deem it best to retain it as distinct.

Sp. H. marginatum, Presl (v v.).

\section{4.-Ceterach, Willd., in part (1810).}

Asplenium, sect. Hemidictyum, Hook. Sp. Fil.

Vernation fasciculate, acaulose, becoming cæspitose. Fronds 2 to 12 inches long, sinuose-pinnatifid, the under side densely squamose. Veins forked; venules anastomosing, obscure. Sporangia unilateral, anterior. Indusium rudimentary. Sori oblong, the sporangia protruding through dense scales.

Type. Asplenium Ceterach, Linn.

Illust. Hook. and Bauer Gen. Fil., t.113 A.; Moore Ind. Fil., p. 39 A. ; J. Sm. Ferns, Brit. and For., fig. 117.

OBs.-This genus is founded on a solitary species, which in habit, and the nature of its fructification, is so peculiar that it has given rise to much diversity of opinion as to its proper place in any arrangement, whether natural or artificial. In my "Genera of Ferns" (1841) I stated that its unilateral sporangia indicated it to belong to Aspleneos, and that the imperfect or obsolete indusium was owing to the suppression of that organ, caused by the density of the squamm on the under side of the frond. More recent observations have shown the presence of a narrow linear indusium, which is more evident in the large fronded species called $C$. aurea, of Madeira, than in the common form. It must, however, be confessed that its peculiarities prevent its association with any species of the asplenoid tribe, except with Asplenium alternans of Wallich, already noticed. In the "Species Filicum" it is placed in the 

Pl. 24.

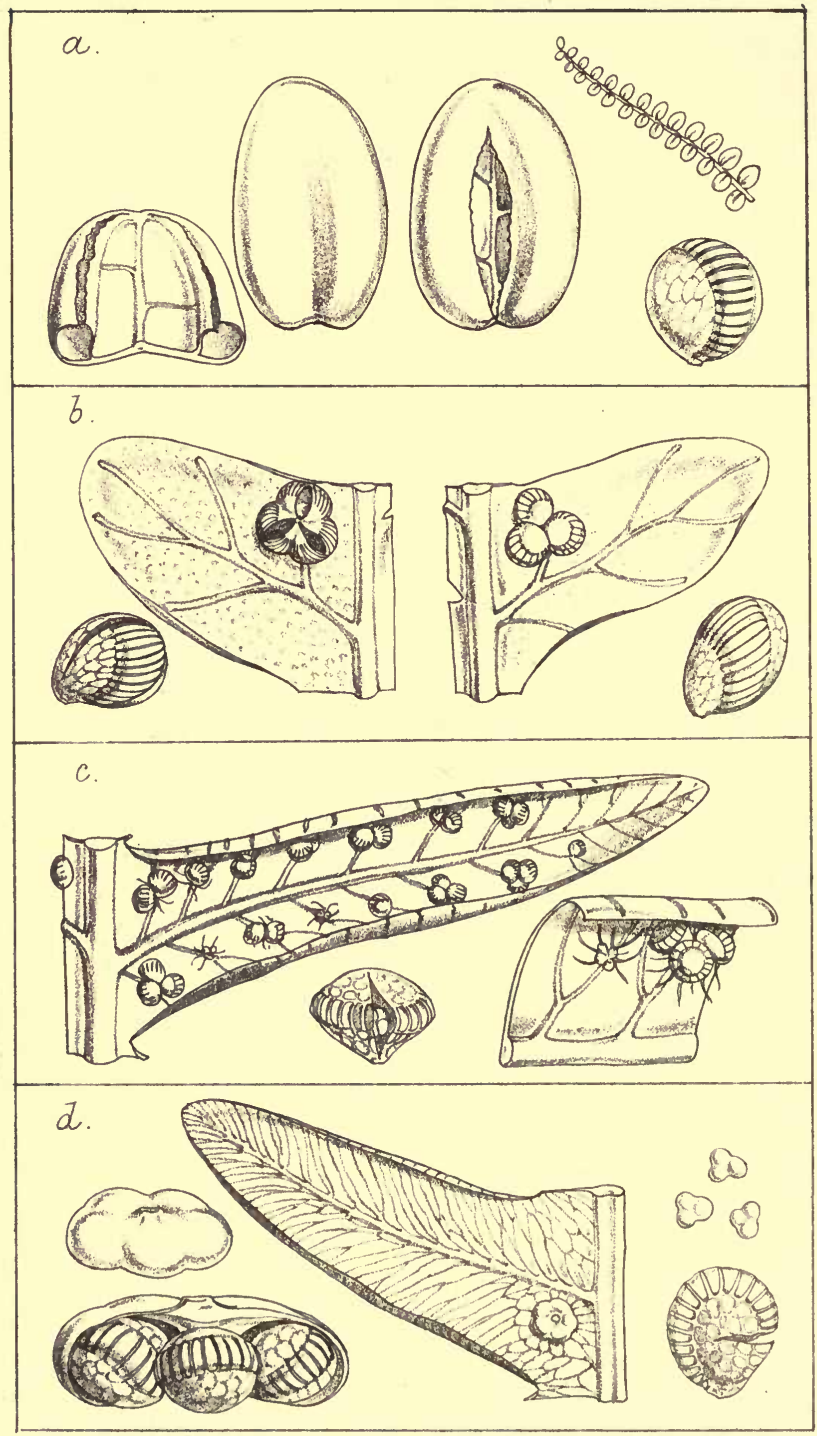

W.H. Fitch, del.et Fith. 
section Hemidictyum, along with the two species of Asplenidictyum and Hemidictyum marginatum, all three very distinct in habit. Although I now place Ceterach after Hemidictyum it is not that I consider it has any relationship, but merely on account of having no ally for it, I place it as an anomalous genus at the end of the tribe.

Sp. C. officinarum, Willd. (v v.) (Grammitis, Sw. ; Scolopendrium, Sm.).

OBs.-Found in rocky places, and on old walls in this country, and throughout Europe and the temperate regions of the Northern hemisphere generally. In Madeira the fronds attain a large size, and which by some authors has been described as a distinct species under the name of C. aureum.

B. Ring of Sporangia horizontal, central.

Sect. 1.-Sori discal, punctiform, naked, rarely indusiate.

Tribe 24.-GLEICHENEA. (Plate 24).

(Gleicheniacece, R. Br.)

OBs.-This Tribe includes a peculiar group of Ferns, consisting of about thirty described species, technically distinguished from Polypodiacece by the sporangia being surrounded with a horizontal ring generally at right angles with the axis of attachment. This direction of the ring is common to the whole of true Gleicheniacece, but in Matonia it is partially oblique.

Independent of the structure of the sporangia, Gleicheniacece are readily known from all other Ferns by their fronds being once or many times dichotomously branched or flabelliform (two species excepted, which have simple fronds). 
They have a wide geographical range, chiefly tropical, extending to Japan in the north, and New Zealand in the south. With a few exceptions, they present great uniformity in general character and appearance; in some instances the same or closely allied species are found in the old and new worlds. They often grow among bushes, and their fronds being indefinite they attain a great length. In the Bellenden Ker range of mountains, Queensland, Gleichenia Hermanni is described as forming an impenetrable jungle among tree Ferns and other trees, attaining the height of 50 or 60 feet, supported by its horizontal pinnæ similar to Lygodium.

* Sori non-indusiate.

$$
\text { 195.-Platyzoma, R. Br. (1810). }
$$

Vernation sarmentose. Fronds contiguous, linear, 6 inches to a foot long, pinnatifid, pinnate; segments numerous, small, sub-orbicular, 1 to 2 lines long, revolute saccate. Veins simple. Sporangia 2 to 4 terminal, included under the revolute margins, immersed in powdery matter.

Type. Platyzoma microphylla, $R$. Br.

Illust. Hook. and Bauer Gen. Fil., t. 41, C. ; Moore Ind. Fil., p. 87, A; Hook. Syn. Fil., t. 1, fig. 1.

OBs.-This genus is founded on a solitary species, first found on the shores of the Gulf of Carpentaria, and since then in other parts of tropical and sub-tropical Australia. It is scarcely distinct from Gleichenia, except in the fronds being simple; in habit it resembles Jamesonia, but the divisions of the fronds are even smaller than in the smallest of that genus.

Sp. As above. 


\section{6.-Gleichenta, Sm. (1793).}

Hook. Sp. Fil.; Mertensia, Willd.; Dicranopteris, Bernh.; Sticherus and Calymella, Presl.

Vernation sarmentose. Fronds long stipate, 1 to 6 or more feet high, once or many times dichotomously branched, ultimate divisions (pinnæ) linear lanceolate, lacinæ plain or recurved and saccate, smooth, glaucous, or more or less pubescent or squamose. Veins simply or pinnately forked, venules free, the lower exterior one fertile, sporangiferous receptacle, terminal, lateral, or nearly axillary superficial. Sporangia 3 to 8 , forming punctiform naked sori.

Type. Polypodium dichotomum, Thunb.

Illust. Hook. and Bauer, t. 39 and $41 \mathrm{~A}$ and B; Moore Ind. Fil., p. 87, B; J. Sm. Ferns, Brit. and For., f. 136 ; Hook. Syn. Fil., t. 1, fig. 3.

OBs.-The species of this genus present two very distinct aspects, which form two groups. In the first the lacinø are plain, and often 1 inch or more in length, constituting the genus Mertensia of Willdenow ; in the second the lacinæ are very small and revolute; these are by some termed true Gleichenia, but as the habit of growth of the two groups is the same, and there is not sufficient difference in the character of the sori to warrant their separation as genera, I therefore arrange the species as follows :-

\section{Gleichenia vera. (Calymella, Pr.).}

Lobes of the pinnce small, sub-rotund, generally revolute. Sporangia terminal.

Sp. G. microphylla, R. Br. ( $\vee$ v.); G. dicarpa, $R . B r$. ( $\nabla$ v.) ; G. semivestita, Labill. ( $\nabla$ v.); G. hecistophylla, $A$. 
Cunn. ( $\nabla_{0}$ ) ; G. rupestris, R. Br. ( $\vee v_{0}$ ) ; G. alpina, R. Br. ( $\vee$ v.); G. speluncæ, R. Br. ( $\vee \nabla_{0}$ ) ; G. polypodioides, $S m$.

OBs.-In the two last species the lobes of the pinnæ are but slightly revolute.

\section{Mertensta, Willd.}

Pinnce pinnatifid, lacince plain, oblong, linear lanceolate, some an inch or more in length. Sporangia lateral.

Sp. G. flabellata, R. Br. ( $v$ v.); G. dichotoma, Hook. (v v.); G. furcata, Spreng. (v v.); G. pectinata, Pr. (v v.); G. pubescens, Kunth. ( $\mathrm{v}_{0}$ ); G. cryptocarpa, Hook. ( $\mathrm{v}$ v.); G. Cunninghami, Hew. ( $\mathrm{v}$ v.); G. longissima, Bl. (G. glauca, Hook.; G. gigantea, Wall.; G. excelsa, J.Sm.; G. Bancroftii, Hook.; Mertensia pinnata, Kze.; G. arachnoides, Mett.; G. bullata, Moore ; Hook in "Synopsis Filicum.").

Ons.--It is probable that several of these synonyms are distinct species, as they are found in very different regions, but this can only be determined by seeing them side by side under cultivation.

\section{** Sori indusiate. \\ 197.-Matonia, $R . B r$. (1830).}

Vernation sarmentose. Stipes 4 to 6 feet high, smooth, rigid. Fronds bi-partite, flabelliform, with a cordate base, $1 \frac{1}{2}$ to 2 feet wide; segments numerous, uniform, linear lanceolate, equally pinnatifid, lacinæ about 1 inch in length, linear lanceolate or obtuse, costate, plane. Veins the sterile, forked, free; the fertile anastomosing. Sporangia definite (4 to 6), disposed in a single series round a punctiform receptacle, seated on the confluence of 5 to 10 veinlets, furnished with an orbicular, inflated, central attached, stipate indusium, constituting globose sori. 
Type. Matonia pectinata, $R$. Br.

Illust. Hook. and Bauer Gen. Fil., t. 43 ; Moore Ind. Fil., p. 86 B.; Hook. Syn. Fil., t. 1, fig. 8.

Ons.-This genus is founded on a unique and rare Fern, as yet only known to be a native of Mount Ophir, in the peninsular of Malacca. On account of the sori being furnished with a peltate indusium $\mathrm{I}$ originally placed it in Aspidece, but with which it has no other point of relationship. With Gleichenia (with which I now associate it), it not only agrees in habit but also in the character of the sori, differing only in the sori being compital and indusiate.

Sp. M. pectinata, R. Br.; Wall. Pl. As. Rar. Ic., t. 16.

\section{8.-Stromatopteris, Mett. (1861).}

Gleichenía sp., Hook. Syn. Fil., 1865.

Caudex slender, subfrutescent, branching, erect. Fronds in terminal tufts on the branches, and distant lateral ones below the tuft, linear, about 12 inches in length, pinnatifidly pinnate; segments sub-rotund, about an inch in length, numerous, contiguous, adnate to the rachis, coriaceous and concave on the under side. Veins pinnate, 2 to 3 venules on each side, the lower forked. Sori punctiform, solitary on each segment near the base. Sporangia 3 to 6 , mixed with numerous pilose hairs. Ring horizontal, broad.

OBs. - This genus is founded on a remarkable Fern, a native of New Caledonia, of which there are specimens in the Kew Herbarium, but those having arrived since the failure of my sight I have consequently not been able to examine them. It was first described as a new genus by Mettenius in 1861. In the first part of the "Synopsis Filicum," published in 1865, Sir William Hooker places it in Gleichenia, with which it agrees in the sori being formed 
of a definite number of sporangia and the ring being horlzontal, its mode of growth is, however, very different from Gleichenia, the caudex being woody, erect, and branching, bearing tufts of fronds in many respects similar to Oleandra neriiformis, but differs in having pinnatifidly pinnate fronds, much resembling the larger forms of Jamesonia.

The above character is drawn up from description and from notes communicated to me by Mr. Baker.

Sp. S. moniliformis, Mett, in Ann. Soc. Nat., 1861, p. $84, t .3$.

Sect. 2.--Sori (sporangia) in marginal bilabiate cysts, opening exteriorly.

\section{Tribe 25.-HYMENOPHYLLE无. (Plate 25.)}

(Hymenophyllaceo, $\mathrm{Pr}$.).

Fronds membranous, generally pellucid, entire, or variously compound, from less than an inch to a foot or more in length. Sporangia sessile, compactly seated round a columnar terminal receptacle, which is formed by a free prolongation of the venule, included within a bilabiate or urceolate usually vertical cyst, open exteriorly.

OBs.-This is an extensive and very distinct tribe of Ferns, differing from all others by the extremely delicate and in general thin pellucid texture of the fronds, and also by the form and attachment of the sporangia. The fronds vary much in form and size, some being simple entire, forked or flabelliform, not more than half an inch in length, while others are more or less compound, or multifidly divided into fine hair-like segments, and vary from a few inches to 1 or $1 \frac{1}{2}$ feet in length.

The distinct habit and peculiar structure of the sporangium led some Pteridologists to characterise Hymenophyllece 
P2. 25.

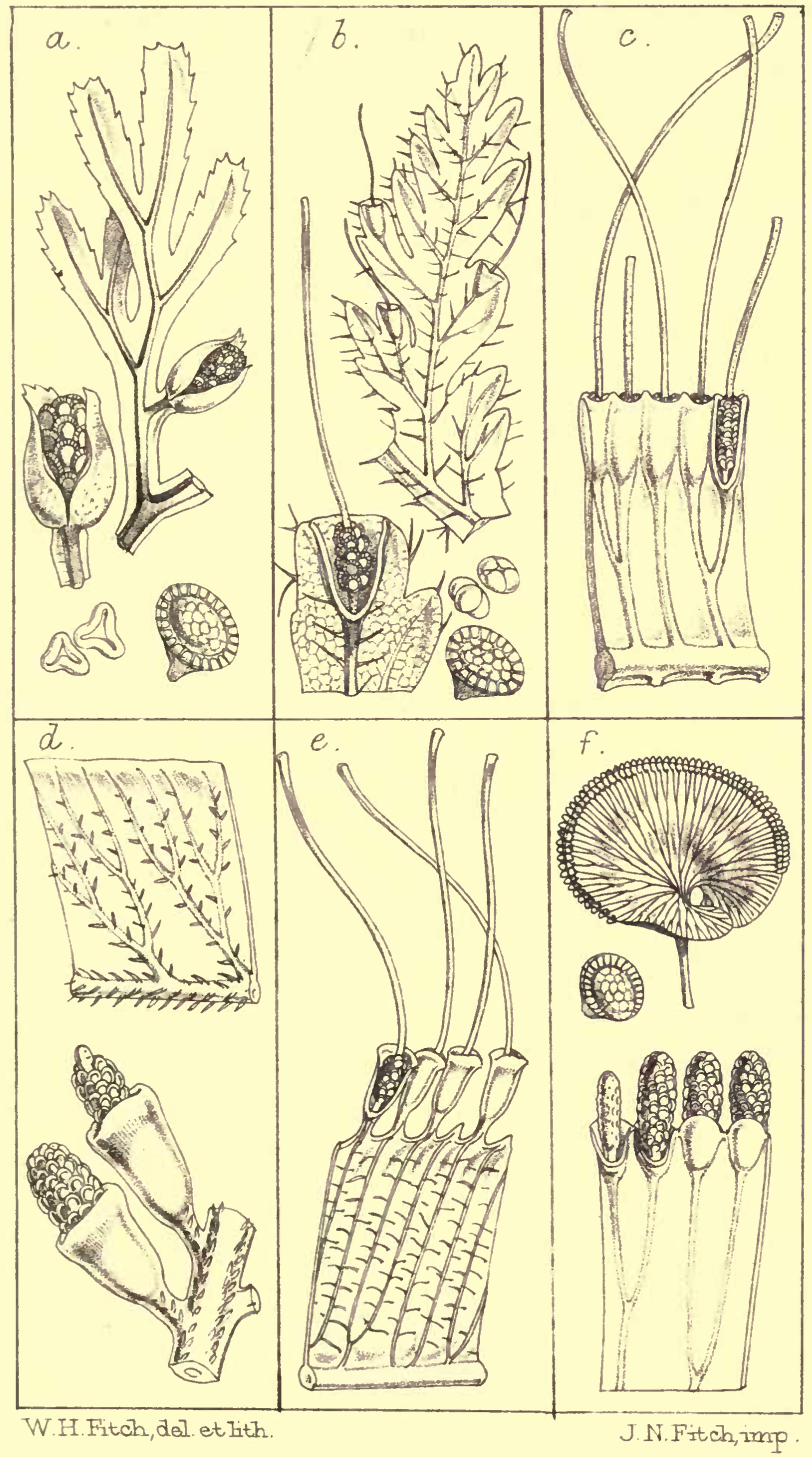



as a distinct natural order of Ferns, which I do not deem it desirable to adopt. I must, however, admit that it has no direct affinity with any other family of Ferns, except with the tribe Saccolomoce, through the genera Loxsoma and Microlepia.

The peculiarity of the sporangia consists in being sessilely attached by its inner side to the columnar receptacle, the point of attachment being central, or more generally eccentric towards the lower limb, and the numerous sporangia being compactly seated round the receptacle, they consequently acquire a flattened form, each having an articulated ring passing round it, at a more or less oblique or at a right angle with the point of attachment, being thus analogous to the flattened sporangia of many Cyathece, as noticed at page 41 .

Most authors place the whole of the species under the genera Hymenophyllum and Trichomanes. On comparing the respective characters of these two genera it will be observed that their technical distinctions are not very definite, depending chiefly upon the difference in length and more or less bilabiate character of the indusium, in conjunction with the varying length of the sporangiferous receptacle. In those species which may respectively be considered as typical, these characters are sufficiently manifest, and leave no doubt as to the genus to which they should be referred; but the numerous intermediate forms, and the different appearances presented by some species at different periods of growth, often render the determination of the genus by herbarium specimens very embarassing, and the difficulty is still further increased by the fact that the two genera contain individual species agreeing perfectly in general habit. It therefore appears to me that the distinction between Hymenophyllum and Trichomanes is 
more ideal than actual. But, for the sake of convenience, I admit the necessity of following the usual practice of authors, and consequently adopt the genera as heretofore.

In at least two species the fertile fronds are contracted into a linear entire or racemose rachiform spike, and upon this character Bory founded two genera, Hymenostachys and Féea. The first of these has the peculiarity of being the only species of Hymenophyllece having anastomose reins; and that circumstance, in conjunction with the contracted form of the fertile frond, induced me in 1841 to adopt it as a distinct genus, which I still continue to do. In Féea the venation is free, and it consequently differs from Trichomanes only by the contraction of its fertile trond, so that I did not at the same period regard it as distinct; but upon reconsidering the subject, I see no reason why Féea should not have as good a right as Lomaria to be considered a distinct genus, it having the same relationship with Trichomanes that Lomaria has with Blechnum.

In the preceding observations I have mentioned the chief points of structure employed by authors for classifying the species; and, although I have given the subject much consideration, I can find no other tangible characters whereby the number of genera may be advantageously increased. This is, however, different from the view taken by Presl, who arranges the whole under no less than twenty-three genera, as stated at page 30. A critical review of these so-called genera would occupy more space than can be afforded in the present work, and would serve no practical purpose. The characters of his new genera appear to me to be in many cases imaginary or derived from imperfect materials, the same species being in some cases placed under separate genera. 
Hymenophyllacece have a wide geographical range, abounding in the tropical regions of America and the West Indian Islands, in India, the Islands of the Indian and Pacific Oceans, and extending as far as New Zealand and Lord Auckland's Islands in the southern hemisphere, and Norway and the Faroe Islands in the northern; but very sparingly found on the African continent. They love shade and moisture, many being epiphytal and clothing trees like moss, or growing in shady ravines or caves; but the same species often occurs under different influences, and consequently assumes different appearances, which has led to an unnecessary increase in the specific nomenclature. The number of species varies according to the views held by different authors, 172 are described in the "Species Filicum," and are nearly equally divided between the two genera, Hymenophyllum and Trichomanes, which in the "Synopsis" are reduced to 149.

This, however, falls far short of the number given by Dr. Van Den Bosch, who, in his "Synopsis Hymenophyllacearum," enumerates no less than 302 species, as already shown at page 31.

\section{9.-Hrmenophyllum, Sm. (1793).}

Vernation uniserial and sarmentose. Fronds varying from simple to decompound multifid, membranaceous and pellucid, smooth, or bearing simple forked or stellate hairs. Veins simple or forked, free. Sori terminal. Indusium urceolate, bilabiate, or bivalved. Receptacle short, included within the indusium.

Type. Hymenophyllum Tunbridgense, Sm.

Illust. Hook. and Bauer Gen. Fil., t. 32 ; Moore Ind. Fil., p. 90, A. ; J. Sm. Ferns Brit. and For., fig. 137; Hook. Syn. Fil., t. 2, fig. 16. 
* Fronds glabrous.

+ Segments entire, plane, or undulated. Stipes and rachis rarely pilose.

Sp. H. cruentum, Cav. ; H. marginatum, Hook.; H. asplenioides, $S w$. ( $\mathrm{v}$ v.); H. abruptum, Hook. (v v.); H. reniforme, Hook.; H. axillare, Sw.; H. gracile, Bory.; H. capillaceum, Roxb. ; H. polyanthos, $S w$. ( $\vee$ v.) ; H. abietinum, Hook. and Grev. Ic. Fil., t. 127; H. protrusum, Hook.; H. recurvum, Gaud. ; H. undulatum, $S w$. ; H. myriocarpum, Hook.; H. badium, Hook.; H. rarum, R. Br. ( v.); H. flabellatum, Labill. ( $\nabla$ v.); H. demissum, Sw. ( $\nabla$ v.); H. exsertum, Wall. ; H. scabrum, A. Rich. ( $\nabla$ v.) ; H. crispatum, Wall. ( $\nabla$ v.); H. flexuosum, A. Cunn. ( $\left.\nabla \nabla_{0}\right)$; H. javanicum, Spr.; H. caudiculatum, Mart. ( $\nabla$ v.); H. fuciforme, $S w_{0}(\nabla \nabla$.$\left.) ; H. pulcherrimum, Col. ( \nabla \nabla_{0}\right)$; H. dilatatum, $S w .\left(\nabla \nabla_{0}\right)$.

t† Segments dentate or spinulose, serrate or undulate.

H. Tunbridgense, Sm. ( $\nabla$ v.); H. unilaterale, Willd. ( $\checkmark$ v.); H. cupressiforme, Lab. ; H. peruvianum, Hook.; H. Jamesoni, Hook. ; H. Smithii, Hook. ; H. Bridgesii, Hook.; H. multifidum, $S w_{\text {. ( }} \mathrm{v}_{\text {. }) \text {; H. bivalve, } S w . ;}$. H. attenuatum, Hook.; H. tortuosum, Hook.; H. dichotomum, Cav. ; H. Neesii, Hook. ; H. secundum, Hook. ; H. cristatum, Hook.; H. fucoides, $S w$. ( v v.) ; H. pectinatum, Cav.

** Fronds pilose. Hairs simple, binate, or stellate.

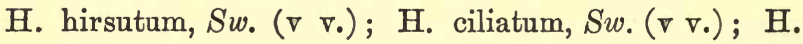
hirtellum, $S w$. ( $\nabla$ v.) ; H. Boryanum, Willd.; H. chiloense, Hook. ( $\vee$ v.); H. organense, Hook.; H. valvatum, Hook. ( $\left.\nabla \nabla_{0}\right)$; H. lineare, $S w .\left(\nabla \nabla_{\bullet}\right)$; H. pulchellum, Schlecht.; H. sericium, $S w$. ( v.); H. obtusum, Hook.; H. Berteroi, 
Hook. ; H. interruptum, Kunze ; H. æruginosum, Carm. ( $\vee$ จ.); H. lanceolatum, Hook.; H. Lindeni, Hook.

\section{0.-Trichomanes, Linn., in part (1742).}

Vernation fasciculate, erect or decumbent acaulose, or uniserial and sarmentose. Fronds varying from simple to decompound multifid, membranaceous and pellucid, smooth, or bearing simple forked or stellate hairs. Veins simple or forked, free. Sori terminal, often sub-pedicellate. Indusium urceolate or tubular; receptacle continued beyond the sporangia and mouth of the indusium, often elongated and filiform.

Type. Trichomanes scandens, Linn.

Illust. Hook. and Bauer Gen. Fil., t. 31 ; Moore Ind. Fil., p. 88, B. ; J. Sm. Ferns Brit. and For., fig. 138; Hook. Syn. Fil., t. 2, fig. 17.

* Vernation uniserial; sarmentum slender.

T. reniforme, Forst. ( $\nabla$ v.); T. membranaceum, Linn. ( $\nabla$ v.) ; T. punctatum, Poir. ( $\nabla$ v.) ; T. reptans, $S w$. ( $\nabla$ v.); T. Bojeri, Hook. ( $\nabla$ v.); T. muscoides, Sw. ( $\nabla \nabla$.$) ; T. pusil-$ lum, Sw. ( $\vee$ v.) ; T. apodum, Hook. ; T. parvulum, Poir. ; T. proliferum, $B l$. ; T. digitatum, $S w$. ; T. humile, Forst.; T. intramarginale, Hook. ; T. Krausii, Hook. ( $\nabla$ v.) ; T. venosum, $R . B r$. ( $\vee$ v.); T. cæspitosum, Hook.; T. quercifolium, Hook.; T. sinuosum, Rich. ( $\nabla$ v.); T. pyxidiferum, Linn. ( $\left.\nabla \nabla_{0}\right)$; T. Filicula, Bory. ( $\left(\mathrm{v}_{0}\right)$; T. angustatum, Carm. ( $\vee$ v.); T. exsectum, Kunze ( $\vee \nabla_{0}$ ); T. trichoideum, $S w$. ( $\vee \nabla_{\bullet}$ ); T. auriculatum, $B l_{\text {. }}$; T. melanorhizon, Hook.; T. radicans, $S w$. ( $\nabla$ v.); T. scandens, Linn. ( $\nabla$ v.); T. Kun. zianum, Hook. ; T. incisum, Kaulf. ( $\nabla$ $\left.\nabla_{0}\right)$; T. Ankersii, Hook.; T. brachypus, Kunze; T. glauco-fuscum, Hook. 
**Vernation fasciculate, decumbent.

T. crispum, Linn. ( $\nabla$ v.); T. pinnatum, Hedw. ( $\nabla$ v.); T. lucens, $S w . ;$ T. Lambertiana, Hook. ; T. attenuatum, Hook.

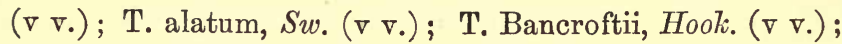
T. crinitum, $S w$. ( $\vee$ v.); T. superbum, Back. ( $\vee$ v.)

\section{*** Vernation fasciculate, erect.}

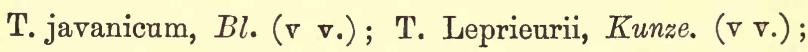

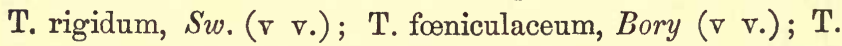
meifolium, Bory ( $\nabla$ v.); T. polyanthos, Hook. Ic. Pl., t. 703 ; T. strictum, Menz.; T. gigantum, Bory ; T. Smithii, Hook. ; T. elongatum, A. Cunn. ( $\nabla$ v.); T. saxatile, Moore ( $\left.\nabla \nabla_{0}\right)$;

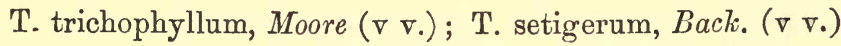
OBs.-I have above shown that the only technical difference between Hymenophyllum and Trichomanes is that in the latter the receptacle is prolonged beyond the sporangia, even in some to the length of a quarter of an inch, having the appearance of bristles excerted beyond the margin of the frond.

In this country Hymenophyllacese is represented by three species, namely, Hymenophyllum Tunbridgense, H. unilaterale, and Trichomanes radicans. They are, however, very rare, being found in a few special localities; the latter is becoming very rare in England, but is found in several localities in the south of Ireland. Since the invention of Wardian cases, these " Filmy Ferns" so called, have become great favourites with amateur cultivators; and the great demand for them is bringing about their extermination in this country.

With regard to Exotic species, in my "Catalogue of Cultivated Ferns" for 1846, only two species are enumerated, which in 1864 had increased to sixty-three, as recorded in "Ferns, British and Foreign," pages 249 and 324. 


$$
\text { 201.-FeEA, Bory. (1824). }
$$

Vernation fasciculate, erect, acaulose. Fronds of two forms, 2 to 6 inches high; the sterile pinnatifid or subpinnate, the fertile contracted, rachiform, stipate, longer than the sterile. Veins simple or forked; venules free, pedicellate, in a row along both sides of the rachis. Indusium tubular, calyciform. Receptacle filiform, continued beyond the sporangia and mouth of the indusium.

Type. Trichomanes spicata, Hedwig.

Illust. Hook. Exot. Fl., t. 52 ; Moore Ind. Fil., p. 89 A.;

J. Sm. Ferns, Brit. and For., fig. 139.

Sp. F. spicata, Pr. ( $\nabla$ v.); F. nana, Bory. ( $\nabla$ v.).

Natives of the West Indies and Tropical America.

\section{2.-Hymenostachys, Bory. (1824).}

Vernation fasciculate, erect, acaulose. Fronds of two forms ; the sterile pinnatifid ; veins forked ; venules anastomosing, forming oblique elongrated areoles ; fertile frond contracted, longer than the sterile, linear rachiform, constituting a distichous spike of connate, urceolate, calyciform indusia, each containing a free columnar exserted receptacle.

Type. Trichomanes elegans, Rudge.

Illust. Hook. and Bauer Gen. Fil., t. 108 ; Moore Ind. Fil., p. 89 B. ; J. Sm. Ferns, Brit. and For., fig. 140. OBs.-This genus is founded on an elegant and remarkable Fern, first described by Rudge in a work on the plants of Guiana, with a figure (t.35) in which this and leca spicata are represented as one species. This I have long ago verified as a mistake on examining the original specimens in Rudge's herbarum. It differs from Trichomanes in having the fertile fronds contracted into a linear 
spike, having a line of connate sori on both its margins, and also in the venation being reticulated, being the only instance of such in this extensive family.

Sp. H. diversifrons, Bory. ( $\mathrm{v}$ v.).

A native of Guiana, parts of Tropical America, and Trinidad.

C. Ring of Sporangia horizontal, apical, in some incomplete or rudimentary only.

Tribe 26.-SCHIZ压艮 (Plate 26).

(Schizeacece, Kaulf.)

Sporangia produced on contracted racemes or panicles, or on marginal lobules or spikelets, oval or oblong, rarely globose, apex striated, annulatiform, opening lengthways, vertical.

OBS.-The oval sporangia, furnished with a striated apex, analogous to a transverse ring, readily distinguishes Schizoeacece from the two preceding divisions (A. and B.). They were originally comprehended under Osmundacece, and to judge by the structure of their sporangia, the slight difference scarcely warrants their separation; but as they differ much in habit, it is deemed most natural to view them as separate tribes.

In the "Synopsis" sixty species are enumerated, widely dispersed over the Old and New World, extending to New Zealand in the south, and to lat. $40^{\circ}$ in the North (New Jersey). With few exceptions the species are contained under the genera Lygodium, Anemia, and Schizau. 
PI. 26 .

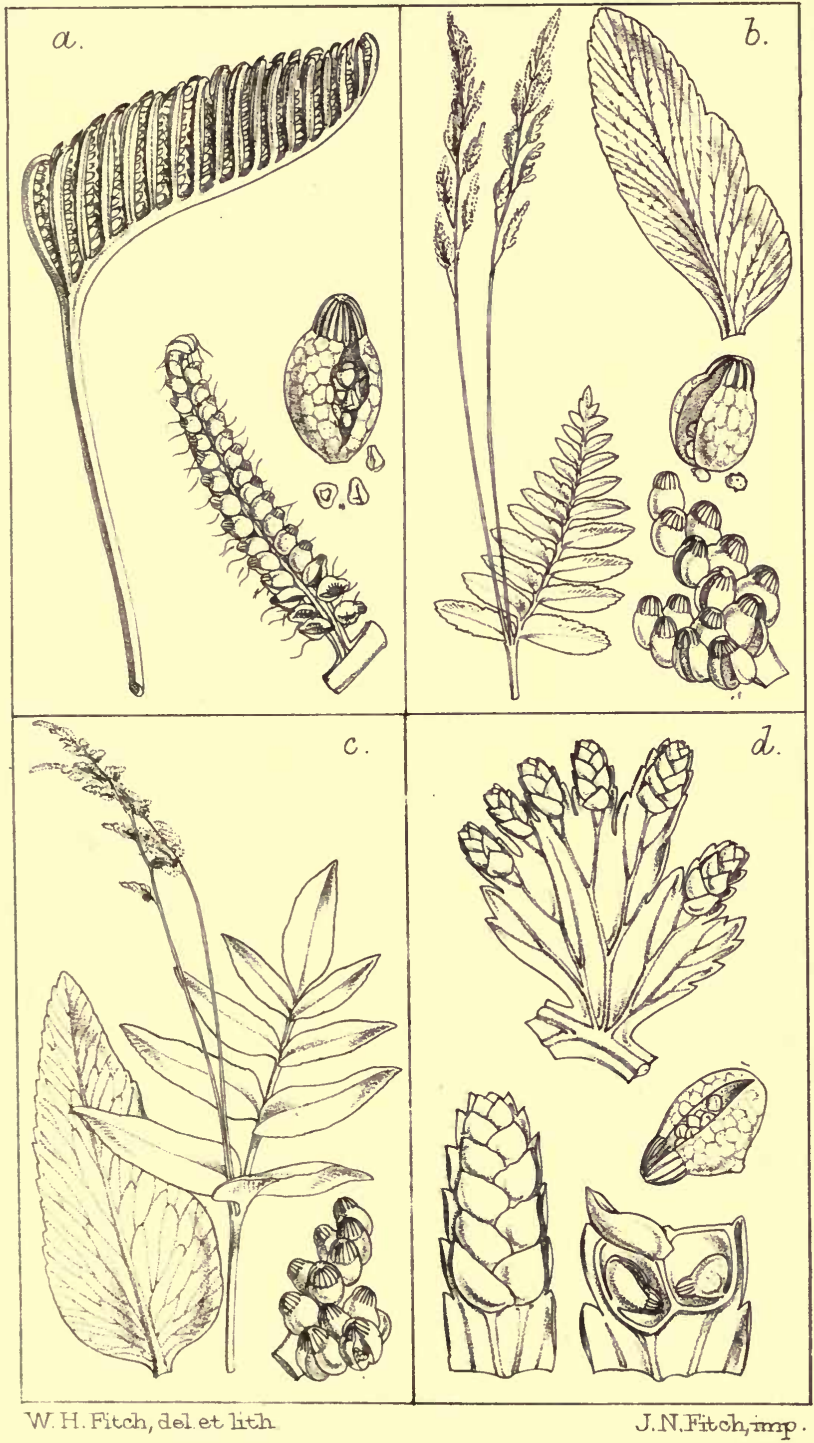



203.-Lygodidm, Sw. (1800).

Hook. Syn. Fil.

Vernation uniserial, distant and sarmentose, or contiguous and cæspitose. Fronds scandent, twining, extending to an indefinite length ; pinnæ conjugate, palmate lobed, pinnatifid or pinnate. Veins forked, free. Sporangiferous spikelets marginal, composed of two rows of imbricate indusæform cysts, each cyst containing an oval, resupinate sporangium attached by its inner side, and opening lengthwise on its outer side.

Type. Iygodium circinatum, $S w$.

Illust. Hook. and Bauer, Gon. Fil., t. 28 ; Moore, Ind. Fil., p. 90 B. ; J. Sm., Ferns, Brit. and For., fig. 141 ; Hook., Syn. Fil., t. 9, fig. 68, a, b, d.

OBs.-The Ferns constituting this genus are readily known from all others by their climbing habit; the fronds being permanent, and increasing in length indefinitely by their twining and interlacing with one another, and with other plants, they form impervious thickets. The various forms they assume, and the divisions of the fronds, render it difficult to arrive at any satisfactory conclusion as to the number of distinct species. Presl enumerates forty species, but in the "Synopsis Filicum" only sixteen are described, which I consider to be nearer the true number of distinct species. They abound within the tropics, and extend to New Zealand in the southern, and L. palmatum extends to Canada in the northern hemisphere.

* Petiole of pinnules articulate with the rachis.

Sp. L. articulatum, Rich. ( $\nabla \nabla$.$) ; L. scandens, Sw. ( \nabla$ v.); L. venustum, $S w$. ; L. volubile, $S w$. ; L. pinnatifidum, $S w$. L. polystachyum, Wall. ( $\nabla$ v.). 
** Petiole of the pinnules decurrent on the rachis.

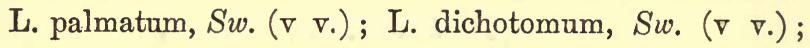
L. digitatum, Eaton; L. semi hastatum, Desv.; L. trifurcatum, Baker; L. subalatum, Bojer; L. japonicum, Sw. ( $v$ v.).

\section{4. -Lygodictron, $J$. Sm. (1841).}

Lygodium sp. auct., Hook. Syn. Fit.

Vernation and general character the same as in Lygodium, differing only in the veins being reticulated.

Type. Iygodium reticulatum, Schk.

Illust. Hook. and Bauer, Gen. Fil., t. 111 B.; Moore, Ind. Fil., p. 91 A. ; J. Sm., Ferns, Brit. and For., fig. 142 ; Hook. Syn. Fil., t. 9, fig. 68 c.

Sp. L. reticulatum (Schk.) ( $\nabla \nabla$.$) ; L. heterodoxum (Kzc.)$ ( $\nabla$ v.)

\section{5.-Anemia, $S w$. (1806). Hook. Syn. Fil.}

Vernation fasciculate, erect, acaulose, rarely sarmentose. Fronds pinnate or bi-tri-pinnatifid, dimorphus, from a few to 18 inches in height, the fertile contracted, distinct, simple or tripartite, the two opposite segments contracted, erect, constituting two sporangiferous panicles, the third segment sterile, and pinnate or bi-tripinnate, with forked free veins. Sporangia oval, attached by the base, opening vertically on the exterior side.

Type. Anemia aurita and $A$. adiantifotia, $S w$.

Illust. Hook. and Bauer Gen. Fil., t. 90 ; Moore Ind. Fil., p. 92 A. ; J. Sm. Ferns, Brit. and For., fig. 143 ; Hook. Syn. Fil., t. 8, fig. 65 a. b. c. d. 
OBS.-This genus, as originally characterised by Swartz, contains species differing, in some having their fertile fronds wholly contracted, forming a panicle, and in others the fertile frond is tripartite, one branch being always sterile, the other two always fertile. In my "Genera of Ferns," published in the "Journal of Botany" for 1841, I restricted true Anemia to the species possessing the latter character, a few of which, having anastomose venation, I separated as a distinct genus (Anemidictyon), those with the sterile and fertile fronds wholly distinct I added to the genus Mohria of Swartz. Subsequent observation has, however, induced me to alter this view, and to consider them more nearly related to Anemia than to Mohria.

Presl enumerates no less than forty species of Anemia, which in the "Synopsis Filicum" are reduced to twentysix. A number are, however, termed varieties, the numerous intermediate forms of herbarium specimens naturally lead to such a conclusion. With the exception of A. Wightiana, a native of the Neilgherries, A. Schimperiana, a native of Abyssinia, and $A$. Dregeana, a native of South Africa, the whole are natives of the West Indies and Tropical and Sub-tropical America.

* Fertile fronds simple, paniculate (Coptophyllum, Gard.).

Sp. A. aurita, Sw., Hook. Ic. Pl., t. 903 ; A. buniifolia, Gard., Hook. Ic. Pl., t. 477 ; A. millefolia, Gard., Hook. Ic. $P l .$, t. 478; A. bipinnata, Moore (Osmunda bipinnata, Linn., herb. only; A. intermedia, R. Br. herb. Brit. Mus.; A. cicutaria, Kze., Anal. Pterid. 9, t, 5, fig. 2).

** Fertile fronds tripartite (Anemia vera.)

+ Vernation fasciculate.

A. Gardneri, Hook. Ic. Pl. t. 190 ; A. oblongifolia, Sw., Schk. Fil., t. 142 ; A. Dregeana, Kze., Hook. Ic. Pl., $t$. 


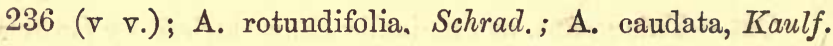
(A. radicans, Raddi Fil. Bras., t. 10); A. mandioccana, Raddi, Hook., Gard. Ferns, t. 36 (v v.); A. collina, Raddi, Hook. Fil. Exot., t. 1 ( ( v v.); A. hirsuta, Sw. ( $\nabla$ v.); A. tomentosa, Sw. (A. flexuosa, Sw., Hook. Fil Exot., t. 30) ( $\vee$ v.); A. Schimperiana, Pr.; A. Wightiana, Gard., Bedd., F. S. Ind., t. 65 ; A. trichorbiza, Gard., Hook. Ic. Pl.t. 876 ; A. fulva, Sw., Hool. Fil. Exot., t. 126 (v v.); A. cuneata, Kze., Anal. Pter. 8, t. 5.

\section{†† Vernation sarmentose (Anemirhiza, J. Sm.).}

Sp. A. adiantifolia, Sw. (v v.) (Plum. Fil., t. 32) var. asplenifolia, Hook. and Grev. Ic. Fil. t. 16.

Ors.-This species differs from all the preceding in the fronds being distantly produced on a sarmentum. In the "Botany of the Voyage of the Herald" (1853), 1, p. 242, I noticed this peculiarity, and considered it might be suffcient to characterise a distinct genus under the name of Anemirhiza, but further consideration induces me to retain it as a section only.

\section{6.-Anemidictyon, J. Sm. (1841).} Anemia sp., Hook. Syn. Fil.

Vernation fasciculate, erect, acaulose. Fertile fronds tripartite, the two lateral branches fertile, paniculate, the central ones sterile, pinnate. Veins reticulate. Sporangia as in Anemia.

Type. Anemia Phyllitidis, Sw.

Illust. Hook. and Bauer Gen. Fil., t. 103 ; Moore Ind. Fil., p. 92, B ; J. Sm. Ferns, Brit. and For., fig. 144 ; Hook. Syn. Fil., t. 8, fig. 65, e.

Sp. A. Tweediana, Hook. Ic. Pl., t. 906 ; A. Phyllitidis (Sw.) (v v.) (Plum Fil., t. 156). 
OBs.-The first is a native of South Brazil, and the other very generally distributed throughout the West Indies and Tropical America. As might be expected, the plants of the different localities have been described under no less than ten specific names, their differences resting entirely on the difference of length and breadth of the sterile pinnæ, which, although retained under cultivation, I do not consider it a sufficient character to be specific.

\section{7.-Trochopteris, Gard. (1842).

$$
\text { Hook. Syn. Fil. }
$$

Vernation fasciculate, acaulose. Fronds depressed, rosulate, $\frac{3}{4}$ to 1 inch in length, half an inch in breadth, fivelobed, the two lower lobes small, contracted, laciniated, the lacinæ bearing the sporangia. Veins flabellate, dichotomously forked, venules free.

Type. Trochopteris elegans, Gard.

Illust. Hook. and Bauer Gen. Fil., t. 104, A; Moore Ind. Fil., p. 93, B ; Hook. Syn. Fil., t. 8, fig. 67.

OBs.-This is a peculiar little Fern, a native of Brazil, growing on the face of rocks. The fronds lying flat, their appearance led Dr. Gardner to compare them to little wheels. It may be considered to be a modified state of Anemia, but its distinct habit is sufficient to mark it as a separate genus.

Sp. T. elegans, Gard. Hook. Lond. Journ. Bot. 1, t. 4.

$$
\begin{gathered}
\text { 208.-Mohria, Sw. (1806). } \\
\text { Hook. Syn. Fil. }
\end{gathered}
$$

Vernation fasciculate, acaulose, cæspitose. Fronds linear, bi-tri-pinnatifid, 6 to 12 inches or more in length, the fertile partially contracted, segments small. Veins free. Spo- 
rangia sessile few, seated in concave segments formed by the revolute margin, globose, opening vertically on their exterior side.

Type. Mohria thurifraga, $S w$.

Illust. Hook. and Bauer Gen. Fil., t. 104, B; Moore Ind.

Fil., p. 93, A ; J. Sm. Ferns, Brit. and For., fig. 145;

Hook. Syn. Fil., t. 8, fig. 66.

OBs.-This genus is founded on a solitary species, a native of South Africa and Madagascar.

Sp. M. thurifraga, Sw. ( $\nabla$ v.) (M. achillaefolia, Lowe's New Ferns, $t .42, B_{\text {.) }}$

OBs.-This Fern much resembles some species of Cheilanthece, the concave segments containing the sporangia being similar to Myriopteris.

\section{9.—ScHIZÆA, Sm. (1793). \\ Hook. Syn. Fil.}

Vernation fasciculate, erect, acaulose, rarely distant. Fronds linear, simple, stipitiform, simply forked or flabellate, 2 to 20 inches high. Veins forked, free; fertile appendices terminal, pinnate, cristæform; margins of the segments involute, each bearing on its inner side two compact rows of sessile oval sporangia, attached by their base, and opening vertically.

Type. Schizoea pectinata, Smith.

Illust. Hook. and Bauer Gen. Fil., t. 19 ; Moore Ind. Fil., p. 91 B. ; J. Sm. Ferns, Brit. and For., fig. 146 ; Hook. Syn. Fil., t. 8, fig. 64.

OBs.-This is a curious genus, differing from Anemia in the sporangia being borne on crestlike terminal spikes, which being resupinate give the appearance of the sporangia being produced on the upper surface. 
Sixteen species are described in the "Synopsis Filicum," and are widely distributed throughout the tropics and subtropics of both northern and southern hemispheres. In general the species are very local, S. dichotoma is, however, found in the West Indies, Tropical America, Now Zealand, Australia, and the Polynesian, Malayan, and Mascarene Islands.

* Fronds simple, linear.

Sp. S. australis, Gaud.; S. pusilla, Pursh. ( $\nabla$ v.); S. tenella, Kaulf.; S. fistulosa, Labill. ; S. pectinata, Sm.

** Fronds forked, linear.

S. incurvata, $S c h k . ;$ S. bifida, $S w$.

*** Fronds bifid, dichotomously forked or flabelliform, segments broad.

S. rupestris, R. Br. ( $\left.\begin{array}{l}\mathrm{v} \\ \mathrm{v} .\end{array}\right)$; S. fluminensis, Miers.; S. Sprucei, Hook. MSS.; S. dichotoma, Sw.; S. elegans, Sw. (v v.), Hook. Gard. Ferns, t. 54.

OBS.-The latter species differs in the fronds being more or less divided, becoming entire and fan-shaped, and has been described by Martius as a distinct species under the name of S. flabellum.

\section{0.-Actinostachys, Wall. (1828).}

Schizcea, Hook. Syn. Fil.

Vernation uniserial, contiguous; sarmentum short. Fronds linear, simple, stipitiform, compressed, triquetrous at the base, 9 to 18 inches high. Costæ prominent, continuous. Fertile appendices terminal, 6 to 12, digitate flabellate, 1 to $1 \frac{1}{2}$ inch long, cristæform; segments involute, 
each bearing on its inner side four rows of sessile, oval sporangia, attached by their base and opening vertically.

Type. Schizcea digitata, Swartz.

Illust. Hook. and Bauer Gen. Fil., t. 111 A.; J. Sm.

Ferns, Brit. and For., fig. 147.

Oвs.-This genus differs from true Schizcea by the fertile appendices being produced on a digitate cluster, and in the sporangia being produced in two rows on each side of the midrib, the attachment of each of the two rows being on the same line (receptacle).

Sp. A. digitata, Wall. ( $\nabla$ v.); A. pennula, Sw. (A. trilaterales, Schk. crypt., t. 136).

OBs.-The first species is widely distributed, being found in Ceylon, India, and the Malay and Polynesian Islands. The second is also widely diffused, being found in the West Indies, Guiana, and Brazil.

\section{Tribe 27.-OSMUNDAE $\not$ (Plate 27).}

\section{OSMUNDace $\mathrm{R}, \mathrm{R} . \mathrm{Br}$.}

Sporangia globose, reticulated, short pedicellate, oblique and gibbous at the apex, opening by a vertical slit (subbivalved). Ring apical, rudimentary, or absent.

OBs.-The absence or but slight evidence of annulus or stria is the chief technical character that distinguishes this from Schizceacece, they however, differ essentially in habit and general appearance, having leafy, pinnate, or bi-pinnate fronds.

Presl enumerates twenty-four species, which may be safely reduced to one-half, indeed, in the "Synopsis Filicum " only ten species are described. Several of the species have a very wide geographical range, being common to 


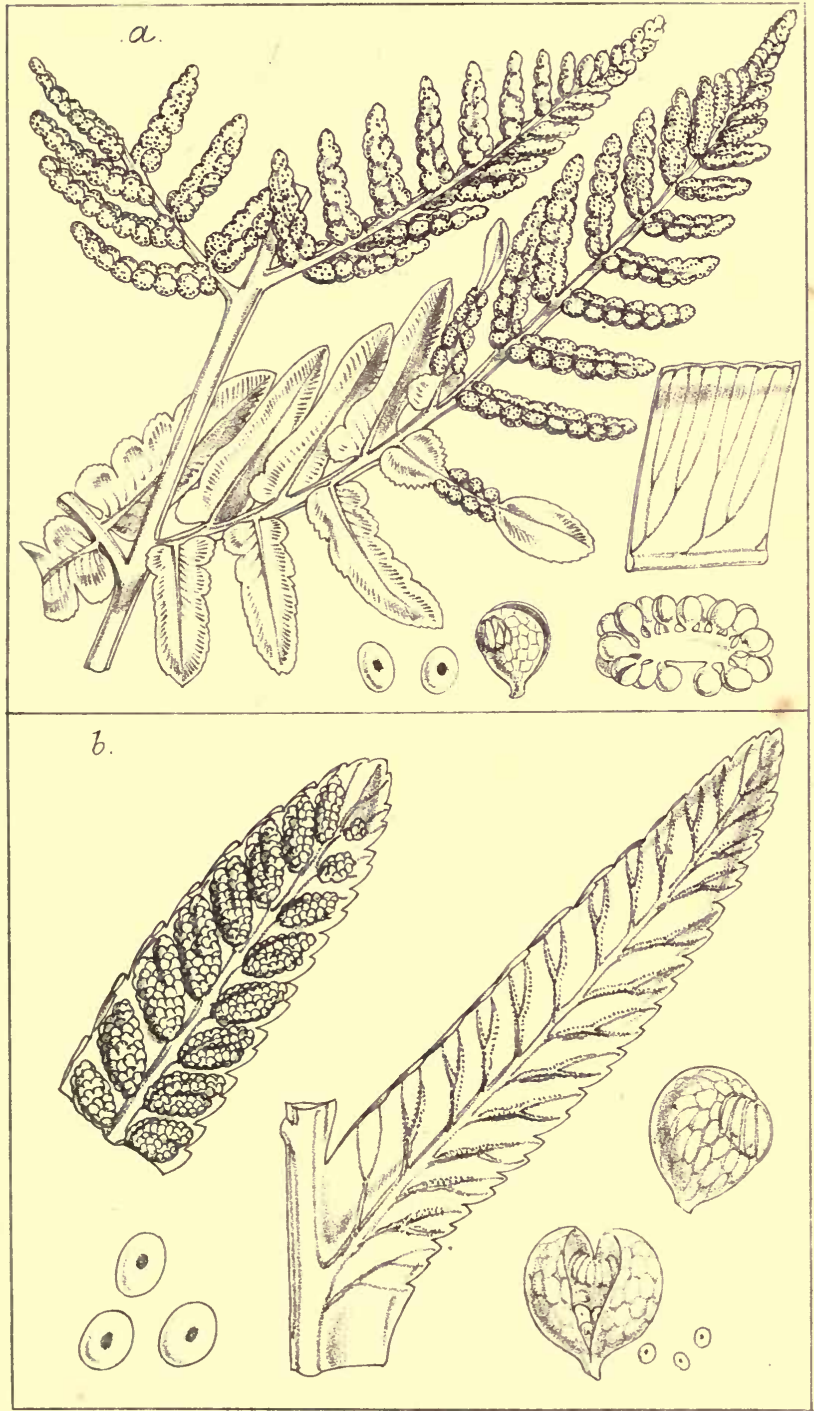



both the Old and New World, which, as in many other instances, has led to their being considered as distinct species.

\section{1.-OsMunda, Linn. (1737).}

Vernation fasciculate, erect, acaulose, sub-arboroid, producing outgrowing aerial, mossy roots, forming a spongy mass. Fronds pinnate or bi-pinnate, 3 to 10 feet high, pinnæ articulated with the rachis. Veins forked; venules free. Fertile fronds wholly, or the upper or middle portion, contracted, forming simple or compound sporangiferous panicles.

Type. Osmunda regalis, Linn.

Illust. Hook. and Bauer Gen. Fil., t. 46 A.; Moore Ind, Fil., p. 94 B. ; J. Sm. Ferns, Brit. and For., fig. 148; Hook. Syn. Fil., t. 8, fig. 62.

* Fertile fronds wholly contracted (Osmundastrum, Pr.).

Sp. O. cinnamomea, Linn. ( $\nabla$ v.); O. lancea, Thunb.

** Lateral pinnce of fertile frond contracted (Plenasium, Pr.)

O. Javanica, Blume.; O. Claytoniana, Linn. ( $\nabla$ v.); O. bipinnata, Hook. Fil. Exot., t. 15.

*** Terminal pinnce of fertile frond contracted (Euosmunda).

O. regalis, Linn. ( $\nabla$ v.); O. spectabilis, Willd. ( $\nabla$ v.); O. gracilis, Link. ( $\nabla \mathrm{v}$.).

OBs.- -0 . cinnamomea and $O$. regalis have a wide geographical range, the first being found throughout tropical and temperate America, Eastern China, and Japan, the second being found in most countries conducive to Fern life. 


\section{2.-Todea, Willd. (1802).}

Vernation fasciculate, erect, sub-arboroid, naked, or producing outgrowing aerial roots, forming a spongy mass. Fronds bi-tri-pinnatifid, 2 to 6 feet high ; pinnæ coriaceous or membranaceous; fertile frond sub-contracted. Veins forked; venules free sporangiferous, forming oblong linear sori, often confluent.

Type. Acrostichum barbarum, Linn.

Illust. Hook. and Bauer Gen. Fil., t. 46 B., f. 1 ; Moore Ind. Fil., p. 95 ; J. Sm. Ferns, Brit. and For., fig. 149 ; Hook. Syn. Fil., t. 8, fig. 63.

OBs.-This genus differs from Osmunda merely by its fronds being not at all or only slightly contracted, the sporangia produced on evident venules. Leptopteris of Presl is in my view not sufficiently distinct as a genus from Osmunda.

\section{* Fronds firm, opaque (Eutodea).}

Sp. T. barbara, Moore, Bot. Mag., t. 5954, 1872. (T. Africana, Willd.; T. rivularis, Sieb.).

Obs.-Originally found in the Cape of Good Hope, but more recently found distributed throughout New Zealand and Australia.

** Fronds membraneous, segments in some multifit.

(Leptopteris, $P r_{\text {r. }}$ ).

T. hymenophylloides, Rich. ( $\nabla$ v.); T. superba, Colenso (v v.) ; T. Fraseri, Hook. and Grev.; T. Wilkesiana, Brack.

OBS.-The two first are natives of New Zealand, the third of New South Wales, and the fourth a native of Fiji ; in the "Synopsis Filicum" it is considered a variety of T. Fraseri, but its slender, walking-stick-like stem, 



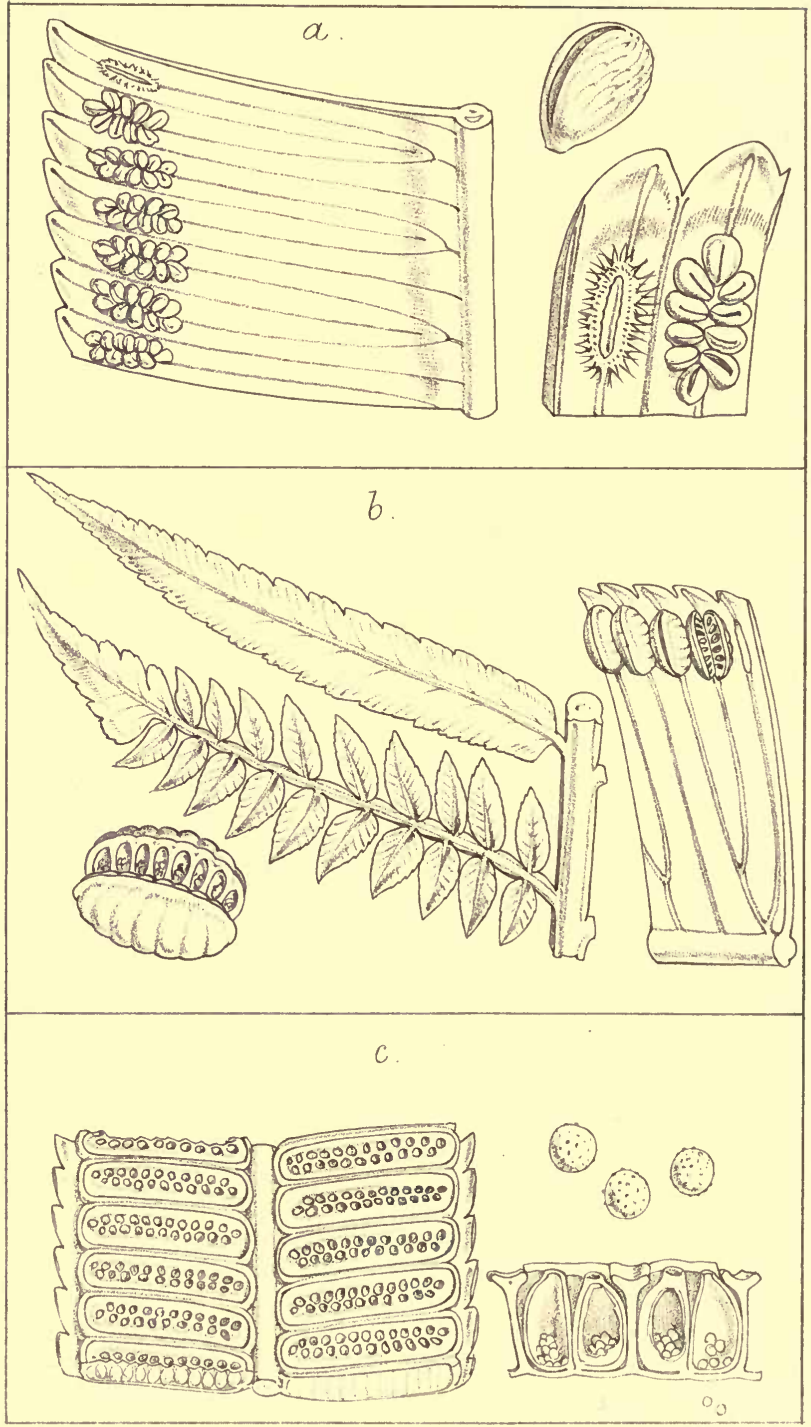


marks it as a very distinct species. In the "United States' Exploring Expedition" it is spoken of as the "little tree Fern." This presents a great contrast to Osmunda regalis and Todea barbara; these produce from their axis a dense mass of aerial outgrowing mossy roots, which increase in bulk with age, and in which the early axis of the vernation becomes imbedded, its apex continuing to maintain its position on the surface by the successive evolution of the fronds, and often producing offsets (cæspitose); numerons crowns of fronds are thus formed, and which continue to develope rootlets from their base, thus gradually increasing the size of the spongy mass. By this mode of increase specimens of $O$. regalis attain the height of 2 or more feet, with a diameter about the same, but this is exceeded in size by Todea barbara, specimens of it having been received in Europe from the Victorian Alps in Australia, one measuring 5 feet 8 inches in height, its diameter being 7 feet 9 inches, its weight 1 ton $3 \mathrm{cwt}$. In 1869 a specimen was received at Kew weighing $15 \mathrm{cwt}$., having $30 \mathrm{crowns}$, producing 160 fronds, the weight of these great masses being due to their being retentive of water like a sponge.

\section{Division III.-SCAPHOBRYA.}

Fronds terminal, rising from between two stipuliform or socket-like appendages, and articulate with the caudex. Sporangia opaque, horny, destitute of a ring.

\section{Tribe 28.-MARATTIE 2 (Plate 28). Maratriacez, Kaulf.}

Vernation terminal, articulate.

OBs.-Although this tribe agrees with the whole of the preceding in the fronds being spirally developed, it is 
hevertheless very distinct not only in the spore cases being destitute of a ring, but also in the vernation being terminal and articulate with the axis of development, similar to certain species of Cyathea already noticed. This articulation must not, however, be confounded with the Eremobryous division Polypodiacoe, in which the fronds are produced solitary on the sides of the axis. In most of the annulate Ferns the roots are hard and wiry, often spreading over and clinging to the surface on which they grow, whereas in the exannulate the roots are soft, sticky, and fleshy, often penetrating deeply into the soil, in that respect being analogous to many of the endogenous orders, such as Cycadece, Cyclantheoe, Amaryllea, and Liliacoe. They are generally large growing Ferns consisting of about twenty or thirty species, arranged under the following genera :-

\section{3.-ANGIOPTERIS, Hoffm. (1793).}

Vernation fasciculate, erect, sub-arboroid; each frond rising from between two fleshy stipulæform appendages; base of the stipes clavate, pseudo-articulated with the axis. Fronds 6 to 18 feet in length, spreading, bi-pinnate ; pinnæ and pinnules articulated with the rachis. Veins simple or forked, free. Receptacles oblong, linear, terminal. Sporangia 6 to 24 , bi-serial, sessile, free, opening by a slit on the inner side. Sori oblong, laterally contiguous (confluent), forming a broad, sub-marginal transverse band of sporangia.

Type. Angiopteris evecta, Hoffm.

Illust. Hook. and Bauer Gen. Fil., t. 10 ; Moore Ind. Fil., p. 96 A.; J. Sm. Ferns, Brit. and For., fig. 152 ; Hook. Syn. Fil., t. 9, fig. 69.

OBs.-This genus is represented throughout the tropical 
countries of the eastern hemisphere and islands of the Pacific, the numerous localities presenting different phases of what some authors suppose to be one species only, while De Vriese describes no less than sixty species. On judging from my examination of authentic specimens from De Vriese, in the Hookerian herbarium, I have no hesitation in saying they may be safely reduced to one-sixth of that number, indeed in the "Synopsis Filicum" the whole are reduced to one species, namely, the original type, $A$. evecta. Judging from the aspect, and some special differences of cultivated plants, I consider the following as distinct species. The chief difference besides the aspects consists in the number of sporangia forming the sorus, which varies from a few to many; these numbers appear to be constant and uniform in individual plants, but the various intermediate numbers observed in others destroys the well marked difference between the lesser and greater numbers. In some a narrow fimbriate membrane is observed under the sporangia, which is considered to represent an indusium.

Sp. A. evecta, Hoffm. ( $\nabla$ v.) ; A. Teysmanniana, De

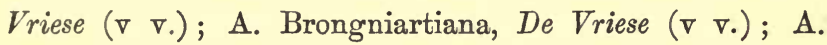
pruinosa, Kze. ( $(\nabla \nabla$.$) ; A. hypoleuca, De Vriese ( \nabla$ v.); A. Miqueliana, De Vriese ( $\nabla$ v.).

OBs.-In Sikkim a plant of $A$. evecta has been measured having a caudex 2 feet 4 inches high and 2 feet 6 inches in diameter, the spread of fronds being 24 feet, being ten less than a plant cultivated at Kew.

\section{4.-Marattia, Sm. (1793).}

Vernation fasciculate, erect, sub-arboroid; each frond rising from between two fleshy stipulæform appendages (which sometimes assume the character of abnormal 
fronds). Fronds bi-tripinnate, 6 to 8 or more feet high; pinnæ and pinnules articulated with the rachis. Veins simple or forked, free. Sporangia sub-terminal, connate, forming a bivalved synangium, each valve consisting of 3 to 12 cells, opening by slits. Receptacles ovate, oblong, some species furnished with an indusoid fimbriate membrane.

Type. Marattia alata, Sm.

Illust. Hook. and Bauer Gen. Fil., t. 26; Moore Ind. Fil., p. 96 B.; J. Sm. Ferns, Brit. and For., fig. 150; Hook. Syn. Fil., t. 9, fig. 70.

OBs.-The general habit and mode of development of the fronds of this genus does not differ from Angiopteris, it is, however, readily distinguished by its sporangia being wholly united, the two series forming a double multilocular spore case, which, when mature, opens lengthways in two lobes (valves), each lobe containing a series of cells equivalent to the sporangia of Angiopteris. Marattia is sparingly represented in India, but it is common to the Islands of the Indian and Pacific Oceans, extending to Norfolk Island and New Zealand in the South, it is also found in South Africa, Tropical America, the West Indian Islands, and is one of the few plants forming the indigenous flora of the Island of Ascension.

Presl enumerates twenty species, which he places under four distinct genera, but I find no sufficient character to warrant their adoption, his species are also fully double in excess. In the "Species Filicum" only seven species are described, and the following, which have all been cultivated at Kew, appear to me to have sufficient character to be considered distinct species. Different fronds, or even different parts of the frond of the same plant when separate, and placed in the herbarium, have been accepted as at least four distinct species. 
Sp. M. alata, $S m .(\nabla \nabla$.$) ; M. cicutæfolia, Kaulf. ( \nabla$ $\nabla$.$) ;$

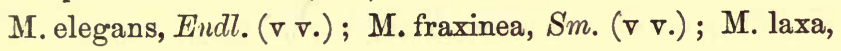
Kze. ( $\mathrm{v}$.) ; M. purpurascens, De Vriese ( $\vee$ v.) (Marattia Ascensionsis, J.Sm. Cat., 1856); M. Verschaffeltiana, J. Sm. ( $\nabla$ v.).

\section{5.-Eupodrum, J. Sm. (1841).}

Vernation and general character as in Marattia, differing in the synangia being pedicellate.

Type. Marattia laevis, Kaulf.

Illust. Hook. and Bauer Gen. Fil., t. 118; Moore Ind. Fil., p. 97 B. ; J. Sm. Ferns, Brit. and For., fig. 151.

OBs.-This genus agrees with Marattia in general character, but differs in the synangia being seated on a little foot stalk (pedicel), similar to the genus Peranema.

Sp. E. Kaulfusii, J. Sm. (Marattia Kaulfussii, Hook. 2nd Cent. Ferns, t. 95) ( $\mathrm{\nabla}$ จ.).

A rare Fern, native of Brazil.

$$
\text { 216. -DANEA, Sm. (1793). }
$$

Vernation, uniserial, contiguous, decumbent; sarmentum thick, fleshy; each frond rising from between two short stipulæform appendages, and having the stipes once or more times articulated. Fronds pinnate, rarely simple, 1 to 3 feet high, the fertile usually somewhat contracted; pinnæ opposite, linear-lanceolate, articulated with the rachis. Veins forked; venules parallel, their apices arcuate and anastomosing at the margin. Synangia sessile, immersed, linear contiguous, occupying nearly the whole length of the venules; each consisting of two rows of numerous laterally and oppositely connate cells, united into a concrete mass, forming a linear synangia, each cell opening by a circular pore. 
Type. Danoea nodosa, Smith.

Illust. Hook. and Bauer Gen. Fil., t. 7; Moore Ind. Fil., p. 99 A.; J. Sm. Ferns, Brit. and For., fig. 153; Hook. Syn. Fil , t. 9, fig. 71.

OBs.-This is a curious genus of Ferns, of which about a dozen species are described. The whole are natives of the West Indies and Tropical America. The synangia opening by pores readily distinguishes this from the preceding genera.

Sp. D. simplicifolia, Rudge.; D. nodosa, Sm. ( $\nabla$ v.); D. alata, Sm. ( $\vee$ v.) ; D. elliptica, Sm.; D. stenophylla, Kze.

\section{7.-Kadlfussia, Blume. (1828).}

Vernation uniserial, contiguous; sarmentum thick, fleshy; each frond rising from between two short, fleshy stipuliform appendages. Fronds 2 to 3 feet high, long stipate, palmately lobed, lobes oblong-elliptical. Veins costæform, parallel ; venules compound anastomosing, with free veinlets terminating within the areoles. Receptacles punctiform, compital, sub-biserial between the primary veins. Sporangia 10 to 20 , laterally connate, forming a circular synangium, the cells opening by slits.

Type. Kaulfussia cesculifolia, Blume.

Illust. Hook. and Bauer Gen. Fil., t. 59 A.; Moore Ind. Fil., p. 98 ; J. Sm. Ferns, Brit. and For., fig. 154; Hook. Syn. Fil., t. 9, fig. 72.

OBs.-This genus is founded on a remarkable Fern, a native of the Malay and Philippine Islands, it is also found in Assam, and has been described as a distinct species by Griffiths under the name of $K$. assamica, but, judging from herbarium specimens, it appears not to be distinct from $K$. cesculifolia. 

PL. 29 .

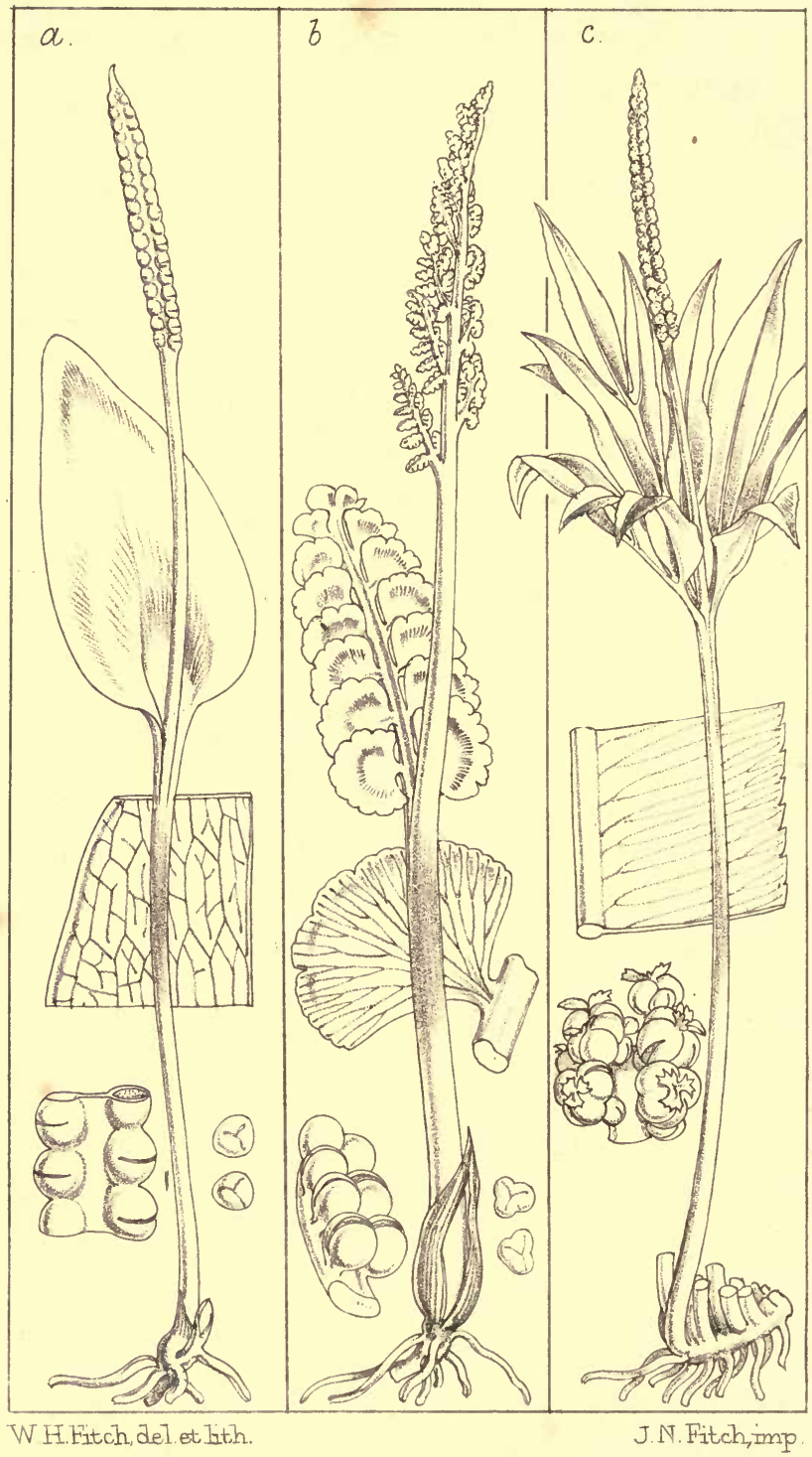


Sp. K. æsculifolia, Bl. ( $\nabla$ v.) (K. Assamica, Griff., Hook., Journ. Bot., 2, t. 11, 12).

OBs.-The under side of the frond of this Fern is peculiar in being covered with stomata-like pores.

Evolution of the fronds straight.

Tribe 29.-OPHIOGLOSSE $A, R . B r$. (Plate 29).

Epigeous or epiphytal leafy plants, spores generated in sudglobose, unilocular, coriaceous, homogenous, bivalved sporangia, borne on special spikes or on panicles.

OBs.- This tribe is distinguished by the vernation of the fronds being straight, not spirally coiled, as in what is generally called true Ferns; it consists of about twenty species, comprehended under the three following genera.

In this country Ophioglossece is represented by the common Adder's-tongue Fern, O. vulgatum and Botrichum lunaria, which, with several congeners, have a wide geographical range, being found in all countries between the limits of the south and north temperate zones. The few epiphytal species are tropical or sub-tropical.

\section{8.-Ophioglossum, Linn. (1737).}

Fronds ovate elliptical, lanceolate, entire or long and linear, dichotomously forked or palmate. Veins reticulated. Sporangia connate, in two rows, forming a distichous, spike, produced from the disk of the frond, rarely a special spike rising direct from the corm.

Type. Ophioglossum vulgatum, Linn.

Illust. Hook. and Bauer Gen. Fil., t. 59 B.; Moore Ind. Fil., p. 100 B. ; J. Sm. Ferns, Brit. and For., fig. 155; Hook. Syn. Fil., t. 9, fig. 73. 
OBs.-Presl, in his "Supplementum Tentaminis Pteridographiæ," enumerates twenty-eight species of this genus, three of which he characterises under three distinct genera, but which I consider of sectional value only. In the "Synopsis Filicum" the species are reduced to one half of the above number.

Fronds ovate elliptical or linear, 2 to 10 inches in length, bearing the fertile simple spikes; epigeous. (Ophioglossum vera.)

Sp. O. lusitanicum, Linn. ( $\nabla$ v.) ; O. pedunculosum, Desv. ( $\left.\nabla \nabla_{.}\right)$; O. nudicaule, Linn.; O. vulgatum, Linn. ( $\mathrm{v}$ v.); L. reticulatum, Linn. ( $\mathrm{v}$ v.).

** Fronds pendulous; the sterile segments long, ribbon-like, usually dichotomously branched, 2 to 10 or more feet in length. Epiphytal. (Ophioderma, Pr.)

O. pendulum, Linn. ( $\nabla$ v.); O. furcatum, J. Sm. ( $\nabla$ v.).

*** Fronds palmate, pendulous, 6 to 10 inches long, fertile spikes numerous, epiphytal. (Cheiroglassa, Pr.)

O. palmatum, Linn. ( $\nabla$ v.).

**** Fertile spike, rising direct from the Corm.

$$
\text { (Rhizoglossum, Presl.) }
$$

O. Bergianum, Schlecht.

OBs.-This is a curious and rare little plant, a native of the Cape of Good Hope, having the sterile and fertile fronds distinct, not more than half an inch in length, its nearest ally being O. lusitanicum, a native of the South of Europe, of recent years found in Guernsey. 


\section{9.-Helminthostachys, Kaulf. (1824).}

Fronds produced from a stout, short sarmentum, stipate 1 to $1 \frac{1}{2}$ feet long; sterile segments foliaceous, digitate, pedate. Veins forked, free. Fertile spike rising from the base of the leafy segment. Sporangia sub-globose, sessile, in pedicellate crested whorls, opening vertically by a slit on their exterior side.

Type. Osmunda Zeylanica, Linn.

Illust. Hook. and Bauer Gen. Fil., t. 47 B.; Moore Ind. Fil. p. 100 A. ; J. Sm. Ferns, Brit. and For., fig. 156 ; Hook. Syn. Fil., t. 9, fig. 74.

Sp. H. Zeylanica, Hook. (H. dulcis, Kaulf.).

OBs.-First known as a native of Ceylon, and described by Linnæus under the name of Osmunda Zeylanica, but is now found in India, Eastern Australia, and New Caledonia.

\section{0.-Botrychiom, Sw. (1800).}

Fronds erect, with dissimilar sterile and fertile segments. Sterile segments foliaceous, deltoid, bi-tripinnatifidly decompound, rarely pinnate. Veins forked, free. Fertile segment rachiform, compound, paniculate. Sporangia subglobose, free, coriaceous, opening vertically in two equal valves.

Type. Botrychium Lunaria, Sw.

Illust. Hook. and Baner Gen. Fil., t. 47 A.; Moore Ind. Fil., p. 99 B. ; J. Sm. Ferns, Brit. and For., fig. 157 ; Hook. Syn. Fil., t. 9, fig. 75.

Sp. B. simplex, Hitch. ( $\nabla$ v.); B. lunaria, Sw. (v v.); B. ternatum, $S w_{.}$; B. lunarioides, $S w_{0}\left(\mathrm{v}_{\mathrm{v}}\right)$; B. Virginicum, Willd. ( $\nabla$ v.).

OBs.-This is a very widely diffused genus, $B$. lunaria being found in both the northern and southern temperate 
zones. B. ternatum and $B$. Virginica have also a wide geographical range, being found very generally throughout the temperate and tropical zones; the influence of the various climates causing much variation in the more or less divisions of the fronds, many of the states having been described as distinct species.

Presl describes no less than seventeen species, which in the "Synopsis Filicum" are reduced to six.

Total number of species quoted, 1815. 


\section{PART III.}

\section{ON THE REPRODUCTION OF FERNS.}

In Phænogamous plants, the flower and its parts, consisting of calyx, corolla, stamens, pistils, ovary, seed, position and mode of germination of the embryo furnish the data on which all systematic arrangements are based. With the exception of the embryo these organs are in general visible to the naked eye, and require but little aid from the miscroscope. This, however, is not the case with Ferns, at least as regards their organs of reproduction, for although they have no visible stamens and pistils like flowering plants, for generating seeds, nevertheless it was known to early observers that they had seeds, but so small as to be invisible to the naked eye; the microscope, however, revealed that they are of definite forms, which was first observed by W. Cole in 1669, and it is recorded that young Fern plants were raised from these invisible seeds in the Oxford Garden in 1715.

At page 8 it is explained that these seeds are called spores, and are contained in cases called sporangia, which are of various forms, the form most common being girded by a ring. When the sporangium is mature, the elasticity of the ring causes it to burst, and, under favourable circumstances as regards light, the spores are seen to issue like a puff of smoke; this apparent smoke consists of atoms varying in form in the different genera, being globose, oval, or angular, smooth, plain, striated, or echinate, presenting very beautiful microscopic objects. Much examination is, however, yet required before they can be made practically available for assisting in defining genera or 
species (see page 37). Although these spores are so small they are nevertheless endowed with an extraordinary power of retaining their vitality; and, being easily wafted by currents of air, readily account for the wide geographical range of some species of Ferns. When naturally or artifically placed under favourable conditions they burst, and expanding in the form of a simple oblong cell, on which other cells are successively developed, ultimately form a thin green membrane called the prothallium, which, when arrived at full size, is of a reniform cordate shape, or sometimes bilobed, or obcordate, varying from about $\frac{1}{4}$ to $\frac{1}{2}$ inch in diameter, and adhering to the surface on which it vegetates, it has much the appearance of a small foliaceous lichen or Marchantia. In time a small bud makes its appearance near the base of the prothallium, which increases in size, and ultimately a small frond is produced, which is succeeded by others successively larger, thus becoming a plant.

The increase of the prothallium and sprouting of the bud is readily seen by the naked eye, and the cultivator is satisfied with the result; but he finds himself often disappointed, for after having obtained abundance of prothallia from many different species, they nevertheless do not always produce a bud germ. This is now supposed to be explained by the discovery made in 1848 by Count Suminski, a Polish botanist, that Ferns possessed organs analogous to the stamens and pistils of flowering plants, and that these were produced on the under side of the prothallium; they are represented by two kinds of cells, one called Antheridia and the other Archegonia. The first (of which there are generally between 30 and 40 ) consist of round cells, which contain vermicular spermatozoids that issue from the cells when arrived at maturity. The cells of the 
Archegonia differ considerably in their structure from the Antheridia, they consist of bottle-shaped cells into which the spermatozoids have been seen to enter, and are supposed to fertilize the embryo contained in the cells, the result being the production of a young plant on the upper surface of the prothallium, as above stated. According to what is now explained a prothallium is monœcious, in some cases supposed to be dioecious. The latter having recently been found to be specially the case with the prothallia of Osmundece. This singular discovery has excited considerable interest among physiologists ; and has been carefully investigated by several, especially in this country, by the late Professor Henfrey, as recorded in "Linnean Transactions," vol. xxi, 1853. Recently considerable attention has been paid to the subject by M. E. Meyer, Inspector of Carlsruhe Botanic Gardens, who in the "Gartenflora" for February, 1875, gives his practical experience regarding raising Ferns from spores. He says he has only succeeded in raising one plant of the genus Gleichenia, G. dicarpa, and one plant of Marattia, M. latifolia,* and that he has failed in raising Hymenophhyllece, which he accounts for by the moist nature of the fronds, and the spores bursting in the sporangia soon losing their vitality by becoming dry.

Much investigation is, however, required before many circumstances attending the germination of spores can be explained, such as, why the Desmobrya division does, as a general rule, increase the abundance of spores, even to some species becoming weeds in the hothouses; while, on the other hand, those of the division Eremobrya are comparatively few.

* This, however, is no rule, for about 20 years ago numerous plants of Marattia cicutrefolia were raised from spores at Kew. 
Although the spores of many species germinate in profusion, it often happens that no plant bud is formed, even under the most favourable circumstances of atmospheric heat and moisture. This failure of plant bud may be possibly due to the spores being, as above stated, unisexual, and therefore producing only dicecious prothallia.

The time required before the spores germinate varies greatly, some taking eighteen months, others two or three weeks. Some species of Gymnogramma and Cheilanthes germinate in as many days, while Brainea insignis will germinate in as short a time as forty-eight hours. Few prothallia of the latter, however, produce plants, while, on the other hand, Ceratopteris thalictroides germinates quickly and produces abundance of plants, even becoming weeds.

Of late years some intermediate forms of species, especially of the genus Gymnogramma, have been raised in gardens, which are by some called sports or hybrids, whether such is simply the effect of cultivation, or by the prothallia of two distinct species being so contiguous to one another that the spermatzoids of the one have the power of passing and fertilizing the archegonia of the other, thus generating hybrids, as in flowering plants. In general prothallia produce only a single bud, but on the bud being removed it is succeeded by others, and thus as many as eight or ten young plants have been produced from a single prothallium of Hymenodium crinitum; but what is even still more singular, is, that by dividing the prothallia from the base upwards into two or even four parts, each part produces a plant bud. An explanation of this, as also of many other points connected with the subject, is yet to be discovered; for instance, in 1830, plants of Lomaria Patersoni, a native of Tasmania, made 
their appearance at $\mathrm{Kew}$, the only specimen in this country then known being in the herbarium of the British Museum, which I had not then seen. The botanical collector, Allan Cunningham, failed to find it in Tasmania, and was very much surprised on my presenting him with fine specimens grown at Kew. This was also the case with Doodia blechnoides, and Asplenium squamulata, by what means the spores of these plants found their way into the pots at the hothouses at Kew it is impossible to say.

In spite of the very delicate nature of the prothallia, it is nevertheless endowed with great vitality, as may be seen by Ferns appearing on dry rocks, walls, and such like, resisting the extremes of heat and cold. For example, in 1829, I found a plant of Ceterach officinarum growing in a crevice of masonry on one of the towers of the new palace at Kew (since taken down). As this Fern is not found wild near London, it would be useless to speculate where the solitary spore came from; it seemed, however, to have found a proper nidus in the crevice, enabling it to germinate and resist all untoward influences, to pass through the prothallium state, and become a plant.

I must here state, that not long after Count Suminski's discovery became known to me my sight began to fail, which necessitated me to give up the use of the microscope, therefore my own practical observations on this important subject are but limited.

In many cases Ferns not only reproduce their like by spores, but also by the viviporous bads generally produced on the upper side of the frond, or on the apex of the fronds or segments, which when mature become plants. This is specially characteristic of many species of Asplenium, Goniopteris, Woodwardia, Meniscium, and others; but so far as has come under my notice, no bulbils are produced 
in any species of the division Eremobrya. It also appears that bulbils are latent in some; for instance, if portions of the base of the fronds, or of the margin of Scolopendrium vulgare, be placed under favourable circumstances, bulbils are formed which become plants of the same variety and form of that part of the frond from which the bit was taken; by this means the numerous abnormal forms of this Fern are propagated. Ferns are also increased by lateral offsets, thus forming cæspitose tufts, some occupying a considerable area, as also by stolens and sarmenta, the latter often extending to a great length, as in Pteris aquilina. 


\section{ON THE GEOGRAPHICAL DISTRIBUTION OF FERNS.}

As already stated, the number of species of Ferns amounts to about 2,500, which are widely spread over the earth, being found more or less numerous in all climates between the most northern and southern limits of vegetable life; and within the tropics from the sea level to elevations of from 14,000 to 15,000 feet, their number in any locality being generally in proportion to the degree of atmospheric moisture in conjunction with elevation. Few or none are found in dry or flat countries, such as grassy, scrubby, or thinly-wooded plains, or mountain slopes, extensive tracts of which are often in possession of one of the most cosmopolitan and abundant of all Ferns, the common Brake (Pteris aquilina). In hot and moist plains the number of species is comparatively small; even in the extensive lower valley of the Amazon, teeming as it does with vegetable life, the number of Ferns found by Dr. Spruce after he left the coast Flora at Para, in his journey of 2,000 miles, was small, but they gradually became more numerous on attaining an elevation of 1,500 feet; and in one locality at a higher elevation he found 250 species in an area of fifty miles in diameter. Another tract with but few Ferns is the dry region of Northern Africa and Arabia, and few as yet have been recorded from the interior of Australia; while on the contrary, on many elevated coasts and islands they form a large portion of their Flora.

They are most numerous both as regards genera and species in the tropical and sub-tropical regions; and although, as a general rule, the different zones or latitudes contain species peculiar to the different regions, yet many 
circumstances, such as the relation of land and water, mountains and valleys, cause great deviation from this; thus, species of the cooler temperate regions are also found in warmer regions, and those considered tropical often extend to the warm valleys of the temperate zones; the favourite place of growth of many being groves and ravines, and even in caves, while others make themselves at home on rocks exposed to the extremes of heat and cold.

With regard to their nature, as indicated by their places of growth, they may be classed under three heads-first, those that grow upon the ground (Epigeous); secondly, those that grow in the crevices, or adhere to rocks, or in caves open to the light (Epipetreous); and, thirdly, those that grow upon trees (Epiphytal). Lastrea Filix-mas, Athyrium Filix-foemina, Pteris Aquilina, and all tree Ferns, are examples of the first class, while Asplenium septentrionale, A. Ruta-muraria, A. trichomanes, A. marinum, Ceterach officinarum, and Scolopendrium vulgare are our native representatives of the rock and stone lovers of temperate regions, the different species of Nothochlena and Cheilanthes taking their places in warmer regions.

It may be taken as a rule that the greater number of the division Desmobrya belong to the two first, while the Epiphytal class belong chiefly to the division Eremobrya. There are, however, many deviations from these rules, as, for instance, there are many scandent species of Desmobrya; and some Eremobrya, such as Polypodium vulgare, are often found Epipetreous as well as Epiphytal, and even on the ground, indeed many species conform to climatic influences of very different natures. Some grow in very wet places, as Osmunda regalis, which attains a very large size in bogs of this country, and even grows in caves facing 
the sea. Many Hymenophyllece grow within the spray of cascades or on dripping rocks, and on mossy trunks of trees. Ceratopteris thalictroides grows in shallow waters, its sterile fronds floating on the water, and may be said to be the only truly aquatic Fern, and one of the very few annuals; like many other aquatic plants it has a wide geographical range within or near the tropics of both hemispheres.

Many have a great predilection for the works of man, whether elevated in the air or sunk below the earth, such as old castles, walls, embankments, hedge and road-side banks, quarries, or deep open pits or wells, this being common to species of both tropical and temperate countries, it is, therefore, not surprising to find the same species assume different sizes and forms, as, for instance, the common Hart's-tongue Fern, Scolopendrium vulgare, which on walls and other dry places produces fronds only a few inches in length, while in shady places or open pits or wells they may be found lining the sides with fronds two to three feet in length.

Another example of a Fern making itself at home under very opposite conditions is Pteris longifolia, which is common in or near the tropics of both hemispheres. On the island of Ischia (in the Bay of Naples) it is found luxuriating within the influence of the hot vapours rising from the fissures of latent volcanic heat, growing in soft mud at a temperature ranging from $140^{\circ}$ to $160^{\circ}$. In hothouses its spores vegetate abundantly upon all moist surfaces, and in crevices close to hot water tanks. It also establishes itself in dry places, even in situations where the temperature is often at or near freezing point.

Although Ferns thus conform themselves to different climates, many being wanderers, yet on taking a view of 
the general distribution of the family it is found that a greater or lesser number of allied species are confined to special regions, some species restricted to very small areas, and even to special localities.

From the above it will be readily seen that it becomes difficult to draw up any statement of the number of species peculiar to different countries or regions.

This subject has, however, been fully gone into by $\mathrm{Mr}$. Baker, who, in an elaborate memoir of 47 pages quarto,* shows the general distribution of the order through the different zones and regions, and the relation of the species of the regions to one another; the data which he has adopted are the localities given in the "Species" and "Synopsis Filicum," the number of species recorded being 2228, which are arranged and tabulated in a form showing the regions and countries where each species is found, and the species peculiar to each region. He divides the earth into four zones, namely, Arctic zone, North temperate zone, South temperate zone, and Torrid zone. These are subdivided into ten regions, of which the following is a summary, showing the total number of species, and also those peculiar to each region.

\section{ArCTIC Zone.}

1. Arctic zone or region. This region contains 26 species, none of which are peculiar to it, all being found in the adjoining zone.

\section{North Temperate Zone.}

This zone is divided into three regions, as follows :-

2. Temperate Europe and North Africa. This region includes Europe and the whole length of North

* "Linnæan Transactions," vol. 26, 1867. 
Africa contiguous to the Mediterranean, the Canaries, Madeira, and the Azores. It contains 81 species, of which 6 are peculiar to Europe, 12 to the above-named islands, and 2 only are recorded as peculiar to North Africa.

3. Temperate Asia, including Japan and Chinese Islands. 431 species have been recorded as belonging to this region, of which about 120 to 130 are peculiar to it. 4. Temperate North America. This region contains 114 species, of which 37 are peculiar to it.

\section{Sodth Temperate Zone.}

This zone comprehends Temperate South Africa, Temperate South America, Australia beyond the tropics, and New Zealand, \&c.

5. Temperate South Africa. 152 species are recorded as belonging to this region, of which 27 are peculiar to it, 4 of which extend to the small island of Tristan d'Acunha.

6. Temperate Australia and New Zealand. This region contains 212 species, of which about 25 are peculiar to Australia and 34 to New Zealand.

7. South Temperate America. This region contains 118 species, of which 32 are peculiar.

\section{TORRID ZONE.}

8. Tropical Africa, including the Mascerene Islands, St. Helena, and Ascension. This region contains 346 species, of which 127 are peculiar, 54 of which belong to the Mascarene Isles, 13 out of 25 to St. Helena, and 2 out of 6 to Ascension.

9. Tropical Asia, including the Polynesian Islands. 863 
species are enumerated as belonging to this region, of which 477 are peculiar.

10. Tropical America. This region contains 946 species, of which 708 are peculiar, thus showing that this and the preceding are the two richest regions in Ferns.

The above is sufficient to give a general view of the distribution of the Fern flora over the earth.

With regard to the greater or lesser number of allied species common to any district, Mr. Baker says, "The remarkable point about the distribution of Ferns is, that there is so little trace amongst them of the concentration of allied forms in the same district."

There can be no doubt that this view is consequent on the character of the fructification being made the bond of union of species, by which large unnatural genera are formed as in the "Species Filicum," which I have already commented upon; but on breaking up these large genera we obtain smaller genera of a few or many naturally allied species, which in many instances may be termed geographical genera, and which coincides with Mr. Darwin's view on the distribution of plants generally, for he says that, "Some few families, many sub-families, very many genera, and a still greater number of sections of genera, are confined to a single region, and it has been observed by several naturalists, that the most natural genera in which the species are most closely allied to one another are generally local or confined to one area."

In support of this may be mentioned the genera Niphobolus, Drynaria, great part of Phymatodes, Platycerium, and Thamnopteris, which have their head-quarters in the regions of the East, and by restricting Davallia, as I do, to the species with articulate vernation, all belong to the Eastern 
regions; while Campyloneuron, Phlebodium, Goniophlebium, and Polypodium, are, with a few exceptions, natives of the Western.

It is very remarkable that genera with single species, such as Matonia, Peranema, Loxoma, Dictyoxiphium, and Trichiocarpa are found only in very limited areas; while, on the other hand, two Ferns of special habit, Didymochloena truncatula and Oleandra neriiformis, are found in the tropical regions of both hemispheres. The small Island of St. Helena contains 25 species, of which 13 have been found nowbere else.

Besides the above conclusions arrived at by $\mathrm{Mr}$. Baker, another view of the number of species found in different countries is derived from local "Floras" and "Catalogues," of which the following are the principal ; it must, however, be understood that many of the species found in one country are also common to other countries :-

Great Britain and Ireland, 36.

Europe. Sadler and other authors, 67.

Asia Minor and Syria, 25. All European.

India. Wallich's MS. Catalogue of the Plants of India, 475 .

India. Hooker and Thomson's Collection (J. Smith's MS. List), 319.

Ceylon. Thwaites' Flora, 214.

Mauritius. Prof. Boutan's List, 235.

China and Japan, 118.

Japan alone. A. Black's Enumeration, 82.

Hong Kong. Benthem's Flora, 76.

Java. Blume's Enumeration, 460.

Philippine Islands. J. Smith's Enumeration, 297.

Fiji. Flora Vitiensis Seemann's, 185. 
Vite, Samoa, Tonga, Ellias Islands. Dr. Chr. Luerssen's Enumeration, 209.

Australia and Tasmania. Brown's Prodronus, 106.

New Zealand. Hooker's Handbook, New Zealand Flora, 121.

Temperate South Africa. Pappe and Rawson's Enumeration, 177.

Chili. Strume's Enumeration, 180.

Brazil. Baker's, in Martin's Flora, 387.

British Guiana. Schomburgh's Collection (J. Smith), 86

British West Indies. Greisbach's Flora, 340.

Isthmus of Panama. Seemann's Voy. Herald (J. Smith). 117.

North-West Mexico. Seemann's Voy. of Herald (J. Smith), 64 .

Cuba and Venezuela. Eaton's Enumeration of Wright and Fendler's Collections, 354. Hymenophyllece not enumerated. 


\section{PROPERTIES AND USES OF FERNS.}

Although Ferns rank as one of the few great families of the Vegetable Kingdom that contain upwards of 2,000 species, and, as already shown, are widely distributed over the earth, they nevertheless possess but few economic properties useful to man, either as food, medicine, or in the arts. The following are the names of the principal, and the uses to which they have been applied.

\section{Phlebodium aureum.}

The fleshy caudex is purgative, and it is one of the Ferns called Calahula.

\section{Phymatodes vulgaris.}

The fronds are slightly fragrant, and are used by the South Sea Islanders for perfuming cocoa-nut oil. $P$. pustulata is used by the New Zealanders to scent their oil and food.

\section{Polypodium vulgare.}

By the ancients, and our old doctors and herbalists, many medical virtues were ascribed to the common Polypody. In Greece, and other parts of Europe, it is used as a cure for ringworm; and in this country an infusion of the fresh root is still regarded as a mild laxative. In some places a decoction of the dried fronds is still used as a remedy for colds and whooping cough. Its fronds yield carbonate of potass.

\section{Campyloneuron Phyllitidis.}

This is one of the Ferns termed in South America Calahula, which with the natives is a celebrated medicine for many complaints, especially for syphilis, gout, and 
rheumatism; it is used in dropsy as a diuretic; it is also used for wounds and contusions. Goniophlebium attenuatum and Pleuridium crassifolium are also called Calahula, and are considered to possess the same properties as the preceding, and to be particularly efficacious in syphilis.

\section{Lastrea Filix-Mas.}

Of all the Ferns celebrated by the ancients for their medicinal virtues, the male Fern ranks the highest, its reputation as a vermifuge having descended from the time of Disscorides to the present, the part used being the hard woody portion of the caudex, which is either taken in the form of a powder, decoction, or etherial extract. But notwithstanding its ancient celebrity and fame acquired during the latter part of the last century, when it was discovered to form the basis of the Swiss remedy for tænia, the secret of which Louis XVI. purchased of Madame Mouffer for the sum of 18,000 francs, its use is, however, gradually becoming obsolete.

A Fern called "Filix-Mas" has lately come into repute in Australia and Tasmania as a cure for snake bites. (What Fern is this?)

L. athamantica, a Fern found near Port Natal; it is called Umkomo-komo by the natives, and is used by them as a vermifuge, and its caudex given in the form of a powder, infusion, or electuary, has been proved to be excellent in the cure of tape worm.

$L$. fragrans and $L$. cemula are two of the few sweet smelling Ferns ; the first is a native of the north temperate zone, used in some countries as a substitute for tea; the second is a native of Madeira, Azores, and also of Britain; it has the scent of hay, and on that account has been called L. Fonisecii. 


\section{Polystichum coriaceum.}

This is common to many countries. In Chili it is one of the plants terined Calahula, and like the others is reputed for the cure of syphilis.

\section{Nephrolepis tuberosa.}

This is a native of Nepaul. It produces underground tubers like small potatoes, which are used for food by the natives.

\section{Alsophila excelsa.}

A native of Norfolk Island, which when first discovered, abounded in examples of this Fern, averaging in height from 25 to 50 feet, or even, it is said, 80 feet. The centre of the stem contains a white pith, in consistency resembling a yam, which is greedily eaten by hogs; it is also common to the Fiji and other islands of the Pacific. The stems are much used for building purposes, being hard and fire-proof, and lasting an incredibly long time; it is also cut into ornamental forms, and placed round tombs.

A. australis is a native of Tasmania; it grows in gullies on Mount Wellington at an elevation even reaching the snow-line; its stems are used in the same manner as the preceding.

\section{Cyathea medullaris.}

A fine tree Fern; a native of New Zealand, Queensland, and Pacific Isles. The interior of its trunk contains a soft mucilaginous pulp, which may be compared to sago; it is extensirely used as an article of food by the natives, to obtain which fine trees are cut down. 


\section{Cibotium Barometz.}

A native of China and Tartary. The fronds of this Fern are bipinnate, and rise to the height of 10 to 14 feet, produced from a decumbent and progressing caudex, which is densely covered with long light brown silky hairs (characteristic of the genus), when old looking like wool, and when lying on the ground having the appearance of a wool-clad animal. The story told to early travellers led them to describe it as a plant of flesh and blood. The travellers' tale upon the subject is, that on an elevated plain of vast extent, in countries east of the Volga, grows a wonderful plant, with the shape and appearance of a lamb, having feet, head, and tail distinctly formed, and its skin covered with soft down. The "lamb" grows upon a stalk about 3 feet high, the part by which it is sustained being a kind of navel it turns about and bends to the herbage which serves for its food, and when the grass fails it dries up and pines away. The real facts are that the caudex of this Fern is decumbent, progressing in length a foot or more according to age, and is 3 or more inches in diameter. Its woolly appearance has led it to be likened to a lamb, the native name for it being Barometz, and by travellers the "Tartarian lamb," and others "Agnus Scythicus."

To make the story plausible the natives turn the woolly stipes upside down, cutting away the fronds, leaving a portion of the lower part of the stipes, four of which serve as legs, and thus the resemblance to a woolly animal is complete, and, being so manipulated, much resembles a weasel.

The Chinese traveller and botanist Lourier was the first 
to describe it as a Fern, to which Linnæus gave the name of Polypodium Barornetz.

About fifty years ago the late Mr. John Reeves, who had long resided at Canton, succeeded in obtaining living plants of it, which he transmitted to this country, and which first produced fructification in the Birmingham Botanic Garden, which having come under my notice it became at once obvious that it was a species of Cibotium, and which, in my Definition of Ferns, 1841, I called C. Barometz.

A closely allied species, C. Cummingii, is found in Luzon, and another, C. Assamica, in Assam; this Fern also appears to be represented in Sumatra, as some of the soft silky hairs similar to those of Barometz have been imported from that island into Holland, under the name of "Penghawar D'joumbi," and are found to be useful as a styptic.

C. Chamissoi, C. Menziesii, and C. glaucum, natives of the Sandwich Islands, differ from C. Barometz in being arborescent, the stem of $C$. glaucum attaining the height of 24 feet, the crown of fronds adding 12 feet more, making the total height of the tree 36 feet. The base of the stipes of the fronds is densely furnished with fine silky hairs, which being permanent clothe the stem, forming a thick wool-like coat, which is collected and used for stuffing cushions, mattrasses, and the like. During the ten years previous to 1865 it became an article of commerce under the name of Pulu, and ship loads of it were sent to Australia and California, but lately it' has fallen into disuse.

Dicksonia chrysotricha.

This is a tree Fern, a native of Java. Its silky hairs have been imported and used as a styptic. 


\section{Adantium Capillus Veneris.}

Venus' Hair, or Maiden Hair Fern.

This Fern is found in many countries, and is abundant in the South of Europe ; it derives the name of Maiden Hair from the circumstance of a syrup being prepared from it called Capillaire, which being slightly odoriferous, or made so by the addition of Orange flower water, is used by the women in dressing their hair, and for promoting its growth. Dioscorides, and other physicians of his time, attributed numerous medicinal virtues to it, and our old herbalists held it in high repute. Ray, in his "History of Plants," details at great length its wonderful properties, his catalogue of diseases curable by preparations of this Fern seems to include nearly' "all the ills that flesh is heir to." Its fronds are still sold in herb shops for the preparation of "Syrup of Capillaire," from which, by dilution with water, a refreshing beverage is made. It contains tannic and gallic acids, and is slightly astringent.

A. pedatum. In North America this is used for making Capillaire. It is included in the list of herbs prepared by the Shakers, who subject them to heavy pressure, producing, for trade purposes, a kind of hard cake in the form of a brick, of which there are many specimens in the Kew Museum.

A. trapeziforme is a native of the West Indies, it possesses the same qualities as A. Capillus Veneris.

A. Ethiopicum is used in South Africa as a pectoral medicine, and A. dolabriforme is used for the same purpose in Brazil.

\section{Ornithopteris aquilina.}

This Fern is well known by the name of Brake or Braken, it is the most common and at the same time the most useful of Ferns in an economic point of view. 
In this and other countries the fronds are cut and dried, and used for many domestic purposes, such as thatching, and for protecting vegetables and tender plants from frost, and the young fronds are given to swine. The fronds are burned in large heaps, and the ashes contain a considerable quantity of alkali, which is made into cakes or balls, which form an article of trade, especially in Wales, and are used as soap in washing, it is also used by glass makers. The whole plant contains a considerable amount of tannic and gallic acids, and its astringency is such that in some countries it is used for tanning leather.

Many medical properties have been ascribed to it, but with the exception of being used as a vermifuge its many extolled virtues are now obsolete.

It is, however, an important food 'fern, its creeping underground stems contain a quantity of starch and mucilage, and are used in some parts of Europe and other northern countries for mixing with meal to make bread; even in the Canary Islands, especially those of Palma and Gomera, where food is often scarce, it is mixed with barley meal and made into a kind of gruel. Of late years it has been brought into notice as a substitute for better food in this country. The Rev. M. J. Berkeley, in an article in the Journal of the Linnæan Society, says the roasted roots are eatable, but extremely disagreeable from their slimy nature and peculiar flavour, in both of which they resemble ill-ripened Bringles, but by cutting up and soaking them in water the slimy matter and astringent principle is got rid of, and the pulp, when sufficiently dry and made into cakes, forms a coarse but palatable food.

In 1857 it was again brought into notice by Mr. Benjamin Clark, who, in an article in Hooker's “Journal of Botany," described its qualities as a vegetable, but in this 
case the young fronds were used, being cut when very young, cooked and eaten as asparagus. He says, "I took it exclusively as a dinner vegetable for more than a month, no objection arising except that the last week or two I thought it was slightly astringent. It tastes like asparagus, and is very cooling and suitable for salt provisions." Although such is the case this article has not yet appeared in the London vegetable markets.

In the southern hemisphere $O$. esculenta takes the place of $O$. aquilina in the northern. In Australia and New Zealand it forms a great part of the food of the aboriginal natives, but, like other plants that contain only starch, it is incapable of supporting life without the addition of some other substance containing nitrogenous matter. Since the colonization of these countries, and the introduction of the potato and corn, it will ere long cease to be an article of food.

In some parts of this country it is a vulgar belief that the burning of Fern brings down rain, of which the following is a curious illustration. In a volume containing a miscellaneous collection by Dr. Richard Pocock, in the British Museum, is the copy of a letter written by Philip Herbert, third Earl of Pembroke, Lord Chamberlain, to the Sheriff of Staffordshire. It is as follows :-

"Sir,-His Majesty taking notice that the burning of Ferne doth draw down rain, and being desirous that the country and himself may enjoy fair weather as long as he remains in these parts, his Majesty has commanded me to write to you to cause all burning of Fern to be forborne until his Majesty be past the country. Wherein not doubting but the consideration of their own interest as well as of his Majesty's will invite the country to a ready observance of this his Majesty's commands, I rest, your very loving friend, 


\section{Asplenium lucidum.}

A Fern with pinnate shining fronds, 2 or more feet in length. By the New Zealanders it is regarded as a sacred plant; it is used by their priests when praying over a sick person; holding a frond of it in his hand, he waves it over the patient, and if it happens to break it is regarded as a fatal omen. Before engaging in any war-like enterprise, it is also waved in the same manner whilst offering up prayers to the spirits for success; if it breaks it is supposed the gods are adverse to their engaging in war. When the chief has his hair cut, he holds a frond of this Fern in his hand, and when finished the priest takes it and waves it over his head, and at the same time prays; it is afterwards dipped in water, and shaken over the chief's head; if the frond does not break it is considered to indicate long life, but if it breaks it is regarded as a sign that he will not live long. It is also used as an emblem of mourning. The European Asplenive, such as A. Ruta-muraria, A. Trichomanes, A. Adiantum nigrum, and A. murinum, well known by the name of spleenworts, have in old times been famed for their many remedial virtues, but are now of no repute.

\section{Scolopendrium vulgare.}

The Hart's Tongue was in ancient times highly reputed for its medicinal properties; it is considered astringent and useful in diarrhœa; the fronds are also made into an ointment for scalds, wounds, \&c.

\section{Ceterach officinarum.}

At one time this was in high repute as a remedy in diseases of the spleen and jaundice. Gerard, however, in his Herbal, says, that many of the properties attributed to it are no better than "old wives' fables." 


\section{Mohria thurifraga.}

A native of South Africa. When burnt it has the scent of benzoin or olibanum, and is made into an ointment, and used for burns, \&c.

\section{Osmunda regalis.}

In some parts of England the fronds of this are in high repute as an external application for bruises, sprains, and the like; the fleshy part of the rhizome is made into a drink for internal injuries; it also has the repute of being a styptic.

\section{Angiopteris evecta.}

This, under different forms, is found in India, Malay, Philippine, Pacific, and Polynesian Islands; the caudex, as also the thick part of the stipes, is of a mealy and mucilagenous nature, which is eaten by the natives in times of scarcity. The fronds possess a peculiar odour, and are used by the women of Tahiti for making into crowns, which they wear on feast days.

\section{Marattia alata.}

The fleshy caudex of this is used in the Sandwich Islands as food when better food is scarce.

M. attenuata. - In Fiji the fronds are used as a pot herb; they are very tender, and taste not unlike spinach. In Now Zealand the soft part of the stem is eaten.

\section{Botrychum virginicum.}

A widely diffused species; the succulent fronds are eaten by the natives of Now Zealand and Upper India. 


\section{Ophioglossum vulgatum.}

Adders' Tongue Fern in this country is extensively collected by herb gatherers; being mucilagenous it is used in the preparation of salves, but now, with its congener, the moonwort, its use has become obsolete.

\section{Helminthostachys dulcis.}

A native of Ceylon, India, and Malay Islands, and is used as a pot herb; the young fronds are eaten as asparagus. 


\section{PART IV.}

\section{LIST OF AUTHORS AND BOOKS.}

TIE AUTHORITIES FOR THE GENERIC AND SPECIFIC NAMES QUOTED IN THIS WORK.

N.B. - When no special book is quoted after an author's name, his writings on Ferns are to be found in botanical and other scientific journals of their time, especially in the "Linnæ," a German periodical work; and botanical journals in this and other countries.

Agardh. J. C. Agardh, Professor of Botany at Stockholm; author of a "Monograph on the genus Pteris."

Ait. W. \&W. T. Aiton, father and son, Directors of the Royal Botanic Gardens, Kew, from 1760 to 1841; authors of 1st and 2nd edition of "Hortus Kewensis," 1793 and 1813.

Andrews. W. Andrews, an Irish amateur botanist; "On British Hymenophylleæ."

A. Rich. A. Richard, a French botanist; "Voyage de l'Astrolabe (Botanique)."

Arn. Walker Arnott, Professor of Botany at the University, Glasgow (see Hook. et Arn.)

Bab. C. C. Babington, Professor of Botany at the University, Cambridge ; an eminent British botanist.

Backhouse. James Backhouse \& Son, nurserymen, York; importers and cultivators of Ferns.

Bak. J. G. Baker, Assistant Curator of the Kew Herbarium ; editor of Hooker's "Synopsis Filicum," 1 vol., 1868 ; second edition and appendix to the above, 1874 ; "Ferns of Brazil" in "Martius' Flora" of Brazil; 
On the geographical distribution of Ferns in "Linnæn Transactions," vol. 26, 1867.

Bauer. Francis Bauer, a celebrated botanical painter (see Hook. et Bauer).

Beauv. Palisot de Beauvois, a French botanist; author of "Flore d'Oware ;" figures and descriptions of plants in the Bight of Benin, 1810.

Bedd. Captain R. H. Beddome, Officiating Conservator of Forests of India; "Ferns of Southern India," being descriptions and plates of the Ferns of the Madras Presidency, 271 plates, Madras, 1863; "Figures and Descriptions of the Ferns of British India" (exclusive of the above), 345 plates, quarto, Madras, 1870.

Bernh. J. J. Benhardi, Professor of Botany at Erfurt. Blume. C. L. Blume, Director of the Botanic Garden, Batavia; "Enum. Plant. Jav.," 1830; "Fl. Jav.," figures and descriptions of the plants of Java. Bolt. J. Bolton, an English botanist; "Fil. Brit.," figures of British Ferns, 1790.

Bomm. J. E. Bommer, Secretary of Royal Botanic Society, Belgium ; "Monographie de la Classe des Fougeres," Paris and Brussels, 1867.

Bory, J. B. G. Bory de St. Vincent, a French traveller and botanist.

Brack. W. D. Brackenridge, Botanist to the United States' exploring expedition; Descriptions and figures of the Ferns of the expedition.

Braun. A. Braun, Professor of Botany, Berlin; "Monograph on Selaginella."

Br. R. Brown, the most celebrated of botanists; "Prodromus Floræ Novæ Hollandiæ," 1810 ; "Observations on Ferns in Wallich's Plantæ Asiaticæ Rariores;" Horsfield's "Plantæ Javæ." 
Br. P. Brown, author of a "History of Jamaica," 1756. Brongn. A. Brongniart, a French botanist.

Burm. J. Burmann, a Dutch botanist, and writer on plants of India, Ceylon, \&c.

Carm. Captain D. Carmichael, a Scotch cryptogamic botanist.

Carr. W. Carruthers, Keeper of National Herbarium, British Museum; "An Enumeration of the Ferns collected by Dr. Seemann in Fiji ;" published in Flora Vitiensis.

Cav. A. J. Cavanilles, Professor of Botany, Madrid. Colenso. Rev. W. Colenso, a New Zealand botanist. Coll. A. Colla, a collector and namer of Chilian Ferns.

Cunn. A. Cunningham, a celebrated botanist and traveller in Brazil and New South Wales from 1815 to 1830.

Dec, Aug. Decandolle, a celebrated French systematic botanist.

Desf. M. Desfontaines, a French botanist and traveller in Barbary; "Flora Atlantica."

Desv. N. A. Desvaux, an eminent French botanist; author of several papers on Ferns, from 1808 to 1814.

De Vriese. G. H. De Vriese, a Professor of Botany, Leyden; "Monograph on the genus Angiopteris."

Dick. J. Dickson, an English cryptogamic botanist.

Don. D. Don, Professor of Botany, King's College, London ; "Prodromus Floræ Nepalensis," 1825.

Dry. Jonas Dryander, librarian to Sir Joseph Banks; a writer on Ferns in the "Linnæan Transactions."

Eat. D. C. Eaton, an American botanist; "Enumeration of the Ferns of Cuba and Venezuela," 1860. 
Ehrhart. F. Ehrhart, a German botanist.

Endl. Endlicher, Professor of Botany, Vienna; "Prodromus Floræ Norfolkicæ."

Eng. Bot. English Botany, "Figures and descriptions of British plants," by Sir J. E. Smith and Jas. Sowerby. Eschw. F. L. Eschweiler, a German botanist.

Fée. A. F. A. Fée, Professor of Botany, Strasburg, an eminent pteridologist; "Genera Filicum," descriptions and figures of the genera of Ferns, 1850-52; "Memoirs on Acrostichum and other Genera."

Fisch. Dr. Fischer, a Russian botanist, and Director of the Imperial Botanic Garden, St. Petersburg (see Lang. et Fish.).

Fl. d'Oware (see Beauv.).

Forsk. Peter Forskahl, a Danish naturalist and traveller in Arabia ; "Flora Agyptiaca."

Forst. John Reinhold Forster, botanist to Captain Cook's second voyage; "Figures of Ferns in Schkuhr's 'Cryptogamia,'” 1787.

Gal. H. Galeotti, a German botanical collector in Mexico. Gard. Chron. Gardeners' Chronicle, a weekly journal. New garden ferns described by T. Moore.

Gardn. Dr. G. Gardner, a botanical traveller in Brazil, and Director of the Botanic Garden, Ceylon.

Gaud. M. C. Gaudichaud, a French botanist; "Plants of Freycinet, Voyage de l'Uranie," 1817-1820.

Gill. Dr. Gillies, a Scotch botanist and collector of plants in Chili.

Gmel. J. G. Gmelin, a Russian botanist and traveller in Siberia; author of a "System of Plants" and "Flora Sibirica." 
Gray. Dr. Asa Gray, Professor of Botany, Harvard University, United States.

Grev. Dr. R.K. Greville, an eminent botanical artist (see Hook. et Grev.).

Griseb. A. H. R. Grisebach, a German botanist; "Flora of the West Indies," 1864.

Haenk. (see Presl).

Ham. Dr. Francis Hamilton, an Indian botanist.

Hance. Dr. H. F. Hance, an English botanist, and writer on

Chinese Ferns.

Hedw. J. Hedwig, a German cryptogamic botanist.

H. et B.\&H.B.K. Humboldt, Bonpland, and Kunth. The

two first famous travellers and botanists in South

America. Kunth, a German botanist.

Hew. Robert Heward, a zealous botanist, and writer on Ferns of Jamaica, in the "Magazine of Natural History."

Hitch. - Hitchcock, a North American writer, "Sillimann's Journal."

Hoff. G. F. Hoffmann, a German botanist, and writer on cryptogamic plants, 1784.

Homb. et Jacq. Hombron et Jacquemont, French voyagers to the South Pole ; "Voyage au Pol Sud," \&c., History of the Voyage and Plants.

Hook. Sir W. J. Hooker, Director of the Royal Botanic Garden, Kew, from 1841 to 1865 ; an admirable descriptive botanist and eminent Pteridologist; "Exotic Flora," figures of rare plants, 1823; "Icones Plantarum," figures of 1,000 rare plants-many Ferns; "Second Century of Ferns," 100 figures of rare Ferns; "Filices Exoticæ," figures of 100 Ferns; "Garden Ferns," 64 figures; "Journal of Botany," 4 vols. ; "London Journal of Botany," 7 vols.; "Journal of 
Botany and Kew Miscellany," 9 vols.; "Species Filicum," 5 vols., description of all known Ferns with upwards of 300 figures, 1844-64 ; "Synopsis Filicum," completed by J. Baker in 1868.

Hook. et Arn. Hooker and Arnott, "Botany of Captain Beechey's Voyage."

Hook. et Bauer. Hooker and Bauer, the "Genera Filicum," figures of the genera of Ferns, illustrated by Bauer, 1838.

Hook. et Grev. Hooker and Greville; "Icones Filicum," figures of rare Ferns, 230 plates, 2 folio vols., 1831. Hook. fil. Dr. Joseph Hooker, Director of the Royal Botanic Gardens, Kew ; appointed 1865 ; "Flora Antarctica," "Flora of New Zealand," "Flora of Tasmania."

Hoppe. J. C. Hoppe, a German botanist, and collector of plants.

Hort. Gardens; Hort. Ang. English gardens ; Hort. Berol. Berlin garden; Hort. Linden. Horticultural Gardens, Brussels.

Houlst. (see Moore et Houlst.).

Huds. W. Hudson, an English writer on British plants.

Humb. A. V. Humboldt, a celebrated traveller and philosopher (see H. B. K.).

Jaqq. Nicolas Joseph and François Jacquin, father and son, eminent Austrian botanists ; "Icones rariorum," figures of rare plants.

Johns. J.Y. Johnson, a writer on Madeira Ferns.

J. Sm. John Smith, Curator Royal Botanic Gardens, Kew, (retired 1864); "Gen. Fil.," an arrangement of the genera of Ferns in Hooker's "Journal of Botany," 1841 ; "Enum. Fil. Philipp.," an enumeration of the Ferns collected by H. Cuming in the Philippine Islands;

D D 
"Seem. Bot. Voy. Herald," an enumeration of the Ferns in Seemann's "Botany of the Voyage of the 'Herald ;" "Cat." Ferns cultivated at Kew, in appendix to Botanical Magazine, 1846 ; "Cat. Cult. Fern," catalogue of Ferns cultivated in British gardens in 1857; "Ferns, British and Foreign," history and enumeration of Ferns cultivated at Kew, with definitions of the genera, illustrated by 164 wood-cuts, and treatise on their cultivation, 1 vol., 1866.

Karst. Dr. Karston, a German botanist and traveller in

Tropical America ; "Flora Columbiæ."

Kaulf. G. F. Kaulfuss, Professor of Botany, Leipsic; "Enum. Fil.," Enumeration of the Ferns collected in Chamisso's Voyage, 1821.

Klot. Dr. Klotzsch, a German botanist.

Kunze. G. Kunze, Professor of Botany, Leipsic ; "Analecta Pteridographia," figures and descriptions of Ferns, 1834 ; “Schkuhr's Cryptogamia," continued, 1841-51; numerous other papers on Ferns in the Linnæ.

Labill. J. J. Labillardière, a French navigator sent in search of M. La Perouse; “Nov. Holl. Plant. Spec.,” figures and descriptions of New Holland plants, 1804-1806 ; "Sertum Austro-Caledon.," figures and descriptions of plants in New Caledonia.

Lag. M. Lagasca, Professor of Botany, Madrid.

Lam. Jo. Bapt. Monet de Lamarck, a celebrated French naturalist and compiler, 1783-1796.

Lang. et Fisch. G. Langsdorf, a Russian botanist. "Icon.

Fil.," figures of Ferns, chiefly Brazilian, 1810.

L'Hérit. C. L. L'Héritier, a French botanist.

Lieb. Liebmann, a German botanist. 
Lieb. Liebold, a German traveller and botanist, and collector of plants in Mexico.

Linden. J. Linden, a nurseryman at Brussels, and traveller

Mexico and Peru; a collector and importer of rare plants.

Lindl. Dr. John Lindley, an eminent systematic botanist, Professor of Botany, University College, London; "Lindl. and Moore: Nature-printed British Ferns."

Link. H. F. Link, Professor of Botany, Berlin ; "Enumeration of the Ferns of the Berlin Garden," 1833-1841.

Linn. Car. Linnoeus, the celebrated Swedish botanist, and founder of modern botany.

Lodd. Conrad Loddiges and Son, nurserymen and great cultivators of Ferns at Hackney.

Lour. Loureiro, a Portuguese botanist and traveller in Cochin China : "Flora Cochinchinensis."

Lowe. E.J. Love; "Lowe's Ferns," figures and descriptions of exotic Ferns, in 9 vols.

Lowe. R. T. Lowe, a writer on Madeira Ferns.

Luer. Dr. C. Luerssen, a German botanist; "Enumeration of Ferns of Vite, Samoa, Tonga and Ellice's Islands ;" Leipsic, 1874.

Mart. et Gal. "Figures and descriptions of Mexican Ferns," H. Galeotti and M. Martens.

Mart. C. F. P. Martius, Professor of Botany in Munich; "Icon. Crypt.," figures and descriptions of Brazilian Ferns, 1820.

Metten. Dr. G. Mettenius, Professor of Botany at Leipsic, and eminent writer on Ferns ; "Figures and descriptions of the Ferns in the Leipsic Gardens ;" "Monograph on the genus Asplenium," \&c., and many articles on Ferns in the Linnæ. 
Mey. C. Meyer, a German botanist.

Michx. A. Michaux, a French botanist and traveller in

North America; "Flora Boreali-Americana," 1803.

Mild. Dr.J.Milde; "Filicis Europæ et Atlantidis, Asiæ Minoris et Siberiæ," Liepsic, 1867.

Miq. F. A. G. Miquel, a Dutch botanist.

Moore. T. Moore, Curator of the Apothecaries' Garden, Chelsea ; "Index Filicum," an alphabetical list of all names of Ferns; various books on British Ferns (see Lindl.).

Moore et Houlst. T. Moore and $W$. Houlston; "Descriptions and Wood-cuts of Cultivated Ferns," published in Ayer's "Magazine of Botany."

Muhl. Muhlenberg, a North American botanist.

Newm. Edwd. Newman, author of works on British Ferns. Nutt. D. Nuttall, a North American botanist.

Papp. et Raw. L. Pappe, M.D., and Hon. R. W. Rawson; "Synopsis of the Ferns of South Africa," 1858.

Plum. Car. Plumier, a French botanist and traveller in the West Indies; "Plum. Fil.," figures and descriptions of Ferns, chiefly of the French West India Islands, 1666.

Poir. M. Poiret, a French botanical compiler.

Presl. C. B. Presl, Professor of Botany, Prague; a famous Pteridologist; "Reliqua Haenkæna," figures and descriptions of Ferns collected by the traveller Haenke, 1825 ; "Tent. Pterid.", a new arrangement of the genera of Ferns, 1836 ; “ Epimeliæ Botanicæ," figures and descriptions of Ferns, being an addenda to the preceding, 1849. 
Pursh. Frederick Pursh, author of a "Flora of North America."

Radd. J. Radai, a German botanist, who travelled in Brazil ; "Fil. Bras.," figures and descriptions of Brazilian Ferns, 1825.

Raoul. M. M. E. Raoul, a French botanist and writer on New Zealand Ferns.

Regel. - Regel, Director of the Imperial Garden, St. Petersburgh, 1866.

Retz. A.J. Retzius, a German botanist and writer on plants of Ceylon.

Rheede. H. van Rheede, a Dutch botanist; "Hortus Indicus Malabaricus," a large work on the plants of Malabar, 1703.

Reichenb. - Reichenbach, a German botanist; "Flora Germanica."

Reinw. - Reinwardt, Professor of Botany, Leyden, and traveller and collector of plants in Java and other Malayan islands.

Remy in Gay. Remy, an authority in Cl. Gay's "Flora of Chili."

Rich. L. R. Richard, a writer on the plants of Guiana." Roth. A. G. Roth, a celebrated German botanist and writer on Ferns.

Rox. Dr. Roxburgh, an English botanist; "Observations on St. Helena Ferns."

Rudge. E. Rudge, author of a work on the plants of Guiana.

Sadl. J. Sadler, a Hungarian botanist; "An enumeration and description of the Ferns of Hungary and adjoining countries," 1830.

Schk. C.Schkuhr, a German botanist; "Crypt. Schk.," 
figures of cryptogamic plants, 1809 ; "Crypt. Supp.," supplement of the above, continued by Kunze.

Schlecht. D.F. L. Schlechtendahl, Professor of Botany in

Berlin; Schlecht. Adumb. "Adumbratio Plantarum,"

figures and descriptions of South African Ferns.

Schott. Heinrich Schott, Director Royal Gardens, Vienna;

"Schott Gen. Fil.," the genera, illustrated by figures, 1834.

Schreb. J.C. Schreber, a German botanist.

Schum. - Schumacher, a writer on plants of Guinea.

Scott. J. Scott, Curator of Botanic Gardens, Calcutta;

"Tree Ferns of India," Linnean Transactions, 1874.

Seemann. Dr. Berthold Seemann, an eminent botanist and voyager ; "Botany of the Expedition of the Surveying Ship Herald," "Flora Vitiensis."

Sibth. Dr. Sibthorp, an English traveller and botanist in Greece; author of "Flora Græca."

Sieber. - Sieber, a celebrated German botanical traveller and collector in various parts of the world.

Sim. R. Sim, a nurseryman and celebrated grower of Ferns at Foot's Cray, Kent.

Sloan. Sir Hans Sloane, a traveller in the West Indies; author of "History of Jamaica," and founder of the British Museum.

Sm. Sir James Edward Smith, a celebrated British botanist and writer on botany in various journals ; first President of the Linnæan Society, and purchaser of the "Linnæan Herbarium."

Smith, John. See J. Sm.

Sowerby. E. Sowerby, a British botanist, author of a work on British Ferns.

Spenn. - Spenner, a German botanist. 
Split. F. L. Splitgerber, a Dutch botanist; "An Enumeration of the Ferns of Surinam."

Spreng. C. Sprengel, Professor of Botany, Halle ; “Syst.," a systematic enumeration of plants according to the Linnæan arrangement, 1827.

Spring. - Spring, a German botanist and writer on Lycopodiacece.

Stansfield. - Stansfield, a nurseryman at Todmorden, Yorkshire, celebrated as a discoverer and cultivator of numerous varieties of British species of Ferns.

Strume. Dr. J. W. Strume, German botanist; "Enumeration of the Ferns of Chili," 1858.

Sw. Olaf Swartz, a Swedish botanist and traveller in Jamaica; "Synopsis Filicum," an enumeration and description of all known Ferns since 1806.

Thunb. P. Thunberg, a Dutch traveller and botanist in Japan and Cape of Good Hope; "Fl. Jap." the Flora of Japan, 1784.

Thwartes. G.J.Thwaites, Director Botanic Garden, Ceylon ; author of "Flora of Ceylon."

Tuckerman. E. Tuckerman, a United States botanist.

Vahl. Mart. Vahl, a German botanist.

Van den Bosch. Dutch botanist; "Synopsis Hymenophyllaceæ," 1858.

Van Houte. L. Van Houte, a Belgian nurseryman ; author of several periodical botanical works.

Veitch. James Veitch \& Son, nurserymen, London, celebrated importers and cultivators of rare Ferns.

Vent. E. P. Ventenat, a French botanist.

Vogler. - Vogler, a German botanist. 
Wall. Dr. Nathaniel Wallich, Director Botanic Garden, Calcutta; MSS. catalogue of the plants contained in the "Wallichian Herbarium" at the Linnæan Society. Watson. Hewet Cottrell Watson, an eminent British botanist.

Webb. P. B. Webb, an English botanist; "Flore des Canaries."

Weis. F. W. Weis, a German cryptogamic botanist.

Wel. Dr. Frederick Welwitsch, a botanical collector for the King of Portugal, in Angola, and author of an illustrated work on the plants of that country, 1852 to 1861.

Willd. C. L. Willdenow, Professor of Botany, Berlin; "Species Plantarum ;" Enumeration of plants in the Berlin Garden, 1809.

Wollast. T. Wollaston, an English botanist and writer on Ferns.

Wulf. F. H. Wulfen, a German botanist.

Zenk. - Zenker, a German botanist and writer on plants of the Neilgherry. 


\section{2.-ETYMOLOGY.}

DERIVATION OF THE GENERIC NAMES ADOPTED IN THIS WORK.

As a general rule it may be admitted that the generic names of plants are derived from three principal sources. The first, and greater number, being generally a compound of two Greek words. The second, names of persons, with the addition of a Latin termination. The third source is various, such as the adoption of local aboriginal names, names from Heathen Mythology, and often words of doubtful origin, and incomprehensible application, have been given as generic names by botanists.

N.B.-For all names ending and beginning with Pteris, see Pteris.

Aconiopteris, akon, a point, and pteris ; the veins forming sharp angles close to the margin of the frond in the typical species.

Acrophorus, akros, highest, phoreo, to bear ; the position of the sori on the veins.

Acrostichum, akros, highest, stichos, order ; the fructification at the top of the fronds.

Actinostachys, actin, rays, stachys, spike; the fructification spikes in rays.

Adenoderris, aden, a gland, derma, skin ; the frond covered with glands.

Adenophorus, aden, a gland, phoreo, to bear; bearing glands.

Adiantum, adiantos, dry; when plunged in water comes out dry.

Aglaomorpha, aglao, splendid, morpha, form ; splendid form. 
Allantodia, allantos, a sausage ; indusium like a sausage. Allosorus, allo, a heap, and sorus, in allusion to the crowded sori.

Alsophila, alsos, grove, phileo, to love; grows in groves and shady places.

Amphiblestra, a word meaning the fronds are reticulated. Amphidesmium, amphi, around, or on both sides, desmos, a band; relating to the position of the sori to one another.

Anapeltis, ano, without, peltis, shield ; the sori naked, in opposition to Pleopeltis.

Anchistea, agnati, kindred; intermediate between Woodwardia and Doodia.

Anemia, aneimon, naked; naked spikes of fructification. Anemidictyon, veins reticulated; not free as in Anemia. Anetium, probably from the Greek anaitos, guiltless. This is perhaps meant to indicate that $A$. citrifolium has been put wrongfully to Acrostichum.

Angiopteris, angio, open, pteris; the open sporangia.

Antigramma, anti, opposite, gramma, a line; the linear sori being in pairs opposite to each other.

Antrophyum, antrum, a den or hollow; the receptacles of sporangia being in a groove or channel.

Arthrobotrya, arthron, joint, botrys, bunch; the segments articulate with the rachis, thus differing from Polybotrya.

Arthromeris, arthron, joint, meris, parts ; the pinnæ articulate with the rachis.

Arthropteris, arthron, joint, pteris; the frond and pinnæ being articulate.

Aspidium, aspidos; the indusium being like a buckler or shield. 
Asplenidictyon, dictyon, netted, Asplenium, with netted veins.

Asplenium, a, privative, splen, the spleen ; medical qualities. Athyrium, unexplained.

Balantium, balantion, a purse or bag; the form of the indusium.

Blechnum, one of the Greek names for a Fern.

Botrychium, botrys, bunch or raceme ; the fructification like a bunch of grapes.

Brainea, in honour of C. Braine, Esq., who introduced the first plant.

Callipteris, kallos, beautiful, and pteris, beautiful Fern.

Calymmodon, kalymma, cover, odon, tooth; the dents of the pinnæ being folded like a hood, enclosing the sporangia.

Campteria, kamptos, arched; the veins meeting forming an arch.

Camptodium, kamptos, bent; the form of the indusium (not very applicable).

Campyloneurum, kamptos, arched, neuron, a nerve; the veins forming arches.

Cassebeera, in honour of J. H. Cassebeero, a German pharmaceutist.

Ceratopteris, keras, keratos, a horn, pteris; horned Fern.

Ceterach, a name given by Persian physicians.

Cheilanthes, cheilos, lip or margin, anthos, flower; the fructification on the margin.

Cheiropleuria, cheiro, a band, pleuria, sides; alluding to the sporangia on each side of the costa.

Cibotium, kibotos, a casket or coffer; the form of the indusium. 
Cincinalis, meaning unknown.

Colysis, kolysis, separation, ; a species separated from other genera.

Coniogramma, konis, dust, gramma, a line; imperfect sporangia, but not applicable in perfect specimens.

Cryptosorus, kryptos, hidden, sorus, the sori ; sori immersed in the substance of the frond.

Ctnopteris, ptilon, pluma or wing; the small plume-like fronds of many of the species.

Cyathea, kyathos, a cup; the form of indusium.

Cyclodium, kyklos, circle; the form of indusium.

Cyclopeltis, kyklos, circular, peltis, shield; the form of indusium.

Cyrtogonium, kurtos, convex, gonia, an angle; the anastomose of the veins.

Cystodium, a cyst, and odium, a tooth ; form of indusium. Cystopteris, kystos, a cyst; the inflated indusium.

Danæ, in honour of Pierre Martin Dana, a Piedmont botanist.

Davallia, in honour of Edmond Davall, a Swiss botanist.

Dennstadtia, Dennstadt, a German writer.

Deparia, a cup or basin; the form of the indusium.

Diacalpe, dia and kalpe, a vessel; in allusion to the cup indusium.

Dicksonia, in honour of James Dickson, a British cryptogamist.

Diclidopteris, di, two, klidia, a bed, pteris; the two receptacles of the sporangia.

Dicranoglossum, dikranos, forked, glossa, tongue ; the fronds forked and pendulous.

Dictymia, diktyon, a net; the netted venation. 
Dictyocline, diktyon, a net, kline, a bed; the receptacles netted.

Dictyogramma, diktyon, gramma, a line; the sori reticulated.

Dictyopteris, diktyon, pteris; the veins reticulated.

Dictyoxiphium, diktyon, xiphion, sword; the veins reticulated, and the form of the frond.

Didymochlæna, didymos, two or double, chlcena, a cloak; the indusium being double.

Diplazium, diplazo, to be double; two indusia on the same vein.

Diplora, in allusion to the double bordered receptacle. Dipteris, $d i$, two, pteris; the fan fronds in two parts. Doodia, in honour of Samuel Doody, a London apothecary, and British cryptogamist.

Doryopteris, dory, spear or halbert, pteris; form of the frond̄s.

Drymoglossum, drymos, wood, glossa, tongue; the fronds like tongues upon trees.

Drynaria, dryads; the sterile fronds being like oak leaves, which tree was sacred to the Dryads or wood nymphs. Dryomenis, dryos, dryads (as above), meniskos, a crescent; shape of the sori.

Dryostachum, dryos (as above) stachys, spike; the form of the fertile pinnæ.

Egenolfia, in honour of Christian Egenolph, a German author of a book on Herbs.

Elaphoglossum, elaphos, a stag, glossa, tongue; the fronds being like the stag's tongue.

Eupodium, eu, good, pous, podos, a foot; the sorus having a foot-stalk. 
Fadyenia, in honour of Dr. M'Fadyen, an eminent physician in Jamaica.

Feea, in honour of Mons. A. L. A. Fée, Professor of Botany at Strasburg, a celebrated writer on Ferns.

Gleichenia, in honour of Baron P. von Gleichen, a German botanist.

Glyphotænium, glyphis, sinuose, tainia, a fillet or ribbon; form of fronds.

Goniophlebium, gonia, angle, phlebes, veins; the veins meeting, forming angles.

Goniopteris, gonia, angle, pteris ; the veins meeting, forming angles.

Grammitis, gramma, a line; the sori being linear.

Guernia, in honour of M. C. Guerin, a French officer under

Captain Freycinet in the voyage of the Urania.

Gymnogramma, gymnos, naked, gramma, a line; the sori

on the veins in lines, and naked.

Gymnopteris, gymnos, naked, pteris ; the fructification naked.

Haplopteris, haploos, simple, pteris ; simple venation. Hecistopteris, hecistos, very small, pteris; a small Fern. Helminthostachys, helminthos, worm, stachys, a spike; the fructification in compact spikes, worm-like.

Hemidictyum, hemi, half, diktyon, a net; the outer portion only of the veins being reticulated.

Hemionites, a name given by ancient botanists to a plant now called Asplenium hemionites, but retained as a generic name for a West Indian Fern by Linnæus.

Hewardia, in honour of Robert Heward, a collector and writer on West Indian Ferns.

Histiopteris, unexplained.

Humata, humatus, humid; in opposition to Adiantum. 
Hymenodium, hymen, membrane; the character of the frond.

Hymenolepis, hymen, membrane, lepis, a scale; membraneous scales covering the fructification.

Hymenophyllum, hymen, membrane, phyllon, leaf; "Filmyleaf Fern."

Hymenostachys, hymen, membrane, stachys, a spike; the fructification on spikes.

Hypoderris, hypo, under, derma, skin ; the indusium under the sori, like a thin skin.

Hypolepis, hypo, under, lepis, a scale; the sporangia under the indusium.

Isoloma, isos, equal, loma, a border or margin; the indusium and margin equal.

Jamesonia, in honour of Dr. Jameson, a zealous botanical collector, many years resident in Quito.

Kaulfussia, in honour of D. G. F. Kaulfuss, of Halle, a celebrated writer on Eerns.

Lastrea, in compliment to Chev. de Lastre, a French nobleman,

Lecanopteris, lekane, a basin, pteris; the sori on concave lobes.

Lepicistis, lepis, scale, kistis, a cyst or cell; the sori being immersed in scales, which form a cyst.

Leptochilus, leptos, slender, cheilos, lip ; narrow indusium. Leptogramma, leptos, slender, gramma, a line ; short linear sori.

Leucostegia, leukos, white, stegos, a cover; the indusium being pale-coloured, approaching white. 
Lindsæa, in honour of Dr. Lindsay, of Jamaica, a writer on the germination of mosses and Ferns.

Lithobrochia, lithos, a stone, brocha, spots; the aeroles of the reticulated veins like pavement.

Llavea, named by Lagasca after a Mexican traveller.

Lomaphlebia, lomma, a margin, phlebia, a vein ; marginal vein.

Lomaria, loma, a fringe or border ; relating to the indusium. Lomariopsis, lomaria, opsis, like ; like Lomaria.

Lonchitis, logche, a lance; form of pinnæ.

Lopholepis, lophos, a crest, lepis, scale; the sori being furnished with a tuft of slender scales.

Lophosoria, lophos, crest or tuft; sori furnished with hairs like a tuft.

Lorinseria, in honour of Gustave Lorinser, a Bohemian physician.

Loxsoma, loxos, oblique, soma, band; the oblique broad ring of the sporangium.

Loxoscaphe, loxos, oblique, scaphe, a scathe; the form of the sori.

Lygodium, lygodes, flexible; climbing plant.

Marattia, in honour of J. F. Maratti, of Tuscany, who wrote on Ferns.

Matonia, in honour of Dr. Maton, an eminent London physician.

Meniscium, meniskos, crescent; shape of the fructification.

Mesochlæna, mesos, middle, chlocna, a cloak; attachment of the indusium.

Microgramme, mikros, small, gramma, a line; sori in short lines.

Microlepia, mikros, small, lepis, scale; the indusium small. Micropodium. Small footed. In allusion to the stipes. 
Micropteris, mikros, small, pteris, a small Fern.

Microsorum, mikros, small; small sori.

Microstaphyla, miliros, small, staphyle, a bunch ; the fertile frond being like a little bunch.

Mohria, in honour of D. D. Mohr, a German botanist.

Monogramma, mono, one, gramma, a line; sori in one line on each frond.

Myriopteris, myrios, myriad, pteris; the frond being divided into a number of small parts.

Neottopteris, neottia, nest, pteris; Bird's-nest Fern. Nephrodium, nephros, kidney; form of the indusium. Nephrolepis, nephros, kidney, lepis, scale; the indusium being kidney-shaped and scale-like.

Neurocallis, neuron, a nerve, kallos, beautiful; the venation. Neurodium, neuron, nerve; the venation.

Niphidium, niphos, of snow, idium, like ; like niphobolus. Niphobolus, niphos, of snow, bolos, a large pill; the under side of the frond densely covered with white scales, snow-like and the round sori.

Niphopsis, niphos, snow, opsis, like; like niphobolus. Notholæna, nothos, spurious, chloena, cloak ; the imperfect indusium.

Ochropteris, ochros, pale ; pale Fern.

Odontosoria, odontos, of a tooth, sori; the sori-like teeth. Oleandra, resemblance to Nerium Oleander; the Oleander. Olfersia, in honour of Professor Olfers, a celebrated astronomer.

Onoclea, onos, a vessel, kileio, to enclose; the rolled-up fertile segments of the frond.

Onychium, onychion, a little nail ; resemblance to the fertile segments of the fronds. 
Ophioglossom, ophios, of a serpent, glossa, tongue; the spikes of fructification.

Ormopteris, ormos, a necklace, pteris; the form of fronds. Osmunda, Osmunder, one of the names of Thor, a Celtic divinity.

Paragramma, para, near to, gramma, a line; the sori in short lines parallel with and close to the margin.

Pellæa, pellos, dark-coloured; the dusky colour of the fronds. Pellæopsis, Pelloca-opsis, like; like pellæa.

Peranema, peri, around, nema, a thread; the sori born on a slender thread like stalk.

Phegopteris, phegos, beech; beech Fern, by some called Sun Fern.

Phlebodium, phlebes, veins, odous, a tooth ; the joining of the veins in the areoles being like teeth.

Photenopteris, photeinos, shining, pteris; shining Fern.

Phymatodes, phymata, tubercles; the impressed sori having the appearance of tubercles on the upper side of the frond.

Phymatopsis, Phymatodes, opsis, like ; like Phymatodes. Plagiogyria, plagios, oblique, gyros, a circle; the obliquity of the ring of the sporangia.

Platycerium, platys, broad, keras, horn; the fronds divided in broad segments like stags' horns. (The Stags'horn Fern).

Platyloma, platys, broad, loma, border; having broad sori close to the margin.

Platyzoma, platys, broad, zoma, a band; the ring of the sporangia broad.

Plecosorus, plektos, plaited; relating to the form and position of the sori. 
Pleocnemia, pleos, full, lenemia, rays; full of rays; the venation.

Pleopeltis, pleos, full, peltis, shield; the sori being furnished with numerous round scales.

Pleuridium, pleura, side (ribs); the primary veins being costæform, like ribs.

Pleurogramma, pleura, side, gramma, a line; sori on the side of the mid-rib.

Podopeltis, pous, foot, peltis, a shield ; the indusium.

Pœcilopteris, poekilos, spotted, pteris; the appearance of the venation.

Polybotrya, polys, many, botrys, bunch; the fructification being in bunch-like racemes.

Polypodium, polys, many, pous, foot; polypus ; the rhizome, when destitute of the fronds, having the appearance of some kind of sea-polypus.

Polystichnm, polys, many, stichos, order; not especially applicable to the genus Polystichum, as now defined.

Prosaptia ; sori immersed in the margin of the frond. Psomiocarpa, psomion, a small pellet, karpa, fruit; the sporangia being in small round patches, in spikes.

Pteris, pteryx, wing; the scientific name given to the plant known by the names of Brake, Brackien, and Fern; on account of the supposed likeness of the branching of its fronds to wings. This, being the commonest of all Ferns, has become the type of the whole race; hence Pteris means Fern, all generic names of Ferns ending in pteris; stch as Ceratopteris means horned Fern, Dictyopteris netted Ferr; also, if at the beginning of a word, as Pteridography, a book or writing on Ferns; Pteridologist, a studier and writer on Ferns; Pteridophilist, a lover of Forns. 
Rhipidopteris, rhipis, fan; shape of the fronds like a fan.

Saccoloma, sakkos, a bag or sack, loma, margin; the union of the indusium with the margin, forming a hood or cyst.

Sadleria, in honour of Josephus Sadler, an Hungarian botanist.

Salpichlæna, salpi, pipe, chloena, a cloak; the indusium being like a pipe.

Schaffneria, in honour of - Schaffner, a German botanical collector in Mexico.

Schellolepis, schello, skeleton, lepis, scale ; the character of the scale surrounding the sori.

Schizolepton, schizo, to cut, leptos, slender; sporangia seated in a slit.

Schizoloma, schizo, I cut, loma, a border or margin $;$ the sori in the form of a slit on the margin of the frond. Scolopendrium, stoolopendra, a centipede; the appearance of fructification on the under side of the frond.

Scypholepia, skyphos, a cup, lepis, scale ; the form of the indusium.

Selliguea, in memory of M. Selligue, a French optician. Soromanes, soros, heap, mania, fancy; the sporangia in fanciful and irregular heaps.

Stegnogramma, stegnos, a cover, gramma, a line; sori linear, but not furnished with indusia, as stated by Blume.

Stenochlæna, stenos, narrow, chloena, cloak; narrow indusium.

Stenosemia, stenos, narrow, sema, standard; the fertile frond with its narrow segments being like a flag. Stromatopteris, stroma, a cover; the sori being covered with wool-like hairs. 
Struthiopteris, struthios, ostrich; the fronds being like the feathers of an ostrich.

Syngramma, syn, to unite, gramma, a line; the sori in united lines.

Tænitis, tainia, a fillet or ribbon; the linear pinnæ of the fronds.

Thylacopteris, thelo, a nipple; the sori like teats or nipples on the upper side of the frond.

Thyrsopteris, thyrsos, bunch or raceme, pteris; the fructification in raceme bunches.

Todea, in honour of Henry Julius Tode, of Mecklenburg, an experienced mycologist.

Trichocarpa, thrix, trichos, a hair, karpa, fruit; the fructification borne on a hair-like stalk.

Trichomanes, thrix, hair, manos, soft; the delicate nature of the fronds.

Trichopteris, thrix, hair, pteris; the sori being furnished with hairs.

Trochopteris, trochos, a wheel, pteris; the disposition of the fronds.

Vittaria, vitta, riband ; shape of narrow fronds.

Woodsia, in honour of Joseph Wood, a celebrated British botanist (died 1864).

Woodwardia, in honour of Thomas Jenkinson Woodward, an English botanist.

Xiphopteris, xiphos, sword, pteris; form of the frond. 


\section{3.-ALPHABETICAL LIST OF GENERIC NAMES GIVEN to FerNs}

BY DIFFERENT AUTHORS NOT ADOPTED, EACH FOLLOWED BY THE NAMES OF THE GeNera ADOPTED IN THIS WORK, UNDER WHICH ALL OR PART OF THE SPECIES OF THE NON-ADOPTED Genera ARE RECORDED.

Abacopteris, Fée-Nephrodium. Abrodictyum, Pr.-Trichomanes. Achomanes, Neck.-Trichomanes. Acropteris, Link.-Asplenium. Actinopteris, $J$. Sm.-Cheilanthes. Actinophlebia, $\mathrm{Pr}$.-Hemitelia. Adectum, Link.-Dennstædtia. Adiantellum, Pr.-Adiantum. Adiantopsis, Fée-Cheilanthes. Alcicornium, Gaud.-Platycerium. Aleuritopteris, Fée-Cheilanthes. Amauropelta, Kze.-Lastrea. Amblia, Pr. - Cyrtomium. Amesium, New.-Asplenium. Ampelopteris, Kze.-Goniopteris. Amphaenadenium, Desv.-Adenophorus.

Amphicosma, Gard.-Alsophila. Amphipterum, Pr.-Trichomanes. Amphoradenium, Desv.-Adenophorus.

Anapausia, Pr.-Gymnopteris. Anaxetum, Schott.-Pluridium. Anemirhiza, J. Sm.-Anemia. Anisocampium, $P r$. - Goniopteris. Anisogonium, Pr.-Callipteris. Anogramma, Link.--Gymnogramma Apalophlebia, Pr.-Niphobolus. Aphyllocalpa, Cav.-Osmunda. Arachniodes, $B l$. - Alsophila. Argyria, Fée-Gymnogramma. Aristaria, Mull.-Vittaria. Arsenopteris, $W e b b .-N e p h r o d i u m$. Arthrobotrya, $W$ all. - Lastrea. Anthrodanæa, Pr.-Danæa. Arthrolygodes, Pr.-Lygodium. Aspidotis, Mett.-Pellæa. Asteroglossum, J. Sm.-Drymoglossum.

Bathmium, Pr.-Aspidium. Belvisea, Mirb. - Ceratopteris, Schizæa, Hymenolepis, Asplenium
Bergera, Schaff.-Trichomanes. Blechnidium, Moore-Blechnum. Blechnopsis, Pr.-Blechnum. Bolbitis, Schott. - Poecilopteris. Botryogramma, Fée-Llavea. Botryopteris, Pr. - Helminthostachys.

Botryothallus, $K l$. -Polybotrya. Botrypus, Bich.-Botrychium. Bowringia, Hook.-Brainea. Brachysorus, Pr.-Asplenium.

Cænopteris, Berg.-Asplenium. Cænopteris, Thunb.-Onychium. Cafraria, Pr.-Stenochlæna. Callogramma, Fée-Syngramma. Callymella, Pr.-Gleichenia. Calypterium, Pr.-Onoclea. Campium, Pr.-Poecilopteris. Camptosorus, Link.-Antigramma. Candollea, Mirb.-Niphobolus. Cardiochlæna, Fée-Aspidium. Cardiomanes, Pr.-Trichomanes. Cardiostegia, Moore-Nephrolepis. Cassiopteris, Karst.-Ophioglossum Catenularia, Zeppel.-Ctenopteris. Celanthera, Thouin.--Marattia. Cephalomanes, Pr.-Trichomanes. Cephalosorium, Moore-Campyloneurum.

Ceramium, Reinw.-Didymochlæna Ceratodactylis, J. Sm. - Llavea. Ceterach, Pr.-Leptogramma. Charitophyllum, Van den Bosch.Hymenophyllum.

Cheilolepton, F'ée-Lomogramma. Cheiloplecton, Fée-Yellæa. Chilodium, Pr.-Trichomanes. Chladostachys, Wall. - Ceratopteris Chorizopteris, Moore-Cyrtogonium. Chnoophora, Kaulf.-Alsophila. Chrysodia, Fée-Gymnogramma. Chrysodium, Fée-Acrostichum. 
Chrysopteris, Link.-Phlebodium. Cionidium, Moore-Trichiocarpa.

Cistopteris, Auct.-Cystopteris.

Clementea, Cav.-Angiopteris.

Cnemidaria, Pr.-Hemitelia.

Cochlidium, Kaulf.-Pleurogramma.

Cœlopteris, A.Braun, MS.-Cryptosorous.

Colposoria, Pr.-Odontosoria.

Cormophyllum, New. - Cyathea.

Craspedaria, Link.-Lopholepis and Anapeltis.

Craspedophyllum, Pr.-Hymenophyllum.

Craspedoneuron, Van den Bosch.Trichomanes.

Cremidaria, Hook.-Hemitelia.

Crepidium, Pr.-Hymenophyllum.

Crepidomanes, Pr.-Trichomanes.

Crypsinus, Pr.-Niphobolus.

Cyrpteris, Nutt.-Pellæ.

Cryptogenis, Rich., MS.-Ceratopteris.

Cryptogramma, R. Br.-Allosorus.

Cryptostigma, A. Braun-Plecosorus.

Cteisium, Rich.-Lygodium.

Ctenopteris, New.-Polypodium.

Culcita, Pr. - Balantium.

Cuspidaria, Fée-Dicranoglossum.

Cyatheopsis, Karst. - Cyathea.

Cycloglossum, Pr.-Hymenophyllum.

Cyclophorus, Desv.-Niphobolus.

Cyclopteris, Gray-Cystopteris.

Cyclosorus, Link.-Nephrodium.

Cyrtomiphlebium, Hook. - Cyrtomium.

Cyrtophlebium, R. Br. - Campyloneurum.

Cystea, Sm.-Cystopteris.

Cystidium, J. Sm.-Cryptosorus.

Danæopsis, Pr. -Danæa.

Darea, Juss. - Asplenium.

Dareastrum, Fée-Asplenium.

Dendroglossa, Pr. - Gymmopteris, in part.

Dermatophyllum, Pr. - Hymenophyllum.

Diafina, Pr. - Blechnum.

Diagramma, Bl.-Callipteris.

Diblemma, J. Sm.-Colysis.
Dichasium, A. Braun-Lastrea. Dichorexia, Pr.-Alsophila. Dichsodon, Moore-Lastrea. Dicranodium, New. - Gymnogramma.

Dicranopteris, Bernh._Gleichenia. Dicranophlebia, Mart. - Alsophila.

Dictyoglossum, J. Sm.-Hymenodium.

Didymochlamys, Moore-Diplazium Didymoglossum, Desv. - Trichomanes.

Diellea, Brack. -Schizoloma.

Digrammaria, Pr. - Callipteris.

Digramma, Kze.-Antrophyum.

Discostegia, Pr.-Marattia.

Disphenia, Pr. - Cyathea.

Distaxia, Pr.-Blechnum.

Dorcapteris, $P r$. - Olfersia.

Eleutheria, Kze.-Hemitelia. Ellodocarpus, Kaulf. - Ceratopteris. Eriosorus, Fée.-Gymnogramma.

Euplasium, R. Br.-Dryostachyum. Eupteris, Agardh.-Pteris.

Euphorophyllum, Van den Bosch. -Hymenophyllum.

Eurostichum, Pr.-Gymnopteris.

Furcaria, Desv._Ceratopteris.

Galeoglossa, Pr.-Niphobolus. Gastromeria, J. Sm. MS:-二Loxoscaphe.

Gisopteris, Bernh.-Lygodium.

Glaphyropteris, Pr.-Phegopteris.

Gleicheniastrum, Pr._Gleichenia.

Granulina, Bory-Egenolfia.

Gymnia, Ham.-Cheilanthes.

Gymnodium, $A$. $B r$.-Polypodium. Gymnosphœra, $B l$.-Alsophila. Gymnothalmium, Jenk. MS.-Lastrea.

Gymnotheca, Pr.-Marattia. Gymnosorium, Bak.-Niphobolus. Gyrosorium, Pr. -Niphobolus.

Habrodictyon, Pr.-Trichomanes. Haplodictyon, Pr. - Nephrodium. Haplophlebia, Mart.-Alsophila. Haplopteris, Pr. - Vittaria. Hemicardion, Fée.-Cyclopeltis. Hemigonium, $J$. Sm.-Cyrtomium. 
Hemiotheum, New.-Lastrea.

Hemiphlebium, Pr.-Trichomanes.

Hemistegia, Pr. - Hemitelia.

Heterodanæa, Pr.-Danæa.

Heterogonium, Pr.-Stenosemia.

Heteroneuron, Fée and Pr.-Poecilopteris.

Heterophlebium, Fée-Litobrochia.

Heteropteris, Fée-Nevrodium.

Hicriopteris-Pr.-Gleichenia.

Hippodium,Gaud.-Didymochlæna.

Holcosorus, Moore-Drymoglossum.

Homaloneuron, Klotch-Asplenium.

Hommeotes, Pr.-Trichomanes.

Homopteris, Ruprecht - Crypto. gramma:

Hyalolepis, Kze.-Hymenolepis.

Hydroglossum, Willd. - Lygodictyon.

Hymenocystis, Mey.-Woodsia.

Hymenoglossum, Pr. - Hymenophyllum.

Hymenolæna, Mey.-Woodsia.

Hymenostomia, Gaud. - Odontosoria.

Hypochlamys, Fée--Diplazium.

Hypodematium, Kze.-Lastrea.

Hypopeltis, Bory-Aspidium.

Hysterocarpus, Langsd.-Didymochlæna.

Jenkinsia, Hook. and Bauer-Pœcilopteris.

Lacaussadea, Gaud._Egenolfia.

Lecanium, Pr.-Trichomanes.

Lemmaphyllum, Pr.-Drymoglossum.

Lepidoneuron, Fée-Nephrolepis.

Leptocionium, Pr.--HymenophylIum.

Leptoneuron, $K l$.-Pteris.

Leptopteris, Pr. -Todea.

Leptopleurea, Pr:-Nephrolepis.

Leptostegia, Don.-Onychium.

Lencomanes, Pr.-Trichomanes.

Lindsaynium, Fée-Lindsaya.

Lobochlæna, Fée-Sagenia.

Lomaridium, Pr.-Lomaria.

Lomariobocrys, Fée-Stenochlæna.

Lophidium, Pr. - Schizæa.

Lophodium, New.-Iastrea.

Lotzea, Klot.-Diplazium.
Loxoscaphe, Moore-Asplenium. Lytoneuron, Klot.-Doryopteris.

Macroglena, Pr.-Trichomanes. Macroplethus, Pr.-Hymenolepis. Marginaria, Bory-Lepicystes. Marginaria, Pr., in part-Goniophlebium.

Mecodium, Pr.-Hymenophyllinm.

Mecosorus, Klot. - Pleopeltis, in part.

Melanopteris, J. Sm. Herb.-Dryomenis.

Meringium, Pr.-Trichomanes.

Mertensia, Willd.-Gleichenia.

Metaxya, Pr.-Amphidesminm.

Microgonium, Pr.-Trichomanes.

Microbrochis, Pr.-Psmiocarpa.

Micropteris, Desv.-Pleurogramma.

Microsorum, Link.-Colysis.

Microstegia, Pr. -Callipteris.

Microstegnus, Pr.-Hemitelia.

Microterus, Pr.-Pleuridium.

Monachosorum, Kze.-Phegopteris.

Monochlæna, Gaud. - Didymochlæna.

Monogonia, Pr.-Pteris.

Myriotheea, Lam.-Marattia.

Myrmescostylum, Pr. - Hymenophyllum.

Nedroglossa, Pr.-Aconiopteris.

Nematopera, Kunze-Peranema.

Neurogramma, Link. - Gymnogramma.

Neuromanes, Pr.-Trichomanes.

Neuronia, Don.-Oleandra.

Neurophyllum, Pr. - Trichomanes.

Neuropteris, Desv. - Saccoloma.

Neuroplatycerus, Pluk.-Platycerium.

Notogramma, Pr.-Dictyogramma. Notocarpia, Pr.-Schizochenia.

Notolepium, New.-Ceterach.

Nymphopteris, Webb. and Berth.Pteris.

Ochlogramme, Pr.-Callipteris. Odontopteris, Bernh.-Lygodium. Odontomanes, Pr.-Trichomanes. Oetosis, Neck.-Pteris.

Onopteris, Neck.-Asplenium. Ophioderma, Endl. -Ophioglossum. 
Ophiola, Desv. - Helminthostachys. Ophiopteris, Reinw.-Oleandra. Orthogramma, Pr.-Lomaria. Ornithopteris, Bernh.-Anemia. Othonoloma, Link.-Cheilanthes.

Pachychrtum, Pr.-Trichomanes. Pachyderis, J. Sm.-Camptodium. Pachyloma, Van den Bosch.-Hy. menophyllum.

Pachypleuria, Pr.-Humata.

Pæsia, St. Hil._Ornithopteris.

Paltonium, Pr.-Neurodium.

Panicularia, Colla.-Thyrsopteris.

Parablechnum. Pr.-Blechnum.

Parenclymaria, Mull. - Vittaria.

Parestia, Pr.-Davallia.

Parkeria, Hook.-Ceratopteris.

Patania, Pr. - Dennstadtia.

Peltapteris, Link.-Rhipidopteris.

Peltochlæna, Fée-Aspidium.

Pericoptis, Wall. -Sehizoloma.

Phanerophlebia, Pr.-Cyrtomium.

Phlebigonium, Fée-Aspidium.

Phorolobus, Desv. - Cryptogramma.

Phyllistis, Neck. - Asplenium.

Physapteris, Pr.-Cheilanthes.

Physematium, Kaulf.-Woodsia.

Pinonia, Gaud.-Cibotium.

Plectopteris, Fée-Calymmodon.

Plenasium, Pr.-Osmunda.

Pleurogoniun, Pr.-Lepicystis and Anapeltis.

Pleurogramma, R. Br.-Leptogramma.

Pleuromanes, Pr.-Trichomanes.

Pleurosorus, Fée-Aspidium.

Podeilema, $R$. Br.-Sphæropteris.

Podopeltis, Fée-Aspidium.

Polycampium, Pr.-Niphobolus.

Polydictyum, Pr.-Aspidium.

Polygramma, Pr.-Plagiogyria.

Polytrnium, Desv.-Antrophyum.

Prionopteris, Wall.-Matonia.

Profera, Pr. - Pleocnemia.

Pronephrium, Pr.-Nephrodium.

Pseudachomanes, Pr.- Trichomanes

Pseudathyrum, New.-Polypodium.

Psilodochea, Pr.-Acrostichum.

Psidopodium, Neck.-Polypodium.

Psygmium, Pr.-Aglaomorpha.

Pteridopsis, Link.-Pteris.

Pteriglyphis, Fée-Callipteris.
Pteroneuron, Fée-Humata.

Pterozonium, Fée-Gymnogramma. Ptychophyllum, Pr. - Hymenophyllum.

Ptychomanes, Hedweg.-Hymenophyllum.

Pycnodoria, Pr.-Pteris.

Pycnopteris, Moore-Lastrea.

Pyrrhosia, Mirb.-Niphobolus.

Ragatelus, Pr. - Struthiopteris and Onoclea.

Ragiopteris, $\mathrm{Pr}$.-Onoclea, in part. Ramondia, Mirb.-Iygodium.

Rhizoglossum, Pr.-Ophioglossum.

Riedlea, Mirb.-Osmunda.

Ripidium, Bernh.-Schizæa.

Rumohra, Radd.-Polystichum.

Runcinaria, Mull.-Vittaria.

Sagenia, $P r .-$ Aspidium.

Schaffneria, Fée-Antigramma.

Scoliosorus, Moore-Antrophyum.

Scyphofelix, Aub. Pet. Thu.-Humata.

Scyphularea, Fée-Davallia.

Scytopteris, Pr.-Niphobolus.

Selenidium, Kze.-Davallia.

Serphyllopsis, $\mathrm{Pr}$. ? - Trichomanes.

Sitobolium, Desv. - Dennstadtia.

Solenopteris, Wxll.-Sellegua and

Loxogramma.

Solenopteris, Zenk. MS. - Athyrium.

Sphærocionum, Pr.-Hymenophyllum.

Sphærodium, Pr. - Hymenophyllum.

Sphæropteris, Wall.-Peranema.

Sphæropteris, Bernh.-Cyathea.

Sphærostephanos, J. Sm.-Mesochlæna.

Sphærostichum, Pr.-Niphobolus. Spathepteris, Pr. - Pteris and Gymnogramma.

Spicanta, Pr.-Lomaria.

Stegania, $R$. Br.-Lomaria.

Stenolobus, Pr.-Davallia.

Stenoloma, Fée-Odontosoria.

Stibasia, Pr.-Marattia.

Sticherus, Pr.-Gleichenia.

Struthiopteris, Bernh.-Osmunda.

Syzammia, Pr.-Goniophlebium. 
Tæniopsis, $J$. Sm.-Vittaria. Tæniopteris, Hook.-Vittaria Tapenidium, Pr.-Asplenium. Tarachia, Pr.-Asplenium. Taschneria, Pr.-Trichomanes. Tectaria, Cav.-Polystichum. Tegularia, Reinw._Didymochlæna. Teleozoma, $R$. Br.-Ceratopteris. Thamnopteris, Pr.-Neottopteris. Thelipteris, Desv._Lastrea. Trichipteris, Pr.-Alsophila.
Triblemma, $J$. Sm.-Asplenium. Trichothemilium, Kze. - Grammitis. Trichosorus, Leibm.-Lophosorus. Trismeria, Fée-Gymnogramma.

Ugena, Cav.--Lygodium.

Vaginularia, Fée-Monogramma. Vallifelix, Thou.-Lygodium.

Wibelia, Bernh.-Davallia.

$$
\begin{aligned}
& \text { Genera not adopted . . . . } 354 \\
& \text { Genera adopted . . . . . } 220 \\
& \text { Total . . . } \overline{574}
\end{aligned}
$$




\section{4.-INDEX TO THE GENERA ADOPTED IN THIS WORK.}

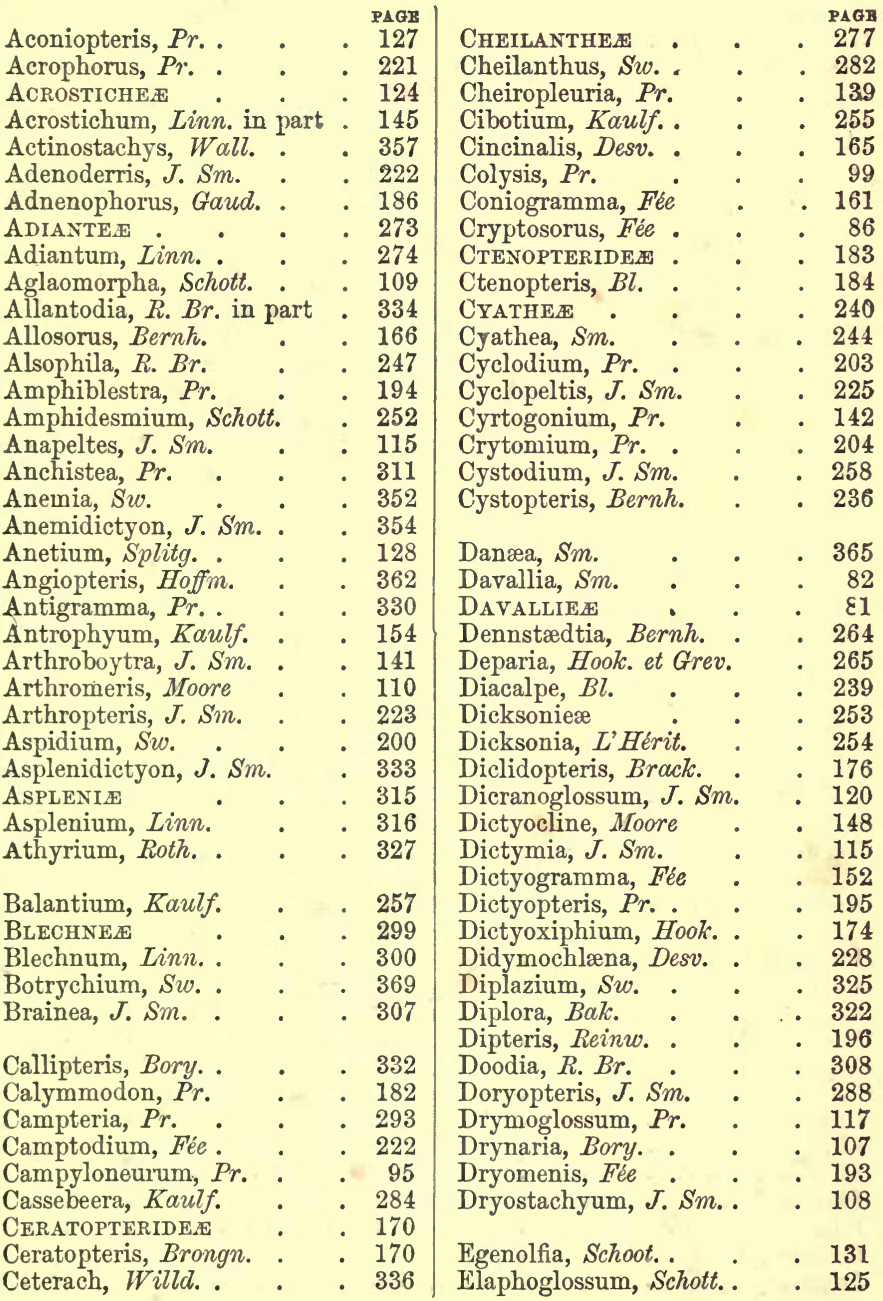


Eupodium, J. Sm.

Fadyenia, Hook. .

Féea, Bory. .

Gleichenia, Sm. .

Glyphotænium, $\dot{J}$. $S m$.

Goniophlebium, $B$.

Goniopteris, Pr. .

GramMitideA :

Grammites, $S w$. in part

Guernia, J. Sm. . .

Gymnogramma, Desv. .

Gymnopteris, Bernh.

Hecistopteris, $J$. Sm.

Helminthostachys, Kaulf.

Hemidictyon, $\mathrm{Pr}$.

Hemionitis, Linn.

Hemitelia, R. Br.

Hewardia, J. Sm.

Histiopteris, $J$. Sm.

Humata, Cav.

Hymenodium, $P r$.

HYMENOLEPIDEA .

Hymenolipis, Kaulf.

HYMENOPHYLLEE

Hymenophyllum, Sm.

Hymenostachys, Bory .

Hypoderris, $h$. $B r$.

Hypolepis, Bernh.

Isoloma, $J . S m$.

Jamesonia, Hook. et Grev.

Kaulfussia, $B l$.

Lastrea, Pr. .

Lecanopteris, $B l$.

Lepicystis, $J$. Sm.

Leptochilus, Kaulf.

Leptogramma, J. Sm.

Leucostegia, $\mathrm{Pr}$.

LINDS $\$$ EE

Lindsæa, Dry.

Litobrochia, Pr.

Llavia, Lag.

Lomogramma, $J$. Sm.

Lomaria, Willd.

Lomariopsis, Fée
PAGE

365

211

349

339

337

187

89

191

149

179

272

157

137

178

369

335

150

246

277

294

82

128

117

118

342

345

349

197

234

227

167

366

212

105

112

119

231

83

266

267

290

161

143

302

139
Lomaphlebia, J. Sm.

PAGE

Lonchitis, Linn.

182

Lopholepis, $J$. Sm.

292

111

251

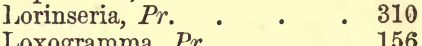

Loxogramma, Pr. $\quad$ • $\quad 156$

Loxoma, $R . B r$. . $\quad$. $\quad 262$

Lygodictyon, $J$. Sin. $\quad$ • $\quad$ • 352

Lygodium, $S w . \quad$. $\quad$. 351

Marattiest . . . . 361

Marattia, Sm. . . . 363

Matonia, R. Br. . $\quad$. $\quad$. 340

Menisceas . . . . 147

Meniscium, Schk. . . . 147

Mesochlæna, $R . B r . \quad$. 210

Microgramma, $P r . \quad$. $\quad 116$

Microlepia, $\mathrm{Pr}$. . $\quad$. $\quad$. 260

Micropodium, Mett. $\quad$. $\quad$. 323

Micropteris, J. Sm. $\quad$. $\quad$. 186

Microstaphyla, $\mathrm{Pr} . \quad$. $\quad .130$

Morhia, Sw. . . . 355

Monogramma, Schk. . . 175

Myriopteris, Fée . . . 280

Neottopteris, J. Sm. $\quad$. $\quad$. 328

Nephrodium, Schott. . . 206

Nephrolepis, Schott. . . 226

Neurocallis, Fée . . . 145

Neurodium, Fée . . . 121

Niphidium, J. Sm. $\quad$. $\quad$. 99

Niphobolus, Kaulf. $\quad$. $\quad$. 97

Niphopsis, J. Sm. $\quad$. $\quad .105$

Nothochlæna, R. Br. . . 278

Ocropteris, J. Sm. $\quad$. $\quad$. 287

Odontoloma, J. Sm. $\quad$. $\quad .269$

Odontosoria, Pr. . . . 263

OlEANDREA $\quad . \quad$. 80

Oleandra, Cav. . . $\quad$. 80

Olfersia, Radd. $\quad$. $\quad$. $\quad$. 133

Onoclea, Linn. . . . $\quad$. 311

Onychium, Kaulf. $\quad$. $\quad .286$

OPHIOGIOSSEA . . . 367

Ophioglossum, Linn. . $\quad$. 367

Ormopteris, J. Sm. $\quad$. 281

Ornithopteris, Agardh. $\quad . \quad 297$

OSMUNDEA . . . . 358

Osmunda, Linn. • $\quad . \quad$. 359

Oxygonium, Pr. . . . 331

Paragramma, $B l$. . . $\quad$. 114 


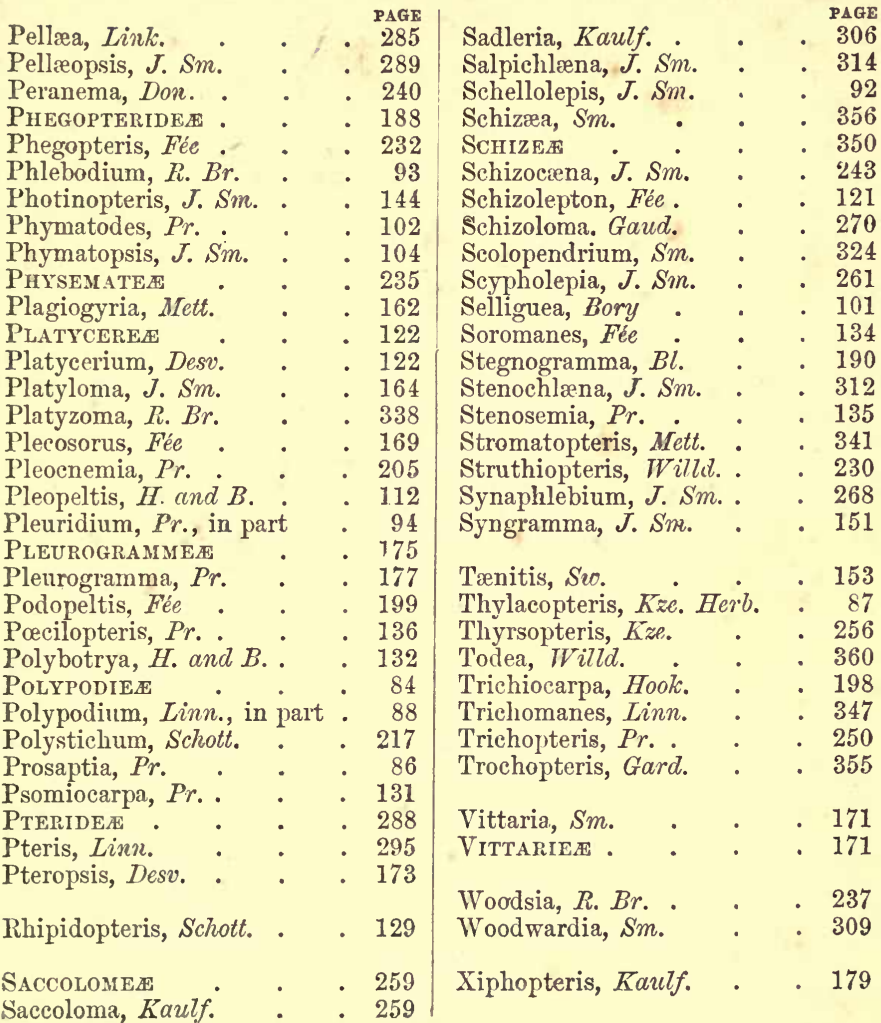







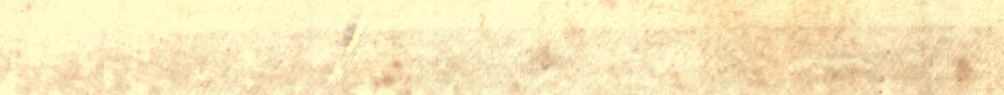

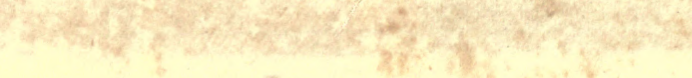

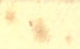

the

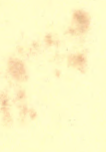

y.

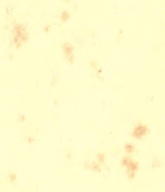

y

49

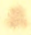

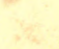


RETURN ENVIRONMENTAL DESIGN LIBRARY TO $\longrightarrow 210$ Wurster Hall

\begin{tabular}{l|l|l}
\hline $\begin{array}{c}\text { LOAN PERIOD } \\
\text { QUARTER }\end{array}$ & 2 & 3 \\
\hline 4 & 5 & 6 \\
\hline
\end{tabular}

ALL BOOKS MAY BE RECALLED AFTER 7 DAYS

Return books early if they are not being used

\section{DUE AS STAMPED BELOW}

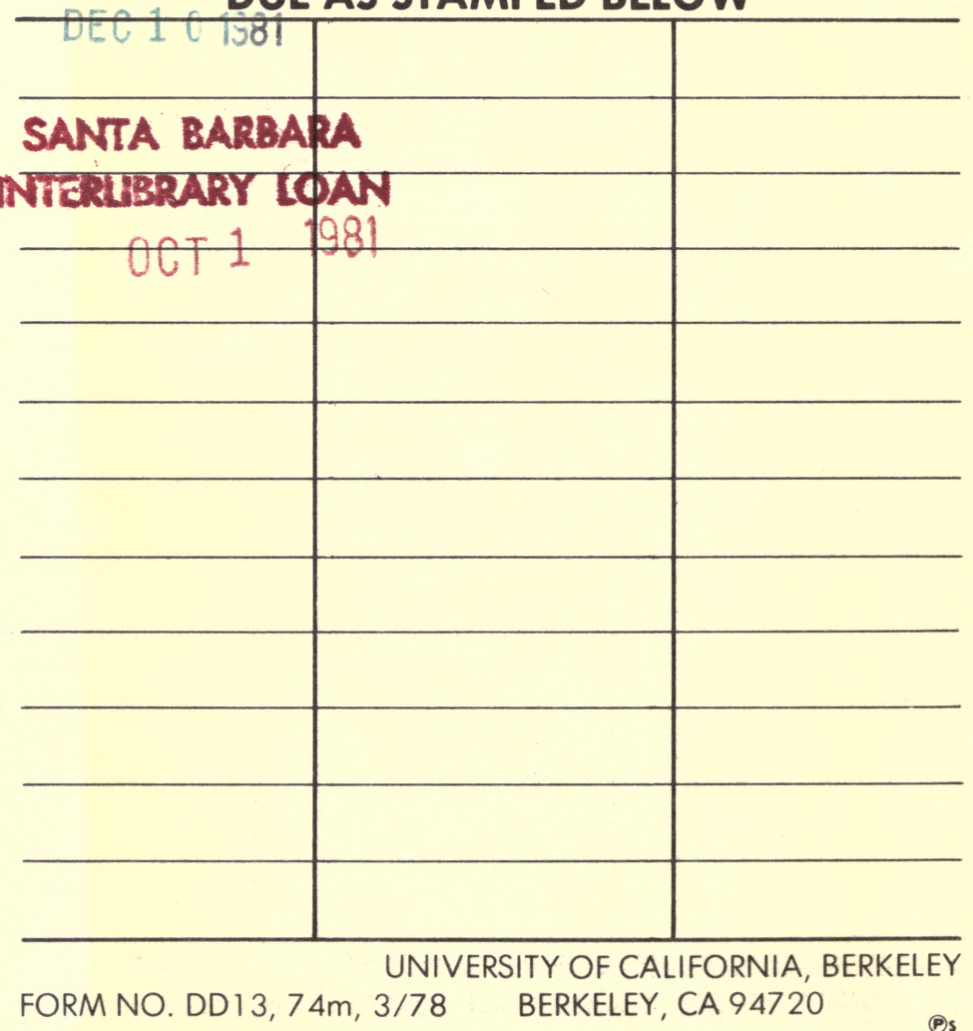


U.C. BERKELEY LIBRARIES

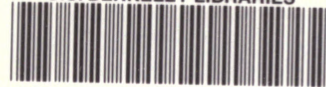

C03494557 
H.

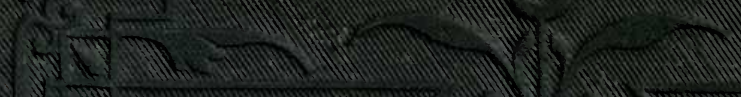
MH

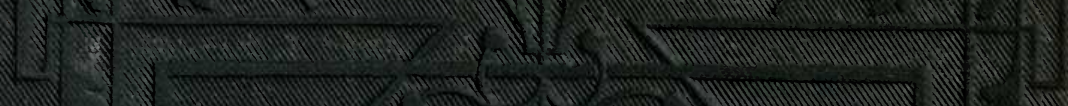

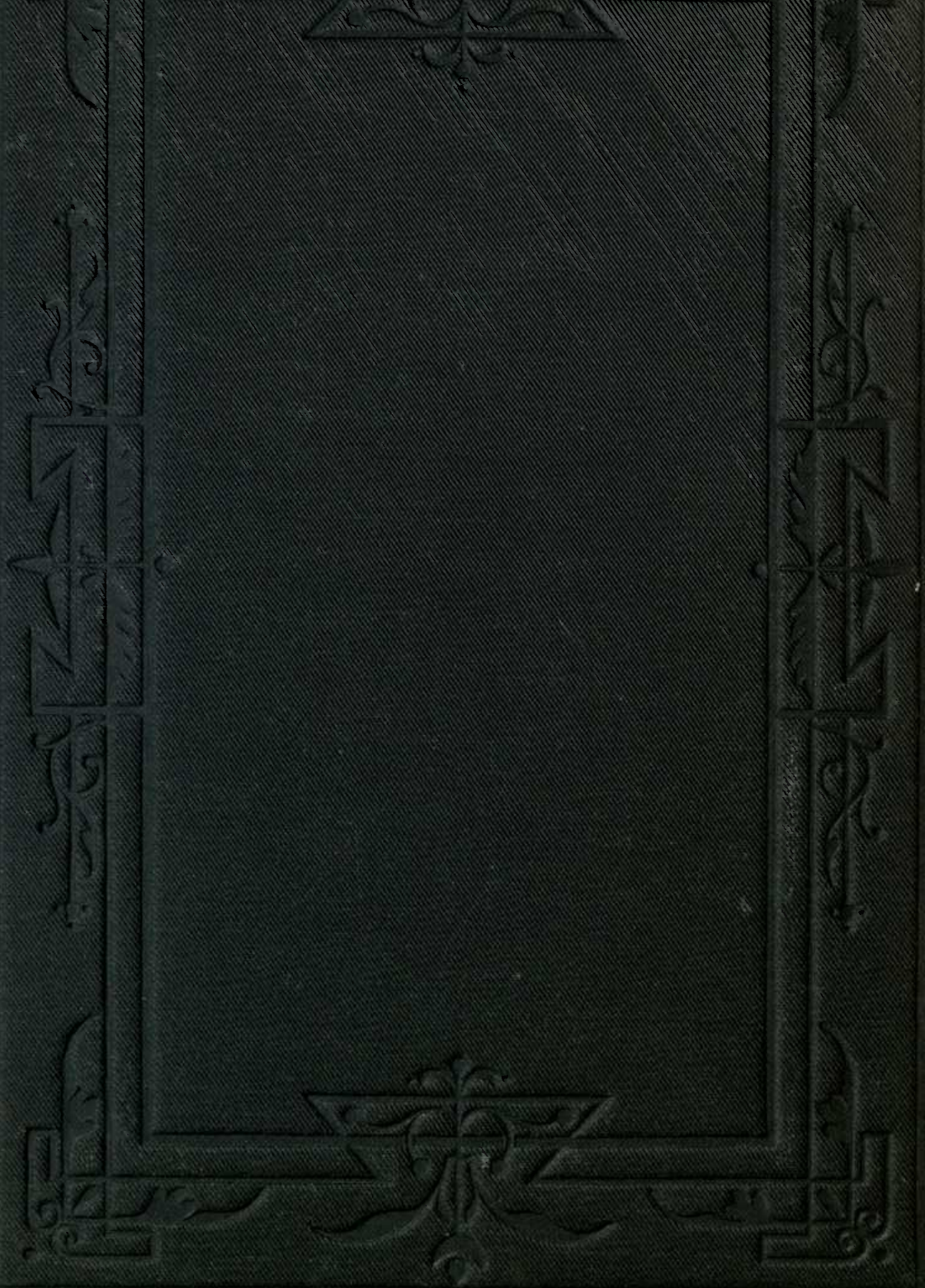

